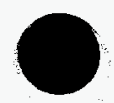

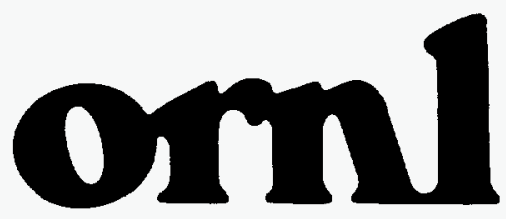

OAK RIDGE

NATIONAL

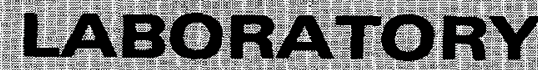

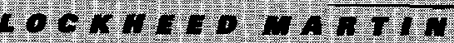

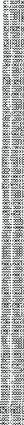
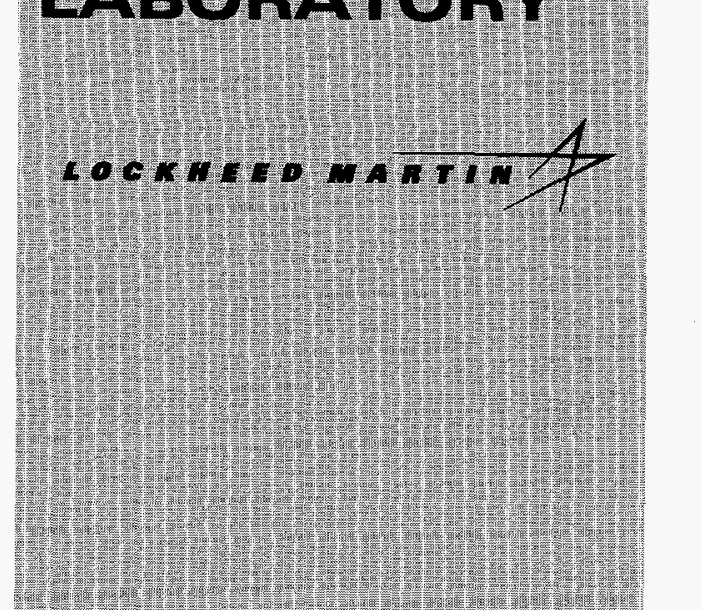

\section{AECEIVFD \\ MAY 19 \\ $08 T 1$}

X-231A Demonstration of In Situ Remediation of DNAPL Compounds in Low Permeability Media by Soil Fracturing with Thermally Enhanced Mass Recovery or Reactive Barrier Destruction

\author{
R. L. Siegrist \\ K. S. Lowe \\ L. D. Murdoch \\ W. W. Slack \\ T. C. Houk
}

March 1998

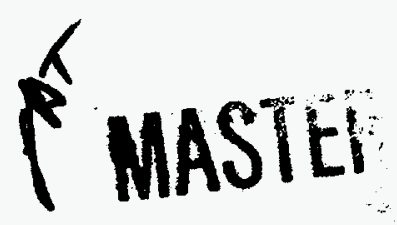

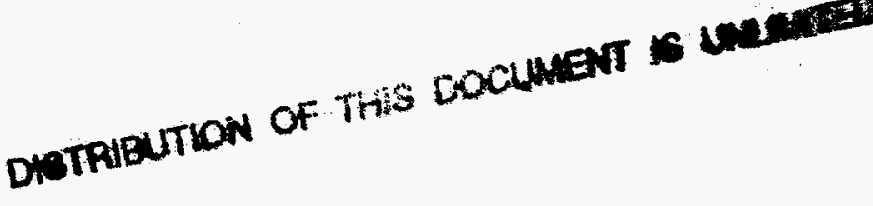


This report was prepared as an account of work sponsored by an agency of the United States Government. Neither the United States Government nor any agency thereof, nor any of their employees, makes any warranty, express or implied, or assumes any legal liability or responsibility for the accuracy, completeness, or usefulness of any information, apparatus, product, or process disclosed, or represents that its use would not infringe privately owned rights. Reference herein to any specific commercial product, process, or service by trade name, trademark, manufacturer, or otherwise, does not necessarily constitute or imply its endorsement, recommendation, or favoring by the United States Government or any agency thereof. The views and opinions of authors expressed herein do not necessarily state or reflect those of the United States Government or any agency thereof. 


\title{
X-231A Demonstration of In Situ Remediation of DNAPL Compounds in Low Permeability Media by Soil Fracturing with Thermally Enhanced Mass Recovery or Reactive Barrier Destruction
}

\author{
R. L. Siegrist ${ }^{1}$ \\ K. S. Lowe \\ L. D. Murdoch \\ W. W. Slack ${ }^{4}$ \\ T. C. Houk \\ March 1998 \\ Prepared for \\ U. S. DEPARTMENT OF ENERGY \\ Office of Technology Development \\ Washington, D. C. 20585 \\ and \\ Office of Environmental Restoration \\ Portsmouth Gaseous Diffusion Plant \\ Piketon, Ohio 45661 \\ Prepared by \\ OAK RIDGE NATIONAL LABORATORY, AND COLLABORATORS FROM \\ FRx, Inc., AND COLORADO SCHOOL OF MINES \\ ORNL is Managed by \\ LOCKHEED MARTIN ENERGY RESEARCH CORPORATION \\ for the \\ U. S. DEPARTMENT OF ENERGY \\ under contract DE-AC-05-96OR22464
}

\footnotetext{
${ }^{1}$ Oak Ridge National Laboratory, Environmental Sciences Division, Oak Ridge, TN;

Colorado School of Mines, Environmental Science \& Engineering Division, Golden, CO.

${ }^{2}$ Oak Ridge National Laboratory, Life Sciences Division, Grand Junction, CO.

${ }^{3} \mathrm{FRx}$, Inc., Cincinnati, Ohio and Clemson University, Clemson, SC.

${ }^{4}$ FRx, Inc., Cincinnati, OH.

${ }^{5}$ Lockheed Martin Energy Systems, Piketon, OH.
} 


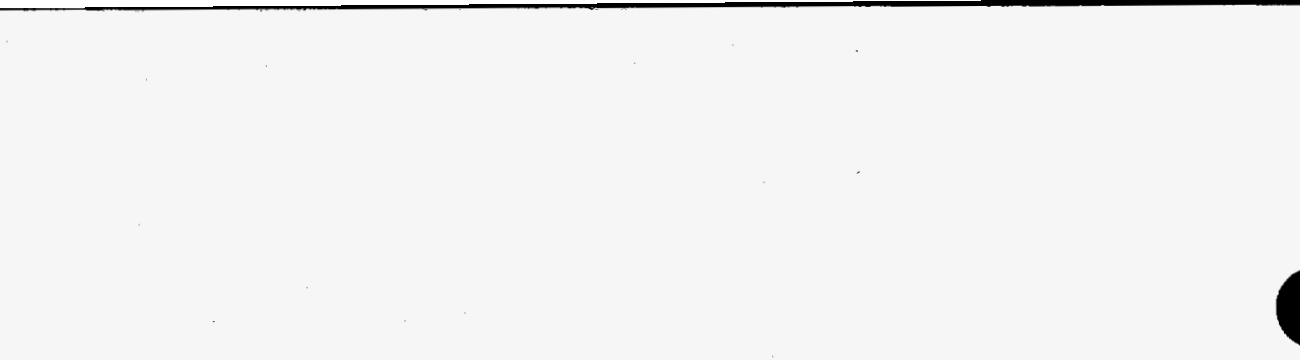

•

$\bullet$ 


\section{DISCLAIMER}

Portions of this document may be illegible in electronic image products. Images are produced from the best available original document. 


\section{CONTENTS}

Page

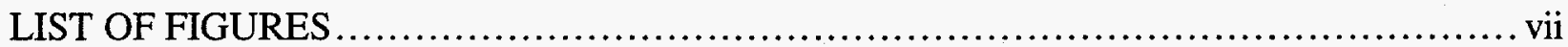

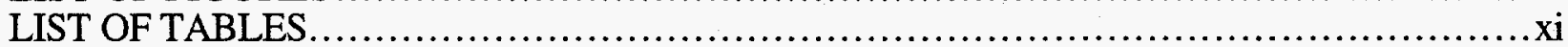

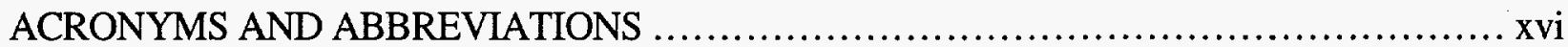

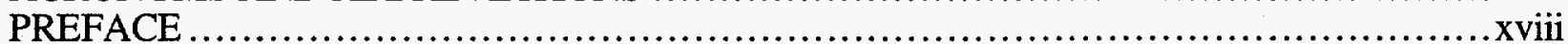

ACKNOWLEDGMENTS .................................................................... xix

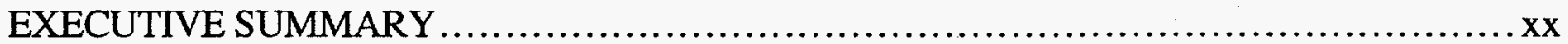

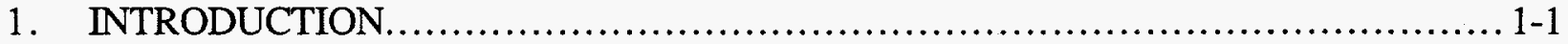

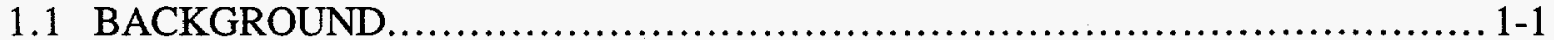

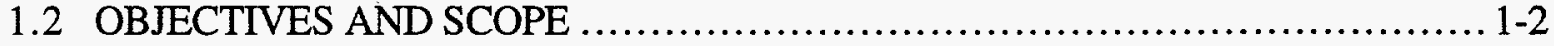

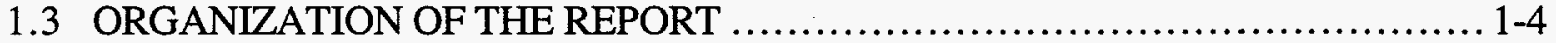

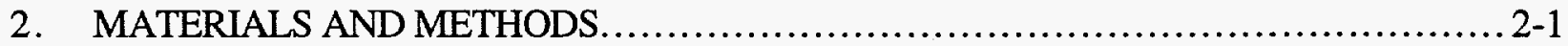

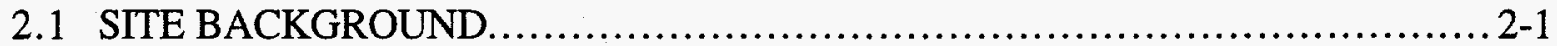

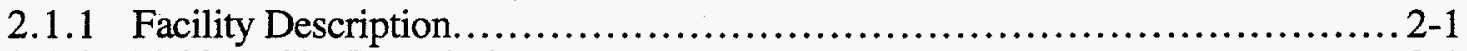

2.1.2 X-231A Site Description ............................................ 2-1

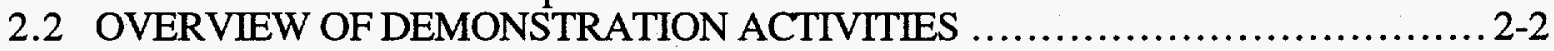

2.2.1 Site Reconnaissance and Pre-Demonstration Testing ...................... 2-2

2.2.1.1 Site Reconnaissance .......................................... 2-2

2.2.1.2 Equipment Testing and Shakedown .......................... 2-3

2.2.1.3 Reactive Fracture Proppant Formulation and Testing............... 2-3

2.2.2 Phase 1 Demonstration Activities (Fall 1996) ............................. 2-4

2.2.2.1 Test Cell Setup and Operation .................................. 2-4

2.2.2.2 Monitoring and Measurement................................ 2-6

2.2.3 Phase 2 Demonstration Activities (Summer 1997) ....................... 2-7

2.2.3.1 Characterization of the Test Site ............................... 2-7

2.2.3.2 Subsurface Heating Achieved via Fractures in Test

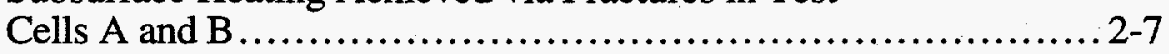

2.2.3.3 Morphology and Degradation Efficiency of Reactive

Fractures in Test Cells $\mathrm{C}$ and $\mathrm{D}$................................. 2-7

2.2.3.4 Injection/Percolation within Test Cells $\mathrm{C}$ and D.....................2-7

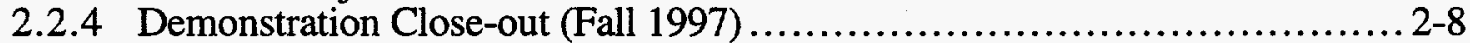

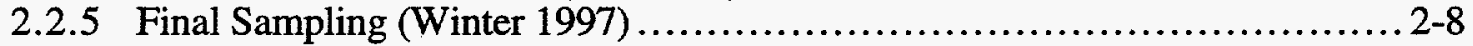

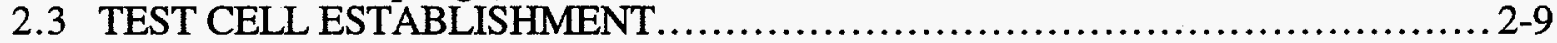

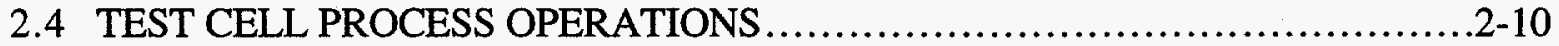

2.5 MONITORING OF PROCESS FUNCTION AND PERFORMANCE $\ldots \ldots \ldots \ldots \ldots \ldots . .2-11$

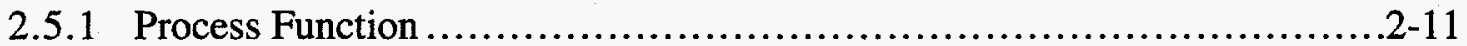

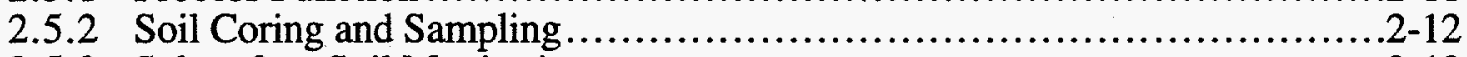

2.5.3 Subsurface Soil Monitoring ........................................... $2-13$

2.5.3.1 Hot Fluid Test Cells A and B ...................................2-13

2.5.3.2 Reactive Fracture Cells $\mathrm{C}$ and D...................................2-14

2.5.4 Ground Water Monitoring..............................................2-14

2.5.5 Helium Tracer Tests......................................................2-15

2.5.6 Fracture Zone Characterization and Degradation Tests .......................2-15

2.5.7 Injection/Percolation Tracer Tests .......................................2-18

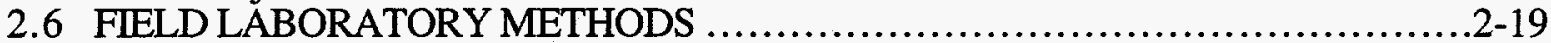

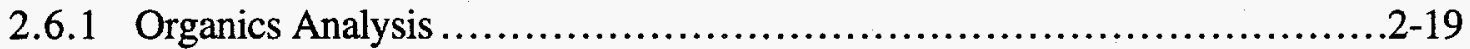

2.6.2 Inorganics Analysis ....................................................... 20

2.6.3 Physical Parameters....................................................... 


\section{CONTENTS cont.}

3. HOT FLUID INJECTION AND MASS RECOVERY SYSTEM RESULTS .............. 3-1

3.1 TEST CELL FEATURES AND OPERATIONS .................................. 3-1

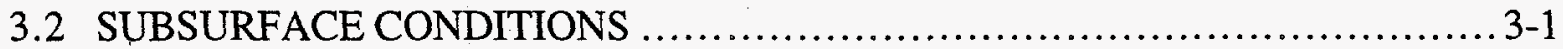

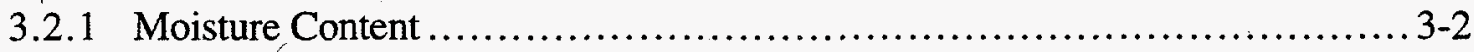

3.2.2 Temperature .....................................................................

3.2.3 Hydraulic Heads from Water Level Measurements ............................... 3-4

3.3 STEAM INJECTION AND MASS RECOVERY ................................ 3-4

3.3.1 Dewatering in Test Cell A ...............................................

3.3.2 Vapor Extraction in Test Cell A ...........................................

3.3.3 Steam Injection in Test Cell A .................................................. 3-7

3.3.3.1 Power and Water Consumption ................................. 3-7

3.3.3.2 Equipment Operation and Maintenance......................... 3-7

3.3.4 Effects of Steam Injection on Subsurface Characteristics .................... 3-8

3.3.4.1 Moisture Content.......................................... 3-8

3.3.4.2 Surface Temperatures........................................ 3-9

3.3.4.3 Temperature Cross-Sections ............................... 3-9

3.3.5 Contaminant Off-Gas Characteristics and Mass Recovery ...................3-10

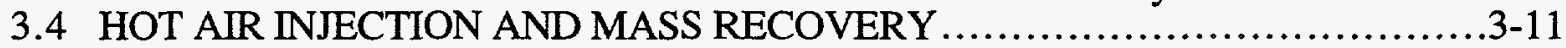

3.4.1 Dewatering in Test Cell B .............................................

3.4.2 Vapor Extraction in Test Cell B..................................................

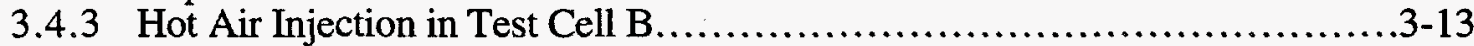

3.4.3.1 Injection Rates, Pressures, and Temperatures..........................3-13

3.4.3.2 Equipment Operation and Maintenance...........................3-14

3.4.4 Effects of Hot Air Injection on Subsurface Characteristics..................

3.4.4.1 Near Ground Surface Pressures...............................3-14

3.4.4.2 Moisture Content .............................................

3.4.4.3 Ground Surface Temperatures...............................

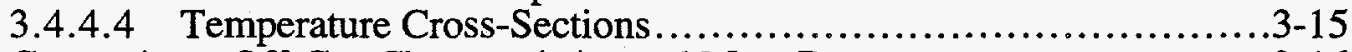

3.4.5 Contaminant Off-Gas Characteristics and Mass Recovery .....................3-16

3.4.5.1 Off-gas Composition and Removal Rates............................3-16

3.4.5.2 Soil Concentrations and Reduction Efficiency......................3-17

3.5 COMPARISON OF THE STEAM AND HOT AIR PROCESSES $\ldots \ldots \ldots \ldots \ldots \ldots \ldots . . .18$

3.5.1 Water: Recovery, Moisture Content, and Consumption ....................

3.5.2 Heat: Thermal Injection and Energy Content ...........................3-20

3.5.2.1 Hot Air Injection ..........................................

3.5.2.2 Steam Injection ..............................................

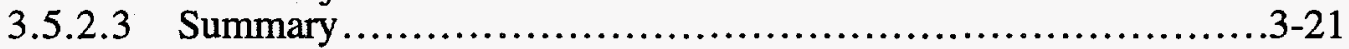

3.5.3 Contaminant Mass: Removal and Soil Concentrations ....................3-22

3.6 VIABILITY OF HOT FLUID INJECTION FOR MASS RECOVERY $\ldots \ldots \ldots \ldots \ldots . .3-23$

3.6.1 Water Balance...........................................................

3.6.2 Air Balance...............................................................

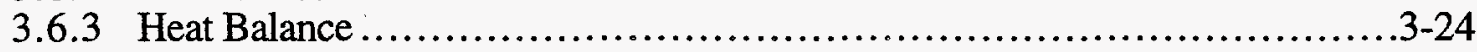

3.6.4 Contaminant Mass Balance................................................... $3-25$

4. REACTIVE BARRIER IN SITU DESTRUCTION SYSTEM RESULTS ................ 4-1

4.1 IRON METAL HORIZONTAL BARRIERS ...................................... $4-1$

4.1.1 Iron Metal Reactive Fracture Morphology and Properties .................... 4-1

4.1.2 DNAPL Compound Degradation in Iron Metal Fracture Zones .............. 4-1

4.1.3 Subsurface Characteristics within Test Cell C ............................. 4-3 
4.2 PERMANGANATE GROUT HORIZONTAL BARRIERS $\ldots \ldots \ldots \ldots \ldots \ldots \ldots \ldots \ldots . .44$

4.2.1 Permanganate Fracture Morphology and Properties ......................... 4-4

4.2.2 DNAPL Compound Degradation in Permanganate Fracture Zones ............ 4-5

4.2.3 Subsurface Characteristics within Test Cell D ................................ 4-5

4.3 INJECTION/PERCOLATION TRACER TESTS $\ldots \ldots \ldots \ldots \ldots \ldots \ldots \ldots \ldots \ldots \ldots \ldots ., 7$

4.4 COMPARATIVE FEATURES OF BARRIER TYPES $\ldots \ldots \ldots \ldots \ldots \ldots \ldots \ldots \ldots \ldots \ldots, 7$

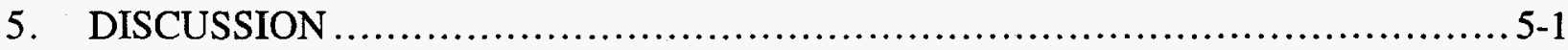

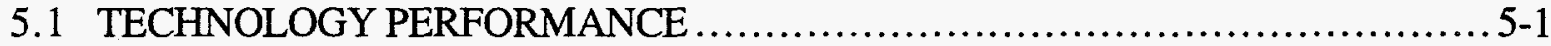

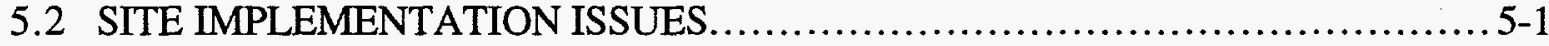

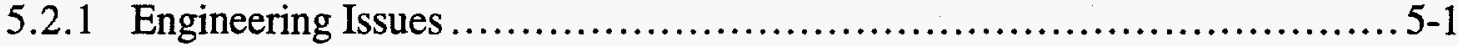

5.2 .2 Waste Management.................................................... 5-1

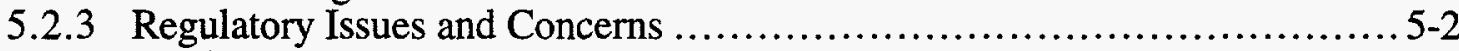

5.2 .4 Worker and Environmental Safety ...................................... 5-2

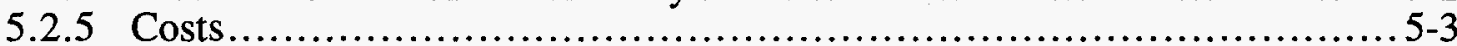

5.3 FURTHER DEVELOPMENT OPPORTUNITIES $\ldots \ldots \ldots \ldots \ldots \ldots \ldots \ldots \ldots \ldots \ldots \ldots \ldots$

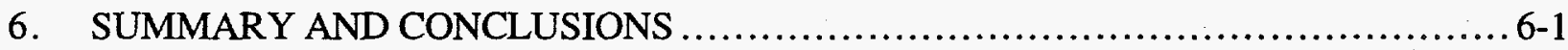

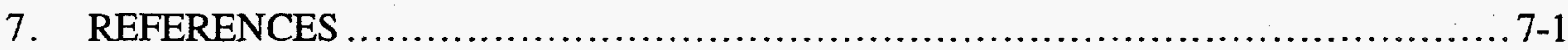

8. APPENDICES

A. PRE-DEMONSTRATION RECONNAISSANCE AND TECHNOLOGY

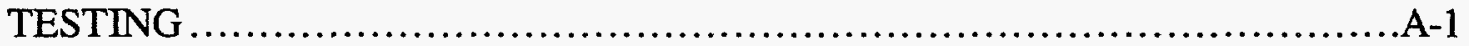

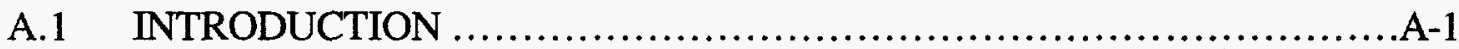

A.2 TESTING OF A DOWN-HOLE STEAM GENERATOR .....................

A.2.1 Above Ground Testing...............................................A-1

A.2.2 Down-Hole Testing.............................................

A.3 TESTING OF A DOWN-HOLE HOT AIR GENERATOR ..................

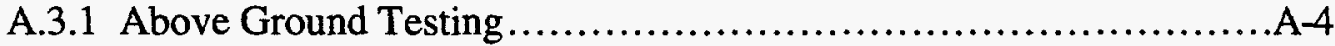

A.3.2 Down-Hole Testing..................................................

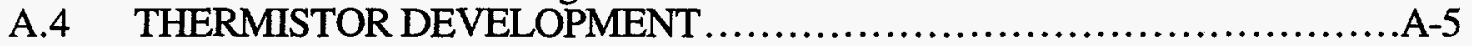

A.5 DEMONSTRATION SITE RECONNAISSANCE $\ldots \ldots \ldots \ldots \ldots \ldots \ldots \ldots \ldots \ldots . .6$

A.6 SOIL FRACTURING AND HOT FLUID TESTING AT THE CTS .........A-7

A.6.1 Fracture Emplacement .........................................

A.6.2 Down-Hole Hot Air Generator Testing ............................. A-7

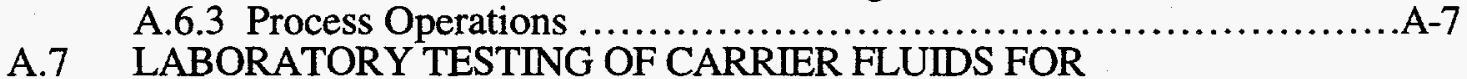

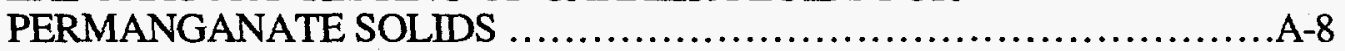

B. TEST CELL FEATURES AND PROCESS OPERATION $\ldots \ldots \ldots \ldots \ldots \ldots \ldots \ldots \ldots . . . \ldots \ldots$

C. PRE-OPERATIONAL TEST SITE CHARACTERISTICS ......................

D. OPERATIONAL AND POST-TREATMENT HOT FLUID
CELL CHARACTERISTICS $\ldots \ldots \ldots \ldots \ldots \ldots \ldots \ldots \ldots \ldots \ldots \ldots \ldots \ldots \ldots \ldots \ldots \ldots \ldots \ldots \ldots \ldots \ldots \ldots \ldots \ldots \ldots$ 
CONTENTS cont.

E. OPERATIONAL AND POST-TREATMENT BARRIER

CELL CHARACTERISTICS

F. GROUND WATER CHARACTERIZATION AND MONITORING ................F-1

G. REACTIVE FRACTURE ZONE CHARACTERISTICS ......................... G-1

H. POST-DEMONSTRATION RECONNAISSANCE .......................... H-1 


\section{LIST OF FIGURES}

1.1 Illustration of the remediation problem posed by DNAPL compounds in low permeability media ...............................................................

2.1 Location of the DOE Portsmouth Gaseous Diffusion Plant............................2-22

2.2 Location of the X-231A unit at the DOE Portsmouth Plant ..........................2-23

2.3 Representative lithology of the shallow subsurface at the DOE Portsmouth Plant ..........2-24

2.4 Photograph of the lithology of the DOE Portsmouth Plant as observed in a core sequence collected from the Clean Test Site during May $1996 \ldots \ldots \ldots \ldots \ldots \ldots \ldots \ldots .2-25$

2.5 Photograph of the established demonstration test area at the X-231 A site ...............2-26

2.6 Location of reconnaissance probe holes and historical borings within the X-231A site....2-27

2.7 Location of the pilot-test fracture cells at the PORTS CTS..............................2-28

$2.8 \mathrm{X}-231 \mathrm{~A}$ test cell layout and baseline characterization soil boring locations ................2-29

2.9 Cross-section of the test cells at the X-231A demonstration site .......................2-30

$2.10 \mathrm{X}-231 \mathrm{~A}$ demonstration site plan view indicating test cell instrumentation

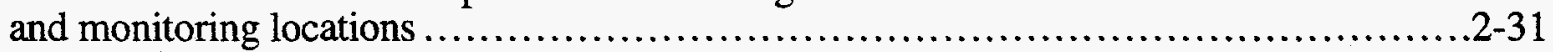

2.11 Illustration of the water infiltration/percolation system used for test cells C and D

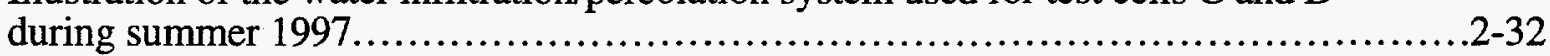

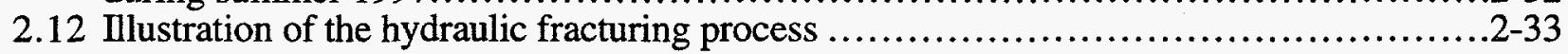

3.1 Photograph of a sand propped fracture .................................................

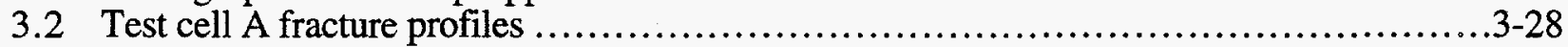

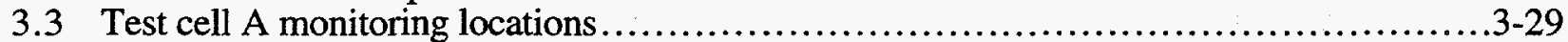

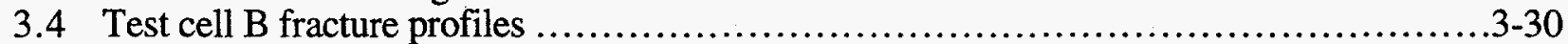

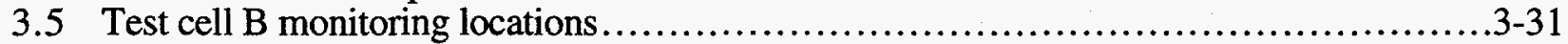

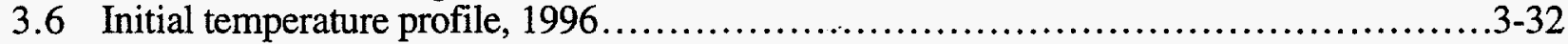

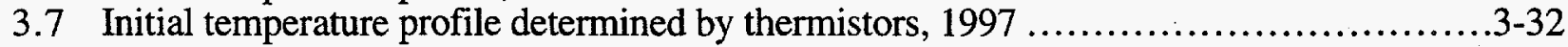

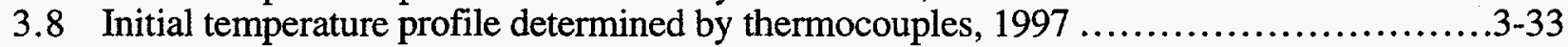

3.9 Depth of far-field water table during fall 1996 tests...................................3-33

3.10 Relative depth to water table within test cells A and B during $1996 \ldots \ldots \ldots \ldots \ldots \ldots \ldots \ldots . .3-34$

3.11 Depth of far-field water table during summer 1997 tests.............................3-34

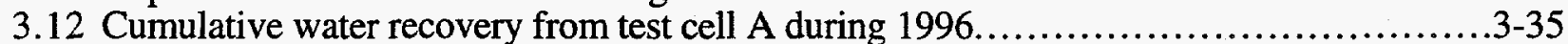

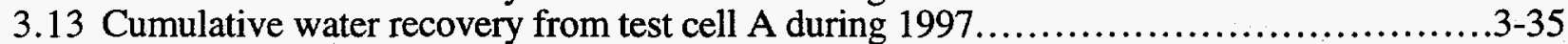

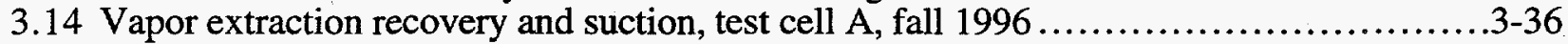

3.15 Vapor extraction recovery and suction, test cell A, summer $1997 \ldots \ldots \ldots \ldots \ldots \ldots \ldots \ldots .3-36$

3.16 Specific discharge of test cell $A$ vapor extraction during fall 1996 tests...................3-37

3.17 Specific discharge of test cell A vapor extraction during summer 1997 tests ...............3-37

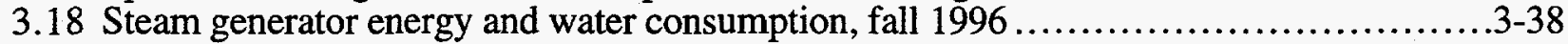

3.19 Steam generator energy and water consumption, summer $1997 \ldots \ldots \ldots \ldots \ldots \ldots \ldots \ldots \ldots .3-38$

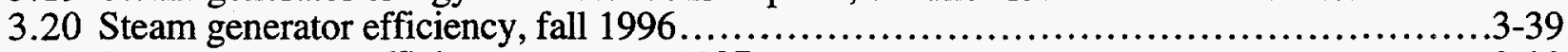

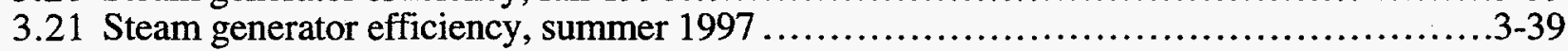

3.22 Volumetric moisture content as a function of depth and time in cell A.....................3-40

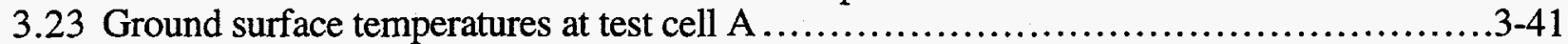

3.24 Initial and early temperature cross-sections at test cell A ..................................... $3-42$

3.25 Progression of temperature cross-sections in test cell A................................ 43

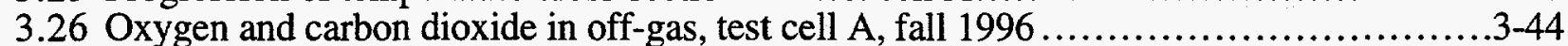

3.27 Methane in off-gas, test cells A and B, fall 1996....................................

3.28 Composition of A-4 off-gas ............................................................

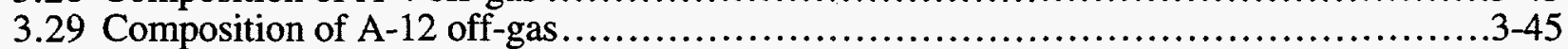




\section{LIST OF FIGURES cont.}

3.30 Recovery rate of contaminants........................................................

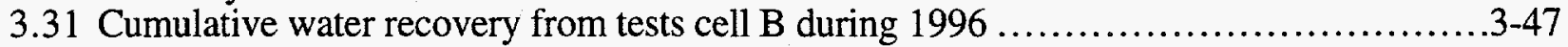

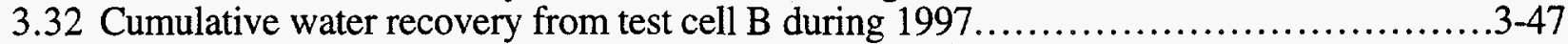

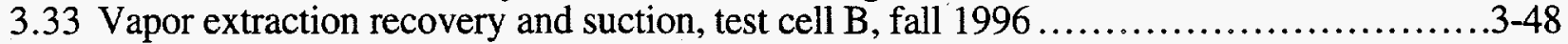

3.34 Vapor extraction recovery and suction, test cell B, summer $1997 \ldots \ldots \ldots \ldots \ldots \ldots \ldots \ldots . .3-48$

3.35 Specific discharge of test cell B vapor extraction during fall 1996 tests...................3-49

3.36 Specific discharge of test cell B vapor extraction during summer 1997 tests ...............3-49

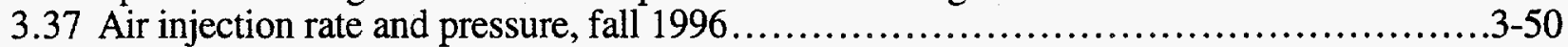

3.38 Air injection rate and pressure, summer 1997 ............................................

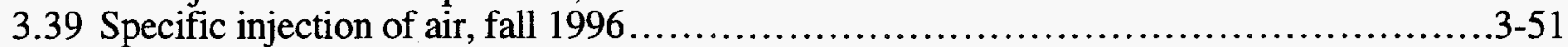

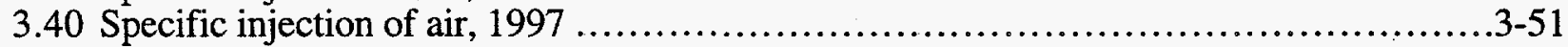

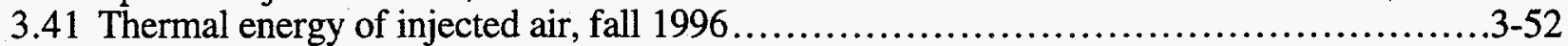

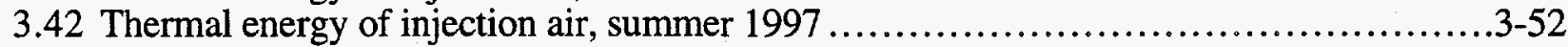

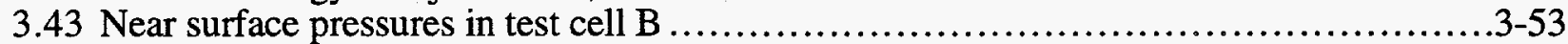

3.44 Volumetric moisture content as a function of depth and time in cell B..................... 34

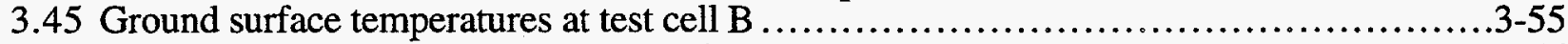

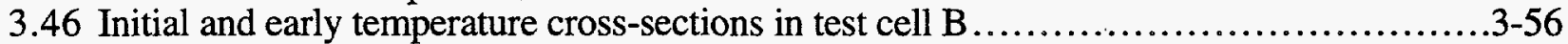

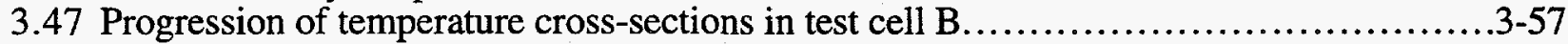

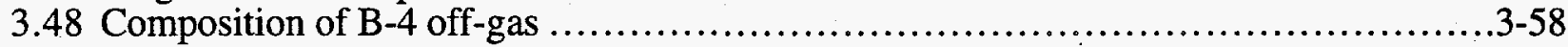

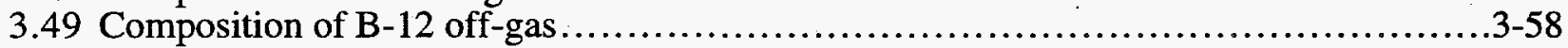

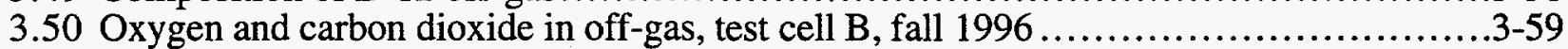

3.51 Typical contaminant concentrations in cell B soil ...................................... $3-59$

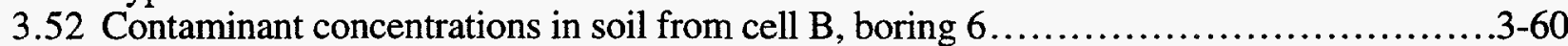

3.53 Comparison of contaminant concentrations in soil before and after hot air injection........3-60

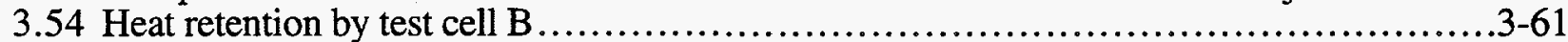

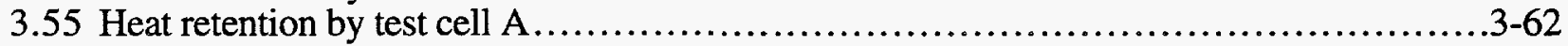

4.1 Plan view of the horizontal barrier cell with iron metal particle proppant (test cell C) .......4-9

4.2 Profile view of the fractures emplaced in iron metal test cell C.........................4-10

4.3 Photograph made during December 1996 illustrating the morphology of the

iron metal propped fracture and the formation above and below it..................... 4-11

4.4 Photomicrographs made during July 1997 illustrating the micromorphology of the iron metal proppant (a) as compared to comparable fresh iron (b) ....................... $4-12$

4.5 Properties in the vicinity of an iron filled fracture 3 months after emplacement ............4-13

4.6 Properties in the vicinity of an iron filled fracture 10 months after emplacement............4-14

4.7 TCE degradation in ground water after a 24-hr reaction time versus distance from an iron filled fracture 3 months after emplacement. GW initial TCE $=144 \mathrm{mg} / \mathrm{L} \ldots \ldots \ldots . .15$

4.8 TCE degradation in ground water after 24- or 48-hr reactive times versus distance from an iron filled fracture 10 months after emplacement. (a) GW1 initial

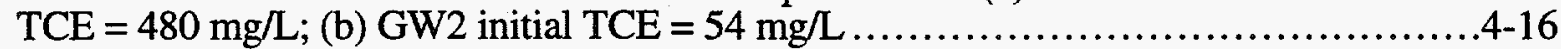

4.9 TCE degradation with iron metal retrieved from fractures after 15 months of emplacement. FC2T1 $=$ iron metal and $25 \mathrm{mg} / \mathrm{L}$ TCE at 20C. FC3T1 $=$ iron metal

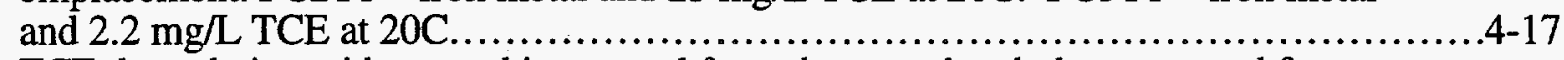

4.10 TCE degradation with unused iron metal from the same batch that was used for

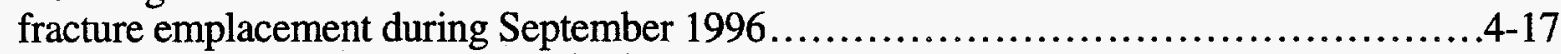

4.11 Representative soil water content in the iron cell initially and 10 months

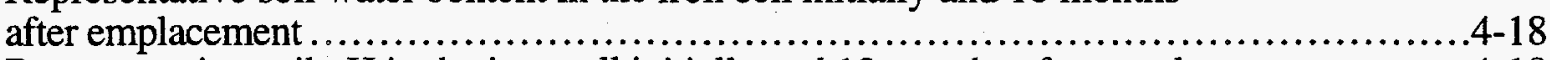

4.12 Representative soil $\mathrm{pH}$ in the iron cell initially and 10 months after emplacement ..........4-18 


\section{LIST OF FIGURES cont.}

4.13 Representative soil potassium levels in the iron cell initially and 10 months after emplacement ..............................................................

4.14 Representative soil iron levels in the iron cell initially and 10 months after emplacement. .4-19

4.15 Representative soil manganese levels in the iron cell initially and 10 months after emplacement

4.16 Ground water $\mathrm{pH}$ and iron concentrations in piezometer X231A-TCP1 beneath the iron cell.

4.17 Ground water concentrations of DNAPL VOCs beneath the iron cell over time ...........4-21

4.18 Ground water $\mathrm{pH}$ and ion concentrations in piezometers X231A-BGP1 and X231A-BGP2.

4.19 Ground water concentrations of DNAPL VOCs in background piezometers..............4-23

4.20 Plan view of the horizontal barrier cell created with permanganate grout proppant ........4-24

4.21 Profile view of the fractures emplaced in the permanganate test cell D ....................4-25

4.22 Photograph made during December 1996 illustrating the morphology of the permanganate grout fracture and the soil above and below it .........................4-26

4.23 Properties in the vicinity of a permanganate filled fracture 3 months after emplacement ...4-27

4.24 Properties in the vicinity of a permanganate filled fracture 10 months after emplacement. .4-28

4.25 TCE degradation in ground water after a 24-hr reaction time versus distance from a permanganate filled fracture 3 months after emplacement. GW initial TCE $=144 \mathrm{mg} / \mathrm{L} . .4-29$

4.26 TCE degradation in ground water after 2- and 24-hr reaction times versus distance from a permanganate filled fracture 10 months after emplacement. (a) GW1 initial $\mathrm{TCE}=480 \mathrm{mg} / \mathrm{L} ;$ (b) GW2 initial TCE $=54 \mathrm{mg} / \mathrm{L}$

4.27 Representative soil water content in the permanganate cell initially and 10 months

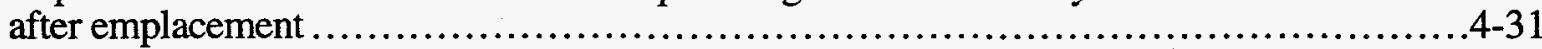

4.28 Representative soil $\mathrm{pH}$ in the permanganate cell initially and 10 months after emplacement ........................................................................

4.29 Representative soil potassium levels in the permanganate cell initially and 10 months

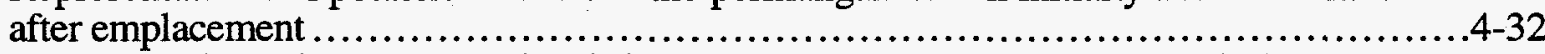

4.30 Representative soil manganese levels in the permanganate cell initially and 10 months

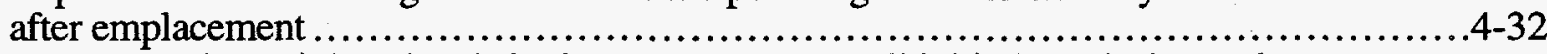

4.31 Representative soil iron levels in the permanganate cell initially and 10 months after emplacement

4.32 Ground water $\mathrm{pH}$ and iron concentrations in piezometer X231A-TDP1 beneath the permanganate cell

4.33 Ground water concentrations of DNAPL VOCs beneath the permanganate cell.

A.1 Location of May 1996 reconnaissance cores and historical borings ................... A-10 A.2 X-231A reconnaissance characterization sample data: (a) TCE and (b) 1,1,1-TCA....... A-11

A.3 Location of fracture test cells at the CTS ........................................... A-12

A.4 Hydraulic fracturing uplift, Clean Test Site Cell A, $2 \mathrm{~m}$ fracture....................... A-13

A.5 Hydraulic fracturing uplift, Clean Test Site Cell B, 2 m fracture...................... A-14

A.6 Hydraulic fracturing uplift, Clean Test Site Cell B, $3 \mathrm{~m}$ fracture....................... A-15

A.7 Hydraulic fracturing uplift, Clean Test Site Cell B, $4 \mathrm{~m}$ fracture $\ldots \ldots \ldots \ldots \ldots \ldots \ldots \ldots \ldots$ A-16

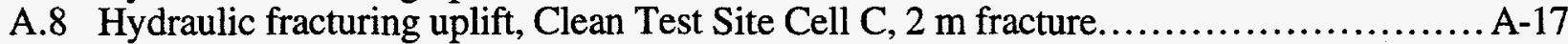

A.9 Hydraulic fracturing uplift, Clean Test Site Cell C, $3 \mathrm{~m}$ fracture ...................... A-18

A.10 Hydraulic fracturing uplift, Clean Test Site Cell C, $4 \mathrm{~m}$ fracture....................... A-19

A.11 Hydraulic fracturing uplift, Clean Test Site Cell D, $18 \mathrm{ft}$ fracture.................... A-20 


\section{LIST OF FIGURES cont.}

$\begin{array}{ll}\text { B.1 } & \text { Hydraulic fracturing uplift, test cell A, } 4 \mathrm{ft} \text { fracture }(8 / 24 / 96) \ldots \ldots \ldots \ldots \ldots \ldots \ldots \ldots \ldots \ldots \ldots \ldots \ldots \ldots \ldots \ldots \ldots \ldots \ldots \ldots \ldots \ldots \ldots \ldots \\ \text { B.2 } & \text { Hydraulic fracturing uplift, test cell A, } 4 \mathrm{ft} \text { fracture }(8 / 25 / 96) \ldots \ldots \ldots \ldots \ldots \ldots \ldots \ldots \ldots\end{array}$

B.3 Hydraulic fracturing uplift, test cell A, $8 \mathrm{ft}$ fracture ......................................

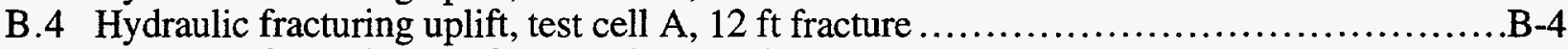

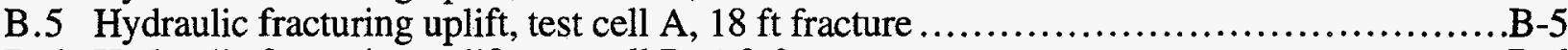

B.6 Hydraulic fracturing uplift, test cell B, $4 \mathrm{ft}$ fracture........................................ 6

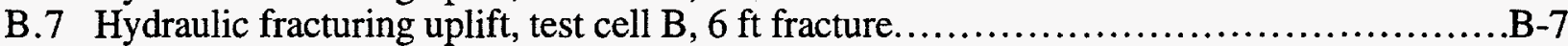

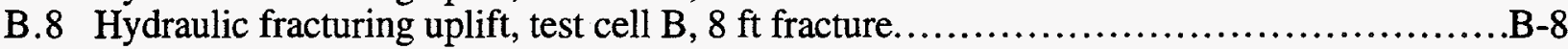

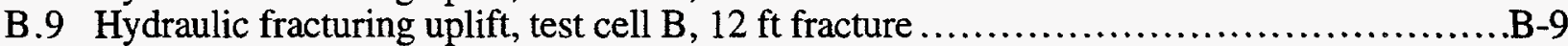

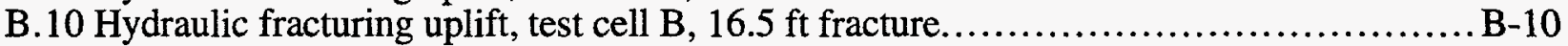

B.11 Hydraulic fracturing uplift, test cell C, $4 \mathrm{ft}$ fracture ...............................

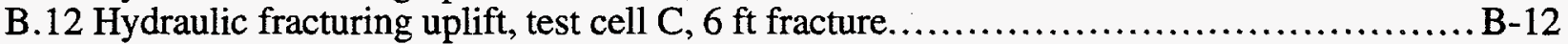

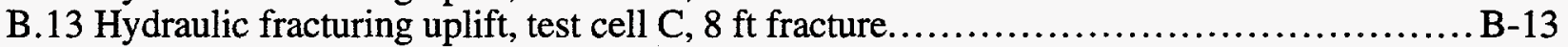

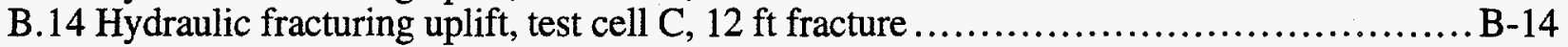

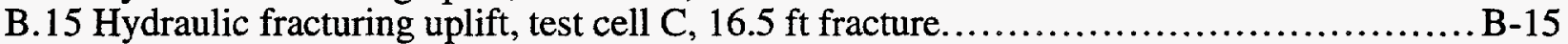

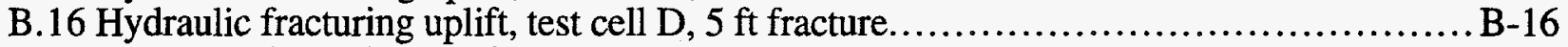

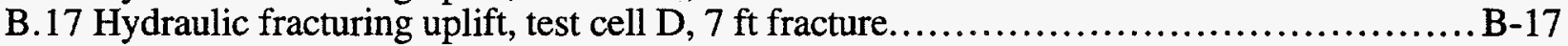

B. 18 Hydraulic fracturing uplift, test cell D, $9 \mathrm{ft}$ fracture ................................

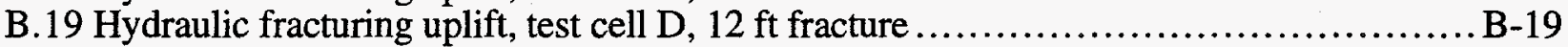

B.20 Hydraulic fracturing uplift, test cell D, $16.5 \mathrm{ft}$ fracture..............................

B.21 Rates and volumes injected at test cell $C$ and $D($ summer 1997) .......................

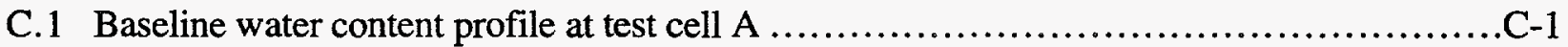

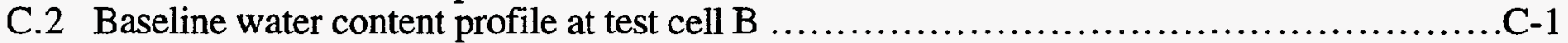

C.3 Baseline water content profile at test cell C ................................................

C. 4 Baseline water content profile at test cell D . ........................................

C.5 Volumetric moisture content as a function of depth and time in from background boring ..C-3

E.1 Test cell D, representative Eh profile (location TDM2) ..............................

E.2 Volumetric moisture content as a function of depth and time in cells C \& D...............E-2

F.1 Ground water iron concentrations at test cell C......................................F-1

F.2 Ground water Mn concentrations at test cell D .............................................. 1

F.3 Ground water $\mathrm{MnO}_{4}$ concentrations at test cell D ........................................

F.4 Ground water alkalinity at test cell D ................................................... 2

F.5 Test cell A (TAP1) ground water quality parameters .................................

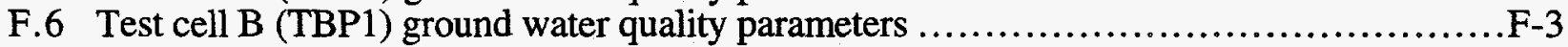

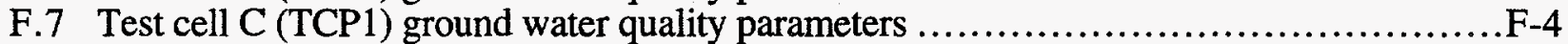

F.8 Test cell D (TDP1) ground water quality parameters .................................. 
2.1 Summary of selected X-231A site characteristics ....................................2-34

2.2 Chronology of 1996 field activities during the X-231A demonstration ....................2-35

2.3 Chronology of 1997 field activities during the X-231A demonstration ...................2-36

2.4 Summary of subsurface sampling completed during a reconnaissance survey in

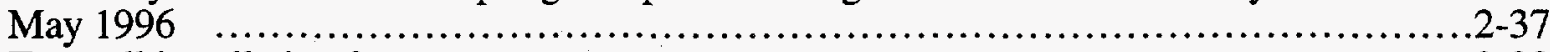

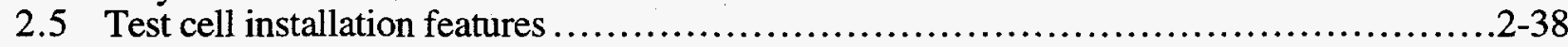

2.6 Summary of baseline characterization laboratory analysis .............................2-39

2.7 Analyses for soil properties for each depth interval sampled during the baseline characterization......................................................2-40

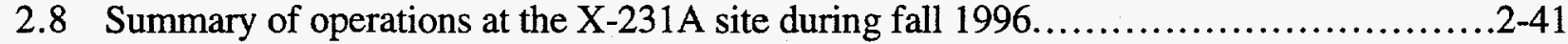

2.9 Summary of operations at the X-231A site during summer $1997 \ldots \ldots \ldots \ldots \ldots \ldots \ldots \ldots \ldots .2-42$

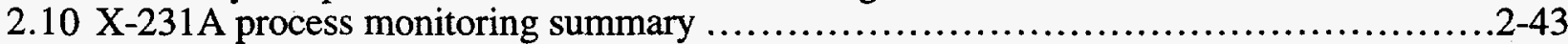

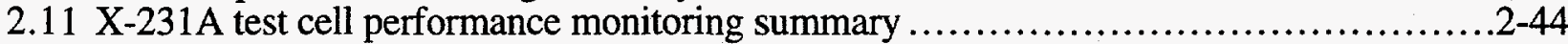

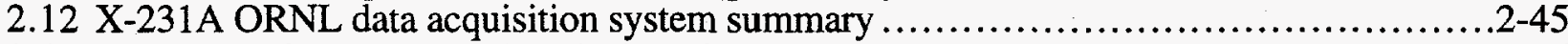

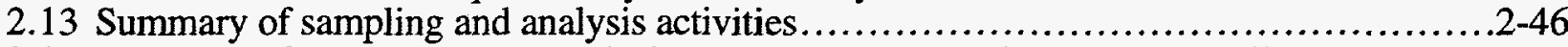

2.14 Summary of target analytes, analysis methods, and detection limits for soil samples ......2-47

2.15 Summary of target analytes, analysis methods, and detection limits for aqueous samples. 2-48

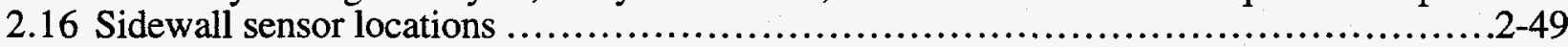

2.17 Helium tracer tests conducted in test cells A and B during fall 1996....................2-51

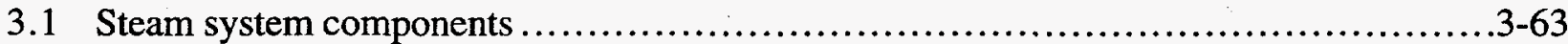

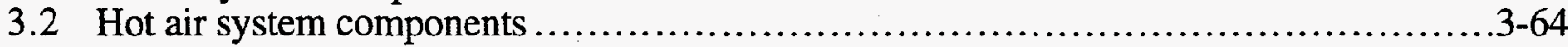

4.1 TCE degradation during batch test using iron metal collected from the fracture after emplacement as compared to the unused iron used to create the fracture ..................4-35

4.2 Ground water characteristics beneath the reactive fracture cells as compared to

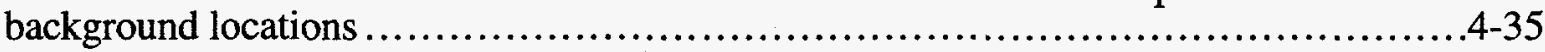

4.3 TCE degradation in the permanganate fracture and the reactivity of the enveloping zone..4-36

5.1 Features and relative merits of individual technologies tested at the X-231A site .......... 5-5

5.2 Implementation issues and concerns that need resolution to support full-scale application at PORTS .................................................................

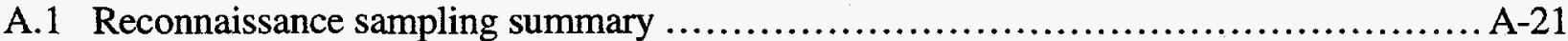

A.2 VOC and TOC concentrations in soil with depth from reconnaissance sampling, May 1996

A.3 Metals concentrations in soil with depth from reconnaissance sampling, May 1996;

PORTS laboratory analyses..................................................... A-24

A.4 Other parameters from reconnaissance sampling, May 1996; PORTS laboratory analyses

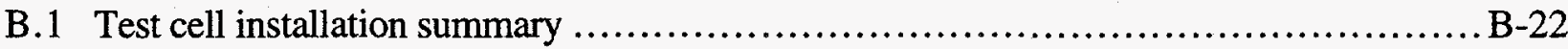

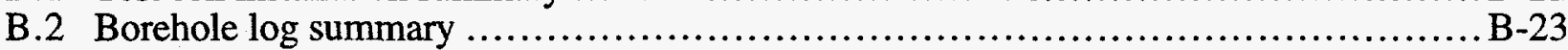

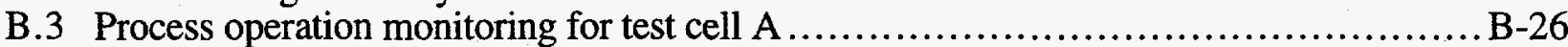

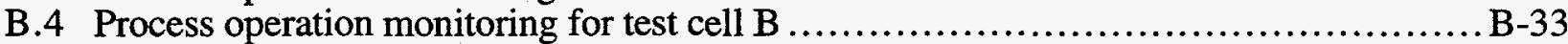

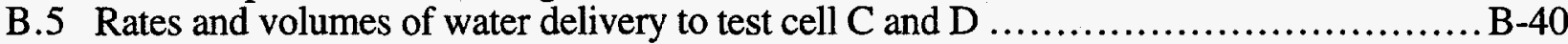




\section{LIST OF TABLES cont.}

C.1 Physical/chemical characteristics with depth as observed in a background borehole adjacent to the test cells (August 1996). ..C-4

C.2 Selected metal content with depth as observed in water extracts made from soil collected from a background borehole adjacent to the test cells (August 1996).........C-4

C.3 TDR measurements in the background monitoring location ( $\%$ moisture) ................ -5

C. 4 VOC concentrations in soil with depth as observed in a background borehole adjacent to the test cells, field laboratory analysis (August 1996) .............................

C.5 Test cell A physical/chemical characteristics with depth as observed shortly after establishment and before process operation was initiated (August 1996) ...................

C.6 Test cell B physical/chemical characteristics with depth as observed shortly after establishment and before process operation was initiated (August 1996) ...................8

C.7 Test cell C physical/chemical characteristics with depth as observed shortly after establishment and before process operation was initiated (August 1996) ..................9

C.8 Test cell D physical/chemical characteristics with depth as observed shortly after establishment and before process operation was initiated (August 1996) ................. C-10

C.9 Physical/chemical characteristics by depth from selected boreholes as determined by laboratory analysis at Colorado School of Mines (August 1996).................... C-11

C. 10 Selected metal content with depth as observed in water extracts made from soil samples collected from test cells A and B (August 1996) ..................... 12

C. 11 Selected metal content with depth as observed in water extracts made from soil samples collected from test cell C (August 1996) ............................... 12

C.12 Selected metal content with depth as observed in water extracts made from soil samples collected from test cell D (August 1996) ............................ C-14

C.13 Metal content in soil with depth from selected boreholes, PORTS laboratory

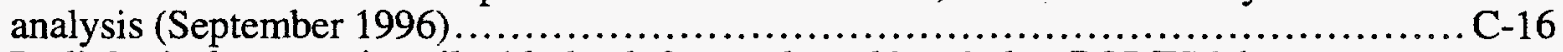

C.14 Radiological content in soil with depth from selected boreholes, PORTS laboratory

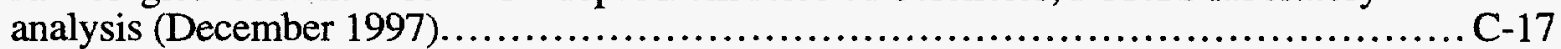

C.15 Microbiological characteristics with depth within the test cells shortly after fracture installation (August 1996) ..............................................

C.16 VOC concentrations in soil with depth within test cell A shortly after fracture installation (August 1996).................................................. 18

C.17 VOC concentrations in soil with depth within test cell B shortly after fracture installation (August 1996)...

C.18 VOC concentrations in soil with depth within test cell $\mathrm{C}$ shortly after fracture

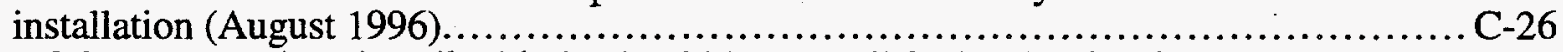

C. 19 VOC concentrations in soil with depth within test cell D shortly after fracture

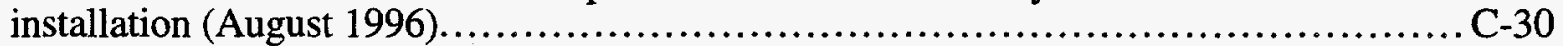

C.20 In situ Eh measurements at background location (in $\mathrm{mV}$ ) ............................. C-34

C.21 Wiping thermocouple measurements at background location $\left({ }^{\circ} \mathrm{C}\right) \ldots \ldots \ldots \ldots \ldots \ldots \ldots \ldots . .34$

C. 22 VOC concentrations with depth from selected boreholes in test cell A shortly after fracture installation. PORTS laboratory analysis using a soil sample preserved in methanol

C. 23 VOC concentrations with depth from selected boreholes in test cell A shortly after fracture installation. PORTS laboratory analysis using a standard EPA soil analysis method

C. 24 VOC concentrations with depth from selected boreholes in test cell $\mathrm{B}$ shortly after fracture installation. PORTS laboratory analysis using a soil sample preserved in methanol 


\section{LIST OF TABLES cont.}

Page

C. 25 VOC concentrations with depth from selected boreholes in test cell B shortly after fracture installation. PORTS laboratory analysis using a standard EPA soil analysis method

C.26 VOC concentrations with depth from selected boreholes in test cell C shortly after fracture installation. PORTS laboratory analysis using a soil sample preserved in methanol

C. 27 VOC concentrations with depth from selected boreholes in test cell C shortly after fracture installation. PORTS laboratory analysis using a standard EPA soil analysis method

C. 28 VOC concentrations with depth from selected boreholes in test cell D shortly after fracture installation. PORTS laboratory analysis using a soil sample preserved in methanol

C.29 VOC concentrations with depth from selected boreholes in test cell D shortly after fracture installation. PORTS laboratory analysis using a standard EPA soil analysis method

D.1 Test cell A, physical/chemical characteristics with depth as observed in the field following treatment (December 9, 1996)

D.2 Test cell B, physical/chemical characteristics with depth as observed in the field following treatment (December 10-11, 1996)

D.3 VOC concentrations in soil with depth within test cell A following treatment (December 1996)

D.4 VOC concentrations in soil with depth within test cell B following treatment (December 1996)

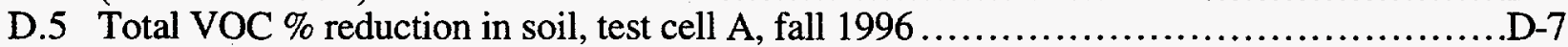

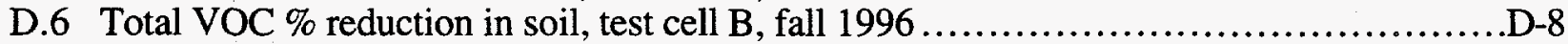

D.7 Test cell A, off-gas monitoring at A4 (4 ft fracture) ......................................

D.8 Test cell A, off-gas monitoring at A12 (12 ft fracture) ............................... D-11

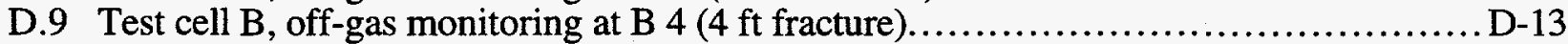

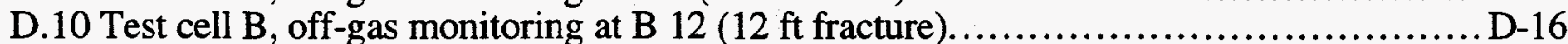

D.11 Test cell A, A4 (4 ft fracture) off-gas GC results .................................... D-19

D.12 Test cell A, A12 (12 ft fracture) off-gas GC results .............................. D-20

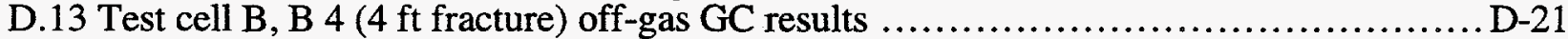

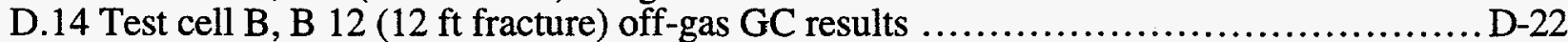

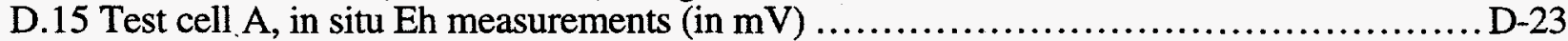

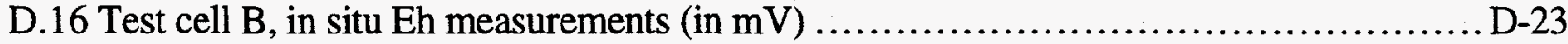

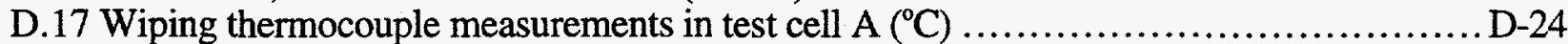

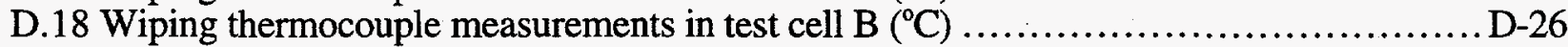

D.19 TDR measurements in test cell A monitoring location (\% moisture) .................... D-28

D.20 TDR measurements in test cell B monitoring location (\% moisture) ...................... D-29

D.21 Helium tracer test, injection in fracture B-8, test cell B, October 27, 1996 ................. D-30

D.22 Helium tracer test, injection in fracture B-8, test cell B, October 28, 1996 .................. D-32

D.23 Helium tracer test, injection in soil mini-piezometer NW-2, test cell A, November 22,1996

D.24 Helium tracer test, injection in B-6 fracture at high flow rate, test cell B, November 23, 1996 .

D.25 Helium tracer test, injection in soil mini-piezometer BN-1, test cell B,

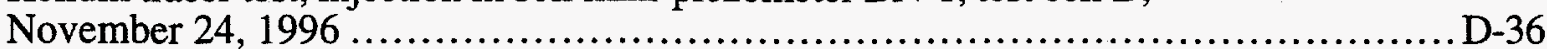

D.26 Helium tracer test, injection in fracture B-6, test cell B, December 9, $1996 \ldots \ldots \ldots \ldots \ldots$. D-37 


\section{LIST OF TABLES cont.}

D.27 Helium tracer test, injection in fracture B-8, test cell B, December 9, 1996............. D-38

D.28 Helium tracer test, injection in fracture A-8, test cell A, December 12,1996........... D-39

E.1 Test cell $\mathrm{C}$ physical/chemical characteristics with depth as observed in the field at $\sim 3,10$, and 15 months after fracture emplacement...................................

E.2 Test cell D physical/chemical characteristics with depth as observed in the field at $\sim 3,10$, and 15 months after fracture emplacement.................................

E.3 Selected metal content with depth as observed in sample extracts made from soil samples collected from Test Cell $\mathrm{C}$, field laboratory analysis ..........................

E.4 Selected metal content with depth as observed in sample extracts made from soil samples collected from Test Cell $\mathrm{D}$, field laboratory analysis ............................

E.5 VOC concentrations in soil with depth within test cell $\mathrm{C}$ following treatment (December $1996 /$ July 1997$)$.......................................................

E.6 VOC concentrations in soil with depth within test cell D following treatment (December 1996/July 1997) ..........................................................

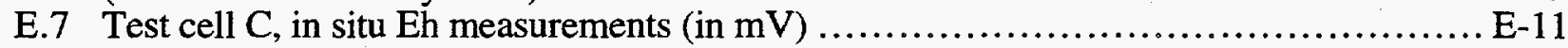

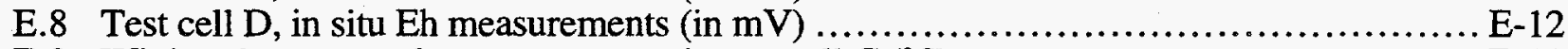

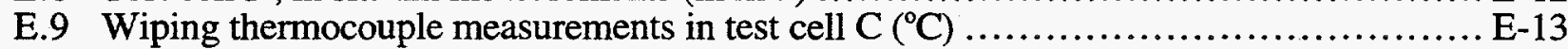

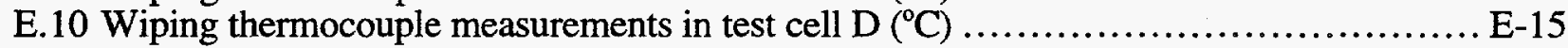

E.11 TDR measurements in test cell $\mathrm{C}$ monitoring locations ( $\%$ moisture) .................. E-17

E.12 TDR measurements in test cell D monitoring locations ( $\%$ moisture) .................. E-17

F.1 VOC concentrations in background monitoring locations, field laboratory analysis.........F-5

F.2 VOC concentrations in test cell A monitoring locations, field laboratory analysis ............F-7

F.3 VOC concentrations in test cell B monitoring locations, field laboratory analysis ...........F-8

F.4 VOC concentrations in test cell $C$ monitoring locations, field laboratory analysis ............F-9

F.5 VOC concentrations in test cell D monitoring locations, field laboratory analysis ......... F-10

F.6 VOC concentrations in background monitoring locations, PORTS laboratory analysis... F-11

F.7 VOC concentrations in test cell A, B, C and D monitoring locations, PORTS

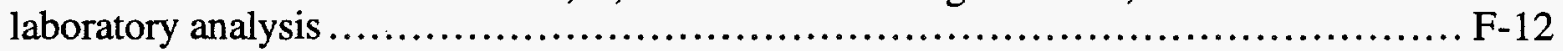

F.8 Inorganics concentrations in background monitoring locations, field laboratory analysis F-13

F.9 Inorganics concentrations in test cell A monitoring locations, field laboratory analysis... F-15

F.10 Inorganics concentrations in test cell B monitoring locations, field laboratory analysis... F-16

F.11 Inorganics concentrations in test cell $\mathrm{C}$ monitoring locations, field laboratory analysis... F-17

F.12 Inorganics concentrations in test cell D monitoring locations, field laboratory analysis... F-18

F.13 TOC, TSS, TDS, and inorganics concentration in background locations, ORNL laboratory analysis

F.14 TOC, TSS, TDS, and inorganics concentration in test cell A locations, ORNL

F.15 TOC, TSS, TDS, and inorganics concentration in test cell B locations, ORNL

F.16 TOC, TSS, TDS, and inorganics concentration in test cell $\mathrm{C}$ locations, ORNL

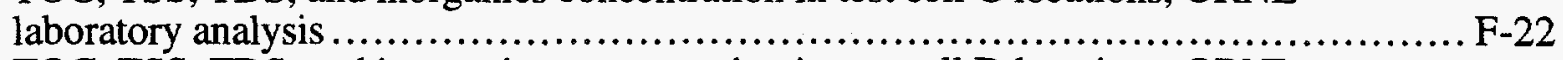

F.17 TOC, TSS, TDS, and inorganics concentration in test cell D locations, ORNL laboratory analysis

F.18 Ground water quality parameters in background monitoring locations.................... F-24

F.19 Ground water quality parameters in test cell A monitoring locations .................. F-26

F.20 Ground water quality parameters in test cell B monitoring locations . ................ F-27

F.21 Ground water quality parameters in test cell $\mathrm{C}$ monitoring locations .................. F-28 


\section{LIST OF TABLES cont.}

F.22 Ground water quality parameters in test cell D monitoring locations .................... F-29

F.23 Water levels measured in all monitoring locations, by date $\ldots \ldots \ldots \ldots \ldots \ldots \ldots \ldots \ldots \ldots$ F-30

G.1 Characteristics of the iron metal fracture zone in December $1996 \ldots \ldots \ldots \ldots \ldots \ldots \ldots \ldots$. G-1

G.2 Characteristics of the iron metal fracture zone in July $1997 \ldots \ldots \ldots \ldots \ldots \ldots \ldots \ldots \ldots \ldots \ldots$. G-1

G.3 Degradation of DNAPL compounds in an iron metal fracture zone as measured

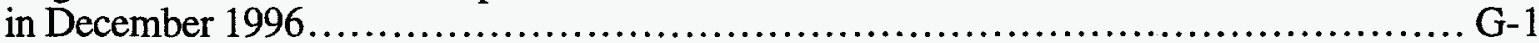

G.4 Degradation of DNAPL compounds in ground water 1 contacting an iron metal fracture zone with 24-48-hr reaction periods as measured in July 1997.

G.5 Degradation of DNAPL compounds in ground water 2 contacting an iron metal fracture zone with $24-48$-hr reaction periods as measured in July $1997 \ldots \ldots \ldots \ldots \ldots \ldots . . .6-3$

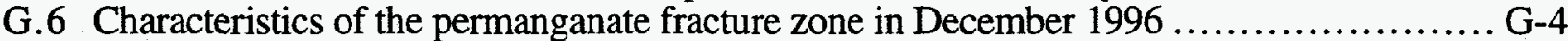

G.7 Characteristics of the permanganate fracture zone in July $1997 \ldots \ldots \ldots \ldots \ldots \ldots \ldots \ldots \ldots . . .6 \ldots$

G.8 Degradation of DNAPL compounds in the permanganate fracture zone as measured in December 1996.

G.9 Degradation of DNAPL compounds in the permanganate fracture zone as measured in July 1997 with ground water 1 and reaction times 1 and $2 \ldots \ldots \ldots \ldots \ldots . .6 .6$

G.10 Degradation of DNAPL compounds in the permanganate fracture zone as measured in July 1997 with ground water 2 and reaction times 1 and 2

H.1 Analytical results from the aqueous phase of a DNAPL sample collected from X231A-BGP3, PORTS laboratory analysis

H.2 Analytical results from the free phase of a DNAPL sample collected from X231A-BGP3, PORTS laboratory analysis

H.3 VOC concentrations in soil with depth from post-demonstration reconnaissance samples, December 1997

H.4 Radioactive materials in soil with depth from post-demonstration reconnaissance samples, PORTS laboratory analysis (December 1997). H-6 


\section{ACRONYMS AND ABBREVIATIONS}

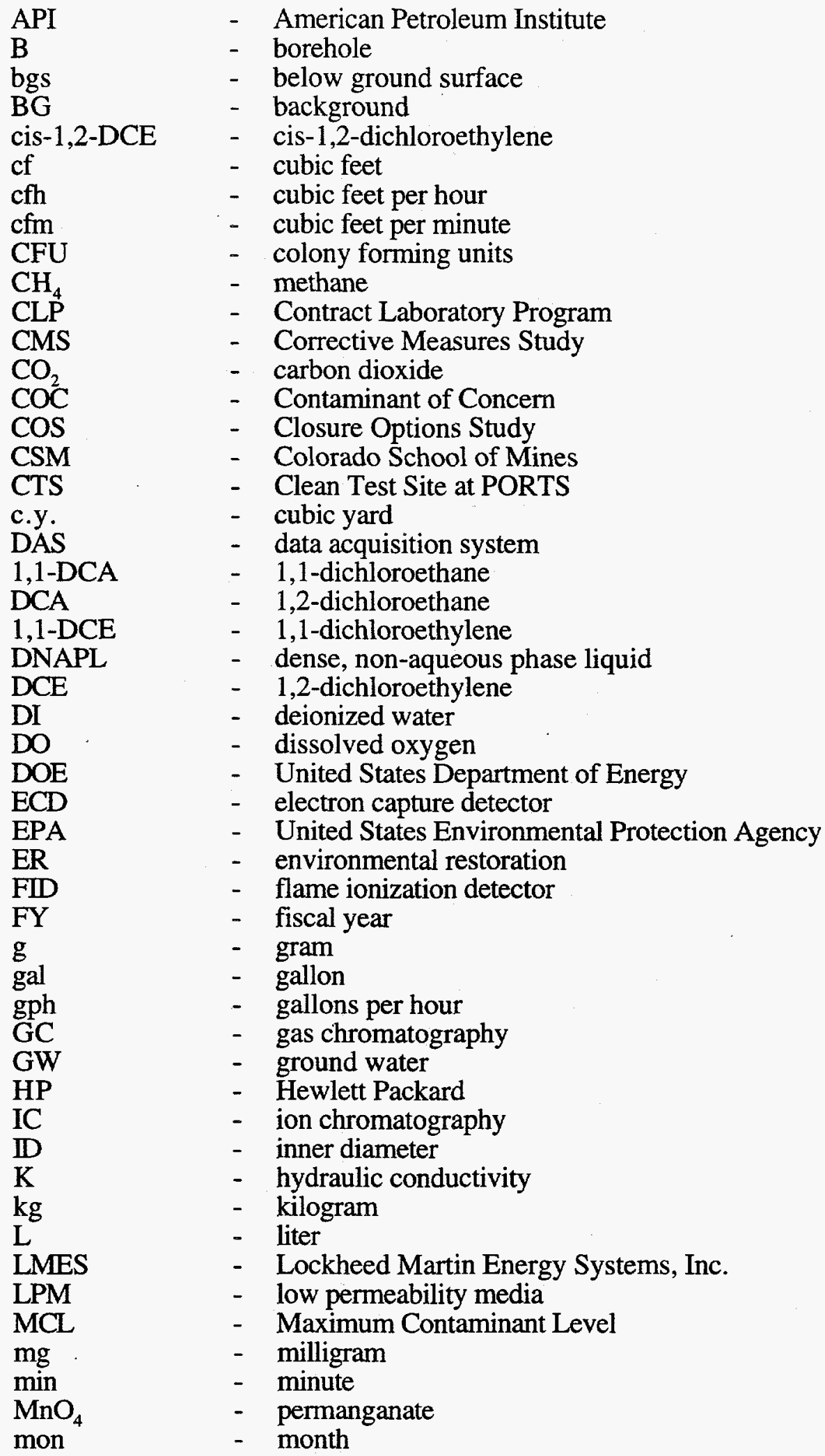




\section{ACRONYMS AND ABBREVIATIONS cont.}

\begin{tabular}{|c|c|}
\hline MPN & - most probable number \\
\hline MS & - mass spectrometer \\
\hline MW & - monitoring well \\
\hline NA & - not analyzed \\
\hline $\mathrm{NaBr}$ & - sodium bromide \\
\hline NAPL & - non-aqueous phase liquid \\
\hline nd, ND & - not detected \\
\hline $\mathrm{nm}$ & - nanometer \\
\hline $\mathrm{NE}$ & - Northeast \\
\hline $\mathrm{NO}_{3}$ & - nitrate \\
\hline NOM & - natural organic matter \\
\hline NPDES & - National Pollutant Discharge Elimination System \\
\hline$O D$ & - outer diameter \\
\hline ORNL & - Oak Ridge National Laboratory \\
\hline OST & - Office of Science and Technology \\
\hline PCE & - perchloroethylene \\
\hline $\mathrm{ppm}$ & - parts per million \\
\hline $\mathrm{ppm}_{\mathrm{V}}$ & - parts per million volumetric \\
\hline psi & - pounds per square inch \\
\hline QA/QC & - Quality Assurance/Quality Control \\
\hline $\mathrm{PC}$ & - personal computer \\
\hline PCE & - perchloroethylene (tetrachloroethylene) \\
\hline PID & - photoionization detector \\
\hline PLFA & - phospholipid fatty acid \\
\hline PORTS & - Portsmouth Gaseous Diffusion Plant \\
\hline PVC & - polyvinyl chloride \\
\hline RCRA & - Resource Conservation and Recovery Act \\
\hline RFI & - RCRA Facilities Investigation \\
\hline RPD & - relative percent difference \\
\hline RPM & - revolutions per minute \\
\hline $\mathrm{rxn}$ & - reaction \\
\hline $\mathrm{SO}_{4}$ & sulfate \\
\hline SVE & - soil vapor extraction \\
\hline SW & - Southwest \\
\hline SWMU & - solid waste management unit \\
\hline TCA & - 1,1,1-trichloroethane \\
\hline TCE & - trichloroethylene \\
\hline TCLP & - Toxic Characteristic Leaching Procedure \\
\hline TDR & - time domain reflectometry \\
\hline TDS & - total dissolved solids \\
\hline TOC & - total organic carbon \\
\hline trans-1,2-DCE & - trans-1,2-dichloroethylene \\
\hline TSS & - total suspended solids \\
\hline TVS & - total volatile solids \\
\hline VOA & - volatile organic analyses \\
\hline VOC & - volatile organic compound \\
\hline v.p. & - vapor pressure \\
\hline WC & - water content \\
\hline
\end{tabular}




\section{PREFACE}

Chlorocarbons like trichloroethylene (TCE) are ubiquitous contaminants of concern (COCs) at U.S. Department of Energy (DOE) facilities and industrial sites across the United States and abroad. These COCs are present in source areas or in soil and ground water plumes as dense nonaqueous phase liquids (DNAPLs) and as dissolved or sorbed phase constituents. Moreover, there may also be co-contaminants such as heavy metals (e.g., chromium) and radionuclides (e.g., uranium). When DNAPL compounds are present in low permeability media (LPM) like silt and clay layers or deposits, there are major challenges for assessment of their behavior and implementation of effective in situ remediation technologies.

A research and development project was initiated by the DOE Office of Science and Technology (OST) and the DOE Portsmouth Gaseous Diffusion Plant (PORTS) in collaboration with the American Petroleum Institute (API) in 1993. In this project, in situ remediation technologies were to be evaluated for both enhanced mass removal and in place destruction of DNAPL compounds in LPM. This effort was focused on chlorinated solvents (e.g., TCE, perchloroethylene) in the vadose and saturated zones of LPM. At the onset, the project was initiated as an interdisciplinary and multi-institutional effort and it has included participants from Oak Ridge National Laboratory (ORNL), University of Cincinnati, Oregon Graduate Institute, Colorado School of Mines, FRx Inc., Hayward Baker Environmental Inc., as well as others. The overall project has included a series of related tasks: (1) preparation of 16 DNAPL focus papers and reports, (2) a field pilot test of hydraulic fracturing for dewatering, (3) a field test of enhanced air flushing for NAPL removal, (4) a field test of hydraulic fractures for hydraulic and pneumatic control and hot fluid injection, (5) a field comparison of multiple point injection and permeation dispersal of different reactants, (6) a field-scale demonstration of soil fracturing for thermally enhanced mass recovery and in situ degradation by reactive barriers, and (7) numerical and experimental analyses of the mobility of residual NAPLs versus varying degrees of remediation. The in situ remediation technologies selected for demonstration evolved to include subsurface manipulation through soil fracturing and lance permeation coupled with enhanced mass transfer or in place destruction. The field testing activities have occurred at three locations: Sarnia, Canada; Aber Road outside Cincinnati, Ohio; and the DOE PORTS site near Piketon, Ohio.

This report describes a field demonstration that occurred during August 1996 through December 1997 at the X-231A land treatment site at the DOE Portsmouth Gaseous Diffusion Plant (PORTS) near Piketon, Ohio. Other facets of the project have been reported elsewhere (e.g., API 1995, DOE 1996, Freeze and McKay 1997, Pfiffner et al. 1997) with a final overall project report to be completed and published during September 1998. The X-231A demonstration described in this document was focused on soil fracturing of LPM to enable thermally enhanced mass recovery by soil vapor extraction as well as to emplace reactive horizontal barriers for in place destruction. The PORTS plant has several Resource Conservation and Recovery Act (RCRA) regulated units where assessment and remediation of DNAPL compounds in LPM is required as part of the RCRA Corrective Measures and Corrective Actions program and the DOE accelerated clean-up plan. Previous work at PORTS had included a major demonstration of in situ mixed region vapor stripping that supported full-scale application of the technology for closure of the X-231B unit (e.g., Davenport et al. 1994, Siegrist et al. 1995). The adjacent X-231A site was chosen as a location to carry out another in situ remediation technology demonstration jointly funded by DOE OST and the PORTS environmental restoration program. 


\section{ACKNOWLEDGMENTS}

This report on the X-231A Demonstration at the DOE Portsmouth Gaseous Diffusion Plant is based on the combined efforts of scientific and engineering staff at Oak Ridge National Laboratory and FRx, Inc. in collaboration with the Colorado School of Mines and others. Project sponsorship has been provided through the Subsurface Contaminant Focus Area of the DOE Office of Science \& Technology along with the DOE Office of Environmental Restoration at the DOE Portsmouth Gaseous Diffusion Plant.

The following individuals are specifically recognized for their valuable contributions to the $\mathrm{X}-231 \mathrm{~A}$ demonstration (alphabetical order):

\begin{tabular}{lcl} 
Skip Chamberlain & - & DOE Office of Science \& Technology \\
Tom Early & - & Subsurface Contaminant Focus Area \\
Johnny Moore & - & DOE Oak Ridge Operations Office \\
Elizabeth Philips & - & Subsurface Contaminant Focus Area, Product Line Manager \\
John Sheppard & - & DOE Site Office, Portsmouth Gaseous Diffusion Plant \\
Jim Wright & - & DOE Site Office, Savannah River Site; Subsurface Contaminant \\
& & Focus Area \\
Phil Borris & - & LMES, Health Physics \\
Paula Burleson & - & LMES, Environment Safety and Health \\
John Callan & - & LMES, Planning and Integration \\
Traci Case & - & Colorado School of Mines, Environmental Science \& Engineering \\
Phil Cluxton & - & FRx, Inc. \\
Jim Ervin & - & LMES, Construction Engineering \\
Baohua Gu & - & ORNL Environmental Sciences Division \\
Mark Kemper & - & FRx, Inc. \\
Mark Mumby & - & ORNL Environmental Technology Section \\
Tony Palumbo & - & ORNL Environmental Sciences Division \\
Susan Pfiffner & - & Univ. Tennessee, Center for Environmental Biotechnology \\
Doug Pickering & - & ORNL Environmental Technology Section \\
Mike Roulier & - & US EPA, ORD \\
Kevin Strohmeier & - & FRx, Inc. \\
John Taphorn & - & LMUS, Analytical Laboratory \\
Mike Urynowicz & - & Colorado School of Mines, Environmental Science \& Engineering \\
Olivia West & - & ORNL Environmental Sciences Division \\
John Wilson & - & ORNL Environmental Technology Section \\
\hline
\end{tabular}




\section{EXECUTIVE SUMMARY}

In December 1997, field activities were completed on a technology demonstration at the U.S. Department of Energy (DOE) Portsmouth Gaseous Diffusion Plant (PORTS), X-231A Oil Biodegradation Plot. The PORTS plant has several Resource Conservation and Recovery Act (RCRA) regulated units where assessment and remediation of DNAPL compounds in low permeability media (LPM) is required as part of the RCRA Corrective Measures and Corrective Actions program. These regulated units are also included in the PORTS accelerated clean-up plan. This technology demonstration was jointly funded by the PORTS Environmental Restoration Program and by the DOE Office of Science and Technology (OST) and it was focused on soil fracturing to increase mass recovery by thermally enhanced soil vapor extraction as well as to achieve in place destruction by emplacement of reactive horizontal barriers.

During May through August 1996, planning activities and initial site work for the demonstration were completed. Project planning was based on information gained during equipment field testing of in situ hot air and steam generators at an uncontaminated site near Cincinnati as well as soil fracturing at the PORTS Clean Test Site in May 1996. The active demonstration phase began in August 1996 when four primary test cells (A-D) were established using hydraulic fracturing methods. Each of the test cells encompassed a subsurface region of $\sim 30 \mathrm{ft}$. in diameter and up to $18 \mathrm{ft}$. below ground surface (bgs) and each was composed of a set of stacked horizontal fractures. Test cell A consisted of sand-propped fractures for injection of steam from a down-hole steam generator and vapor extraction via overlying and underlying fractures. Test cell B consisted of sand-propped fractures for injection of hot air from a down-hole hot air generator with vapor extraction via overlying and underlying fractures. Test cell $\mathrm{C}$ contained iron-metal propped fractures to create a set of horizontal permeable barriers for interception and in situ destruction by reductive dechlorination. Test cell $\mathrm{D}$ was composed of fractures that were emplaced and propped with a new permanganate particle grout. These stacked horizontal fractures were used to create a set of permeable reactive barriers that provided interception and in situ destruction by oxidation of organic compounds.

Pre-operational site characterization revealed that concentrations of trichloroethylene (TCE) and related hydrocarbons were highly variable within the test site with concentrations ranging from non-detectable levels to $\sim 100 \mathrm{mg} / \mathrm{kg}$. Free product was encountered in one of the ground water piezometers adjacent to test cell $\mathrm{B}$. In total, over 600 samples were collected to establish baseline contamination levels and to define biogeochemical properties including soil water content, Eh, $\mathrm{pH}$, grain size distribution, mineralogy, organic carbon content, soil cation and anion contents, and microbial populations. The test cells and the test area as a whole were also instrumented with various samplers and monitoring devices to enable periodic measurement of selected subsurface properties.

After final pre-operational process and monitoring system checks, active operation of test cell A and test cell B was initiated on October 19, 1996. To establish baseline ambient air flushing characteristics, the initial operation was ambient air injected into a sand-propped fracture at 8-ft. bgs with active vapor extraction occurring via sand-propped fractures at 4- and 12-ft. bgs. The test cell was operated in this manner for $\sim 15$ days. During this baseline period the cells were monitored by flow meters, temperature and pressure sensors, and an on-line volatile organic compound (VOC) flame ionization detector (FID). Following the baseline operating period, test cells $\mathrm{A}$ and $\mathrm{B}$ were converted to hot fluid injection with down-hole steam generation/injection (test cell A) or down-hole hot air generation/injection (test cell B) and operated for $\sim 60$ days. Rates of vapor extraction averaged $\sim 4 \mathrm{cfm}$ from the shallow fractures at 4 - $\mathrm{ft}$ bgs and $\sim 1 \mathrm{cfm}$ or less from the deeper fractures at 12 -ft bgs. Off-gas VOC concentrations were in the 3000 to 5000 ppmv range from the shallow fractures and 20,000 to $>100,000 \mathrm{ppmv}$ from the deeper fractures. Additional preliminary analysis of the off-gas from the deep fractures indicated up to $17 \%$ methane and $>800$ 
ppmv of TCE at test cell B. Rates of removal of volatile constituents gradually declined during ambient air passive inlet. The rate of removal increased when hot fluid injection began and then was followed by a gradual decline.

During the week of December 9, 1996, the X-231A field demonstration site was sampled and monitored and then placed in a passive mode for the winter. In all test cells and across the site, post-treatment subsurface measurements were made. Continuous cores collected across the emplaced fracture zones in each cell were carefully examined and dissected with analyses made for $\mathrm{Eh}, \mathrm{pH}$, and water content. Degradation tests were also completed with soil cores collected from the reactive fracture barriers in test cells $C$ and D. Samples of the reactive fractures and of the soil within a 30-cm thick zone above or below the fractures were employed in batch tests to evaluate TCE degradation potential. Results indicated highly reactive zones were present in these two cells after 3 months of emplacement. In the permanganate barrier cell the TCE degradation efficiencies were $>99 \%$ after $24-\mathrm{hr}$ of reaction throughout a $10-\mathrm{cm}$ thick soil zone, while in the iron metal barrier cell the efficiencies were only $-35 \%$ and only within the iron-filled fracture itself. Assuming pseudo first-order kinetics with respect to TCE concentration and also normalizing the degradation rates based on a solid:solution ratio representative of the reactive solids in a fracture, these degradation rates observed were equivalent to half-lives in the range of $40 \mathrm{~min}$ for the iron.

During July to early September 1997, further process operation and performance evaluation of the two air flushing cells and two in situ destruction cells were carried out. In test cells A and B efforts were made to enhance subsurface heating by elevating input temperatures and flow rates. This proved effective in the hot air cell (B) as subsurface temperatures were elevated to nearly $60^{\circ} \mathrm{C}$. The down-hole steam generator was operated continuously for nearly four weeks producing maximum subsurface temperatures of $100^{\circ} \mathrm{C}$ in the vicinity of the deep fracture at 8-ft bgs. To assess more active operation of test cells $\mathrm{C}$ and $\mathrm{D}$, tapwater with a conservative tracer was injected into the shallow sand-filled fractures in each test cell for $\sim 45$ days. Infiltration and percolation of the tapwater and tracer downward through the underlying reactive-fracture zone was evaluated. Additionally, a second round of continuous coring and reactive fracture examination of test cells $\mathrm{C}$ and D corroborated the findings of the December 1996 work. The reactive barrier in test cell C, composed of iron metal particles, was still reactive at approximately the same level of $35 \%$ degradation (equivalent to $\sim 1 \mathrm{~g} \mathrm{TCE}$ per $\mathrm{kg}$ of iron particles) after $24-$ to 48 -hr of contact. Only the iron metal itself, not the surrounding soil, was reactive. The permanganate grout barrier of test cell $\mathrm{D}$ exhibited greater degradation over a larger zone than earlier tests. Degradation on the order of 3 $\mathrm{g} \mathrm{TCE} / \mathrm{kg}$ of permanganate-effected soil occurred over a 2 -hr contact period.

In early September 1997, the X-231A demonstration field activities were completed. The test site was decommissioned and restored. Selected monitoring devices were left in place to facilitate future data collection as necessary and appropriate. A final set of continuous cores was collected from test cells C and D in December 1997. Examination of the reactive fractures corroborated and extended the findings of the December 1996 and July 1997 work. In the iron-filled fractures the redox potential remained highly reducing with little effect on the surrounding soil. Kinetic tests with the iron metal and different concentrations of TCE indicated reductive dechlorination was still viable. However there were indications that the degradation rates were lower than previously observed and there was some concentration dependency related to the initial TCE concentration. In the permanganate fracture zones, there were still highly oxidizing conditions present after 15 mon of emplacement and high concentrations of permanganate were still present in the subsurface in zones that were nearly $90-\mathrm{cm}$ thick.

The hot air flushing and permanganate grout barriers appear most promising for further focused demonstration and implementation. A proof-of-principal document that summarizes the applicability of permanganate grout barriers for vadose zone VOC removal at PORTS was issued in April 1998. 


\section{INTRODUCTION}

\subsection{BACKGROUND}

Chlorocarbons like trichloroethylene (TCE) are common contaminants of concern (COCs) at U. S . Department of Energy (DOE) facilities and industrial sites across the United States and abroad (Huling and Weaver 1991, U.S.EPA 1992, MacDonald and Kavanaugh 1994). These COCs are present in source areas and in soil and ground water plumes as dissolved or sorbed phase constituents as well as dense non-aqueous phase liquids (DNAPLs). These DNAPL compounds can be released to the environment through a variety of means including leaks in storage tanks and transfer lines, spills during transportation, and land treatment of wastes. In some situations there may also be co-contaminants such as heavy metals (e.g., chromium) and radionuclides (e.g., uranium). When DNAPL compounds are present in low permeability media (LPM) like silt and clay layers or deposits, there are major challenges with assessment of their behavior and implementation of effective in situ remediation technologies.

In the DOE complex there are significant problems with DNAPL compounds in LPM (e.g., the Portsmouth, Paducah, Rocky Flats, and Savannah River sites). Despite the overall low permeability of silt and clay deposits (e.g., Ksat $<10^{-5} \mathrm{~cm} / \mathrm{s}$ ), DNAPL compounds can contaminate them by preferentially moving into and through naturally occurring pore and fracture systems. Within LPM, the DNAPL compounds partition between the nonaqueous, gas, aqueous, and sorbed phases within the pores and fractures and also diffuse into the fine-grained matrix of the deposit (Fig. 1.1). They may also form isolated "blobs" and "ganglia" known as residuals, as well as connected DNAPL pools. As a result of this contamination process, removal of contaminants from an LPM deposit and/or delivery of treatment agents into and throughout the deposit are often hindered, making rapid and extensive remediation difficult. In the vadose zone, DNAPL compounds can continually volatilize into the soil air or leach into percolating water. In the saturated zone, DNAPLs can slowly dissolve and contribute contaminants into flowing ground water. The rate and extent of migration in LPM of various contaminants remains uncertain, yet is critical to the design of in situ treatment technologies and risk management.

In situ remediation technology development has largely overlooked treatment of DNAPLs in LPM. Poor accessibility to the contaminants and the difficulty in delivery of treatment reagents have rendered conventional bioremediation, vapor extraction, and pump-and-treat ineffective for this type of media. As a result, effective in situ treatment methods for DNAPL compounds in finegrained deposits was recently one of the top-ranked environmental restoration needs across the DOE Complex. Similarly, within the petroleum industry, nearly $40 \%$ of the underground storage tanks in the world are located on clay soils and remediation of contaminants from leaking underground tanks in these settings has been a major challenge.

DOE was confronting these problems at several sites across the United States including the Portsmouth Gaseous Diffusion Plant (PORTS) near Piketon, Ohio. In attempting to implement effective solutions, PORTS and other sites were supporting technology development activities and these were enabling some advancements (e.g., West et al. 1995; Siegrist et al. 1995a; Gierke et al. 1995). In addition, there were some research and demonstration efforts ongoing at the DOE national level through funding from the Office of Science and Technology (OST). There was however, no research and development project specifically targeted at LPM.

As a result of the need for solutions and the gap in the current knowledge and technology base, a project was initiated by the DOE OST and the DOE PORTS site in collaboration with the American Petroleum Institute (API) in 1993. (API 1995; DOE 1996). In this project, in situ remediation technologies are being evaluated for both enhanced mass removal and in place destruction of DNAPL compounds in LPM, specifically chlorinated solvents (e.g., TCE, perchloroethylene 
[PCE]) in the vadose and saturated zones of LPM. The overall project has included a series of related tasks including: (1) preparation of 16 DNAPL focus papers and reports, (2) a field pilot test of hydraulic fracturing for dewatering, (3) a field test of enhanced air flushing for NAPL removal, (4) a field test of hydraulic fractures for hydraulic and pneumatic control and hot fluid injection, (5) a field comparison of multiple point injection and permeation dispersal of different reactants, (6) a field-scale demonstration of soil fracturing for thermally enhanced mass recovery and reactive barrier degradation, and (7) numerical and experimental analyses of the mobility of residual NAPLs versus varying degrees of remediation. The field testing activities have occurred at three locations: Sarnia, Canada; Aber Road outside Cincinnati, Ohio; and the DOE PORTS site.

This report describes a field demonstration that was completed at the X-231A land treatment site at PORTS. Other facets of the project have been reported elsewhere (e.g., API 1995; DOE 1996; Freeze and McKay 1997; Pfiffner et al. 1997) with a final overall project report to be completed and published during September 1998. The PORTS plant has several Resource Conservation and Recovery Act (RCRA) regulated units where assessment and remediation of DNAPL compounds in LPM is required as part of the RCRA Corrective Measures and Corrective Actions program and the DOE accelerated clean-up plan. Previous work at the site had included a major demonstration of in situ mixed region vapor stripping that supported full-scale application of the technology for closure of the X-231B unit (Davenport et al. 1994; West et al. 1995; Siegrist et al. 1995a; Gierke et al. 1995). The adjacent X-231A site was chosen as a location to carry out another in situ remediation technology demonstration with joint funding from DOE OST and the PORTS environmental restoration program. This demonstration was focused on soil fracturing of LPM to enable thermally enhanced mass recovery by soil vapor extraction as well as to achieve in place destruction by emplacement of reactive horizontal barriers.

\subsection{OBJECTIVES AND SCOPE}

The overall goal of the program of activities is to demonstrate robust and cost-effective technologies for in situ remediation of DNAPL compounds in LPM, including adaptations and enhancements of conventional technologies to achieve improved performance for DNAPLs in LPM (DOE 1996). The technologies sought should have potential for application at simple, small sites (e.g., gasoline underground storage tanks) as well as at complex, larger sites (e.g., DOE land treatment units). The technologies involved in the X-231A demonstration at PORTS utilized subsurface manipulation of the LPM through soil fracturing with thermally enhanced mass recovery or horizontal barrier in place destruction. To enable field evaluation of these approaches, a set of four test cells was established at the X-231A land treatment unit at the DOE PORTS plant in August 1996 and a series of demonstration field activities occurred through December 1997.

Each of the four X-231A test cells (A to D) was comprised of a set of stacked horizontal fractures within a subsurface region $\sim 30 \mathrm{ft}$. in diameter and up to $18 \mathrm{ft}$. below ground surface (bgs). Test cells $\mathrm{A}$ and $\mathrm{B}$ were designed for evaluation of down-hole hot fluid generation/injection and vapor phase mass recovery. Test cell A consisted of sand-propped fractures for injection of steam from a down-hole steam generator with vapor extraction via overlying and underlying sand-propped fractures. This cell was used for evaluation of steam enhanced air flushing and mass recovery. Test cell B consisted of sand-propped fractures for injection of hot air from a down-hole hot air generator with vapor extraction via overlying and underlying sand-propped fractures. This cell was used for evaluation of hot air enhanced air flushing and mass recovery. Test cells C and D were designed for evaluation of horizontal reactive barriers for in place destruction. Test cell $\mathrm{C}$ contained iron-metal propped fractures to create a set of horizontal permeable barriers for interception and in situ destruction by reductive dechlorination. Test cell D was composed of fractures that were emplaced and propped with a new permanganate particle grout. These stacked horizontal fractures were used to create a set of permeable reactive barriers that provides for interception and in situ destruction by oxidation. 
The principal objectives of the PORTS X-231A demonstration were to:

o Determine and compare the operational features of hydraulic fractures as an enabling technology for steam and hot air enhanced soil vapor extraction and mass recovery, in situ interception and reductive destruction by zero valent iron, and in situ interception and oxidative destruction by potassium permanganate;

o Determine the interaction of the delivered agents with the LPM matrix adjacent to the fracture and within the fractured zone and assess the beneficial modifications to the transport and/or reaction properties of the LPM deposit; and

o Determine the remediation efficiency achieved by each of the technology strategies.

The above objectives were accomplished through field activities and laboratory studies. The first phase of field activities was conducted in spring/summer of 1996 and included test site reconnaissance and down-hole equipment testing. The second phase of field activities was conducted during summer/fall 1996 when the test cells were established and active demonstration was accomplished. During summer/fall 1997 additional field tests were completed at the X-231A site prior to closing out the site. The final field activities were conducted in December 1997. The specific objectives and tasks of the different field activities are highlighted below:

\section{Spring/summer 1996}

o Conduct field evaluation and equipment development of hydraulic fracturing and hot fluid injection equipment at the Aber Road site near Cincinnati,

- Conduct equipment shakedown at the PORTS clean test site (CTS) prior to the X-231A demonstration to evaluate the feasibility of hydraulic fracturing at PORTS,

- Develop and test, under laboratory conditions, a carrier fluid formulation for delivery of reactive proppants during hydraulic fracturing, and

o Perform site reconnaissance and site selection for the X-231A demonstration.

\section{$\underline{\text { Summer/fall } 1996}$}

o Initiate test cell set-up and conduct pre-operational characterization of the X-231A site,

- Emplace stacked fractures propped with sand or reactive media in each of four test cells,

o Instrument the test site with a variety of sensors (pressure, soil moisture content, temperature, redox) for subsurface monitoring across the demonstration site,

- Conduct active operation of the hot fluid injection test cells A and B,

- Conduct passive operation of the horizontal reactive barrier test cells C and D,

- Perform concurrent monitoring and measurement of process operations and geochemical and physical properties across the demonstration site, and

o Place the test site in a standby mode until summer 1997.

\section{$\underline{\text { Summer/fall } 1997}$}

o Characterize the test site and the four test cells following $~ 10$ mon of passive operation,

- Evaluate subsurface heating as achieved by aggressive hot fluid injection (steam or hot air) via sand-propped fractures at test cells $A$ and $B$,

o Characterize the morphology, biogeochemistry, and destruction efficiency around the reactive fractures in test cells $C$ and $D$, and

o Demobilize equipment and instrumentation and close-out the X-231A demonstration site.

\section{Winter 1997}

o Characterize the test site and test cells following $~ 15$ mon of passive operation, and

- Perform site reconnaissance and site selection for implementation of horizontal reactive barriers at X-231A. 


\subsection{ORGANIZATION OF THE REPORT}

This report is organized in sections and related appendices. Section 2 provides a description of the materials and methods employed for all facets of the X-231A demonstration. Section 3 describes the results of the hot fluid injection and mass recovery testing. Section 4 discusses the results from the horizontal reactive fracture testing. Section 5 presents a discussion of the results of the demonstration including the factors affecting implementation of the technology at the PORTS site. Section 6 summarizes the conclusions derived from the X-231A work. Appendices to the report provide tabulations and graphs of the numerous data collected during the X-231A demonstration. 
Figure 1.1. Illustration of the remediation problem posed by DNAPL compounds in low permeability media.

\section{DNAPLS (PCE, TCE, DCE) Natural Fractures}

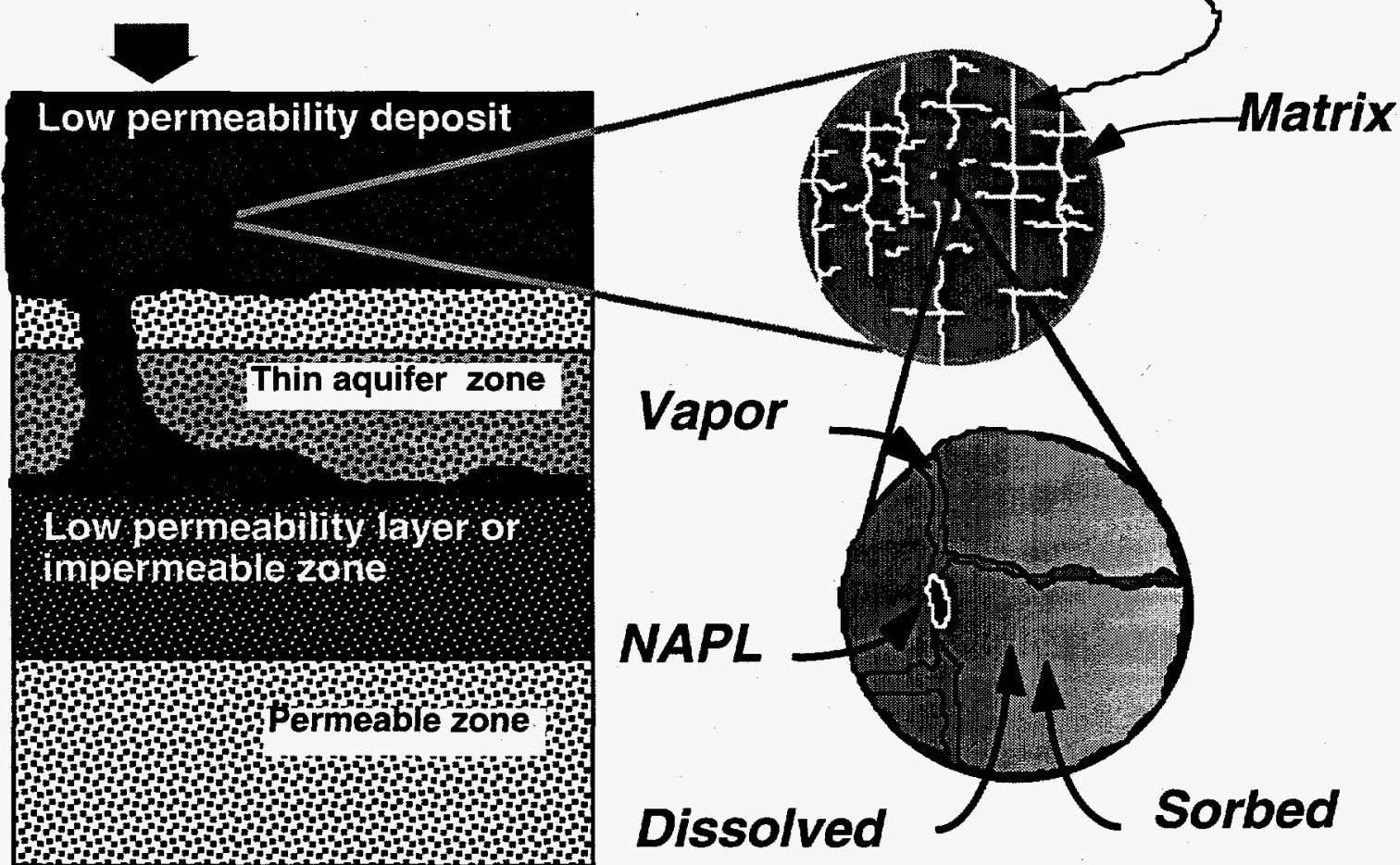




\section{MATERIALS AND METHODS}

This section describes the materials and methods employed during the X-231A demonstration. A description of the site is provided first followed by an overview of the demonstration activities. Then a detailed description of the methods employed is given.

\subsection{SITE BACKGROUND}

\subsubsection{Facility Description}

PORTS is a federal facility owned by DOE. The plant is operated by Lockheed Martin Utility Services under a contract with the United States Enrichment Corporation, a government owned corporation. Environmental restoration and waste management activities are managed and performed for DOE by Lockheed Martin Energy Systems (LMES). The 3,714-acre federal reservation lies in Pike County, Ohio, between the cities of Chillicothe and Portsmouth and $\sim 70$ miles south of Columbus, Ohio (Fig. 2.1).

The PORTS facility has been operating since 1954 and is used to enrich uranium for commercial nuclear reactors. The enrichment process uses molecular diffusion techniques to separate the ${ }^{235} \mathrm{U}$ isotope from the ${ }^{238} \mathrm{U}$ isotope. The PORTS facility consists of a complex cascade of compressors and converters through which gaseous uranium hexafluoride feed is processed. The plant has an extensive support complex that consists of machine shops, laboratories, utilities, and decontamination facilities. As a result of plant operations, PORTS generates a wide variety of wastes, including low-level radioactive wastes, spent solvents, polychlorinated biphenyl (PCB) contaminated oils, electroplating wastes, paint wastes, metal sludges, acids, and caustics. As a result of waste disposal practices many years ago that included land treatment by either surface land spreading or infiltration lagoons, several contaminated sites exist today. These are undergoing investigation and remediation as part of an active environmental restoration program in compliance with RCRA regulations.

\subsubsection{X-231A Site Description}

The X-231A unit is located in the southeastern portion of the PORTS site in Quadrant I (Fig 2.2) (DOE 1994a). The X-231A unit consists of an old waste oil biodegradation site. The unit, approximately $950-\mathrm{ft}$ by $225-\mathrm{ft}$ in area, was reportedly used for the treatment and disposal of waste oils and degreasing solvents, some containing uranium $\left({ }^{235} \mathrm{U}\right)$ and technetium $\left({ }^{99} \mathrm{Tc}\right)$. A similar land treatment site, the X-231B unit, is located nearby.

Soil sampling and installation of two piezometers was conducted at the X-231A unit in 1987 (ASI 1988). The soil above bedrock at the X-231A unit is composed of unconsolidated Quaternary age fluvial deposits (Table 2.1). These deposits consist of 5 to $25 \mathrm{ft}$ of lowpermeability clays and silts of the Minford member, which are underlain by a moderately permeable sand unit known as the Gallia member (Fig. 2.3 and 2.4). The Gallia consists of pebbles and gravel in a fine-grained silty-sand matrix and is -3 to $7 \mathrm{ft}$ thick at the PORTS site and surrounding area.

The bedrock underlying the Quaternary deposits is composed of Mississippian-age Sunbury shale and Berea sandstone and shale. The Sunbury is a very low permeability shale unit that underlies the Gallia, which is the shallow water-bearing unit at the site. The Sunbury Shale is 10 to $12 \mathrm{ft}$ thick, slightly fractured, and has very low permeability. 
Previous soil sample results indicated total volatile organic compounds (VOCs) (primarily TCE and 1,1,1-trichloroethane [TCA]) ranging from less than 1 to $282 \mathrm{mg} / \mathrm{kg}$ at the southeast corner of the site (ASI 1989). Low concentrations of metals (primarily $\mathrm{Ba}, \mathrm{Cr}, \mathrm{Pb}$, and $\mathrm{Ni}$ ) were detected throughout the unit. Low total beta activities and total $U$ were also detected throughout the unit ranging from 11 to $64 \mathrm{nCi} / \mathrm{kg}$ and 1 to $11 \mathrm{mg} / \mathrm{kg}$, respectively. No PCBs were detected. In the $\mathrm{X}-231 \mathrm{~A}$ demonstration area, the Minford is $\sim 20 \mathrm{ft}$ thick and the ground water table is $\sim 10$ to $14 \mathrm{ft}$ bgs. Ground water flow occurs vertically downward through the Minford Member into the Gallia Member where flow is predominantly horizontal to the south toward the X-230K pond.

With regard to the focus of this project on DNAPL compounds in LPM, the distribution of DNAPL compounds, such as TCE, within the Minford deposit is controlled by the properties of the organic compound and the characteristics of the deposit. A variety of equilibrium and fugacity based approaches are commonly used to assess how DNAPL compounds are distributed under a given set of conditions. A fugacity based model (Dawson 1997) was used for this purpose to asses the TCE distribution within the Minford. Based on literature data for key properties of TCE and using representative measured values (Siegrist et al. 1995, West et al. 1995, and Gierke et al. $1995)$ of porosity $(40 \% \mathrm{v} / \mathrm{v})$, volume fraction of water $(36 \% \mathrm{v} / \mathrm{v})$, and mass fraction of organic carbon $(500 \mathrm{mg} / \mathrm{kg}$ ) for the Minford, a bulk concentration of $300 \mathrm{mg}$ TCE per $\mathrm{kg}$ of soil can result in $15 \%$ of the mass of TCE being present in a nonaqueous phase with $69 \%$ in the soil water, $14 \%$ on the soil solids, and $2 \%$ in the soil air.

\subsection{OVERVIEW OF DEMONSTRATION ACTIVITIES}

The demonstration was accomplished through a series of field activities divided into phases (Tables 2.2-2.3). As summarized below, these activities led to establishment of a set of test cells at the X-231A site as shown in Figure 2.5. Preparation of necessary plans and permit applications are not described herein but were done in support of the activities outlined below. Further details regarding the materials and methods associated with the different phases and activities are described in subsequent parts of this section.

\subsubsection{Site Reconnaissance and Pre-Demonstration Testing}

The initial demonstration field activities were focused on site selection for the demonstration and development and testing of equipment, materials and methods. The methods and results of these efforts are highlighted in part below while further details may be found in Appendix A.

\subsubsection{Site Reconnaissance --}

The site reconnaissance included sampling six coreholes spread across the X-231A unit with onsite field analyses for VOCs (Fig. 2.6). Because the targeted zone for the demonstration was the unsaturated low permeability Minford soils ( 0 to $\sim 18 \mathrm{ft}$. bgs), coring and sample collection was conducted to the top of the Gallia with an effort made to not penetrate the Gallia. Corehole depth ranged from 16 to $20 \mathrm{ft}$. The top of the Gallia was encountered in only one location and at a depth of $19.5 \mathrm{ft}$. (Figure 2.6, GP02).

Soil samples were collected at 2-ft intervals the entire length of each core and analyzed for VOCs (PCE, TCE, and 1,1,1-TCA). At two locations samples were taken at 1 to $2 \mathrm{ft}$., 7 to $8 \mathrm{ft}$., 11 to $12 \mathrm{ft}$., and 15 to $16 \mathrm{ft}$ and analyzed at the PORTS laboratory for PCBs (Aroclor 1254 and 1260), radionuclides (total alpha, total beta, and total uranium), RCRA metals (As, $\mathrm{Ba}, \mathrm{Cd}, \mathrm{Cr}, \mathrm{Pb}, \mathrm{Hg}$, $\mathrm{Se}$, and $\mathrm{Ag}$ ), and physical properties ( $\mathrm{pH}$, moisture content, total organic carbon [TOC]) (Table 2.4). Results of the reconnaissance activities are summarized in Appendix A. 


\subsubsection{Equipment Testing and Shakedown --}

Development testing of down-hole hot air and steam generators was accomplished at the Aber Road site located -30 miles east of Cincinnati, Ohio and subsequently at the PORTS clean test site (CTS). The methods and results of the development and testing of the down-hole steam generator and hot air heater conducted at the Aber Road site are discussed in Appendix A.

Following equipment development and testing at Aber Road, stacked fractures were emplaced to create two test cells at the PORTS CTS (Fig. 2.7). In each cell, sand-propped fractures were emplaced at 6, 9 and $12 \mathrm{ft}$ bgs. Additionally, one deep fracture was emplaced at $18 \mathrm{ft}$ bgs, just west of the two CTS test cells, to conduct dewatering tests and obtain process operation information necessary for dewatering during the X-231A demonstration. The two primary cells were then instrumented with various monitoring devices and sensors (e.g., pressure, temperature and water content) using a new sidewall sampler device developed by FRx, Inc. Sensors were installed at four monitoring locations at each of the two test cells with the stacked fractures (Fig. 2.7). Three monitoring locations (two thermistor temperature monitoring locations and one neutron probe monitoring location) were installed using a truck-mounted hydraulic probe to create a $\sim 2$-in. diameter hole to $20 \mathrm{ft}$ bgs. Casings (stainless steel for the neutron probe casing and polyvinyl chloride (PVC) for the temperature casings) were then pushed into the corehole and grouted in place. The fourth monitoring location was drilled to $\sim 16 \mathrm{ft}$ bgs using a hollow-stem auger ( 7.5 in OD). This location was instrumented with sidewall sensors (time domain reflectometry [TDR] and piezometers) at discrete locations (10 locations at the first test cell and 7 locations at the second test cell) within the borehole using the innovative sidewall sampling device developed by FRx, Inc. Following installation of the sidewall sensors, a 0.5 -in diameter PVC pipe with a plugged end was placed in the borehole to allow temperature logging and then the borehole was filled with grout. Cores collected during sidewall instrumentation were visually inspected, but no samples were collected or analyzed for biogeochemical properties.

One of the cells was equipped with a down-hole hot air generator feeding the middle fracture and the other cell was similarly equipped with a down-hole steam generator. The upper and lower fractures in each cell were used for vapor extraction. The two test cells were operated for a period of approximately two mon to check on heating equipment mechanical function, monitoring and sensor performance, and subsurface heating achieved. TDR and piezometer measurements were collected for two mon to verify the viability of the sensors and placement techniques. This test demonstrated the feasibility of using hydraulic fractures as an enabling technology for in situ remediation at the PORTS site.

\subsubsection{Reactive Fracture Proppant Formulation and Testing --}

During the spring and summer of 1996, work was completed at Colorado School of Mines (CSM) and ORNL to develop and test proppant formulations that could be used to create the reactive fractures containing iron metal or permanganate particles in test cells C and D. This work was primarily focused on development of a suitable carrier for potassium permanganate particles. The objective was to develop a proppant that would contain a high mass $\%$ of permanganate solids but still be pumpable and have adequate strength for fracture propagation. Various types of guar gum gels and mineral-based mixtures were tried with fluid strength and viscosity used as indicators of suitable fracturing properties. Due to the oxidation potential of the permanganate, the common guar gum carriers were found to be unsuitable, but a mineral-based carrier was developed that appeared suitable for fracture emplacement. In addition, the TCE oxidation kinetics with the permanganate grout were equal to or faster than those of permanganate alone (Case 1997). 


\subsubsection{Phase 1 Demonstration Activities (Fall 1996)}

\subsubsection{Test Cell Setup and Operation --}

Test Cell Setup. A set of four test cells was established in the southeastern portion of the X-231A land treatment unit (Fig. 2.8). The test cells were unconfined (i.e., no sheet pile walls) to reduce costs and to limit the site disruption and potential artifacts caused by installation of sheet-pile or other cell enclosure barriers on subsurface transport and treatment properties. In each cell, hydraulic fractures were emplaced at depths of approximately $4,6,8,12$, and $18 \mathrm{ft}$. bgs in the Minford vadose and saturated zones (Fig. 2.8 and 2.9, Table 2.5). The geometry of the fractures within each cell was roughly elliptical with a length of $\sim 25 \mathrm{ft}$. and a width of $\sim 20 \mathrm{ft}$. The treatment technologies assigned to the four cells as described in Table 2.5 and outlined below were:

Cell A: Injection of steam into sand-propped fractures to enhance mass recovery by SVE,

Cell B: Injection of hot air into sand-propped fractures to enhance mass recovery by SVE,

Cell C: Iron metal particles as proppants for horizontal barriers for in situ dechlorination, and

Cell D: Permanganate grout as proppants for horizontal barriers for in situ oxidation.

After the fractures were emplaced but prior to the initiation of process operation, the test site was thoroughly characterized and instrumented. In 35 locations across the test area of the X-231A site (eight locations each at test cells A, C and D, seven locations at test cell B, and four background locations), continuous soil cores ( $1.75 \mathrm{in}$. diameter) were collected in $4 \mathrm{ft}$. long sleeves from ground surface to $\sim 17 \mathrm{ft}$. bgs using a truck-mounted hydraulic probe (Fig. 2.10). Soil lithology and morphology as well as fracture locations and orientation were observed and recorded. At each corehole location soil samples were collected at $1-\mathrm{ft}$ intervals and analyzed on-site for VOCs $(1,1-$ dichloroethene (1,1-DCE), cis-1,2-dichloroethene (cis-1,2-DCE), trans-1,2-dichloroethene (trans1,2-DCE), TCE, PCE, 1,1,1- TCA and 1,1-dichloroethane (1,1-DCA) and methylene chloride). Soil samples were also collected at three discrete intervals (4 to 5,8 to 9 , and 13 to $14 \mathrm{ft}$. bgs) and analyses were conducted on-site for temperature, Eh, water content, $\mathrm{pH}$, cations $(\mathrm{K}, \mathrm{Fe}, \mathrm{Mn})$ and permanganate $\left(\mathrm{MnO}_{4}^{-}\right)$. Additionally, at three corehole locations within each test cell, samples were collected for various biogeochemical properties and confirmatory DNAPL compound analyses including; methanol extraction and standard EPA analysis methods for VOCs, anions $(\mathrm{Cl}$, sulfate $\left[\mathrm{SO}_{4}\right]$, nitrate $\left[\mathrm{NO}_{3}\right]$ ), cations $(\mathrm{Ca}, \mathrm{Mg}, \mathrm{Fe}$ ), total organic carbon (TOC), grain size, and microbial populations. Soil sample analyses, frequency and intervals are summarized in Tables 2.6 and 2.7. These baseline characterization results were used to identify both short-range and long-range spatial heterogeneity in geochemical and contaminant properties (Appendix C).

The test cells and the test site area as a whole were instrumented with various samplers and monitoring devices to enable periodic measurement of selected subsurface properties (Fig. 2.10, individual maps for each test cell are presented in Sections 3 and 4). Both test cell A and B received variable numbers of thermistors and thermocouples for intermittent and/or continuous temperature measurements. Additionally, high density arrays of shallow piezometers (1.5 ft bgs) were installed in test cells A and B to permit characterization of near surface fluxes caused by fluid injection and extraction. One or more neutron probe access casings were emplaced for water content profiling with depth. Using a new sidewall sampler and implantation apparatus, TDR antennae, redox electrodes, and sidewall piezometers were implanted at multiple depths through the treated region enabling observation and measurement of soil gas pressures, soil water content, and redox potential. Ground water piezometers were also installed to $17 \mathrm{ft}$ bgs (15.5 to 16.5 screened interval) at one location in each test cell and at three background locations between the test cells.

Ground water samples were collected from each piezometer and from the deepest sand-propped fracture in each test cell (i.e., 18-ft bgs fracture in test cell A and 16.5-ft bgs fracture in test cells B, $\mathrm{C}$, and $\mathrm{D}$ ). For the baseline characterization, ground water samples were analyzed on-site for VOCs, temperature, dissolved oxygen (DO), conductivity, Eh, $\mathrm{pH}$, alkalinity and selected ions (K, 
$\mathrm{Fe}, \mathrm{Mn}, \mathrm{MnO}_{4}$ ). Samples were also collected, preserved and shipped off-site to ORNL for additional geochemistry and contaminant determinations including total dissolved and suspended solids, TOC, anions ( $\mathrm{Cl}, \mathrm{SO}_{4}, \mathrm{NO}_{3}$ ), cations ( $\mathrm{Ca}, \mathrm{Mg}, \mathrm{K}, \mathrm{Fe}, \mathrm{Mn}$ ), and microbial populations.

Concentrations of TCE and related halocarbons were highly variable with concentrations up to $100 \mathrm{mg} / \mathrm{kg}$ (Appendix A). The water table in the silty clay soils occurred at $\sim 11.5 \mathrm{ft}$. bgs and due to the fine-grained matrix, soil water contents were near saturation up towards ground surface. Soil $\mathrm{pH}$ and $\mathrm{Eh}$ were in the range of 4 to 5 and $200 \mathrm{mV}$, respectively. Microbial densities per gram of soil included 100 anaerobic heterotrophs, 10,000 to 100,000 aerobic heterotrophs, and no detectable iron-oxidizers.

Active Operation of the Hot Fluid Injection Cells. A water recovery system, which permitted dewatering and commensurate enhancement of vapor flow, was installed in test cells A and B. Pneumatically driven bladder pumps, which could operate within closed wells connected to the SVE system, were installed in wells accessing the 12- and 18-ft bgs fractures in cell $\mathrm{A}$ and the 12and 16.5-ft bgs fractures in cell B. The pumps discharged to separators (39-in long vertically mounted sections of 4-in diameter PVC pipe equipped with float switches) that measured recovery volumes by counting fill-up cycles. The inlet to a liquid ring vacuum pump (Travaini Model PLT3106) was split to provide suction to both test cells. A header at each cell further allocated suction to individual wells. The vacuum pump discharged to a separator, which also served as a reservoir for "ring water" used by the pump, followed by a carbon absorption canister. The vapor extraction well heads were each equipped with a type $K$ thermocouple and a miniature pressure transducer. The vacuum headers were equipped with ports to measure pressure and attach variable area flow meters.

After final pre-operational process and monitoring system checks, active operation of test cell A (steam injection) and test cell B (hot air injection) was initiated on October 19, 1996 (Table 2.8 and 2.9). To establish ambient air flushing characteristics, the initial operation occurred with ambient air passively vented into a sand-propped fracture at $8 \mathrm{ft}$ bgs with active vapor extraction occurring at the 4- and 12-ft bgs sand-propped fractures in test cell $\mathrm{A}$ and at the 4-, 6-, and 12-ft bgs sand-propped fractures in test cell B. The test cells were operated in this manner for $\sim 15$ days. During this period, process operation and performance were monitored as described in the following paragraph. Helium tracer tests were completed in both cells A and B to characterize air flow patterns between the passive inlet fracture and the extraction fractures above and below the inlet fracture. Following the baseline operating period, test cells A and B were converted to hot fluid injection with down-hole steam and hot air generation/injection initiated, respectively.

Process operation and performance of test cells A and B were monitored by flow meters, temperature and pressure sensors, and on-line hydrocarbon detectors. These sensors were monitored intermittently and/or continuously by manual methods and/or two computerized data acquisition systems. Field analyses were made for off-gas hydrocarbons from each extraction fracture using a real time flame ionization detector (FID) and an on-line atmospheric analyzer for carbon dioxide $\left(\mathrm{CO}_{2}\right)$, methane $\left(\mathrm{CH}_{4}\right)$, and oxygen $\left(\mathrm{O}_{2}\right)$; off-gas samples were also collected periodically and analyzed on-site using a gas chromatograph with an electron capture detector (GC/ECD). Subsurface conditions (temperature, soil moisture content, and ground water geochemical properties) were monitored continuously to intermittently depending on the expected rate of change. Fracture flow rates averaged $\sim 4 \mathrm{cfm}$ in the shallow $4-\mathrm{ft}$ bgs fractures and $\sim 1 \mathrm{cfm}$ in the deeper $12-\mathrm{ft}$ bgs fractures.

Test cells A and B were actively operated until the week of December 9, 1996, when the demonstration site was intensively sampled and monitored before it was placed in a passive mode for the winter. 
Passive Operation of the Horizontal Reactive Barrier Cells. Passive operation of the two reactive horizontal barrier cells began in September 1996 immediately following fracture emplacement. No fluids were injected into the test cells, but rather they were monitored in a passive mode until midDecember 1996. In December, intact cores were collected from each of the test cells and the fracture zone morphology was observed, characteristics were measured, and experiments were conducted to evaluate the degradation potential of the reactive fractures and the zone of influence. The entire demonstration site was then placed in a passive mode through the winter until additional field activities were initiated in summer 1997.

\subsubsection{Monitoring and Measurement --}

Monitoring and sampling/analysis activities were conducted before, during, and after all field testing activities and included various process operational features and subsurface soil, soil solution, and ground water conditions (Table 2.10 and 2.11).

During active hot fluid injection in test cells $\mathrm{A}$ and $\mathrm{B}$, equipment operations were monitored to determine delivery pressures, flow rates and volumes, and temperatures. Two data acquisition systems were used to collect and record information and enable real-time examination of results. Subsurface sensors and surface instrumentation were also monitored during remediation activities. Chemical analyses were conducted on soil gas for VOCs using an on-line FID and GC/ECD and for atmospheric conditions (pressure, methane, oxygen) using a field portable gas analyzer. Ground water samples were also collected from the piezometers and deep fractures and analyzed in the field for VOCs, temperature, conductivity, $\mathrm{pH}, \mathrm{DO}$, and ions $\left(\mathrm{K}, \mathrm{Fe}, \mathrm{Mn}, \mathrm{MnO}_{4}\right)$. During passive operation of test cells $C$ and $D$, ground water samples were collected and analyzed for the same geochemical properties and contaminants as in test cells A and B.

Following active and passive remediation, soil and ground water samples were again collected in December 1996. Continuous soil cores were collected from one location in test cell A and C, six locations in test cell B, and two locations in test cell D. Geochemical and contaminant analyses, as conducted before treatment began, were repeated including both on-site and off-site analyses. These measurements enabled characterization of the treatment effects throughout the test cells, the interactions of the added fluids with the silty clay matrix, and any leaching to the saturated zone and ground water. Gas-phase tracer experiments were also conducted in test cells A and B to assess pore size and continuity as affected by in situ treatment.

A field experiment was then conducted on soil core segments collected in test cells C and D to assess the affects of the reactive fractures on subsurface properties after approximately three months of passive emplacement (i.e., no substantial advection of ground water through the fractured region). Batch tests were completed on cores collected at 7-8 $\mathrm{ft}$ bgs in test cell C (TCB9) and at 8-10 ft bgs in test cell D (TDB10). Each core was analyzed intact and then transects were carefully made to encompass a depth interval of $\sim 15 \mathrm{~cm}$ above and $\sim 15 \mathrm{~cm}$ below the fracture and measurements were made on-site at $\sim 15$ locations for $\mathrm{Eh}, \mathrm{pH}$, and water content. The oven dried sample residual from the water content analysis was shipped to CSM for TOC analysis. A degradation test was then conducted using plugs of field moist media from each core. A -5-g plug of media was collected from $\sim 6$ locations within the $30-\mathrm{cm}$ interval. These plugs were placed in $40-\mathrm{mL}$ vials and then filled with DNAPL contaminated ground water (well $76 \mathrm{G}$ at the X-701B site). The concentration of TCE and related halocarbons in this ground water was $\sim 145 \mathrm{mg} / \mathrm{L}$. The soil plugs were contacted with the DNAPL ground water for 24 hours (the permanganate samples were quenched with sodium thiosulfate at $24 \mathrm{hr}$.) after which time analyses were made for residual VOCs. 


\subsubsection{Phase 2 Demonstration Activities (Summer 1997)}

\subsubsection{Characterization of the Test Site --}

The characterization of the test site and the individual test cells was conducted at the onset of the field activities. One round of ground water samples was collected from all piezometers and from the deepest sand-propped fracture in each test cell before starting any operations. The ground water head, temperature, conductance, and $\mathrm{pH}$ was measured at each location and a sample was collected for analyses of alkalinity, $\mathrm{DO}, \mathrm{Fe}$ (total and ferrous), $\mathrm{Mn}, \mathrm{K}, \mathrm{MnO}_{4}$, chloride, bromide, and VOCs. Also, prior to start-up of activities at any of the test cells, measurements were collected for soil temperature, water content, and Eh. In test cell $\mathrm{C}$ and D soil samples were also collected and analyzed for VOCs and selected ions $\left(\mathrm{K}, \mathrm{Fe}, \mathrm{Mn}, \mathrm{MnO}_{4}\right)$. These data were included with the information collected during the fall 1996 activities. Additional characterization activities (the same as those listed above) were completed during and after conduct of the activities outlined below.

\subsubsection{Subsurface Heating Achieved Via Fractures in Test Cells A and B --}

Both steam and hot air injection via sand-propped fractures were studied as means of introducing heat to the subsurface more aggressively than attempted during fall 1996. Somewhat higher air pressures and a second air blower were used to enable higher air flow rates, and the temperature of the hot air was approximately doubled to $470^{\circ} \mathrm{C}$ by installing a second heating element. The focus of the monitoring efforts was on temperature and water content changes during operation. Due to the prior operation of both test cells in an active air flushing mode for 60 days in 1996 as well as budget limitations, detailed off-gas or soil core monitoring was not conducted (e.g., off-gas VOCs by FID and GC/ECD or atmospheric composition of $\mathrm{O}_{2}, \mathrm{CO}_{2}$, and $\mathrm{CH}_{4}$ ).

\subsubsection{Morphology and Degradation Efficiency of Reactive Fractures in Cells C and D --}

Continuous cores were collected at three locations from test cell C (iron-metal) and D (permanganate grout) at the beginning of the summer 1997 field activities. In test cell $\mathrm{C}$, cores were located near TCB9 (previously examined in Dec. 1996), TCB6, and TCB5. In test cell D, cores were located near TDB10 (previously examined in Dec. 1996), TDB2, and TDB7. The intact cores were subsampled to $\sim 17 \mathrm{ft}$. bgs. Samples were collected at 2 -ft intervals beginning $1 \mathrm{ft}$ bgs (e.g., 1, 3, 5, 7, etc.) and field analyses were made for VOCs, water content, $\mathrm{pH}$, Eh, and selected ions $\left(\mathrm{K}, \mathrm{Fe}, \mathrm{Mn}, \mathrm{MnO}_{4}\right)$. Each sample core was visually inspected and the reactive fractures were located, described, and analyzed as outlined below.

At the 7-ft fracture interval from test cell C (TCB13) and from the 9-ft fracture interval in test cell D (TDB12), transects along the core were carefully made to encompass a depth interval of $\sim 30 \mathrm{~cm}$ above and $-30 \mathrm{~cm}$ below the fracture. Analyses were made at intervals above and below the fracture for Eh, $\mathrm{pH}$, water content and TOC. Degradation tests were completed on-site following the procedures employed during December 1996 wherein $~ 5-g$ plugs of media were collected from $\sim 8$ locations within the $60-\mathrm{cm}$ interval. These plugs were placed in $40-\mathrm{mL}$ vials and then filled with DNAPL contaminated ground water from well X231A-BGP3 at the X-231A demonstration site. The concentration of TCE and related halocarbons in this ground water was in the range of $500 \mathrm{mg} / \mathrm{L}$. The degradation tests were conducted with two ground water VOC concentrations (i.e., raw ground water at $\sim 480 \mathrm{mg} / \mathrm{L}$ and diluted ground water at $\sim 54 \mathrm{mg} / \mathrm{L}$ ) and over two reaction periods (i.e., 24- and 48-hr for cell C and 2- and 24-hr for cell D). After contact, analyses were made for residual reaction potential, $\mathrm{pH}$, and chlorides.

\subsubsection{Injection/Percolation within Test Cells C and D --}

Following completion of the core collection, an active water injection system was set up for test cells $C$ and $D$ as indicated in Fig. 2.9 and 2.11. The injection system was designed to feed potable 
water from the site (supplemented with sodium bromide $(\mathrm{NaBr})$ tracer at $\sim 100 \mathrm{mg} / \mathrm{L}$ ) into the upper most fracture. Maintaining a 1- to 2-ft. head of water above the inlet fracture, the volume and rate of addition of water added to the inlet fracture would be controlled by the flux rates that the Minford system and emplaced fractures would accept (i.e., water was added to the inlet fracture when the head fell to $1 \mathrm{ft}$ ).

The active period of injection was 45 days. It was assumed that if the saturated bulk hydraulic conductivity of the Minford zone was $\sim 0.00001 \mathrm{~cm} / \mathrm{s}$ and the operating unit gradient was effectively $\sim 1: 1$, the flux density would be $\sim 0.9 \mathrm{~cm} / \mathrm{d}$. Assuming a fracture diameter of $\sim 6.1 \mathrm{~m}$ ( $20 \mathrm{ft}$.), the test cell flux rate per day was expected to be up to $\sim 250 \mathrm{Lpd}(\sim 66 \mathrm{gpd})$. Further, if the Minford effective porosity were $\sim 0.05$ to $0.10 \mathrm{v} / \mathrm{v}$, then the pore velocity would be $\sim 8$ to $17 \mathrm{~cm} / \mathrm{d}$. At this rate, assuming no preferential vertical flow, water infiltrating from the sandpropped fractures at $\sim 4 \mathrm{ft}$. bgs would take roughly 3.5 to 7.5 days to reach the first reactive fracture at $\sim 6 \mathrm{ft}$ bgs. The time required to reach the underlying sand-propped fracture at $16.5 \mathrm{ft}$. bgs would take $\sim 26$ to 55 days. With preferential flow, the rate could be substantially faster and the appearance of tracer and fluid in the underlying fracture much earlier.

During infiltration, monitoring included recording the volume of water added to each cell over time, and sampling and analysis of ground water in the underlying sand-propped fracture, and the nearby ground water piezometers. Water quality analyses were made for temperature, $\mathrm{pH}, \mathrm{DO}$, conductance, alkalinity, $\mathrm{Fe}, \mathrm{Mn}, \mathrm{K}, \mathrm{MnO}_{4}, \mathrm{Cl}$, and $\mathrm{Br}$.

\subsubsection{Demonstration Site Close-Out (Fall 1997)}

Sampling, demobilization and close-out of the X-231A site were completed in September 1997 (Table 2.9). However, the fracture access tubes, sensors in the multilevel locations, and the piezometers were left in place for possible future sampling and monitoring of the demonstration site as necessary. All other monitoring locations were plugged and abandoned per PORTS requirements.

\subsubsection{Final Sampling (Winter 1997)}

Morphology and degradation efficiency of reactive fractures in test cells C and D were examined again in December 1997 following the same procedures as described above (Sect. 2.2.3.3). Intact cores were collected from cell C (TCB14 and TCB15) and fracture zone morphology was observed and measurements were made for redox potential, $\mathrm{pH}$, and water content. Iron particles from the shallowest two fractures in TCB14 and TCB15 were retrieved, homogenized, and then used for a series of TCE kinetics experiments. In cell D, an intact core was collected (TDB14) and examined for morphology, redox potential, and $\mathrm{MnO}_{4}$ concentrations.

During December 1997, reconnaissance borings were made in a DNAPL contaminated area south of the demonstration site to assess its suitability for production-level deployment and evaluation of horizontal reactive fractures at X-231A. This characterization included sampling eight coreholes at the X-231A unit south and west of the demonstration area with on-site field analyses for VOCs (Fig. 2.10). Because the targeted zone for was the Minford soils ( 0 to $\sim 18 \mathrm{ft}$. bgs), coring and sample collection was conducted to the top of the Gallia and corehole depth ranged from 15 to 17 $\mathrm{ft}$. bgs. Soil samples were collected at 2-ft intervals the entire length of each core and analyzed onsite for VOCs (methylene chloride, cis- and trans-1,2-DCE, PCE, TCE, and 1,1,1-TCA). At five locations samples were taken and analyzed at the PORTS laboratory for radionuclides (total alpha, total beta, technetium, and total uranium, and \% U235). 


\subsection{TEST CELL ESTABLISHMENT}

A set of four test cells was established in the southeastern region of the X-231A unit (Fig. 2.8, Table 2.5). In each cell, hydraulic fractures were targeted at depths of approximately $4,6,8,12$, and $18 \mathrm{ft}$. bgs in the Minford vadose and saturated zones (Fig. 2.9, see Sections 3 and 4 for cell cross-sections). The hydraulic fractures were created using a 2-in. steel casing and PVC drive point driven into the subsurface by a pneumatic hammer (Fig. 2.12). After driving the casing to the desired depth, the drive point was dislodged downward an additional 1 to 4 inches, exposing an open hole in the subsurface from which fractures were nucleated. A high-pressure (2,500 psig) water jet was then used to cut a horizontal notch into the soil. The slot cut into the soil served as the nucleation point for the fracture, a process known as "notching".

After the subsurface was notched, hydraulic fracturing was initiated by injecting fluid into the borehole at a constant rate. Pressure quickly exceeded a critical value and the fracture was nucleated. Coarse-grained sand was then injected as a slurry while the fracture grew away from the borehole. Guar gum gel, a viscous fluid, was used to facilitate transport of the sand grains into the fracture for this work. Guar gum, a food additive derived from the guar bean, was mixed with water to form a short-chain polymer with the consistency of mineral oil. A crosslinker was then added to form a thick gel capable of suspending high concentrations of coarse-grained sand. For this project, borax mixed at roughly $1 \%$ with the guar gum gel was used as the crosslinker. After pumping, the fracture remained propped open by the sand, and the guar gum gel was decomposed by an enzyme added during injection and the gel was subsequently recovered.

The above procedure was repeated to create fractures at $4,8,12$, and $18 \mathrm{ft}$. bgs in test cell A and at $4,6,8,12$, and $16.5 \mathrm{ft}$ bgs in test cell $\mathrm{B}$. During hydraulic fracturing in test cells $\mathrm{C}$ and $\mathrm{D}$, the same procedure was used to create sand-propped fractures at 4 and $16.5 \mathrm{ft} \mathrm{bgs,} \mathrm{while} \mathrm{iron} \mathrm{was}$ injected into the fractures at 6,8 , and $12 \mathrm{ft}$ bgs in test cell $\mathrm{C}$ and a specially formulated $\mathrm{KMnO}_{4}$ grout was injected into the fractures at 7, 9, and $12 \mathrm{ft}$ bgs in test cell D. Table 2.5 presents a summary of the test cell fractures. Additional detail on the fracture geometry and configuration during propagation is presented in Appendix B.

The fracturing equipment normally includes a continuous mixer consisting of a hopper with an auger feeder to store and meter the proppant (e.g., sand); metering pumps for gel, crosslinker, and breaker; and an inclined auger mix tube to blend the ingredients. The mixer feeds a progressive cavity pump. Both the pump and mixer are mounted on an equipment trailer, along with a suitable prime-mover, approximately $8 \mathrm{ft}$ wide, $18 \mathrm{ft}$ long, and $8 \mathrm{ft} \mathrm{high}$.

The pressure required to initiate a fracture in a borehole depends on the confining stress, the toughness of the enveloping formation, the initial rate of injection, the size of incipient fractures, pores, or defects in the borehole wall, and other factors. In general, the injection pressure will increase with increasing depth, increasing injection rate, and increasing fluid viscosity. The pressure required to propagate a fracture created by injecting liquid into soil at $75 \mathrm{~L} / \mathrm{min}$ at a 6 -ft depth is on the order of 50 to $75 \mathrm{kPa}$ (approximately 7 to $11 \mathrm{psig}$ ) and increases approximately $20 \mathrm{kPa}$ (approximately $3 \mathrm{psig}$ ) every $3 \mathrm{ft}$. The pressure during propagation typically decreases during most operations, but may vary based on several factors. For example, slight increases in pressure may occur when the sand concentration in the slurry increases.

Propagation could continue indefinitely if the fracture were created in an infinitely impermeable material, but in real materials, there are several factors that will limit the size of the fracture. Some of the injected fluid will flow out through the walls of the fracture and into the pores of enveloping soil or rock. This process has been dubbed leak-off by workers in the oil industry. The rate of leak-off increases as the fracture grows and more fracture surface area is available through which the injected fluid can flow. The leak-off rate is also affected by the relative permeability of the fractured formation, the viscosity of the fluid, the pressure of the fluid, and other factors. 
Accordingly, the rate of propagation of the fracture will decrease as the rate of leak-off increases, and propagation will cease entirely when the leak-off rate is equal to the rate of injection. For soils such as at PORTS and the techniques and equipment used at X-231A, leak-off involves only a small portion of the injected fluid.

When fractures are created at shallow depths in silty clay by injecting water or viscous gel, other effects, such as intersecting the ground surface, become important before the fractures become large enough to be affected by leak-off. Leak-off had negligible effects at X-231A, however three fractures ( $4 \mathrm{ft}$ bgs at $\mathrm{B}, 6 \mathrm{ft}$ bgs at $\mathrm{C}$, and $7 \mathrm{ft}$ bgs at $\mathrm{D}$ ) vented to the surface.

Displacement of the ground surface was used to monitor fracture locations (Appendix B). The displacement over the gently dipping fractures at shallow depths appeared as an asymmetric dome. Net displacements were determined by surveying an array of staffs with finely graduated scales before and after fracturing. The array used during this project consisted of six lines of four staffs spaced at approximately $4.5-\mathrm{ft}$. intervals. Another staff was located at the center of the array near the injection point. Scales on the staffs were measured with a leveling telescope before and after fracturing and the net uplift was determined.

The pattern of uplift was analyzed for characteristics of the fractures at depth. A broad, symmetric dome indicates that a fracture is gently dipping and roughly symmetric. A preferred direction of propagation was reflected by displacements that are asymmetric with respect to the borehole. At shallow depths (where the ratio of fracture length to depth is roughly three), the magnitude of uplift appears to be roughly equivalent to the aperture of the fracture; therefore, fracture aperture and extent can be estimated directly from the uplift. At lesser ratios of length to depth (deeper fractures), mathematical inversion of appropriate analyses are generally required to estimate the geometry of the fracture.

\subsection{TEST CELL PROCESS OPERATIONS}

Planning activities and preliminary site work at X-231A occurred during FY 1996 with the active demonstration phase beginning in August 1996 (Table 2.8 and 2.9). Four primary test cells were established with hydraulic fractures having diameters of $\sim 30 \mathrm{ft}$ and installation depths of $\sim 4,6,8$, 12 and 16-18 ft bgs (Fig. 2.8 through 2.10). Following emplacement of fractures, the test cells were sampled and instrumented as described in Section 2.5. Then, after final pre-operational process and monitoring system checks, active operation of test cell A (steam injection) and test cell B (hot air injection) was initiated on October 19, 1996 (Table 2.8).

To establish ambient air flushing characteristics, initial operation involved ambient air passively vented into a sand-propped fracture at $8 \mathrm{ft}$ bgs with active vapor extraction occurring at 4 and $12 \mathrm{ft}$ bgs via sand-propped fractures. The test cells were operated in this manner for $\sim 15$ days. During this period, process operation and performance were monitored as described in Section 2.5. Helium tracer tests were completed in both cells A and B to characterize air flow patterns between the passive inlet fracture and the extraction fractures above and below the inlet fracture. Following the baseline operating period, test cells A and B were converted to hot fluid injection with downhole steam generation/injection and down-hole hot air generation/injection.

During the week of December 9,.1996, the X231-A site was sampled and monitored and then placed in a passive mode for the winter. In all test cells and across the site, post-treatment subsurface measurements were made including operational measures, tracer tests, soil coring and analyses, and ground water monitoring. Continuous cores collected across the emplaced fracture zones in each cell were carefully examined and characterized. Degradation tests were also completed with soil cores from the in situ barrier cells C and D. 
In mid-July, 1997, the hot fluid injection cells were re-initiated and were aggressively treated with down-hole steam (test cell A) or hot air (test cell B) injection (Table 2.9). The passive barrier cells, $\mathrm{C}$ and $\mathrm{D}$, were operated in a semi-active mode with water infiltration/percolation beginning in midJuly. Operation and monitoring of all four test cells continued until September 6, 1997 when the demonstration site was sampled and closed out. A final round of continuous cores were collected from test cells C and D in December 1997 to evaluate the reactive fractures $\sim 15$ months after emplacement. Table 2.9 summarizes the materials injected into all four test cells during this period. No analysis of the injected fluids was performed as the fluids injected into the test cells were comprised of potable water from the PORTS plant (test cell A), ambient air (test cell B), or potable water from the PORTS plant with $100 \mathrm{ppm} \mathrm{NaBr}$ tracer (test cells $\mathrm{C}$ and $\mathrm{D}$ ).

\subsection{MONITORING OF PROCESS FUNCTION AND PERFORMANCE}

Monitoring of process function and performance included a range of activities encompassing (1) operational parameters (e.g., vacuums, air flow rates, temperatures), (2) changes in subsurface conditions and contaminant levels, (3) degradation experiments, and (4) ancillary tests (e.g., helium tracer tests). The materials and methods used for these activities are described in this section while the results and their interpretation are given in Sections 3 to 5 of the report.

\subsubsection{Process Function}

During active operation of the hot fluid injection test cells (A and B), treatment process operations were monitored continuously by a data acquisition system (DAS) and daily by visual observation (Table 2.12). Parameters monitored included injection pressures, hot fluid injection temperatures, injection and extraction flow rates, energy use, and dewatering volumes and rates. The horizontal reactive barrier test cells (C and D) were operated in a passive mode during fall 1996 and did not require operational monitoring. However, during summer 1997, test cells $C$ and D did receive infiltration of potable water with $\mathrm{NaBr}$ tracer. During this period, process monitoring consisted of injected water volume and rate. Process operating parameters monitored are summarized in Table 2.10. During operation of the test cells during fall 1996 and summer 1997 activities, monitoring also included off-gas samples for total hydrocarbons and VOCs.

To record much of the process function data, a computerized DAS developed by ORNL was used (Table 2.12). This DAS was developed from a DAS used previously at ORNL for a field demonstration of deep soil mixing at the X-231B site (Summer 1992) and more recently at the deep soil mixing demonstration at the Kansas City Plant (Summer 1996). The X-231A process function DAS consisted of 7 main parts: personal computer (PC), custom software, a Keithley-Metrabyte DAS-16G1 analog to digital (A/D) board, a Keithley-Metrabyte FWA-37U field wiring access board, a Keithley-Metrabyte EXP-1600 thermocouple conditioning board, and 2 National Instruments PC-TIO-10 counter boards (with wiring access blocks). Input from thermocouples was through the EXP-1600 board into the DAS-16G1. The system (as configured) could read as many as 16 thermocouples, though only 10 were used for the project. Input from pressure transducers was through the FWA-37U board into the DAS-16G1. The system (as configured) could read as many as 15 pressure transducers, though only 5 were used for the project. Liquid and vapor process volumes were counted by the two PC-TIO-10 boards. These boards counted events, such as a signal each time a knock-out pot was emptied. The system (as configured) could read as many as 16 different events, though only 15 were used for the X-231A project.

The custom software program, written by ORNL, ran on a PC under the Windows operating system. The program monitored and controlled the DAS-16G1 and the two PC-TIO-10 boards. It provided graphical and numerical display of the different devices attached to those boards, as well as graphs and printouts of process operations. The program also logged data to computer 
files for later analysis. A summary of the process operation DAS is presented in Table 2.12. Labview software within the DAS allowed real-time evaluation of incoming data in the form of trend charts including pressure and temperature data, flow rates, and dewatering volume. Additional features included on-line comment log and error reporting screens which facilitated monitoring of the status of the DAS and expedient correction of any problems during test runs. The DAS real time graphical displays were used for process monitoring and real time evaluation of results. Scheduled backups of the data files to tape storage were conducted by demonstration field staff. Data was recorded in raw voltage signal level format in order to reduce the possibility for engineering unit conversion error.

\subsubsection{Soil Coring and Sampling}

Soil sampling was conducted at the X-231A demonstration site during four periods: (1) baseline characterization during August - September 1996, (2) characterization of all test cells during December 1996, (3) characterization of the horizontal reactive barrier cells in July 1997, and (4) characterization of the horizontal reactive barrier cells in December 1997. The locations of all the borings are shown in Fig. 2.10 and the sampling and analysis is outlined in Tables 2.13 through 2.15, while more details are provided for each test cell in Sections 3 and 4 . Two reconnaissance events also included soil coring and sampling. The results from these events are presented in Appendix A.

During all soil coring and sampling activities, soil cores were collected using a small trailermounted hydraulic probe rig. Soil samples were collected using a Geoprobe/Terraprobe sampling method. A 4-ft.-long $\times$ 1.375-in.-diameter shelby tube assembly with plastic liners (poly ethylenterephthalate, [PETG]) was used to collect continuous, relatively undisturbed samples and provide a lithologic log at each sample location. Upon retrieval of the assembly to the surface, the PETG liner encased soil core was removed from the sampler. Prior to subsampling, the sample core was screened with a photoionization detector (PID), primarily as a health and safety measure, but also to provide some level of field screening baseline data for the test cells. Any anomalous readings and their associated intervals were noted in the sample logbook. Starting at ground surface, soil samples were then collected at $1-\mathrm{ft}$. intervals continuously to the bottom of the borehole, $\sim 17 \mathrm{ft}$ bgs. Visual classification of the soils and locations of the fractures were noted in the sample logbook.

The soils retrieved during each coring event were analyzed at on-site field laboratories for VOCs, cations, and various physical properties (water content, $\mathrm{pH}$, Eh) (Table 2.13 through 2.15). During the baseline characterization, selected boreholes were more extensively sampled and analyzed at the PORTS laboratory. Analyses were made at the PORTS lab for VOCs using different sample preservation methods and cations. Analyses were made off-site at ORNL and CSM for grain size, color, TOC, free iron oxides, cations, anions, and microbiological properties.

Each 4-ft long core section (still within the PETG liner) was subsampled first for VOCs. The sample core and liner were cut at the desired sample interval and a subsample ( $\sim 5$ gram plug) was collected utilizing a sterile $10-\mathrm{mL}$ syringe with the end cut off. The soil plug was extruded directly into a $40-\mathrm{mL}$ vial containing $5 \mathrm{~mL}$ of reagent grade hexane and $5 \mathrm{~mL}$ of deionized (DI) water for analyses of VOCs by GCIECD. During baseline characterization, duplicate subsamples were collected and preserved using different methods to evaluate the efficacy of VOC sample collection and analysis. In this case, in addition to the hexane VOC sample analyzed at the on-site field lab, a subsample ( $\sim 5$ gram plug) was collected and placed in a separate vial containing $10 \mathrm{~mL}$ of methanol, and a third sample (20 grams) was collected and placed in an empty $40 \mathrm{~mL}$ vial with minimal headspace. Both of these samples were analyzed on-site at the PORTS laboratory (Appendix C). 
Following VOC sample collection, the remainder of the core was subsampled for other analyses. Samples were placed in appropriate sample containers immediately upon retrieval. Samples were analyzed on-site for geochemical properties. Soil samples collected for microbial analysis were not collected using sterile instruments in the field. Rather, a sufficiently large core segment $(\sim 25$ to $75 \mathrm{~g}$ ) was removed from the sample liner and immediately placed into a sterile plastic bag (Whirlpaks) and placed on blue ice and stored at $4^{\circ} \mathrm{C}$. These samples were shipped by overnight courier to ORNL for assays of microbial biomass including microbial enumeration (by colony forming units [CFU] and most probable number [MPN]), and microbial community structure.

\subsubsection{Subsurface Soil Monitoring}

Subsurface conditions within and around each test cell were monitored during the demonstration activities of fall 1996 and summer 1997. Following soil coring and sampling of the test cells during pre-test characterization, each sample borehole was instrumented with various sensors and probes. Additionally, 8-in diameter boreholes were augured and instrumented using an innovative side-wall sampler developed by FRx, Inc. There were also separate emplacements of 1-in. diameter PVC tubing in each test cell for collection of subsurface temperature measurements using a wiping thermocouple. The locations and types of instrumentation are shown on Fig. 2.10 (also see Sections 3 and 4).

\subsubsection{Hot Fluid Test Cells A and B --}

Several types of monitoring devices and/or access casings were installed in the hot fluid injection test cells: (1) sidewall piezometers for pressure/moisture content, (2) sidewall Eh probes for redox potential, (3) sidewall TDR for soil moisture content, (4) multi-level in situ thermistors for temperature, (5) wiping thermocouple casings for temperature, and (6) neutron probe access casings for soil moisture content.

For the multilevel instrumented locations, 8-in. diameter boreholes were drilled with conventional auger methods to 17-ft. bgs. Pressure piezometers, TDR soil moisture sensors, and Eh electrodes were inserted into the sidewall of the borehole (Table 2.16). Sensors were inserted at various levels above and below each fracture to provide a vertical profile of pressure, soil moisture, and redox potential variations during active operation. A 0.5 -in. diameter PVC tube was also installed in the center of the borehole to allow access for wiping thermocouple temperature measurements. The sensors were attached to tubing or cable that extended to the top of the borehole enabling quickconnect fittings to be attached to the sensors for rapid data collection. After the sensors were installed, the borehole was completed with Portland cement. Intrusion-Aid was added to all Portland cement mixes at a ratio of $(1: 100)$ to enhance sealing of boreholes. Pressure, soil moisture content, and Eh measurements were taken prior to initiation of hot fluid injection to establish baseline conditions and periodically thereafter to monitor changes in the subsurface due to hot fluid injection.

Subsurface temperature data were collected using in situ thermistors and wiping thermocouple wands. In situ multilevel thermistors were located at various locations and depths within a 2-in. diameter borehole drilled with the GeoProbe rig (Fig. 2.10). Each thermistor wand consisted of a 20-ft long, 1-in diameter PVC pipe that was cut longitudinally to permit installation of 32 thermistors along its interior. Thermistors were attached to 50-conductor computer ribbon cable that exited the upper end. The two sections of the pipe were reassembled with heat-shrink tubing to form the cylindrical wand and the interior of the wand was filled with self-expanding insulating foam. Thermistors were grouted in place in the 2 inch boreholes. During active operation, in situ thermistor data were collected every 4 to $6 \mathrm{hr}$. A second DAS, developed by FRx Inc., was used for logging temperature data from the in situ thermistors in test cells $\mathrm{A}$ and $\mathrm{B}$. The temperature logging DAS consisted of a custom 4 kilo-channel multiplexor, a thermistor signal processor with 
serial communication capabilities and a 286 generation computer. Custom software written by FRx, Inc. drove the multiplexor and signal processor and stored data in compressed binary files. All thermistor data was collected on 30 second intervals during active operation. The DAS could acquire a full round of temperature data from the thirteen thermistor wands in about 15 minutes. The thermistor DAS displayed tables of temperature during logging, but did not otherwise provide real-time review. However, the software package included utilities for on-site conversion of the compressed binary files to text files that could be manipulated and plotted with spreadsheet software.

Soil temperatures were also monitored periodically by logging 0.5 -in diameter PVC casings located at baseline coreholes with a wiping thermocouple. Temperature data from these casings were manually collected every few days during active operation.

The soil moisture tubes for use of the neutron probe consisted of a 2-in. diameter galvanized steel with a drive point. The tubes were driven to $\sim 16-\mathrm{ft}$ bgs using a pneumatic hammer. Soil moisture content measurements were collected twice with a down-hole neutron probe: once prior to initiation of hot fluid injection and once at the end of the demonstration.

Several shallow casings were installed in the test cells to provide greater detail in temperature variation data using a wiping thermocouple and pressure data using a hand-help electronic manometer. These shallow casings consisted of a 0.5 -in. diameter PVC pipe grouted into a 3-in. diameter hole drilled with a hand auger to a depth of approximately $1.5 \mathrm{ft}$. bgs. The casing was grouted to the surface.

\subsubsection{Reactive Fracture Cells C and D --}

Four types of monitoring devices and/or access casings were installed in the horizontal reactive barrier test cells: sidewall Eh electrodes, sidewall TDR, neutron probe access casings, and wiping thermocouple access casings. The multilevel instrumented locations were installed as described for test cells A and B. However, the only sensors placed into the borehole sidewall were Eh and TDR probes (Table 2.16). Sensors were inserted at various levels above and below each fracture to provide a vertical profile of redox potential and soil moisture variations throughout the demonstration. A 0.5-in. diameter PVC tube was also installed in the center of the borehole to allow access for wiping thermocouple temperature measurements. Additionally, access casings (0.5-in. PVC) for wiping thermocouple measurements were placed in each borehole and grouted to the surface.

\subsubsection{Ground Water Monitoring}

One ground water piezometer was installed in each test cell. Additionally, one background piezometer was installed between each test cell for a total of three background locations (Fig. 2.10, Appendix B). Each piezometer was installed to a depth of $17 \mathrm{ft}$. bgs using solid stem augers and standard well construction practices. All piezometers were 2 -in. diameter with 1 - $\mathrm{ft}$. long well screens located at 15.5 to $16.5 \mathrm{ft}$ bgs.

Piezometers were sampled before, during, and after testing (Appendix F). Prior to sampling, the well was purged using the micropurge method and a peristaltic pump. Samples were collected directly into the appropriate sample container and placed on blue ice. Each round of samples was analyzed on-site in the field for VOCs, selected ions ( $\mathrm{K}, \mathrm{Mn}, \mathrm{MnO}_{4}$, total $\mathrm{Fe}$, and ferrous iron), and water quality parameters ( $\mathrm{pH}$, temp, conductivity, alkalinity and DO) (Tables 2.13 through 2.15). Water quality parameters were measured at the piezometer during sample collection using a Hydrolab flow through cell. During the baseline characterization one round of ground water 
samples was also shipped off-site to ORNL for additional analyses. Ground water samples collected in 1997 were also analyzed in the field for bromide.

\subsubsection{Helium Tracer Tests}

During fall 1996, eight gas phase (helium) tracer tests were conducted in test cells A and B to determine flow paths and potential short circuiting between the fractures during hot fluid flushing. The tests are summarized in Table 2.17. Results of the tests are discussed in Section 3.

\subsubsection{Fracture Zone Characterization and Degradation Tests}

Intact cores were collected from 7 locations in all four test cells (A to D) in December 1996 -3 mon after emplacement, from 3 locations in test cells C and D in July $1997 \sim 10$ mon after emplacement, and then again from 3 locations in test cells $C$ and $D$ in December $1997 \sim 15$ mon after emplacement. These cores were collected to enable observation of subsurface conditions and sampling and analysis of the fracture contents and the soil above and below it within each of the test cells. The soil cores were collected using a hydraulic probe and a 1.75-in. diameter thin-tube sampler device. Soil cores were collected in $\sim 4-\mathrm{ft}$. lengths and each length was then divided into sections $\sim 1$-ft. long. Immediately upon sectioning, a micro-coring syringe was used to collect $\sim 5 \mathrm{~g}$ of soil which was immediately immersed in $5 \mathrm{~mL}$ of reagent grade hexane and $5 \mathrm{~mL}$ of deionized (DI) water. These sample extracts were subsequently analyzed on-site for TCE and related halocarbons. Additional subsamples were also collected and analyzed on-site for water content, $\mathrm{pH}, \mathrm{K}, \mathrm{Fe}$, and $\mathrm{MnO}_{4}$.

During the soil coring activities carried out in December 1996, July 1997, and December 1997, several cores from cells $\mathrm{C}$ and D were observed and representative cores were then collected for spatial characterization and controlled DNAPL compound degradation experiments (Fig. 2.10). In December 1996, soil cores segments were collected and examined from cell C at location B9 (7 to $9 \mathrm{ft}$. depth), and from cell D at location B10 (8 to $10 \mathrm{ft}$. depth). In July 1997, soil core segments were collected within three feet of the previously sampled locations. Core segments examined were obtained from cell C at location B13 (6 to $8 \mathrm{ft}$. depth) and cell D at location B12 (7 to $9 \mathrm{ft}$. depth). In December 1997, soil core segments were again collected within three feet of the previously sampled locations. Core segments examined were obtained from cell C at location B 14, ( 3 to $5 \mathrm{ft}, 5$ to $7 \mathrm{ft}$, and 10 to $12 \mathrm{ft}$ depths) and B15 ( 3 to $5 \mathrm{ft}, 6$ to $8 \mathrm{ft}$, and 11 to $13 \mathrm{ft}$ depths) and from cell D at location B14 (8 to $13 \mathrm{ft}$ depth). During each of the three monitoring events, each core segment was examined on-site in a temperature controlled laboratory trailer following the methods outlined below. Precleaned stainless steel knives were used for the core dissection and sampling, and efforts were made to minimize cross-location transfer of substances or properties to be analyzed for.

The core segment was left in the acrylic sampling tube and was brought into the laboratory from the field shortly after collection. The soil core was carefully extruded onto a clean aluminum foil covered work surface. Then using a precleaned knife, a thin slice of soil was removed along the length of the core to expose fresh soil. Soil redox was measured at discrete intervals along the length of the core above and below the reactive fracture by pressing a platinum microelectrode and reference electrode several $\mathrm{mm}$ beneath the freshly exposed soil surface. The electrode was calibrated to Zobell's solution before and after each core was examined. Then the outer few millimeters of soil from the entire core length were carved off, and the core was cut into $\sim 1-\mathrm{cm}$ thick sections at selected depths above and below the fracture. Each section was homogenized, and then the soil media was distributed into different containers for different purposes. 
During the December 1996 studies, soil samples were collected at $\sim 4$ to 6 selected locations including those above and below the fractures. These were distributed between several containers for on-site and off-site analyses as follows.

$40 \mathrm{~mL}$ volatile organic analyses (VOA): TCE degradation with DNAPL contaminated ground water (GW) and reaction (rxn) time 1;

40 mL VOA: A companion vial for TCE degradation with GW and rxn time 1 but used only for post-rxn $\mathrm{pH}$ and also $\mathrm{MnO}_{4}$ - for cell $\mathrm{D}$;

$15 \mathrm{~mL}$ tube: Soil $\mathrm{pH}$; and

Alum. pan: Soil water content on-site, followed by soil TOC analyses off-site.

On-site analyses were made for $\mathrm{pH}$ in field moist soil using 1:1 solid to distilled water extracts, rotated for $30 \mathrm{~min}$., then centrifuged for $15 \mathrm{~min}$. Water content was determined by gravimetric analyses before and after drying for 12 to $24 \mathrm{hr}$ at $110^{\circ} \mathrm{C}$. $\mathrm{MnO}_{4}$ was measured on a soil extract (10-g soil and $15-\mathrm{mL}$ DI water) via absorbance at $525 \mathrm{~nm}$ with a Hach DR/2000 spectrophotometer. Oven-dried soil from the water content analyses were refrigerated and transported off-site where analyses were made for soil TOC by a digestion and electrochemical procedure.

To determine the treatment capacity of the reactive media in the fracture as well as the soil above and below it, a batch degradation test was completed on-site using DNAPL contaminated ground water from the PORTS X-701B site (well 76G). This ground water was from a known DNAPL contaminated subsurface region and previous characterization work revealed TCE at concentrations of $\sim 150 \mathrm{mg} / \mathrm{L}$. Ground water from well $76 \mathrm{G}$ was collected within $24 \mathrm{hr}$ of the batch test and containerized in 1-L glass jars with Teflon-faced screw tops. Immediately after placement of the soil into a 40-mL VOA vial, the vial was filled with TCE laden ground water and then sealed. All of the reaction vials were prepared and then they were placed on a vertical rotation table where they were continuously rotated for a period of $24 \mathrm{hr}$. After the reaction period had passed, the reaction in each $40-\mathrm{mL}$ vial was quenched by adding $\sim 2 \mathrm{~g}$ of sodium thiosulfate to it. Subsequently, a 5$\mathrm{mL}$ sample of the reaction vial contents was taken and immersed in hexane in a $15-\mathrm{mL}$ glass vial with a Teflon-faced solid screw cap. These samples were refrigerated until analyses were made on-site for TCE and related VOCs using a Hewlett Packard (HP) 5890 GC with ECD and autosampler. Post reaction analyses were also made on-site in the companion vial for $\mathrm{pH}$ (combination electrode) and $\mathrm{MnO}_{4}$ (spectrophotometry).

During the July 1997 studies, samples were collected at $\sim 8$ selected distances above and below the fractures. Subsamples of the core segments were collected and distributed between several containers for on-site and off-site analyses as follows.

40 mL VOA: TCE degradation with DNAPL contaminated GW (GW1) and rxn time 1; also post-rxn pH and Cl-; also $\mathrm{MnO}_{4}$ - for cell D;

40 mL VOA: TCE degradation with DNAPL contaminated GW (GW1) and rxn time 2; also post-rxn $\mathrm{pH}$ and $\mathrm{Cl}$-; also $\mathrm{MnO}_{4}$ - for cell $\mathrm{D}$;

$40 \mathrm{~mL}$ VOA: TCE degradation with diluted DNAPL contaminated GW (GW2) and rxn time 1; also post-rxn $\mathrm{pH}$ and $\mathrm{Cl}$-; also $\mathrm{MnO}_{4}$ - for cell $\mathrm{D}$;

40 mL VOA: TCE degradation with diluted DNAPL contaminated GW (GW2) and rxn time 2; also post-rxn pH and $\mathrm{Cl}$-; also $\mathrm{MnO}_{4}$ - for cell $\mathrm{D}$;

$15 \mathrm{~mL}$ tube: Soil $\mathrm{pH}$; and

Alum. pan: Soil water content on-site, followed by soil TOC analyses off-site.

Soil core segments were also taken from the D cell at 6 locations (M1-M6) for analyses of soil $\mathrm{MnO}_{4}$. Analyses were made on-site as follows. Soil $\mathrm{pH}$ was made on a 1:1 solid to DI water extract, rotated for $30 \mathrm{~min}$., then centrifuged for $15 \mathrm{~min}$. Water content was determined by drying for 12 to $24 \mathrm{hr}$ at $110^{\circ} \mathrm{C}$. $\mathrm{MnO}_{4}$ was measured on a $10 \mathrm{~g}$ soil: $15 \mathrm{~mL}$ DI extract via absorbance at 
$525 \mathrm{~nm}$ with a Hach DR/2000 spectrophotometer. Analyses were also made off-site as follows. Soil TOC was measured by a digestion and electrochemical procedure using the dry samples from the water content analyses. Chloride analyses were made on a 1:1 water extract using a Dionex ion chromatograph.

A batch degradation test was completed during July 1997 using DNAPL contaminated ground water. However, this test was conducted using DNAPL ground water from the X-231A site (piezometer X231A-BGP3), undiluted and diluted to yield two TCE concentrations, and with reaction occurring over two time periods. A free organic phase was present in ground water from this well but samples used for the tests were free of observable free phase organics. Ground water GW1, was undiluted X231A-BGP3 ground water. Ground water GW2, was ground water GW1 diluted with DI water at $\sim 1$ part GW1 plus $\sim 9$ parts DI water. Within several hours of adding $\sim 5 \mathrm{~g}$ of moist soil to each $40-\mathrm{mL}$ vial, the prescribed ground water was added to completely fill each vial. The vials were capped with Teflon-faced solid cap screw tops and then rotated during the reaction time. After reaction for either of two different time periods, a 5-mL sample of the reaction vial was taken and immersed in hexane in a $15-\mathrm{mL}$ glass vial with a Teflon-faced solid cap. Samples were refrigerated until analyses were made on-site for TCE and related VOCs using an HP5890 GC with ECD and autosampler. Post reaction analyses were also made on-site for $\mathrm{pH}$ (combination electrode) and $\mathrm{MnO}_{4}$ (spectrophotometry) and off-site for chlorides (ion chromatography).

The micromorphology of the iron was of interest since the reductive dechlorination requires a reactive surface, and there was some question as to whether the iron surface would corrode or otherwise foul after extended emplacement in the wet silt clay soils. A comparison was thus made of the fresh iron particles used to create the fractures versus the used iron particles collected from a fracture during July 1997, 10 mon after initial emplacement. A sample of unused iron particles was obtained from a bulk sample of the raw iron used during the fracturing operation in September 1996. This sample had been stored in a double, zip-closure bag, that was kept in a laboratory at CSM in the dark, under low humidity, and at $20^{\circ} \mathrm{C}$ temperature. The used iron particles were obtained from a core segment taken from cell C at location B9. The samples were stored in glass jars and refrigerated until analyses were made at ORNL. Scanning electron microscopic analyses were made of subsamples from each specimen and photomicrographs were made to record surface features.

During the December 1997 studies, soil samples from the core segment from cell D at location B14 ( 8 to $13 \mathrm{ft}$ depth) were collected at $\sim 7$ to 12 selected locations including those above and below the fracture. These were distributed between several containers for on-site analyses by the same methods as described above:

$15 \mathrm{~mL}$ tube: Soil $\mathrm{pH}$;

$50 \mathrm{~mL}$ tube: Soil manganate; and

Alum. pan: Soil water content on-site.

No DNAPL compound degradation tests were completed with samples from cell $\mathrm{D}$ during December 1997.

Also during December 1997, soil samples were collected from two locations above and below each of three fracture intervals in cell C at location B14. These were distributed between several containers for on-site analyses by the same methods as described above:

$15 \mathrm{~mL}$ tube: Soil $\mathrm{pH}$; and

Alum. pan: Soil water content on-site. 
To determine the reaction kinetics of the iron particles after extended subsurface exposure, batch kinetics tests were completed using iron particles retrieved from the shallowest two fractures encountered at locations B14 and B 15. The iron particles from each of the four fracture intervals were combined and homogenized. A batch degradation test was then completed on-site using DNAPL contaminated ground water from the PORTS X-231A site (piezometer X231A-BGP3) that was diluted $1: 10$ or $1: 100 \mathrm{v} / \mathrm{v}$ with deionized water to yield TCE concentrations of $\sim 25$ and 2 $\mathrm{mg} / \mathrm{L}$, respectively. Subsamples of the retrieved iron $(4 \mathrm{~g})$ were distributed between four series of replicate 40-mL VOA vials, each of which included vials to be sacrificed for analysis of TCE and related halocarbons at up to six time points. One set of each of the two ground water concentrations were reacted at $20 \mathrm{C}$ while the companion set was reacted at $5 \mathrm{C}$. Immediately after placement of the retrieved iron into a $40-\mathrm{mL}$ VOA vial, the vial was filled with TCE laden ground water and then sealed. All of the reaction vials were prepared and then they were placed on their sides and held in the dark. After different periods of reaction, a 5-mL sample of a specified reaction vial's contents was taken and immersed in hexane in a 15-mL glass vial with a Teflonfaced solid screw cap. These samples were refrigerated until analyses were made on-site for TCE and related VOCs using a Hewlett Packard (HP) 5890 GC with ECD and autosampler. Post reaction analyses were also made on-site for $\mathrm{pH}$ (combination electrode). The remaining reaction vials were vigorously shaken and then placed back on their sides.

For comparison purposes, subsamples of unused iron from the same batch used for the fracturing in September 1996 were also used for kinetics experiments. Subsamples of the unused iron (4 g) were distributed between six series of replicate $40-\mathrm{mL}$ VOA vials, each of which included vials to be sacrificed for analysis of TCE and related halocarbons at up to six time points. One set of each of the three ground water concentrations $(\sim 250,25$ and $2 \mathrm{mg} / \mathrm{L}$ TCE) were to be reacted at $20 \mathrm{C}$ while the companion set was to be reacted at 5C. Immediately after placement of the iron into a 40$\mathrm{mL}$ VOA vial, the vial was filled with TCE laden ground water and then sealed. All of the reaction vials were prepared and then they were placed on their sides (i.e., due to the number of vials, continuous rotation was not possible). After varying periods of reaction, a 5-mL sample of the reaction vial contents was taken and immersed in hexane in a $15-\mathrm{mL}$ glass vial with a Teflon-faced solid screw cap. These samples were refrigerated until analyses were made on-site for TCE and related VOCs using a Hewlett Packard (HP) 5890 GC with ECD and autosampler. Post reaction analyses were also made on-site for $\mathrm{pH}$ (combination electrode).

\subsubsection{Injection/Percolation Tracer Tests}

After collection of the soil cores during July 1997, test cells C and D were set up to assess more active operation with water injected into the shallow sand-filled fracture for infiltration and percolation downward through the underlying reactive-fracture zone (Fig. 2.11). For this test, tapwater was used due to constraints on ground water extraction and injection. However, a fullscale application was envisioned to also include a pseudo-closed loop recirculation achieved by the extraction of ground water from a deeper sand-filled fracture with subsequent reinjection to a shallow sand-filled fracture. During the test period, tapwater from a local fire hydrant was used to fill a 500-gal poly tank which was supplemented with $\mathrm{NaBr}$ to yield a bromide concentration of $\sim 100 \mathrm{mg}-\mathrm{Br} / \mathrm{L}$. The feed water from the tank was pumped to the shallow fractures in both test cells $\mathrm{C}$ and $\mathrm{D}$ based on demand as monitored by a low- and high-level sensor system in each cell. When the low-level sensor in a cell was triggered, the pump was activated and flow occurred through a feed tube down to the fracture level until the level in the access tube reached a high-level sensor. Then flow would cease until the water infiltrated into the fracture and soil around it, thereby lowering the level and triggering another dose event. The occurrence of each dose event to each cell was monitored by an electrical counter as well as the DAS. In addition, the cumulative volume was recorded by a simple water meter. The event counter and water meter readings were made manually on a periodic basis while the DAS collected the event occurrence data continuously. 
Water delivery in the mode described above continued from approximately July 14 through September 4, 1997.

\subsection{FIELD LABORATORY METHODS}

The majority of the analytical work was completed on-site in field laboratories. This section describes the materials and methods employed.

\subsubsection{Organics Analysis}

Before collection of soil samples, each $40 \mathrm{~mL}$ vial was prepared as follows: a sample label was attached, $5 \mathrm{~mL}$ of hexane and $5 \mathrm{~mL}$ of DI water were placed in each vial, the vial was weighed, and this "tare" weight was recorded on the vial's label. These vials were placed in a cooler with Blue Ice and taken to the field for sample collection. Unused vials and vials containing samples were stored in separate coolers. Upon return to the field laboratory, each vial was weighed and the weight recorded on the vial's label. This method provides a true weight of the field moist soil in the vial. The DI water in the vial helps break up the clay soils while the hexane absorbs the contaminants of interest. Soil sample vials were placed on a shaker for 30 minutes prior to extraction of an aliquot of the hexane phase for GC/ECD analysis.

Ground water samples were collected by filling a $40-\mathrm{mL}$ glass VOA vial in the field. Care was taken to ensure zero headspace in each sample vial. In the field laboratory, $5 \mathrm{~mL}$ of the ground water was removed from the ground water vial and placed in a $15 \mathrm{~mL}$ vial containing $5 \mathrm{~mL}$ of hexane. In approximately half the ground water samples, the $15 \mathrm{~mL}$ vial was pre-weighed with just the hexane, then weighed again after addition of the ground water -- providing an accurate measure of ground water added to the vial. In cases where the vial had not been pre-weighed, the volume of ground water was assumed to be $5 \mathrm{~mL}$. As a check, a subset of samples were weighed and showed that sample volume was consistently between 4.95 and $5.03 \mathrm{~mL}$ using the same automatic pipette for sample transfer.

All samples were prepared for organics analysis by removing $1 \mathrm{~mL}$ of the hexane phase from the sample vial and placing it in a $2-\mathrm{mL}$ septa top glass vial. Each $2-\mathrm{mL}$ vial was labeled with the appropriate sample number and loaded into the autosampler for GC analysis.

Following the GC runs, sample reports were analyzed to determine if any of the samples exceeded the calibration range of the GC. These samples were diluted as necessary to bring them into the calibration range. In subsequent analysis of samples from similar media, the earlier sample's dilution was used as a guide. This was to help avoid contamination of the GC and its column. If these subsequently diluted samples showed a non-detect of TCE, the samples were reanalyzed at a lower dilution. The GC logbook contained the dilution of each sample analyzed.

All VOC samples were analyzed on a HP 5890 Series II Gas Chromatograph equipped with a $30 \mathrm{~m}$ x $0.53 \mathrm{~mm}$ capillary column (HP-624), a packed injection port, and an ECD. The GC oven started at $50^{\circ} \mathrm{C}$ and was held for 2 minutes, then ramped at $6^{\circ} \mathrm{C} / \mathrm{min}$ to $80^{\circ} \mathrm{C}$ for a total analysis time of 7 min. The GC was calibrated for 1,1-DCE, cis-1,2-DCE, trans-1,2-DCE, TCE, PCE, TCA, 1,1DCA, and methylene chloride. A calibration curve was generated from standards of 4, 40, 200 , $400,800,1400$, and $2000 \mathrm{ppb}$ of TCE; the standards for the other contaminants were four (4). times the TCE standard. Standards were prepared from custom mix standards diluted to create the range of concentrations. The concentration of individual VOCs in all samples was determined by integrating the area under individual peaks. Following initial calibration, a standard was run every ten samples to check retention times and concentration determination. 
One-half (0.5) microliter of the hexane extractant liquid was injected directly on the column using a HP7673 autosampler. The autosampler and GC were controlled by a computer running HP's ChemStation software. The ChemStation software was provided with the dilution factor of individual samples and, therefore, calculated the concentration of contaminant. The lab technician entered the sample weight and contaminant concentrations from the GC into a spreadsheet. The spreadsheet was configured to calculate the concentration of contaminant per gram or per liter of sample. Paper and electronic copies of individual chromatograms were stored in logbooks and on diskettes.

Organics analysis quality assurance/quality control (QAVQC) procedures were routinely followed. Mechanical pipettes were checked for accuracy by weighing the amount of solution dispensed by the pipette. Mass balances were calibrated daily with known standards. New pipette tips and vials were used for all sample transfers and dilutions, so no cleaning and reuse occurred.

The first vial in the autosampler and every tenth vial from then on were standards of various concentrations, as noted in the GC logbook. Every twentieth vial contained a blank, consisting of $1 \mathrm{~mL}$ of hexane in an autosampler vial. These blanks would reveal if the syringe, septa, or column became contaminated during the run of samples. None of the hexane blanks revealed contamination of the equipment.

\subsubsection{Inorganics Analysis}

For the inorganic soil analyses, extractions were prepared from each soil sample collected. For $\mathrm{pH}$ analysis, equal wts. $(\sim 15 \mathrm{~g})$ of soil and DI water were placed in a $50-\mathrm{mL}$ centrifuge tube. For $\mathrm{MnO}_{4}$ analyses, $10 \mathrm{~g}$ of soil were combined with $15 \mathrm{~mL}$ of DI water in a $50-\mathrm{mL}$ centrifuge tube. For potassium analysis, $7.5 \mathrm{~g}$ of soil plus enough DI water to make $25 \mathrm{~mL}$, and one potassium extract powder pillow (HACH \#14324 - acid/fluoride extraction) were placed in a 50-mL centrifuge tube. For iron and manganese analysis, $12.5 \mathrm{~g}$ of soil, $25 \mathrm{~mL}$ of DI water, and $0.2 \mathrm{~mL}$ of concentrated hydrochloric acid $(12 \mathrm{~N})$ were placed in a $50-\mathrm{mL}$ centrifuge tube. Soil and water were measured using an electronic balance accurate to $0.01 \mathrm{~g}$.

After preparing the above extractions, the $50-\mathrm{mL}$ centrifuge tubes were placed on a shaker for 30 minutes. The shaken tube was allowed to settle overnight, unopened. The liquid in the $50-\mathrm{mL}$ centrifuge tube was decanted into a $15-\mathrm{mL}$ centrifuge tube. The $15-\mathrm{mL}$ tubes were centrifuged at $\sim 14,000 \mathrm{rpm}$ for 15 minutes.

The supernatant from the respective extractions was analyzed using a Hach DR2000 spectrophotometer. Manganese, total iron, and ferrous iron were analyzed from the acid extract. Potassium was analyzed from the acid/fluoride extract, and manganate was analyzed from the water extract. Dilutions were prepared as required to bring the samples into range for the respective methods. All dilutions used DI water and were recorded in the field laboratory logbook.

The Hach DR2000 spectrophotometer was used to directly analyze the ground water samples for potassium, iron (total and ferrous), manganese, and manganate. Dilutions were prepared using DI water as needed to bring the samples into range for the respective method. All results and dilutions were recorded in the field laboratory logbook. Manganate analysis was performed by obtaining a reading of the direct absorbance at $525 \mathrm{~nm}$ wavelength. The calibration curve was generated using known concentrations of manganate. The result from the spectrophotometer was then converted to manganate using the generated curve.

Total alkalinity (as calcium carbonate) was measured with a Hach digital titration and sulfuric acid cartridges. Acid $(1.6 \mathrm{~N})$ was added until the $\mathrm{pH}$ of the sample was reduced to 5.1 as measured with a calibrated $\mathrm{pH}$ probe. 
Bromide analysis was performed on ground water samples collected in the summer 1997 activities prior to and during the addition of $\mathrm{NaBr}$ spiked water to test cells $\mathrm{C}$ and $\mathrm{D}$, as part of the forced advection phase of these test cells. Samples were analyzed for bromide using an Orion bromide selective electrode and a double junction reference electrode connected to a Beckman meter measuring millivolts of output. Six standards of known concentration $(0.8,1.6,3.2,8.0,80$, and $800 \mathrm{ppm}$ as bromide) were used to prepare a calibration curve. Standards were analyzed each day samples were analyzed to check the calibration of the probes used.

\subsubsection{Physical Parameters}

As part of the inorganic soil analyses, extractions were prepared from each soil sample collected from equal parts $(\sim 15 \mathrm{~g})$ of soil and water placed in a $50-\mathrm{mL}$ centrifuge tube. This extract was used for the $\mathrm{pH}$ analysis. After preparing the extractions, the $50-\mathrm{mL}$ centrifuge tubes were placed on a shaker for $30 \mathrm{~min}$. The shaken tube was allowed to settle overnight, unopened. The liquid in the 50 -mL centrifuge tube was decanted into a $15-\mathrm{mL}$ centrifuge tube. The $15-\mathrm{mL}$ tubes were centrifuged at $\sim 14,000 \mathrm{rpm}$ for $15 \mathrm{~min}$. After decanting the liquid from the $50-\mathrm{mL}$ centrifuge tube into the $15-\mathrm{mL}$ centrifuge tube, the sample $\mathrm{pH}$ was measured by placing a calibrated $\mathrm{pH}$ probe directly into the extract remaining in the 50 -mL centrifuge tube.

Eh was measured directly in the soil core. When possible it was measured at the time the soil was collected. However, it was often measured in the field laboratory after sample collection. Eh was measured by exposing a fresh soil face and inserting a platinum electrode and reference electrode in the soil. Soil temperature was measured at the same time. The Eh probe was checked daily with fresh Zobell's solution and results were recorded in the field laboratory logbook.

Water content of the soil samples was determined gravimetrically. Approximately $20 \mathrm{~g}$ of field moist soil was placed on a clean drying tin, the soil was chopped into small pieces $(<1 \mathrm{~cm})$, and the soil plus pan was weighed and the weight recorded. The soil was dried in a $110^{\circ} \mathrm{C}$ oven for at least one hour. The samples were removed from the oven and placed in a vacuum desiccator containing Drierite to allow them to cool. The dry soil and pan were weighed and the weight recorded in the field laboratory logbook. Water content was calculated on an oven-dry soil weight basis.

Physical parameters ( $\mathrm{pH}$, temperature, and conductivity) of the ground water were measured as the samples were collected with a Hydrolab Multiprobe ${ }^{\circledR}$. The Hydrolab was calibrated each day samples were collected. Dissolved oxygen was also analyzed as the ground water was collected using Hach AccuVac® vials (high range) and a HACH DR2000 spectrophotometer. 
Figure 2.1. Location of the DOE Portsmouth Gaseous Diffusion Plant.

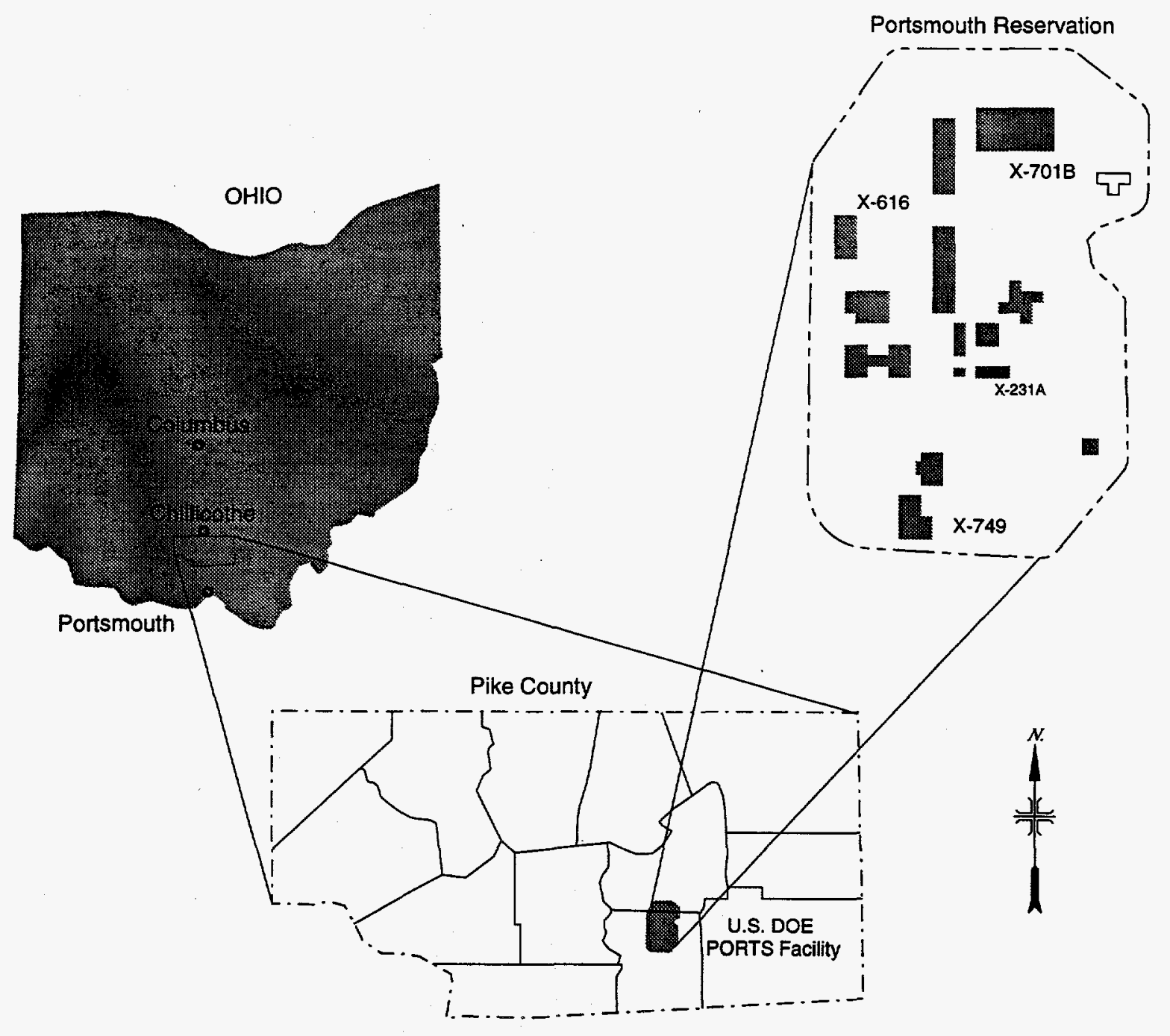


Figure 2.2. Location of the X-231A unit at the DOE Portsmouth Plant.
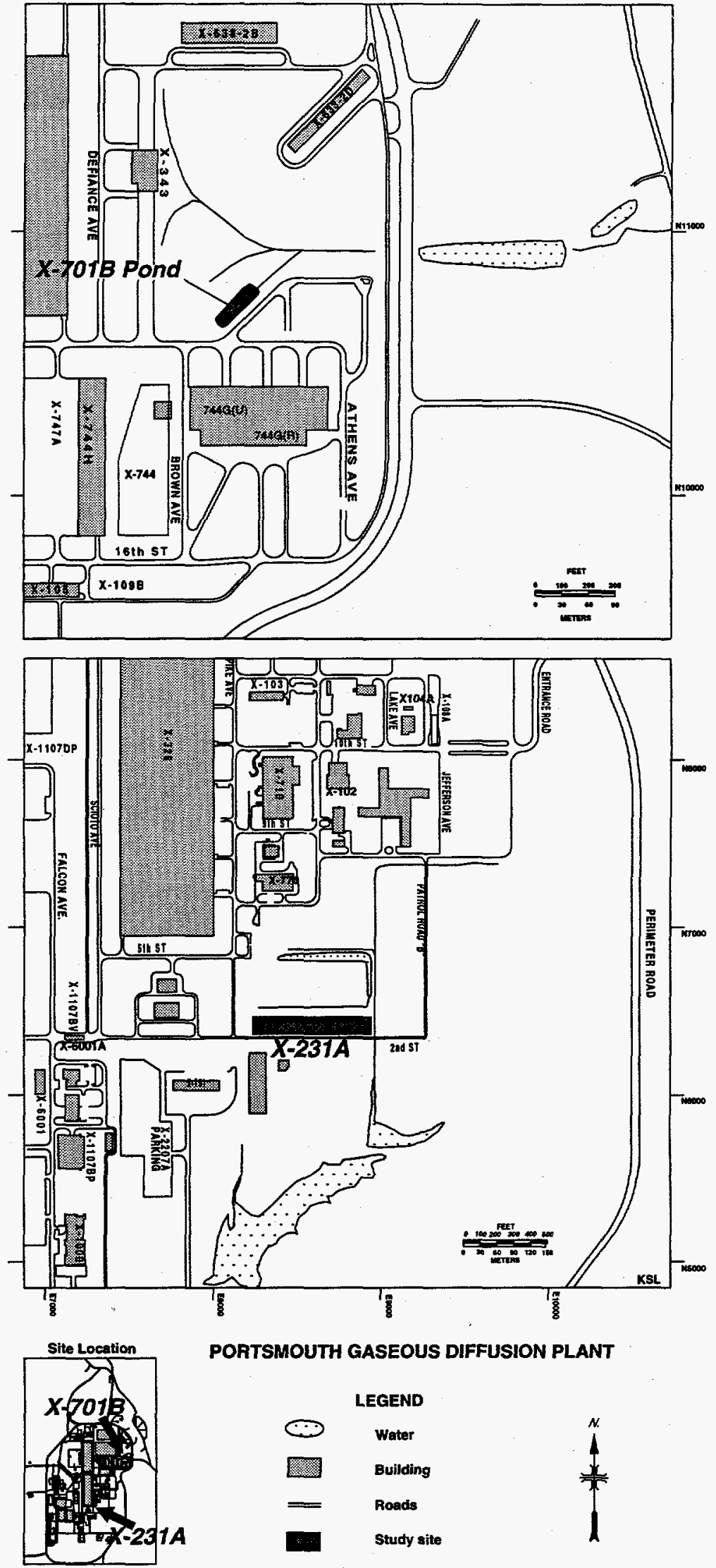

PORTSMOUTH GASEOUS DIFFUSION PLANT

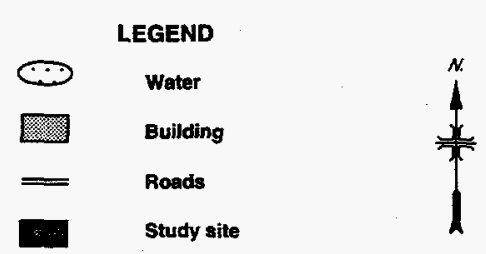


Figure 2.3. Representative lithology of the shallow subsurface at the DOE Portsmouth Plant.

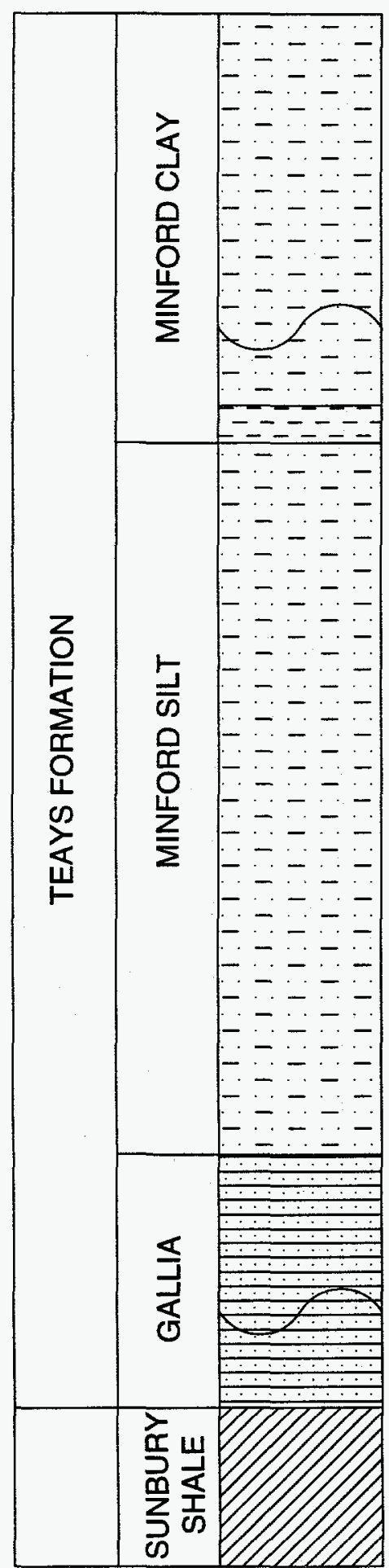

CL SILTY CLAY: yellowish brown (10YR 5/8) with gray mottling (10YR 5/1), firm, slightly moist, scattered organic staining.

CL SILTY CLAY: yellowish brown (10YR 5/4) becoming light gray to gray (10YR 7/1-6/1), moist, firm.

CL CLAY: reddish brown (5YR 4/4), moist, dense, common MnO staining.

ML CLAYEY SILT: yellowish brown (10YR 6/6), moist, firm, sandy in part, angular sandstone pebble and gravels.

ML CLAYEY SILT: as above, grading to silty sand at $20 \mathrm{ft}$.

SM SILTY SAND: light olive brown (2.5Y 5/4) mottled with gray silt, fine grained, abundant limonite staining, moist, friable.

SM SILTY SAND: olive to olive yellow (5Y 5/4-6/6), moist, becoming wet with depth, angular pebbles.

SHALE: black carbonaceous.

PSTRAT 


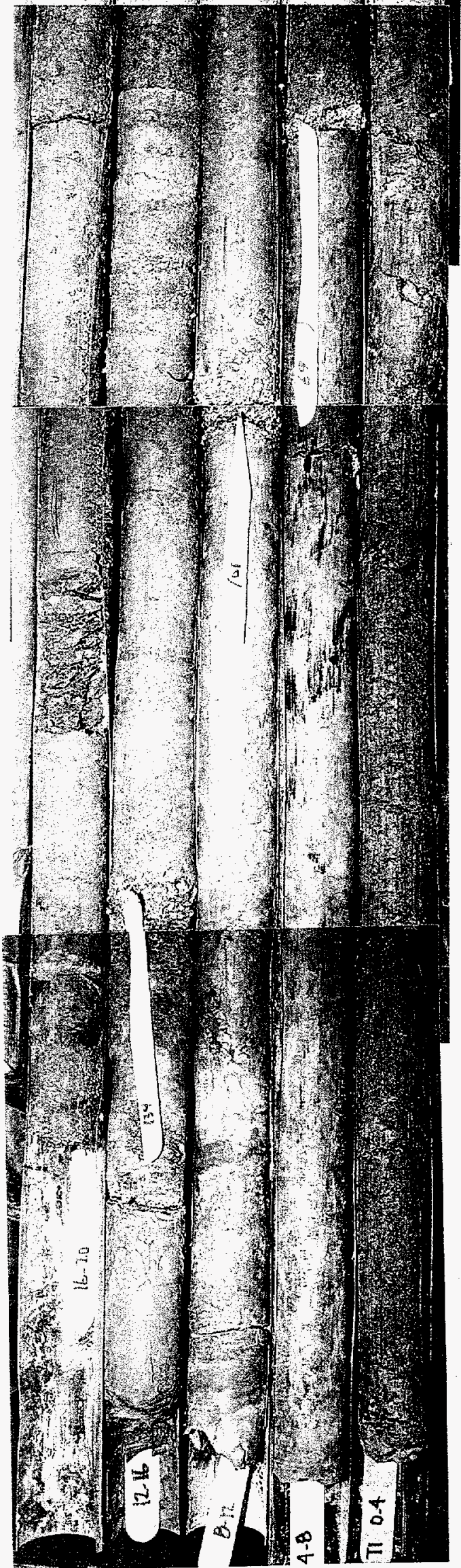


Figure 2.5. Photograph of the established demonstration test area at the X-231A site.

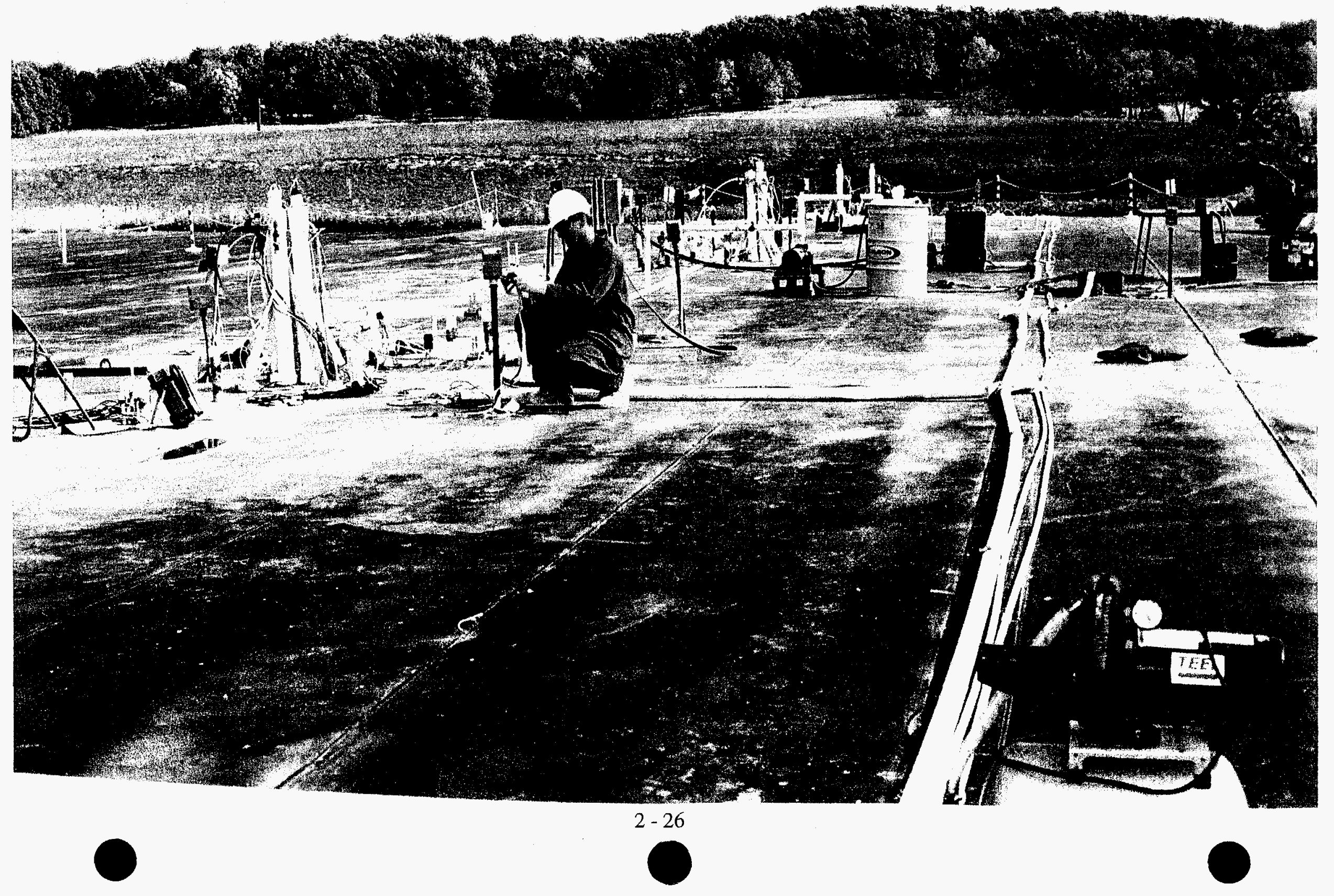


Figure 2.6. Location of May 1996 reconnaissance probe holes and historical borings within the X-231A site.

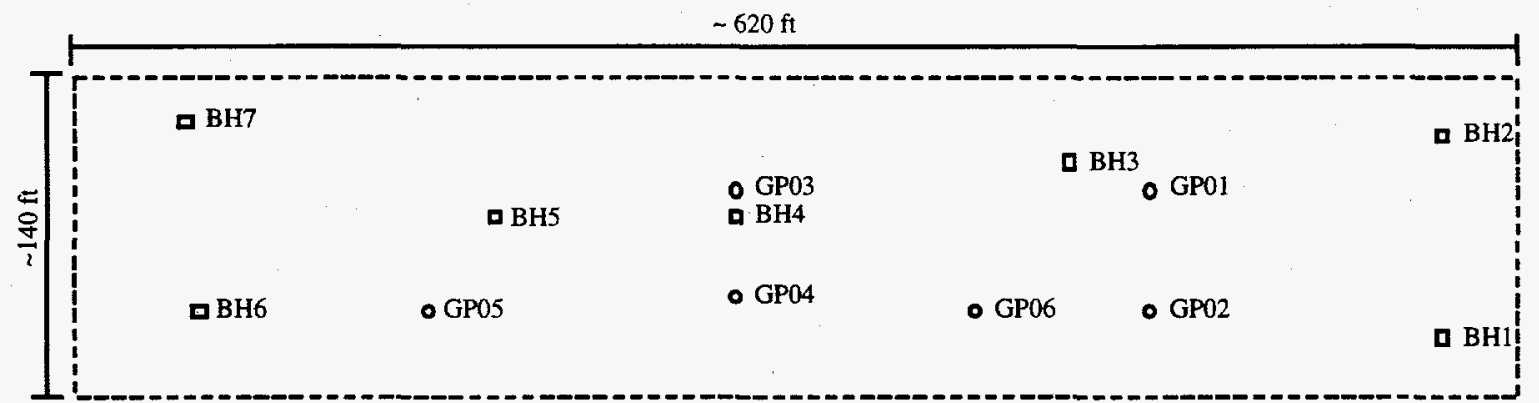

PORTS Perimeter Patrol Road

- 1996 ORNL Geoprobe reconnaissance soil boring location (approximate)

- 1988 ASI soil boring location (approximate)

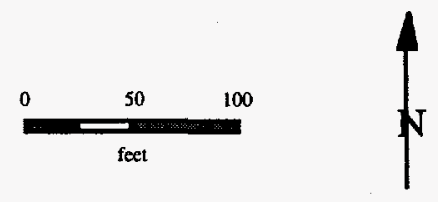

-- approximate location of the X-231A cap 
Figure 2.7. Location of the pilot-test fracture cells at the PORTS CTS.

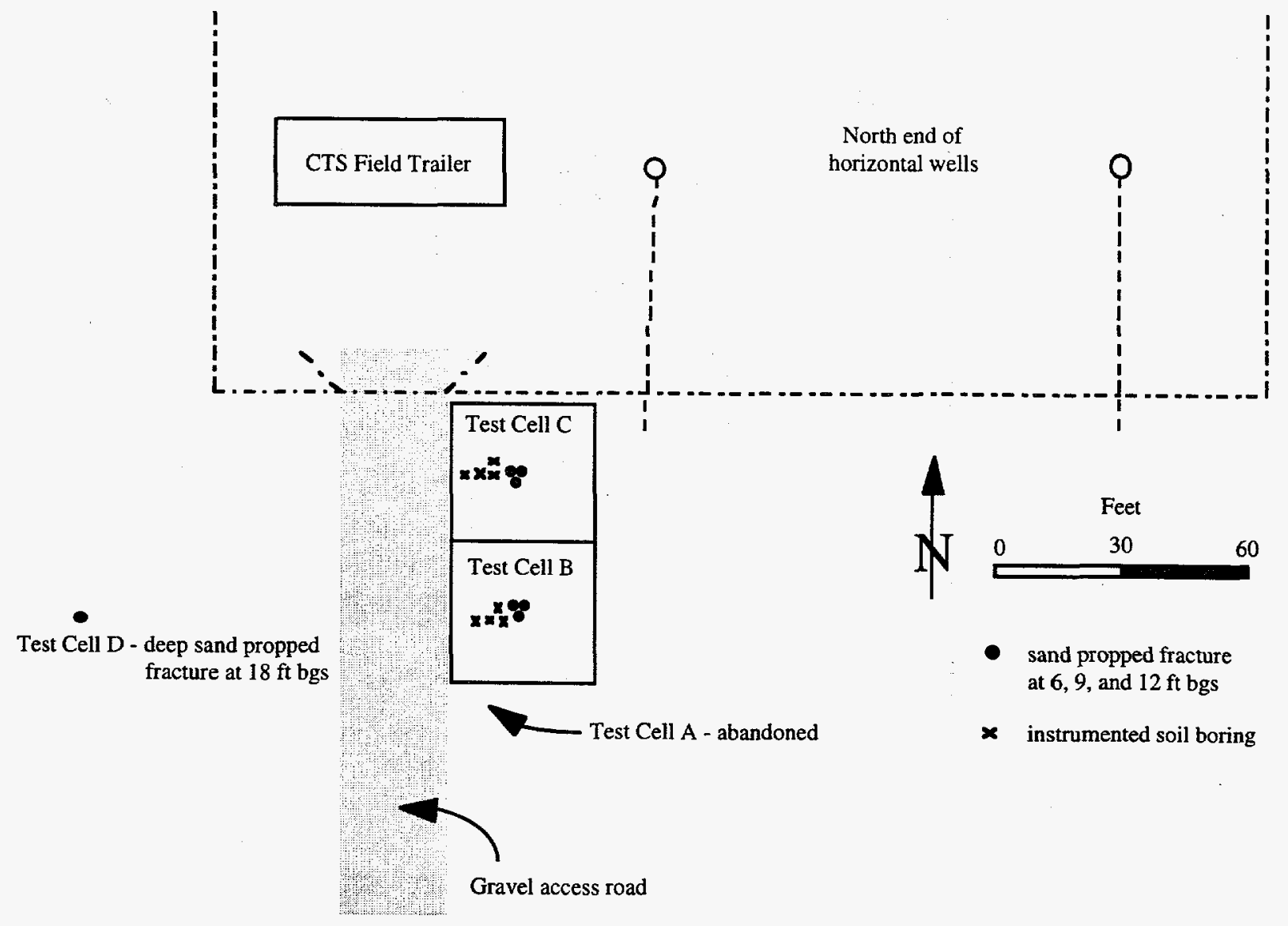


Figure 2.8. X-231A test cell layout and baseline characterization soil boring locations.

(a) Overview of southeast corner where test site was located.

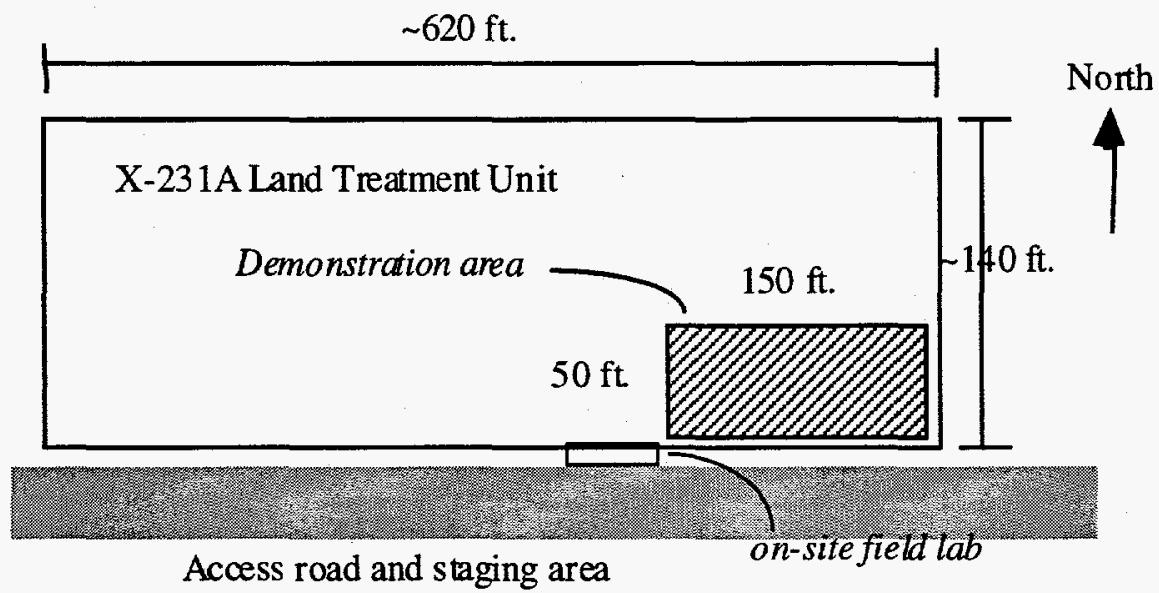

(b) Test cells A to D and the initial borings made after fracture emplacement.

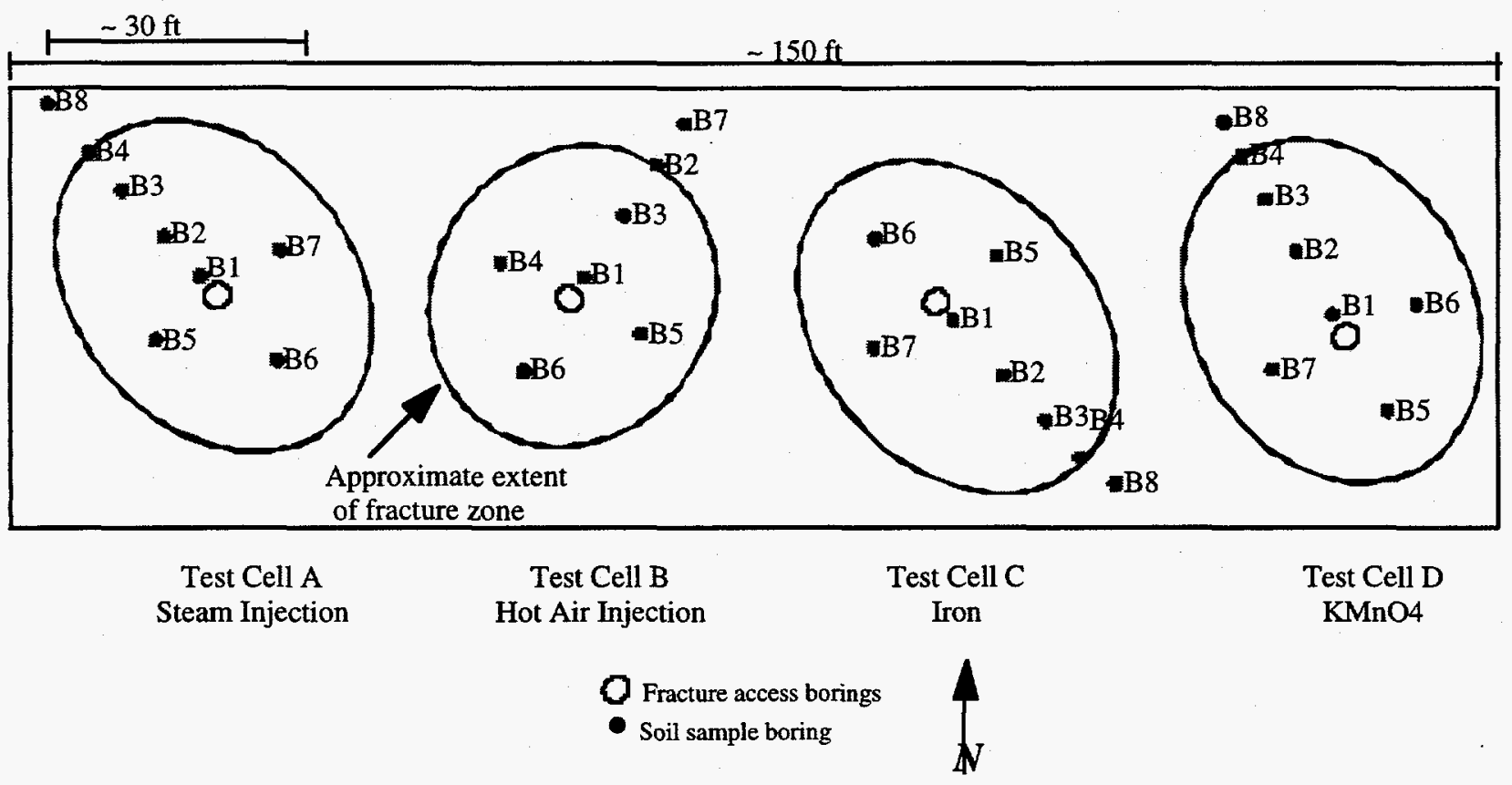


Figure 2.9. Cross-section of the test cells at the X-231A demonstration site.

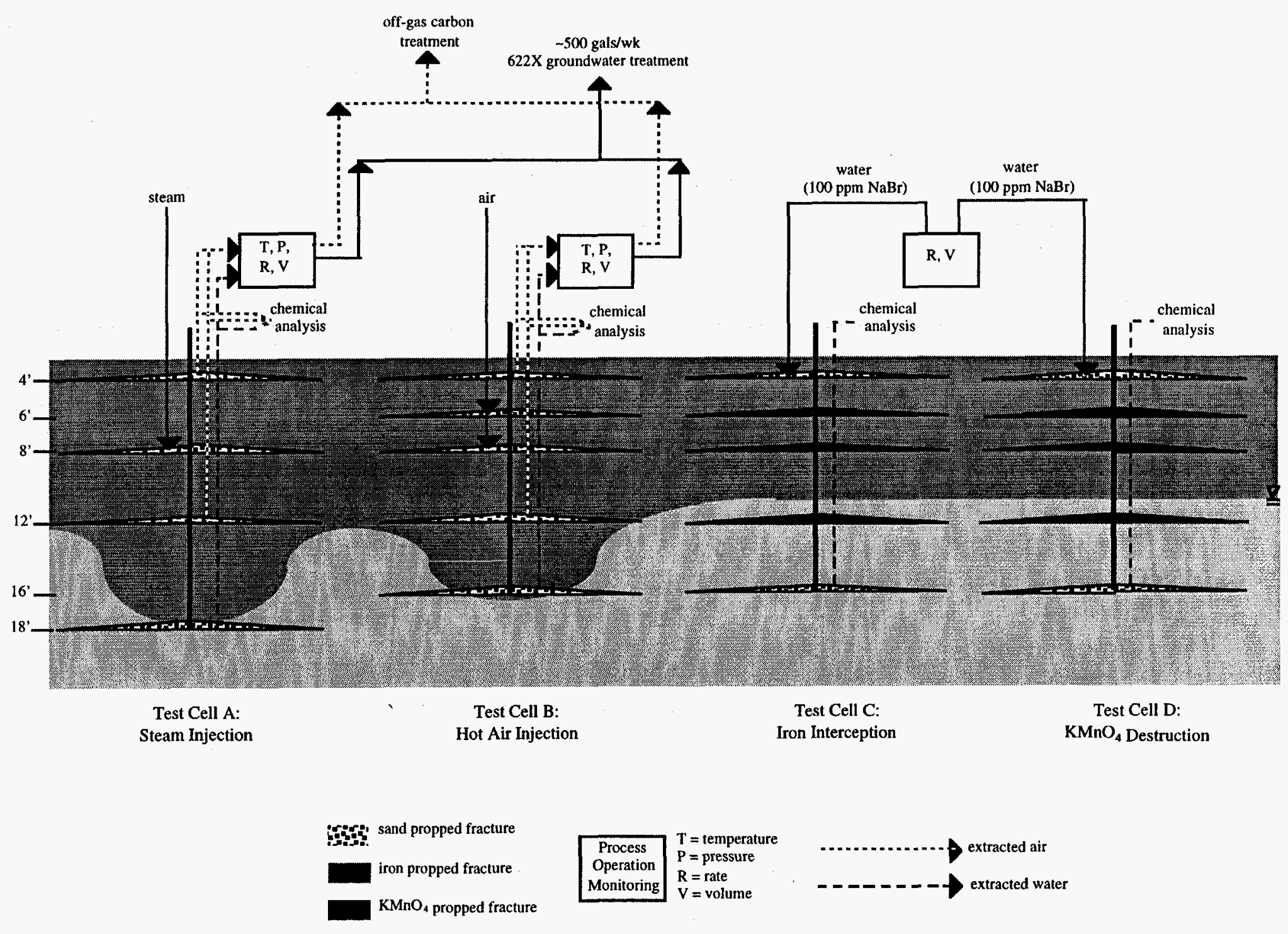


Figure 2.10. $\mathrm{X}-231 \mathrm{~A}$ demonstration site plan vie monitoring locations.

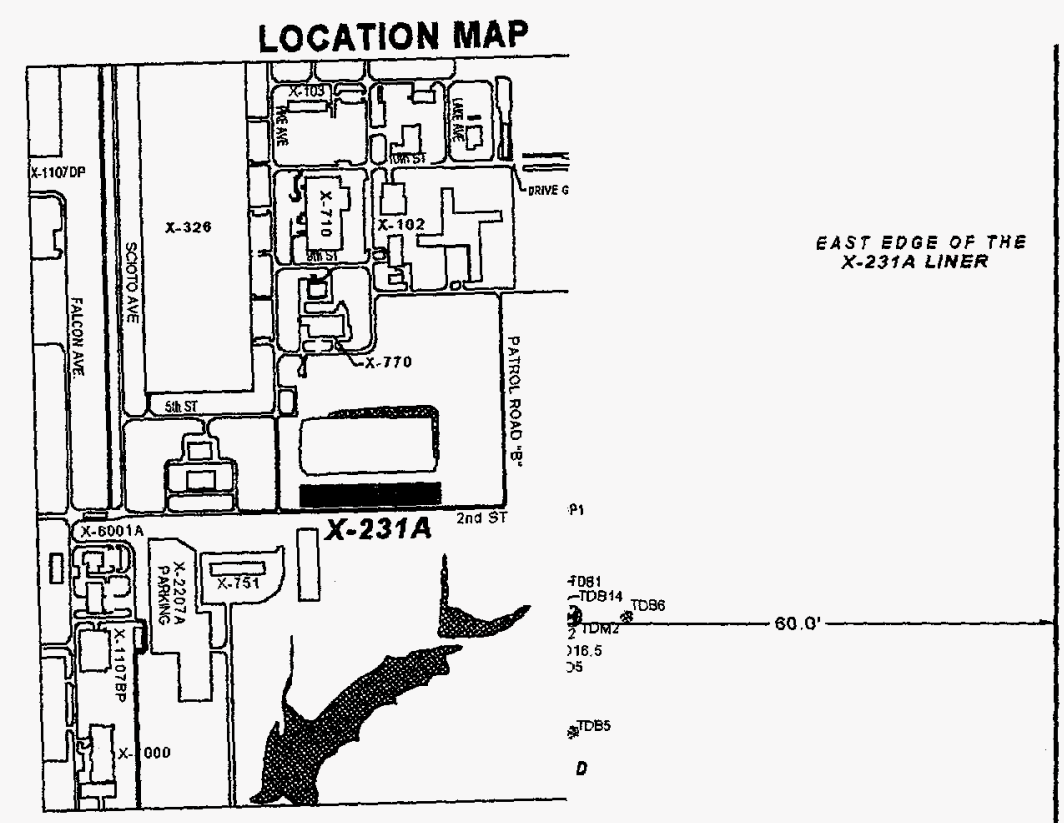

$\frac{6 P 1}{30}$

$\sqrt{ }$

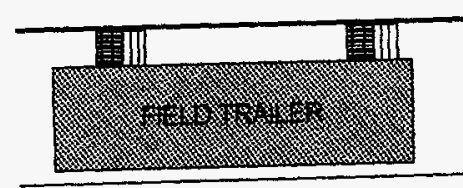


Figure 2.11. Illustration of the water infiltration/percolation system used for test cells C and D during summer 1997.

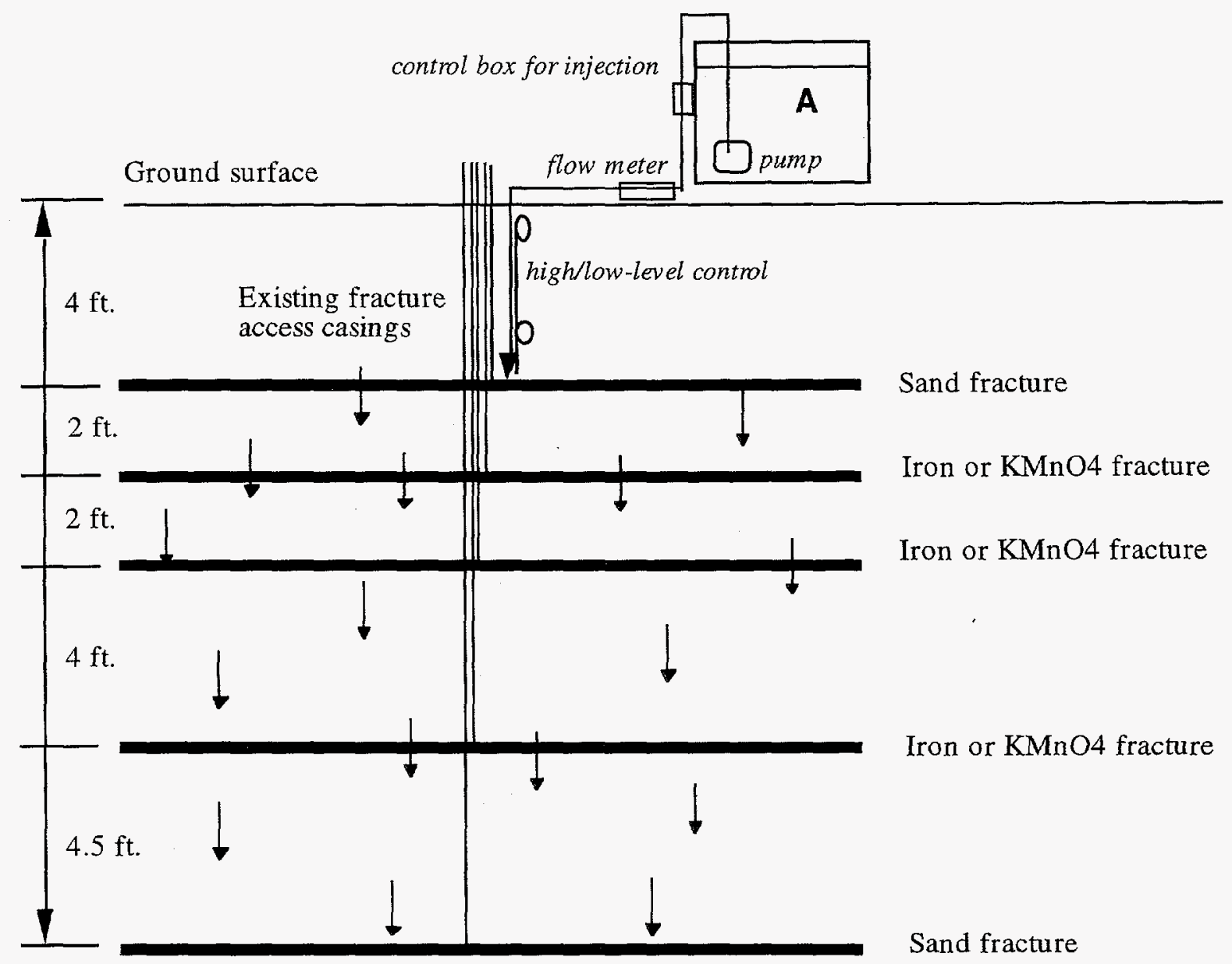

Notes: Basin A is a 500 gal tank filled with potable water supplemented by a $100 \mathrm{mg} / \mathrm{L}$ $\mathrm{NaBr}$ tracer solution for injection into either test cell $\mathrm{C}$ or $\mathrm{D}$. The discharge from Basin $\mathrm{A}$ was controlled by a set of high and low-level float switches installed in the shallow fracture access casing. The float switches provided a constant head of 1 to $3 \mathrm{ft}$. in the shallow sandfilled fracture. The delivery pump in Basin A was operated continuously or intermittently depending on the acceptance rate of the shallow fracture. Basin A fed both test cells $\mathrm{C}$ and $D$ via two independent high and low-level switches in the fractures and the associated control boxes and flow meters located at the feed basin. 
Figure 2.12. Illustration of the hydraulic fracturing process.

(a) General fracturing process steps.
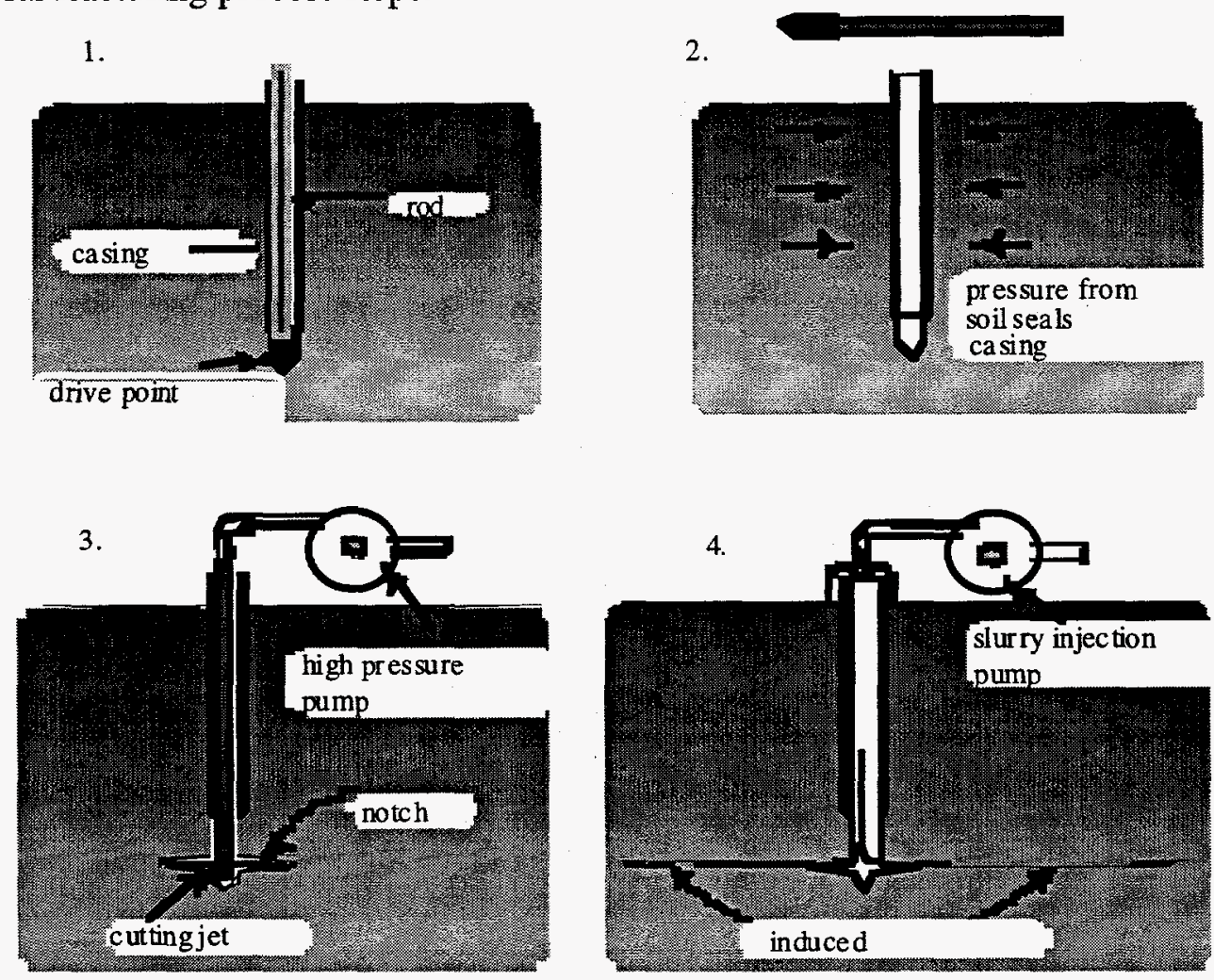

(b) Cross-section illustrating the features of a fracture-enhanced test cell.

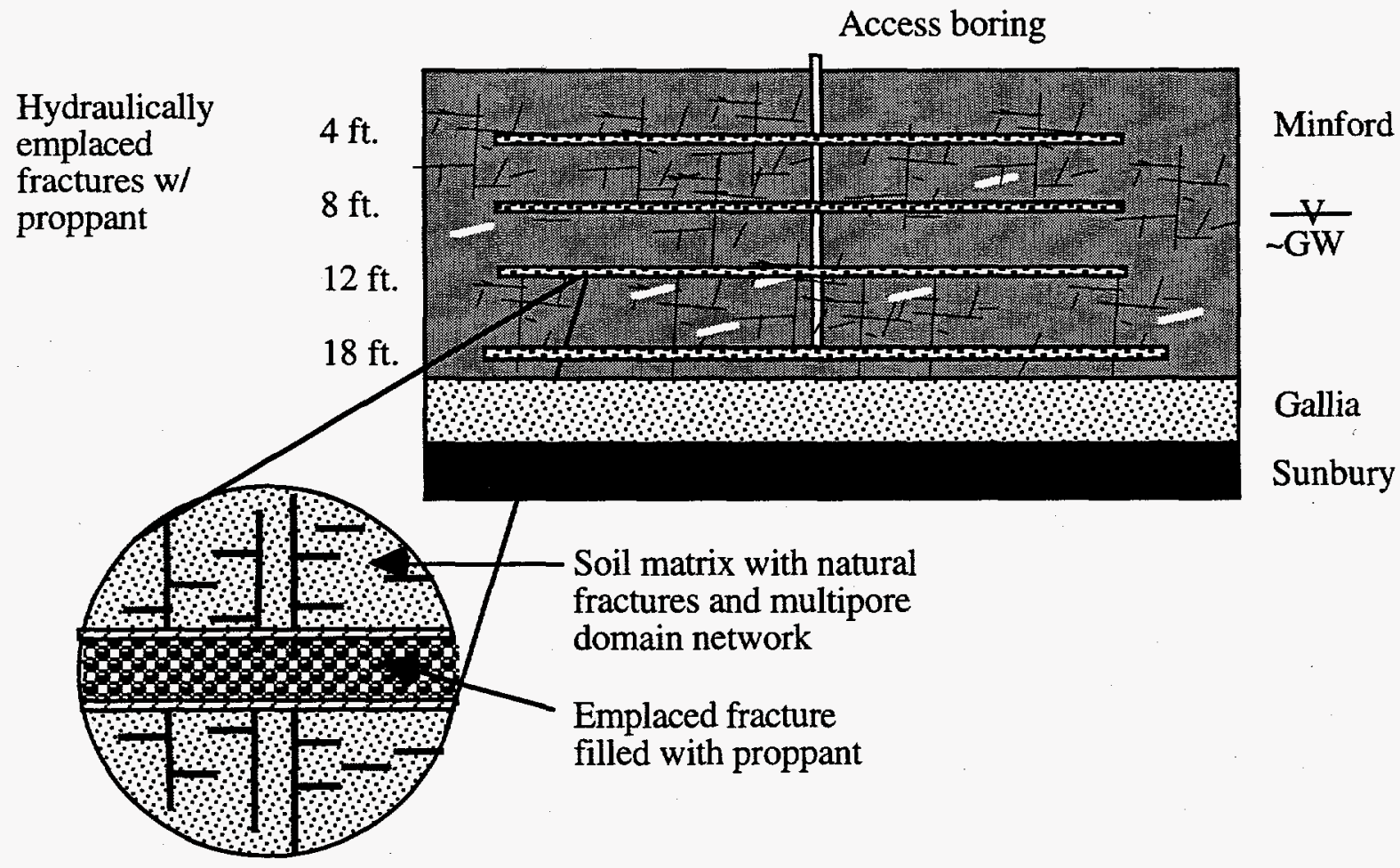


Table 2.1. Summary of selected X-231A site characteristics.

Characteristic Units Conditions

Soil type and genesis $\quad$ Minford silty clay deposit of fluvio- lacustrine origin. Typically $15 \mathrm{ft}$. thick upper clay unit $(\mathrm{CH})$ transitioning to a lower $10 \mathrm{ft}$. thick silt unit (CL).

Soil particle size distribution:

- Sand size (0.050 - $2.000 \mathrm{~mm})$

- Silt size $(0.002-0.050 \mathrm{~mm})$

dry wt.\%

- Clay size $(<0.002 \mathrm{~mm})$

dry wt.\%

$\sim 60$ to 85

dry wt.\%

$\sim 10$ to 35

Soil mineralogy

In the Minford clay unit, the sand fraction consists of mainly quartz with minor geothite. The silt fraction consists of quartz and minor feldspars but no goethite. The clay fraction is a mixture of illite $(\sim 33 \%)$, quartz $(\sim 29 \%)$, kaolinite $(\sim 26 \%)$, and smectite $(\sim 12 \%)$.

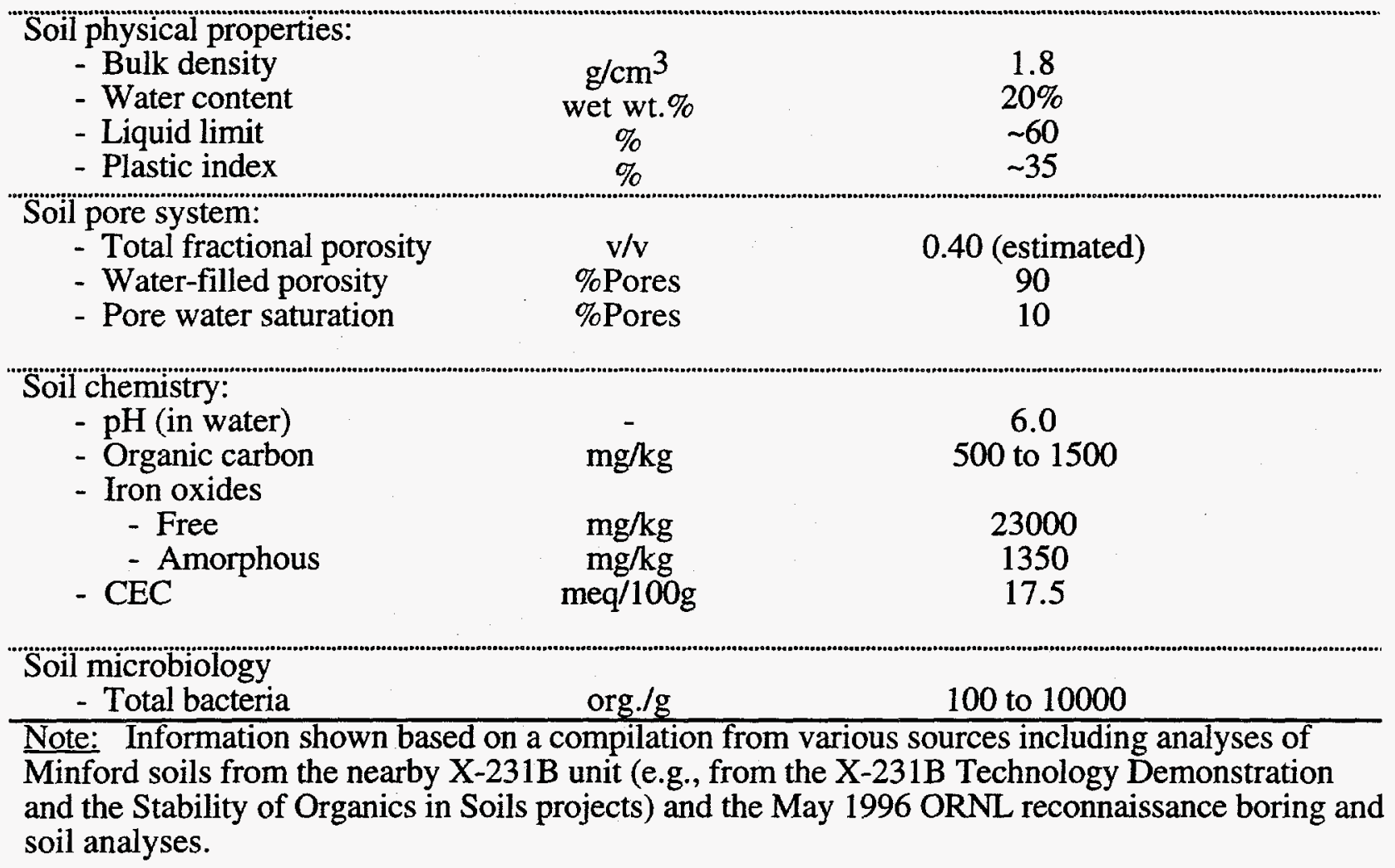

physical properties:

Water content

pore system:

- Total fractional porosity

- Water-filled porosity

(estimated)

$$
10
$$
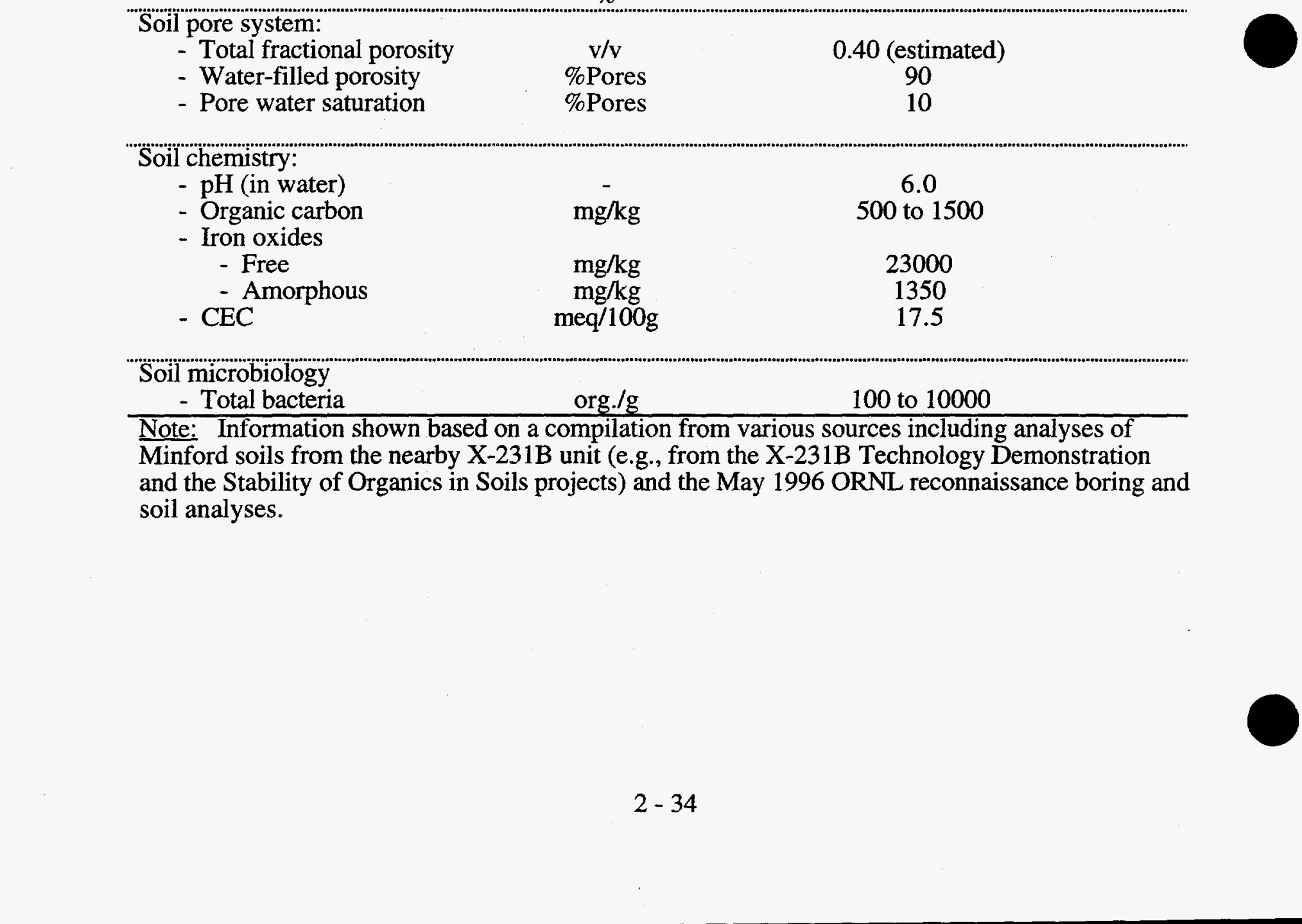
Table 2.2. Chronology of 1996 field activities during the X-231A demonstration.

\begin{tabular}{|c|c|}
\hline Date or period & Description \\
\hline $5 / 06 / 96$ & Reconnaissance sampling at X-231A. \\
\hline $5 / 09 / 96$ & Fracture emplacement and equipment shakedown at the CTS. \\
\hline $5 / 12 / 96$ & Installation of monitoring points at the CTS fracture test cells. \\
\hline $8 / 19 / 96$ & X-231A Readiness Review Meeting. \\
\hline $8 / 20-23 / 96$ & Demonstration test cell preparations. \\
\hline $8 / 24 / 96$ & Fracture emplacement at test cell A. \\
\hline $8 / 25-26 / 96$ & Fracture emplacement at test cell B. \\
\hline $8 / 27-28 / 96$ & Fracture emplacement at test cell $\mathrm{C}$. \\
\hline $9 / 4-26 / 96$ & $\begin{array}{l}\text { Baseline characterization (soil coring and sampling), piezometer } \\
\text { installation, and instrumentation of test cells. }\end{array}$ \\
\hline $9 / 18-19 / 96$ & Fracture emplacement at test cell D. \\
\hline $10 / 1-19 / 96$ & Test cell set up. \\
\hline $10 / 19 / 96$ & $\begin{array}{l}\text { Began vapor extraction (ambient air injection at atmospheric pressure) } \\
\text { at test cell } A \text { and } B \text {. }\end{array}$ \\
\hline $10 / 20 / 96-11 / 03 / 96$ & $\begin{array}{l}\text { Active vapor extraction at test cell } \mathrm{A} \text { and } \mathrm{B} \text { with concurrent process and } \\
\text { performance monitoring. }\end{array}$ \\
\hline $11 / 04 / 96$ & $\begin{array}{l}\text { Began down-hole steam }\left(\sim 230^{\circ} \mathrm{F}\right) \text { and hot air injection }\left(\sim 280^{\circ} \mathrm{F}\right) \\
\text { injection and flushing. }\end{array}$ \\
\hline $11 / 05 / 96-12 / 09 / 96$ & $\begin{array}{l}\text { Active hot fluid injection and flushing at test cell A and B with concurrent } \\
\text { process and performance monitoring. Operation of steam generator } \\
\text { intermittent due to burnout of heating elements. }\end{array}$ \\
\hline $12 / 03 / 96$ & $\begin{array}{l}\text { Discontinued steam injection due to reoccurring problems of the heating } \\
\text { elements burning out. }\end{array}$ \\
\hline $12 / 09 / 96$ & Post-treatment characterization soil sampling and analyses at test cell $\mathrm{A}$. \\
\hline $12 / 10-11 / 96$ & Post-treatment characterization soil sampling and analyses at test cell B. \\
\hline $12 / 12 / 96$ & $\begin{array}{l}\text { Post-treatment characterization soil sampling and analyses at test } \\
\text { cell } C \text { and } D . \text { Hot air injection terminated. }\end{array}$ \\
\hline $12 / 13 / 96$ & $\begin{array}{l}\text { Bench scale degradation tests on cores from test cell C and D after } \\
\sim 3 \text { months of passive operation. }\end{array}$ \\
\hline $12 / 14 / 96$ & Placed demonstration site in passive mode for the winter \\
\hline
\end{tabular}


Table 2.3. Chronology of 1997 field activities during the X-231A demonstration.

Date

Description

7/15-18/97 Baseline monitoring and measurement of site conditions after $\sim 7$ months of passive operation. Preparations for re-initiation of hot fluid injection at test cell $\mathrm{A}$ and $\mathrm{B}$ and forced advection at test cell $\mathrm{C}$ and $\mathrm{D}$.

7/19-20/97 Post-treatment characterization soil sampling and analyses at test cell $\mathrm{C}$ and D. Bench scale degradation tests on cores from test cell C and D after $\sim 10$ months of passive operation.

7/20/97 Began ambient air and hot air injection at test cell B. Ambient air injected at $\sim 12 \mathrm{scfm}$ into the $6 \mathrm{ft}$ fracture and hot air $\left(\sim 420^{\circ} \mathrm{F}\right)$ injected at $\sim 14 \mathrm{scfm}$ into the $8 \mathrm{ft}$ fracture.

$7 / 21 / 97$ Began steam injection at test cell $\mathrm{A}$. Steam $\left(\sim 232^{\circ} \mathrm{F}\right)$ injected into the $8 \mathrm{ft}$ fracture.

7/23-24/97 Subsurface Contaminant Focus Area and PORTS Site Tour.

7/24/97 Began forced advection of potable water and $100 \mathrm{ppm} \mathrm{NaBr}$ tracer into test cell $\mathrm{C}$ and $\mathrm{D}$.

7/29/97 Hot air injection stopped due to power outage and resultant damage to the air compressor motor.

7/30/97 Air compressor repaired and hot air injection restarted.

8/13/97 Steam injection stopped due to loss of instrument air for steam controller and consequent damage to heating elements.

8/15/97 Heating elements replaced and steam injection restarted.

8/18/97 Steam injection stopped due to blown over power panel.

8/19/97 Power panel stabilized, routine maintenance of steam generator performed, and steam injection restarted.

8/21/97 Steam injection stopped due to loss of instrument air for steam controller and consequent damage to heating elements.

8/22/97 Heating elements were replaced in the steam generator and steam injection restarted.

$8 / 25 / 97$ Steam injection was terminated to permit observation of thermal decay during remainder of scheduled field operations.

9/05/97 Injection of water into test cells $C$ and $D$ terminated.

9/06/97 Hot air injection at test cell B terminated.

9/06-16/97 Demonstration site close-out.

12/8-12/97 Bench scale degradation tests on cores from test cell $C$ and $D$ after $\sim 15$ months of passive operation. Limited reconnaissance sampling to define DNAPL area south of the demonstration area. 
Table 2.4. Summary of subsurface sampling completed during a reconnaissance survey in May 1996.

\begin{tabular}{|c|c|c|c|}
\hline Sample type & Sample frequency & $\begin{array}{l}\text { No. of } \\
\text { samples }\end{array}$ & Analytes ${ }^{\mathrm{a}} /$ aboratory \\
\hline $\begin{array}{l}\text { Soil samples from } \\
\text { X-231A corehole } \\
\text { sampling }\end{array}$ & $\begin{array}{l}6 \text { locations with } 9 \text { samples } \\
\text { each: } 1-2,3-4,5-6,7-8,9- \\
10,11-12,13-14,15-16,17- \\
18 \text { ft. bgs. }\end{array}$ & 54 & VOCs/ORNL Field Lab \\
\hline $\begin{array}{l}\text { Soil samples from } \\
\text { X-231A corehole } \\
\text { sampling }\end{array}$ & $\begin{array}{l}2 \text { locations with } 2 \text { samples } \\
\text { each: } 1-2 \text { and } 7-8 \mathrm{ft} \text {. bgs at } \\
\text { GP04, } 11-12 \text { and } 15-16 \mathrm{ft} \text {. } \\
\text { bgs at GP05 }\end{array}$ & 4 & $\begin{array}{l}\text { PCBs/PORTS } \\
\text { Radionuclides/PORTS } \\
\text { RCRA Metals/PORTS }\end{array}$ \\
\hline $\begin{array}{l}\text { QAVQC soil } \\
\text { samples }\end{array}$ & $\begin{array}{l}1 \text { duplicate for every } 10 \text { VOC } \\
\text { samples }(10 \%)\end{array}$ & 5 & VOCs/ORNL Field Lab \\
\hline $\begin{array}{l}\text { QA/QC soil } \\
\text { samples }\end{array}$ & 1 rinsate per sampling event & $\begin{array}{l}1 \\
1\end{array}$ & $\begin{array}{l}\text { VOCs/ORNL Field Lab } \\
\text { PCBs/PORTS } \\
\text { Radionuclides/PORTS } \\
\text { RCRA Metals/PORTS }\end{array}$ \\
\hline Field blanks & $\begin{array}{l}1 \text { per decon water source per } \\
\text { task }\end{array}$ & 1 & $\begin{array}{l}\text { VOCs/ORNL Field Lab } \\
\text { PCBs/PORTS } \\
\text { Radionuclides/PORTS } \\
\text { RCRA Metals/PORTS }\end{array}$ \\
\hline
\end{tabular}

a Methods for the listed analyses are as follows:

VOCs: hexane extraction and on-site field GC for PCE, TCE, 1,1,1-TCA, 1,2-DCE, and 1,1-DCE.

Radionuclides (gross alpha and beta, total uranium): PORTS TSD-553-240 and 230, respectively.

RCRA metals (As, Ba, Cd, Cr, Pb, Hg, Se, and Ag): SW-6010 and SW-7470 (Hg). PCBs (Aroclor 1254 and 1260): SW-8080.

Physical properties: $\mathrm{pH}, \%$ soil moisture, TOC, and bulk density. 
Table 2.5. Test cell installation features.

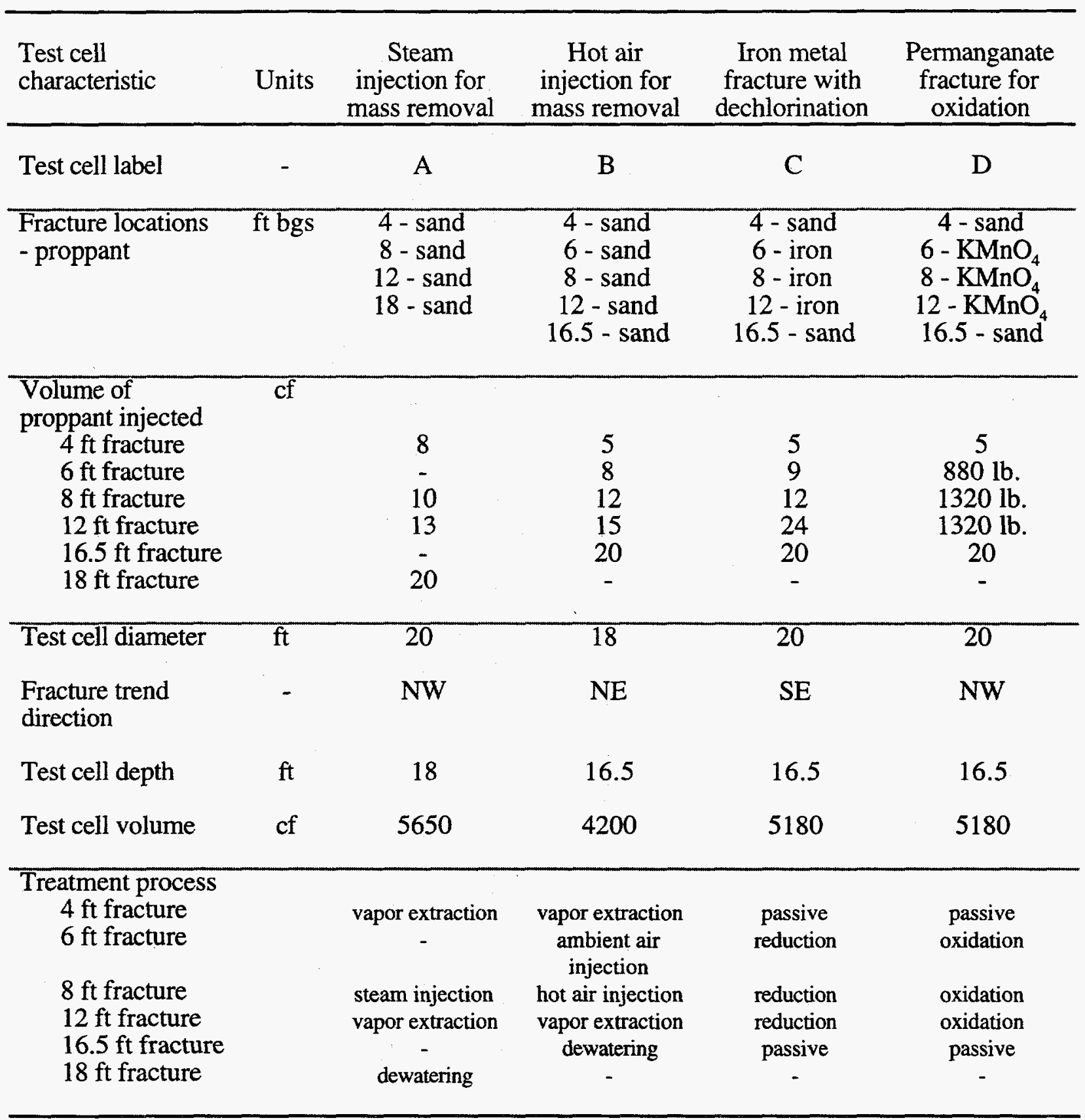


Table 2.6. Summary of baseline characterization laboratory analysis.

\begin{tabular}{|c|c|c|c|}
\hline Sample matrix & Analyte & Analysis method & Analysis location \\
\hline \multirow[t]{10}{*}{ Soil } & $\mathrm{VOCs}^{\mathrm{a}}$ & $\begin{array}{l}\text { Hexane extraction and gas } \\
\text { chromatography (electron capture } \\
\text { detector) }\end{array}$ & ORNL Field GC \\
\hline & $\mathrm{VOCs}^{\mathrm{a}}$ & SW8260a & PORTS \\
\hline & VOCs ${ }^{2}$ & methanol extraction & PORTS \\
\hline & Anions $\left(\mathrm{Cl}, \mathrm{NO}_{3}, \mathrm{SO}_{4}\right)$ & $\begin{array}{l}\text { extraction }(\sim 1: 1 \text { to } 10: 1 \text { soln/solid }) \\
\text { with ion selective electrode or IC } \\
\text { analysis }\end{array}$ & $\begin{array}{l}\text { PORTS } \\
\text { CSM }\end{array}$ \\
\hline & $\begin{array}{l}\text { Cations (K, Mn, } \mathrm{MnO}_{4}, \overline{\mathrm{Fe}} \\
\text { [total and ferrous]) }\end{array}$ & field spectrophotometer & ORNL Field Lab \\
\hline & $\begin{array}{l}\text { Cations (Ca, Mg, K, Mn, } \\
\mathrm{Fe} \text { ) }\end{array}$ & $\begin{array}{l}\text { ammonium acetate method and AA } \\
\text { or ICP analysis }\end{array}$ & PORTS \\
\hline & TOC & dry combustion and $\mathrm{CO}_{2}$ analysis & PORTS \\
\hline & $\begin{array}{l}\text { physical properties (water } \\
\text { content, } \mathrm{pH}, \mathrm{Eh} \text {, } \\
\text { temperature) }\end{array}$ & oven dry method and field sensors & ORNL Field Lab \\
\hline & Grain size & sieve analysis and hydrometer & CSM \\
\hline & microbes & MPN tube or direct count & ORNL/OR \\
\hline
\end{tabular}

Ground water VOCs $^{a}$ and extracted water
Hexane extraction and gas chromatography (electron capture detector)

\begin{tabular}{llc}
\hline VOCs $^{\mathrm{a}}$ & 8240 (EPA SW846) & PORTS \\
\hline TDS & gravimetric & ORNL/OR \\
\hline TSS & filter then dry and weigh & ORNL/OR \\
\hline $\begin{array}{l}\text { Cations (K, } \mathrm{Mn}, \mathrm{MnO}_{4}, \mathrm{Fe} \\
\text { [total and ferrous]) }\end{array}$ & field spectrophotometer & ORNL Field Lab \\
\hline Cations (Ca, $\mathrm{Mg}, \mathrm{Fe}, \mathrm{Mn})$ & spectrophotometer, AA or ICP & ORNL/OR \\
\hline TOC & dry combustion & ORNL/OR \\
\hline alkalinity & digital titrator and sulfuric acid & ORNL Field Lab \\
\hline $\begin{array}{l}\text { water quality parameters } \\
\text { (pH, conductance, temp) }\end{array}$ & $\begin{array}{l}\text { flow through cell at the well } \\
\text { (Hydrolab Multiprobe }(\mathbb{B})\end{array}$ & ORNL Field Lab \\
\hline
\end{tabular}

a VOCs: PCE; TCE; 1,1,1-TCA; 1,1-DCE; 1,1-DCA; 1,2-DCE (cis and trans); and methylene chloride. 
Table 2.7. Analyses for soil properties for each depth interval sampled during the baseline characterization.

\begin{tabular}{|c|c|c|c|c|c|c|c|c|c|c|c|c|c|c|c|}
\hline \multirow[t]{2}{*}{ Depth } & \multirow[t]{2}{*}{$\log$} & \multirow{2}{*}{$\begin{array}{c}\text { ORNL } \\
\text { on-site } \\
\text { GC } \\
\text { VOC-h }\end{array}$} & \multicolumn{5}{|c|}{ PORTS Lab } & \multicolumn{4}{|c|}{$\begin{array}{c}\text { ORNL } \\
\text { on-site field lab }(\mathrm{X}-231 \mathrm{~A})\end{array}$} & \multicolumn{3}{|c|}{ CSM } & \multirow{2}{*}{$\begin{array}{c}\text { ORNL } \\
\text { OR } \\
\text { microbes }\end{array}$} \\
\hline & & & VOC & VOC-m & anions & cations & TOC & $\mathrm{Eh}$ & WC & $\mathrm{pH}$ & cations & $\mathrm{GSA}$ & $\mathrm{WC}, \mathrm{pH}$ & $\mathrm{TOC}$ & \\
\hline $0-1$ & V & $\sqrt{ }$ & & & & & & $\otimes$ & $\otimes$ & $\otimes$ & $\otimes$ & & & & \\
\hline $1-2$ & " & $\sqrt{ }$ & & & & & & & & & & & & & \\
\hline $2-3$ & V & $\sqrt{ }$ & & & & & & $\otimes$ & $\otimes$ & $\otimes$ & $\otimes$ & & & & \\
\hline $3-4$ & $\sqrt{ }$ & $\sqrt{ }$ & & & & & & & & & & & & & \\
\hline $4-5$ & viv & ve & $\otimes$ & $\otimes$ & $\otimes$ & $\otimes$ & $\otimes$ & "Vy" & - & $\sqrt{ }$ & " & $\otimes$ & $\otimes$ & $\otimes$ & $\otimes$ \\
\hline $5-6$ & $\sqrt{ }$ & $\sqrt{ }$ & & & & & & & & & & & & & \\
\hline $6-7$ & $\sqrt{ }$ & $\sqrt{ }$ & & & & & & $\otimes$ & $\otimes$ & $\otimes$ & $\otimes$ & & & & \\
\hline $7-8$ & $\because$ & $\sqrt{ }$ & & & & & & & & & & & & & \\
\hline $8-9$ & $\sqrt{ }$ & $\sqrt{ }$ & $\otimes$ & $\otimes$ & $\otimes$ & $\otimes$ & $\otimes$ & $\sqrt{ }$ & $\sqrt{ }$ & $\sqrt{ }$ & V... & $\otimes$ & $\otimes$ & $\otimes$ & $\otimes$ \\
\hline $9-10$ & $\sqrt[V]{ }$ & $\sqrt{ }$ & & & & & & & & & & & & & \\
\hline $10-11$ & $\sqrt{ }$ & $\sqrt{ }$ & & & & & & $\otimes$ & $\otimes$ & $\otimes$ & $\otimes$ & & & & \\
\hline $11-12$ & "V & $\sqrt{ }$ & & & & & & & & & & & & & \\
\hline $12-13$ & $\sqrt{ }$ & $\sqrt{ }$ & $\otimes$ & (8) & $\otimes$ & $\otimes$ & $\otimes$ & $\sqrt{ }$ & $\sqrt{ }$ & $\sqrt{ }$ & $\sqrt{ }$ & $\otimes$ & $\otimes$ & $\otimes$ & $\otimes$ \\
\hline $13-14$ & $\sqrt{ }$ & $\sqrt{*}$ & & & & & & & & & & & & & \\
\hline $14-15$ & $\sqrt{ }$ & $\sqrt{ }$ & & & & & & $\otimes$ & $\otimes$ & $\otimes$ & $\otimes$ & & & & \\
\hline $15-16$ & $\sqrt{ }$ & $\sqrt{ }$ & & & & & & & & & & & & & \\
\hline $16-17$ & $\sqrt{ }$ & "r" & & & & & & $\otimes$ & $\otimes$ & $\otimes$ & $\otimes$ & & & & \\
\hline $17-18$ & $\sqrt{ }$ & $\sqrt{ }$ & & & & & & & & & & & & & \\
\hline
\end{tabular}

$\sqrt{\text { sample type collected at each corehole (locations } 1 \text { through 8). }}$

$\otimes$ sample collected at three coreholes (locations 2,6, and 8) within each test cell. 
Table 2.8. Summary of operations at the X-231A site during fall 1996.

\begin{tabular}{|c|c|c|c|c|}
\hline Parameters & $\begin{array}{c}\text { (A) } \\
\begin{array}{c}\text { Steam injection } \\
\text { recovery }\end{array}\end{array}$ & $\begin{array}{c}(\mathrm{B}) \\
\text { Hot air injection } \\
\text { recovery }\end{array}$ & $\begin{array}{c}(\mathrm{C}) \\
\text { Iron metal } \\
\text { barrier }\end{array}$ & $\begin{array}{c}\text { (D) } \\
\begin{array}{c}\text { Permanganate } \\
\text { barrier }\end{array} \\
\end{array}$ \\
\hline $\begin{array}{l}\text { Treatment process } \\
4 \mathrm{ft} \text { fracture } \\
6 \mathrm{ft} \text { fracture } \\
8 \mathrm{ft} \text { fracture } \\
12 \mathrm{ft} \mathrm{fracture} \\
16.5 \mathrm{ft} \text { fracture } \\
18 \mathrm{ft} \text { fracture }\end{array}$ & $\begin{array}{c}\text { vapor extraction } \\
- \\
\text { steam injection } \\
\text { vapor extraction } \\
- \\
\text { dewatering }\end{array}$ & $\begin{array}{c}\text { vapor extraction } \\
\text { ambient air injection } \\
\text { hot air injection } \\
\text { vapor extraction } \\
\text { dewatering } \\
-\end{array}$ & $\begin{array}{l}\text { passive } \\
\text { reduction } \\
\text { reduction } \\
\text { reduction } \\
\text { passive } \\
-\end{array}$ & $\begin{array}{c}\text { passive } \\
\text { oxidation } \\
\text { oxidation } \\
\text { oxidation } \\
\text { passive } \\
-\end{array}$ \\
\hline Cell operation & active & active & passive & passive \\
\hline Treatment start date & $\begin{array}{l}\text { 10/19/96 ambient air } \\
\text { flushing; } \\
\text { 11/4/96 steam injection }\end{array}$ & $\begin{array}{l}\text { 10/19/96 ambient } \\
\text { air flushing; } \\
\text { 11/4/96 hot air } \\
\text { injection }\end{array}$ & $8 / 27 / 96$ & $9 / 18 / 97$ \\
\hline Treatment end date & $12 / 3 / 96$ & $12 / 12 / 96$ & $12 / 10 / 96$ & $12 / 10 / 96$ \\
\hline Treatment duration & $\begin{array}{c}10 \text { days } \\
\text { (ambient air) } \\
10 \text { days } \\
\text { (steam, maximum } \\
\text { continuous operation) }\end{array}$ & $\begin{array}{l}10 \text { days } \\
\text { (ambient air) } \\
52 \text { days } \\
\text { (hot air) }\end{array}$ & $\begin{array}{l}\sim 108 \text { days } \\
\text { (passive) }\end{array}$ & $\begin{array}{l}\text { (p6 days } \\
\text { (passive) }\end{array}$ \\
\hline Injected fluid & $\begin{array}{l}\text { potable water as steam } \\
\left(\sim 230^{\circ} \mathrm{F}\right)\end{array}$ & $\begin{array}{l}\text { ambient air into } 6 \mathrm{ft} \\
\text { fracture; heated } \\
\text { ambient }\left(\sim 280^{\circ} \mathrm{F}\right) \\
\text { into } 8 \mathrm{ft} \text { fracture }\end{array}$ & None & None \\
\hline $\begin{array}{l}\text { Hot fluid injection } \\
\text { rate }\end{array}$ & TBD & $\begin{array}{c}3-9.1 \mathrm{cfm}(\sim 5 \text { ave }) \\
\text { into } 6 \mathrm{ft} \text { fracture; } \\
2.1-11.6(\sim 5.9 \text { ave }) \\
\text { into } 8 \mathrm{ft} \text { fracture }\end{array}$ & $\overline{\mathrm{NA}}$ & $\overline{\mathrm{NA}}$ \\
\hline Injection pressure & $8 \mathrm{psi}$ & $\begin{array}{l}0.8-2 \mathrm{psig}(\sim 1 \text { ave }) \\
\text { into } 8 \mathrm{ft} \text { fracture }\end{array}$ & NA & NA \\
\hline Vacuum pump & $0.5 \mathrm{psig}$ & $0.5 \mathrm{psig}$ & $\overline{\mathrm{NA}}$ & NA \\
\hline $\begin{array}{c}\text { Extraction rate } \\
4 \mathrm{ft} \text { fracture } \\
12 \mathrm{ft} \text { fracture }\end{array}$ & $\begin{array}{l}0.5-7.1 \mathrm{cfm} \\
<0.1-4 \mathrm{cfm}\end{array}$ & $\begin{array}{l}1.3-13.1 \mathrm{cfm} \\
<0.1-3 \mathrm{cfm}\end{array}$ & NA & NA \\
\hline $\begin{array}{l}\text { Total injection } \\
\text { volume }\end{array}$ & $1400 \mathrm{gal}$ & $\begin{array}{l}-134,000 \mathrm{cf} \text { into } 6 \mathrm{ft} \\
\text { fracture; } \\
2225,000 \mathrm{cf} \text { into } 8 \mathrm{ft} \\
\text { fracture }\end{array}$ & $\begin{array}{l}500-2000 \mathrm{~kg} \\
\text { (reactant mass } \\
\text { per fracture) }\end{array}$ & $\begin{array}{c}-530 \mathrm{~kg} \\
\text { (reactant mass } \\
\text { per fracture) }\end{array}$ \\
\hline Total energy use & $\begin{array}{c}3200 \mathrm{~kW}-\mathrm{hr} \\
(2.75 \mathrm{~kW}-\mathrm{hr} / \mathrm{gal} \text { ave. })\end{array}$ & $700 \mathrm{~kW}-\mathrm{hr}$ & none & none \\
\hline
\end{tabular}


Table 2.9. Summary of operations at the X-231A site during summer 1997.

\begin{tabular}{|c|c|c|c|c|}
\hline Parameters & $\begin{array}{l}\text { (A) } \\
\text { Steam injection } \\
\text { recovery } \\
\end{array}$ & $\begin{array}{l}\text { (B) } \\
\text { Hot air injection } \\
\text { recovery }\end{array}$ & $\begin{array}{c}\text { (C) } \\
\text { Iron metal } \\
\text { barrier } \\
\end{array}$ & $\begin{array}{c}\text { (D) } \\
\begin{array}{c}\text { Permanganate } \\
\text { barrier }\end{array} \\
\end{array}$ \\
\hline $\begin{array}{c}\text { Treatment process } \\
4 \mathrm{ft} \text { fracture } \\
6 \mathrm{ft} \text { fracture }\end{array}$ & $\begin{array}{c}\text { vapor extraction } \\
-\end{array}$ & $\begin{array}{l}\text { vapor extraction } \\
\text { ambient air } \\
\text { injection }\end{array}$ & $\begin{array}{l}\text { passive } \\
\text { reduction }\end{array}$ & $\begin{array}{l}\text { passive } \\
\text { oxidation }\end{array}$ \\
\hline $\begin{array}{l}8 \mathrm{ft} \text { fracture } \\
12 \mathrm{ft} \text { fracture } \\
16.5 \mathrm{ft} \text { fracture } \\
18 \mathrm{ft} \text { fracture }\end{array}$ & $\begin{array}{c}\text { steam injection } \\
\text { vapor extraction } \\
- \\
\text { dewatering }\end{array}$ & $\begin{array}{l}\text { hot air injection } \\
\text { vapor extraction } \\
\text { dewatering } \\
-\end{array}$ & $\begin{array}{l}\text { reduction } \\
\text { reduction } \\
\text { passive } \\
-\end{array}$ & $\begin{array}{c}\text { oxidation } \\
\text { oxidation } \\
\text { passive } \\
-\end{array}$ \\
\hline Cell operation & active & active & passive & passive \\
\hline Injection start date & $7 / 20 / 97$ & $7 / 21 / 97$ & $7 / 24 / 97$ & $7 / 24 / 97$ \\
\hline Injection end date & $8 / 25 / 97$ & $9 / 06 / 97$ & $9 / 05 / 97$ & $9 / 05 / 97$ \\
\hline Injection duration & 37 days & 49 days & 45 days & 45 days \\
\hline Injected fluid & $\begin{array}{l}\text { potable water as } \\
\text { steam }\left(\sim 232^{\circ} \mathrm{F}\right)\end{array}$ & $\begin{array}{l}\text { ambient air into } 6 \mathrm{ft} \\
\text { fracture; heated } \\
\text { ambient air heated } \\
\left(-420^{\circ} \mathrm{F}\right) \text { into } 8 \mathrm{ft} \\
\text { fracture }\end{array}$ & $\begin{array}{c}\text { potable water } \\
\text { with } 100 \mathrm{ppm} \\
\text { NaBr tracer }\end{array}$ & $\begin{array}{l}\text { potable water } \\
\text { with } 100 \text { ppm } \\
\mathrm{NaBr} \text { tracer }\end{array}$ \\
\hline Injection rate & $\sim 30$ gal/day & $\begin{array}{l}10.5 \text { to } 13 \text { scfm } \\
(\sim 12 \text { ave }) \text { at } 6 \mathrm{ft} \\
\text { fracture; } 13 \text { to } 14.75 \\
\text { scfm ( } 14 \text { ave }) \text { at } 8 \\
\mathrm{ft} \text { fracture }\end{array}$ & $\sim 7.5 \mathrm{gal} / \mathrm{day}$ & $\sim 4.5 \mathrm{gal} / \mathrm{day}$ \\
\hline Injection pressure & 8 psi & $\begin{array}{l}\sim 1.2 \text { psig into } 6 \mathrm{ft} \\
\text { fracture; } \sim 0.95 \text { psig } \\
\text { into } 8 \mathrm{ft} \text { fracture }\end{array}$ & $\begin{array}{l}\text { NA, gravity } \\
\text { feed }\end{array}$ & $\begin{array}{l}\text { NA, gravity } \\
\text { feed }\end{array}$ \\
\hline Vacuum pump & $0.5 \mathrm{psig}$ & $0.5 \mathrm{psig}$ & NA & $\overline{\mathrm{NA}}$ \\
\hline $\begin{array}{c}\text { Extraction rate } \\
4 \mathrm{ft} \text { fracture } \\
12 \mathrm{ft} \text { fracture }\end{array}$ & $\begin{array}{l}<0.1-2.5 \mathrm{cfm} \\
<0.1-2.5 \mathrm{cfm}\end{array}$ & $\begin{array}{c}1.7-4 \mathrm{cfm} \\
4-48 \mathrm{cfh}\end{array}$ & NA & NA \\
\hline $\begin{array}{l}\text { Total injection } \\
\text { volume }\end{array}$ & $\begin{array}{c}1170 \text { gal potable } \\
\text { water }\end{array}$ & $\begin{array}{l}\sim 847,000 \mathrm{cf} \text { into } 6 \\
\mathrm{ft} \text { fracture; } \\
\sim 988,000 \mathrm{cf} \text { into } 8 \\
\mathrm{ft} \text { fracture }\end{array}$ & $350 \mathrm{gal}$ & $201 \mathrm{gal}$ \\
\hline Total energy use & $\begin{array}{c}3000 \mathrm{~kW}-\mathrm{hr} \\
(2.7 \mathrm{~kW} \text {-hr/gal ave.) } \\
\end{array}$ & $3400 \mathrm{~kW}-\mathrm{hr}$ & none & none \\
\hline
\end{tabular}


Table 2.10. X-231A process monitoring summary.

\begin{tabular}{|c|c|c|c|}
\hline Condition & Monitor & Units & Method \\
\hline \multicolumn{4}{|l|}{ Test Cell A - Steam Injection } \\
\hline Steam supply tanks & observation & check/gal & manual \\
\hline Water Use & flow gage & gal & manual \\
\hline Energy Use & power meter & $\mathrm{kWh}$ & manual \\
\hline Injection Temperature & thermocouple & ${ }^{\circ} \mathrm{F}$ & \\
\hline \multicolumn{4}{|l|}{ Extraction Vacuum } \\
\hline A-4 fracture & vacuum gage, pressure transducer & inches $\mathrm{H}_{2} \mathrm{O}$ & DAS; manual \\
\hline A-12 fracture & vacuum gage, pressure transducer & inches $\mathrm{H}_{2} \mathrm{O}$ & DAS; manual \\
\hline \multicolumn{4}{|c|}{ Vacuum Extraction Flow Rate } \\
\hline$A-4$ & flow gage & $\mathrm{scfm} / \mathrm{scfh}$ & DAS; manual \\
\hline A-12 & flow gage & $\mathrm{scfm} / \mathrm{scfh}$ & DAS; manual \\
\hline Dewatering Pumps & observation & check & \\
\hline \multicolumn{4}{|l|}{ Dewatering Volume } \\
\hline A-4 & knock-out pot discharge & counts & DAS; manual \\
\hline A-12 & knock-out pot discharge & counts & DAS; manual \\
\hline A-18 & knock-out pot discharge & counts & DAS; manual \\
\hline \multicolumn{4}{|l|}{ Test Cell B-Hot Air Injection } \\
\hline Injection Temperature & thermocouple & ${ }^{\circ} \mathrm{F}$ & manual \\
\hline Heating Efficiency & & $\%$ (range) & manual \\
\hline \multicolumn{4}{|l|}{ Injection Pressure } \\
\hline B-6 (ambient air) & pressure gage & psi & DAS; manual \\
\hline B-8 (hot air) & pressure gage & psi & DAS; manual \\
\hline \multicolumn{4}{|l|}{ Injection Flow Rate } \\
\hline B-6 & flow gage & scfm & DAS; manual \\
\hline B-8 & flow gage & scfm & DAS; manual \\
\hline \multicolumn{4}{|l|}{ Vacuum Extraction } \\
\hline B-4 & vacuum gage, pres transducer & inches $\mathrm{H}_{2} \mathrm{O}$ & DAS; manual \\
\hline B-12 & vacuum gage, pres transducer & inches $\mathrm{H}_{2} \mathrm{O}$ & DAS; manual \\
\hline \multicolumn{4}{|l|}{ Vacuum Extraction Flow Rate } \\
\hline B-4 & flow gage & $\mathrm{scfm} / \mathrm{scfh}$ & DAS; manual \\
\hline B-12 & flow gage & $\mathrm{scfm} / \mathrm{scfh}$ & DAS; manual \\
\hline Dewatering Pumps & & check & \\
\hline \multicolumn{4}{|l|}{ Dewatering Volume } \\
\hline B-4 & knock-out pot discharge & counts & DAS; manual \\
\hline B-12 & knock-out pot discharge & counts & DAS; manual \\
\hline B-16 & knock-out pot discharge & counts & DAS; manual \\
\hline \multicolumn{4}{|l|}{ Vacuum Pump } \\
\hline Water Level & observation & - & manual \\
\hline Back Pressure & observation & psi & manual \\
\hline \multicolumn{4}{|c|}{ Test Cells C (Iron) and D $\left(\mathrm{KMnO}_{4}\right)^{\mathrm{a}}$} \\
\hline C Injection Volume & water level counter; flow gage & counts; gal & $\begin{array}{l}\text { controller; } \\
\text { manual }\end{array}$ \\
\hline D Injection Volume & water level counter; flow gage & counts; gal & $\begin{array}{l}\text { controller; } \\
\text { manual }\end{array}$ \\
\hline NaBr Tank Volume & observation & gal; inches & manual \\
\hline Feed Water Sample & ion specific electrode & ppm Br & manual \\
\hline
\end{tabular}


Table 2.11. X-231A test cell performance monitoring summary.

\begin{tabular}{|c|c|c|c|c|c|}
\hline Category & Condition & Locations & Monitor & Method & Frequency \\
\hline \multirow[t]{3}{*}{ Off-gas } & $\begin{array}{l}\text { Total } \\
\text { hydrocarbons }\end{array}$ & $\begin{array}{l}\text { A- } 4 \mathrm{ft} \text {. fracture } \\
\text { A- } 12 \mathrm{ft} \text {. fracture } \\
\text { B- } 4 \mathrm{ft} \text {. fracture } \\
\text { B- } 12 \mathrm{ft} \text {. fracture }\end{array}$ & $\begin{array}{l}\text { On-line FID } \\
\text { On-line FID } \\
\text { On-line FID } \\
\text { On-line FID }\end{array}$ & $\begin{array}{l}\text { DAS } \\
\text { DAS } \\
\text { DAS } \\
\text { DAS }\end{array}$ & $\begin{array}{l}\text { Twice a day } \\
\text { Twice a day } \\
\text { Twice a day } \\
\text { Twice a day }\end{array}$ \\
\hline & VOCs & $\begin{array}{l}\text { A- } 4 \mathrm{ft} \text {. fracture } \\
\text { A- } 12 \mathrm{ft} \text {. fracture } \\
\text { B- } 4 \mathrm{ft} \text {. fracture } \\
\text { B- } 12 \mathrm{ft} . \text { fracture }\end{array}$ & $\begin{array}{l}\mathrm{GC} \\
\mathrm{GC} \\
\mathrm{GC} \\
\mathrm{GC}\end{array}$ & $\begin{array}{l}\text { Manual } \\
\text { Manual } \\
\text { Manual } \\
\text { Manual }\end{array}$ & $\begin{array}{l}\text { Daily } \\
\text { Daily } \\
\text { Daily } \\
\text { Daily }\end{array}$ \\
\hline & $\begin{array}{l}\text { Atmospheric } \\
\text { composition }\end{array}$ & $\begin{array}{l}\text { A- } 4 \mathrm{ft} \text {. fracture } \\
\text { A- } 12 \mathrm{ft} \text {. fracture } \\
\text { B- } 4 \mathrm{ft} \text {. fracture } \\
\text { B- } 12 \mathrm{ft} \text {. fracture }\end{array}$ & $\begin{array}{l}\text { Gas analyzer } \\
\text { Gas analyzer } \\
\text { Gas analyzer } \\
\text { Gas analyzer }\end{array}$ & $\begin{array}{l}\text { Manual } \\
\text { Manual } \\
\text { Manual } \\
\text { Manual }\end{array}$ & $\begin{array}{l}\text { Twice a day } \\
\text { Twice a day } \\
\text { Twice a day } \\
\text { Twice a day }\end{array}$ \\
\hline \multirow[t]{4}{*}{ Soil } & Temperature & $\begin{array}{l}\mathrm{A} \text { and B - Multiple } \\
\text { locations \& depths }\end{array}$ & $\begin{array}{l}\text { In situ } \\
\text { thermistors; } \\
\text { thermocouple }\end{array}$ & $\begin{array}{l}\text { DAS; } \\
\text { manual }\end{array}$ & $\begin{array}{l}\text { every } 4 \mathrm{hrs} \text {; } \\
\text { intermittent }\end{array}$ \\
\hline & Water content & $\begin{array}{l}\text { A to D - Multiple } \\
\text { locations \& depths }\end{array}$ & $\begin{array}{l}\text { In situ TDR; } \\
\text { neutron probe }\end{array}$ & Manual & $\begin{array}{l}\text { Weekly; pre-, } \\
\text { post-treatment }\end{array}$ \\
\hline & Pressure & $\begin{array}{l}\mathrm{A} \text { and } \mathrm{B}-\text { Multiple } \\
\text { locations \& depths }\end{array}$ & $\begin{array}{l}\text { In situ } \\
\text { piezometers }\end{array}$ & Manual & Intermittent \\
\hline & Redox & $\begin{array}{l}\text { A to D - Multiple } \\
\text { locations \& depths }\end{array}$ & In situ electrodes & Manual & Weekly \\
\hline \multirow[t]{2}{*}{ Water } & $\begin{array}{l}\text { Water quality, } \\
\text { water level }\end{array}$ & $\begin{array}{l}\text { A- } 18 \mathrm{ft} . \text { fracture } \\
\text { B, C, D- } 16.5 \mathrm{ft} . \text { frac. } \\
\text { Piezometers } \\
\text { Site wells (O1G, } 4 \mathrm{G} 1 \text {, } \\
\text { 5G1) }\end{array}$ & $\begin{array}{l}\text { Dedicated tube } \\
\text { Dedicated tube } \\
\text { Dedicated tube } \\
\text { Dedicated tube }\end{array}$ & $\begin{array}{l}\text { Manual } \\
\text { Manual } \\
\text { Manual } \\
\text { Manual }\end{array}$ & $\begin{array}{l}\text { Weekly } \\
\text { Weekly } \\
\text { Weekly } \\
\text { Pre-, post- } \\
\text { treatment }\end{array}$ \\
\hline & VOCs & $\begin{array}{l}\text { A- } 18 \mathrm{ft} \text {. fracture } \\
\text { B, C, D- } 16.5 \mathrm{ft} \text {. frac. } \\
\text { Piezometers } \\
\text { Site wells (O1G, } 4 \mathrm{G} 1 \text {, } \\
5 \mathrm{G} 1 \text { ) }\end{array}$ & $\begin{array}{l}\text { Dedicated tube } \\
\text { Dedicated tube } \\
\text { Dedicated tube } \\
\text { Dedicated tube }\end{array}$ & $\begin{array}{l}\text { Manual } \\
\text { Manual } \\
\text { Manual } \\
\text { Manual }\end{array}$ & $\begin{array}{l}\text { Weekly } \\
\text { Weekly } \\
\text { Weekly } \\
\text { Pre-, post- } \\
\text { treatment }\end{array}$ \\
\hline
\end{tabular}


Table 2.12. X-231A ORNL data acquisition system summary.

\begin{tabular}{|c|c|c|c|}
\hline Test cell & DAS name/ID & Description & Units \\
\hline A. Steam & $\begin{array}{l}\text { Inject volume } \\
\text { Pressure 1 } \\
\text { Pressure 2 } \\
\text { Pressure 3 } \\
\text { Temperature 1 } \\
\text { Temperature 2 } \\
\text { Temperature 3 } \\
\text { Vapor 1 } \\
\text { Vapor 2 } \\
\text { Liquid volume 1 } \\
\text { Liquid volume 2 } \\
\text { Liquid volume 3 } \\
\text { FID }\end{array}$ & $\begin{array}{l}\text { Steam injection volume } \\
4 \mathrm{ft} \text {. extraction fracture } \\
12 \mathrm{ft} \text {. extraction fracture } \\
8 \mathrm{ft} \text {. inlet fracture } \\
4 \mathrm{ft} \text {. extraction fracture } \\
12 \mathrm{ft} \text {. extraction fracture } \\
\text { Ambient air over X-231A } \\
- \\
- \\
4 \mathrm{ft} \text {. extraction fracture } \\
12 \mathrm{ft} \text {. extraction fracture } \\
18 \mathrm{ft} \text {. dewatering fracture } \\
4 \mathrm{ft} \text {. or } 12 \mathrm{ft} \text {. extraction fracture }\end{array}$ & $\begin{array}{l}\text { L or kg } \\
\text { psi } \\
\text { psi } \\
\text { psi } \\
{ }^{\circ} \mathrm{C} \\
{ }^{\circ} \mathrm{C} \\
{ }^{\circ} \mathrm{C} \\
\\
\mathrm{L} \\
\mathrm{L} \\
\mathrm{L} \\
\mathrm{ppm}\end{array}$ \\
\hline B. Hot Air & $\begin{array}{l}\text { Inject pressure } \\
\text { Pressure 1 } \\
\text { Pressure 2 } \\
\text { Pressure 3 } \\
\text { Temperature 1 } \\
\text { Temperature 2 } \\
\text { Temperature 3 } \\
\text { Vapor 1 } \\
\text { Vapor 2 } \\
\text { Liquid volume 1 } \\
\text { Liquid volume 2 } \\
\text { Liquid volume 3 } \\
\text { FID }\end{array}$ & $\begin{array}{l}\text { Air injection pressure } \\
4 \mathrm{ft} \text {. extraction fracture } \\
12 \mathrm{ft} \text {. extraction fracture } \\
8 \mathrm{ft} \text {. inlet fracture } \\
4 \mathrm{ft} \text {. extraction fracture } \\
6 \mathrm{ft} \text {. fracture } \\
12 \mathrm{ft} \text {. extraction fracture } \\
- \\
- \\
4 \mathrm{ft} . \text { fracture } \\
12 \mathrm{ft} \text {. fracture } \\
18 \mathrm{ft} \text {. fracture } \\
4 \mathrm{ft} \text {. or } 12 \mathrm{ft} \text {. fracture }\end{array}$ & $\begin{array}{l}\text { psi } \\
\text { psi } \\
\text { psi } \\
\text { psi } \\
{ }^{\circ} \mathrm{C} \\
{ }^{\circ} \mathrm{C} \\
{ }^{\circ} \mathrm{C} \\
\\
\mathrm{L} \\
\mathrm{L} \\
\mathrm{L} \\
\mathrm{ppm}\end{array}$ \\
\hline C. Iron & $\begin{array}{l}\text { Extract temperature } \\
\text { Inject temperature } \\
\text { Extract volume } \\
\text { Inject volume }\end{array}$ & $\begin{array}{l}\text { Extracted liquid temperature } \\
\text { Injected liquid temperature } \\
\text { Extracted liquid volume } \\
\text { Injected liquid volume }\end{array}$ & $\begin{array}{l}{ }^{\circ} \mathrm{C} \\
{ }^{\circ} \mathrm{C} \\
\mathrm{L} \\
\mathrm{L}\end{array}$ \\
\hline D. $\mathrm{KMnO}_{4}$ & $\begin{array}{l}\text { Extract temperature } \\
\text { Inject temperature } \\
\text { Extract volume } \\
\text { Inject volume }\end{array}$ & $\begin{array}{l}\text { Extracted liquid temperature } \\
\text { Injected liquid temperature } \\
\text { Extracted liquid volume } \\
\text { Injected liquid volume }\end{array}$ & $\begin{array}{l}{ }^{\circ} \mathrm{C} \\
{ }^{\circ} \mathrm{C} \\
\mathrm{L} \\
\mathrm{L}\end{array}$ \\
\hline
\end{tabular}


Table 2.13. Summary of sampling and analysis activities. ${ }^{a}$

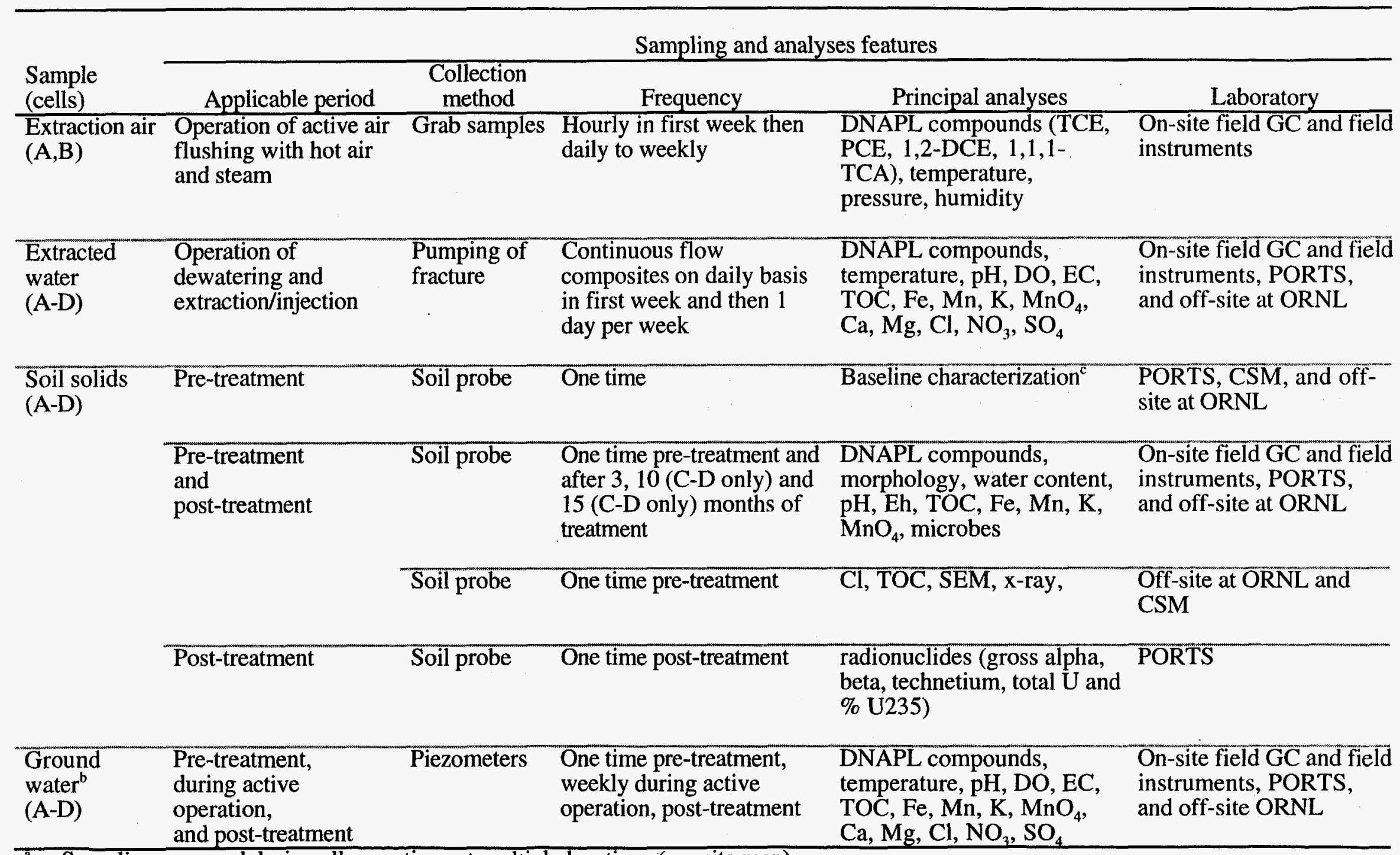

a Sampling occurred during all operations at multiple locations (see site map).

b The extent of any samples collected for soil solution and gas analysis were based on technical feasibility of collection from the LPM and time and budget constraints.

c Baseline analyses included water content, grain size, bulk density, color, $\mathrm{pH}, \mathrm{TOC}$, free iron oxides, cations ( $\mathrm{Fe}, \mathrm{Mn}, \mathrm{K}, \mathrm{Ca}, \mathrm{Mg}$ ) and anions $\left(\mathrm{NO}_{3}, \mathrm{SO}_{4}\right)$.
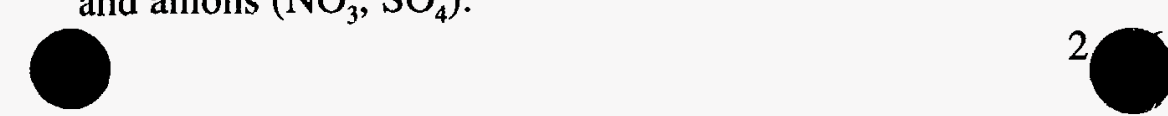
Table 2.14. Summary of target analytes, analysis methods, and detection limits for soil samples.

\begin{tabular}{|c|c|c|c|}
\hline Analysis & Analysis method ${ }^{\mathrm{a}}$ & $\begin{array}{l}\text { Sample } \\
\text { volume } \\
\text { (g) }\end{array}$ & $\begin{array}{l}\text { Detection } \\
\text { limit } \\
(\mathrm{mg} / \mathrm{kg})\end{array}$ \\
\hline Soil DNAPLs & Solvent extraction with GC/ECD & $5 \mathrm{~g}$ & 0.005 \\
\hline Soil water content & Gravimetric & $>25$ & NA \\
\hline Soil grain size analysis & Sieve analysis and hydrometer & 100 & NA \\
\hline Soil color & Munsell color chart & 5 & NA \\
\hline Soil pH & Soil paste $(\sim 1: 1$ to $10: 1$ soln./solid $)$ & 10 & NA \\
\hline Soil Eh & Platinum microelectrode & In situ & NA \\
\hline Soil organic carbon & $\begin{array}{l}\text { Dry combustion and } \\
\mathrm{CO}_{2} \text { analysis }\end{array}$ & 5 & $\begin{array}{l}0.001 \\
\text { wt. } \%\end{array}$ \\
\hline Soil free iron oxides & Extraction and AA analysis & 50 & $<1$ \\
\hline $\begin{array}{l}\text { Soil cations: magnesium } \\
\text { calcium, potassium, } \\
\text { manganese, iron }\end{array}$ & $\begin{array}{l}\text { Ammonium acetate method and } \mathrm{AA} \\
\text { or ICP analysis }\end{array}$ & 50 & NA \\
\hline $\begin{array}{l}\text { Soil anions: chloride, sulfate, } \\
\text { nitrate }\end{array}$ & $\begin{array}{l}\text { Extraction }(\sim 1: 1 \text { to } 10: 1 \text { soln./solid }) \\
\text { with ion selective electrode or IC }\end{array}$ & 25 & $\begin{array}{l}<5 \\
<0.5\end{array}$ \\
\hline Soil bacteria & MPN tube or direct count & 25 & $\sim 100$ \\
\hline Soil macromorphology & $\begin{array}{l}\text { Direct visual examination under } \\
\text { naked } \\
\text { eye and magnifying hand lens }\end{array}$ & 25 & NA \\
\hline \multicolumn{4}{|c|}{$\begin{array}{l}\text { All analyses were made in accordance with standard practices for environmental engineering } \\
\text { research including those referenced in Standard Methods for Examination of Water and } \\
\text { Wastewater, ASTM Methods for Soil and Rock, and SSSA Methods of Soil Analysis (Vol. } 1 \\
\text { and 2). All analyses methods were documented in project logbooks and files and described } \\
\text { in detail in project reports. } \\
\text { NA not applicable }\end{array}$} \\
\hline
\end{tabular}


2.15. Summary of target analytes, methods of analysis, and detection limits for aqueous samples.

\begin{tabular}{|c|c|c|c|}
\hline Analysis & Analysis method ${ }^{a}$ & $\begin{array}{c}\text { Sample } \\
\text { volume } \\
(\mathrm{mL})\end{array}$ & $\begin{array}{c}\text { Detection } \\
\text { limit } \\
(\mathrm{mg} / \mathrm{L})\end{array}$ \\
\hline DNAPL compounds & Solvent extraction with GC/ECD & 1 to 10 & 0.005 \\
\hline $\mathrm{pH}$ & Electrometric & 20 & NA \\
\hline Temperature & Electrometric & 20 & NA \\
\hline Specific conductance (EC) & Electrometric & 20 & NA \\
\hline Dissolved oxygen (DO) & Ampule or Electrometric & 20 & 1 \\
\hline $\begin{array}{l}\text { Total dissolved solids / total } \\
\text { suspended solids }\end{array}$ & Gravimetric and/or test kits & 100 & NA \\
\hline Alkalinity & Titration & 100 & NA \\
\hline Total organic carbon & Dry combustion & 50 & 0.050 \\
\hline $\begin{array}{l}\text { Cations: magnesium calcium, } \\
\text { potassium, manganese, iron }\end{array}$ & $\begin{array}{l}\text { Spectrophotometer, AA or } \\
\text { ICP }\end{array}$ & $25-100$ & $<1$ \\
\hline Anions: chloride, sulfate, nitrate & IC & 100 & $<1$ \\
\hline
\end{tabular}

All analyses were made in accordance with standard practices for environmental engineering research including those referenced in Standard Methods for Examination of Water and Wastewater. All analyses methods were documented in project logbooks and files and described in detail in project reports. 
Table 2.16 Sidewall sensor locations.

\begin{tabular}{|c|c|c|c|}
\hline Boring ID & $\begin{array}{l}\text { Sidewall Piezometer } \\
\text { Location * } \\
\text { (ft bgs) }\end{array}$ & $\begin{array}{l}\text { TDR Antennae } \\
\text { Location } \\
\text { (ft bgs) }\end{array}$ & $\begin{array}{l}\text { Redox Electrode } \\
\text { Location } \\
\text { (ft bgs) }\end{array}$ \\
\hline$\overline{\text { BGM1 }}$ & $\begin{array}{c}8.0 \\
10.0 \\
12.0 \\
13.5 \\
16.0\end{array}$ & $\begin{array}{c}2.0 \\
4.0 \\
6.0 \\
7.8 \\
9.8 \\
11.8 \\
13.0 \\
15.75\end{array}$ & $\begin{array}{c}1.75 \\
3.75 \\
5.75 \\
7.5 \\
9.5 \\
11.5 \\
13.25 \\
15.75\end{array}$ \\
\hline TAM1 & $\begin{array}{l}4.0 \\
6.0 \\
7.0 \\
8.0 \\
10.0 \\
11.0 \\
11.5 \\
14.0\end{array}$ & $\begin{array}{l}3.0 \\
3.8 \\
5.8 \\
6.8 \\
7.3 \\
9.8 \\
11.0 \\
11.5 \\
12.0 \\
13.8\end{array}$ & \\
\hline TAM2 & $\begin{array}{l}3.0 \\
4.8 \\
5.3 \\
5.8 \\
6.5 \\
7.0 \\
7.5 \\
8.0 \\
10.0 \\
12.0\end{array}$ & $\begin{array}{l}3.0 \\
4.8 \\
5.3 \\
5.8 \\
6.5 \\
7.0 \\
7.5 \\
8.0 \\
10.0 \\
12.0\end{array}$ & $\begin{array}{c}2.8 \\
4.6 \\
5.1 \\
5.6 \\
6.3 \\
6.8 \\
7.5 \\
10.0 \\
12.0\end{array}$ \\
\hline TBM2 & $\begin{array}{c}3.0 \\
4.5 \\
5.3 \\
7.5 \\
8.3 \\
9.0 \\
12.0 \\
6.0 \\
7.2 \\
8.0\end{array}$ & $\begin{array}{c}3.0 \\
4.5 \\
5.3 \\
7.5 \\
8.3 \\
9.0 \\
12.0 \\
6.0 \\
7.2 \\
8.0\end{array}$ & $\begin{array}{l}2.9 \\
4.3 \\
5.2 \\
7.5 \\
8.3 \\
8.8 \\
11.8 \\
7.0 \\
7.8\end{array}$ \\
\hline
\end{tabular}


Table 2.16 cont. Sidewall sensor locations.

\begin{tabular}{|c|c|c|c|}
\hline Boring ID & $\begin{array}{c}\text { Sidewall Piezometer } \\
\text { Location * } \\
\text { (ft bgs) }\end{array}$ & $\begin{array}{l}\text { TDR Antennae } \\
\text { Location } \\
\text { (ft bgs) }\end{array}$ & $\begin{array}{l}\text { Redox Electrode } \\
\text { Location } \\
\text { (ft bgs) }\end{array}$ \\
\hline TCM1 & & $\begin{array}{c}2.0 \\
3.9 \\
5.9 \\
7.9 \\
10.0 \\
11.9 \\
14.0\end{array}$ & $\begin{array}{c}2 \\
4.0 \\
4.25 \\
4.5 \\
4.75 \\
5.0 \\
6.0 \\
7.0 \\
8.0 \\
8.25 \\
8.5 \\
8.75 \\
9.0 \\
10.0 \\
11.0 \\
11.5 \\
11.75 \\
12.0 \\
12.25 \\
13.0 \\
13.8\end{array}$ \\
\hline TDM1 & 9.75 & $\begin{array}{c}8.0 \\
9.5 \\
9.75 \\
10.0 \\
12.0 \\
14.0\end{array}$ & $\begin{array}{c}9.25 \\
9.5 \\
9.75 \\
10.0 \\
10.25 \\
11.0 \\
12.0 \\
14.0\end{array}$ \\
\hline TDM2 & & $\begin{array}{c}2.0 \\
4.0 \\
6.0 \\
8.0 \\
9.5 \\
9.75 \\
10.0 \\
12.0 \\
14.0\end{array}$ & $\begin{array}{c}2.0 \\
3.0 \\
3.25 \\
3.5 \\
3.75 \\
4.0 \\
6.0 \\
8.0 \\
9.25 \\
9.5 \\
9.75 \\
10.0 \\
10.25 \\
11.0 \\
12.0 \\
13.0 \\
14.0\end{array}$ \\
\hline
\end{tabular}

* Water levels within the sidewall piezometers did not change over the course of the project. The piezometers may have been plugged at installation. 
Table 2.17. Helium tracer tests conducted in test cells A and B during fall 1996.

Date or period

Description

$10 / 27 / 96$

Test cell B, helium injected into the $8 \mathrm{ft}$ fracture at $3.75 \mathrm{scfh}$ with helium concentrations monitored at the 4 and $12 \mathrm{ft}$ fractures.

$10 / 28 / 96$

Test cell $\mathrm{B}$, helium injected into the $8 \mathrm{ft}$ fracture at $2 \mathrm{scfh}$ total flow of $3.75 \mathrm{scfm}$; helium concentrations monitored at the 4 and $12 \mathrm{ft}$ fractures.

11/22/96 Test cell A, helium injected into the $8 \mathrm{ft}$ fracture at $0.25 \mathrm{scfh}$; test terminated due to problems with the steam generator.

11/22/96 Test cell A, helium injected into the $8 \mathrm{ft}$ fracture at $0.4 \mathrm{scfh}$; test terminated due to problems with water condensation in the helium sample lines.

11/23/96 Test cell B, helium injected into the $6 \mathrm{ft}$ fracture at $1 \mathrm{scfh}$ total flow of 6 $\mathrm{scfm}$; test terminated due to high consumption of helium.

11/24/96 Test cell B, helium injected into the minipiezometer located $\sim 4 \mathrm{ft} \mathrm{NNW}$ of the fracture access casings; helium concentrations monitored at the 4 and $12 \mathrm{ft}$ fractures.

12/9/96 Test cell B, helium injected into the $6 \mathrm{ft}$ fracture at $1.7 \mathrm{~L} / \mathrm{min}$; helium concentrations monitored at the 4 and $12 \mathrm{ft}$ fractures.

12/9/96 Test cell B, helium injected into the $8 \mathrm{ft}$ fracture at $1.7 \mathrm{~L} / \mathrm{min}$ and $14 \mathrm{psi}$ (needed to overcome the hot air injection pressure); helium concentrations monitored at the 4 and $12 \mathrm{ft}$ fractures.

12/12/96 Test cell A, helium injected into the $8 \mathrm{ft}$ fracture at $2.2 \mathrm{~L} / \mathrm{min}$ and $15 \mathrm{psi}$ (needed to overcome the hot air injection pressure); test terminated because flow could not be sustained. 


\section{HOT FLUID INJECTION AND MASS RECOVERY SYSTEMS RESULTS}

\subsection{TEST CELL FEATURES AND OPERATIONS}

Results of hot fluid injection tests conducted during fall 1996 and summer 1997 are described in this section. These tests were intended to demonstrate the effects of injecting thermal energy into contaminated LPM (i.e., the Minford). Thermal energy was injected into one test cell as steam (cell A) and into another test cell as hot air (cell B). Contaminants were captured by vacuum extraction of the surrounding soil. To maximize fluid delivery and recovery, hydraulic fracturing methods were used to create sand-filled fractures (Fig. 3.1) emanating from the injection and extraction wells. The hydraulic fractures were shaped like flat-lying saucers roughly $25 \mathrm{ft}$ in maximum dimension. Four wells and associated fractures were installed in test cell $\mathrm{A}$ and five wells and associated fractures were installed in test cell B. For the discussion throughout this section, the wells are designated using the letter of the test cell and the depth bgs of the fracture at bottom of the casing. The fracture profile and monitoring locations for test cell $\mathrm{A}$ are shown in Figures 3.2 and 3.3 while similar depictions for test cell B are given in Figures 3.4 and 3.5. Appendix B contains additional information on the fracture geometry in each test cell.

The tests during fall 1996 and summer 1997 consisted of injecting hot fluid into one well while recovering air or water from the other ones. At test cell A, steam was injected into well A-8 and water and vapor were recovered from wells A-4 and A-12. At test cell B, hot air was injected into well B-8 while ambient air was injected into well B-6. Water and vapor were recovered from wells B-4 and B-12. Deeper wells in both test cells (i.e., A-18 and B-16) were used to recover water from each cell. Numerous locations were monitored for various parameters throughout the test cells as described previously in Section 2 and shown in Figures 3.2 to 3.5.

The sequence of process operations was similar for both the fall 1996 and summer 1997 tests and at both test cells $\mathrm{A}$ and $\mathrm{B}$, although the details varied somewhat. The beginning of the test including gravity dewatering using down-hole pumps. A few days later suction was applied to initiate vapor extraction and to accelerate dewatering. Hot fluids were injected a few days to two weeks after dewatering was started. Steam injection was terminated prior to the end of the tests and the final stage of operations in test cell $\mathrm{A}$ involved only dewatering and vapor extraction. Hot air injection continued until the end of the tests. During the fall 1996 test, dewatering was started on October 7, 1996, and all other activities that occurred over the following 66 days are referenced to that date. During the summer 1997 test, the start date was July 20 and all activities over the subsequent 46 days are referenced to that start date.

Test cells A and B shared a common vapor extraction system. Suction was applied to wells A-4, A-12, B-4 and B-12 during the test using a liquid ring pump. This process was initiated on day 12 in 1996 and on day 1 in 1997 and proceeded throughout the test. Individual separators for each well and headers at each test cell permitted measurements of rate and suction for each well.

\subsection{SUBSURFACE CONDITIONS}

Characteristics of the X-231A site are described in Section 2 and Appendix $C$ of this report. The in situ soil properties and conditions at locations distant from the test cells were expected to be unaffected by the tests. However, small temporal variations or seasonal trends could be expected to occur, and background monitoring locations were established at areas beyond the X-231A demonstration site. The background and initial measurements of moisture content, temperature, and ground water hydraulic head with some references to changes that were induced during process operations are described below. 


\subsubsection{Moisture Content}

Volumetric moisture content of soil in the vicinity of the test cells was measured in situ using TDR waveguides emplaced into the sidewalls of boreholes over the depth range of 2 to $14 \mathrm{ft}$ bgs (Figs. 2.16, 3.3 and 3.5). Moisture content was also estimated from soil samples obtained using a directpush sampler. The gravimetric moisture contents measured on soil from the cores were converted to volumetric contents using $2.0 \mathrm{~g} / \mathrm{cm}^{3}$ as the average bulk density for the silty clay soils at the X231A site. Only volumetric moisture contents are presented in this report.

Volumetric moisture contents were determined using TDR approximately 5 times during the fall 1996, and 3 times during the summer 1997. Volumetric moisture contents were estimated from soil core data several times during the fall 1996 and at least once during the summer 1997. The data from the TDR measurements are presented on figures in this report by indicating the suite of measurements from the fall 1996 with filled symbols and the data from the summer 1997 with open symbols.

Background measurements made using TDR indicate moisture contents varied between 0.25 and $0.35 \mathrm{v} / \mathrm{v}$ (Appendix C, Fig. C.5). Most of the measurements are roughly $0.30 \mathrm{v} / \mathrm{v}$ and repeated background moisture contents measured by TDR varied by only a few percent from fall 1996 through summer 1997. These slight variations through the year likely indicate some moisture movement at the background location. An increase in moisture content between the fall and summer measurements at shallow depths is consistent with moist soil observed at several locations beneath the X-231A cap during the summer 1997 field work. Volumetric water contents estimated using the soil cores ranged from 0.28 to $0.35 \mathrm{v} / \mathrm{v}$, the same range as the data from the TDR. The soil core data indicate that moisture increases from 0.28 to $0.35 \mathrm{v} / \mathrm{v}$ with depth down to $10 \mathrm{ft}$ bgs, and then it decreases from 0.35 to $0.30 \mathrm{v} /$ between 10 and $15 \mathrm{ft}$ bgs. This water content profile with depth is correlated with the lithologic profile at the X-231A site (i.e., clay transitioning to silt with depth).

The particular results for test cells A and B are discussed below while those for test cells C and D are highlighted as follows. The moisture content in cell $\mathrm{C}$ as measured before the test varied between 0.25 and $0.35 \mathrm{v} / \mathrm{v}$, according to both the TDR and soil core data (Appendix E). The moisture content reaches a maximum at $6 \mathrm{ft}$ bgs, or approximately $1 \mathrm{ft}$ below the shallowest fracture (TCM1). The moisture content at other depths appears to be unrelated to fractures filled with iron particles. The soil core data taken at the end of the test indicate that the moisture content decreased markedly to between 0.20 and $0.25 \mathrm{v} / \mathrm{v}$ in cell C. Some decrease in moisture content in cell $\mathrm{C}$ could have occurred due to reduction of water by reaction with the iron metal, but the magnitude of the apparent decrease is difficult to explain.

In test cell $\mathrm{D}$, the TDR data indicate moisture contents of $\sim 0.30 \mathrm{v} / \mathrm{v}$, except at and below a permanganate-filled fracture at $9.75 \mathrm{ft}$ bgs where the moisture content increases to values of 0.40 $\mathrm{v} / \mathrm{v}$. Similar moisture contents were observed by the TDR data throughout the duration of the test. Moisture contents estimated from the soil cores are consistent with the TDR data at the beginning of the test. However, the soil core data taken at the end of the test indicate drying to between 0.22 and $0.28 \mathrm{v} / \mathrm{v}$ by the end of the test, which is not consistent with moisture content measurements made using TDR. The decrease in moisture content in cell $\mathrm{D}$ indicated by the soil core data is difficult to explain, but differences between the TDR and soil core data could be due to the permanganate present in the soil system.

Minor variations in moisture content are expected beneath a capped site underlain by silty clay, such as X-231A and the TDR signals are consistent with this expectation. The novel application of TDR waveguides in the sidewall of boreholes appear to have given a reasonable assessment of moisture content during the test. Future applications of this technique would benefit from the 
development of a site-specific calibration between dielectric constant and moisture content. Moreover, future applications of TDR during hot fluid injection should correct for changes in the dielectric constant of water as a function of temperature.

\subsubsection{Temperature}

Temperature was measured as a function of depth and time at several boreholes in each cell, and it was measured across the ground surface at the end of the project. In each cell, there were 6 boreholes that contained thermistors fixed to a PVC tube that was pushed into a tight-fitting corehole and grouted in place (Sect. 2.5.3.1). Temperature at the thermistors were measured and recorded using a datalogger. Another set of boreholes contained 0.5 -in diameter PVC pipe that was sealed into the hole with cement. A small thermocouple was inserted into the casing and the temperature was measured where the thermocouple wiped against the wall of the casing. Wiper thermocouple measurements were collected intermittently by manual methods.

Measurements made using the wiper thermocouple were probably distorted slightly by heat transfer within the PVC pipe. The thermocouple was measured with a hand-held meter and allowed to equilibrate for several tens of seconds before recording a temperature. This duration appeared to be sufficient to produce a constant temperature reading. Nevertheless, measurements made while inserting the thermocouple could be $1-2{ }^{\circ} \mathrm{C}$ greater than while pulling it out of the ground. It is assumed that the measurements made while inserting the thermocouple were most accurate because the least thermal disturbance occurred. Nevertheless, it is expected that the error associated with the thermocouple measurements is on the order of a few ${ }^{\circ} \mathrm{C}$. The accuracy of the thermistors is on the order of one ${ }^{\circ} \mathrm{C}$, and are immune from heat transfer while inserting a measurement device. However, the thermistors relied on an electronic system that was temporarily inoperational. Moreover, only a limited number of thermistor-monitored boreholes were available. The wiper thermocouple method was thus used when and where the thermistors were unavailable.

The boreholes used to measure temperature were placed at various locations (Figs. 3.3 and 3.5) in each cell in an effort to determine the 3-dimensional temperature field. Representative initial and background temperature profiles through the soil were readily determined by averaging several arrays of thermistor data (Figs. 3.6 and 3.7) and thermocouple data (Fig. 3.8). Below a depth of $3 \mathrm{ft}$, the fall 1996 profile and summer 1997 profiles are similar. The near surface temperatures in the profiles $\left(\sim 15^{\circ} \mathrm{C}\right.$ in the fall of 1996 and $\sim 30^{\circ} \mathrm{C}$ in the summer of 1997) reflect the seasonal temperature and the fact that the site was capped by a black membrane liner.

Evaluation of the data during thermal injection tests indicated that the number of boreholes was insufficient to fully resolve the 3-dimensional temperature field. As a result, the temperature field was assumed to be axially symmetric about the point of injection. Based on this assumption, the locations of each borehole were transformed onto a radial cross-section. Each borehole was located based on its radial location, and then mirrored to produce a cross-section extending through the cell. Note that all the cross-sections produced by this procedure must be axially symmetric which is an artifact of the method used to prepare the cross-sections. The actual temperature fields probably lack rigorous axial symmetry, but this method gives the most complete cross-sectional depiction based on the available data. The projected data were interpolated by kriging with a linear variogram using SURFER ${ }^{\mathrm{TM}}$. The temperature measurements were closely spaced (roughly 10 $\mathrm{cm}$ ) with depth along the boreholes, but each borehole could be a meter or more from neighboring boreholes. For this reason, an anisotropic variogram was used with a horizontal to vertical aspect ratio of 3.5:1. During thermal injection in situ temperatures defined a roughly horizontal diskshaped zone of heated soil, which became more cylindrical as the tests progressed. Specifics for the two test cells are discussed below in the separate sections for the two treatment processes. 


\subsubsection{Hydraulic Heads from Water Level Measurements}

The water table in the vicinity of test cells A and B was measured at several piezometers installed within the test cells and in the vicinity of them. All piezometers (X231A-TAP1, X231A-TBP1, X231A-TCP1, X231A-TDP1, X231A-BGP1, X231A-BGP2, and X231A-BGP3) were completed with a well screen between 15.5 and $16.6 \mathrm{ft}$ bgs (Figure 2.10). The heads measured at each piezometer (Fig. 3.9) were scaled to a reference head measured at that piezometer on July 16, 1996. This was done to highlight changes in head among piezometers over the course of the testing, but it does obscure information about the hydraulic gradient across the site. During the course of the fall 1996 tests, the head in X231A-TCP1, TCD1, X231A-BGP1, X231A-BGP2; and X231A-BGP3 varied above and below initial levels by less than $0.5 \mathrm{ft}$. The magnitude of the temporal variation in these five piezometers was nearly identical, with a few exceptions at days 19 , 32,44 , and 65 . In contrast, the head in the piezometers within cell A (X231A-TAP1) and cell B (X231A-TBP1) deviated from the trend defined by the other five piezometers.

During the fall 1996 test, a relative change in head in X231A-TAP1 is consistent with the removal of 13,500 L (3570 gal) of water from cell A during that period. The head in X231A-TAP1 gradually decreased, as compared to a trend of changes defined by several background piezometers (Fig. 3.9). By day 36 the head was $0.33 \mathrm{ft}$ lower than neighboring piezometers and by day 47 it was $0.75 \mathrm{ft}$ deeper (Fig. 3.10). Water recovery appeared to affect the head in the test cell B piezometer in the same manner as recovery affected water levels in test cell $A$. The water level in X231A-TBP1 became gradually deeper, dropping by $0.25 \mathrm{ft}$ by day 36 and nearly $1.0 \mathrm{ft}$ by day 50. After the end of the test, the water level under both cells had resumed to a normal depth. Thus, the changes in water levels correlate to the recovery rates from cell A and B; that is, the water level decreased when the recovery rate from the lower fractures increased.

During the summer of 1997, heads in the background piezometers (X231A-BGP1, X231A-BGP2, and X231A-BGP3) were about a foot higher than during the fall of 1996 (Fig. 3.11). The higher water level may be seasonal or may reflect increased infiltration through the cap due to holes created during the 1996 tests. Test cells C and D were subjected to active infiltration of water during the 1997 tests, so the heads in X231A-TCP1 and X231A-TDP1 could be expected to deviate from any central trend defined by X231A-BGP1, X231A-BGP2, and X231A-BGP3. Excluding piezometers in test cells $C$ and $D$, the temporal change in head amounted to a half foot lowering during the course of the 1997 test. The deviations of heads in X231A-TAP1 and X231A-TBP1 were not as marked as in 1996.

During the summer 1997 test, water level measurements were only made in piezometer X231ATAP1 before and after the test and on days 4 and 45 during the test, so this sparse data set resolves head variations in considerably less detail than during the fall 1996 test. Heads varied by $0.08 \mathrm{ft}$ from the values defined by the three background piezometers (Fig. 3.11), and this variation is similar to that observed among background water level measurements. Accordingly, there is no evidence that the water level below test cell A was affected during the summer 1997 test, even though it decreased by as much as $0.75 \mathrm{ft}$ during the 1996 test. Water level measurements made in piezometer X231A-TBP1 also dropped a negligible amount $(0.1 \mathrm{ft})$ which is consistent with the scatter observed among background water level measurements. Apparently water recovery at depth during 1996 effected a lowering of water levels while the lack of recovery in 1997 precluded an impact on water level.

\subsection{STEAM INJECTION AND MASS RECOVERY}

The components required for the steam injection include support utilities (water, electric, and instrument air), a control system, and an in-well (a.k.a. down-hole) steam generator. Contaminant recovery required water recovery pumps, pump controllers, separators, separator controllers, 
produced water storage, and a vacuum system. Additional components of these systems are listed in Table 3.1

\subsubsection{Dewatering in Test Cell A}

Water was recovered from three wells in test cell A (i.e., A-4, A-12 and A-18) during both the fall 1996 and summer 1997 tests. Liquid was recovered from A-4 by suction lift and entrainment; a down-hole pump was not used at this well. The deeper wells, A-12 and A-18, were equipped with bladder pumps at the bottom of the wells. The pumps were intended to maintain fluid level at the bottom of the well, thus effecting maximum drawdown. Recovery from A-12 was further enhanced by application of approximately 100-inches of suction while A-18 was open to atmospheric pressure.

During the fall 1996 test, recovery from A-18 started on day 10 at $\sim 250$ liters per day (Lpd) (66 gallons per day [gpd]) (Fig. 3.12). After six days the rate decreased to about $100 \mathrm{Lpd}$, but by day 25 it had increased to $200 \mathrm{Lpd}$. At day 36 the rate decreased to $50 \mathrm{Lpd}$ and remained so for the next 30 days. From day 56 to the conclusion of the test, recovery averaged $150 \mathrm{Lpd}$. The variation in recovery rate may be due to changes of in situ conditions or due to fluctuation in the equipment; the data do not provide indication of the degree of either. In all, about $6200 \mathrm{~L}$ (1640 gal) were recovered from A-18. Recovery from A-12 began on day 20 . The recovery rate was $100 \mathrm{Lpd}$ during the first 3 days, but it decreased to negligible values for the next 14 days. On day 35 the dewatering pump was discovered to be clogged and was repaired. Over the next two weeks the recovery rate averaged $400 \mathrm{Lpd}$. Recovery proceeded at $100 \mathrm{Lpd}$ from day 49 to the conclusion of the test. Almost $7000 \mathrm{~L}$ (1850 gal) of water were recovered from A-12 during the fall of 1996 (Fig. 3.12). Recovery from A-4 also began on day 20. Only $360 \mathrm{~L}$ (95 gal) of water were recovered from this well during 1996 , with $140 \mathrm{~L}(37 \mathrm{gal})$ recovered in the first day. The total recovery from A-4 was approximately equal to the volume of water injected in the slurry that created the fracture in A-4 (Fig. 3.12).

During summer 1997 water recovery from all three wells was initiated on day 1 and the equipment and operating practices were the same as during 1996. Recovery from A-4 was accomplished by suction lift only, whereas bladder pumps were installed in the deeper wells. Drawdown in A-12 was augmented by suction, and A-18 remained open to the atmosphere. A total $15300 \mathrm{~L}$ (4040 gal) of water were recovered from test cell A during 1997 (Fig. 3.13). Recovery from A-18 proceeded at $160 \mathrm{Lpd}$. The recorded water volume shows no recovery from day 13 to day 27 , which was due to an inoperable separator (Fig. 3.13). The separator permitted the downhole pump to discharge directly to the water accumulation tanks without making measurements. The separator was repaired on day 26 and the recovery record resumed. According to the record, about 3600 liters of water were recovered from A-18 during 1997, but if the recovery rate is assumed to have remained constant from day 12 to 28,6700 liters actually were produced. Thus A-18 recovery during the 1997 test could have been consistent with recovery during the fall 1996 test. Water recovery from A-12 during the 1997 test amounted to $500 \mathrm{~L}$ with over half occurring during the first five days. When the pump was retrieved from A-12 at the end of the test, the pump body was badly deformed by heat and the pump bladder was split. The majority of water recovered during 1997 came from well A-4. Substantial recovery began around day 5 and continued in excess of $250 \mathrm{Lpd}$ throughout the test. About $11000 \mathrm{~L}(2910 \mathrm{gal})$ of water were recovered from A-4 during the 1997 test. This result contrasts sharply the results from the previous fall when A-4 produced relatively small amounts of water.

The relative change in head in piezometer X231A-TAP1 is consistent with the removal of ground water from A-18, A-12 and A-4 during the fall 1996 and summer 1997 tests. During 1996, the head in X231A-TAP1 gradually decreased as compared to several background piezometers (Fig. 3.9 ), and by day 47 the water level in X231A-TAP1 was $0.75 \mathrm{ft}$ deeper than the background trend. 
During 1997, the head level was depressed less but then there was much lower recovery from well A-18 during this period. At the end of both test periods, the water level had resumed a normal depth. The changes in water level correlate to the recovery rates from the cell; that is the water level decreased when the recovery rate from the lower fractures increased.

\subsubsection{Vapor Extraction in Test Cell $\mathrm{A}$}

During 1996 the applied suction was between 100 and 150 in $-\mathrm{H}_{2} \mathrm{O}$ at the beginning of the test and decreased to between 50 and 100 in- $\mathrm{H}_{2} \mathrm{O}$ by day 35 (Fig. 3.14). Applied suction was increased markedly on day 42 to between 150 and 200 inches, and this period of increased suction lasted for approximately 1 week until day 50 . On day 50 the applied suction was purposefully reduced in an attempt to limit water production into the vacuum system. Applied suctions were 70 to 80 in $-\mathrm{H}_{2} \mathrm{O}$ from day 50 until the end of the test (Fig. 3.14). The 1997 test started with 110 to 120 in- $\mathrm{H}_{2} \mathrm{O}$ suction, but by the second day the applied suction decreased to 80 in- $\mathrm{H}_{2} \mathrm{O}$ (Fig. 3.15). On day 7 , suction increased to 110 in- $\mathrm{H}_{2} \mathrm{O}$. Throughout the remainder of the 1997 test, suction fluctuated between 95 and 115 in $-\mathrm{H}_{2} \mathrm{O}$, with the exception of no suction on day 15 (Fig. 3.15). An episode of mechanical and electrical problems at the site caused the temporary shut-down.

Vapor recovery rates from A-4 were between 200 and $400 \mathrm{cfh}$ at the beginning of the test in 1996 and generally decreased with operation (Fig. 3.14). The lowest recovery rates from A-4 were less than $50 \mathrm{cfh}$ and occurred between days 30 and 36, when the applied suction was relatively low (50 to 70 in $-\mathrm{H}_{2} 0$ ). Recovery rates from A-4 increased somewhat to approximately $100 \mathrm{cfh}$ when the applied suction was increased between days 40 and 50, but the recovery rate from A-4 never approached the rates observed early in the test. When the applied suction was decreased on day 50 , the rate of recovery from A-4 decreased to roughly $50 \mathrm{cfh}$ and that rate was maintained until the end of the test. During the 1997 test, recovery from A-4 ranged from negligible values to $60 \mathrm{cfh}$, with four outlying measurements in excess of $90 \mathrm{cfh}$. The vapor recovery from A-4 was unaffected by changes in applied suction on days 2,7 , and 15 .

Recovery from A-12 started at nearly negligible rates and increased gradually to $50 \mathrm{cfh}$ by day 35 of the 1996 test, even though suction decreased during the same interval (Fig. 3.14). Around day 45 , recovery increased four-fold to $200 \mathrm{cfh}$, remained so for 5 days, and then abruptly decreased to approximately $30 \mathrm{cfh}$. During the ensuing 10 days, recovery decreased further to $20 \mathrm{cfh}$. From day 61 to the end of the 1996 test, recovery varied from 100 to $225 \mathrm{cfh}$. During the summer 1997 test, recovery during the first two weeks varied from 10 to $50 \mathrm{cfh}$, with a slightly decreasing trend (Fig. 3.15). From 13 days to 35 days recovery varied from 30 to $60 \mathrm{cfh}$. From 35 days to the end of the test recovery was between 20 and $50 \mathrm{cfh}$.

A more general assessment of the recovery rates can be derived from specific discharge, which is the ratio of recovery rate to applied suction. The specific discharge facilitates comparison of discharges at different suctions and thus provides insight into the transmissibility of the soil. At the beginning of the 1996 test, specific discharge from A-4 ranged from 5 to $10 \mathrm{cfh} / \mathrm{in}-\mathrm{H}_{2} \mathrm{O}$ (Fig. 3.16). After a week, specific discharge decreased to approximately $3 \mathrm{cfh} / \mathrm{in}-\mathrm{H}_{2} \mathrm{O}$, and by day 30 specific discharge had decreased to less than $1 \mathrm{cfh} / \mathrm{in}-\mathrm{H}_{2} \mathrm{O}$. Specific discharge remained consistently less than $1 \mathrm{cfh} / \mathrm{in}-\mathrm{H}_{2} \mathrm{O}$ during the 1996 test and also throughout the 1997 test (Fig. 3.17). The specific discharge for A-12 was generally less than from A-4 and varied from 0.3 to $1.8 \mathrm{cfh} / \mathrm{in}-\mathrm{H}_{2} \mathrm{O}$ during both tests. During 1996, the specific discharge can be divided into four distinct periods: $0.5 \mathrm{cfh} / \mathrm{in}-\mathrm{H}_{2} \mathrm{O}$ from day 35 to $40,1.2 \mathrm{cfh} / \mathrm{in}-\mathrm{H}_{2} \mathrm{O}$ from day 45 to $50,0.3$ from day 56 to 62 , and 1.8 from day 62 to 66 (Fig. 3.16). During the 1997 test the specific discharge decreased from 0.4 to $0.2 \mathrm{cfh} / \mathrm{in}-\mathrm{H}_{2} \mathrm{O}$ during the first 12 days, then increased to $0.8 \mathrm{cfh} / \mathrm{in}-\mathrm{H}_{2} \mathrm{O}$ at day 15, which corresponds to an period of interrupted suction (Fig. 3.17). For the next two weeks specific discharge varied around $0.5 \mathrm{cfh} / \mathrm{in}-\mathrm{H}_{2} \mathrm{O}$. During the final two weeks, it gradually decreased to $0.4 \mathrm{cfh} / \mathrm{in}-\mathrm{H}_{2} \mathrm{O}$. 


\subsubsection{Steam Injection in Test Cell A}

\subsubsection{Power and Water Consumption --}

Steam was produced by an in-well generator that was installed in A-8. The generator was electrically powered and used potable water from the PORTS facility. Steam injection occurred during a limited time-frame during both the fall 1996 and summer 1997 tests.

During the fall 1996 test, the steam generator was operated during two periods, each approximately 1 week in duration and separated by 10 days of relative inactivity (Fig. 3.18). The first period from day 28 to 36, was characterized by power consumption of $7800 \mathrm{~W}$ and total liquid usage of about $700 \mathrm{gal}$. The second period, from day 47 to 53 , also utilized approximately $7800 \mathrm{~W}$ and $700 \mathrm{gal}$ of water. In all $3200 \mathrm{~kW}-\mathrm{hr}$ and 1400 gal of water were used during the fall 1996 test.

During the summer 1997 test, steam was injected from day 2 to 37 (Fig. 3.19). Initially, energy was consumed at $6250 \mathrm{~W}$ and then gradually decreased. By day 25 power decreased to $3300 \mathrm{~W}$. Water consumption followed a similar, gradually decreasing trend during the first three weeks of the summer 1997 test. The generator was shut down during the following week and operated intermittently during the final week of the test, which reduced the average power use during the final week to approximately $2100 \mathrm{~W}$. The injection temperature was approximately $235^{\circ} \mathrm{F}$ throughout the test. The steam temperature indicates that injection pressures were about $8 \mathrm{psi}$, according to the equation of state for water.

The ratio of power to water consumption rate, which is a measure of the thermodynamic efficiency of steam production, provides an assessment of the performance of the generator. The theoretical energy requirement for steam generation, including sensible heat for increasing the temperature of the feed water and latent heat at the typical injection pressure, amounted to 2.75 and $2.70 \mathrm{~kW}$ $\mathrm{hr} / \mathrm{gal}$ in the fall 1996 and summer 1997 tests, respectively. The actual performance of the generator is compared to these theoretical values in Figure 3.20 and 3.21. During the first weeklong period of injection during the fall 1996 test, the generator used 1.9 to $2.6 \mathrm{~kW}-\mathrm{hr}$ for every gal of water consumed, with a decreasing trend in the ratio of power:water rate. The deviation from the theoretical should be interpreted as excessive water use. During the second period of injection during the fall 1996 test, the ratio of power to water rate was, in some instances, greater than the theoretical value. In such cases, energy consumed by the generator was used for processes other than steam formation, such as heating the soil adjacent to the well by conduction or heat transfer to the air above the generator in the well. During the summer 1997 test, the power:water rate ratio varied about the theoretical, indicating minor waste of water and effective use of electricity.

The low ratio of power:water rate during the 1996 tests is consistent with visual observation of the generator while partially inserted into the well, which revealed substantial splashing of liquid and turbulence around the exit ports of the generator during fall 1996. Presumably, splashing and turbulence carried unvaporized water out of the generator when it was fully installed. The steam generator was modified by placing internal baffles to minimize water loss due to splashing. The increase in the power:water rate ratio during the summer tests indicates that the baffles performed as designed.

\subsubsection{Equipment Operation and Maintenance --}

The fall 1996 steam injection test is characterized by two periods when the energy production of the steam generator was as expected. These two periods were separated by a period when the energy production was limited by mechanical problems. Additional problems limited the energy production during the last week of the test. The steam generator operated at unusually high 
pressures during the fall 1996 test causing some steam to be lost to the atmosphere through a pressure relief valve. As a result, the amount of steam and heat that was injected into the ground was less than what was produced by the generator. Moreover, the high operating pressures caused a variety of mechanical problems because the generator was operating at pressures that exceeded design specifications. A significant amount of mineral precipitate of unknown composition was discovered in the bottom of the well at the end of the fall 1996 test. The precipitate resembled material that accumulated in the bottom of the steam generator, and it is suspected that it resulted from water splashing out of the steam generator and into the well.

The internal configuration of the steam generator was redesigned to reduce the potential for splashing during the summer 1997 test. The injection pressures increased with time during the summer 1997 test, however, the extent to which this occurred was modest compared to the fall 1996 test. Furthermore, the operational problems that accompanied the high operation pressures during the fall 1996 test were absent during the summer 1997.

The steam generator operated according to design during the first three weeks of the summer 1997 test, and it required three maintenance events after that time. The first event occurred around August 14th when the instrument air supply was inadvertently disabled during routine inspection, which caused the heating elements to malfunction. Shortly after repairs were made, severe weather knocked over the controller which caused safeguards to shut down the generator. After repairs to mounting hardware, the system was restored to operation. A few days later another disruption in the instrument air supply caused the heating elements to become inoperable. The system was repaired and placed on-line. Finally, high injection pressure caused failure in the level detection system. Given the limited time remaining for activities at the site, and the interest in observing decay transients, repairs were not made.

The functionality of the steam generator appeared to be sound during the first three weeks of the summer 1997 test. After that, the system shut down in response to unforeseen events that disabled the water controller. Additional modifications, such as a fail-safe systems that will shut off the generator if the air supply is interrupted, were required to increase the robustness of the generator so that it will handle the types of unforeseen events described above.

\subsubsection{Effects of Steam Injection on Subsurface Characteristics}

\subsubsection{Moisture Content --}

The soil in cell A was the driest at shallow depth (roughly $0.25 \mathrm{v} / \mathrm{v}$ at depths less than $3 \mathrm{ft}$ ) and it varied between 0.30 and $0.40 \mathrm{v} / \mathrm{v}$ at greater depths during the fall 1996 test, according to both TDR and soil sample data (TAM1, Fig. 3.22). Local variations in moisture content are coincident with the locations of hydraulic fractures. The moisture content increases from 0.30 to 0.35 below a fracture at $7.5 \mathrm{ft}$ bgs, and it increases to 0.40 below a fracture at $11 \mathrm{ft}$ bgs. In both cases, the TDR waveguides at the depth of the fracture indicate moisture of $0.30 \mathrm{v} / \mathrm{v}$, but the ones below the fracture indicate greater moisture values. Moisture content measured during the fall 1996 test at boring TAM2 followed a similar pattern. The data range from 0.28 to 0.36 , and there is an increase in moisture content below a hydraulic fracture. The TDR data at each depth are within a few percent throughout the test, indicating only minor variations in moisture during that time.

Moisture content at the beginning of the summer 1997 test was nearly identical to that during the fall 1996 test. However, at the end of the summer test a systematic increase in moisture content is indicated at and above $8 \mathrm{ft}$ bgs, the depth of the fracture where steam was injected. There was a negligible change in moisture below that depth. This change is apparent in the TAM1 data, but there is minor change in the moisture content at TAM2 during the summer. The soil samples 
indicate an opposite trend, however. They show that the moisture content decreased by as much as 0.10 compared to measurements made the previous year in cell A.

The measurements of moisture content using TDR assume that the relationship between dielectric constant of the soil and moisture content remained constant. However, the soil in the vicinity of the TAM1 and TAM2 was heated by as much as $80^{\circ} \mathrm{C}$. The dielectric constant for water is a function of temperature, decreasing as the temperature increases according to the following relationship (eqn. 3.1) (CRC Handbook of Chemistry and Physics):

$$
\varepsilon=80.3710^{-0.002(\mathrm{~T}-20)}
$$

The dielectric constant of water is 84.1 at $10^{\circ} \mathrm{C}$ whereas it is 70 at $80^{\circ} \mathrm{C}$. Thus, the magnitude of temperature change that was observed in the soil would reduce the dielectric constant by approximately $15 \%$. This will cause the soil to appear as if it was drying even though the actual volumetric moisture content was unchanged. The field observations of the TDR measurements indicate that the moisture content increased, even though we expect that heating the soil would have the opposite effect. Correcting the TDR data for temperature was beyond the scope of this investigation, although the corrected data would indicate that the moisture content increased by more than the amount shown in Figure 3.22.

\subsubsection{Surface Temperatures --}

Near surface temperature measurements were collected on September 6, 1997, approximately 2 weeks after termination of steam injection. The surface temperature was measured by inserting a 6-in long thermocouple into the soil on a grid pattern across the entire surface of cell A (Fig. 3.23). Maximum temperature at 6 in bgs was $2.5^{\circ} \mathrm{C}$ warmer than background, which was taken as the average of several remote locations at the site. The maximum temperature was near the injection well while the limit of sensible heat coincided with the extent of the fractures.

The surface temperatures at cell A show that a region approximately $6 \mathrm{~m}(19.6 \mathrm{ft})$ in diameter remains heated above background more than 2 weeks after terminating steam injection. This is approximately the diameter of the region that was heated to temperatures greater than $35^{\circ} \mathrm{C}$ at depth. The surface temperature effect is limited to a few degrees, but it persists both during the heat of the afternoon and during the relatively cool morning (Fig. 3.23). The extent of the temperature effect at the ground surface is consistent with the size of the heated zone at depth, although the temperatures at depth are more than $10^{\circ} \mathrm{C}$ greater than at the ground surface.

\subsubsection{Temperature Cross-Sections --}

Temperature cross-sections were developed by rotating profiles measured by thermistors or thermocouples around the injection well to a common plane and reflecting each to provide mirror images across the axis. Contours were interpolated by kriging with an anisotropic linear variogram (see Section 3.2.2).

In cell $\mathrm{A}$, subsurface temperatures increased markedly over a roughly disk-shaped zone at $2-\mathrm{m}$ (6.6 $\mathrm{ft}$ ) depth by July 30,1997, after 9 days of steam injection. This is the depth of the steam-injection fracture at the location of the thermistor boring. Temperatures in excess of $90^{\circ} \mathrm{C}$ were observed indicating that steam had penetrated at least to the monitoring thermistor $1-\mathrm{m}$ away from the point of injection after nine days. The region heated to more than $40^{\circ} \mathrm{C}$ is between 4 and $6-\mathrm{m}(13.1$ to $19.7 \mathrm{ft})$ in diameter and extends from 3-m $(9.8 \mathrm{ft})$ depth to nearly the ground surface. Since the fracture is dipping approximately $20^{\circ}$, the flat-lying form of the temperature field as shown in Fig. 3.24 is probably an artifact of the lack of resolution of the available data. 
Data taken on day 17 (August 6, 1997) using wiper thermocouples show a temperature field after injecting steam for 16 days that has expanded upward and downward and slightly outward (Fig. 3.25 ). There appears to be a region that is more than $2-\mathrm{m}$ in diameter and $1-\mathrm{m}$ thick in excess of $90^{\circ} \mathrm{C}$. The region greater than $40^{\circ} \mathrm{C}$ extends from below 4-m $(13.1 \mathrm{ft})$ bgs to the ground surface and is approximately $5 \mathrm{~m}(16.4 \mathrm{ft})$ wide. The maximum temperature at the ground surface is approximately $50^{\circ} \mathrm{C}$ so it likely that some heat was lost to the atmosphere at this time.

The temperature field on day 37 (August 26, 1997) is cooler than the one estimated 20 days earlier. This time corresponds to the end of steam injection, although the previous 12 days of steam injection was marked by one week of inactivity followed by a few days of intermittent operation at $50 \%$ capacity. Maximum temperatures at this time are approximately $75^{\circ} \mathrm{C}$ within $1 \mathrm{~m}$ of the injection point. The region in excess of $40^{\circ} \mathrm{C}$ is roughly the same depth and width as 20 days earlier, but the ground surface has cooled from more than $50^{\circ} \mathrm{C}$ to less than $40^{\circ} \mathrm{C}$. Temperature continued to decrease with time after cessation of steam injection and by day 48 (September 6 , 1997), which is 11 days after the data shown in the previous cross-section, the maximum temperature decreased to less than $45^{\circ} \mathrm{C}$ within $1-\mathrm{m}$ of the injection point. The region where temperature exceeds $40^{\circ} \mathrm{C}$ decreased in size to approximately $4 \mathrm{~m}$ in diameter and extending from 1 $\mathrm{m}$ to $3.5 \mathrm{~m}(3.3$ to $11.5 \mathrm{ft})$ bgs.

\subsubsection{Contaminant Off-Gas Characteristics and Mass Recovery}

During the fall 1996 test, onsite analyses were made of off-gas composition from each extraction fracture using a real time FID for off-gas hydrocarbons and an on-line atmospheric analyzer for $\mathrm{CO}_{2}, \mathrm{CH}_{4}$, and $\mathrm{O}_{2}$. Discrete samples of off-gas were also collected periodically and analyzed onsite by GC/ECD (Appendix D).

At the start of vacuum extraction the $\mathrm{CO}_{2}$ and $\mathrm{O}_{2}$ concentrations in $\mathrm{A}-4$ were $9 \%$ and $15 \%$ by volume, respectively, indicating occurrence of respiration reactions such as associated with the decay of guar gel (Fig. 3.26). Over the next three weeks, the composition of vapor from A-4 gradually changed to that of atmospheric air $\left(20 \% \mathrm{O}_{2},<2 \% \mathrm{CO}_{2}\right)$. Methane was negligible at first, but concentrations of $1 \%$ or less were observed from day 30 to 40 and from day 56 to 62 (Fig 3.27). These periods of methane production correlate to periods of relatively smaller vapor discharge rates from $A-4$. The steam generator was injecting during the 30 to 40 day interval but was inactive during the latter interval. Otherwise such correlation suggests changes of in situ flow patterns, the relatively constant specific discharge after day 30 indicates methane production was due to unidentified in situ processes.

The concentrations in the off-gas from A-4 as measured by the on-line FID varied over three orders of magnitude. The concentration decreased from an initial value of several thousand ppmv to a few hundred ppmv in few days, concurrent with the decrease in $\mathrm{CO}_{2}$ concentration as discussed above. From day 16 to day 30 , FID concentrations fluctuated around $100 \mathrm{ppmv}$. During this time frame the $\mathrm{O}_{2}$ and $\mathrm{CO}_{2}$ concentrations were gradually shifting to atmospheric values. After day 36 the FID concentration was relatively stable at $30 \mathrm{ppmv}$. The transition from $100 \mathrm{ppmv}$ to $30 \mathrm{ppmv}$, which was marked by a brief increase to $800 \mathrm{ppmv}$, occurred concurrently with operation of the steam generator.

Concentrations in the off-gas from A-12 revealed a more unchanging trend than from A-4, although scatter about the trend was more pronounced. Oxygen concentrations varied from $14 \%$ to $24 \%$ while averaging $20 \%$. Carbon dioxide concentrations were as much as $5 \%$ initially, but ranged between $0.5 \%$ and $2 \%$ at the end of the test. Methane fluctuated around $1 \%$ throughout the test. The presence of $\mathrm{CH}_{4}$ and $\mathrm{CO}_{2}$ and the slight declining trend in concentration of $\mathrm{CO}_{2}$ suggest respiratory functions were minor and diminishing at depth during the fall 1996 test. 
The FID measurements varied over several orders of magnitude but defined a declining trend in concentration from $20,000 \mathrm{ppmv}$ to $100 \mathrm{ppmv}$. These data scattered about the defined trend by one order of magnitude, so no association or correlation with process operations is evident.

Gas samples were analyzed by the GC/ECD to determine concentrations of TCE and related contaminants in vapors that were recovered by the vacuum extraction system. The analytes were TCE, PCE and related halocarbons. The proportion of individual chlorinated compounds in the off-gas from the extraction wells are shown in Figures 3.28 and 3.29 as determined from concentration data in Appendix D. In general, 1-1-DCE was initially predominant, but diminished during the first 20 days in favor of TCE. The sum of the concentrations of all these chlorinated organic compounds are reported in Appendix D as total VOCs.

The mass recovery rate for total VOCs, which was computed by multiplying the vapor discharge volume of the extraction wells by the total VOC concentration, varied over several orders of magnitude (Fig. 3.30). Upon application of vacuum extraction, the initial recovery rate from A-4 was $0.01 \mathrm{~g} / \mathrm{hr}$, but very shortly increased to $1 \mathrm{~g} / \mathrm{hr}$. It remained at $1 \mathrm{~g} / \mathrm{hr}$ from day 14 to 19 and then decreased to $0.1 \mathrm{~g} / \mathrm{hr}$ at day 37 . For the remainder of the test the recovery rate fluctuated between 0.02 and $0.08 \mathrm{~g} / \mathrm{hr}$. The cumulative recovery of chlorinated hydrocarbons by vapor extraction from A-4 during 1996 was 186 grams. The recovery rate from A-12 varied from 0.0005 to $0.01 \mathrm{~g} / \mathrm{hr}$ and remained roughly constant throughout the test. Cumulative recovery from A-12 was 9.4 kilograms.

\subsection{HOT AIR INJECTION AND MASS RECOVERY}

The components required for the hot air injection include electricity, a control system, an in-well air heater, and a low pressure high volume air compressor. Contaminant recovery required water recovery pumps, pump controllers, separators, separator controllers, produced water storage, and a vacuum system. Additional components of these systems are listed in Table 3.2

\subsubsection{Dewatering in Test Cell B}

Water was recovered from three wells, B-4, B-12 and B-16, in test cell B during the fall 1996 test and from only B-12 and B-16 during the summer 1997 tests. Similar to the configuration of test cell A, liquid was recovered from B-4 by suction lift, and the deeper wells, B-12 and B-16, were equipped with bladder pumps that were positioned at the bottom of the wells. Recovery from B-12 was accelerated by application of suction, while B-16 was open to atmospheric pressure.

Dewatering from B-16, the first process operation conducted at the site, was started on day 1 of the fall 1996 test. Operation during the first nine days was intermittent and recovered only $20 \mathrm{~L}$. Full operations during the fall 1996 test began on day 10 . From day 10 to day 23 and from day 33 to the conclusion of the fall 1996 test, water was recovered from B-16 at a rate of $250 \mathrm{Lpd}$ (69 gpd). From day 23 to 33, recovery averaged $40 \mathrm{Lpd}$ (Figs 3.31 through 3.34). In total, nearly 10,000 L (2640 gal) of water were recovered from B-16 during 1996.

Recovery from B-12 began on day 20 . Recovery rates define four periods during the course of the test: $160 \mathrm{Lpd}$ from day 20 to day 33, $50 \mathrm{Lpd}$ from day 33 to $41,400 \mathrm{Lpd}$ from day 41 to 50 and $50 \mathrm{Lpd}$ from day 50 to the conclusion of the test (Figs 3.31 through 3.34). The applied suction during these four periods was 90 to 110,30 to 60,125 to 200 , and 60 to 100 in $-\mathrm{H}_{2} \mathrm{O}$, respectively (Fig. 3.33). The ratio of liquid recovery to applied suction, which is a portion of the specific drawdown for the well, varied during these four periods, suggesting the possibility of in situ changes or well water levels. Almost $7000 \mathrm{~L}$ (1850 gal) of water was recovered from B-12 during the fall of 1996. 
The suction applied to B-4 was sufficient to lift water out of the well. Upon initial application of suction on day 12 of the fall 1996 test, $110 \mathrm{~L}$ of water were recovered during the first day then water recovery from B-4 was negligible. On day 31 , the discharge of B-4 was redirected from the separator, which measured liquid recovery, to the vacuum manifold because the separator had developed a significant leak. The loss of information about the expected small liquid discharge of B-4 was not deemed worth the effort to repair the separator.

In comparison to the fall 1996 test, much smaller quantities of water were recovered from test cell B during the summer 1997 test. As during the latter portion of the fall 1996 test, liquid recovered from B-4 was not measured because the well was connected directly to the vacuum manifold.

Recovery of water from B-16 began on day 1 of the summer 1997 test. Recovery continued at 180 Lpd until day 16 , after which no liquid recovery was measured. Total recovery of water from B16 during the summer 1997 test amounted to $1600 \mathrm{~L}$ (420 gal). By comparison, $10000 \mathrm{~L}$ (2640 gal) were recovered from this well during the fall 1996 test.

Recovery of water from B-12 also began on day 1 of the summer 1997 test, but significant recovery did not start until day 7 . From day 7 to $11,260 \mathrm{~L}$ of water were recovered. After day 11 , no water was recovered from B-12. Faulty controllers for the down-hole pumps probably caused cessation of water recovery.

During the fall 1996 and summer 1997 tests, water recovery appeared to affect the head in a deep piezometer in test cell B (X231A-TBP1) in the same manner as recovery affected water levels in test cell A. For example, during fall 1996, the water level in X231A-TBP1 as compared to a trend of changes defined by several background piezometers (Fig. 3.9), became gradually deeper and by day 50 the water level was nearly $1 \mathrm{ft}$ deeper than the regional trend (Fig. 3.10). Limited water recovery at depth during summer 1997 precluded an impact on water level during that period. In general, the changes in water level correlate to the different overall recovery rates from the cell, especially with the deepest water level occurring towards the end of the period of maximum recovery rate.

\subsubsection{Vapor Extraction in Test Cell B}

The suction applied to the test cell B wells was similar to that recorded for test cell A (see Section 3.3.2). Differences between applied suctions at test cells $A$ and $B$ are attributed to variations in plumbing and flow characteristics of the wells. Applied suction at test cell B, like at test cell A, varied between 50 and 200 in- $\mathrm{H}_{2} \mathrm{O}$ during the fall 1996 test (Fig. 3.33). Throughout the summer 1997 test, applied suction generally fluctuated between 95 and 115 in- $\mathrm{H}_{2} \mathrm{O}$, with the exceptions as noted in discussion of test cell A (Fig. 3.34).

Recovery rates from B-4 were similar to those of A-4, between 250 and $500 \mathrm{cfh}$, from the start of the 1996 test until day 30 (Fig. 3.33). At that time they increased markedly to between 500 and $800 \mathrm{cfh}$. Interestingly, this increase in rate occurred prior to the increase in applied suction on day 42 , and it was largely unaffected when the suction was increased. The recovery rate from B-4 decreased to between 150 and $300 \mathrm{cfh}$ on day 48 , even though the applied suction was relatively high at that time. That range of recovery rates was maintained for the duration of the test despite reduced suction from day 50 onward. During 1997, sparse data indicate initial recovery rates between 50 and $90 \mathrm{cfh}$ (Fig. 3.34). From day 2 until 7, no recovery was recorded while applied suction ranged from 70 to $80 \mathrm{in}-\mathrm{H}_{2} \mathrm{O}$. At day seven recovery increased to between 50 and $80 \mathrm{cfh}$. Subsequently, recovery decreased gradually during the remainder of the test. At the conclusion of the 1997 , test recovery from B-4 ranged between 100 and $120 \mathrm{cfh}$. 
Recovery rates from B-12 during the 1996 test were similar to those of A-12. Starting at a negligible rate, recovery increased gradually to $50 \mathrm{cfh}$ around day 35 (Fig. 3.33). Subsequent recovery remained around $50 \mathrm{cfh}$, in contrast to the multi-fold increases in rate observed in A-12. Throughout the 1997 test, the recovery rate from B-12 averaged $20 \mathrm{cfh}$ (Fig. 3:34).

The initial specific discharge from B-4 during 1996 averaged $10 \mathrm{cfh} / \mathrm{in}-\mathrm{H}_{2} \mathrm{O}$, somewhat greater than the specific discharge of A-4 (Fig. 3.35). Within one day, however, specific discharge of B4 decreased to $5 \mathrm{cfh} / \mathrm{in}-\mathrm{H}_{2} \mathrm{O}$, and it further decreased to $2 \mathrm{cfh} / \mathrm{in}-\mathrm{H}_{2} \mathrm{O}$ by day 30 . From day 31 to 39 , the marked increase in recovery rates, which occurred prior to increased suction, are manifested by an increase in specific discharge to between 10 and $15 \mathrm{cfh} / \mathrm{in}-\mathrm{H}_{2} \mathrm{O}$. When suction increased on day 42 , specific discharge decreased to $5 \mathrm{cfh} / \mathrm{in}-\mathrm{H}_{2} \mathrm{O}$. After day 42 , specific discharge decreased gradually and with substantial fluctuation to $3 \mathrm{cfh} / \mathrm{in}-\mathrm{H}_{2} \mathrm{O}$ upon the conclusion of the 1996 test. The initial specific discharge of B-4 during the 1997 test was probably 2 cfh/in$\mathrm{H}_{2} \mathrm{O}$ (Fig. 3.36). From day 2 until day 7 specific discharge ranged from 0 to as much as 6.5 $\mathrm{cfh} / \mathrm{in}-\mathrm{H}_{2} \mathrm{O}$, and from day 7 until day 25 it varied within the range of 1.5 to $2.5 \mathrm{cfh} / \mathrm{in}-\mathrm{H}_{2} \mathrm{O}$, with a deviation to $3.5 \mathrm{cfh} / \mathrm{in}-\mathrm{H}_{2} \mathrm{O}$ that was concurrent with the episode of interrupted suction. During the last 20 days of the 45 day test, specific discharge gradually decreased to $1 \mathrm{cfh} / \mathrm{in}-\mathrm{H}_{2} \mathrm{O}$.

The specific discharge from B-12 was relatively consistent in the range of several tenths of cfh/in$\mathrm{H}_{2} \mathrm{O}$, even though the recovery rate from B-12 varied (Fig. 3.35). During 1996 the specific discharge prior to day 34 was less than $0.1 \mathrm{cfh} / \mathrm{in}-\mathrm{H}_{2} \mathrm{O}$, and subsequently was about $0.5 \mathrm{cfh} / \mathrm{in}-$ $\mathrm{H}_{2} \mathrm{O}$. The transition marks the minimum in applied suction. Throughout 1997 the specific discharge was $0.2 \mathrm{cfh} / \mathrm{in}-\mathrm{H}_{2} \mathrm{O}$ (Fig. 3.36).

\subsubsection{Hot Air Injection in Test Cell B}

\subsubsection{Injection Rates, Pressures, and Temperatures --}

Development work at the Aber Road Site showed that injection of hot air caused severe drying and desiccation of soil immediately surrounding the injection well. As a result, hot air was able to readily flow through the opened desiccation cracks and exit at the surface close to the well, limiting the effectiveness of hot air injection. Consequently, the configuration of test cell B was adjusted to inhibit vertical flow of hot air near the injection well and to divert the hot air farther out in to the target formation. Specifically, a fifth fracture, B-6, was created above the hot air injection fracture (B-8) in test cell B, and ambient air was injected into it. The intention was that the ambienttemperature air injected into B-6 would form a no-flow boundary and inhibit the upward migration of hot air from B-8. This would enhance the lateral migration of hot air away from the well.

Hot air was injected into the $8 \mathrm{ft}$ bgs fracture starting on day 28 of the fall 1996 test (Fig. 3.37). After an initial surge that lasted a few hours, the injection rate stabilized around $6 \mathrm{cfm}$ at 2 psi. Ambient air injection started into B-6 on day 29 at a pressure of 1 psi and a rate of $3 \mathrm{cfm}$. The rate and pressure of injection into B-8 decreased to $2 \mathrm{cfm}$ and 1 psi concurrent with initiation of B-6 injection. Injection pressures of both B-6 and B-8 were 1 psi during the remainder of the test, although they were increased to 2 psi for a week at the end of the test. The rate of injection of ambient air increased during the first 10 days, reaching a maximum rate of $9 \mathrm{cfm}$, but it decreased thereafter and was $3 \mathrm{cfm}$ at the end of the test. The rate of injection of hot air increased from 2 to 6 $\mathrm{cfm}$ between day 29 to day 42 . From day 42 to 60 the injection rate of hot air decreased to $4 \mathrm{cfm}$. At day 60 the injection rate increased to $10 \mathrm{cfm}$ in response to an increase in injection pressure.

During the summer 1997 test, hot air injection into the $8 \mathrm{ft}$ bgs fracture continued steadily for seven weeks with one disruption as discussed below. The injection rate of hot air increased from 10 to $14.5 \mathrm{cfm}$ over the course of the summer test (Fig. 3.38). The injection pressure of hot air was initially set at 5 psi but decreased during the two weeks to 2 psi and then to 1.5 psi over the 
subsequent six weeks. The injection temperature was at first $235^{\circ} \mathrm{C}$, but was increased to $425^{\circ} \mathrm{C}$ by installation of a second heating element one week after start-up. Simultaneously, ambient air was injected into the 6-ft-deep fracture to divert the hot air injected below it. The ambient air injection started at $10 \mathrm{cfm}$ and $5 \mathrm{psi}$. Like the hot air, the air injection rate increased and pressure decreased during the first two weeks. During the remainder of the test, ambient air injection proceeded at a rate of $12 \mathrm{cfm}$ and a pressure of 2 psi. A marked decrease in injection rate from 13 to $11 \mathrm{cfm}$ occurred on day 17 , coincident with attempts to plug and seal cracks in the surface soil of the test cell. By day 30 the injection rate had returned to average values of $13 \mathrm{cfm}$.

The ratio of injection rate to injection pressure, or specific injection, provides an assessment of in situ conditions. During the fall 1996 test, trends in specific injection strongly mirrored the injection rate because the recorded injection pressure was almost always 1 psi (Fig 3.39). The initial specific injection of hot air was about $3.2 \mathrm{cfm} / \mathrm{psi}$. Upon initiation of diverting ambient air into B-6, the specific injection of hot air decreased slightly to $2.7 \mathrm{cfm} / \mathrm{psi}$. Subsequently, specific injection of ambient air into B-6 varied from 1 to $9 \mathrm{cfm} / \mathrm{psi}$, while that of hot air varied from 2 to $12 \mathrm{cfm} / \mathrm{psi}$. When, on day 60 , the injection pressure was increased to $2 \mathrm{psi}$, the specific injection of ambient air decreased from 5 to $2 \mathrm{cfm} / \mathrm{psi}$ and the specific injection of hot air increased from 4 to $5 \mathrm{cfm} / \mathrm{psi}$. During the summer 1997 test, specific injection of both ambient and hot air started at 2 $\mathrm{cfm} / \mathrm{psi}$ (Fig 3.40). Over the next two weeks, they increased to 10 and $13 \mathrm{cfm} / \mathrm{psi}$, respectively. At day 17, coincident with grouting of surface cracks, specific injection of B-6 decreased, but little change was noted in the specific injection of B-8. After day 17, both specific injections increased gradually.

The rate of thermal energy injection was determined as the product of air injection rate, air temperature and heat capacity. The injection temperature during the fall 1996 test was about $270^{\circ} \mathrm{C}$. The rate of energy injection started at $400 \mathrm{~W}$, gradually increased to $700 \mathrm{~W}$ by day 43 , and remained nearly constant until injection pressure increased at day 60 (Fig. 3.41). During the final week of the test, the air heater provided heat at $1580 \mathrm{~W}$. Energy injected by hot air during the fall 1996 test was approximately $700 \mathrm{~kW}-\mathrm{Hr}$. During the summer 1997 test, the initial injection temperature of $250^{\circ} \mathrm{C}$ was increased to $420^{\circ} \mathrm{C}$ by installation of a second heating element five days after start-up (Fig 3.42). During most of the test, energy was injected at $3400 \mathrm{~W}$ and the total energy used was $3400 \mathrm{~kW}-\mathrm{Hr}$.

\subsubsection{Equipment Operation and Maintenance --}

Hot air injection was maintained at constant rates throughout most of the fall 1996 and summer 1997 tests. Process continued without incident in 1996, and one maintenance event was required for the air heater in 1997. Severe weather caused fluctuations in power to the site and caused circuit breakers for the compressor to trip. However, power to the heating element was not interrupted, and the elements burned out due to the lack of flowing air. Elements were replaced and a new compressor was installed. An air flow detection switch was fabricated to safeguard against this type of event in the future.

\subsubsection{Effects of Hot Air Injection on Subsurface Characteristics}

\subsubsection{Near Ground Surface Pressures --}

Air pressure at shallow ( $1.5 \mathrm{ft}$ depth bgs) piezometers was greater than ambient pressure by several in $-\mathrm{H}_{2} \mathrm{O}$ at all observation points (Fig. 3.43). Injection affected the air pressure over a broad area greater than $30 \mathrm{ft}$ across, although the extent of the monitoring piezometers was insufficient to identify the full extent of this zone. It is noteworthy, however, that the air pressures were particularly great to the west and northwest of the injection well. This area of increased air pressure corresponds to the area of increased temperatures when air injection was occurring. 
Air was observed flowing from surface cracks and around well casings in the vicinity of the injection points. The surface cracks through which flow was occurring probably were desiccation cracks that were dilated during uplift as the fractures were created. Flow rates from the surface cracks and borings were monitored qualitatively by pouring water on the cracks and observing the bubbling rate. Leakage through these features occurred throughout the test, but it appeared to be roughly the same at the end of the test as it was during the beginning. In contrast, the flow rate along the well casing during the Aber Road test increased markedly with time. As a result, it was concluded that the process of injecting ambient air into the well overlying the hot-air-injection well appeared to limit major desiccation around the well bore due to the flow of hot air along that path.

\subsubsection{Moisture Content --}

TDR measurements at cell $\mathrm{B}$ indicate that the moisture content was 0.28 to 0.33 before testing. The moisture decreased to approximately 0.18 at a depth of $7.5 \mathrm{ft}$ in TBM1 by November 1996, whereas it remained unchanged at other depths (Fig. 3.44). The waveguide at a depth of $7.5 \mathrm{ft}$ bgs was in close proximity to the fracture where hot air was injected. The moisture content at TBM2 was essentially unchanged, according to the TDR measurements. Similar moisture content data were measured during the summer 1997 tests.

The soil core data indicate that the moisture content at cell $\mathrm{B}$ was between 0.30 and $0.35 \mathrm{v} / \mathrm{v}$ prior to the test, which is consistent with the TDR measurements. The core measurements at the end of the test indicate that the moisture content was approximately 0.20 throughout cell $\mathrm{B}$. This value is consistent with measurements made using TDR near the fracture, but it is considerably lower than the TDR values at other depths. It is suspected that the soil moisture content in cell B varied markedly with position and it is possible that some of the differences between the TDR and soil core data reflect the different locations from which these data were obtained.

\subsubsection{Ground Surface Temperatures --}

Temperatures at the ground surface were measured the day the hot air was turned off and again two days later (Fig. 3.45). The maximum temperature at the ground surface ranges from 34.5 to $42^{\circ} \mathrm{C}$ depending on the time of day of the measurement. The region that is heated significantly, however is relatively independent of the time of the measurement. It is approximately $3.7 \mathrm{~m}(12.1 \mathrm{ft})$ in diameter and is roughly centered on the point of injection. This is the diameter of the region in excess of $35^{\circ} \mathrm{C}$ at depth.

Ground surface temperatures were measured again the morning after hot air injection was terminated and the general area of heated ground was unchanged. The maximum temperature decreased to $34.5^{\circ} \mathrm{C}$, although ambient temperatures also decreased to $24.5^{\circ} \mathrm{C}$ due to radiant cooling overnight. In general, hot air injection appears to have created a zone approximately $4.6 \mathrm{~m}$ $(15 \mathrm{ft})$ across where temperatures at the ground surface were significantly greater than ambient.

In general, the area that was heated significantly by air injection appears to be confined to the limits of the $8 \mathrm{ft}$ bgs fracture, although the area over which the air pressure was affected by the process, extends well beyond the limits of the fractures.

\subsubsection{Temperature Cross-Sections --}

Temperature cross-sections were developed from profile data by radial projection and interpolation as described previously. The initial temperatures at cell B are the same as those at cell A (Fig. 3.46). After 9 days of hot air injection, soil $1 \mathrm{~m}$ from the injection point reached a maximum temperature of slightly more than $40^{\circ} \mathrm{C}$. The region in excess of $35^{\circ} \mathrm{C}$ extends over $\sim 3 \mathrm{~m}(9.8 \mathrm{ft})$ width and from a depth of approximately $3 \mathrm{~m}$ bgs up to the ground surface. 
Temperatures increased after 16 days of injection on August 6, 1997, but the pattern of the heated zone is similar to the 9-day cross-section. There is a region in excess of $45^{\circ} \mathrm{C}$ approximately $2 \mathrm{~m}$ in diameter and $2 \mathrm{~m}$ high, between 1 and $3 \mathrm{~m}$ depth bgs. The region in excess of $40^{\circ} \mathrm{C}$, however, is cylindrical and extends to the ground surface. Thus, temperatures slightly less than the maximum extend upward to the ground surface. After 20 more days of hot air injection, the subsurface temperature increases to a maximum of more than $70^{\circ} \mathrm{C}$ within $1 \mathrm{~m}$ of the injection point (Fig. 3.47). In this case, however, the hottest temperatures are overlain by cooler material and appear to have spread laterally. The temperature at the ground surface is within a few ${ }^{\circ} \mathrm{C}$ of the temperature 20 days earlier.

The soil surface was exposed on August 6,1997, in the vicinity of the injection well revealing a network of surface fractures. When water was ponded in the cracks air bubbling through them was observed. Similarly, air was flowing from slight annular gaps between some of the steel well casings and enveloping soil. The rate at which air was flowing through any one of these features was relatively modest. Similar tests conducted around a test well at the Aber Road Site revealed that air flowed at high rates from an annular gap there. Even though it was impossible to quantify the rate flowing through the surface features in cell B, it was markedly less than at Aber Road. Nevertheless, the combined flow rate out of many of these features probably was causing preferential upward air movement. In an attempt to reduce this effect, the air injection was temporarily halted and Portland cement was used to fill cracks and gaps in the vicinity of the injection well on August 6th. It appears that this effort may have contributed to change the shape of the heated zone between August 6 and August 26.

At the end of the test on September 6, the maximum temperatures $1 \mathrm{~m}$ from the injection well are slightly more than $60^{\circ} \mathrm{C}$ and the region in excess of $40^{\circ} \mathrm{C}$ is approximately $3 \mathrm{~m}$ wide and extends from slightly below $3 \mathrm{~m}$ to approximately $1 \mathrm{~m}$ depth bgs. This temperature field is very similar to the one measured on August 26. The temperature field on August 26 was measured using the thermistor array, whereas it was measured using wiper thermocouple on September 6, and it is suspected that much of the difference between the two fields is due to slight differences in the magnitudes of temperatures measured using the two methods and to differences in the locations of the data used for interpolation. Notice for example that the region bounded by the $40^{\circ} \mathrm{C}$ contour is interpolated between thermistor arrays at 1 and $2.75 \mathrm{~m}$ radial distances on August 26, whereas it is more tightly constrained by the data from September 6 to a radial distance of between 1.2 and $1.75 \mathrm{~m}$.

\subsubsection{Contaminant Off-Gas Characteristics and Mass Recovery}

\subsubsection{Off-gas Composition and Removal Rates --}

During the fall 1996 test field analyses were made for off-gas hydrocarbons from each extraction fracture using a real time FID and an on-line atmospheric analyzer for $\mathrm{CO}_{2}, \mathrm{CH}_{4}$, and $\mathrm{O}_{2}$. Off-gas samples were also collected periodically and analyzed on-site by GC/ECD (Appendix D).

The trends in concentrations of $\mathrm{O}_{2}, \mathrm{CO}_{2}$, and $\mathrm{CH}_{4}$ recovered from B-4 were very similar to those observed in A-4. During the first three weeks of vacuum extraction, the concentrations of $\mathrm{O}_{2}$ increased while concentrations of $\mathrm{CO}_{2}$ decreased suggesting the presence of respiratory processes such as the decay of guar gel (Fig 3.50). Methane appeared shortly after day 30, which coincides with initiation of hot air injection, and at day 59, when the ratio of hot and ambient air injection rates was changed (Fig. 3.27). The concentrations reported by the FID decreased from an initial $10,000 \mathrm{ppmv}$ to a minimum of $0.1 \mathrm{ppmv}$ around day 47 . Afterwards, FID concentrations increased and fluctuated between 1 and $50 \mathrm{ppmv}$ during the remainder of the test. The low FID concentrations correlate to high applied suction between day 38 and day 49 . 
Gas analyzer and FID results for B-12 differ substantially from all other wells. Concentrations of $\mathrm{O}_{2}$ and $\mathrm{CO}_{2}$ measured during the first week after starting the vapor extraction process wells were erratic. Gas analyzer and FID results for B-12 are consistent with the very low vapor discharge from that well. Although the first week of data are very erratic, concentrations change steadily throughout the test (Fig. 3.50). Carbon dioxide decreases from an initial value of $29 \%$ to $2 \%$ over the course of the test. Meanwhile, oxygen increases from 5\% to $19 \%$ and methane decreases from $10 \%$ to $0.5 \%$. The FID varies less than in the other wells, fluctuating between 1000 and 10,000 ppmv and defining a slightly decreasing trend. These trends suggest initially strong respiratory processes that continued but which declined throughout the test. This is consistent with slow, ongoing decay of guar gel, which is retarded relative to the other wells by the low flow rate of air.

Gas samples were analyzed by the GC/ECD to determine concentrations of soil contaminants in vapors that were recovered by the vacuum extraction system. The analytes were TCE, PCE and related halocarbons. The proportion of individual species of chlorinated compounds in the off-gas from the extraction wells are shown in Figs. 3.48 and 3.49 as determined from concentration data in Appendix D. In general, 1-1-DCE was initially predominant, but diminished during the first 20 days in favor of TCE. The sum of the concentrations of all these chlorinated organic compounds are reported in Appendix D as total VOCs.

The mass recovery rate for total VOCs, which was computed by multiplying the vapor discharge of the extraction wells by the total concentration, varied over several orders of magnitude (Fig. 3.30). Upon application of vacuum extraction, the initial recovery rate from B-4, like A-4, was modest about $0.13 \mathrm{~g}$ per hour. Very shortly it increased to $2 \mathrm{~g} / \mathrm{hr}$ and remained at $2 \mathrm{~g} / \mathrm{hr}$ from day 14 to 19. From day 20 onward, the recovery rate decreased steadily to $0.02 \mathrm{~g} / \mathrm{hr}$ at 60 days. For the final six days of the test the recovery rate fluctuated between 0.02 and $0.08 \mathrm{~g} / \mathrm{hr}$. Cumulative recovery from B-4 was 405 grams. Recovery of chlorinated hydrocarbons was greatest from B12. The absence of flow precluded recovery upon application of the vapor extraction process, so the first observed recovery rate was $0.3 \mathrm{~g} / \mathrm{hr}$ on day 12. Measurements during the next two days indicated recovery rates less than $0.0001 \mathrm{~g} / \mathrm{hr}$. After day 20, which corresponds to the initiation of significant dewatering in B-12, recovery of VOCs in the vapor discharge accelerated dramatically to rates in excess of $10 \mathrm{~g} / \mathrm{hr}$. The cumulative recovery of chlorinated hydrocarbons by vapor extraction from B-12 during 1996 was approximately 5.5 kilograms.

\subsubsection{Soil Concentrations and Reduction Efficiency --}

Following hot air injection in the fall 1996 test, test cell B was cored and sampled to evaluate VOC contaminant removal rates in the soil. Six additional boreholes were sampled on 1-ft depth intervals and analyzed in the field for DNAPL compounds including DCE, TCE, and PCE (Appendix D). A decrease in total VOCs was observed at all locations except TBB6/TBB13 where a slight increase in concentrations was observed between 13 and $15 \mathrm{ft}$ bgs. This is not surprising as this location is near piezometer X231A-BGP3 where free-phase DNAPL liquid was observed in the ground water.

Contaminant concentrations did show a characteristic pattern as a function of depth. In three of the borings, (B1, B4, and B5) concentrations increase with depth from a few tens to one hundred $\mu \mathrm{g} / \mathrm{kg}$ at shallows depths to several thousand $\mu \mathrm{g} / \mathrm{kg}$ at depths between 8 and $10 \mathrm{ft}$ bgs (Fig. 3.51). Concentrations decrease with depth beyond the 8 to $10 \mathrm{ft}$-depth zone. Three of the other sampling borings have soil concentrations of a few hundred $\mu \mathrm{g} / \mathrm{kg}$ or less. One sampling location, B6, which is $3 \mathrm{~m}$ southwest of the injection well, has particularly high concentrations that reach maximum values of $32,000 \mu \mathrm{g} / \mathrm{kg}$. The general distribution of contaminants at B6 is similar to the other locations, however, in that it increases with depth and reaches greatest values between 8 and $10 \mathrm{ft}$. and then decreases with increasing depth beyond that zone (Fig. 3.52). Again location B6 is near piezometer X231A-BGP3 where DNAPL liquid was observed. 
The contaminant profiles prior to the test were integrated with depth and converted to an estimated mass of contaminant per unit of surface area in plan. The borings B1, B4, and B5 have mass areal densities of $440,000,460,000$, and $660,000 \mu \mathrm{g} / \mathrm{ft}^{2}$, whereas the areal density at B1 is $7,000,000$ $\mu \mathrm{g} / \mathrm{ft}^{2}$, and at B2, B3, and B7 it is less than $20,000 \mu \mathrm{g} / \mathrm{ft}^{2}$. An estimate of mass of contaminant in the cell can be determined by considering the active area accessible by the wells in cell $\mathrm{B}$ to be $40 \mathrm{ft}$ by $40 \mathrm{ft}$ at a maximum and the average areal mass density to be $500,000 \mu \mathrm{g} / \mathrm{ft}^{2}$. These assumptions indicate that the mass of contaminant in the vicinity of the cell is approximately 800 grams.

Contaminant concentrations were measured in soil cores taken in December, 1996, following the test during that fall. The cores were obtained in locations adjacent to those taken prior to testing so that concentrations could be compared to previous values. At locations B1, B4 and B5, the concentrations were markedly reduced compared to samples taken prior to testing (Fig. 3.51).

The location with the highest concentrations in the vicinity of B-6 showed a different pattern. There, the concentrations decreased at shallow depths and increased at greater depths. This concentration data are likely due to the sample being from the saturated zone with an impact due to the free-phase DNAPL present in that area.

The fraction of contaminant removed at B1, B4 and B5 averaged $0.55,0.65$ and 0.61 over the depth range from 0 to $18 \mathrm{ft}$. This suggests that the process removed about 60 percent of the contaminants over that depth range. At B-6, the ratio averaged over depth is approximately 1.0. This suggests that the amount of mass over the entire $18 \mathrm{ft}$ was unchanged by during the 1996 test.

The process of hot air injection into a shallow hydraulic fracture is expected to preferentially treat regions above the fracture into which air is injected. This is because most of the injected air is expect to flow upward toward the ground surface. Air was injected into a hydraulic fracture that was initiated at $8 \mathrm{ft}$ bgs and curved upward to roughly $6 \mathrm{ft}$. The contaminant reductions at shallow depths is much greater than indicated by the averaged values cited above. For example, the fraction removed at depths less than $6 \mathrm{ft}$ is roughly 85 percent with a few outlying points that probably resulted from local heterogeneity (Fig. 3.53). This degree of treatment occurs even at B6 where concentrations are particularly high.

The fraction of contaminant removed cited above is for the fall 1996 test when the air heater was operated at relatively low power. During the summer 1997 test, the power to the air heater was increased by a factor of five. It is expected that this will significantly increase the removal of contaminants compared to values cited above. However, in situ concentrations of contaminants in cell B were not measured following the 1997 test, so an evaluation of the removal and a comparison to the 1996 test is unavailable.

\subsection{COMPARISON OF THE STEAM AND HOT AIR PROCESSES}

\subsubsection{Water: Recovery, Moisture Content, and Consumption}

Water was removed from both test cells by suction lift and downhole pumps, whereas it was added as steam in cell A. No water was added to cell B. The amount of water stored in cell A increased over the fracture receiving steam injection, whereas it decreased in the vicinity of the fracture where hot air was injected according to TDR measurements. Water was released from storage in cells A and $B$ due to drawdown of the water table during the fall.

During the fall 1996 test at cell A, a total of $5300 \mathrm{~L}$ (1400 gal) of water was fed to the steam generator but probably only a small fraction of that was injected into the ground (Fig. 3.18). 
Operational data and observations at the site indicate that much of the water that was fed to the steam generator vented through a pressure release valve during the fall 1996 test. It is estimated that roughly several hundred gallons of water was injected during this test. A total of $13000 \mathrm{~L}$ (3430 gal) was produced from wells in cell A during the fall (Fig. 3.12). The majority of this came from wells at 12 and $16 \mathrm{ft}$ bgs and probably represents recovery of ground water. Approximately $2 \mathrm{ft}$ of drawdown was observed in the 16-ft-deep well, and $0.8 \mathrm{ft}$ of drawdown was observed at a nearby monitoring well, X231A-TAP1, screened at the bottom of the Minford formation (Fig. 3.10). The shallow well in the A cell, A-4, produced approximately $380 \mathrm{~L}$ (100 gal) early in the test and then it ran dry. This is the same volume of water that was injected to create the hydraulic fractures.

The water balance at cell A is significantly different during the summer 1997 test when $4100 \mathrm{~L}$ of water was injected into the ground as steam (Fig. 3.13). The shallow well, A-4, was particularly active, producing $11000 \mathrm{~L}$ (2910 gal) of water during the test. The fracture connected to A-4 reached the ground surface in an area where water ponded during rainfall, so it is suspected that much of the water produced at A-4 was rain that infiltrated through the cover.

The deepest well, A-18, produced about the same volume during the summer $(6700 \mathrm{~L}$ or 1770 gal) as it did during the previous fall even though there was negligible drawdown in the vicinity of the cell during the summer. One reason that there was negligible drawdown may have been because water was produced nearly entirely from A-18; A-12 produced water only during the early stages of the summer test. After that A-12 produced no water, and it was discovered that the pump in A12 was deformed due to high temperatures, presumably because A-12 was pumping condensate from steam injection.

It is suspected that some of the $4100 \mathrm{~L}$ injected as steam was recovered as condensate from A-18 and A-12, and some was stored in the cell as the soil moisture content increased. TDR measurements indicate that the moisture content increased in soil overlying the fracture into which steam was injected (Fig. 3.22). The measurements indicate that the moisture content increased by approximately 0.04 by volume, although temperature corrections to the TDR data indicate that this is a lower bound for the change in moisture content. The change in water stored in the cell is determined by assuming that the moisture content increased by 0.04 over a region $3 \mathrm{~m}$ in diameter, and extending from 2.4 to $0.6 \mathrm{~m}$ depth. That indicates that approximately $500 \mathrm{~L}$ of injected water was stored in the soil.

The volume balance indicates that of the $4100 \mathrm{~L}$ injected, $500 \mathrm{~L}$ were stored in the soil, and $3600 \mathrm{~L}$ were recovered primarily from A-18. A total of $3000 \mathrm{~L}$ of ground water apparently was removed from cell A during the summer test, according to the water balance. This is a small volume relative to the $13,000 \mathrm{~L}$ of ground water produced during the fall, and it explains why drawdown was negligible at the A cell during the summer test.

At cell B the water balance is more straightforward since water was not added by the process equipment. A total of $16,000 \mathrm{~L}$ was produced from cell $\mathrm{B}$ during the fall 1996 test and drawdown at X231A-TBP1 was roughly $0.5 \mathrm{~m}$ (Fig. 3.31 and 3.10). Presumably all of the water recovered during the fall test was ground water. Approximately $1800 \mathrm{~L}$ were produced during the summer 1997 test, but the pumps were operated only temporarily (Fig. 3.32). This amount of recovery produced negligible drawdowns.

The water content of the soil in cell B decreased by 0.12 volume percent at $2.4 \mathrm{~m}$ in the vicinity of the fracture receiving hot air, according to TDR measurements (Fig. 3.44). The water released from storage can be determined by assuming that this moisture change occurred over a $1 \mathrm{~m}$ thick region that is $3 \mathrm{~m}$ in diameter. This indicates that approximately $800 \mathrm{~L}$ of water were removed by drying the soil in the vicinity of the fracture. 
In summary, water could be recovered from at an average rate of $250 \mathrm{Lpd}$ from the lower two wells in either cell. During the fall tests when negligible water was injected, this pumping rate produced a drawdown of $0.2 \mathrm{~m}$ at monitoring piezometers $2 \mathrm{~m}$ from the recovery wells and screened at the bottom of the Minford formation. During the summer test when roughly $4000 \mathrm{~L}$ of water was injected as steam, the discharge from the deep well, A-18, in cell A was similar to that during the fall test, but the drawdown measured at the monitoring well was negligible. It is concluded that roughly half of the water produced by A-18 was condensate from the steam injection and the other half was ground water. Well A-18 appears to have provided containment of the condensate, at least based on a water balance.

Injecting hot fluids changed the water stored in each cell as soil moisture. Approximately $500 \mathrm{~L}$ of the water injected as steam appears to have increased the moisture content above the fracture where steam was injected. A similar volume of water appears to have been removed from cell B during the injection of hot air.

\subsubsection{Heat: Thermal Injection and Energy Content}

A basic conceptual model for heating shallow formations by injecting hot fluids is useful for understanding the results of the tests. Injecting hot fluids will transfer heat to the formation, increasing temperatures in the vicinity of the well. The heated zone increases in size due to conductive heat transfer through the formation and to convective transfer by the heated fluids. As the heated zone increases in size it begins to warm the ground surface and some of the injected heat is lost to the atmosphere, both due to conduction and possibly convection. Furthermore, heat will be removed from the formation in recovered fluids, such as air or water. The rate of heat loss at the ground surface increases with the time, so that the fraction of injected heat that is stored in the formation will diminish. Eventually, the rate of heat lost to the ground surface and to fluid recovery wells may equal the rate at which heat is injected. At this point the amount of heat in the formation will reach a steady state even while hot fluids continue to be injected. When injection of the hot fluid ceases, heat will be lost at the ground surface and it will conduct downward and laterally cooling the formation.

During the field tests, temperature profiles were determined at several boreholes. These measurements were used to estimate the amount of heat energy in the formation by multiplying the difference between the measured temperature at each location along the profile and the background temperature at a similar depth by an assumed heat capacity of $37.5 \mathrm{BTU} / \mathrm{ft}^{3}{ }^{\circ} \mathrm{F}$. The vertical heat density profile was integrated to yield an energy density expressed in energy contained underneath a unit area of test cell surface. The areal energy densities were contoured by hand, and an integration over the contours yielded an estimate of the energy contained within the test cell relative to a similar volume of background soil.

The heat added to the formation is similar to the amounts of electrical energy supplied to both the air heater and the steam generator early in the tests. With increasing time, however, the heat in the formation becomes progressively less than the amount supplied to both the air heater and the steam generator. In three of the tests the amount of heat in the formation reaches a limiting value, even though hot fluids continued to be injected. In a fourth test, the steam injection test during fall, 1996 , the results are difficult to interpret within this framework probably because the injection well was clogged and that led to equipment behavior that limited the amount of heat that was injected.

\subsubsection{Hot Air Injection --}

The conceptual model is particularly well suited to explaining the injection of hot air. During the fall 1996 test, the rate of heat injection was about $14 \mathrm{~kW}$-hr/day and the rate of change of heat in the subsurface was roughly that value during the first few days of the test (Fig. 3.54). During the 
subsequent 30 days, however, the rate of heating of the subsurface was approximately $10 \mathrm{~kW}$ $\mathrm{hr} /$ day, suggesting that about $4 \mathrm{~kW}-\mathrm{hr} /$ day was lost. This heating rate occurred for 25 days, resulting in $250 \mathrm{~kW}-\mathrm{hr}$ in the ground. Heat was probably lost during this test by conduction at the ground surface and recovery of heated air at wells. Furthermore, additional heat was lost as hot air flowed out of the ground to the atmosphere. The rate of heat injection was increased for 1 week at the end of the test, however, the amount of heat that could be accounted for in the subsurface remained approximately $250 \mathrm{~kW}$-hr. Apparently that value represents steady-state conditions for the fall test.

A similar behavior was observed during the summer test, but the limiting value of injected heat was considerably greater. The temperature of the heated air was increased from $235^{\circ} \mathrm{C}$ during the fall test to $425^{\circ} \mathrm{C}$ during the summer test. Thus, heat was injected at about $70 \mathrm{~kW}$-hr/day during the summer test. This caused the heat in the ground to increase at about $50 \mathrm{~kW}$-hr/day for the first 20 days. Approximately $20 \mathrm{~kW}-\mathrm{hr} /$ day of heat was lost on average during the first 20 days. There was approximately $1000 \mathrm{~kW}-\mathrm{hr}$ in the ground after 20 days, and the amount of heat that can be accounted for in the ground remained roughly constant for the remaining 30 days (Fig. 3.54). This indicates that the rate of heat loss was approximately $70 \mathrm{~kW}$-hr/day during the last 30 days of the test.

Increasing the rate of heat injection by a factor of 5 , from 14 to $70 \mathrm{~kW}$-hr/day, caused the amount of heat that could be injected to increase by a factor of 4 , from $250 \mathrm{~kW}$-hr to $1000 \mathrm{~kW}-\mathrm{hr}$. However, limiting values of injected heat were reached in both cases.

\subsubsection{Steam Injection --}

A similar behavior appears to have occurred during steam injection. Heat was injected at approximately $120 \mathrm{~kW}$-hr/day during the first 24 days of the test. Heat accumulated in the formation at approximately $85 \mathrm{~kW}$-hr/day during this time, so that by day 19 there appears to be approximately $1600 \mathrm{~kW}-\mathrm{hr}$ in the ground (Fig. 3.55). After that time, the amount of heat in the ground decreases at approximately $30 \mathrm{~kW}$-hr/day. This behavior resembles cooling of the formation after termination of hot fluid injection. Steam was injected during this time, but the rate at which it was injected was markedly diminished. After day 24 , for example, the steam generator was on intermittently so that the rate of heat input only averaged approximately $30 \mathrm{~kW}$-hr between days 24 and 36 . After day 36 the steam generator was off.

It appears that steam injection at $120 \mathrm{~kW}$-hr/day caused heat to accumulate in the formation at about $85 \mathrm{~kW}-\mathrm{hr} /$ day during the first 19 days. This suggests that $35 \mathrm{~kW}-\mathrm{hr} /$ day of heat was lost on average during the first 19 days. At the end of the test the rate of heat injection diminished to 30 $\mathrm{kW}$-hr/day, and the amount of heat in the formation decreased by about $30 \mathrm{~kW}-\mathrm{hr} /$ day. This suggests that the rate of heat loss at the end of the test, when the formation contained the most heat, was about $60 \mathrm{~kW}-\mathrm{hr} /$ day.

The steam injection test reached a maximum $1600 \mathrm{~kW}$-hr of injected heat after 19 days. This may have been roughly the limiting value of heat that could be injected, although the rate of steam injection diminished after 24 days so it is possible that additional heat could have been injected.

\subsubsection{Summary --}

During the first three weeks of injecting hot air at either $14 \mathrm{~kW}-\mathrm{hr} /$ day or $70 \mathrm{~kW}-\mathrm{hr} /$ day, approximately 75 percent of the injected heat accumulated in the ground and 25 percent was lost. After that time, the rate of heat loss increased to roughly the rate of injection and little additional heat accumulated in the ground. A maximum of $250 \mathrm{~kW}-\mathrm{hr}$ was delivered when injecting hot air at relatively low power $(14 \mathrm{~kW}$-hr/day). The limiting amount of heat increased by a factor of 4 to approximately $1000 \mathrm{~kW}$-hr when the rate of hot air injection was increased by a factor of 5 . 
During the first three weeks of injecting steam at $120 \mathrm{~kW}$-hr/day, approximately 30 percent of the heat was lost and 70 percent accumulated in the formation. A maximum of $1600 \mathrm{~kW}$-hr of heat was delivered to the formation during the test and this should be considered a lower limit of the maximum possible amount of heat that could be delivered by the configuration used for this test.

The rate of energy injection appears to be roughly proportional to the maximum amount of heat that can be injected as either hot air or steam. The ratio of maximum heat injected (kW-hr): rate of energy supplied to generator ( $\mathrm{kW}$-hr/day) is approximately 15 (days). Ratios for the three tests are as follows:

$$
\begin{aligned}
& 18 \text { (days) for low power hot air }(14 \mathrm{~kW}-\mathrm{hr} / \text { day }) \\
& 14 \text { (days) for high temperature hot air }(70 \mathrm{~kW}-\mathrm{hr} / \text { day }) \\
& 13 \text { (days) for steam ( } 120 \mathrm{~kW}-\mathrm{hr} / \text { day) }
\end{aligned}
$$

\subsubsection{Contaminant Mass: Removal and Soil Concentrations}

The primary constituents of the soil contaminants are TCE, DCE, accompanied by related chlorinated ethanes and ethenes that were present in small concentrations. The initial severity of contamination and distribution of total VOCs was determined by an extensive soil sampling program prior to installation of process equipment. Analysis of soil cores for VOCs revealed that cell B was more heavily contaminated than cell A. Four borings in cell B retrieved soils samples that contained VOCs in excess of $10,000 \mathrm{ug} / \mathrm{kg}$ (Fig. 3.51), whereas only one boring in cell A was as heavily contaminated. Mass of contaminant in-place was estimated to be as much as 800 grams in cell $\mathrm{B}$. Cell A could be expected to contain less.

Concentrations of VOCs in the off-gas from the extraction wells were monitored by GC/ECD of frequently collected samples during the fall 1996 test. The cumulative recovery from test cell A was $195 \mathrm{~kg}$, with $95 \%$ produced by the upper fracture, A-4. In contrast $5.5 \mathrm{~kg}$ were recovered from test cell B, most of which was discharged from the deeper fracture, B-12 (Fig. 3.30). The lesser recovery from cell A can be attributed to smaller initial concentrations in the soil and to less thermal injection - the steam generator operated during only a portion of the test and blockages in the injection well impeded delivery of steam to the formation.

A second round of soil sampling was completed in December 1996, after conclusion of the fall 1996 injection and recovery processes. VOC concentrations were determined for soil samples collected near the four significant borings in cell B. Concentrations appeared to have been markedly reduced, especially above $6 \mathrm{ft}$ bgs. The typical fraction of contaminant removed averaged $60 \%$ over the entire $18 \mathrm{ft}$ length of the borings.

In summary, recovery of VOCs through the vapor extraction system exceeded the projected quantity of contaminants initially contained in the cells. Furthermore, any additional recovery by extracted water was not included in this assessment. The difference between the recovery of VOCs and the projected quantity can be attributed to variations in distribution of contaminants in the soil. Organic contaminants, specifically DNAPL compounds, are known to follow preferential pathways and are highly variable in soil making detection by soil sampling difficult. The thermal energy introduced through the hydraulic fractures was well distributed and is expected to have effected most of the dispersed contaminants in the heated soil. Consequently, it is assumed that recovery included pockets of contaminants that were not identified during the soil sampling.

Initial contaminant concentrations in soil, contaminant recovery, and final concentrations were determined only for the fall 1996 test. During the summer 1997 test, both steam and hot air injection were operated more aggressively, and more effective recovery could be expected. 
However, a quantitative comparison between remedial effectiveness of the fall and summer test should not be attempted.

\subsection{VIABILITY OF HOT FLUID INJECTION FOR MASS RECOVERY}

This test was conducted to evaluate the effectiveness of vapor extraction for mass recovery of chlorinated solvents in a LPM, specifically the Minford soils. Soil vapor extraction was augmented by injecting either steam or hot air in order to increase the temperature, and thus the vapor pressure, of the chlorocarbons. Ground water was pumped out of the subsurface in order to increase the air permeability. Furthermore, hydraulic fractures were created to increase the rates of injecting the hot fluids and recovering both air and water.

Two test cells were constructed using similar hydraulic fracturing methods. Cell A contained a flat-lying hydraulic fracture at $4 \mathrm{ft}$, underlain by fractures at 8,12 and $18 \mathrm{ft}$ bgs. Steam was injected into the fracture at $8 \mathrm{ft}$, whereas air and water were recovered from the overlying and underlying fractures. Water was recovered from the deepest fracture. The intention was to inject steam into the middle fracture, heat the formation in the vicinity of that fracture and induce vapor transport to the overlying and underlying fractures where the contaminants would be recovered. Test cell B consisted of five stacked hydraulic fractures. The intention was to operate cell B using a similar approach as cell $\mathrm{A}$, but with hot air injected into a fracture at $8 \mathrm{ft}$ bgs and water and vapor recovered from fractures at 4 and $12 \mathrm{ft}$ bgs. In addition, a fracture was created at $6 \mathrm{ft}$ depth and ambient air was injected into this fracture. This was done in order to reduce desiccation in the vicinity of the injection well as the hot air flowed upward through the formation.

Tests were conducted from mid October to early December 1996, and from late July to early September 1997. There were several important differences between the tests conducted during the fall and summer. At cell A, steam was generated using a compact device placed below ground in the well accessing the fracture. During the fall 1996 test, the well was plugged by mineral precipitates produced by the steam generator and only a limited amount of steam was injected into the subsurface. The design of the steam generator was modified to reduce the formation of precipitates in the well, so that during the summer 1997 test the well remained open throughout the test period. Steam was injected continuously during the first 3 weeks of the summer test, so these data are the most reliable representation of steam injection. At cell B, hot air was generated with an electrical heater that fit down into the access well. During the fall 1996, the injected air was heated to $235^{\circ} \mathrm{C}$ throughout the duration of the test. The heater was then modified, so that during the summer 1997 air was injected at $425^{\circ} \mathrm{C}$. Moreover, an additional compressor was used so that the rate of air injection was doubled. As a result, considerably more heat was injected into the ground at both cells $\mathrm{A}$ and $\mathrm{B}$ during the summer test as compared to the previous fall. The process conducted during this test consisted of injecting and recovering air, water and heat in an effort to remove contaminants from the ground surface. Accordingly, the results of the test are summarized below as mass or volume balances on those phases.

\subsubsection{Water Balance}

Water could be recovered from an average rate of $250 \mathrm{Lpd}$ from the lower two wells in either cell. During the fall tests when negligible water was injected, this pumping rate produced a drawdown of $0.2 \mathrm{~m}$ at monitoring piezometers $2 \mathrm{~m}$ from the recovery wells and screened at the bottom of the Minford formation. During the summer test when roughly $4,000 \mathrm{~L}$ of water was injected as steam, the discharge from the deep well, A-18, in cell A was similar to that during the fall test, but the drawdown measured at the monitoring well was negligible. It is concluded that roughly half of the water produced by A-18 was condensate from the steam injection and the other half was ground 
water. Well A-18 appears to have provided containment of the condensate, at least based on a water balance.

Injecting hot fluids changed the water stored in each cell as soil moisture. Approximately $500 \mathrm{~L}$ of the water injected as steam appears to have increased the moisture content above the fracture where steam was injected. A similar volume of water appears to have been removed from cell B during the injection of hot air.

\subsubsection{Air Balance}

Air was recovered from two wells in both cell $\mathrm{A}$ and $\mathrm{B}$, and it was injected into two wells in cell $\mathrm{B}$. No air was injected into cell A. During the fall test at cell B, air was injected at the two wells at an approximate combined average rate of $720 \mathrm{ft}^{3} / \mathrm{hr}$, whereas it was recovered from the two wells at an approximate combined average rate of $550 \mathrm{ft}^{3} / \mathrm{hr}$. Approximately 25 percent of the injected air was not recovered by wells and presumably flowed to the ground surface.

The specific injection rate (injection rate:pressure) increased during the first three weeks of the summer 1997 test in both the well used to inject ambient air and the one used to inject hot air. After three weeks of injection, the specific injection remained constant through the remaining three weeks of the test. This change in specific capacity probably resulted from an increase in the air permeability of the formation during the first three weeks.

Two compressors were used during the summer 1997 test, whereas only one was used during the fall test. As a result, the average air injection rate was approximately doubled to $1500 \mathrm{ft}^{3} / \mathrm{hr}$ during the summer test. Surprisingly, the rate at which air was recovered diminished to an average of 220 $\mathrm{ft}^{3} / \mathrm{hr}$ or about one-half of that recovered during the fall. This suggests that approximately 85 percent of the air injected during the summer test flowed to the ground surface. Air was observed flowing through fractures in ground surface and through small annular gaps between casing and soil (the observation was made by ponding water in these areas and observing bubbles). An attempt was made to seal these cracks by filling them with cement. This temporarily increased the fraction of the air recovered. In general, however, it is concluded that the injected air that was not recovered by wells flowed to the ground surface through fractures or gaps around casings that presumably were opened by desiccation resulting from the injection of hot air.

The air that was injected was incompletely contained by the vacuum extraction system. This probably occurred because the fractures into which air was injected were deeper and larger than the shallow fracture where air was recovered. Moreover, air flowed out of the ground through cracks in the soil that cut across the shallow fracture. Air flowed out of the ground at a rate that was 5 or more times greater than air recovered at the vapor extraction well.

\subsubsection{Heat Balance}

A conceptual model for heat injected into a shallow well developed for the project indicates that temperature should initially increase in the vicinity of the well, and the total amount of heat accumulated in the formation should equal the amount of heat injected. With increasing time, however, heat will be removed in air and water recovered from wells and considerable amounts of heat may be lost to the atmosphere as the ground surface warms. As a result, the fraction of heat that is lost relative to the amount that accumulates in the subsurface is expected to increase with time. Eventually, steady conditions may occur where the rate of heat injected equals the rate of heat lost. 
During the first three weeks of injecting hot air at either $14 \mathrm{~kW}-\mathrm{hr} /$ day (fall 1996) or $70 \mathrm{~kW}$-hr/day (summer 1997), approximately 75 percent of the injected heat accumulated in the ground and 25 percent was lost. The specific injection rate increased during the first three weeks, indicating that the air permeability was increasing, probably due to desiccation. After that time, the rate of heat loss increased to roughly the rate of injection and little additional heat accumulated in the ground. A maximum of $250 \mathrm{~kW}$-hr was delivered when injecting hot air at relatively low power $(14 \mathrm{~kW}$ $\mathrm{hr} /$ day). The limiting amount of heat increased by a factor of 4 to approximately $1000 \mathrm{~kW}-\mathrm{hr}$ when the rate of hot air injection was increased by a factor of 5 .

During the first three weeks of injecting steam at $120 \mathrm{~kW}$-hr/day, approximately 70 percent of the injected heat accumulated in the formation and 30 percent was lost. A maximum of $1600 \mathrm{~kW}-\mathrm{hr}$ of heat was delivered to the formation during the test and this should be considered a lower limit of the maximum possible amount of heat that could be delivered by the configuration used for this test. The results of the heat balance are consistent with the conceptual model.

Injection of steam caused the temperature to increase rapidly in the vicinity of the fracture and to exceed $95^{\circ} \mathrm{C}$ in less than 9 days within $1 \mathrm{~m}$ from the point of injection. The heated zone increases in size both upward and downward from the injection point and forms a roughly equant zone approximately $6 \mathrm{~m}$ in diameter and 4 to $5 \mathrm{~m}$ deep after 16 days of steam injection. The region at steam temperatures appears to be approximately $3 \mathrm{~m}$ in maximum dimension and less than a few $\mathrm{dm}$ thick at this time. After the steam is turned off, the maximum temperature appears to decrease rapidly, dropping by more than $20^{\circ} \mathrm{C}$ in a few days. A region where temperatures are in excess of $40^{\circ} \mathrm{C}$ does persist for more than a few weeks. The fracture into which steam was injected appears to be slightly elongate and between 6 and $9 \mathrm{~m}$ in maximum dimension, according to measurements of surface uplift (Appendix B). It appears that the heated region is confined to areas above or below the hydraulic fracture.

Injecting hot air also increases subsurface temperatures, but both the maximum temperatures and the size of the heated area are smaller than when steam is used. The region heated by injection of hot air is 3 to $4 \mathrm{~m}$ in diameter and extends to a depth of $4 \mathrm{~m}$. The maximum observed in situ temperature was $70^{\circ} \mathrm{C}$, even though the temperature of the injected air was greater than $400^{\circ} \mathrm{C}$. The hydraulic fracture into which hot air was injected is approximately $7 \mathrm{~m}$ in maximum dimension, according to uplift measurements. Thus, the radius of the heated zone is approximately half the radius of the fracture. This suggests that heat injected into the fracture was lost either by conduction to enveloping soil, or by convection as heated air flowed out of the fracture into the soil. Desiccation of the soil overlying the fracture probably caused the permeability to increase. This would have focused the flow of air and further increased desiccation in the vicinity of the hottest region near the injection well. This positive feedback mechanism is probably the primary reason why the extent of the region that was heated by injected air was smaller than the extent of the fracture.

\subsubsection{Contaminant Mass Balance}

Profiles of contaminant concentration in cell B were integrated with depth and converted to a mass of contaminant per unit of surface area in plan. The borings B1, B4, and B5 have mass areal densities of $440,000,460,000$, and $660,000 \mathrm{ug} / \mathrm{ft}^{2}$, whereas the areal density at B1 is $7,350,000$ $\mathrm{ug} / \mathrm{ft}^{2}$, and at B2, B3, and B7 it is less than $1000 \mathrm{ug} / \mathrm{ft}^{2}$. An estimate of mass of contaminant in the cell can be determined by considering the active area accessible by the wells in cell $\mathrm{B}$ to be $40 \mathrm{ft}$ by $40 \mathrm{ft}$ at a maximum and the average areal mass density to be $500,000 \mathrm{ug} / \mathrm{ft}^{2}$. These assumptions indicate that the mass of contaminant in the vicinity of the cell is approximately 800 grams.

The mass recovered by the process as a function of time was determined by multiplying off-gas concentration by the volumetric flow rate. This method indicates that approximately $6 \mathrm{~kg}$ were 
recovered from test cell $\mathrm{A}$ and $\mathrm{B}$ combined. Although this is slightly higher than the estimated mass of contaminant expected to be in the ground, it is not disconcerting when considered in the context of the variable distribution of DNAPL compounds in soil. Dense phase liquids are distributed along preferred pathways that have limited cross-sectional area in plan view and are difficult to characterize through limited soil sample locations. In contrast, hot fluid injection provides fairly uniform treatment by contacting and volatilizing pockets of contaminant.

An alternative method for assessing process performance is to compare the concentrations in soil before and after testing. This method indicates that the fraction of contaminant removed at B1, B4 and B5 averaged $0.55,0.65$ and 0.61 over the depth range from 0 to $18 \mathrm{ft}$. This suggests that the process removed 60 percent of the contaminants over that depth range. The process of hot air injection into a shallow hydraulic fracture is expected to preferentially treat regions above the fracture into which air is injected. This is because most of the injected air is expect to flow upward toward the ground surface. Air was injected into a hydraulic fracture that was initiated at $8 \mathrm{ft}$ and curved upward to roughly $6 \mathrm{ft}$. The contaminant reductions at shallow depths is much greater than indicated by the averaged values cited above. For example, the fraction removed at depths less than $6 \mathrm{ft}$ is roughly 85 percent with a few outlying points that probably resulted from local heterogeneity. This degree of treatment occurs even at B6 where concentrations are particularly high.

The fraction of contaminant removed cited above is for the fall 1996 test when the air heater was operated at relatively low power. During the summer 1997 test, the power to the air heater was increased by a factor of five. It is expected that this will significantly increase the removal of contaminants compared to values cited above. However, in situ concentrations of contaminants in cell B were not measured following the 1997 test, so an evaluation of the removal and a comparison to the 1996 test is unavailable.

Contaminant was found at only one location in cell $\mathrm{A}$ at the beginning of the project. In light of the sparse distribution of contaminant in cell A, it was only sparsely sampled after the fall 1996, and it was not sampled at all after the summer 1997 test. Contaminant recovery during the steam injection tests cannot be assessed at this time. 
Figure 3.1. Photograph of a sand propped fracture.
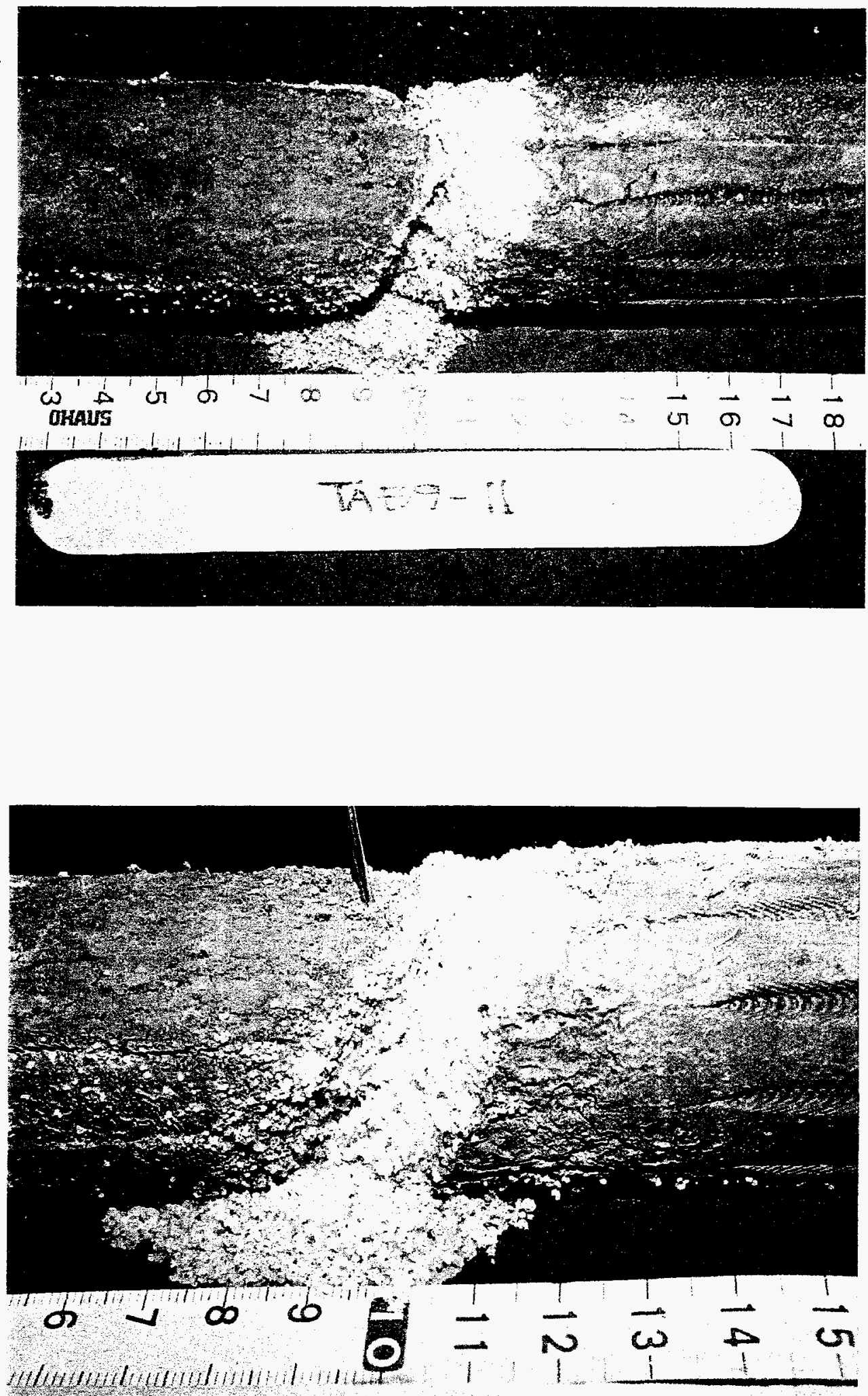


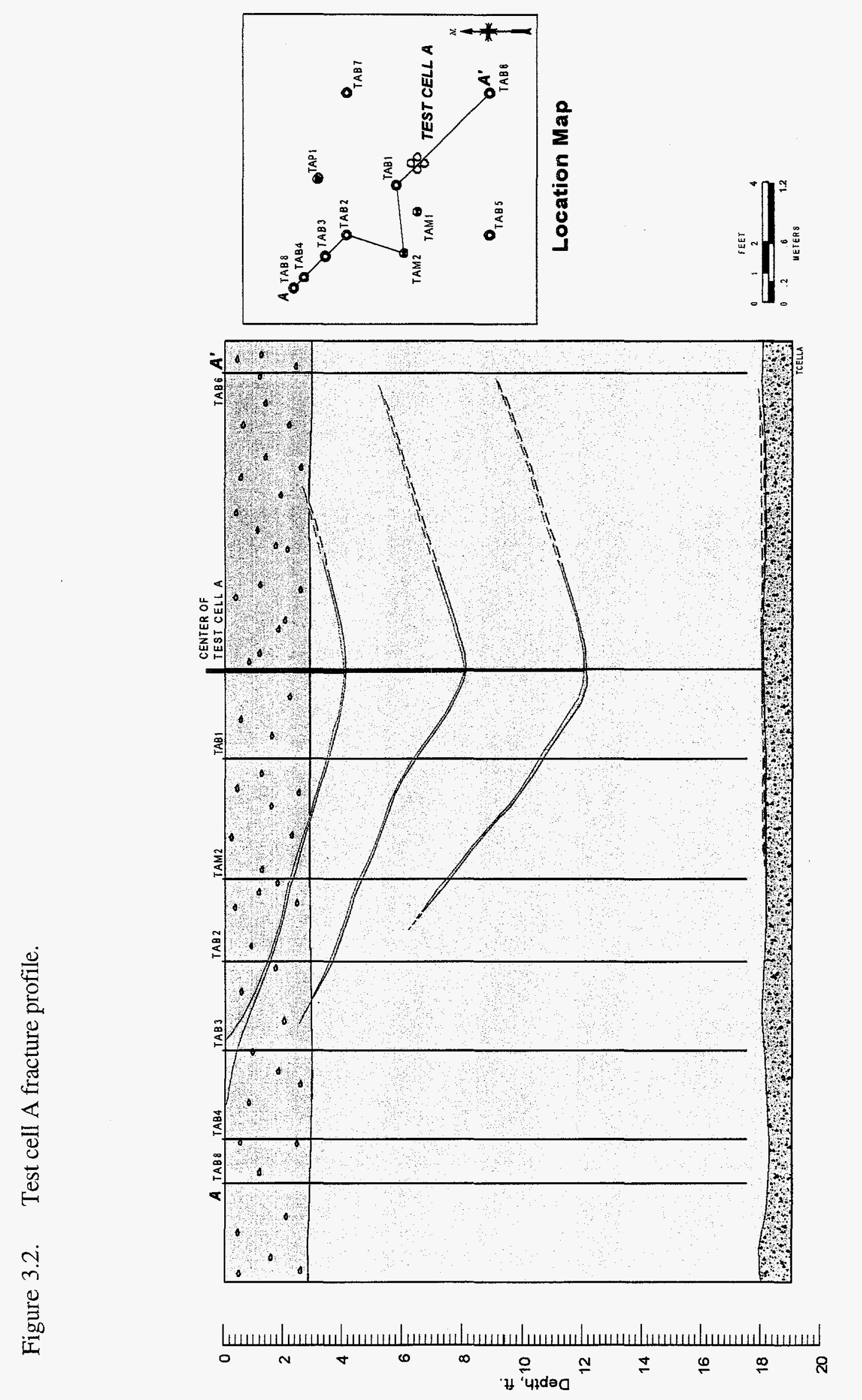


Figure 3.3. Test cell A monitoring locations.

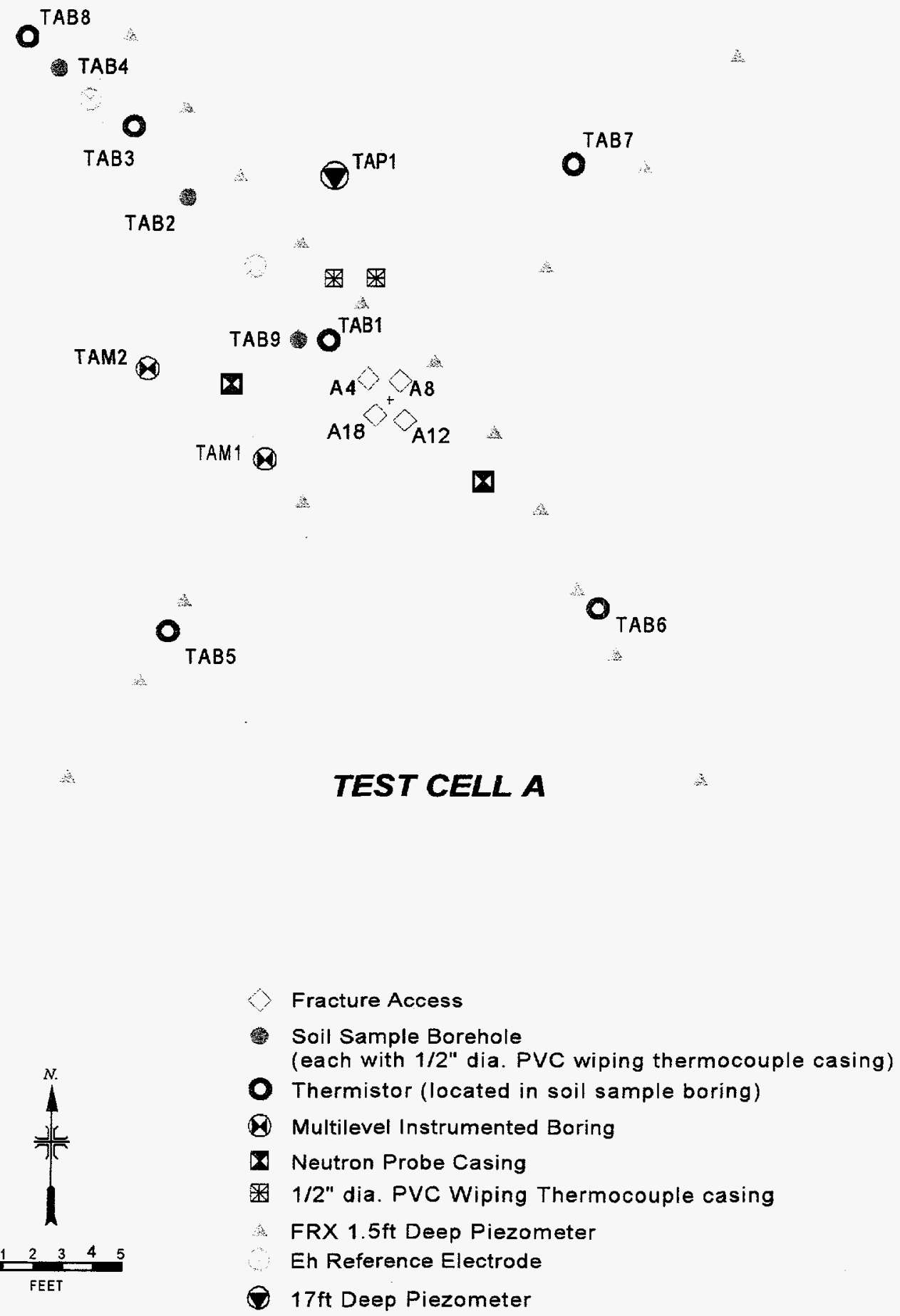


Figure 3.4. Test cell B fracture profiles.

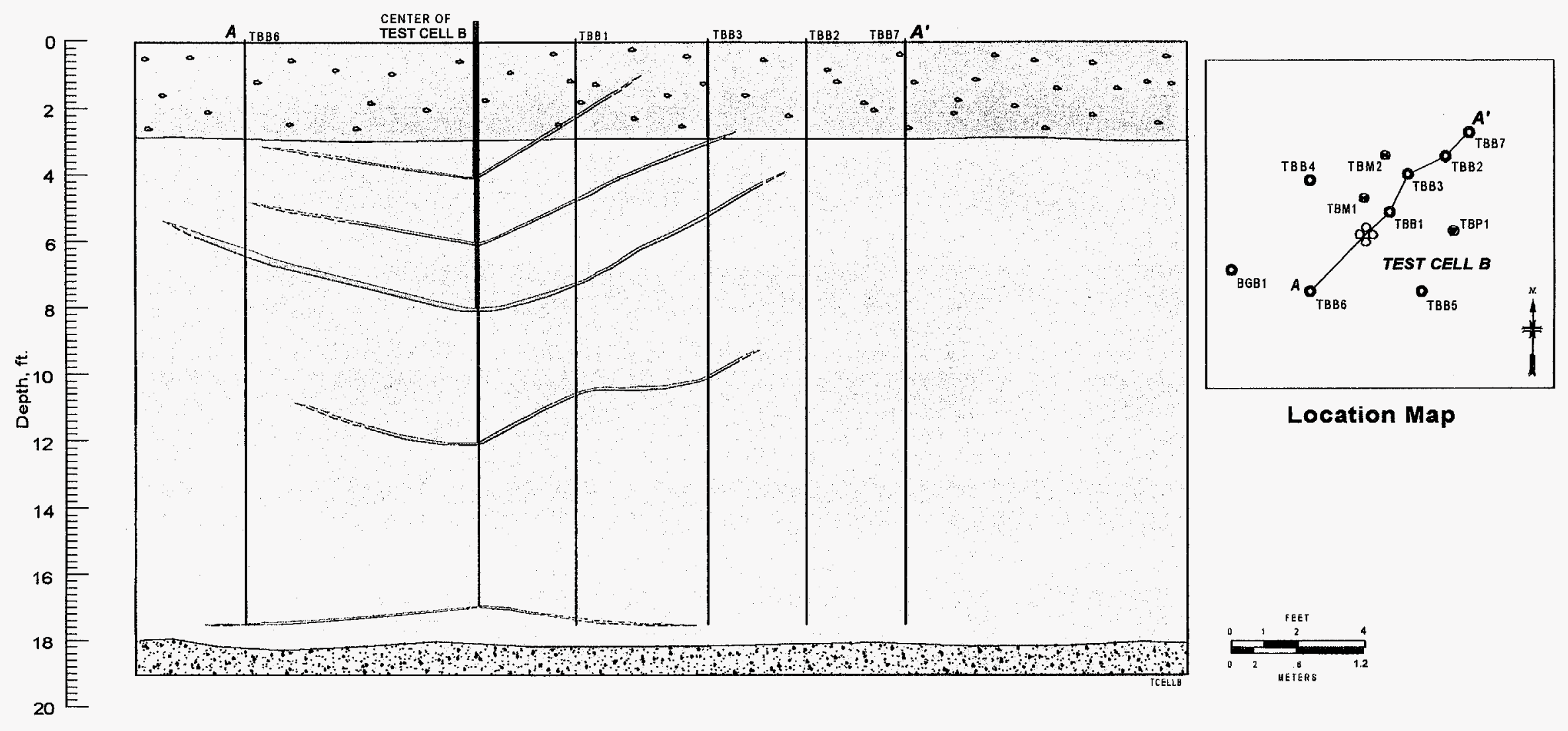


Figure 3.5. Test cell B monitoring locations.

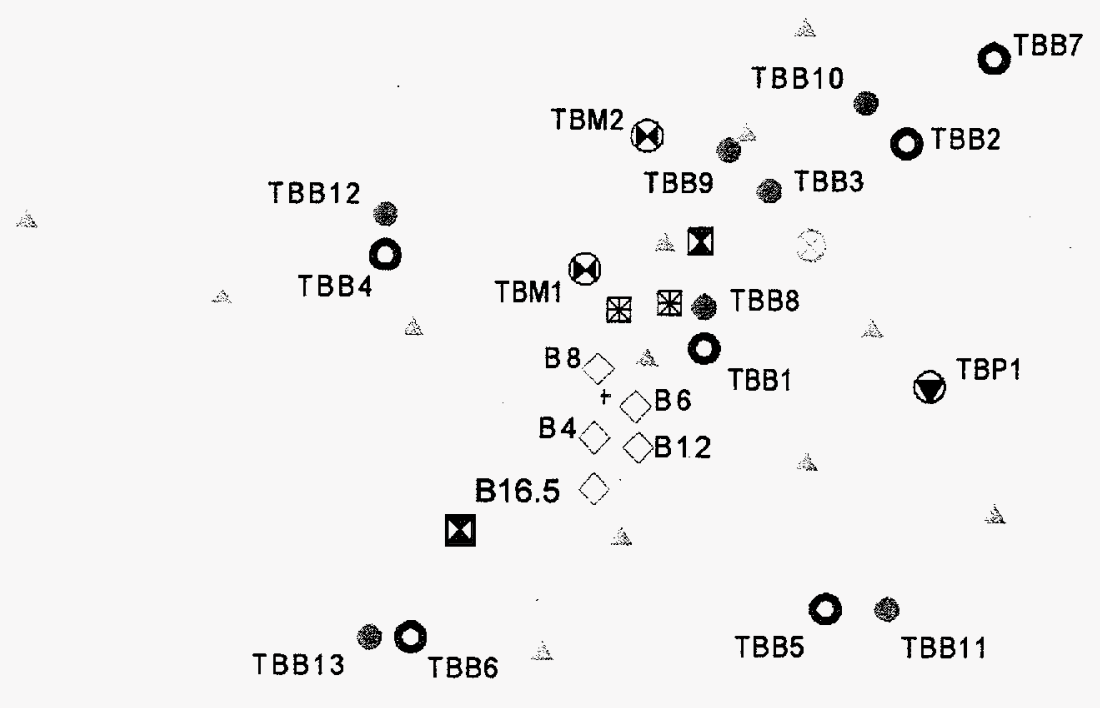

TEST CELL B

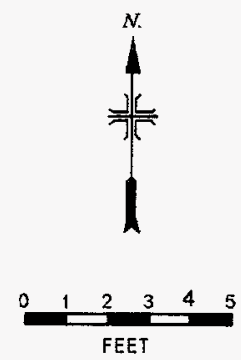

Fracture Access

Soil Sample Borehole (each with 1/2" dia. PVC wiping thermocouple casing)

- Thermistor (located in soil sample boring)

(d) Multilevel Instrumented Boring

D] Neutron Probe Casing

1/2" dia. PVC Wiping Thermocouple casing

a FRX 1.5ft Deep Piezometer

Eh Reference Electrode

( $17 \mathrm{ft}$ Deep Piezometer 
Figure 3.6 Initial temperature profile, 1996.

10/19/96 10:31:06 mq00002. DIT
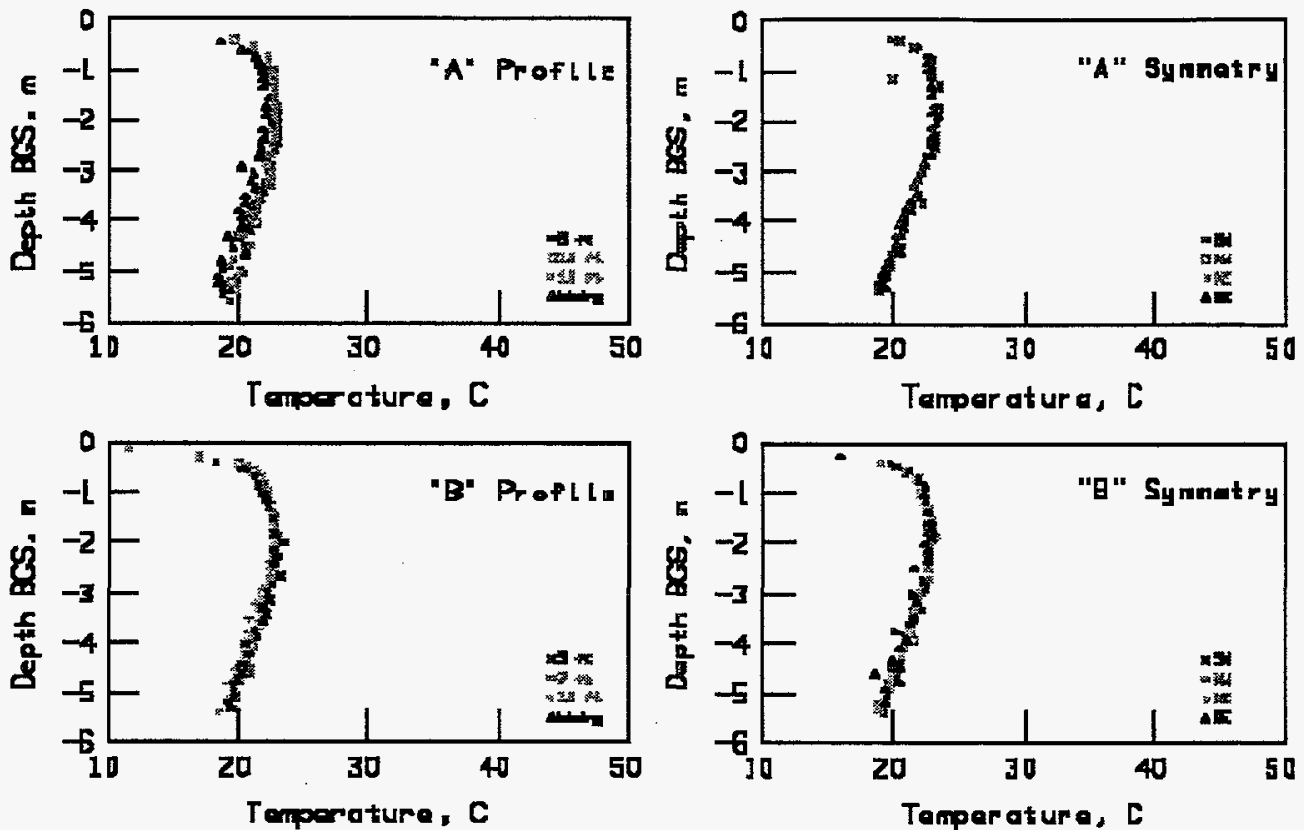

Figure 3.7 Initial temperature profile determined by thermistors, 1997.

07/17/97 ]6: [4:44 23100196_DTT
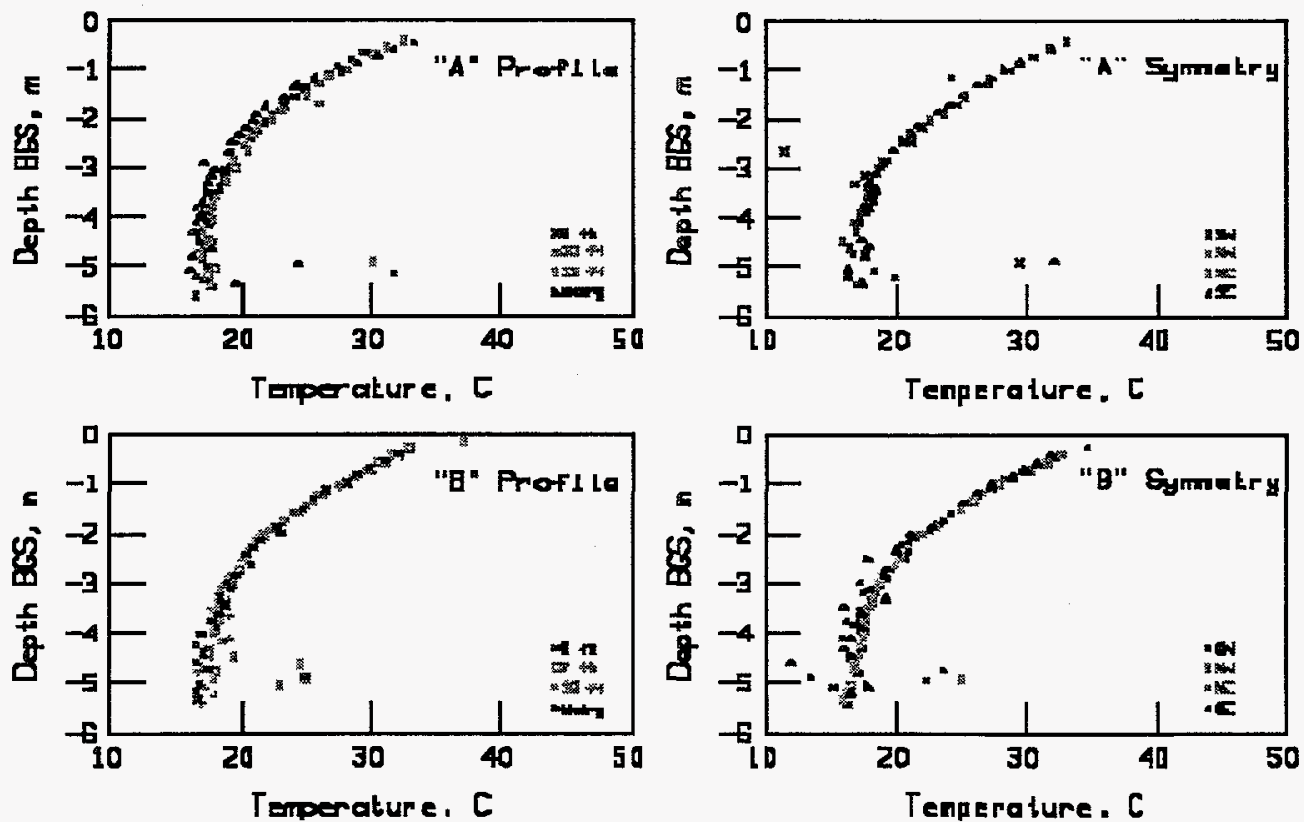
Figure 3.8 Initial temperature profile determined by thermocouples, 1997.

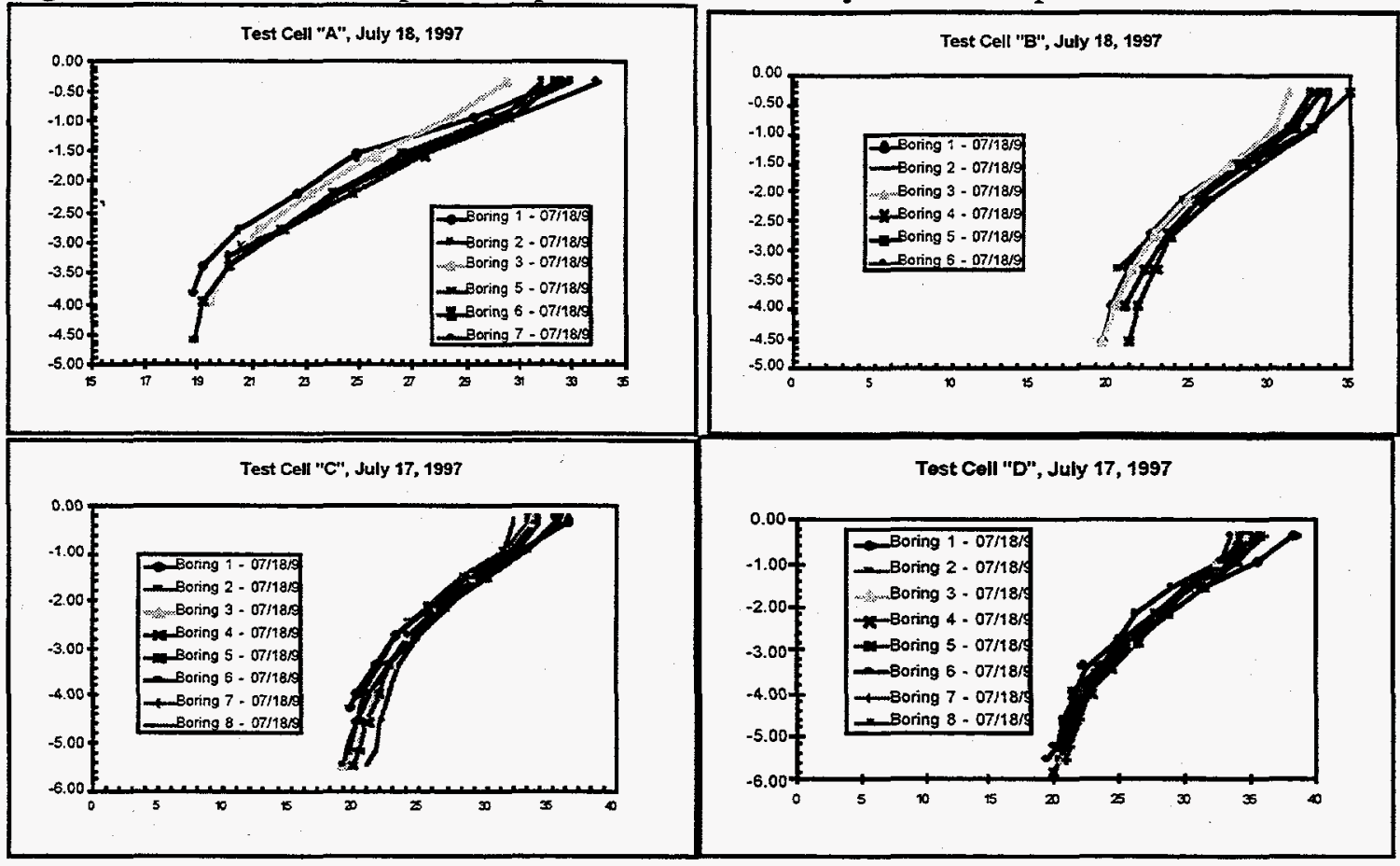

Figure 3.9 Depth of far-field water table during fall 1996 tests.

Water levels in each piezometer scaled by a term sufficient to make all resulting heads coincident on July 16, 1997. Background piezometers BGP1, BGP2, and BGP3 along with TCP1 and TDP2 define temporal changes in head during this test.

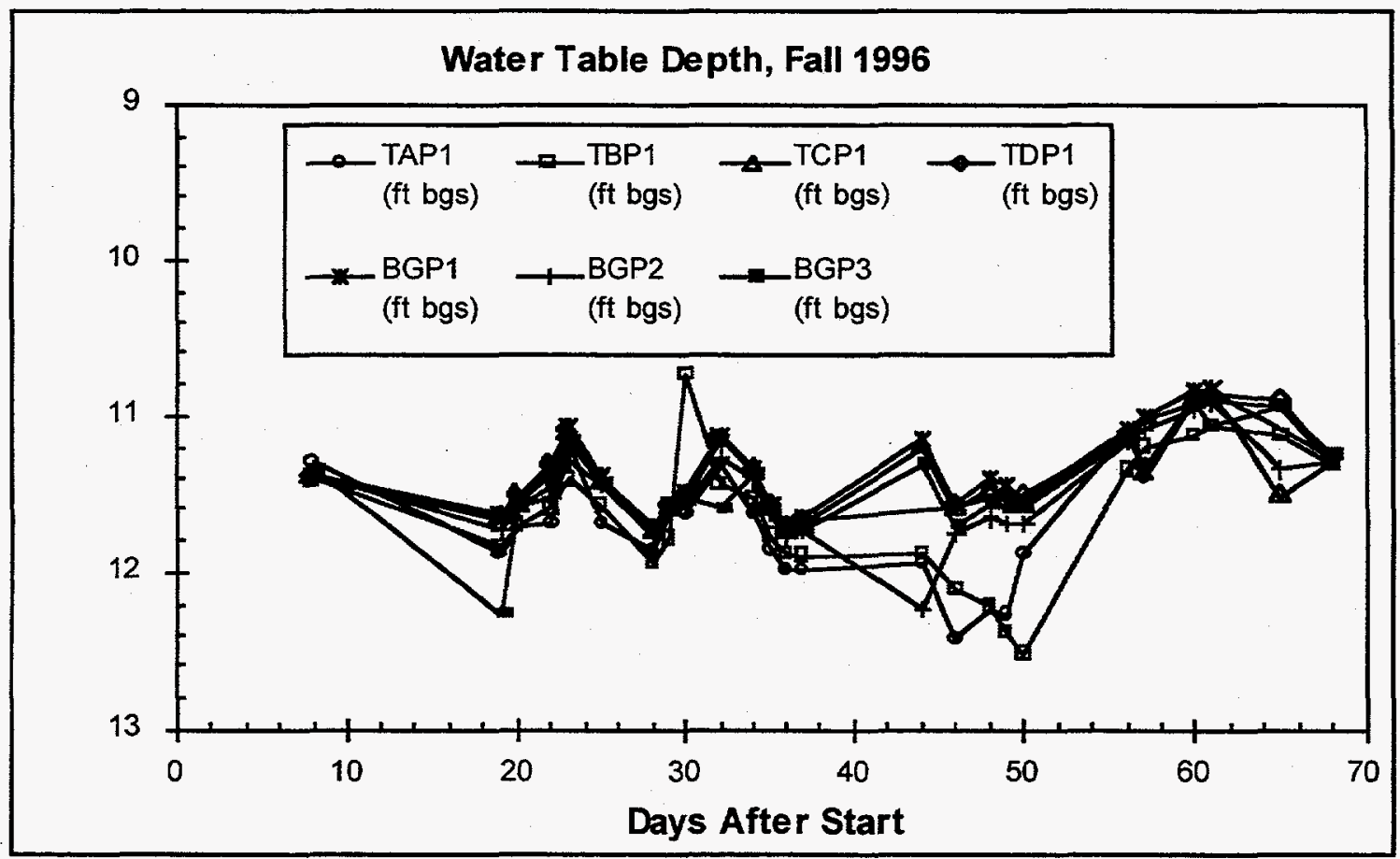


Figure 3.10 Relative depth to water table within test cells A and B during 1996.

The drawdown is computed as the deviation from a trend of heads obtained by comparison on several distant piezometers. See Figure 3.9

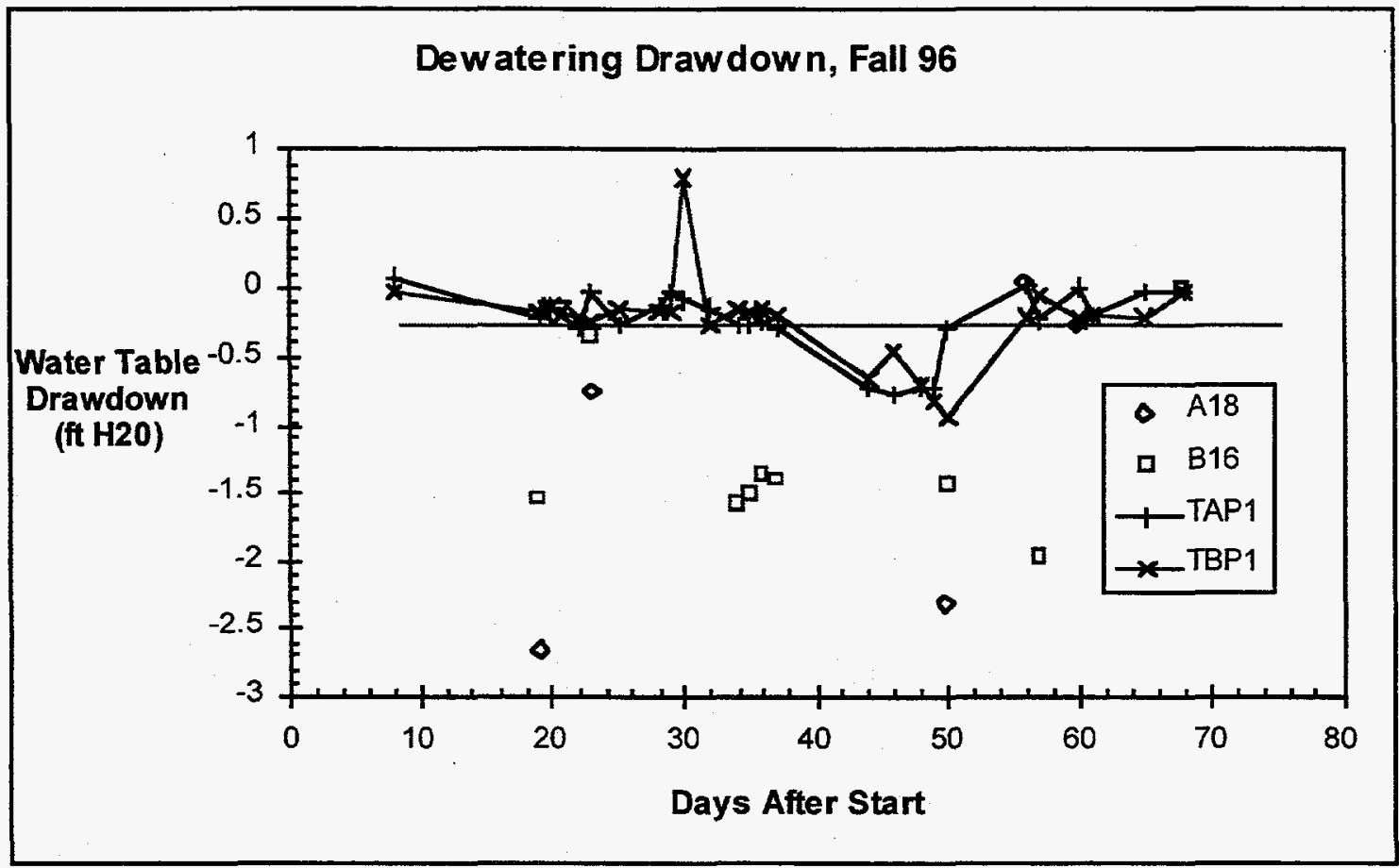

Figure 3.11 Depth of far-field water table during summer 1997 tests.

Water levels in each piezometer scaled by a term sufficient to make all resulting heads coincident on July 16, 1997. Background piezometers BGP1, BGP2, and

BGP3 along with TCP1 and TDP2 define temporal changes in head during this test.

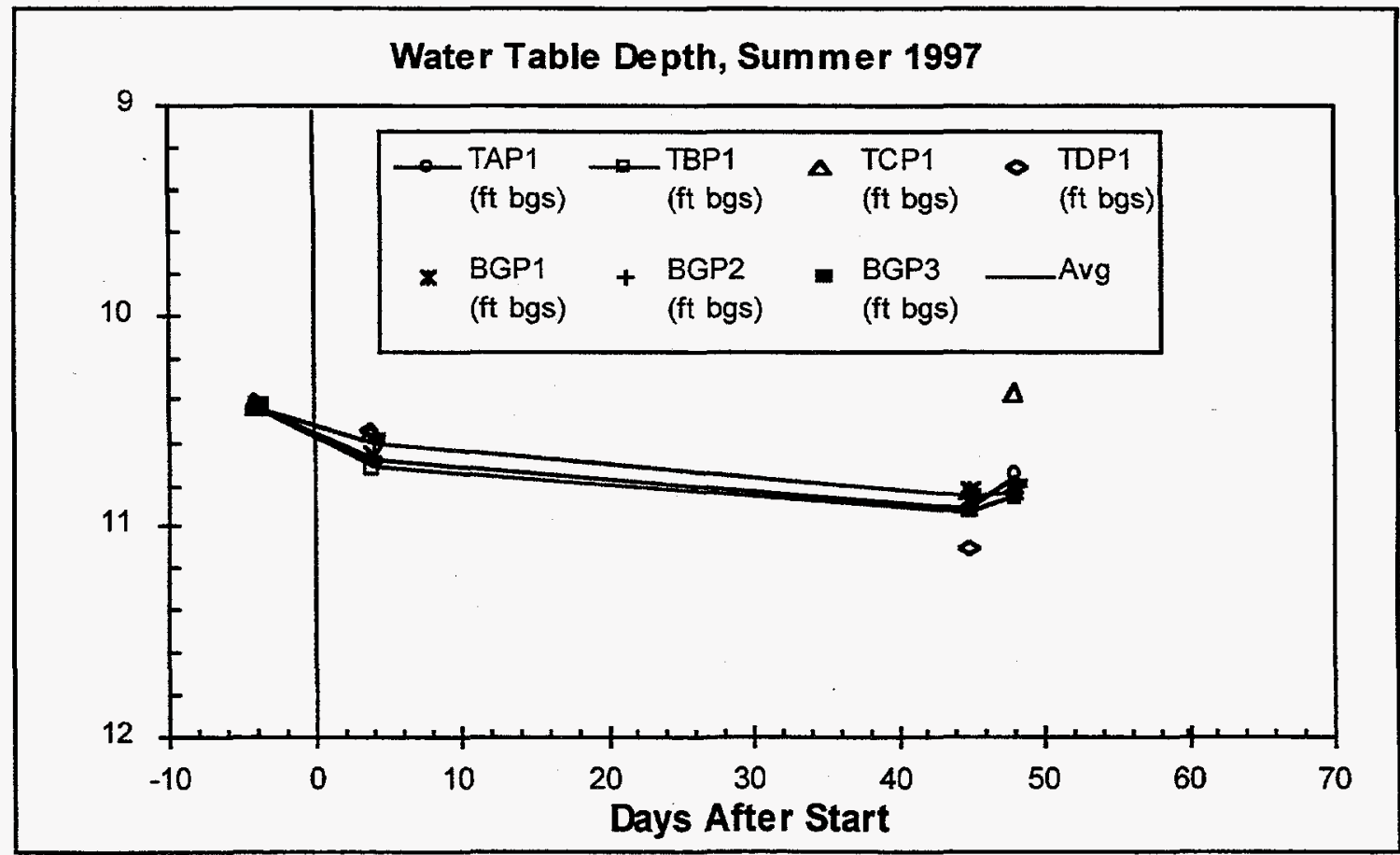


Figure 3.12 Cumulative water recovery from test cell A during 1996.

Water volumes measured by counts of separator fill/empty cycles.

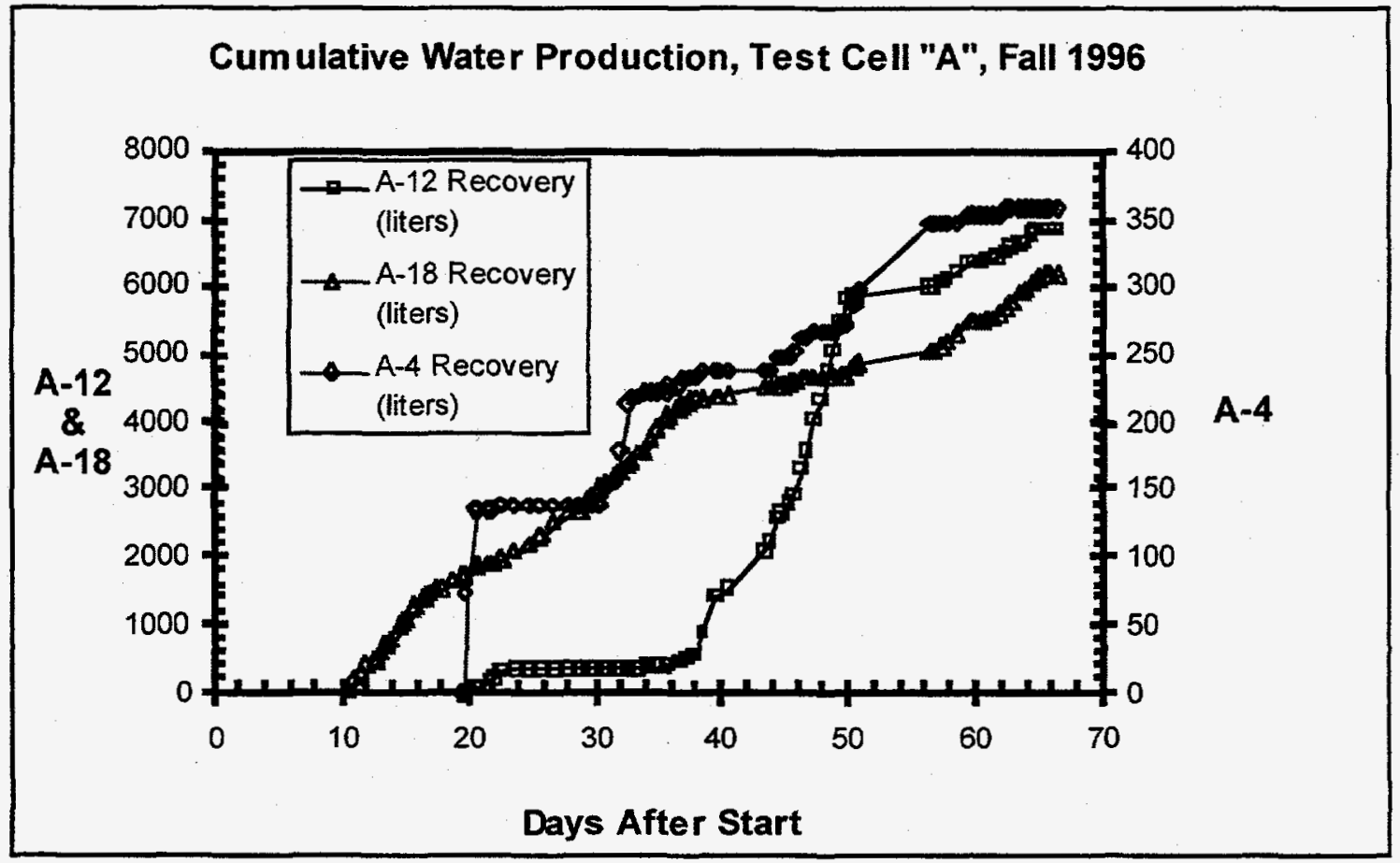

Figure 3.13 Cumulative water recovery from test cell A during 1997.

Water volumes measured by counting separator fill/empty cycles.

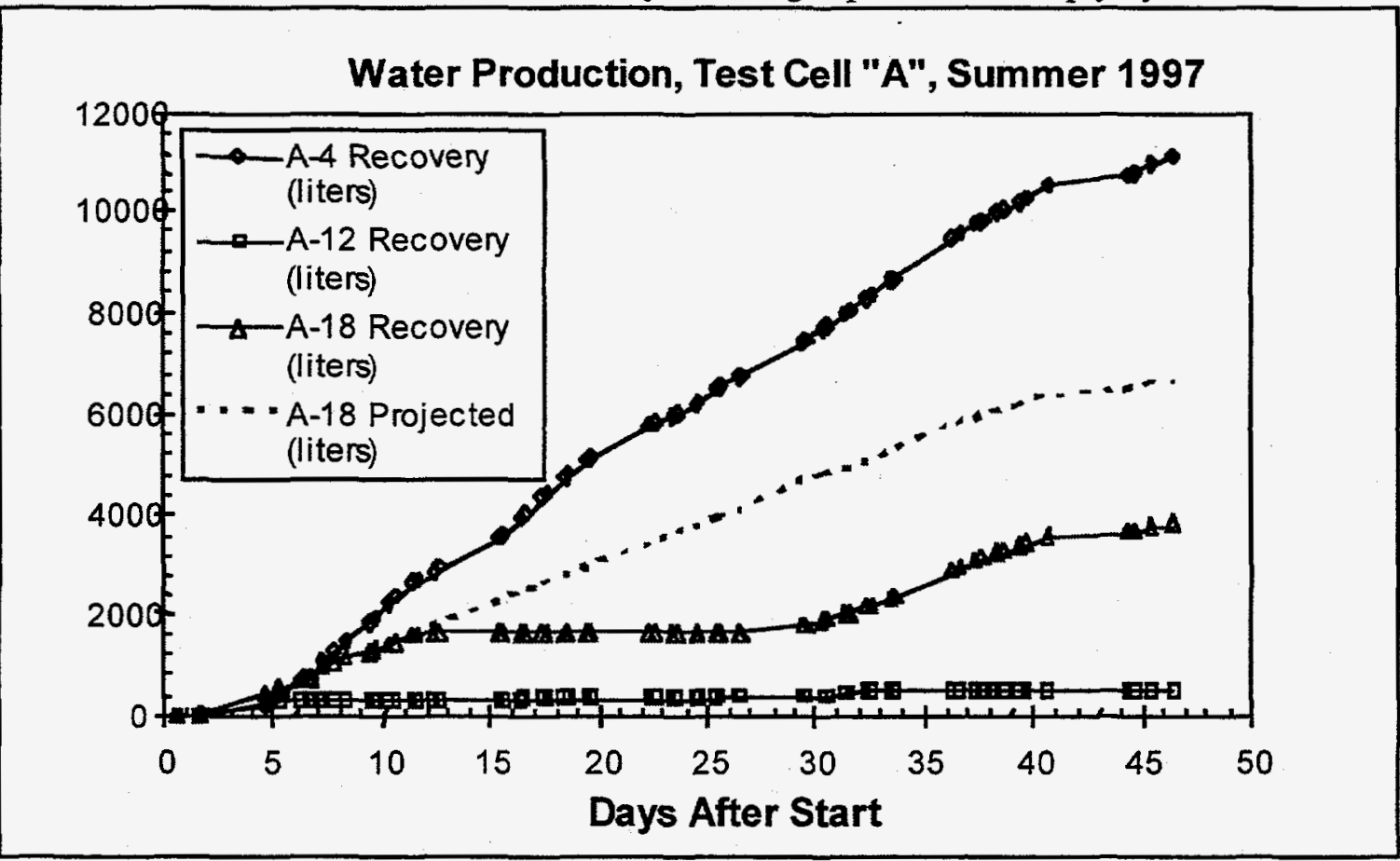


Figure 3.14 Vapor extraction recovery and suction, test cell A, fall 1996.

Volumetric flow rates measured by variable area flowmeters and suction measured by dial gage at the header for each well.

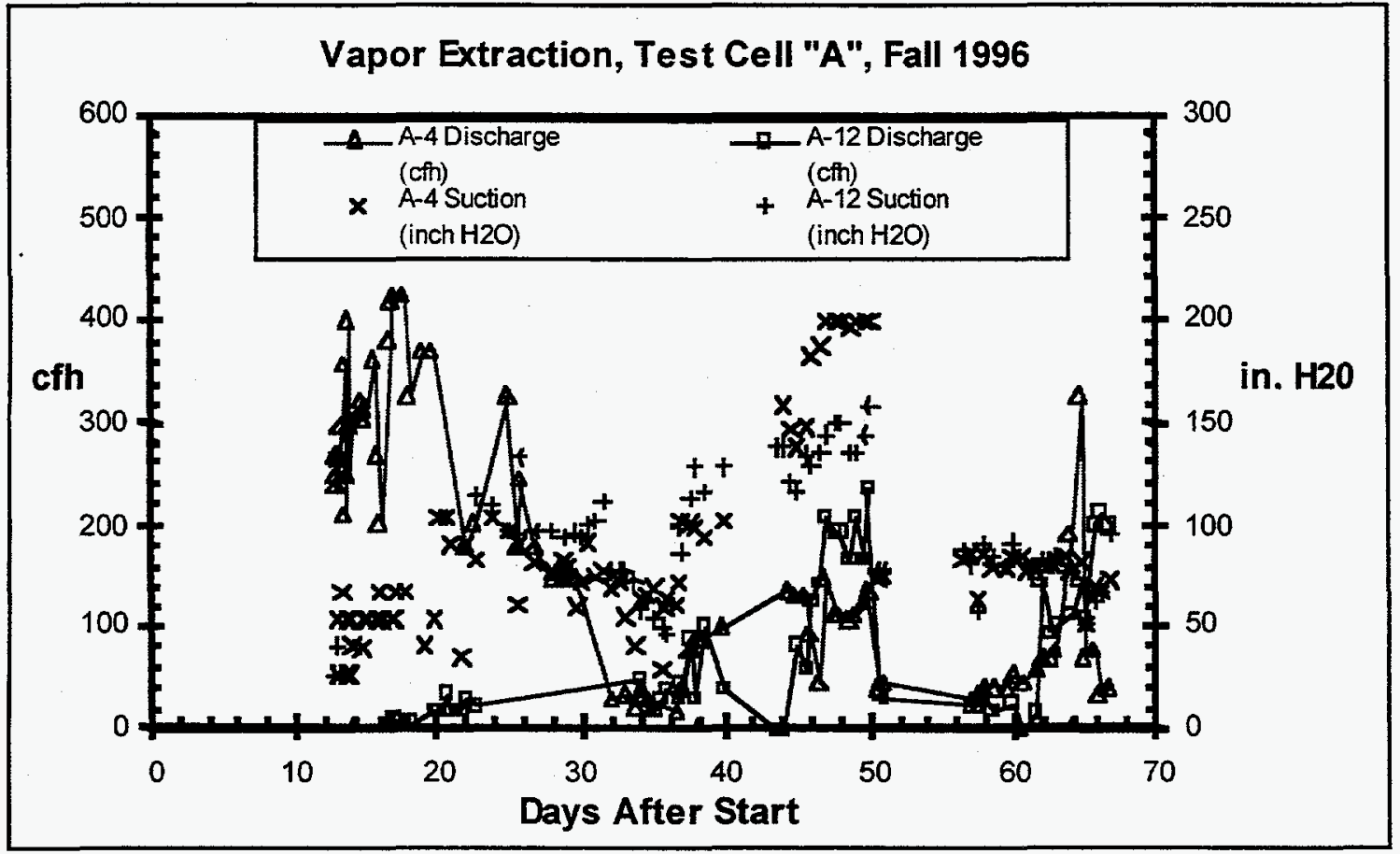

Figure 3.15 Vapor extraction recovery and suction, test cell A, summer 1997.

Volumetric flow rates measured by variable area flowmeters and suction measured by dial gage at the header for each well.

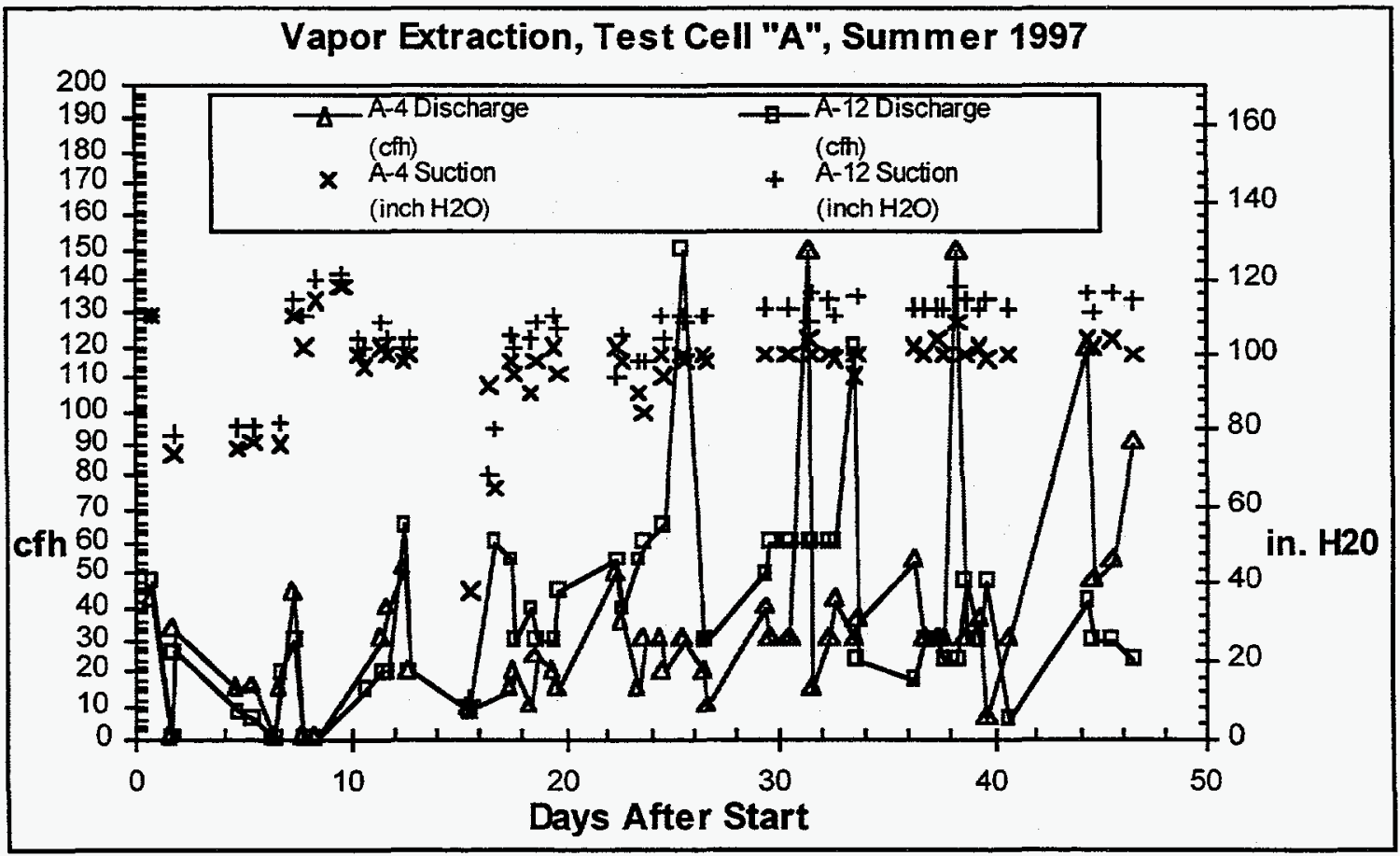


Figure 3.16 Specific discharge of test cell A vapor extraction during fall 1996 tests.

Specific discharge computed as the ratio of flow rate and suction for each well.

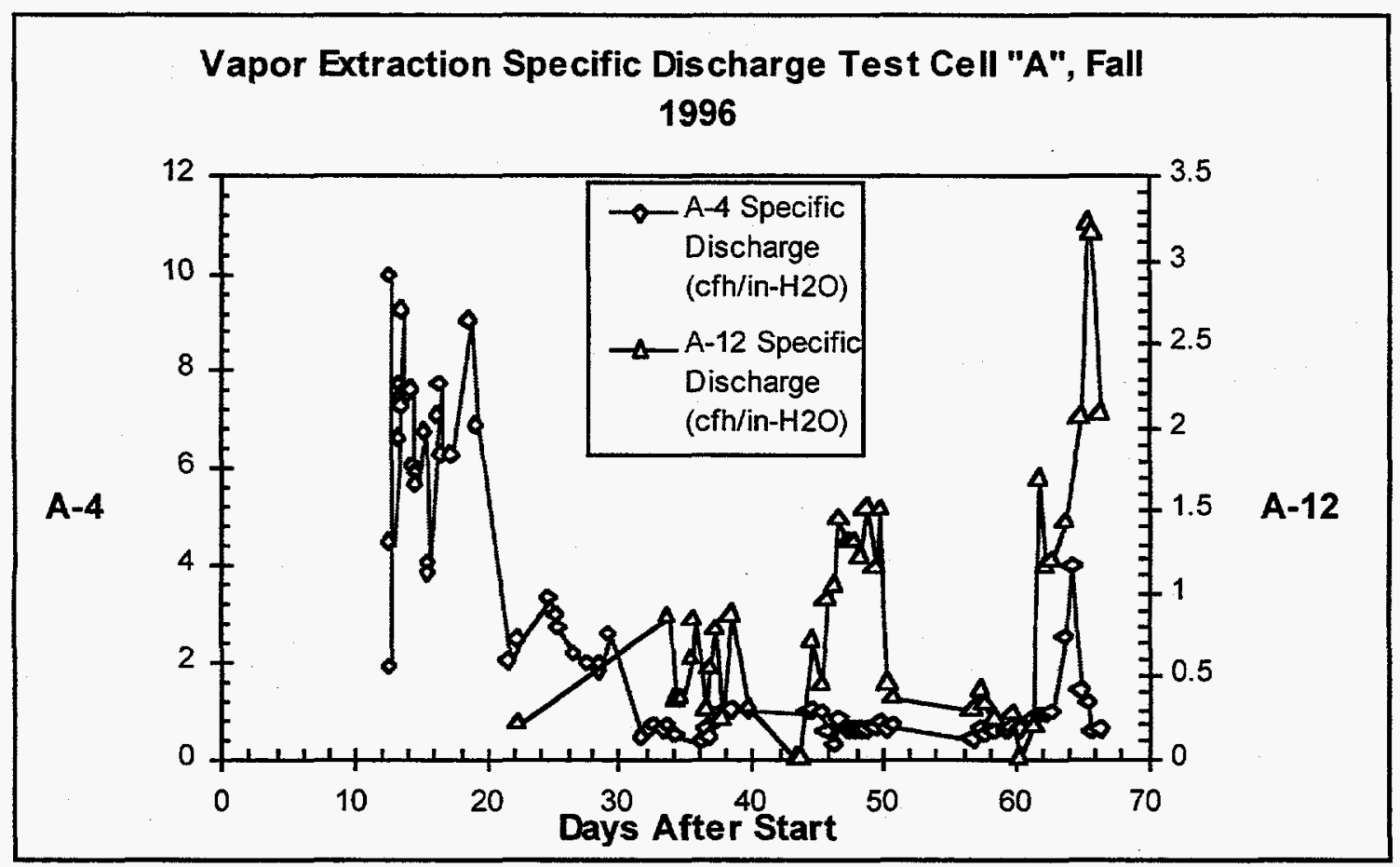

Figure 3.17 Specific discharge of test cell A vapor extraction during summer 1997 tests.

Specific discharge computed as the ratio of flow rate and suction for each well.

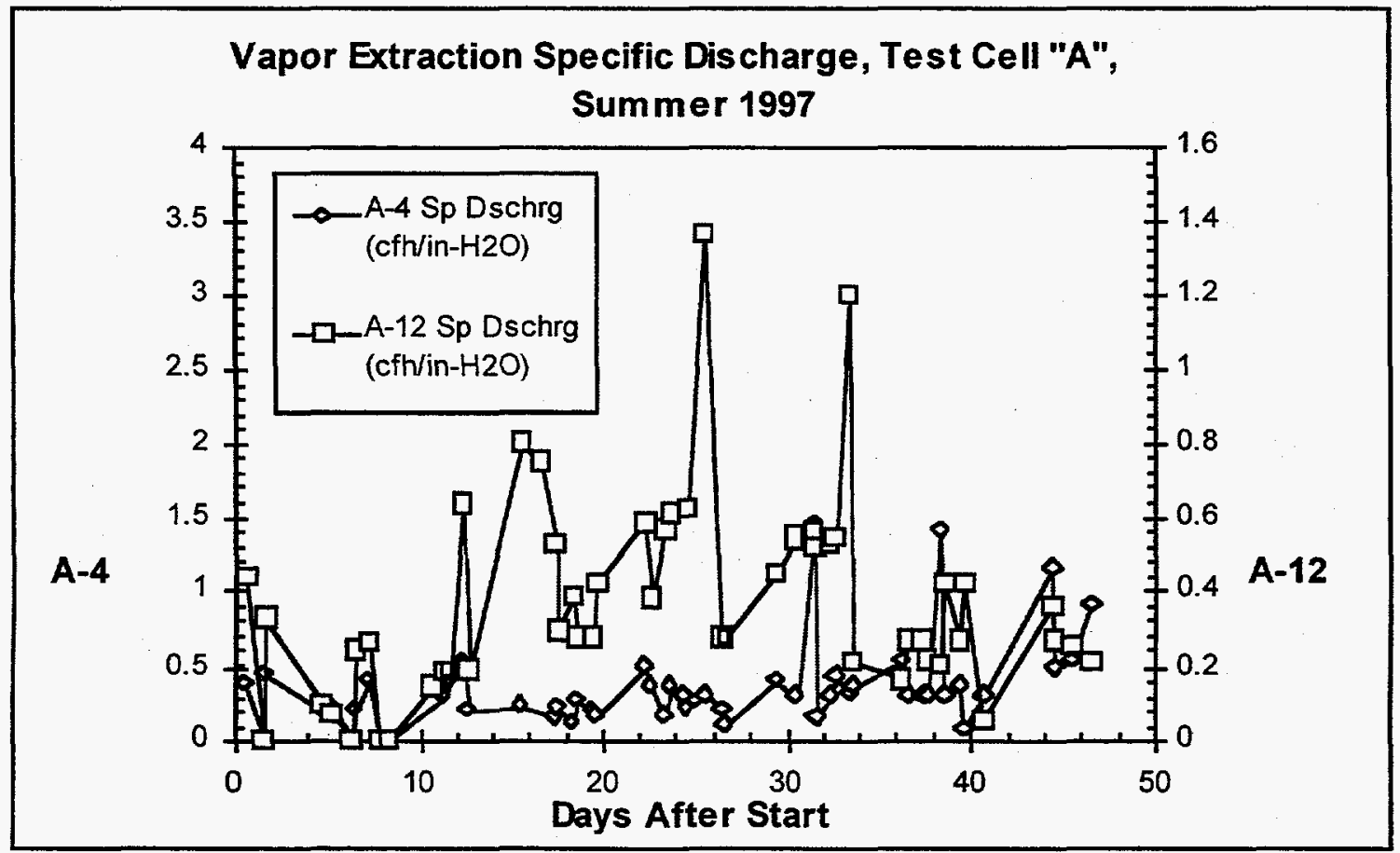


Figure 3.18 Steam generator energy and water consumption, fall 1996.

Water consumption measured by a meter on the supply system and electrical energy by a kw-Hr meter. The on/off state of the generator indicated by the upper/lower level of the dashed line.

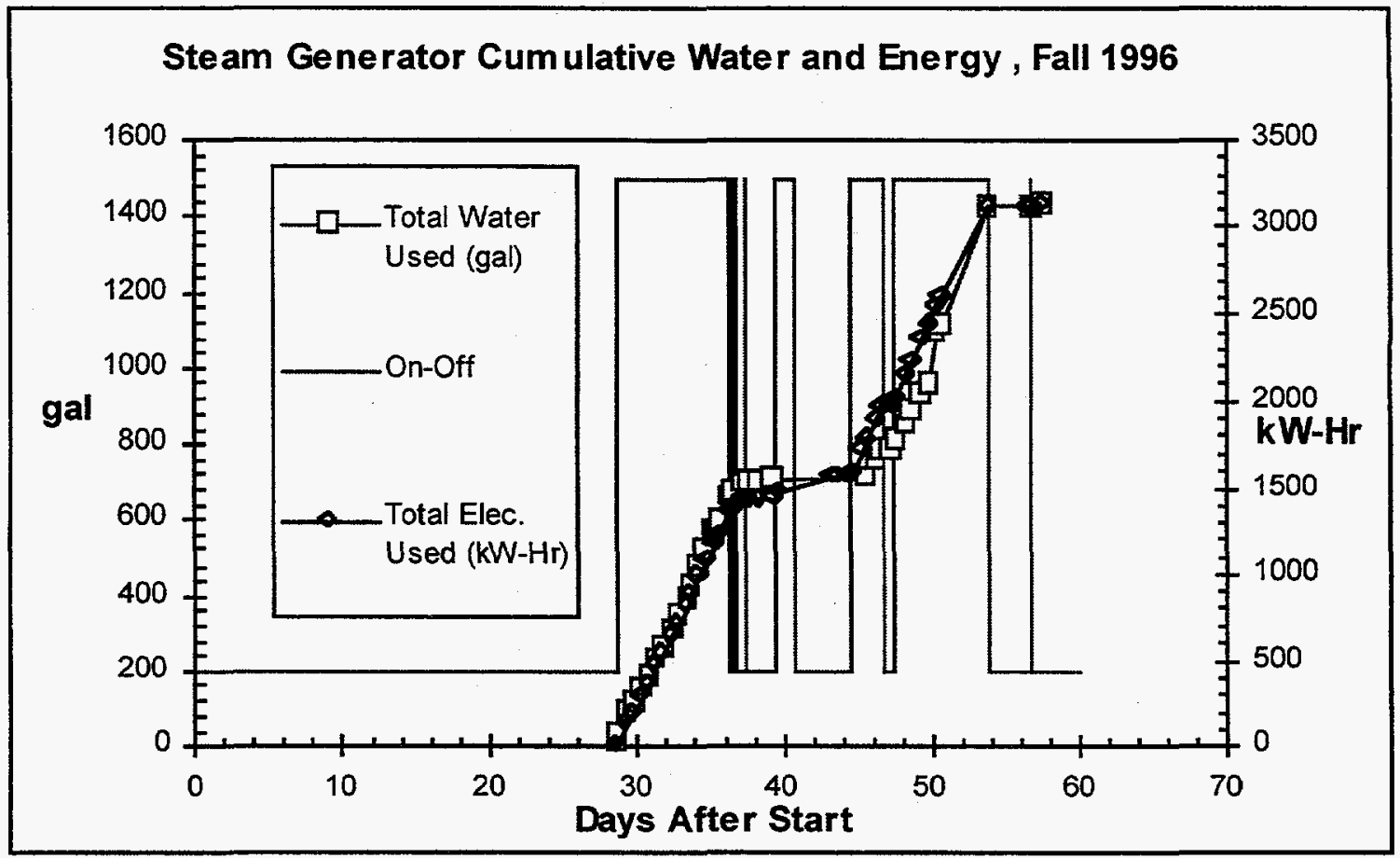

Figure 3.19 Steam generator energy and water consumption, summer 1997.

Water consumption measured by a meter on the supply system and electrical energy by a kw-Hr meter. The on/off state of the generator indicated by the upper/lower level of the dashed line.

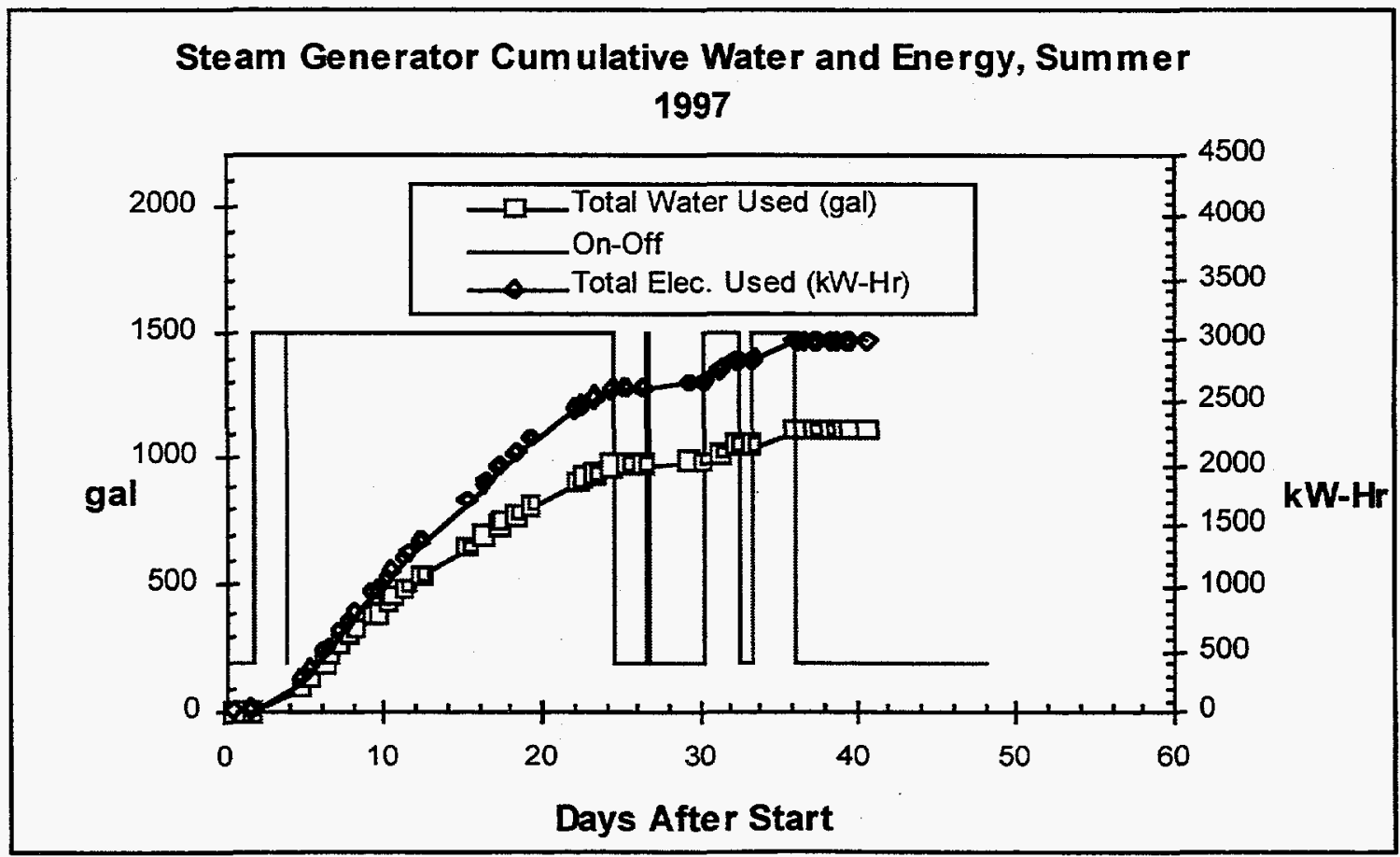


Figure 3.20 Steam generator efficiency, fall 1996.

Effectiveness computed as the ratio of incremental water consummed to incremental energy consumed. The on/off state of the generator indicated by the upper/lower level of the dashed line.

Steam Generator Efficiency, Fall 1996

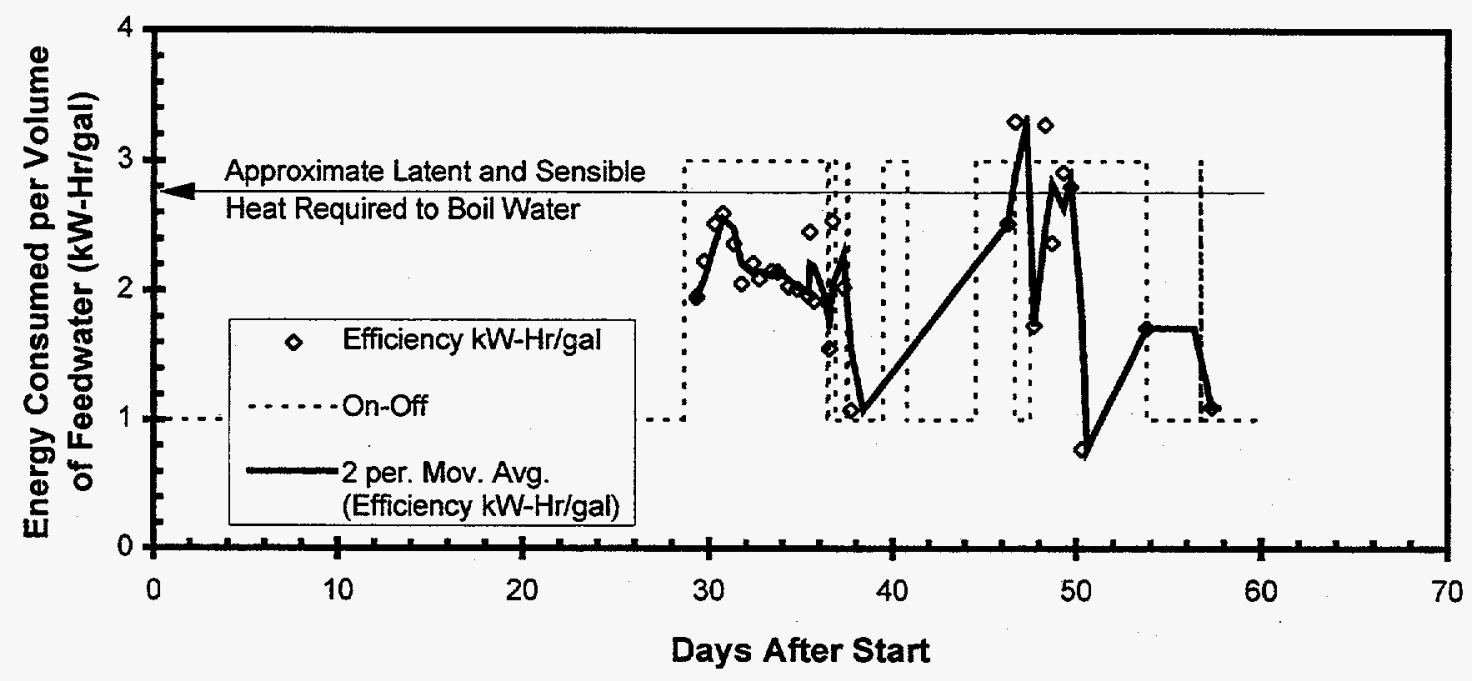

Figure 3.21 Steam generator efficiency, summer 1997.

Effectiveness computed as the ratio of incremental water consummed to incremental energy consumed. The on/off state of the generator indicated by the upper/lower level of the dashed line.

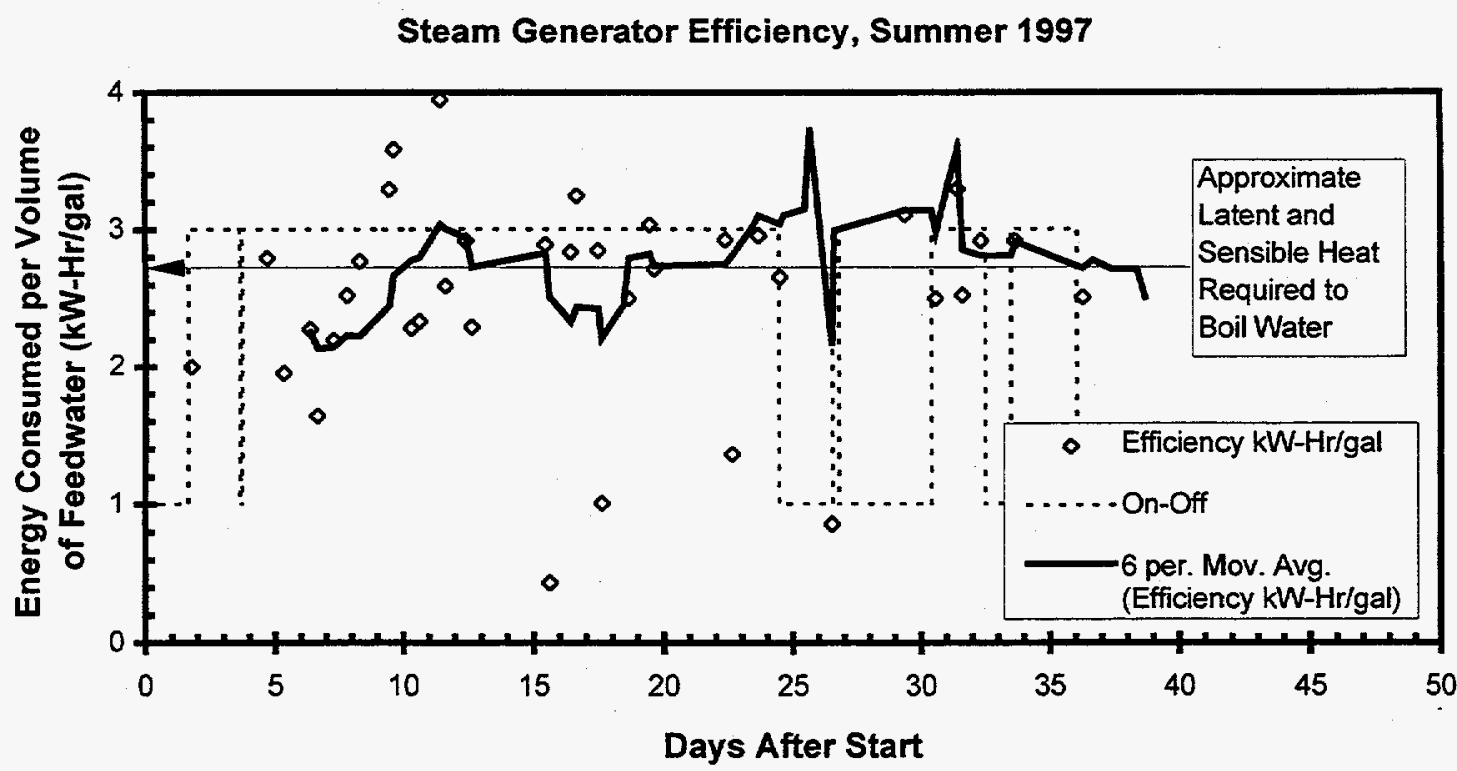


Figure 3.22 Volumetric moisture content as a function of depth and time in Cell A. Boring M1 (upper) and M2 (lower). Open symbols are from Fall, 1996, filled symbols from Summer, 1997, measured using TDR. Circles with internal cross measured in lab before testing (Fall 1996), squares with internal cross measured in lab after testing (Fall, 1997).
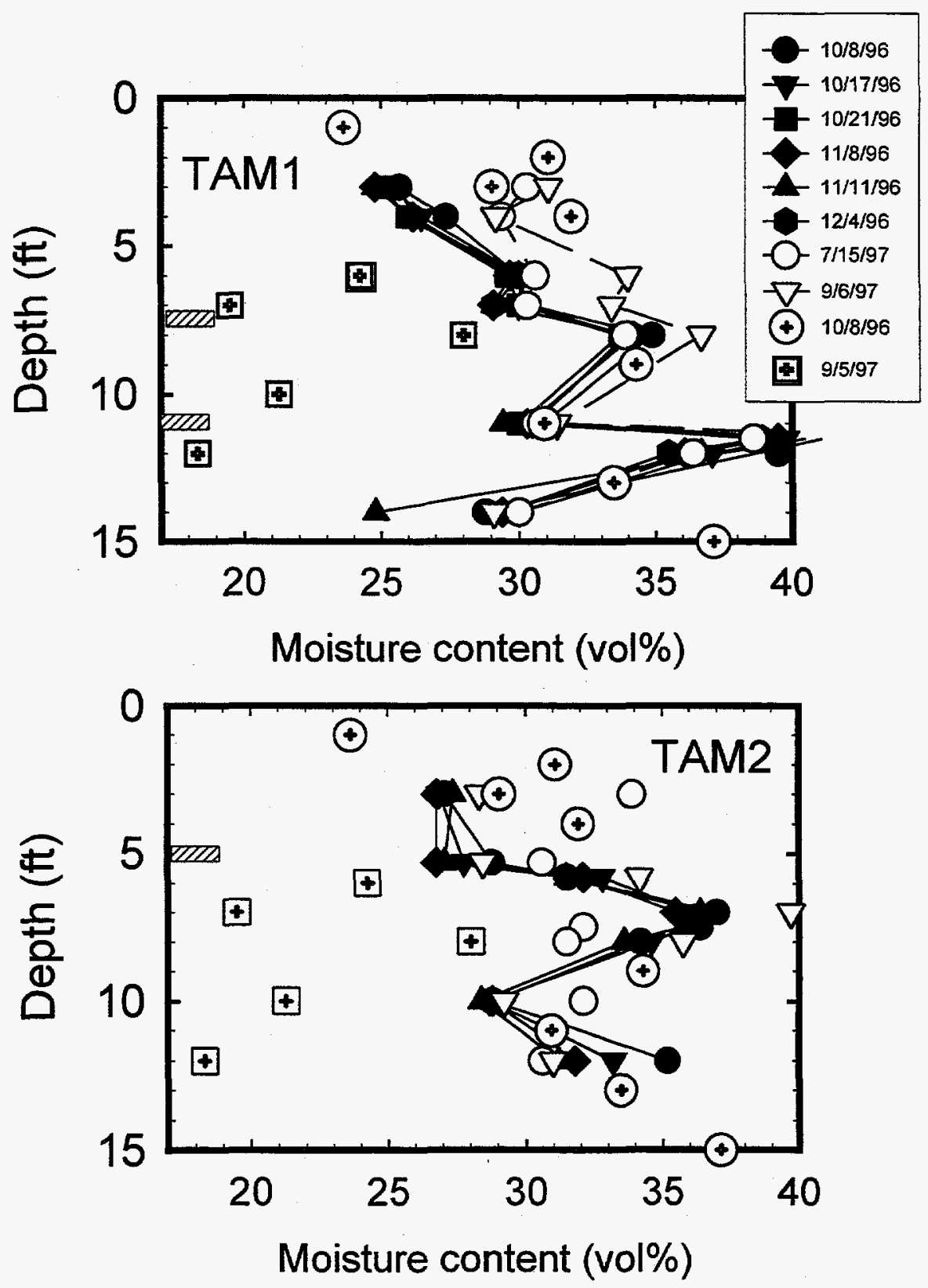
Figure 3.23 Ground surface temperatures at test cell A.
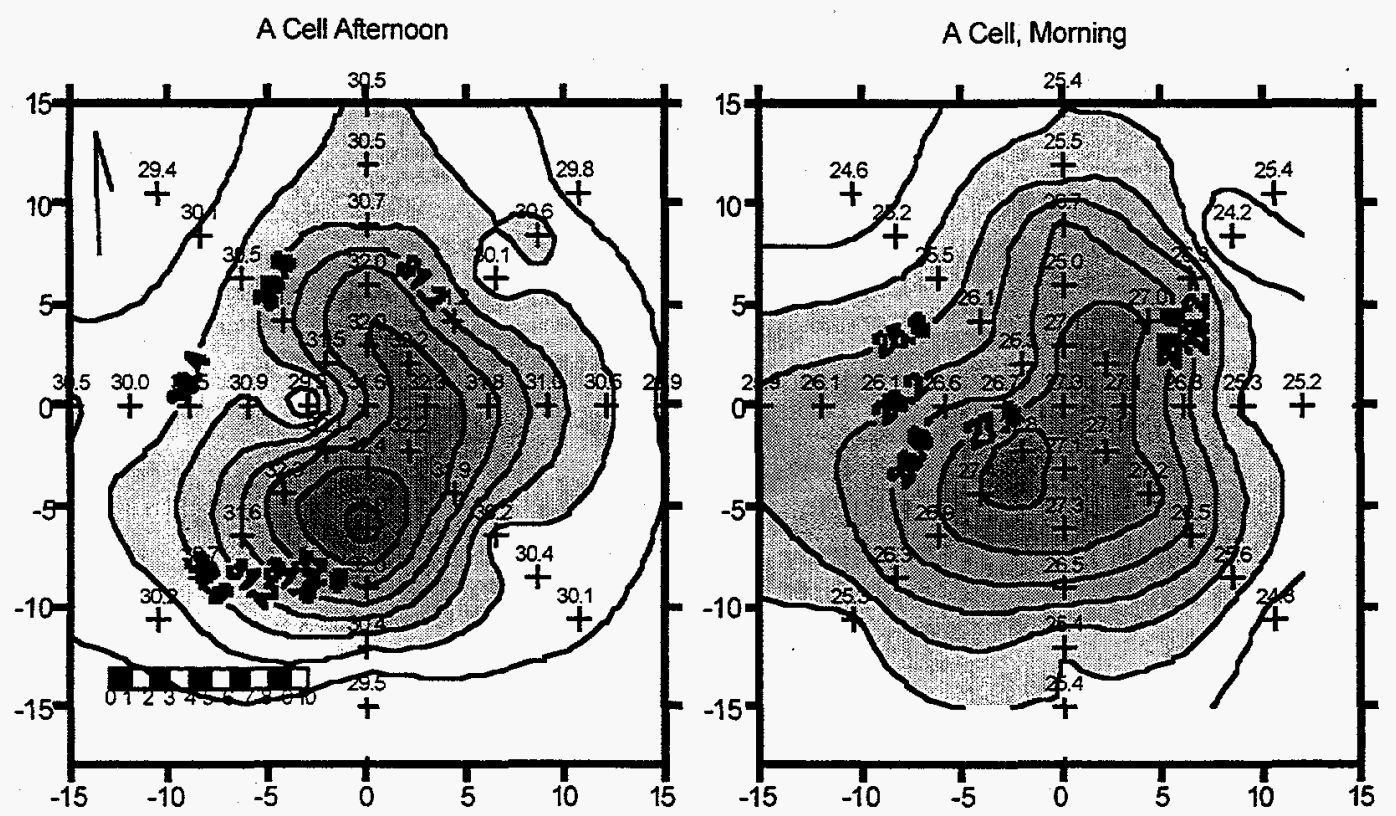
Figure 3.24 Initial and early temperature cross-sections at test cell A.

Projected cross section of background temperatures at Cell A (upper), and temperatures recorded on July 30, 1997 by thermistors. Measurement points are indicated with plus signs. Projection created by rotating each measurement location around the injection well to a common plane and reflecting each to provide mirror images across the axis. Contours interpolated by kriging with an anisotropic linear variogram.

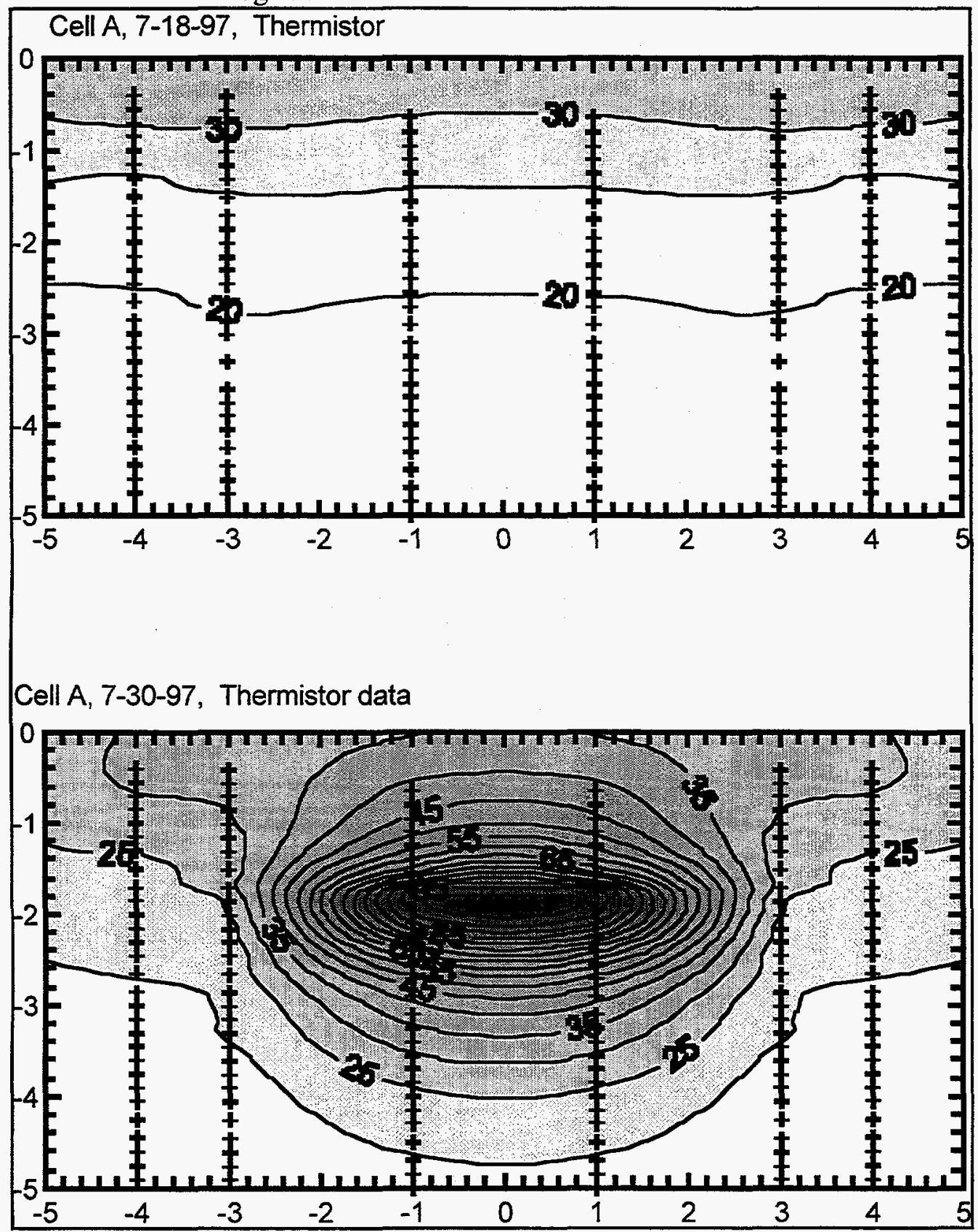


Figure 3.25 Progression of temperature cross-sections in test cell A.

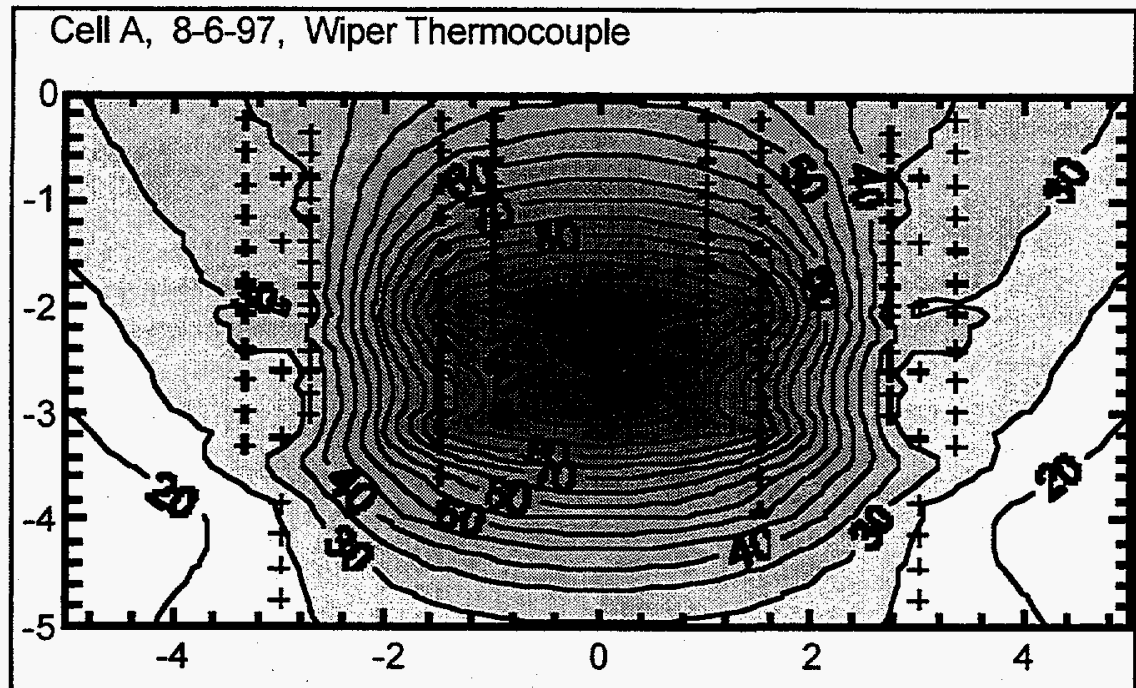

Cell A 8-26-97, Thermistor

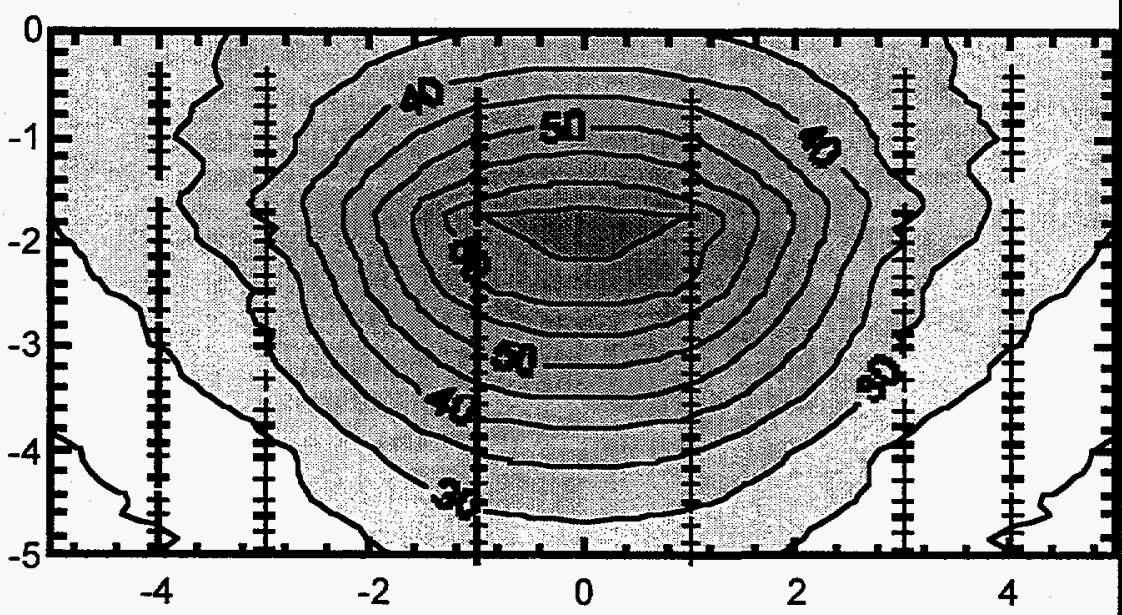

Cell A, 9-6-97, Wiper thermocouple

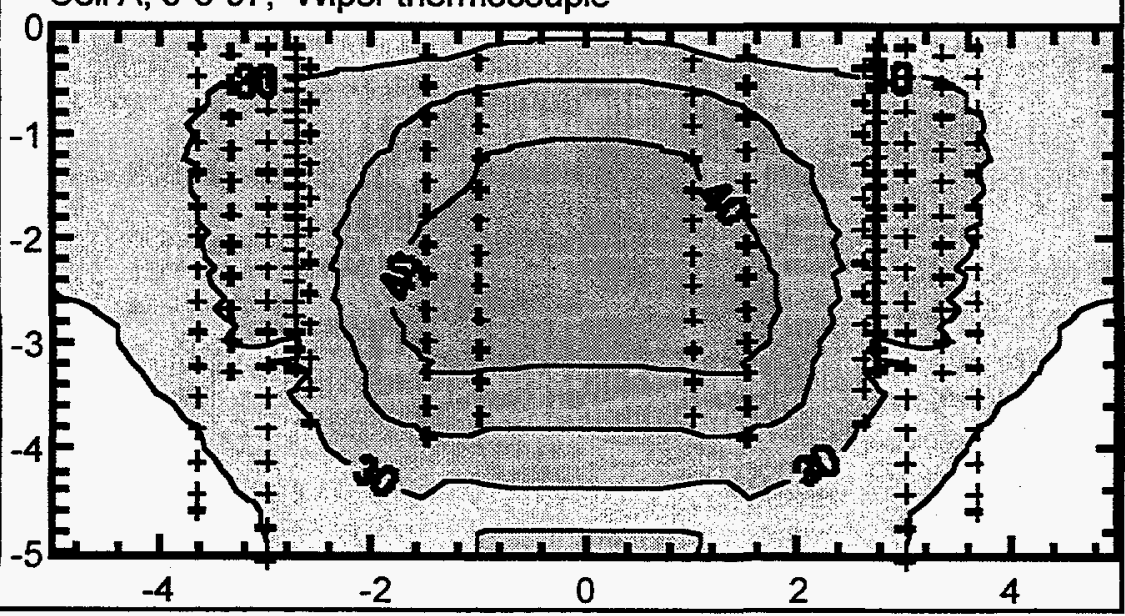


Figure 3.26. Oxygen and carbon dioxide in off-gas, test cell A, fall 1996.

On-Line Off-Gas Concentrations From A-4

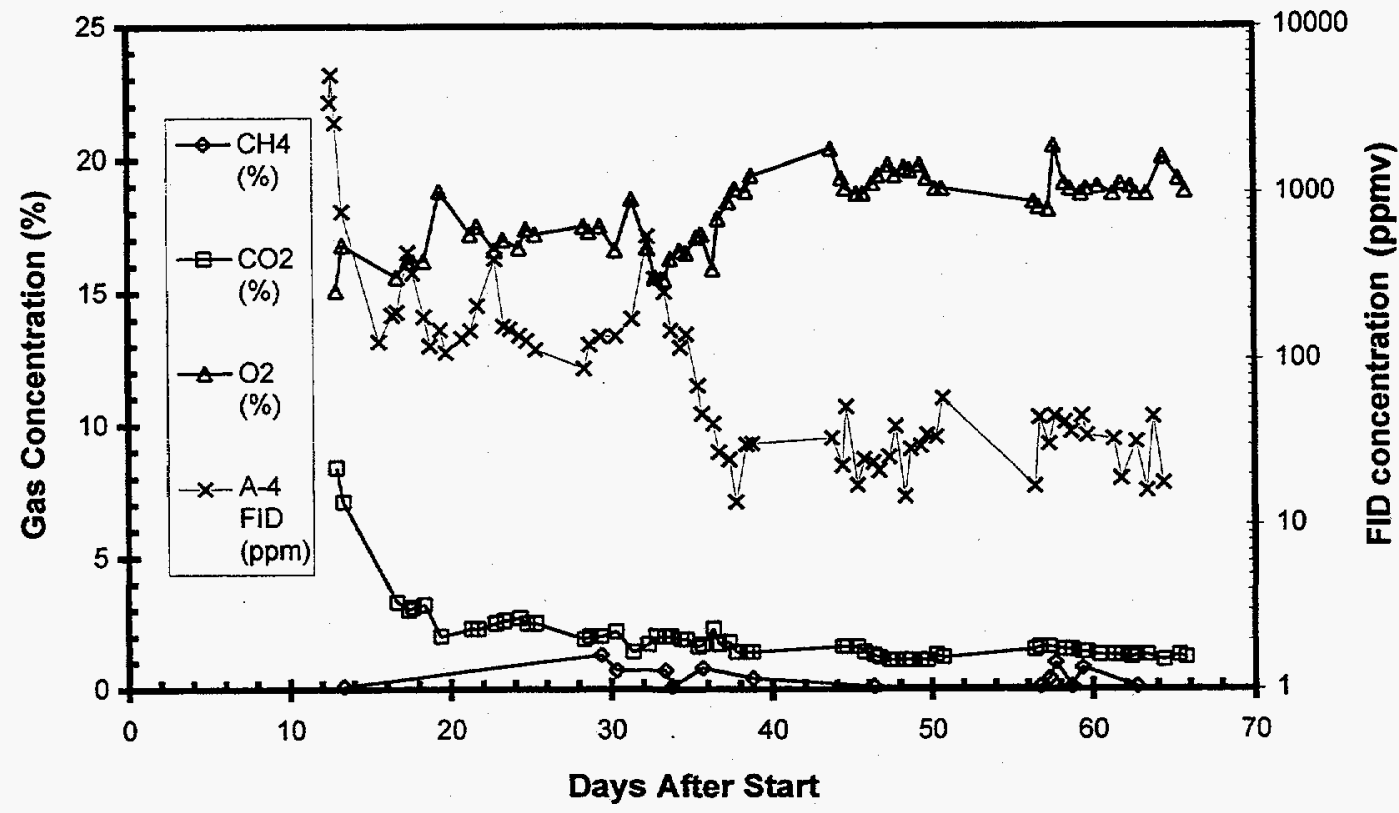

Figure 3.27. Methane in off-gas at test cell A and B, fall 1996.

\section{On-Line Off-Gas Concentrations From A-12}

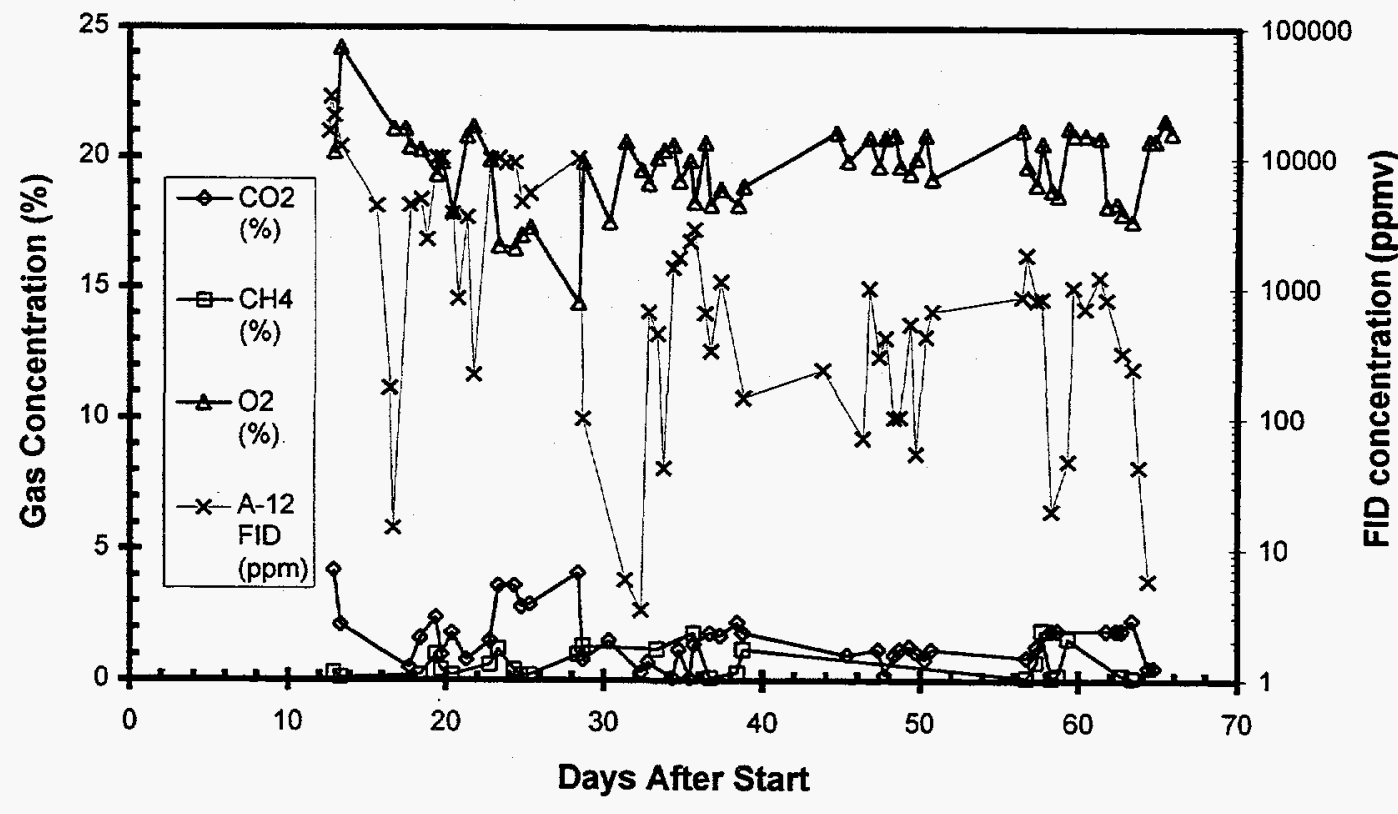


Figure 3.28 Composition of A-4 off-gas.

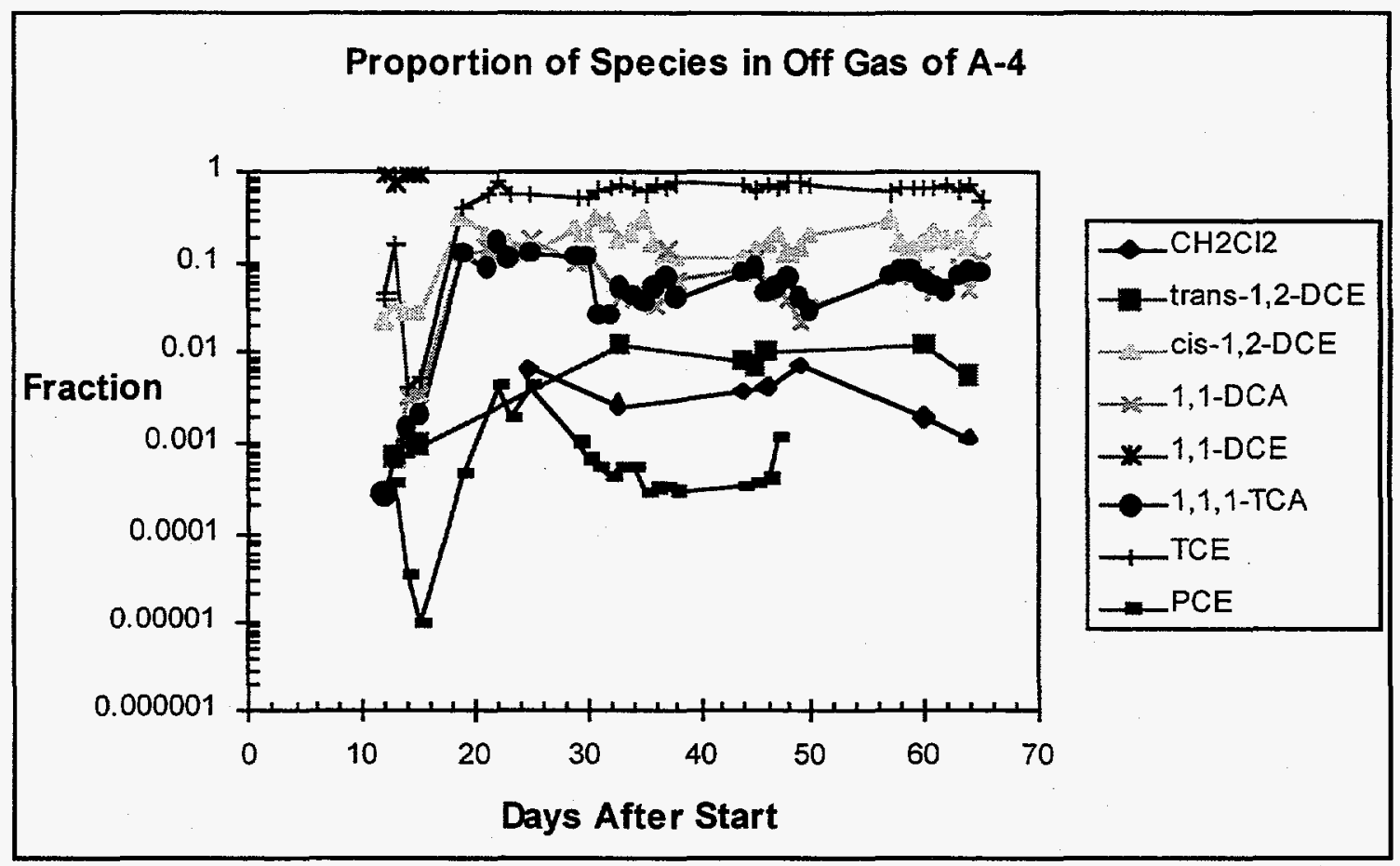

Figure 3.29 Composition of A-12 off-gas.

Proportion of Species in Off Gas of A-12

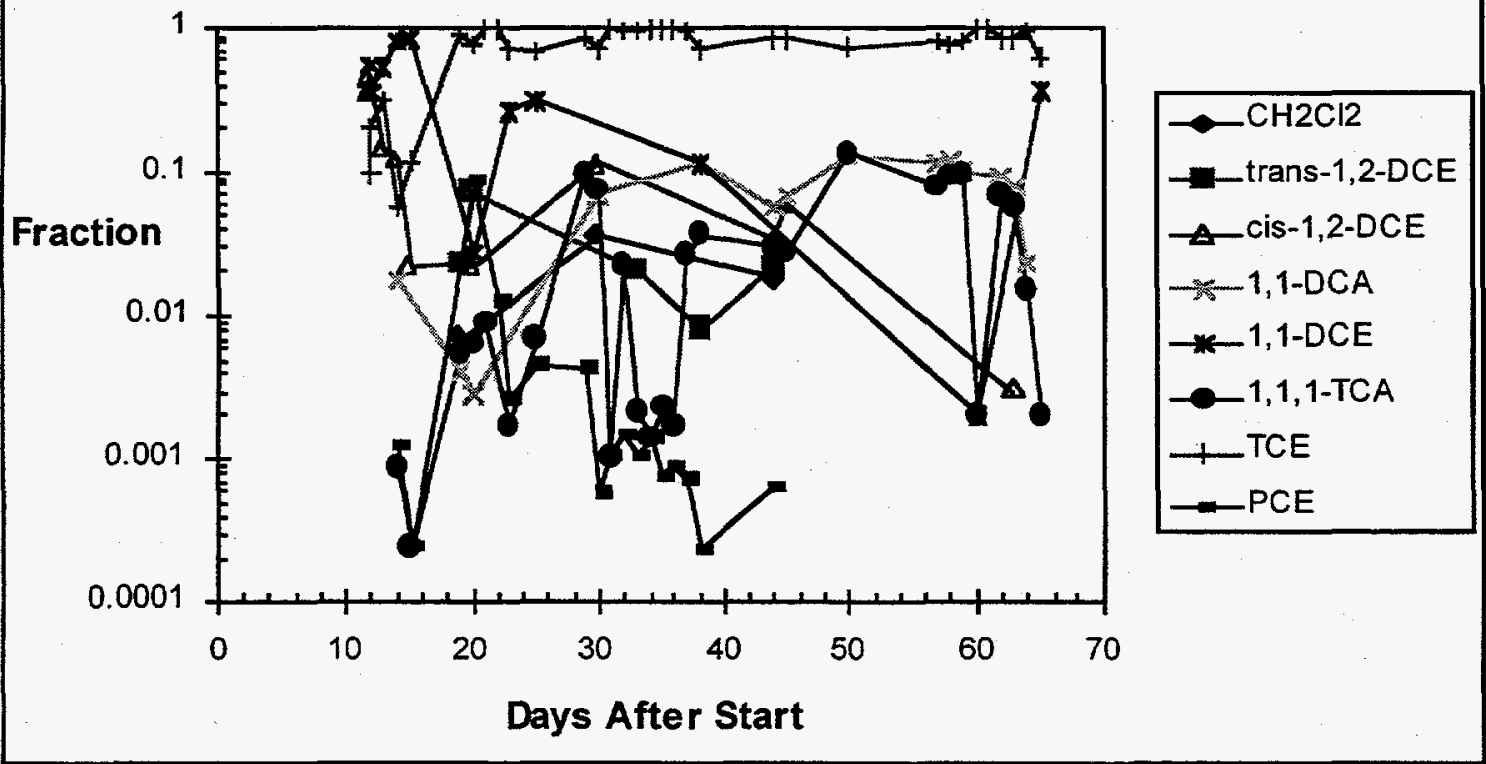


Figure 3.30 Recovery rate of contaminants.

Recovery rates computed from measured volumetric flow rates and concentrations measured by GC/ECD in collected samples. Analytes were TCE, PCE, c-DCE, tDCE, 1-1-DCE, TCA, 1-1-DCA, and methylene chloride.

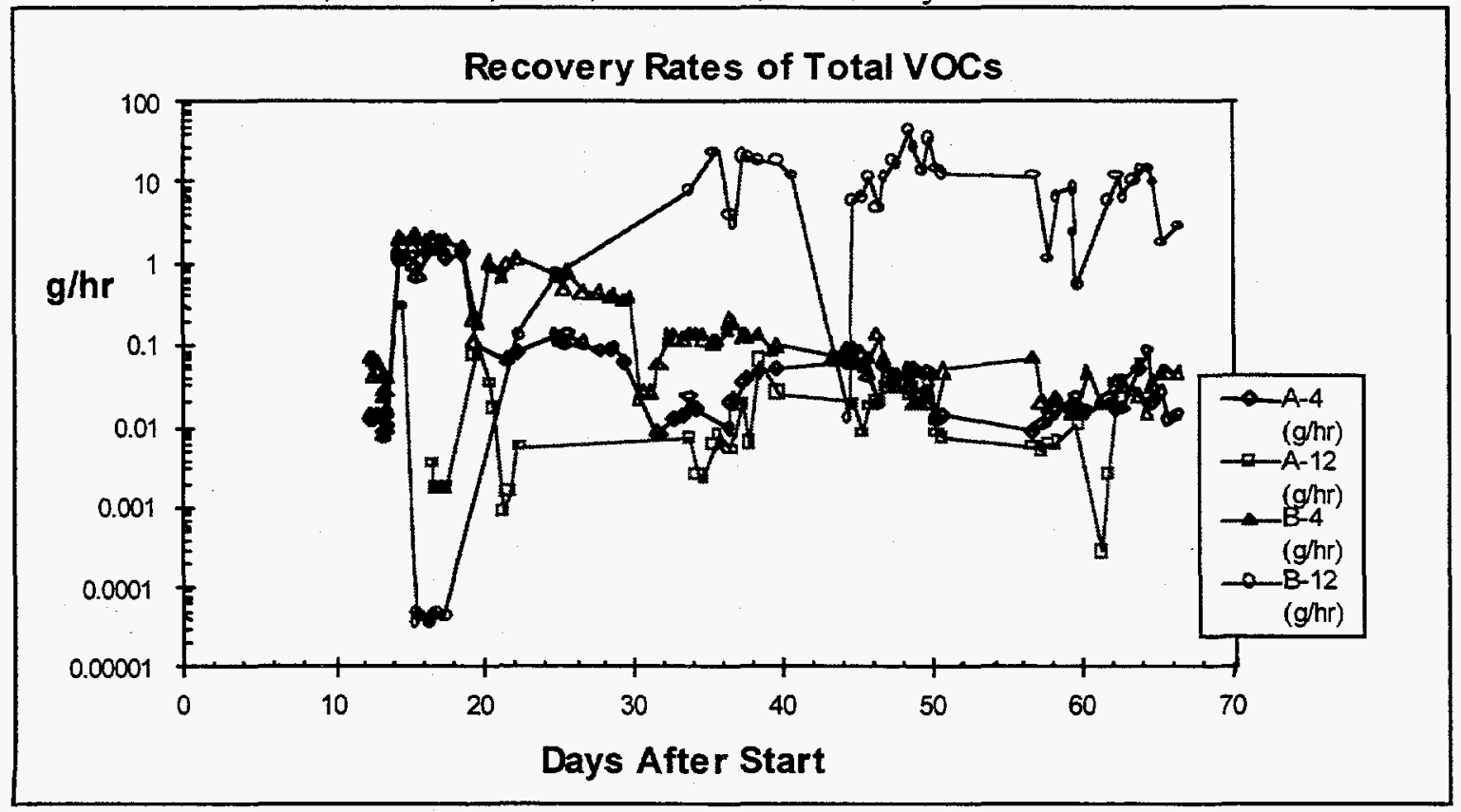


Figure 3.31 Cumulative water recovery from tests cell B during 1996.

Water recovery volumes measured by counting separator fill/empty cycles.

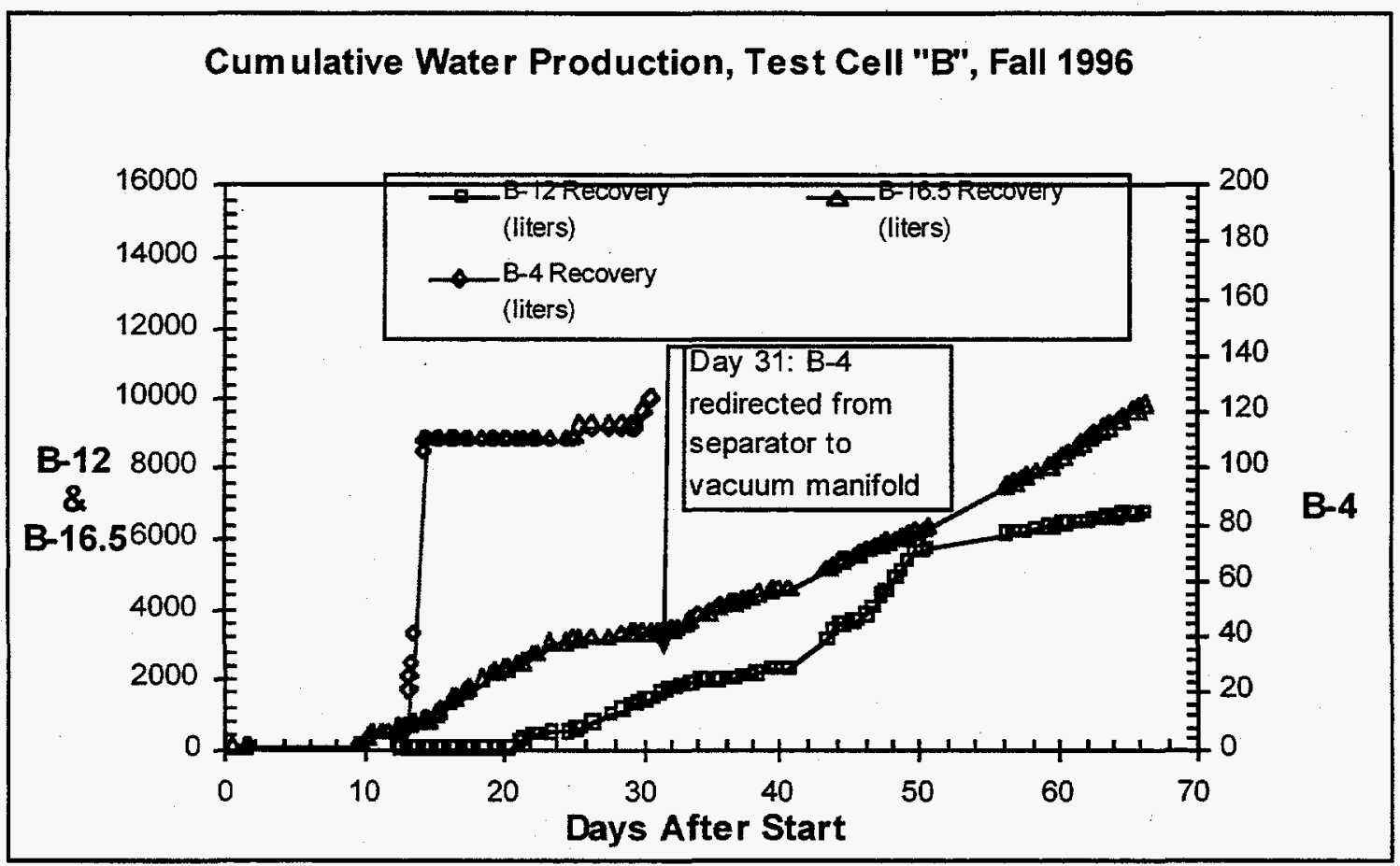

Figure 3.32 Cumulative water recovery from test cell B during 1997.

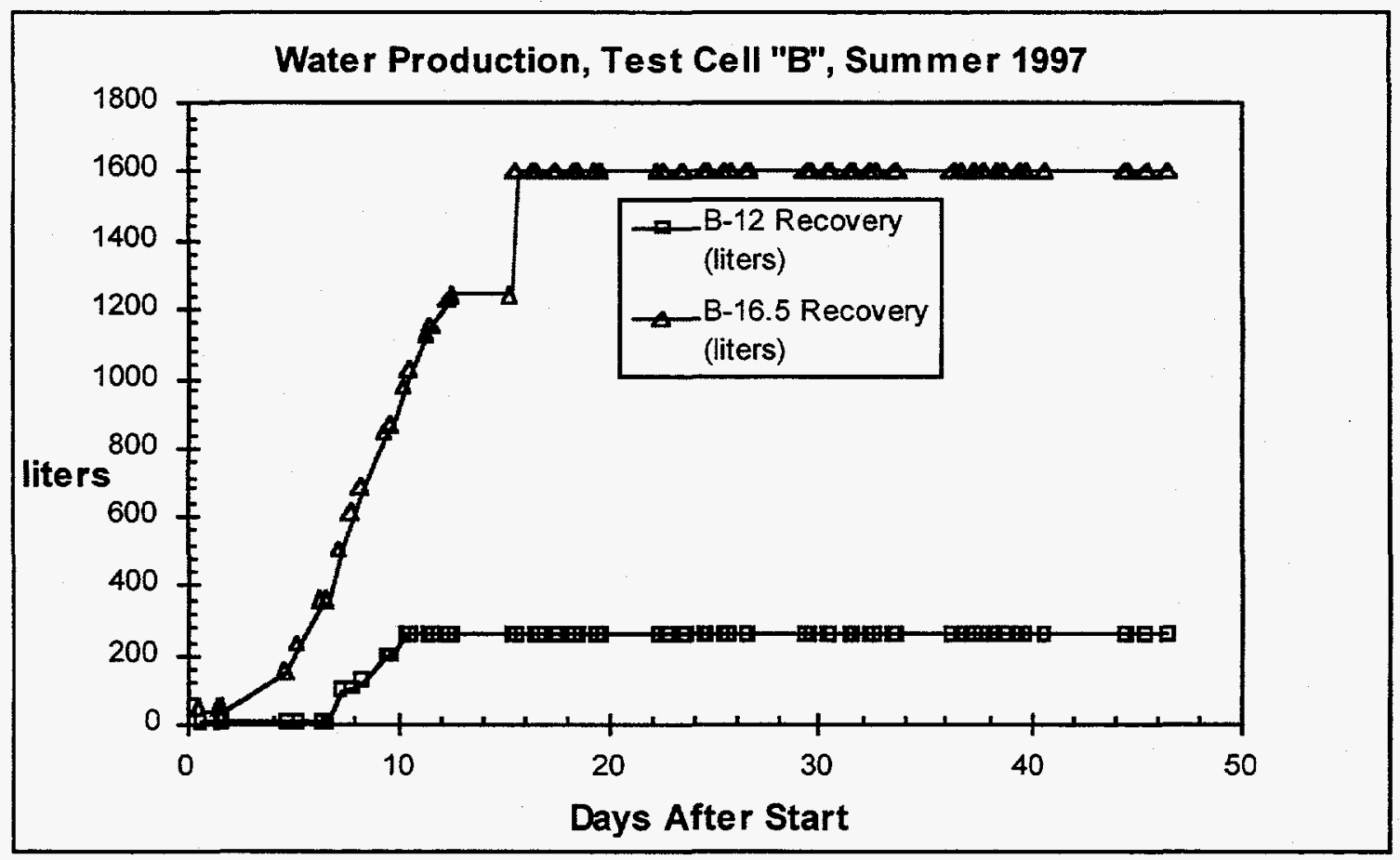


Figure 3.33 Vapor extraction recovery and suction, test cell B, fall 1996.

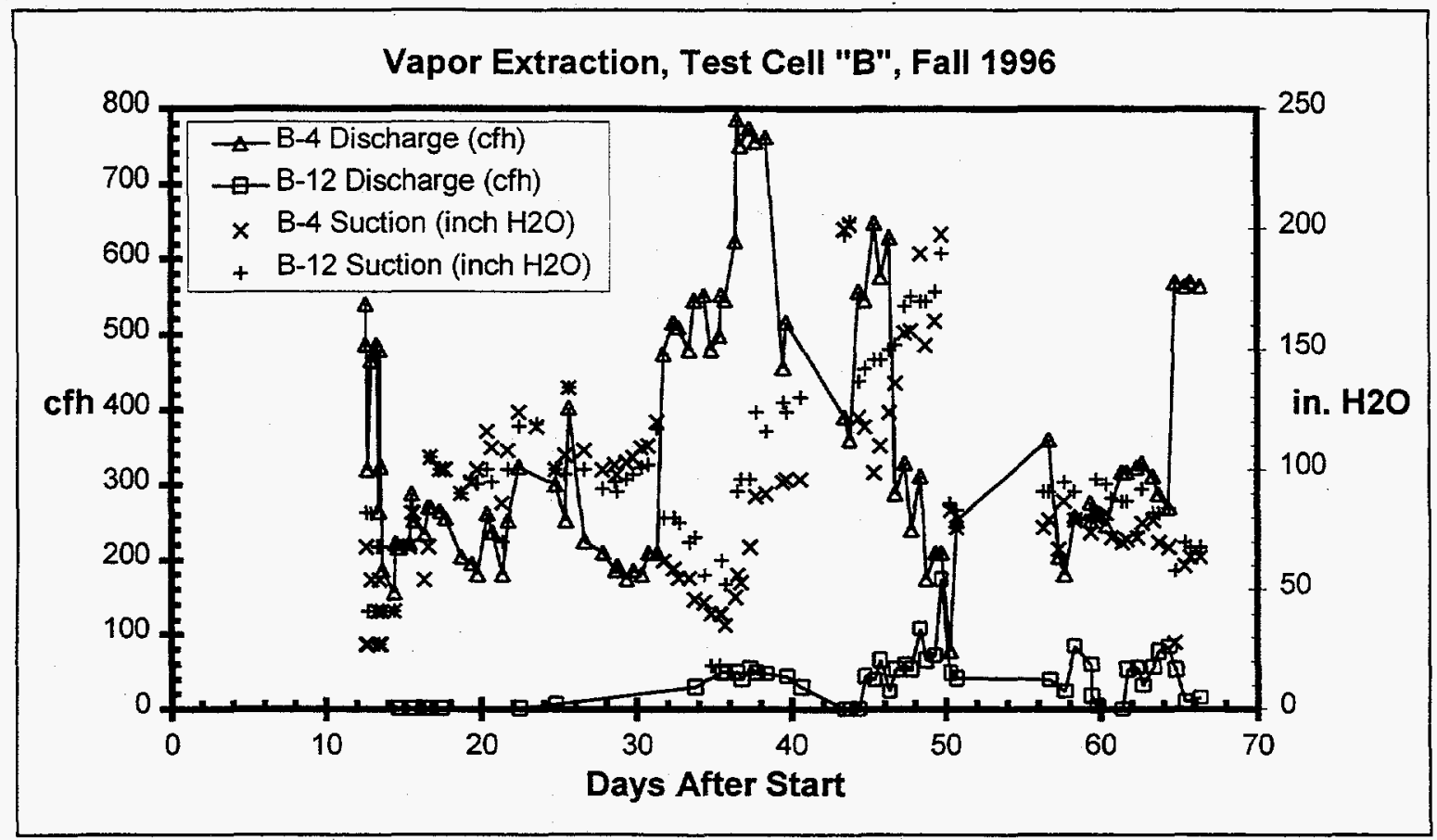

Figure 3.34 Vapor extraction recovery and suction, test cell B, summer 1997.

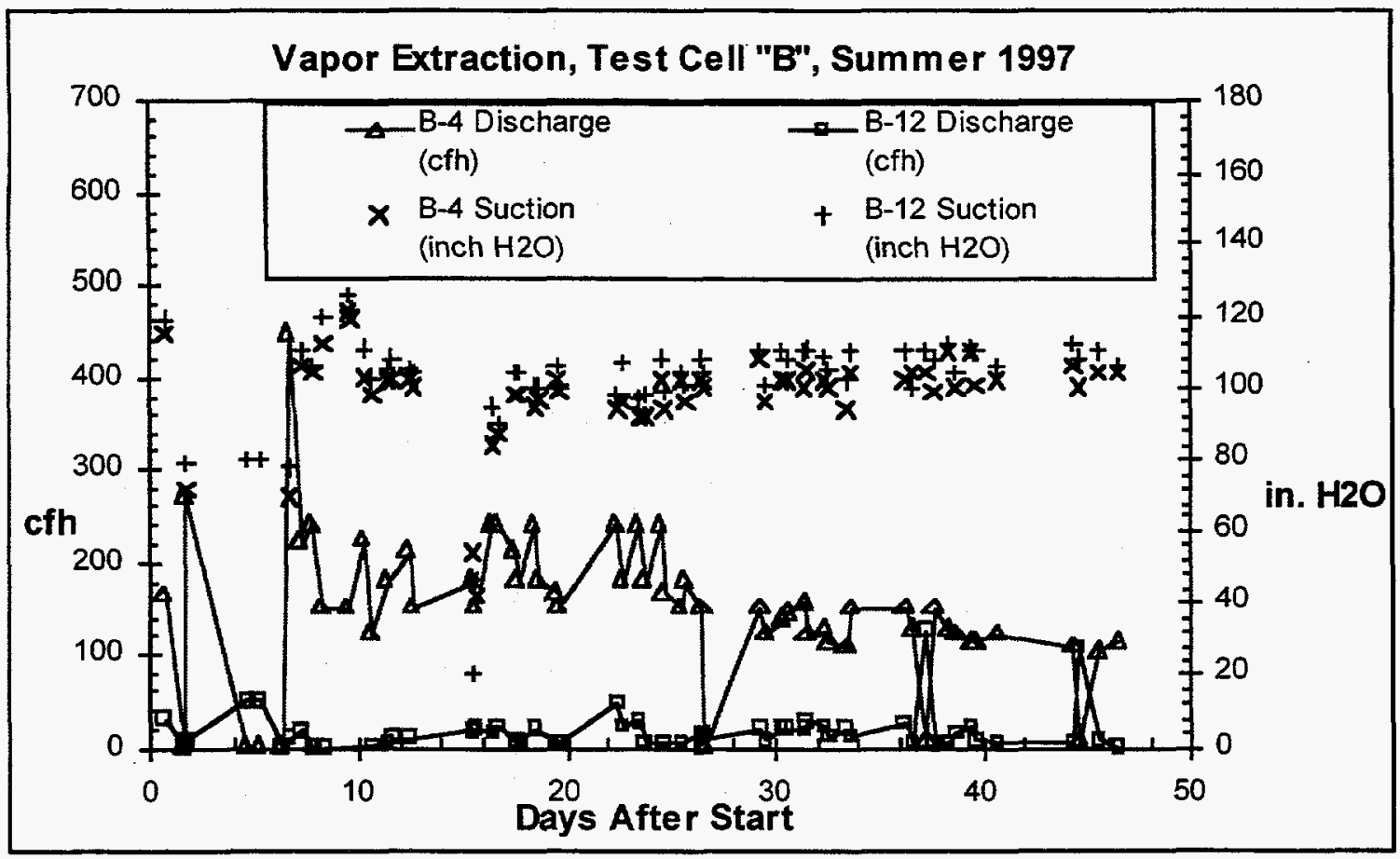


Figure 3.35 Specific discharge of test cell B vapor extraction during fall 1996 tests.

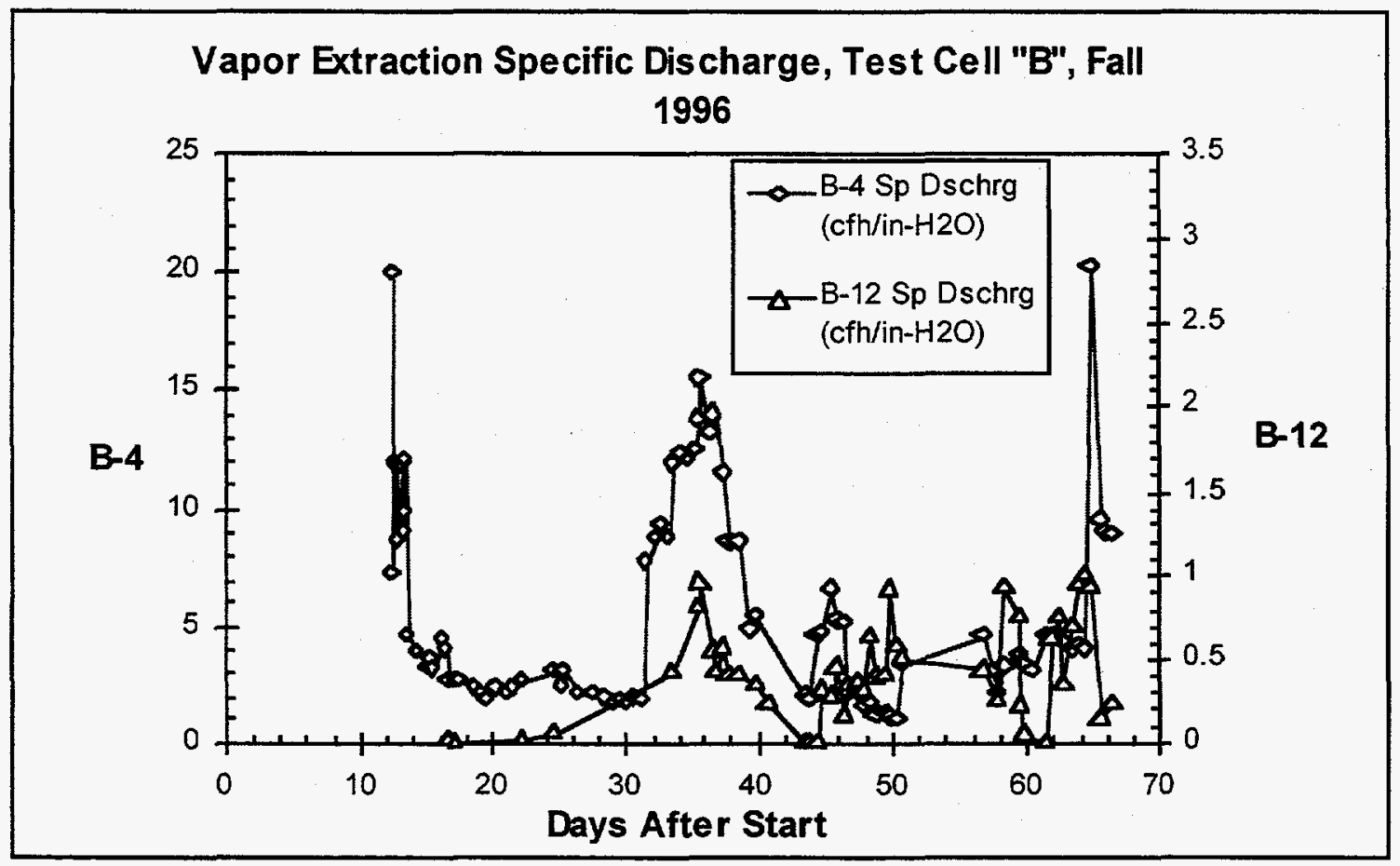

Figure 3.36 Specific discharge of test cell B vapor extraction during summer 1997 tests. Specific discharge calculated as the ratio of measured flow rates and observed pressures.

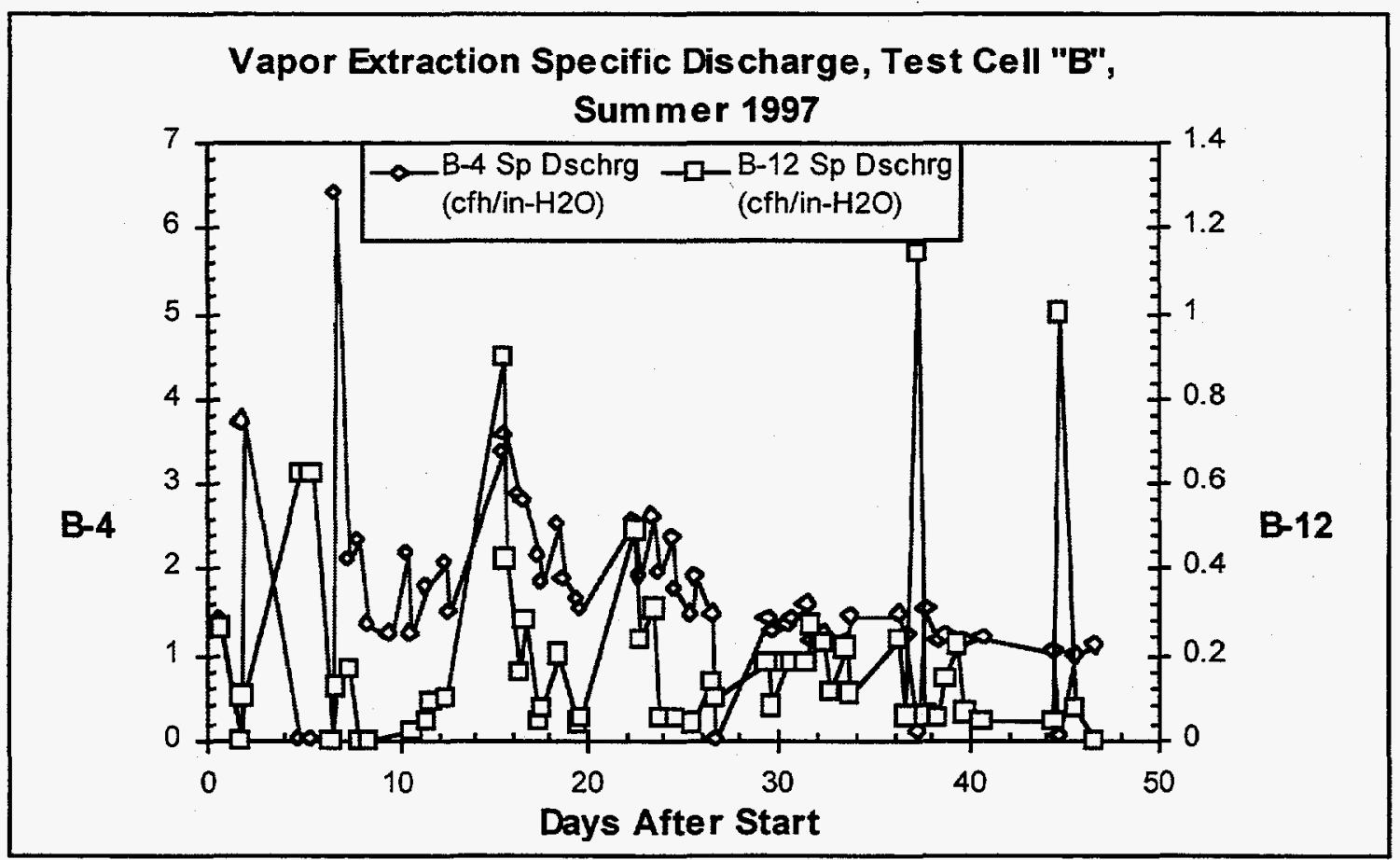


Figure 3.37 Air injection rate and pressure, fall 1996.

Flow rates measured by variable are flow meters and pressure by dial gage.

Injection stream of a single compressor was delivered to both B-6 andB-8, so injection pressures into the two fractures were identical.

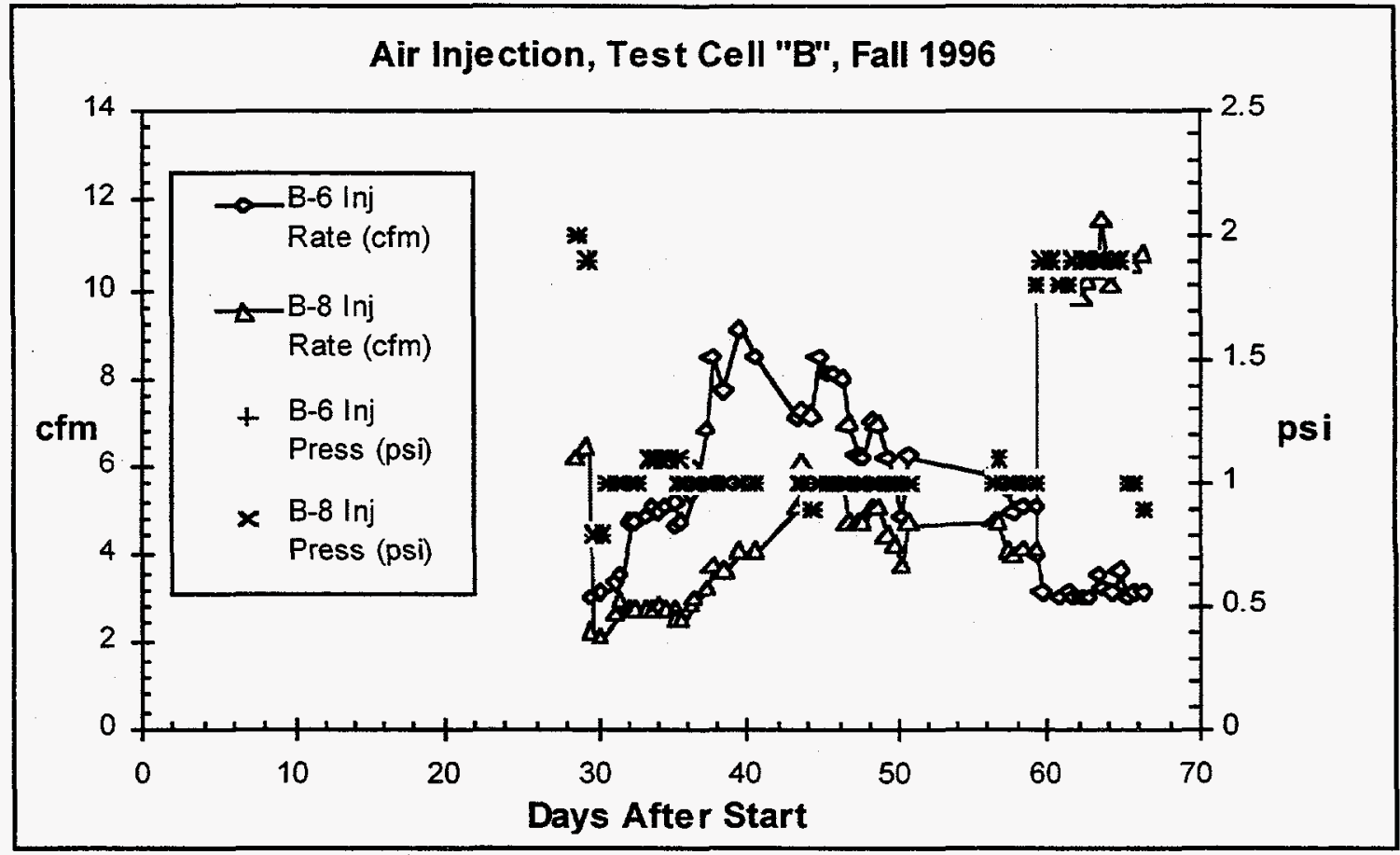

Figure 3.38 Air injection rate and pressure, summer 1997.

Flow rates measured by variable are flow meters and pressure by dial gage. A separate compressor was used for each fracture.

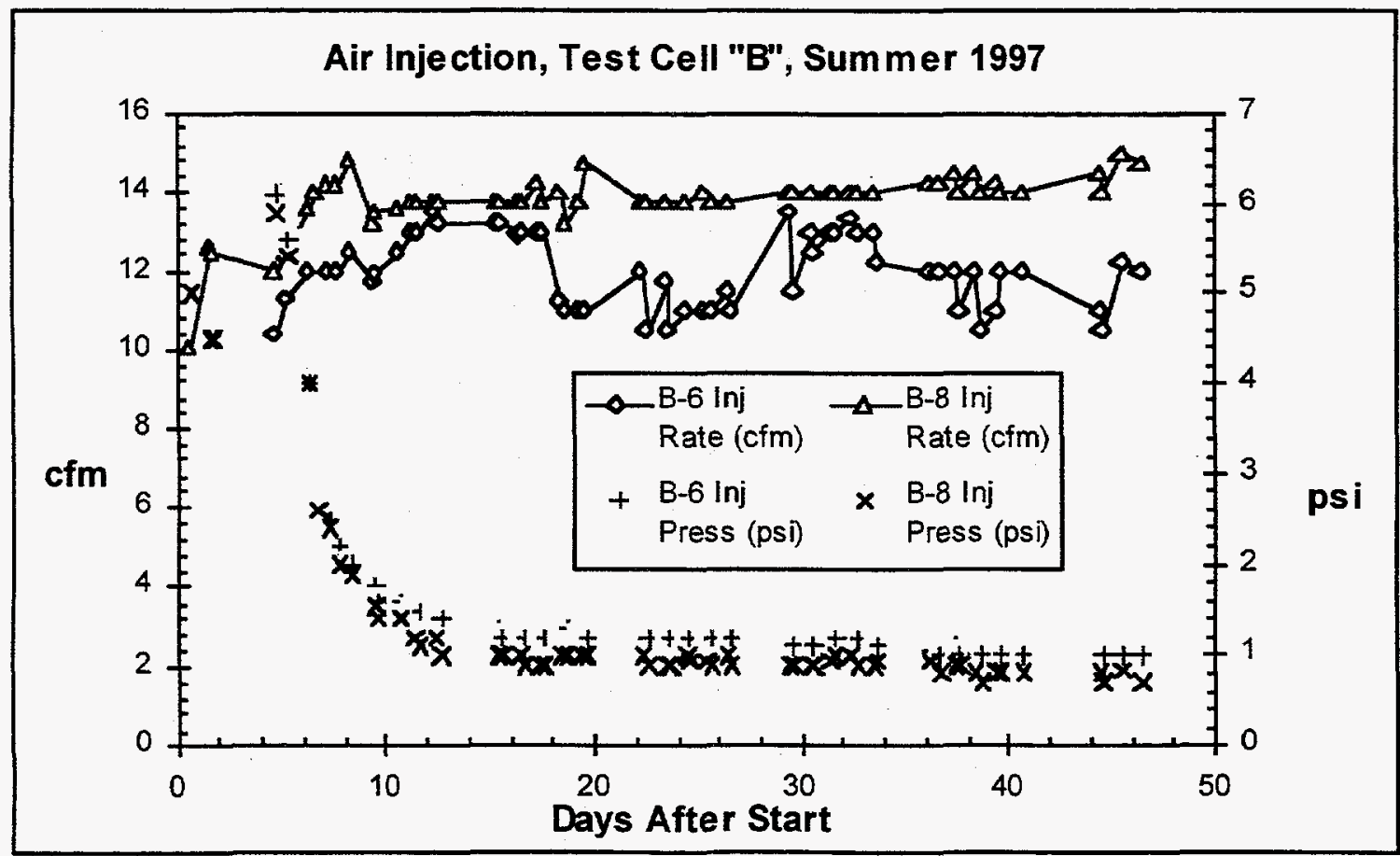


Figure 3.39 Specific injection of air, fall 1996.

Specific injection calculated as the ratio of injection rate and injection pressure.

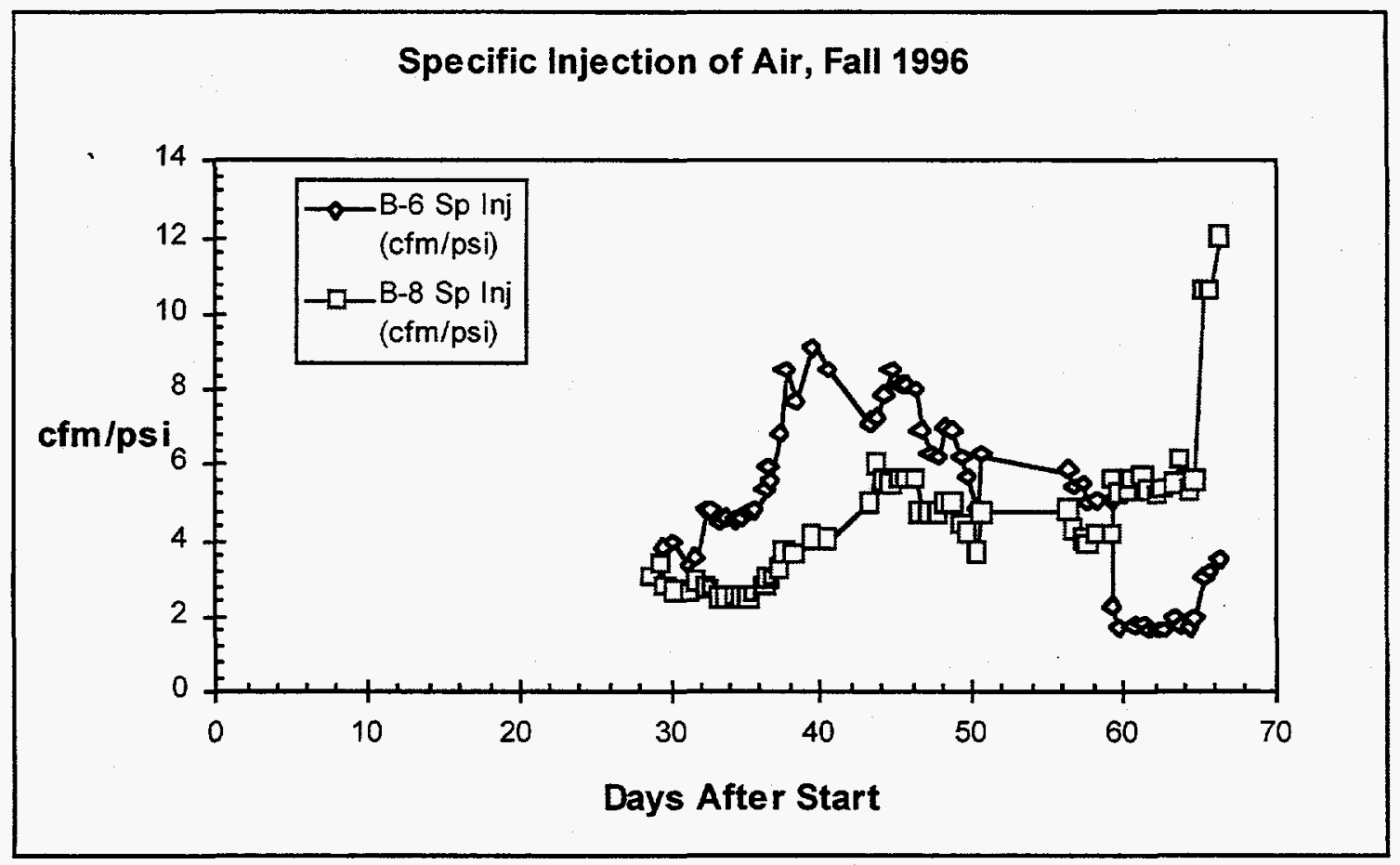

Figure 3.40 Specific injection of air, 1997.

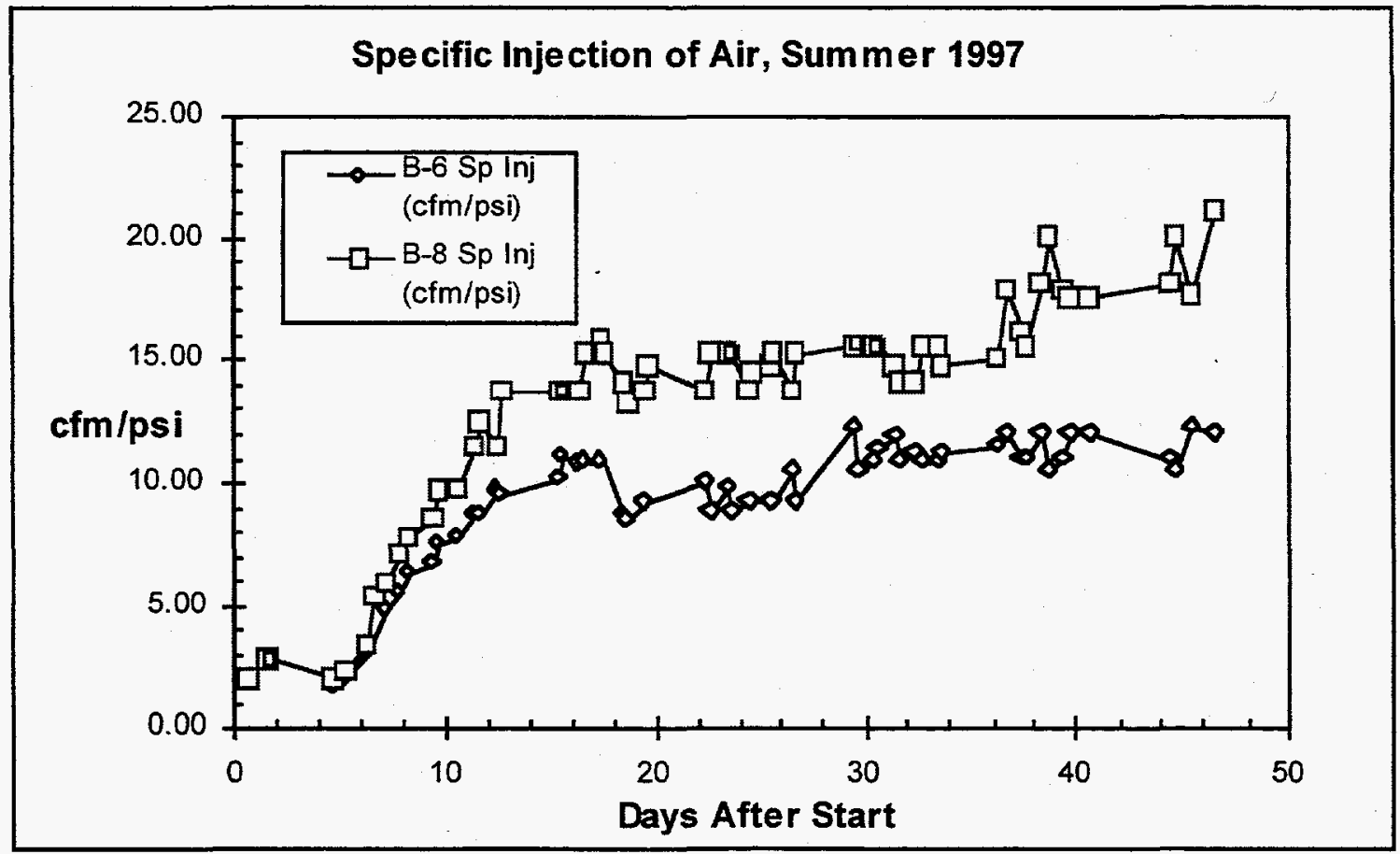


Figure 3.41 Thermal energy of injected air, fall 1996.

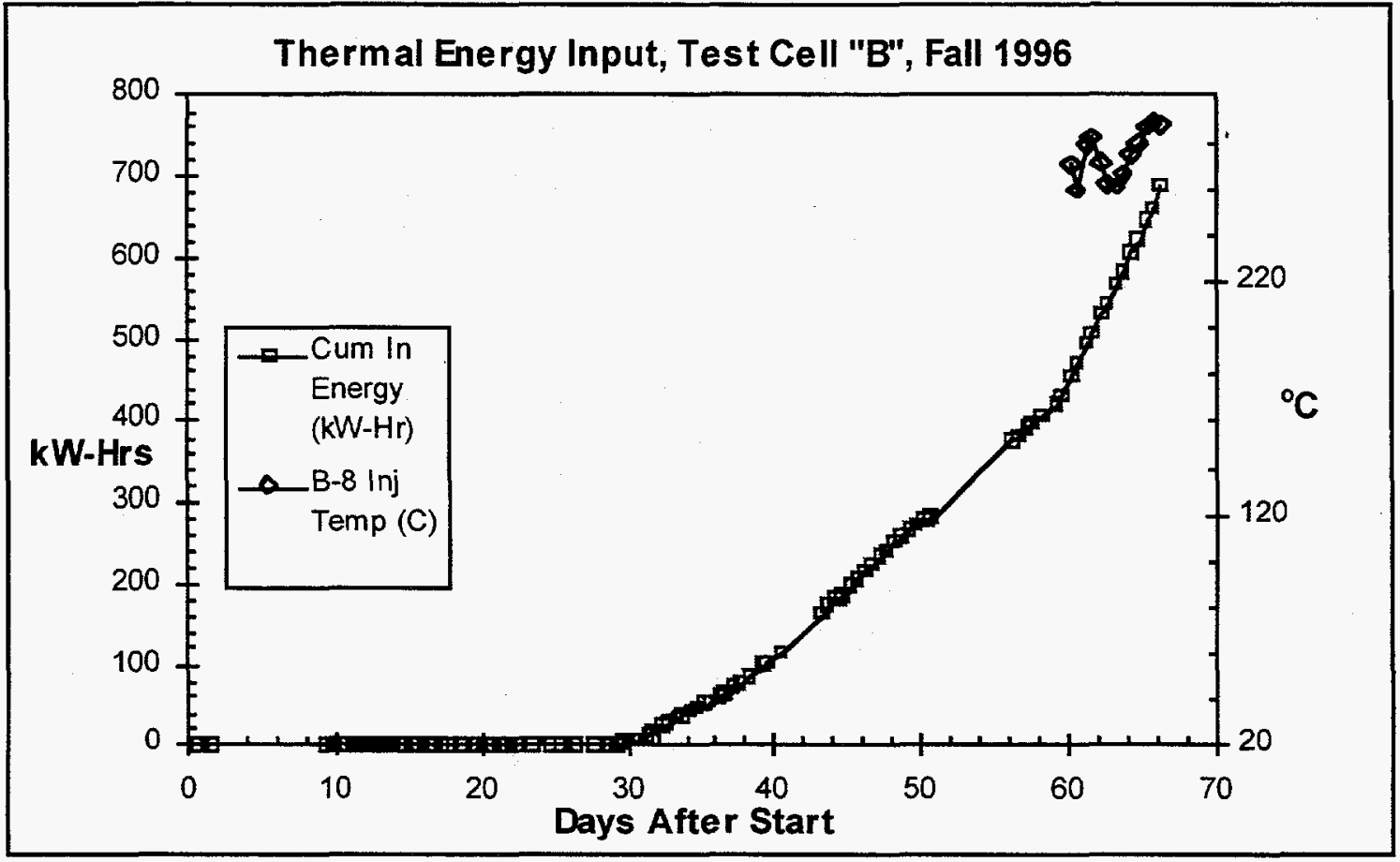

Figure 3.42 Thermal energy of injection air, summer 1997.

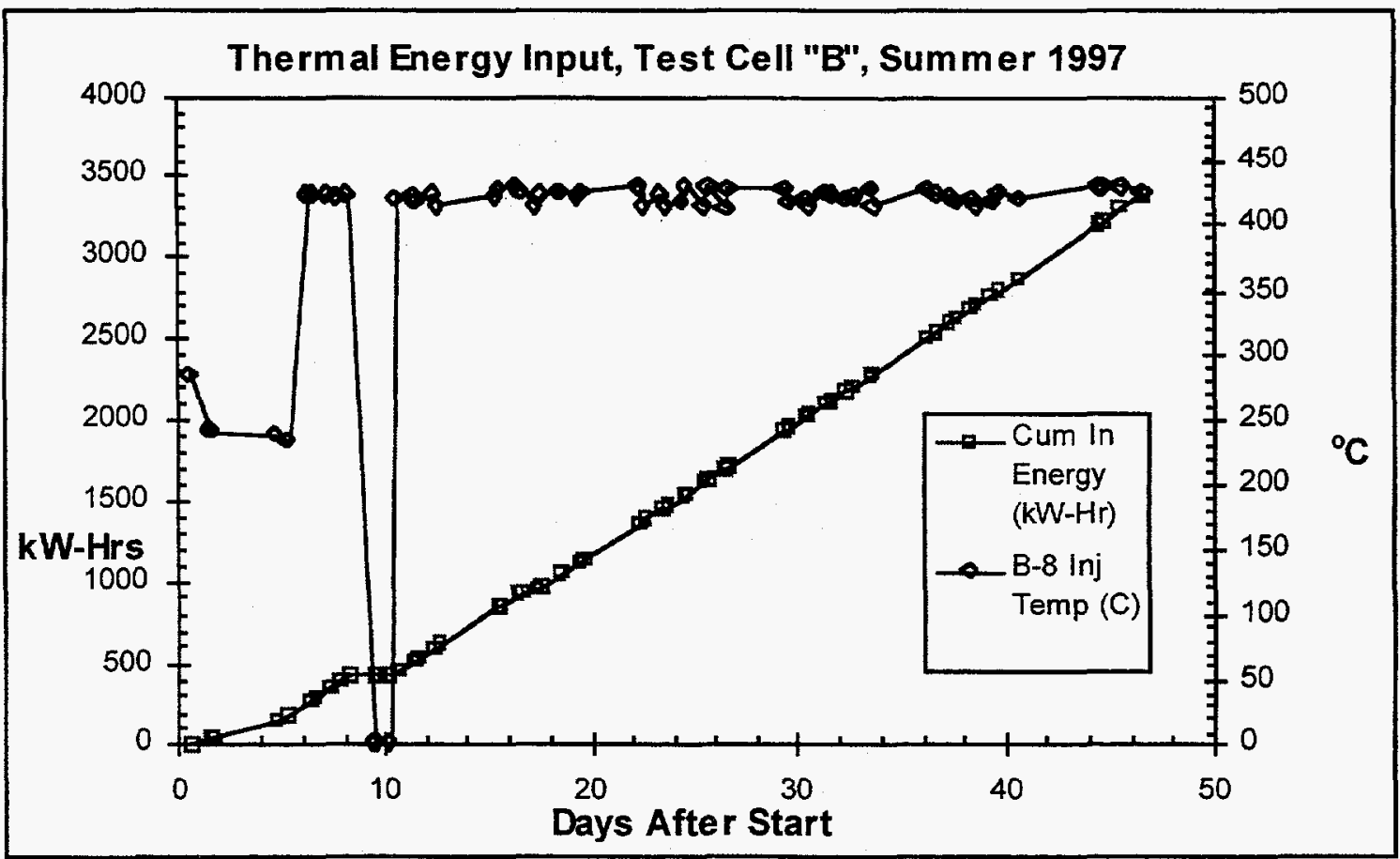


Figure 3.43 Near surface pressures in test cell B.

Air pressures at shallow depth $(1.5 \mathrm{ft})$ in test cell $\mathrm{B}$ during hot air injection and vapor extraction at the end of the summer 1997 test. Contours are in inches- $\mathrm{H}_{2} 0$ pressure relative to atm.

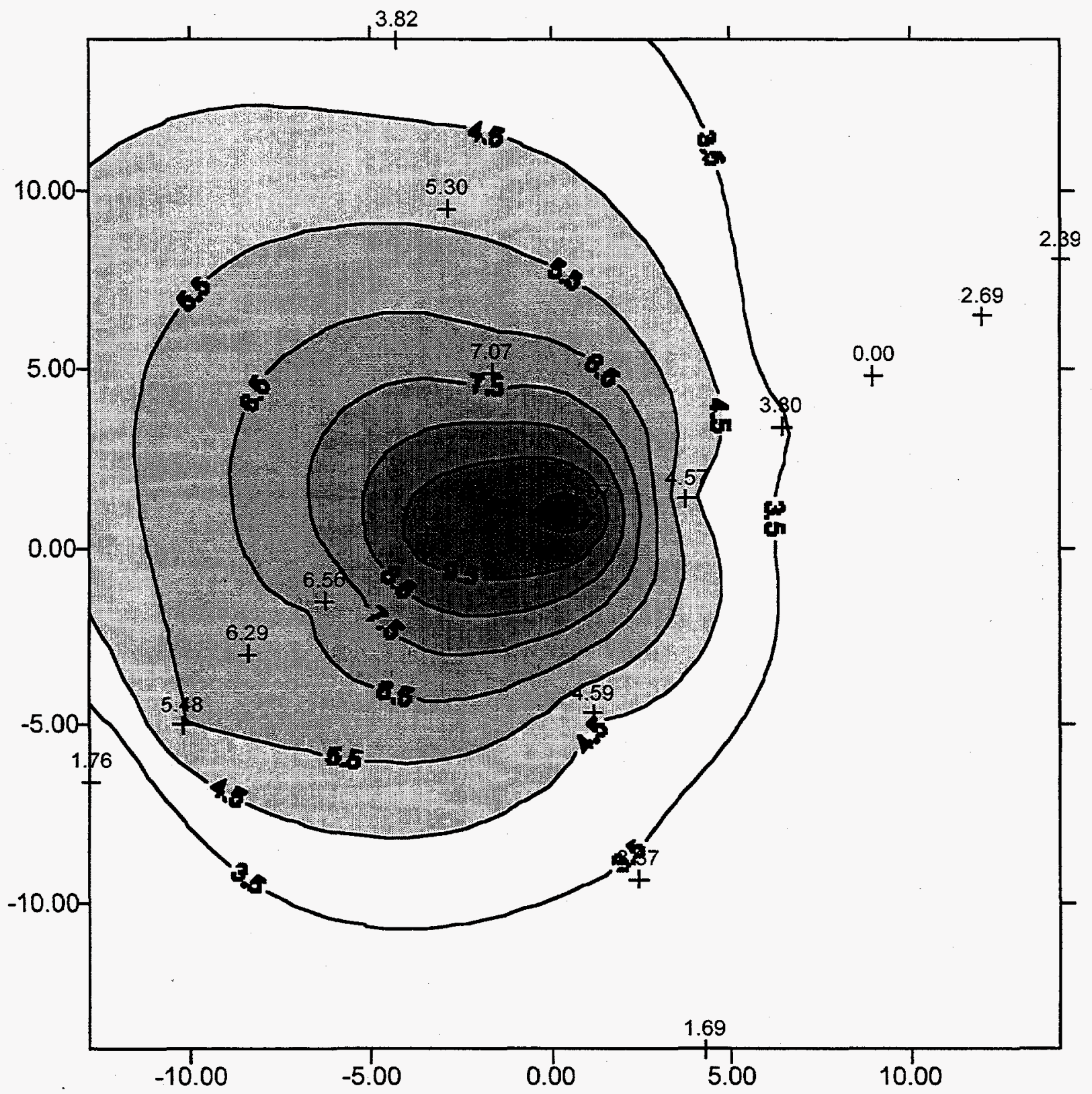


Figure 3.44 Volumetric moisture content as a function of depth and time in Cell B. M1 (upper) and M2 (lower). Open symbols are from Fall, 1996, filled symbols from Summer (1997) measured using TDR. Circles with internal cross measured in lab before testing (Fall 1996), squares with internal cross measured in lab after testing (Fall, 1997)
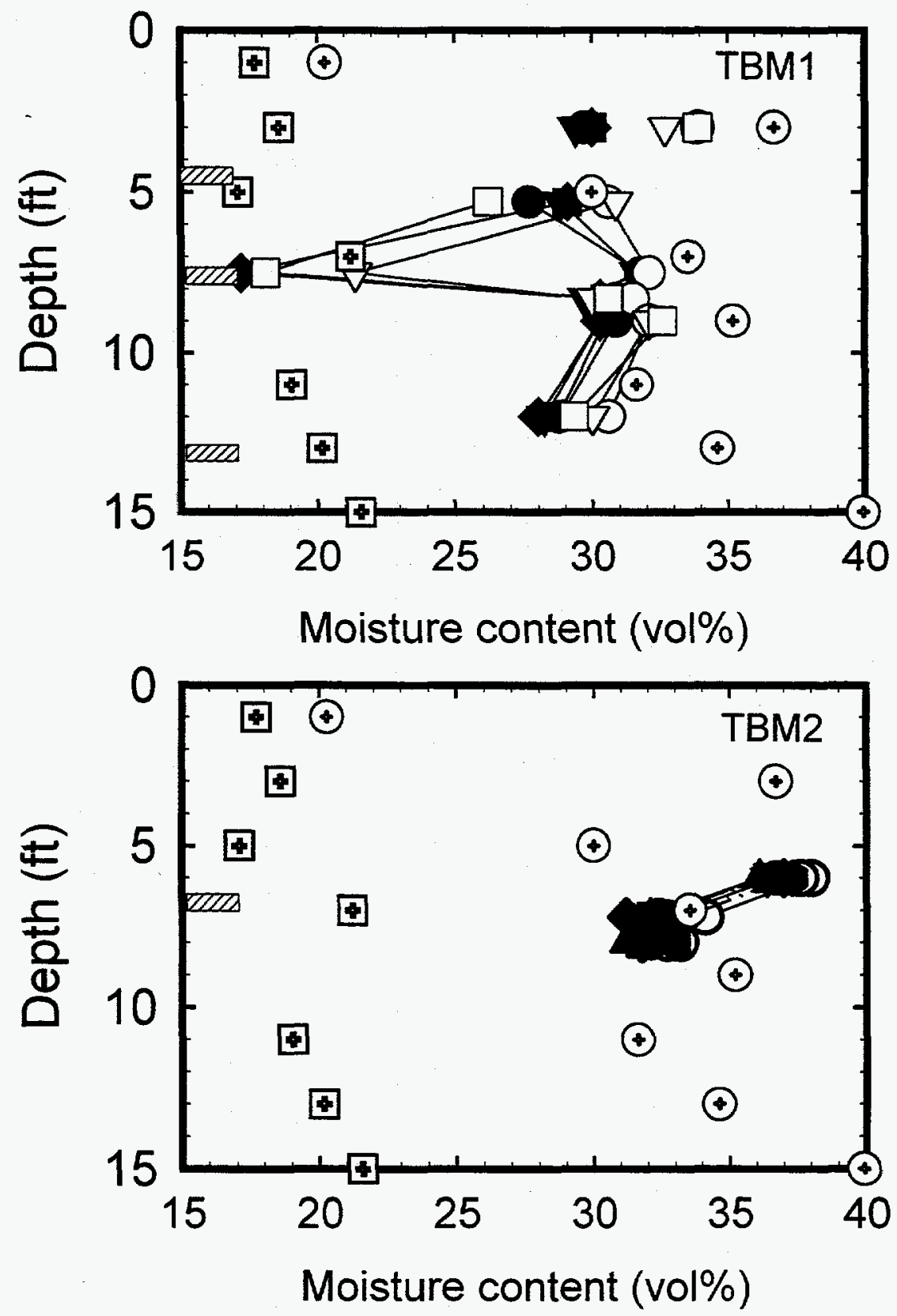
Figure 3.45 Ground surface temperatures at test cell B.

Temperature (C) of the ground surface measured on the afternoon of 6 Sept. And the morning of Sept 81997 in Cells B. Scale is in feet.
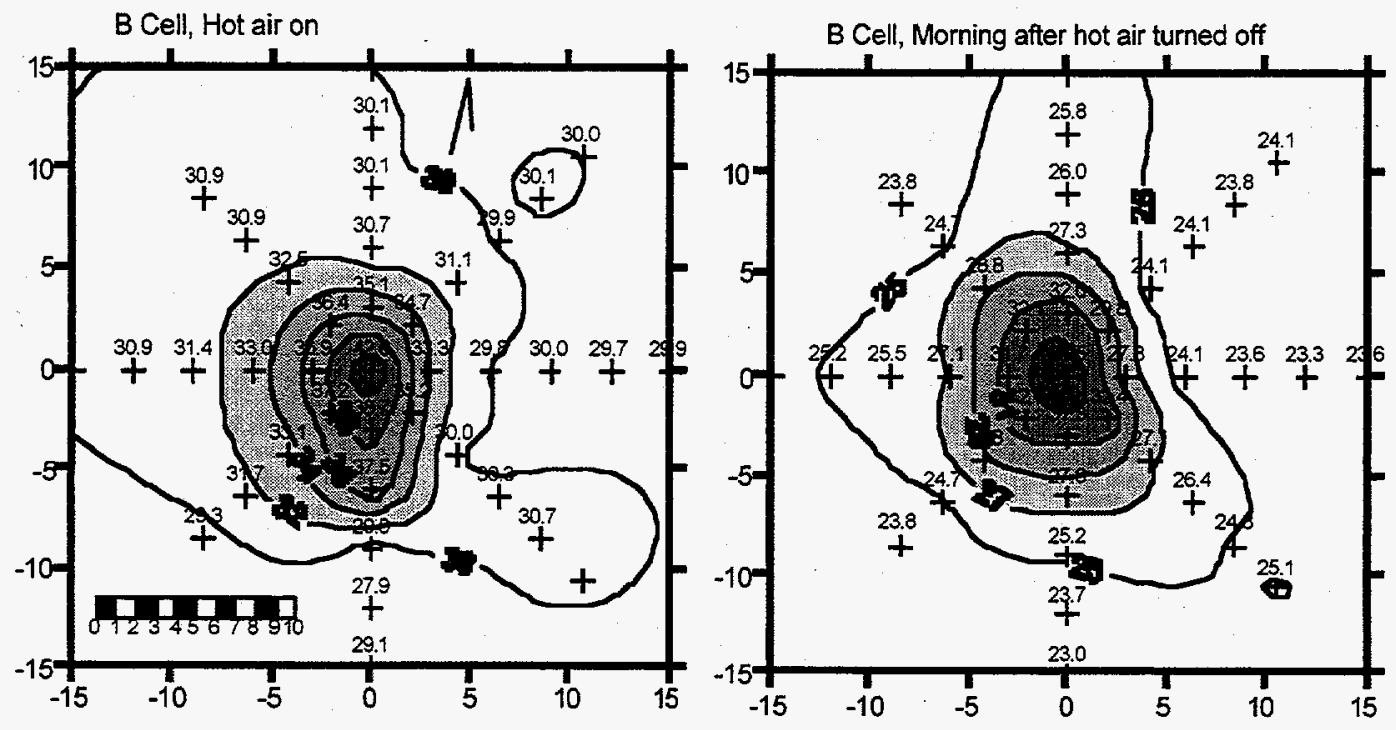
Figure 3.46 Initial and early temperature cross-sections in test cell B.

Background Temperature, 7-18-97

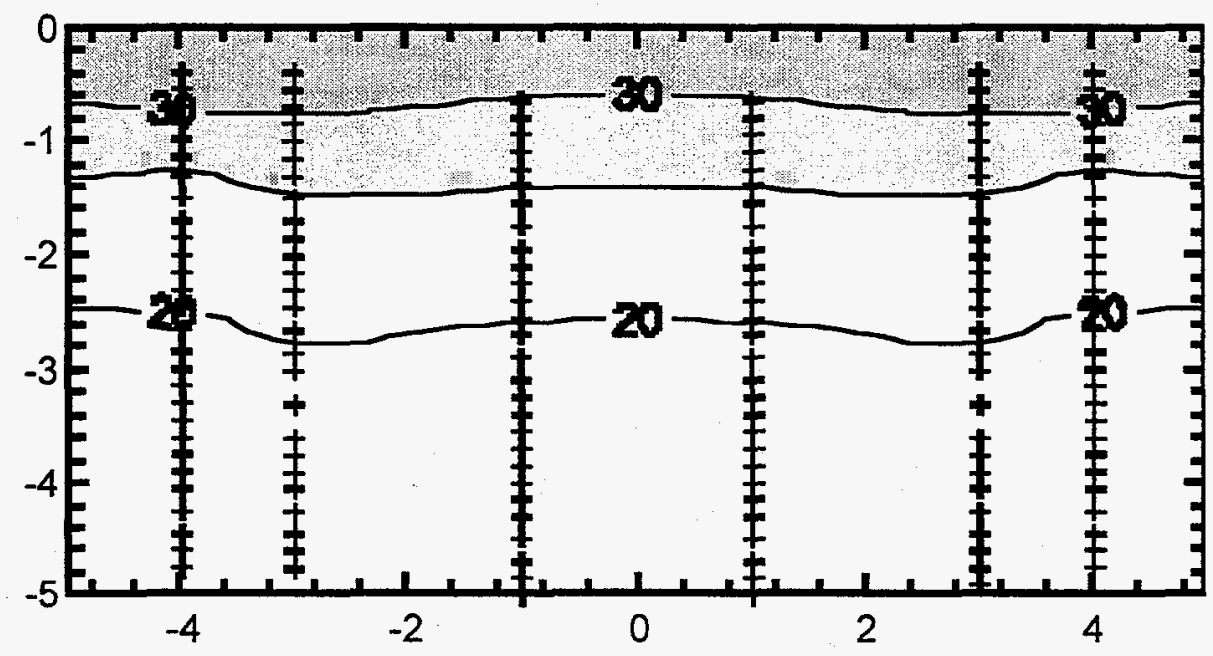

Cell B, 7-30-97, Thermistor

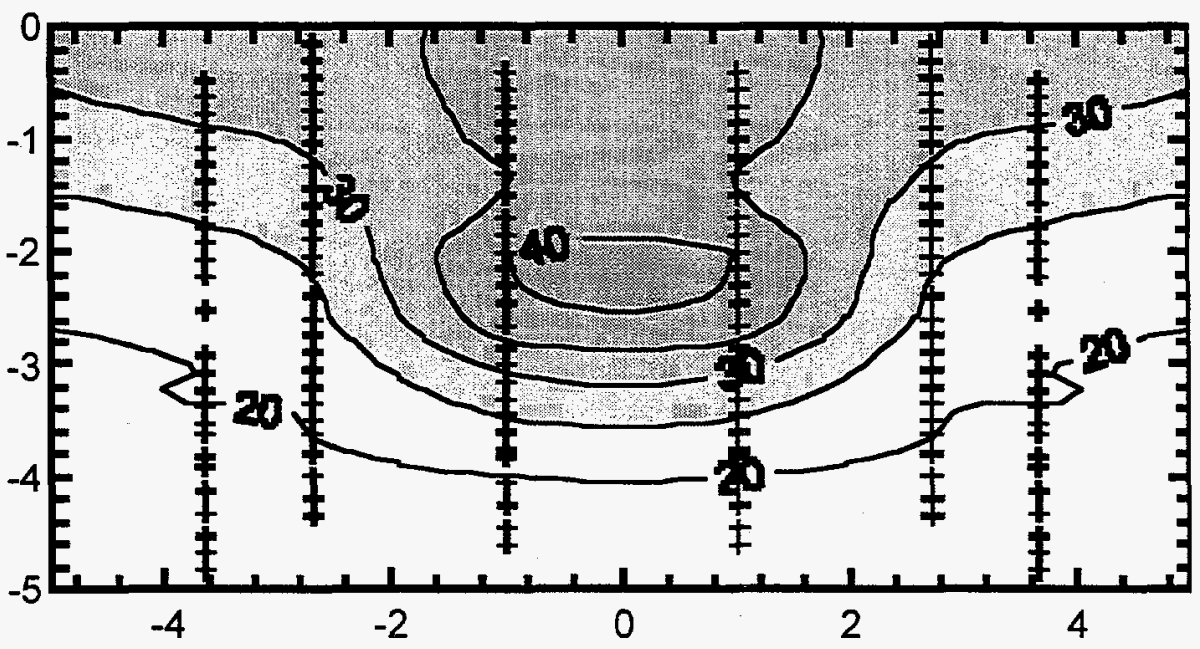


Figure 3.47 Progression of temperature cross-sections in test cell B.

Projected cross-section of temperatures at Cell B on 8-6-97 using thermocouple data (upper), on 8-26-97 using thermistor data (middle) and on 9-6-97 using thermocouple data (lower). Spatial scale in meters.

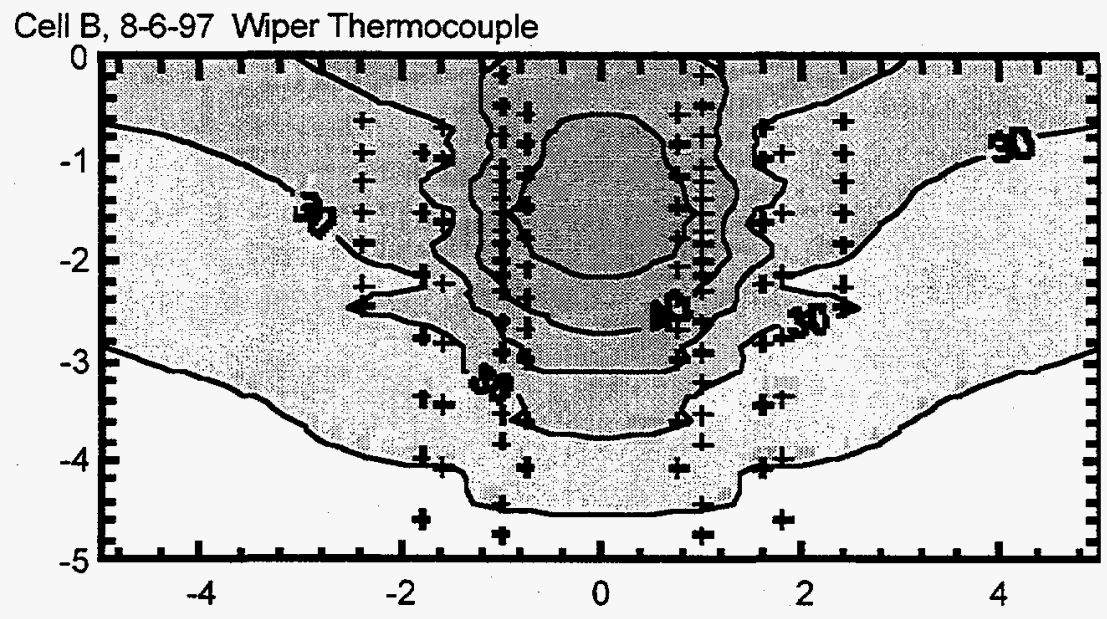

B Cell, 8-26-97, Thermistor
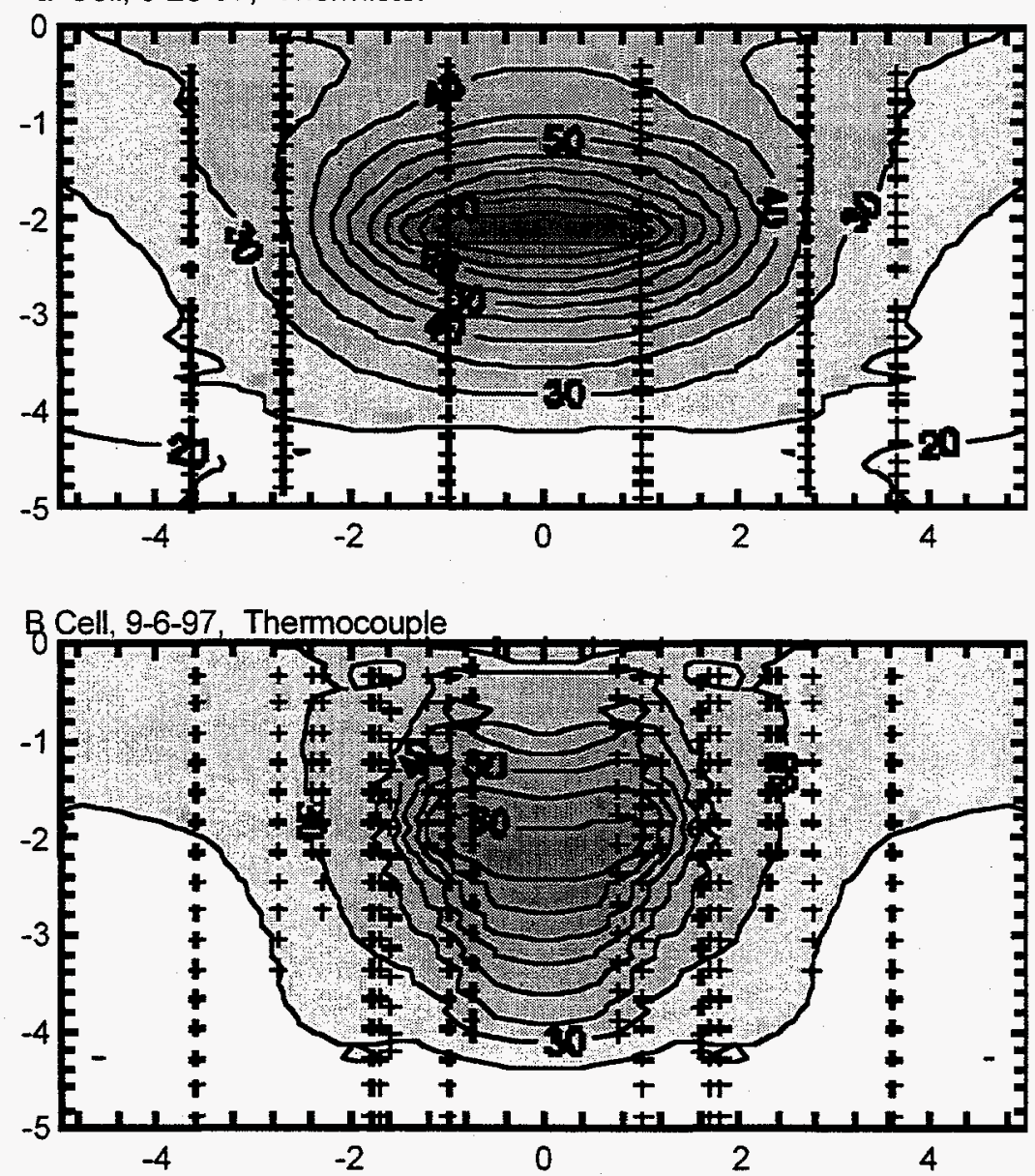
Figure 3.48 Composition of B-4 off-gas.

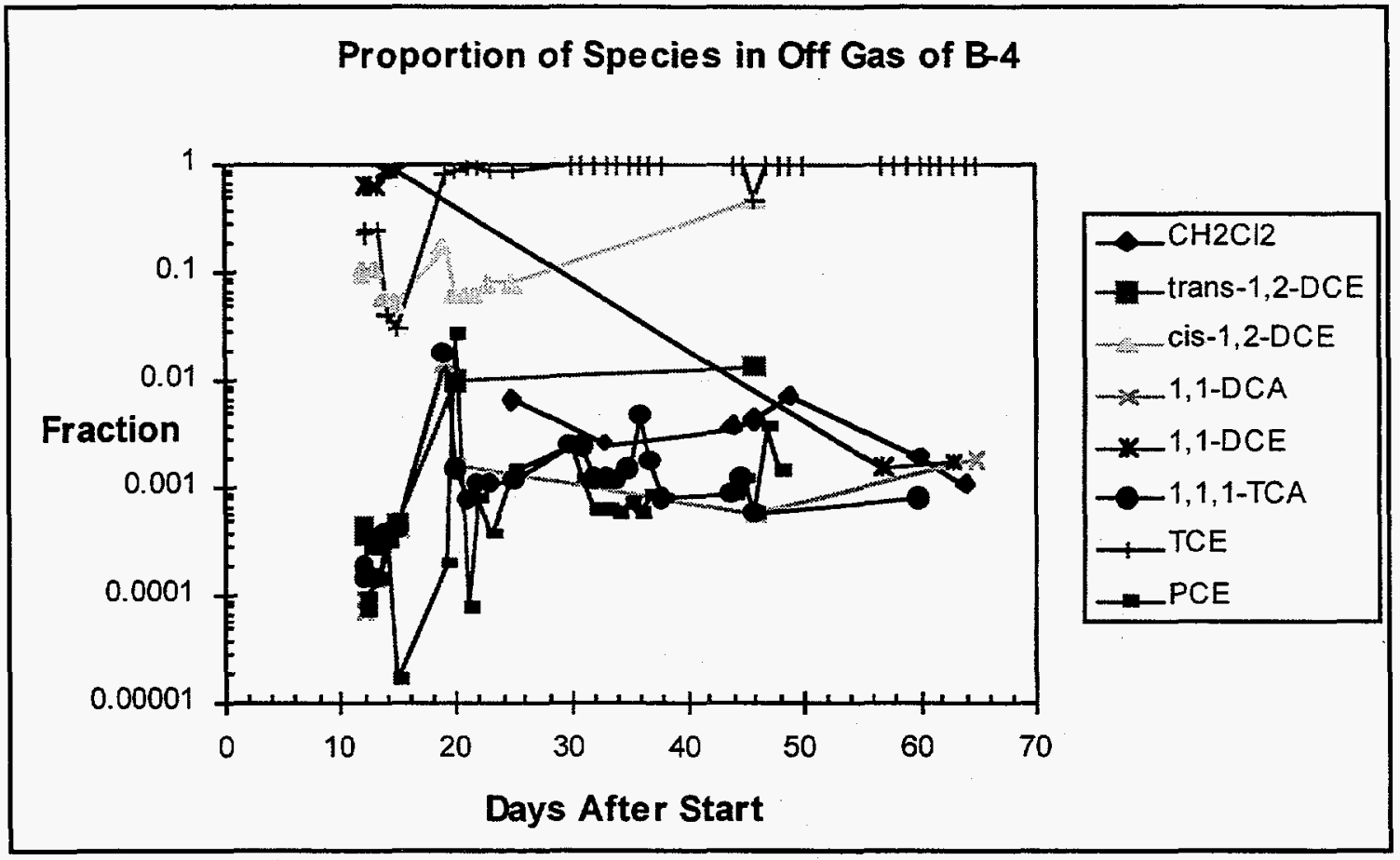

Figure 3.49 Composition of B-12 off-gas.

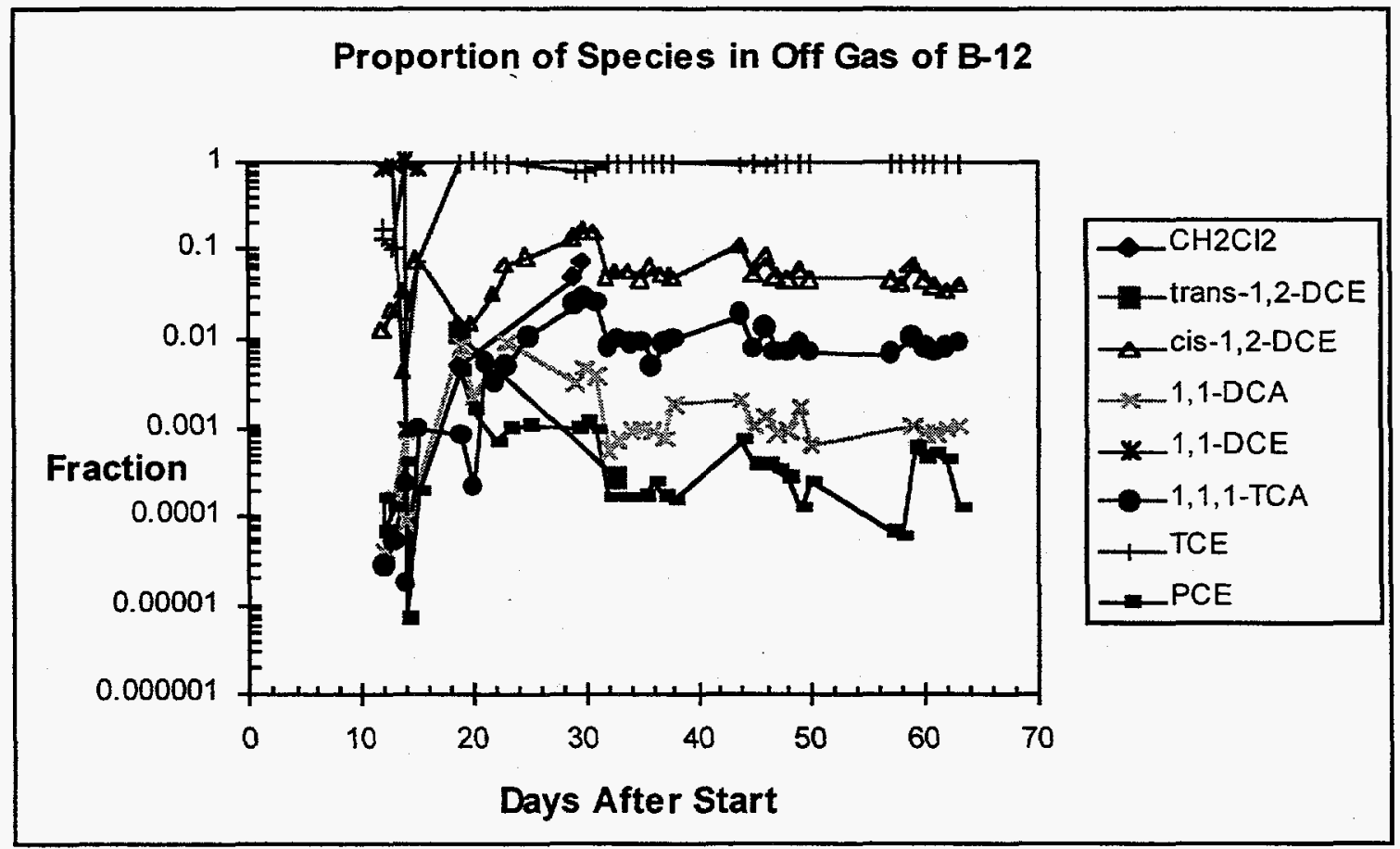


Figure 3.50 Oxygen, carbon dioxide and methane in off-gas, test cell B, fall 1996 .

\section{On-Line Off-Gas Concentrations From B-4 (upper) \& B-12 (lower)}
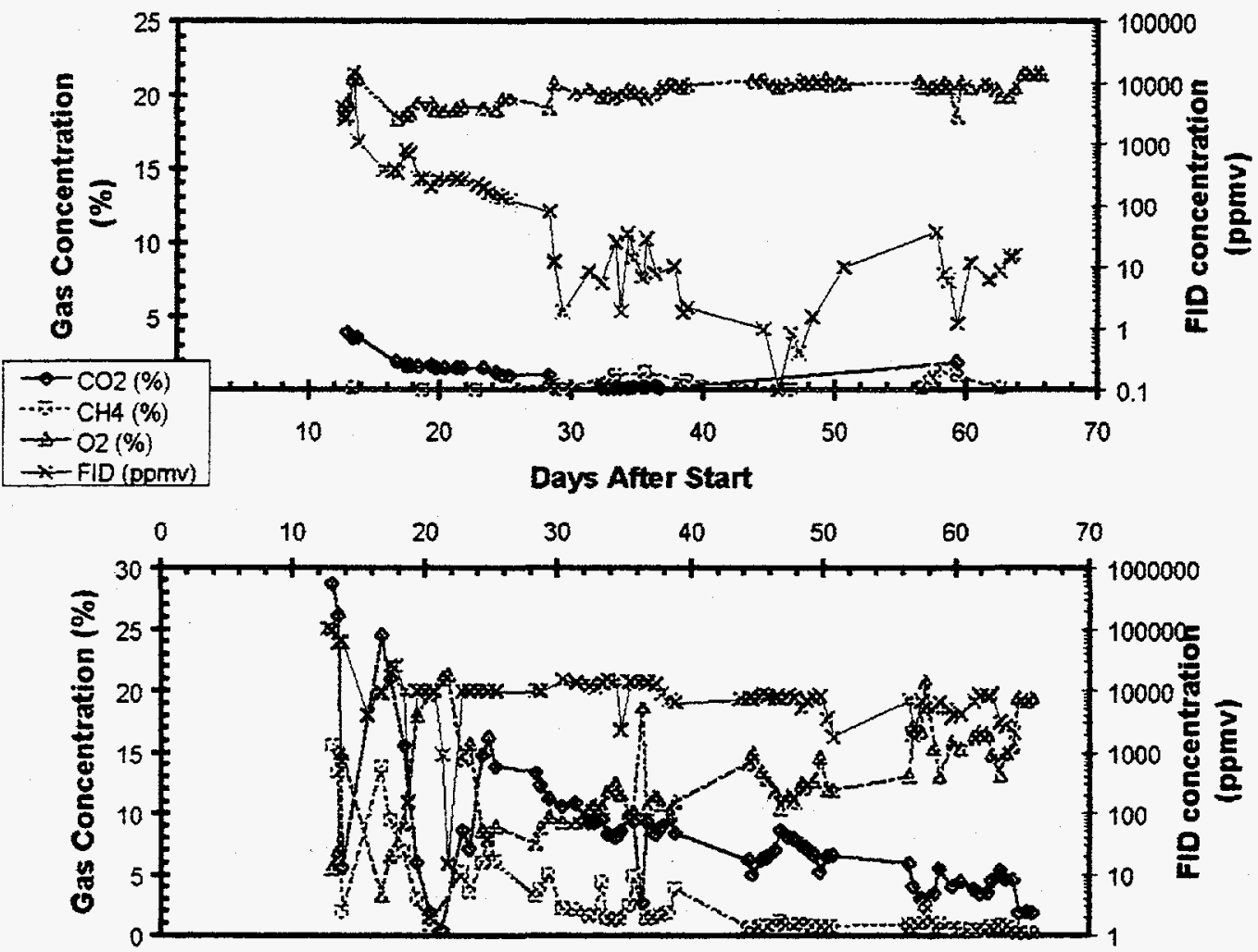

Figure 3.51 Typical contaminant concentrations in cell B soil.

Concentration as a function of depth at three (B1, B4, B5) of the seven locations sampled in the $B$ cell. Three of the other locations have minor concentrations, and one of the others has high concentrations and is shown in Fig. 3.52. Filled symbols are before, open symbols are after treatment during fall, 1996.

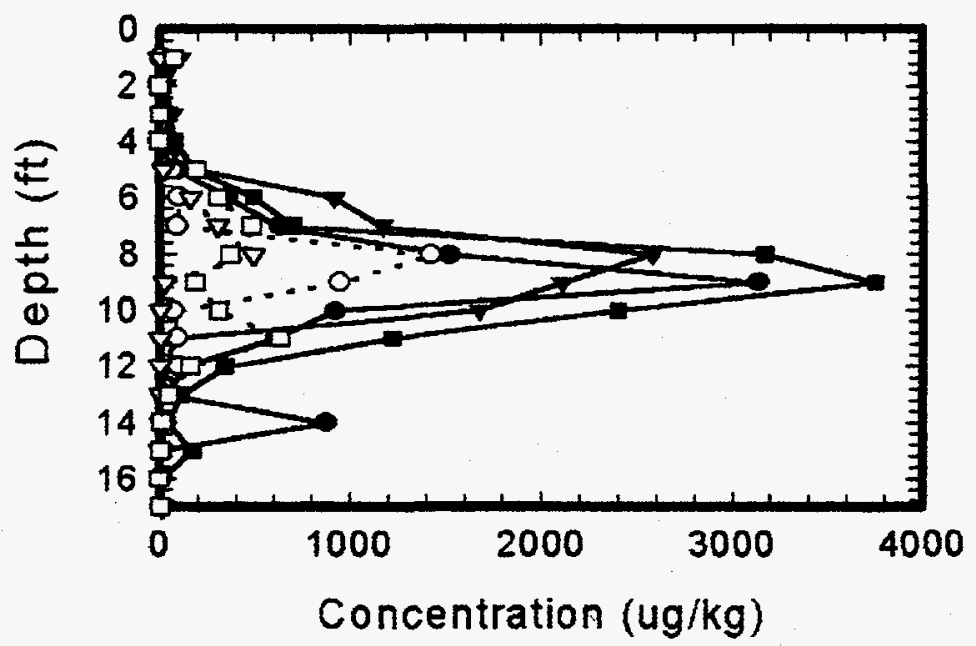


Figure 3.52 Contaminant concentrations in soil from cell B, boring 6 .

Concentration as a function of depth before treatment (filled) and after treatment (open symbols) during the fall 1996 test at location B6.

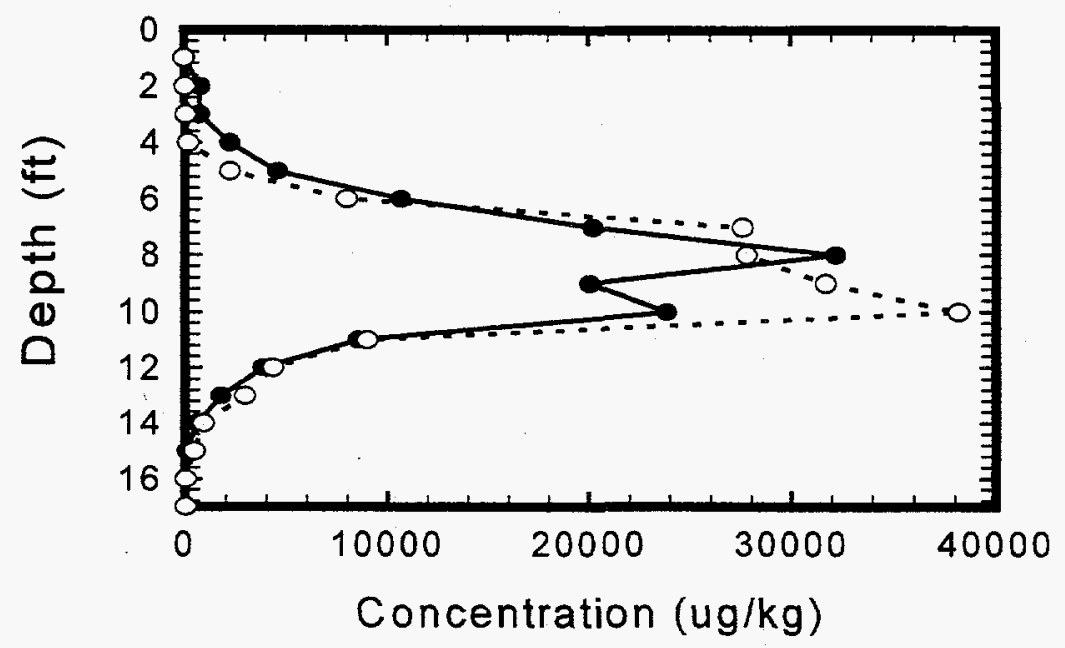

Figure 3.53 Comparison of contaminant concentrations in soil before and after hot air injection.

Ratio of the concentration before:concentration after treatment during the fall 1996 test in cell B. Open symbols are from B6, filled symbols are from B1, B4, and B5.

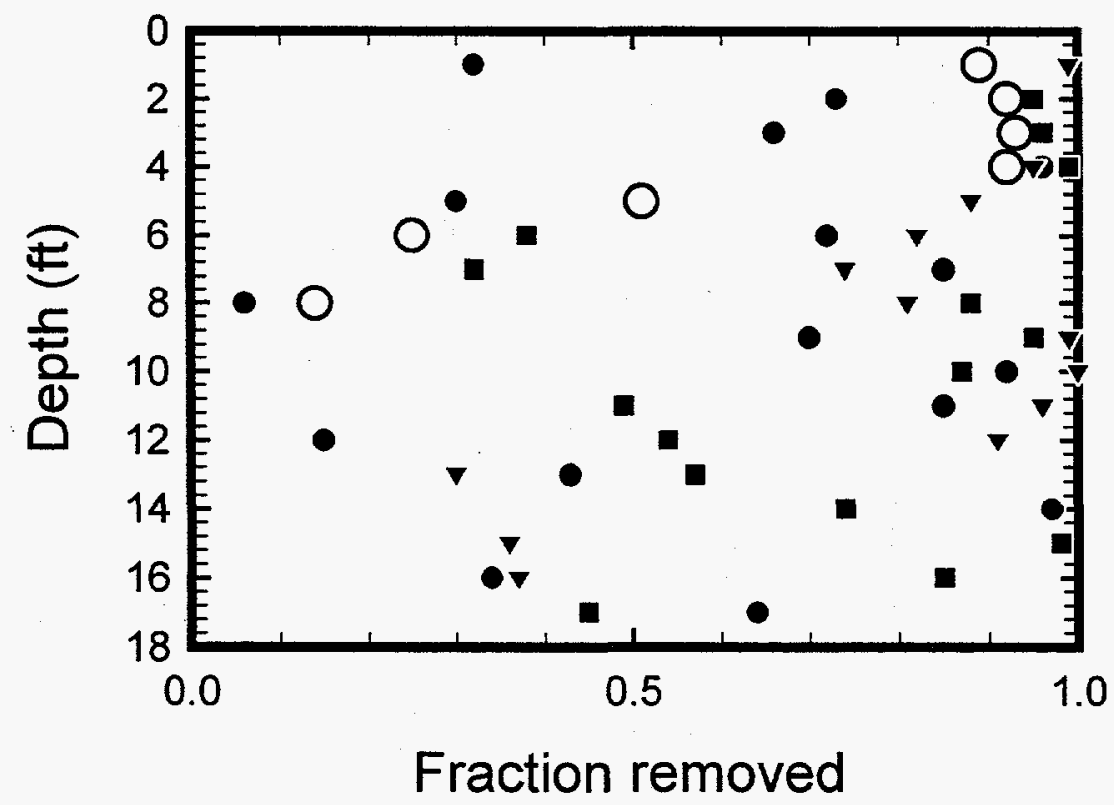


Figure 3.54 Heat retention by test tell $\mathrm{B}$.

Energy supplied to air heater (filled circles). Heat energy in the ground estimated from change of in situ temperature (open circle). During fall 1996 (upper) and summer 1997 (lower) tests.
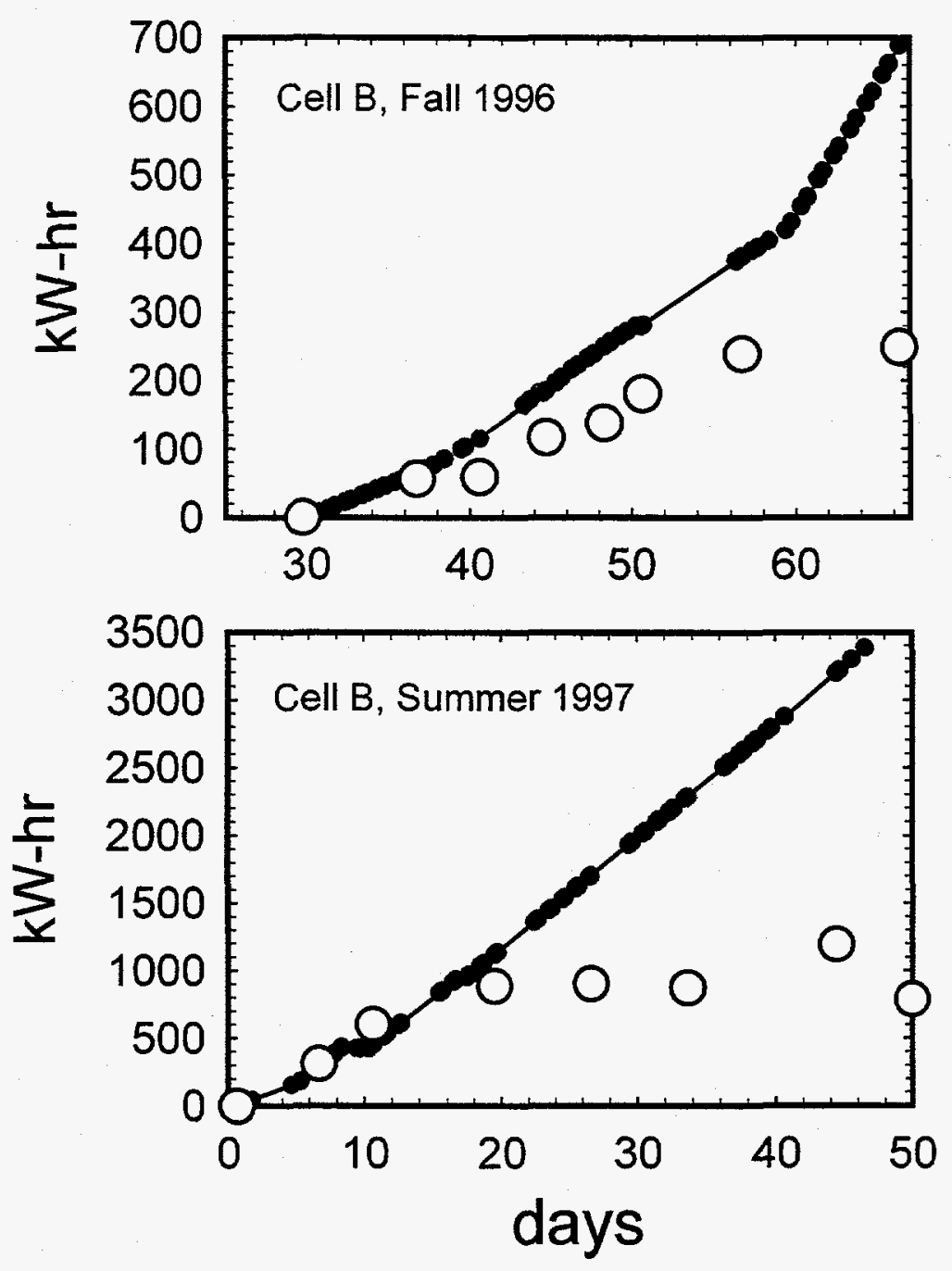
Figure 3.55 Heat retention by test cell A.

Energy supplied to steam generator (filled circles). Heat energy in the ground estimated from change of in situ temperature (open circle). During fall 1996 (upper) and summer 1997 (lower) tests.
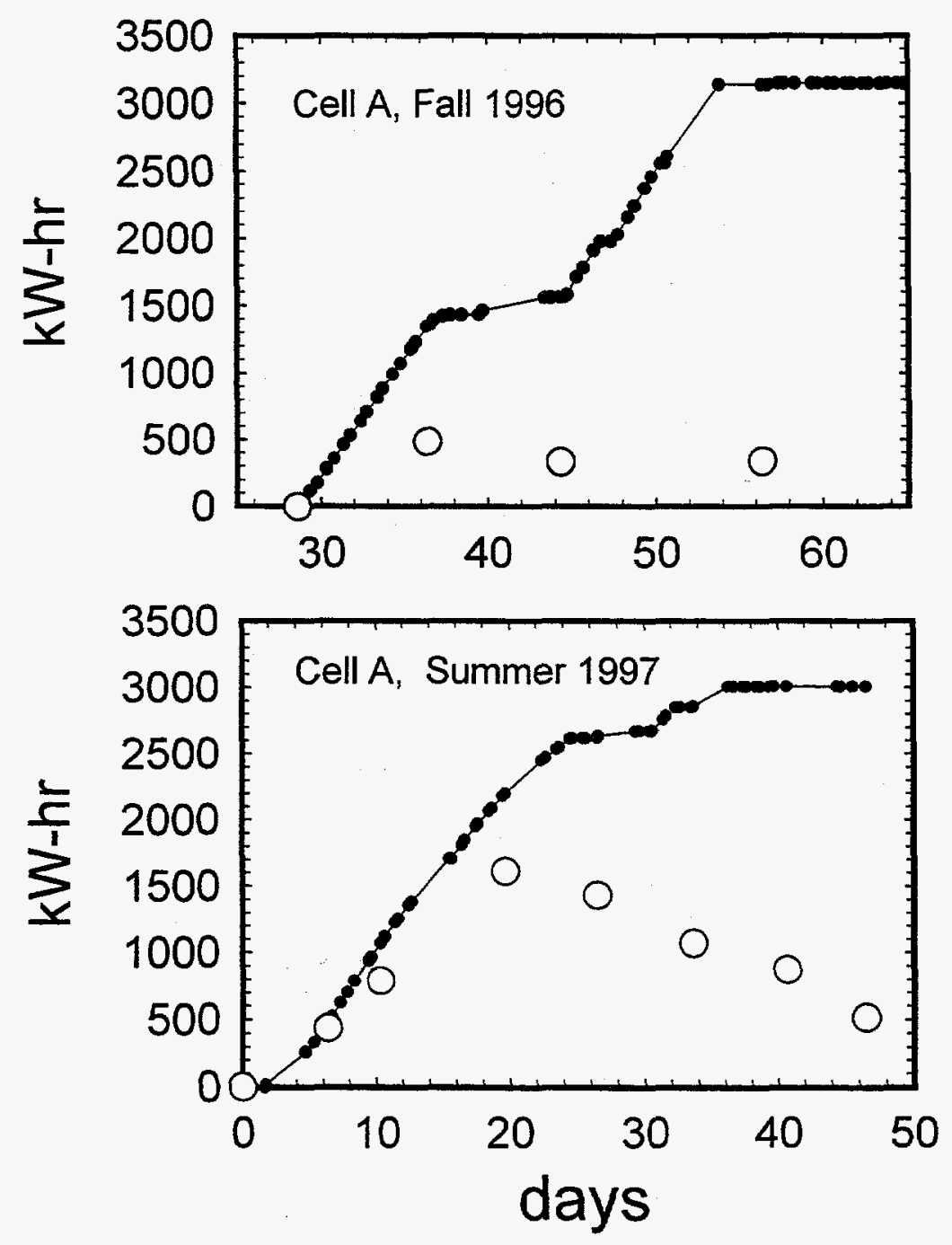
Table 3.1. Steam system components.

System component Description

Water supply system

PORTS hydrant - PORTS potable water system

$\sim 1000 \mathrm{ft}$ fire hose / garden hose

two 500 gal. storage tanks $50 \mathrm{ft}$ from test cell A

charge pump \& pressured storage beside storage tanks

water meter

distribution lines

\begin{tabular}{ll}
\hline Power supply & $\begin{array}{l}\text { 220v 50 amp single phase } \\
\text { power meter }\end{array}$ \\
\hline Instrument air supply & on-site 2 HP compressor \& distribution line \\
\hline Power and supply water controller & $\begin{array}{l}\text { temperature controller } \\
\text { level logic board } \\
\text { low pressure air shut off } \\
\text { water control valve } \\
\text { power control relay }\end{array}$ \\
\hline In-well steam generator & as described in Appendix A \\
\hline Dewatering system & $\begin{array}{l}\text { pumps } \\
\text { pump controller } \\
\text { separator pots } \\
\text { drains } \\
\text { produced water accumulation tanks }\end{array}$ \\
\hline $\begin{array}{l}\text { Vacuum system (shared with Hot air } \\
\text { system) }\end{array}$ & $\begin{array}{l}\text { liquid ring pump } \\
\text { ring liquid cooler loop and heat exchanger } \\
\text { ring liquid circulation pump } \\
\text { ring liquid reservoir }\end{array}$ \\
55 gal. carbon adsorption canisters for off-gas \\
\hline
\end{tabular}


Table 3.2. Hot air system components.

\begin{tabular}{|c|c|}
\hline Component & Description \\
\hline Power supply & $\begin{array}{l}120 \text { v } 20 \mathrm{amp} \\
220 \text { v } 20 \mathrm{amp}\end{array}$ \\
\hline Power and supply water controller & $\begin{array}{l}\text { temperature controller } \\
\text { low power control relay }\end{array}$ \\
\hline $\begin{array}{l}\text { Low pressure high volume } \\
\text { compressor }\end{array}$ & as described in Appendix $A$ \\
\hline In-well air heater & as described in Appendix $A$ \\
\hline dewatering system & $\begin{array}{l}\text { pumps } \\
\text { pump controller } \\
\text { separator pots } \\
\text { drains } \\
\text { produced water accumulation tanks }\end{array}$ \\
\hline $\begin{array}{l}\text { Instrument air supply (shared w/ } \\
\text { steam system) }\end{array}$ & on-site 2 HP compressor \& distribution line \\
\hline $\begin{array}{l}\text { vacuum system (shared with steam } \\
\text { system) }\end{array}$ & $\begin{array}{l}\text { liquid ring pump } \\
\text { ring liquid cooler loop and heat exchanger } \\
\text { ring liquid circulation pump } \\
\text { ring liquid reservoir } \\
55 \text { gal. carbon adsorption canisters for off-gas }\end{array}$ \\
\hline
\end{tabular}




\section{REACTIVE BARRIER IN SITU DESTRUCTION SYSTEM RESULTS}

\subsection{IRON METAL HORIZONTAL BARRIERS}

A plan view of test cell $\mathrm{C}$ comprised of a set of iron metal propped fractures is shown in Fig. 4.1 while a cross-section showing the vertical locations and shapes of the fractures is given in Fig. 4.2. The installation features of test cell $\mathrm{C}$ were presented previously in Table 2.5. A discussion of the morphology and properties of the iron metal fractures is given below followed by the results of TCE degradation testing. At the end of this section, observations regarding the characteristics of the subsurface within test cell $\mathrm{C}$ are given.

\subsubsection{Iron Metal Reactive Fracture Morphology and Properties}

The morphology and properties of the iron metal fractures and the soil zones above and below it were assessed during soil coring and sampling/analysis activities conducted during December 1996 (3 months), July 1997 (10 months), and December 1997 (15 months). The iron-filled fractures encountered during those coring activities exhibited very similar macromorphology. There was a discrete layer of moist black iron particles that was 2 to $10 \mathrm{~mm}$ thick within the otherwise yellowbrown silty clay soil deposit (Fig. 4.3). The iron particles were generally loose and unconsolidated and the layer of iron readily broke into small granules (e.g., 0.5 to $1 \mathrm{~mm}$ in size) upon handling (Fig. 4.3). There were no visually apparent changes within the soil matrix above and below the iron-filled fracture itself (e.g., discoloration, interfacial deposits, etc.). There were no apparent differences in the overall character of the iron-filled fracture and surrounding deposit as observed at 3,10 , or 15 months after emplacement.

During the July 1997 coring activity, the micromorphology of the iron metal proppant was also assessed. Figure 4.4 presents photomicrographs of the iron retrieved from the fracture after 10 months of emplacement as compared to the fresh iron that was used to create the fractures. The micromorphology of the emplaced iron indicated a partial surface coating of iron oxides, presumably due to oxidation and corrosion of the iron surface. The degree of surface coverage was limited however (e.g., <20\%) and thus the overall effect of the corrosion on reductive dechlorination would seem to be limited in these specimens. If longer periods of emplacement are considered (e.g., 5 to 10 years), then surface corrosion in a relatively stagnant vadose zone system (i.e., without high advection of ground water through the iron layer) could become an issue with regard to surface reactivity and reductive dechlorination efficiency.

Examination of chemical properties were consistent with the results of the visual observation. For example, redox potential and $\mathrm{pH}$ were generally stable and unrelated to proximity to the iron particle fracture. Only within the fracture and the iron particles, was redox highly reducing (e.g., $-400 \mathrm{mV}$ ) and the $\mathrm{pH}$ elevated somewhat ( $\mathrm{pH} \mathrm{8)}$ after three months of emplacement (Fig. 4.5, Appendix G). There were no effects on water content or TOC (Fig. 4.5). After $\sim 10$ and 15 months of emplacement similar conditions were noted with the exception that the Eh was somewhat lower $(\sim-600 \mathrm{mV})$ and the $\mathrm{pH}$ also somewhat lower ( $\mathrm{pH} 7)$ (Fig. 4.6). Other than that, there were no appreciable differences in behavior between the three durations of emplacement studied.

\subsubsection{DNAPL Compound Degradation in Iron Metal Fracture Zones}

The potential for degradation of TCE was evaluated under controlled conditions using subsamples of the fracture contents or the soil above and below it as collected during December 1996 and July 1997. A separate set of kinetics experiments were carried out using only iron metal retrieved from 
the fractures in test cell $\mathrm{C}$ during December 1997. These tests were conducted using 40-mL reaction vials containing the iron metal or soil solids and DNAPL compound contaminated ground water. This approach was used to enable more rigorous evaluation of the reactive fracture zone treatment characteristics. Also, as it turned out the concentrations of ambient TCE in the test cell used for these barriers turned out to be too low to simply rely on changes in ambient TCE levels for an accurate assessment of treatment efficiency. For these batch tests, the ground water concentrations of TCE during December 1996 were $144 \mathrm{mg} / \mathrm{L}$ while those in July 1997 were $\sim 480 \mathrm{mg} / \mathrm{L}$ (GW1) and $54 \mathrm{mg} / \mathrm{L}$ (GW2) (Appendix G). During December 1996 the reaction period was $24 \mathrm{hr}$ while during July 1997 the reaction period included $24 \mathrm{hr}$ as well as $48 \mathrm{hr}$.

The results for degradation of TCE as a function of proximity to the iron-filled fracture are shown in Figures 4.7 and 4.8 and tabulated in Appendix G. These data revealed that the fracture itself was reactive but the soil media above and below it was not. This is as expected given the morphology and physicochemical data from the fracture zones as discussed above. Those data indicated no marked effects on reactivity properties such as Eh and $\mathrm{pH}$ in the soil above and below the iron-filled fracture.

The degradation of TCE by the iron metal under the different conditions is summarized in Table 4.1. The degradation efficiency of TCE by the iron metal appeared sensitive to the initial TCE concentration and reaction time. With relatively lower TCE levels (i.e., 54 and $144 \mathrm{mg} / \mathrm{L}$ ), the degradation achieved during a 24 -hr reaction period was in the range of $\sim 28$ to $36 \%$ with no marked differences between the samples taken after 3-versus 10-months of emplacement or the fracture iron versus fresh iron. Extending the reaction period to 48-hr with the fresh iron yielded only a minor increase in the \% degradation achieved (Table 4.1). Extending the reaction period with the 10-months old iron, however, gave results that depended on both the initial concentration of TCE and reaction time. That material degraded much less (relative to initial concentration) of the concentrated TCE ( $480 \mathrm{mg} / \mathrm{L}$ initial) compared to the more dilute groundwater $(54 \mathrm{mg} / \mathrm{L})$ after $24-$ $\mathrm{hr}$ of reaction. It degraded about $30 \%$ of both ground water concentrations after 48 -hr of reaction, however. Interestingly, the fresh iron exposed to $480 \mathrm{mg} / \mathrm{L}$ TCE exhibited a similar low degradation at $24-\mathrm{hr}$ but no increase in degradation at $48 \mathrm{-hr}$. The iron metal retrieved from the fractures did show signs of surface corrosion after 10 months of emplacement (Fig. 4.4), but the degradation efficiency was comparable to that of fresh iron even after extended emplacement in the very moist, silty clay subsurface.

If pseudo first-order kinetics are assumed for the reduction reaction, the half-life of the degradation reaction as measured during the batch tests exceeds $48 \mathrm{hr}$. It is noted that these degradation rates are for batch tests with either $5 \mathrm{~g}$ or $4 \mathrm{~g}$ of moist iron immersed in $40 \mathrm{~mL}$ of contaminated groundwater for the December 1996 or July 1997 tests, respectively. To assess the degradation rate that would occur during ground water flow through an iron-filled fracture, the batch test rates must be normalized to account for the much higher solid:solution ratios in the latter application. If pseudo first-order kinetics are assumed for the TCE degradation reaction, the half-life of the degradation observed in the batch tests exceeds $48 \mathrm{hr}$ (Fig. 4.7 and 4.8). However when considering the degradation rate in an iron-filled fracture, the batch test data need to be corrected for the solids to solution ratio differences. Assuming a half-life for TCE degradation by iron in a packed bed scenario that is in the range of $40 \mathrm{~min}$ as reported for PORTS ground water by Liang et al. (1997) and adjusting the solids:solution ratio used during the batch tests to that of an iron-filled fracture by a factor of 60 , then it would take approximately $40 \mathrm{hr}$ of contact within the iron-filled fracture to achieve 50\% degradation. As described above, the batch test results observed during this project are generally consistent with this normalized degradation rate.

Batch kinetic tests conducted during December 1997 with iron metal retrieved from the fractures in test cell C 15 months after initial emplacement and fresh iron from the same batch, revealed reaction rates that appeared to be slower than those measured at 3 and 10 months (Fig. 4.9 and 4.10). These tests were conducted with $4 \mathrm{~g}$ of moist iron in $40 \mathrm{~mL}$ of groundwater so the 
normalization factor would be approximately 80 rather than 60 . Again assuming pseudo-first order kinetics and a half-life of $40 \mathrm{~min}$ after Liang et al. (1997), this equates to a batch test half life of 53 $\mathrm{hr}$ for $50 \%$ TCE degradation. As shown in Figure 4.9, 50\% degradation of ground water containing only $2.2 \mathrm{mg} / \mathrm{L}$ TCE took approximately $42 \mathrm{hr}$ while that with $25 \mathrm{mg} / \mathrm{L}$ TCE did not achieve $50 \%$ reduction even after $84 \mathrm{hr}$. Batch tests completed with the fresh iron (after storage in plastic bags in a laboratory at $20 \mathrm{C}$ in Golden, $\mathrm{CO}$ ) from the same batch of iron that was used to create the fractures, showed very slow degradation rates and appeared to indicate limited temperature dependency but some concentration dependency (Fig. 4.9 and 4.10). The reason for the initial increase in TCE during the initial reaction period is unknown, however it can not be due to dechlorination of PCE as there was little PCE in the ground water used for the batch tests at time zero.

This reaction rate for TCE degradation by "aged" iron metal (either unused or fracture emplaced) appears to be slower than previously observed. One possible explanation is that corrosion of the iron surface inhibited the degradation reaction. However, even the reaction rate of unused and relatively fresh iron, which lacked corrosion, was slower than reported elsewhere after more than a year of aging. It is speculated that the reaction rate observed in this work was slow because the TCE concentrations used in the experiments were high, although the mechanism of this effect is not known. Most previous work with TCE degradation by iron metal has employed TCE concentrations in the range of $50 \mathrm{mg} / \mathrm{L}$ or less. Work that has been completed with higher concentrations has revealed similar slow rates with some apparent TCE concentration dependency (Wust et al. 1998).

\subsubsection{Subsurface Characteristics within Test Cell C}

The characteristics of the soil and ground water within the test cell containing the iron metal reactive fractures were determined periodically from September 1996 through December 1997. Activities included soil core collection and examination with depth from the ground surface to approximately $17 \mathrm{ft}$. bgs in September 1996 (within a few days of initial fracture emplacement) and again in July 1997 after approximately 10 months after emplacement. In addition, ground water monitoring was carried from September 1996 through December 1997, including periodic sampling and analysis of the deepest sand-filled fracture and also the piezometer placed within the test cell with a screened interval beneath all of the fractured zones. The results of soil core data for water content, $\mathrm{pH}$, and extractable $\mathrm{K}$, total $\mathrm{Fe}$ and $\mathrm{Mn}$ are depicted in this section as representative values based on the average for a given depth interval as measured at three separate borehole locations in September 1996 (TCB2, TCB6, TCB8) and again in July 1997 (TCB10, TCB11, TCB12) (Fig. 4.11 to 4.15 ) while the individual data for these and additional parameters are tabulated in Appendix E. The results of ground water concentrations are presented as time series graphs in Fig. 4.16 and 4.17 with the same and additional data tabulated in Appendix F. For comparison purposes, ground water characteristics in two background piezometers (X231A-BGP1 and X231A-BGP2) are presented in Fig. 4.18 and 4.19. Table 4.2 presents a summary of ground water characteristics beneath the test cell as compared to two background piezometers.

Soil characteristics within the subsurface of test cell $\mathrm{C}$ revealed possible subtle changes as a result of 10 months of emplacement. Soil water content increased from 12 to $25 \%$ (dry. wt. basis) with depth bgs. and with the only apparent changes between September 1996 and July 1997 being an increase in water content at the shallowest depths (Fig. 4.11). This is reasonable since the site was covered by a temporary geomembrane cap and there were no process operations with the cell that would have impacted water contents, however, the various core holes did create punctures in the geomembrane which could have increase rainwater infiltration. The soil $\mathrm{pH}$ ranged from 5.5 to 6.5 during September 1996 with somewhat lower values (about $0.5 \mathrm{pH}$ units) evidenced during July 1997 (Fig. 4.12). Acid-extractable levels of soil potassium, iron, and manganese were all low during both periods (Fig. 4.13-4.15) with representative $\mathrm{mg} / \mathrm{kg}$ values of potassium of 0.5 to 
2.5 , iron of 5 to 180 , and manganese of 5 to $150 \mathrm{mg} / \mathrm{kg}$. Soil iron levels appeared elevated by a factor of two or more in all depth intervals observed, possibly attributable to migration of dissolved iron generated during corrosion of the iron metal in the emplaced iron fractures (Fig. 4.14).

Ground water $\mathrm{pH}$ observed in X231A-TCP1 varied mostly within the range of 6.0 to 7.0 (Fig. 4.16), which was somewhat elevated as compared to background (Fig. 4.18, Table 4.2). Dissolved iron levels also appeared to increase somewhat over time (Fig. 4.16, Table 4.2) and this is consistent with the general increase in extractable iron concentrations within the soil profile of test cell C as noted above. Concentrations of the target DNAPL compounds (e.g., TCE) in the ground water beneath test cell C were monitored in TC16 and X231A-TCP1 and they appeared to decline during the late fall of 1996 before rebounding during the fall of 1997 (Fig. 4.17). However this behavior was also exhibited in the background piezometers, X231A-BGP1 and X231A-BGP2 (Fig. 4.19), suggesting that it was due to regional conditions (e.g., water table fluctuations) as opposed to any effects attributable to test cell C emplacement in September 1996.

\subsection{PERMANGANATE GROUT HORIZONTAL BARRIERS}

A plan view of test cell $D$ comprised of a set of permanganate grout propped fractures is shown in Fig. 4.20 while a cross-section showing the vertical locations and shapes of the fractures is given in Fig. 4.21. The installation features of test cell $\mathrm{D}$ were presented previously in Table 2.5. A discussion of the morphology and properties of the permanganate fractures is given below followed by the results of TCE degradation testing. At the end of this section, observations regarding the subsurface characteristics within the test cell $\mathrm{D}$ region are given.

\subsubsection{Permanganate Fracture Morphology and Properties}

The morphology and properties of the reactive fractures containing permanganate grout exhibited markedly different morphology and properties as compared to the iron-filled fracture zones. Rather than a thin isolated reducing layer, the permanganate filled fracture was enveloped by a zone of silty clay that was stained purple by dissolved permanganate (Fig. 4.22). The permanganate stained zone was $20-\mathrm{cm}$ thick $(10 \mathrm{~cm}$ above and below the fracture) 3 months after emplacement, and it was $30-\mathrm{cm}$ thick after 10 months, and as much as $90-\mathrm{cm}$ thick after 15 months.

Careful inspection of several core segments using a hand lens indicated that the staining thoroughly penetrated all pores, from fine intragranular spaces to small, naturally occurring cracks. The intensity of staining was uniform from the fracture to the leading edge of the zone, although staining within preexisting fractures was slightly more intense than elsewhere (Fig. 4.22). The leading edge of the stained zone away from the fracture was sharp, with the intensity of staining diminishing from full to negligible values over a few $\mathrm{cm}$. This sharp boundary was nearly planar and horizontal, essentially parallel to the permanganate filled fracture which always occurred in the middle of the stained zone.

The permanganate was probably transported out of the fracture by advection and diffusion. The symmetry of the purple stained zone about the fracture suggested that gravity was relatively unimportant during permanganate transport, which is consistent with a diffusion mechanism. Diffusion from a source of constant concentration is expected to produce a concentration profile that decreases steadily with distance from the source. The intensity of staining was fairly uniform with distance away from the filled fracture until a zone transitioning from purple to background soil color was observed. The soil was only partially saturated at the time the fractures were created, so capillary forces would have caused a head gradient that induced advection from the fracture. Advection of permanganate-saturated water would produce a zone of uniform concentration with a relatively sharp but transitional front, as was observed. The thickness of the zone about the filled 
fracture would be symmetric if advection was dominated by gradients induced by capillary forces, as would be expected in unsaturated soil. However, advection would also be driven by gravity, which would cause the thickness of the stained zone below the fracture to be somewhat greater than that above it.

Transport of permanganate out of the initial fracture emplacement is important for creating a thick, potentially reactive zone from a thin, isolated fracture. Observations indicate that both advection and diffusion were likely important at this field site, although more detailed transport analyses are required to sort out the relative importance of these processes and to predict the development of a reactive zone in other settings.

Examination of the properties of the fracture zone revealed strong spatial trends in $\mathrm{Eh}, \mathrm{pH}$, and TOC (Figs. 4.23 and 4.24) within a few dm of a fracture. In general, the vicinity of the fracture was characterized by soil that is strongly oxidizing, relatively acidic, and depleted in TOC. The elevated Eh (as high as $+800 \mathrm{mV}$ ) suggests very high oxidation potential in the permanganate fracture zone. The low $\mathrm{pH}$ of 4.5 adjacent to the fracture may be due to oxidation of VOCs as well as natural organic matter. The relatively higher $\mathrm{pH}$ in the fracture itself is believed to be due to buffering by the mineral-based gel which has a $\mathrm{pH}$ of about 11.5. Consistent with the morphology observed and described above, the interval that was chemically different from background was $<10$ $\mathrm{cm}$ thick a few days after the fractures were created, but had grown to $-20 \mathrm{~cm}$ thick after 3 months, $30-\mathrm{cm}$ thick after 10 months and nearly $90-\mathrm{cm}$ thick after 15 months (e.g., Fig. 4.23 vs. 4.24). This indicates that growth of the chemically affected zone starts early and occurs long after the fracture was initially emplaced.

\subsubsection{DNAPL Compound Degradation in Permanganate Fracture Zones}

For the same reasons as outlined for the iron fractures (Section 4.1.2), the degradation potential of the permanganate fracture zone was assessed through on-site field experiments with DNAPL contaminated ground water from the site. The methods employed are described in detail in Section 2. The results of these tests are depicted in Fig. 4.25 and 4.26 and summarized in Table 4.3. These studies confirmed that there was a diffuse reactive zone with high and sustained oxidative degradation potential.

TCE was degraded rapidly and thoroughly by both the material from within a fracture and by the soil around it. Three months after emplacement, samples of soil $10 \mathrm{~cm}$ from a fracture degraded more than $99 \%$ of TCE in ground water in 24-hr (Fig. 4.25, Table 4.3). After 10 months, the reactive zone was nearly $30-\mathrm{cm}$ thick (Fig. 4.26), but the soil within it continued to degrade TCE remarkably rapidly (e.g., 99\% degradation of $54 \mathrm{mg} / \mathrm{L}$ initial TCE in $2 \mathrm{hr}$ ). TCE remained after reaction during a batch test only when a high initial concentration of $480 \mathrm{mg} / \mathrm{L}$ dissolved TCE was used. In this case, $70 \%$ of the TCE was degraded in $2 \mathrm{hr}$. This response is consistent with a stoichiometric analysis of the degradation reaction. Based on a stoichiometric requirement for oxidation of TCE on a mass/mass basis of $2.5 \mathrm{KMnO}_{4}$ to $1.0 \mathrm{TCE}$, to degrade the $480 \mathrm{mg} / \mathrm{L}$ of TCE requires about $1200 \mathrm{mg} / \mathrm{L}$ of $\mathrm{KMnO}_{4}$. However, samples of soil around the permanganate fracture yielded a maximum solution concentration in the batch reaction vessel of only $900 \mathrm{mg} / \mathrm{L}$ $\mathrm{KMnO}_{4}$. This is an adequate concentration to degrade all of the TCE in the $54 \mathrm{mg} / \mathrm{L}$ vessel but it will degrade only about $75 \%$ of the TCE in the $480 \mathrm{mg} / \mathrm{L}$ vessel.

\subsubsection{Subsurface Characteristics within Test Cell D}

The characteristics of the soil and ground water within the test cell containing the permanganatefilled reactive fractures were measured from September 1996 through December 1997. Activities included soil core collection and examination with depth from the ground surface to approximately 
$17 \mathrm{ft}$. bgs in September 1996 (within a few days of initial fracture emplacement) and again in July 1997 approximately 10 months after emplacement. In addition, ground water monitoring was carried from September 1996 through December 1997, including periodic sampling and analysis of the deepest sand-filled fracture and also the piezometer placed within test cell $\mathrm{D}$ with a screened interval beneath all of the fractured zones. The results of soil core data for water content, $\mathrm{pH}$, and extractable $\mathrm{K}$, total $\mathrm{Fe}$ and $\mathrm{Mn}$ are depicted in this section as representative values based on the average for a given depth interval as measured at three separate borehole locations in September 1996 (TDB2, TDB6, TDB8) and July 1997 (TDB11, TDB12, TDB13) (Fig. 4.27 to 4.31) while the individual data for these and additional parameters are tabulated in Appendix $\mathrm{E}$. The results of ground water concentrations are presented as time series graphs in Fig. 4.32 and 4.33 with the same and additional data tabulated in Appendix F. For comparison purposes, ground water characteristics in two background piezometers (X231A-BGP1 and X231A-BGP2) are presented in Fig. 4.18 and 4.19. Table 4.2 presents a summary of ground water characteristics beneath the test cell as compared to the background piezometers.

Soil characteristics within the subsurface of test cell $\mathrm{D}$ revealed possible subtle changes as a result of 10 months of emplacement. Similar to test cell C, the soil water content increased from about 7 to $22 \%$ (dry. wt. basis) with depth bgs. and there was some increase between September 1996 and July 1997 (Fig. 4.27). Again, this is reasonable based on the geomembrane cap and rainfall infiltration through punctures in it, since there were no process operations with the cell that would have impacted subsurface water contents during this period. During September 1996, the soil pH dominantly was in the range of 4.5 to 5.5 with the lowest values in the 5 to $9 \mathrm{ft}$. bgs. zone (Fig. 4.28). This was lower than in the iron cell (test cell C) and may have been due to production of $\mathrm{H}^{+}$ during permanganate oxidation of natural organic matter and soil VOCs. The $\mathrm{pH}$ appeared to be generally higher at most depths as measured in July 1997, possibly due to buffering reactions within the soil profile following the cessation of active organic matter oxidation. Concentrations of extractable soil potassium and manganese between both measurement periods were comparable and the range of values observed in test cell $\mathrm{D}$ (Fig. 4.29 and 4.30) was similarly low and consistent with that observed in test cell C (Fig. 4.13 and 4.15). Both of these ions would be added to the subsurface as a result of the emplacement of potassium permanganate grout in the three fractures in test cell $\mathrm{D}$. The fact that extractable concentrations of $\mathrm{K}^{+}$and $\mathrm{Mn}^{++}$were not elevated within the soil profile suggests that either the ions did not migrate within the deposit away from the fracture zones, but more likely, the speciation of the ions was not amenable to the extraction procedure used in the analysis. For example the manganese in the permanganate would be reduced during oxidation of organic matter and would likely be present in the form of $\mathrm{Mn}(\mathrm{O})_{2}$ solids and thus not be measurable by weak acid extraction.

Ground water $\mathrm{pH}$ as observed in X231A-TDP1 varied mostly within the range of 6.0 to 7.0 , which was somewhat elevated as compared to background (Fig. 4.32, Table 4.2). Concentrations of potassium and manganese were somewhat elevated beneath test cell $\mathrm{D}$, but ground water concentrations were still very low, typically in the range of 3 to $8 \mathrm{mg} / \mathrm{L}$ and 1 to $2 \mathrm{mg} / \mathrm{L}$, respectively. There were no apparent temporal trends in $\mathrm{pH}$ or ion concentrations during the 15 month observation period. Concentrations of the target DNAPL compounds (e.g., TCE) in the ground water beneath test cell D were monitored in TD16 and X231A-TDP1 and similar to the result for test cell C, the VOC concentrations appeared to decline during the fall of 1996 and into 1997 (Fig. 4.33). However this behavior was also exhibited in the background piezometers, $\mathrm{X} 231 \mathrm{~A}-\mathrm{BGP} 1$ and X231A-BGP2 (Fig. 4.19), suggesting that it was due to regional conditions (e.g., water table fluctuations) as opposed to any effects attributable to test cell D emplacement in September 1996. 


\subsection{INJECTION/PERCOLATION TRACER TESTS}

Tapwater was injected under low pressure (1.5 to $2.2 \mathrm{ft}$. head) into the shallow sand-propped fracture in test cells C and D beginning on July 24, 1997 and continuing until September 8, 1997. The delivery rate (or acceptance rate) was controlled by the amount of water that could flow into the sand-filled fracture from the fracture access tube and then be infiltrated and percolated away into the surrounding natural soil. In test cell $\mathrm{C}$, the initial acceptance rate was $\sim 2.1 \mathrm{gph}$ compared to test cell $\mathrm{D}$ which was slower at only $\sim 0.1 \mathrm{gph}$. Over the next 10 days, the rate in cell $\mathrm{C}$ gradually declined to $\sim 0.1 \mathrm{gph}$ while that of cell D increased to $\sim 0.2 \mathrm{gph}$. For comparison purposes, an acceptance rate of $0.2 \mathrm{gph}$ into a 10 -ft. diameter sand fracture is equivalent to a flux density of only $0.25 \mathrm{~cm} / \mathrm{d}$ or $-3 \times 10^{-6} \mathrm{~cm} / \mathrm{s}$. This flux density is within the range of the bulk saturated hydraulic conductivity for the Minford deposit.

The injection test ran for approximately 45 days until it was terminated due to site decommissioning and close-out in September 1997. During the injection period, the vertical migration of water under uniform infiltration and percolation at a flux density of $0.25 \mathrm{~cm} / \mathrm{d}$ through the Minford with an assumed effective saturation of 0.10 would be in the range of $1 \mathrm{~m}$. If there were significant preferential pathways due to vertical fractures, the migration could be highly nonuniform and the depth of penetration could be much deeper. Regardless, the effect during the relatively short period of the test would not be substantial and would be difficult to assess. Sampling and analysis of ground water samples from the test cells revealed no $\mathrm{Br}$ - suggesting that the injected water had not traveled through the test cell to the underlying ground water. Alternatively, the $\mathrm{Br}$-concentrations were lower than the detection limit of the field method or the infiltrating water may have traveled vertical downward, but the monitoring locations and/or observations made were not conducive to its detection.

\subsection{COMPARATIVE FEATURES OF HORIZONTAL TREATMENT BARRIERS}

The viability of reactive fractures emplaced by hydraulic fracturing methods as horizontal barrier systems requires consideration of the horizontal continuity, degradation capacity, and longevity of the barriers. The results obtained from this study enable an interesting contrast between reactive fractures created with surface reactive media (i.e., iron metal particles) and those created with reactive media that dissolves and permeates into the surrounding soil deposit to produce a wide reactive zone (i.e., permanganate particles). Both types of reactive media were successfully handled and emplaced by conventional hydraulic fracturing equipment and methods. The geometry of the fractures was similar to that of conventional sand-filled fractures emplaced at the same site. Thus, there was no unusual behavior associated with the different fracturing fluids (i.e., iron particles in guar gum gel; permanganate particles in mineral-based gel; sand in guar gum gel).

Since the iron metal fractures are discrete layers, it is likely that their effectiveness would be limited to the fracture boundaries. Moreover, hydraulic fractures may bifurcate to form offset segments (Murdoch 1995) which could produce local areas that are avoided by injected material. This challenges the fracture emplacement to be continuous and uniform horizontally with no breaches through it, a requirement that may require overlapping by fractures created at several depths. Any degradation of TCE or related compounds within the subsurface must rely on contaminants being mobilized to a fracture and then reacting with the iron within it. The TCE reaction rates with iron metal are relatively slow, but appear adequate for significant degradation of TCE to occur. For a pseudo first-order reaction with a half-life in the range of $40 \mathrm{~min}, 99 \%$ removal of TCE at an initial concentration of $100 \mathrm{mg} / \mathrm{L}$ would require a hydraulic retention time of roughly $5 \mathrm{hr}$ during flow through an iron-filled fracture. If flow through the fracture is controlled by unsaturated conductivity in the surrounding soil media and assuming the $\mathrm{K}$ is about $10^{-6} \mathrm{~cm} / \mathrm{s}$ with a hydraulic gradient of unity, then the retention time in a fracture of $5 \mathrm{~mm}$ thickness would be on the order of 1 to 5 days depending on the effective porosity. Adequate retention time apparently could occur, but 
multiple iron filled fractures could be needed to assure complete degradation. As a treatment barrier the reactivity of the iron surface would need to exist for an extended period (e.g., 2 to 5 years). Analysis of the micromorphology of the surface of the fresh and used iron metal revealed some corrosion of the iron surface after aging, either above ground or after residing in the subsurface for approximately 10 months. The effect was limited however to only a fraction of the available iron surface and this had no apparent effect on TCE degradation. There was some reducèd rate of reaction observed after 15 months of aging however.

Fractures filled with particles of potassium permanganate will yield $\mathrm{MnO}_{4}$ - ions that migrate away from their original location by advection and/or diffusion. This will produce a zone at least several $\mathrm{dm}$ wide where resident TCE will be rapidly degraded, and it will be an active barrier that will degrade mobile TCE as well. This behavior suggests that the gaps between offset fracture lobes, or discontinuities between neighboring fractures can be healed by the migration of permanganate ions. The field results suggest that the TCE degradation reaction proceeds stoichiometrically, and these results can be used to estimate the active life of a permanganate filled fracture. If it is assumed that the permanganate is 5-mm thick, then the fracture contains about $0.4 \mathrm{~g} \mathrm{KMnO}_{4}$ per $\mathrm{cm}^{2}$ of fracture horizontal area. Based on complete oxidation and a stochiometric dose $(2.5$ wt./wt.), each $\mathrm{cm}^{2}$ of fracture can treat $\sim 0.16 \mathrm{~g}$ of TCE. This oxidant loading is sufficient to degrade an initial TCE concentration of $1000 \mathrm{mg} / \mathrm{kg}$ within a zone that is $90-\mathrm{cm}$ thick. Alternatively it is sufficient to treat $16 \mathrm{~L}$ of percolate with a concentration of $10 \mathrm{mg} / \mathrm{L}$ of TCE. At a deep percolation flux of $1 \mathrm{~cm} / \mathrm{d}$, this potential is equivalent to about 50 years of life. Realistically though, it is anticipated that advective loss of oxidant out of the treatment region and/or the oxidant demand of natural organic matter could markedly diminish this life. Based on direct observation in this study, the oxidation capacity within and around the permanganate fracture was striking even 10 months after emplacement. If alkenes such as TCE were percolating downward in ground water at reasonably high levels (e.g., 10 to $100 \mathrm{mg} / \mathrm{L}$ ), the capacity of the fractures would be high enough to intercept and treat this mobile TCE. 
Figure 4.1. Plan view of the horizontal barrier cell with iron metal particle proppant (test cell C).
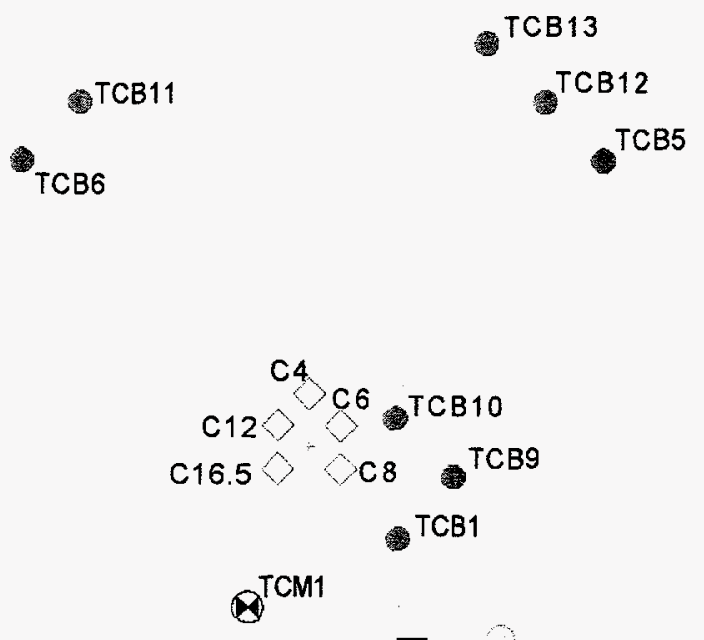

ఐ

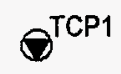

${ }^{\mathrm{TCB} 7}$

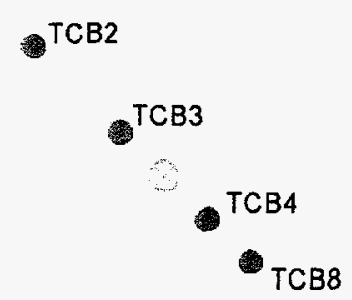

TEST CELLC

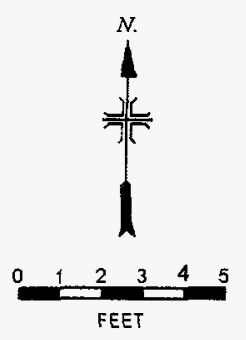

Fracture Access
Soil Sample Borehole
(each with $1 / 2^{\prime \prime}$ dia. PVC wiping thermocouple casing)
Multilevel Instrumented Boring
Neutron Probe Casing
Eh Reference Electrode
17ft Deep Piezometer

4- 9 


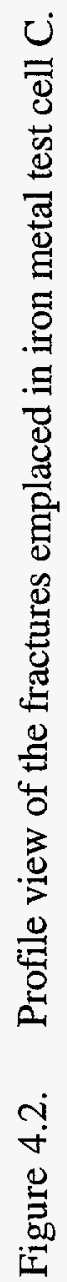
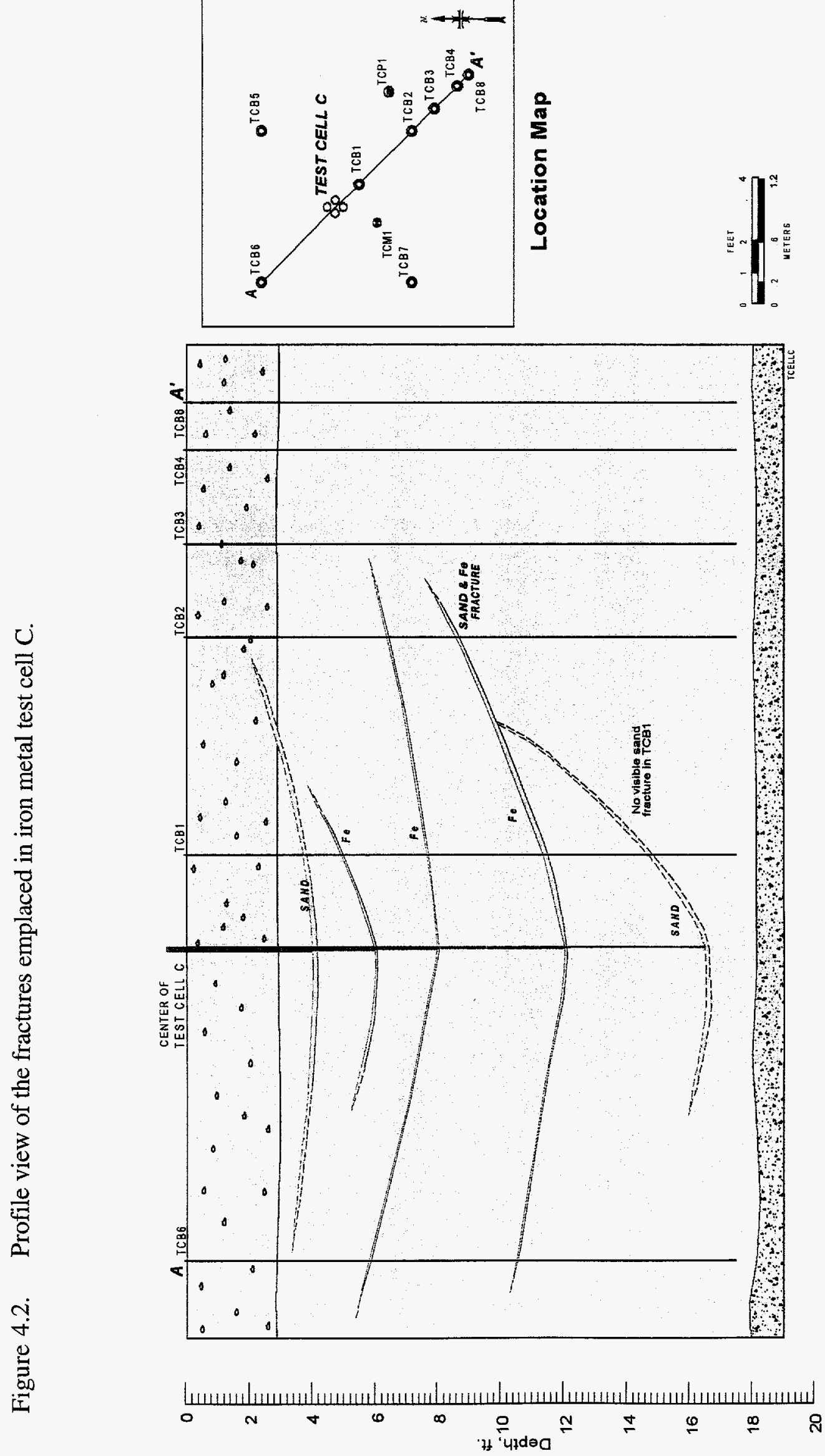
Figure 4.3. Photograph made during December 1996 illustrating the morphology of the iron metal propped fracture and the formation above and below it.
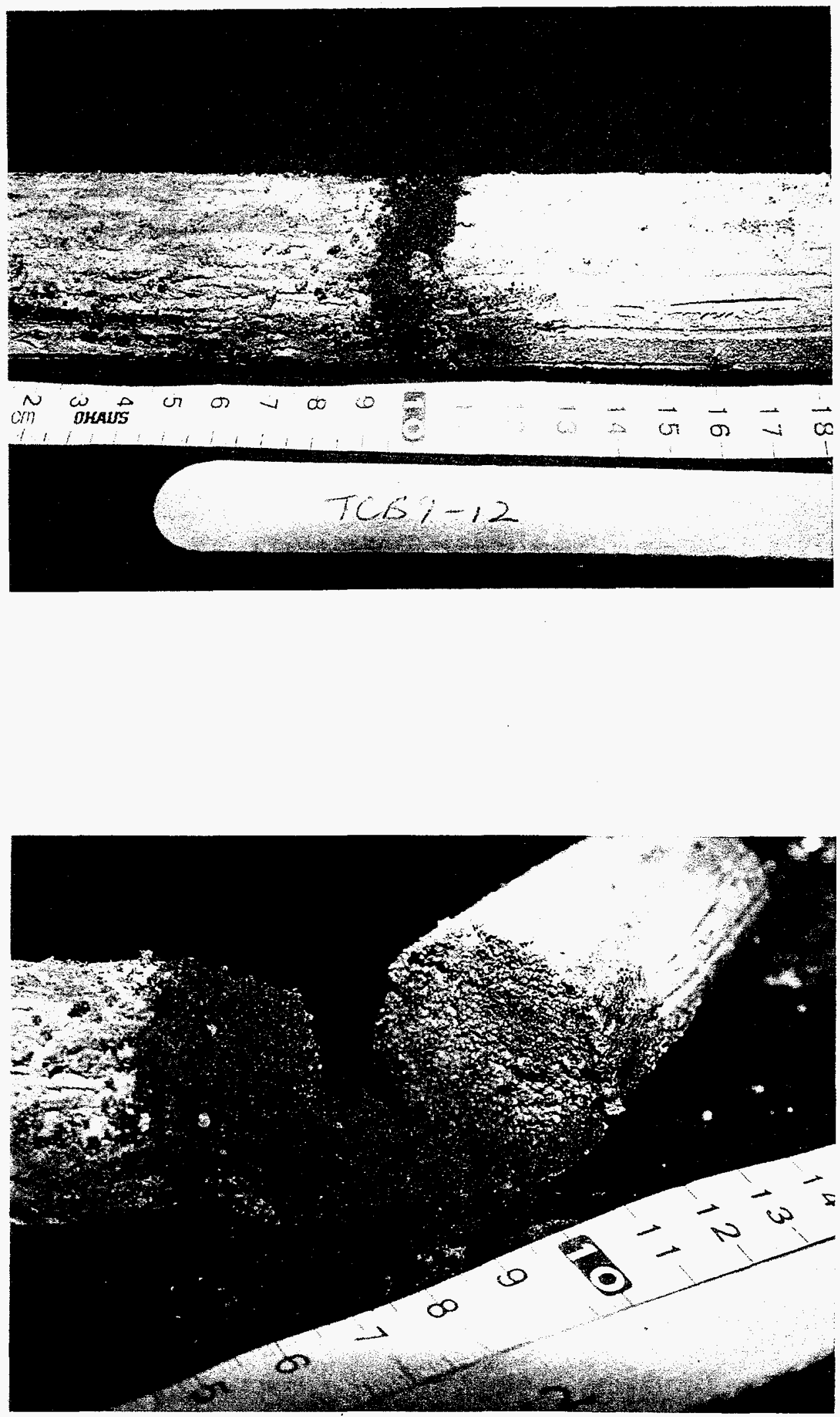
Figure 4.4. Photomicrographs made during July 1997 illustrating the micromorphology of the iron metal proppant (a) as compared to comparable unused iron (b).

(a) Iron metal after $\sim 10$ months of subsurface emplacement (magnification $=1500 \mathrm{x}$ ).

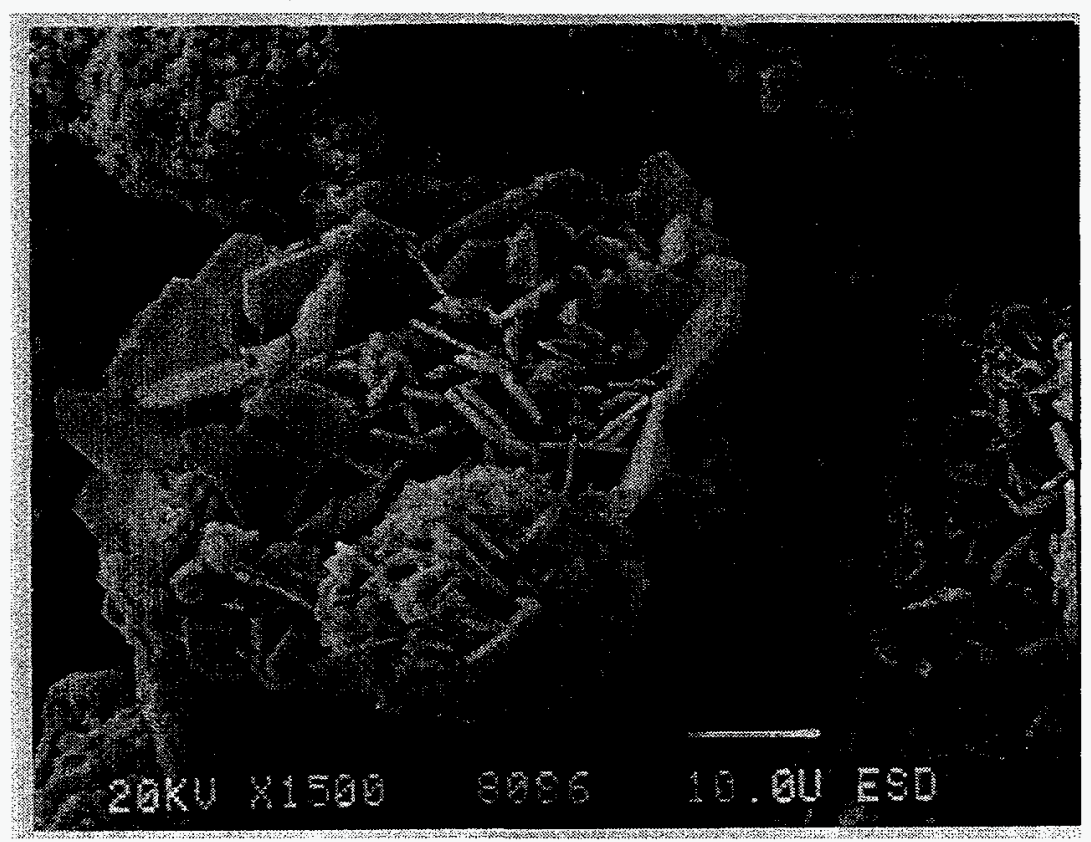

(b) Iron metal prior to fracturing and emplacement (magnification $=1100 \mathrm{x}$ ).

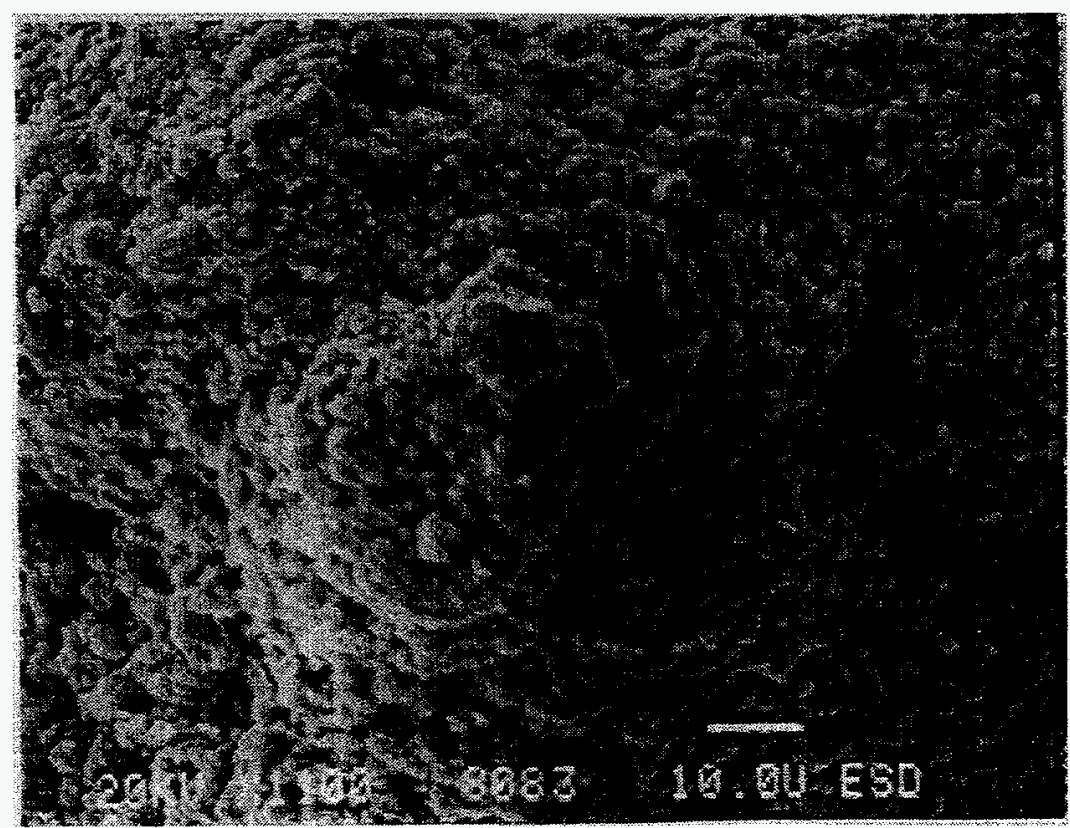


Figure 4.5. Properties in the vicinity of an iron filled fracture 3 months after emplacement.
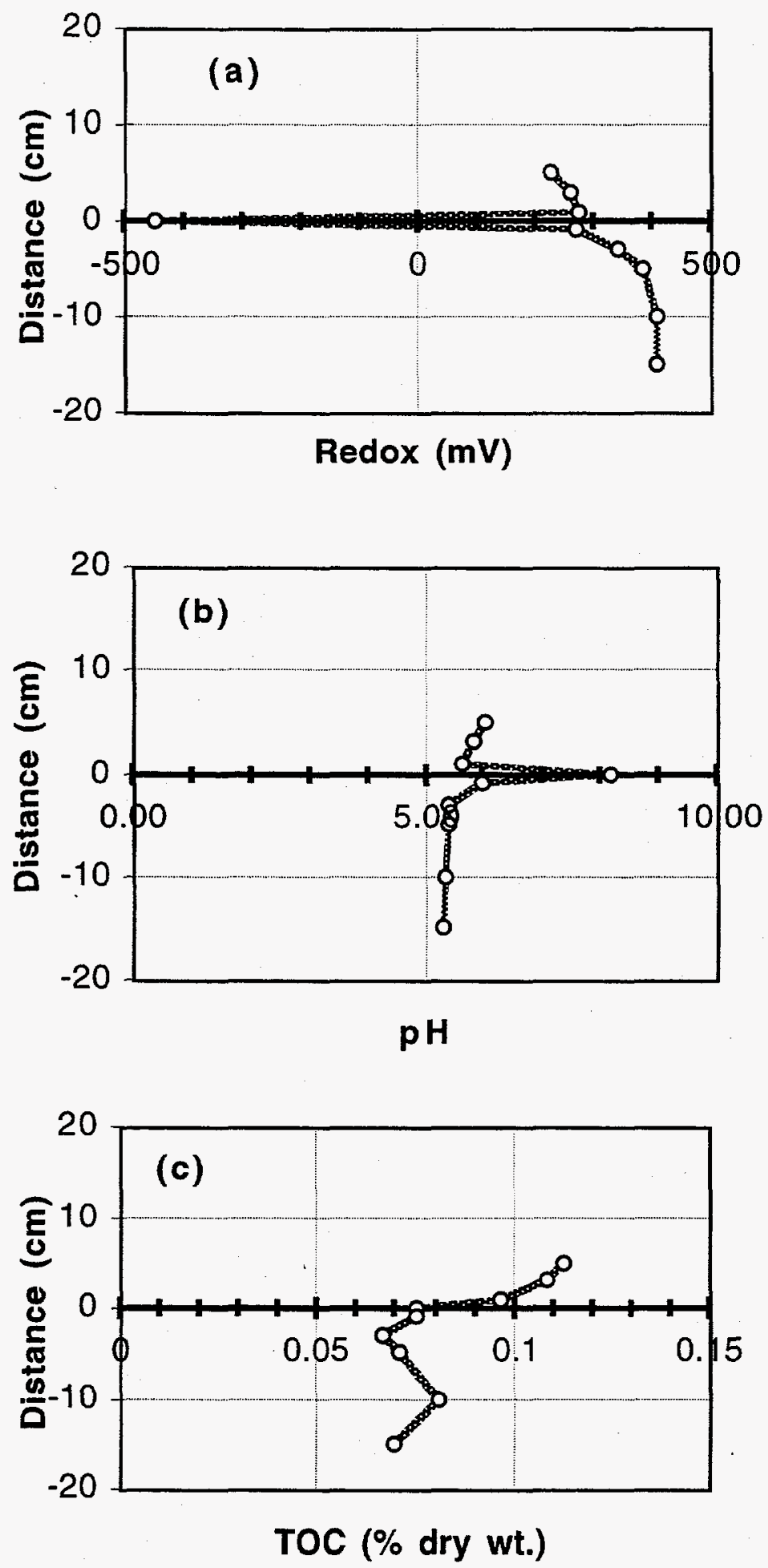
Figure 4.6. Properties in the vicinity of an iron filled fracture 10 months after emplacement.
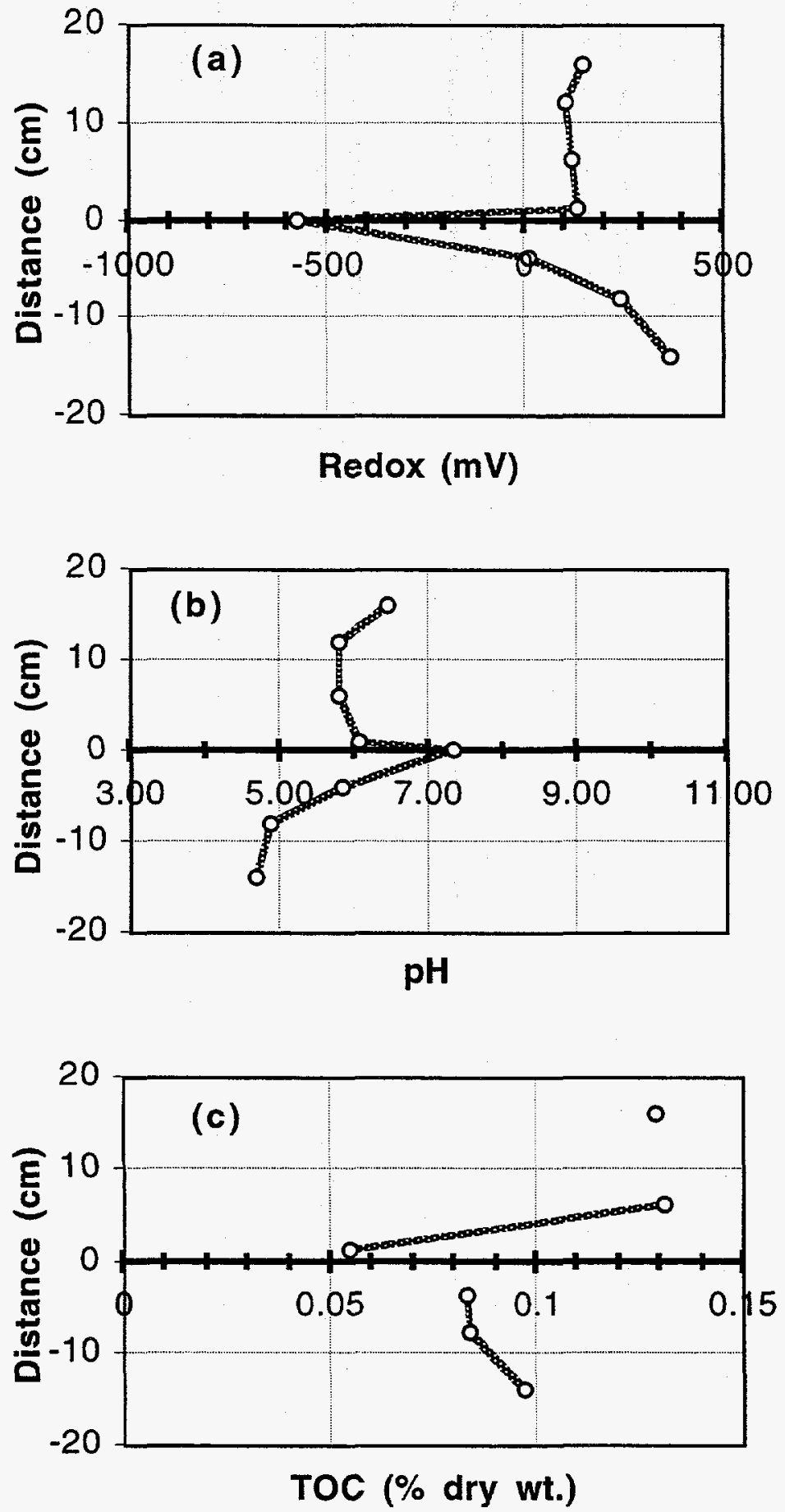
Figure 4.7. TCE degradation in ground water after a 24-hr reaction time versus distance from an iron filled fracture 3 months after emplacement. GW initial TCE $=144 \mathrm{mg} / \mathrm{L}$.

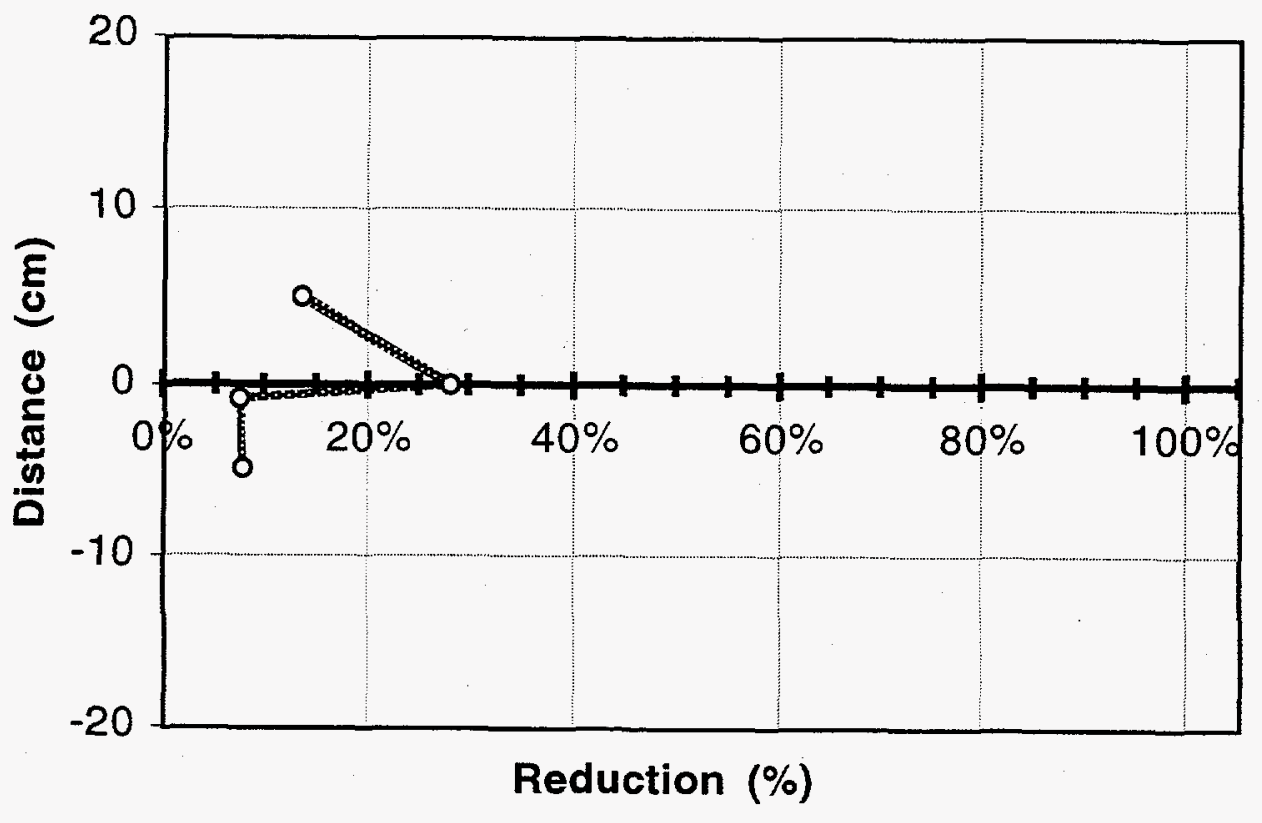


Figure 4.8. TCE degradation in ground water after 24- or 48-hr reactive times versus distance from an iron filled fracture 10 months after emplacement. (a) GW1 initial TCE = $480 \mathrm{mg} / \mathrm{L}$; (b) GW2 initial TCE $=54 \mathrm{mg} / \mathrm{L}$.
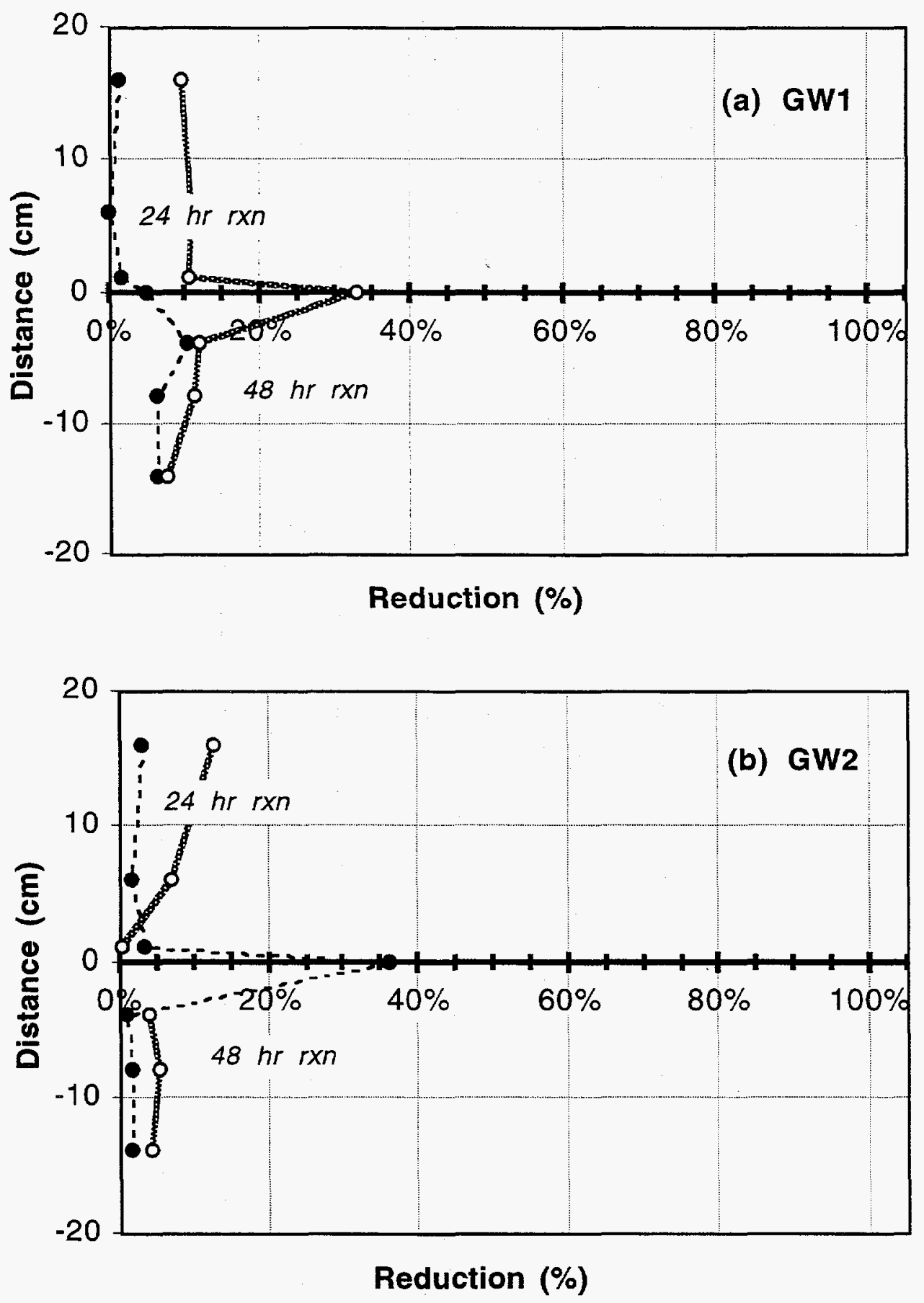
Figure 4.9. TCE degradation with iron metal retrieved from fractures after 15 months of emplacement. $\mathrm{FC} 2 \mathrm{~T} 1=$ iron metal and $25 \mathrm{mg} / \mathrm{L}$ TCE at $20 \mathrm{C}$. FC3T1 $=$ iron metal and $2.2 \mathrm{mg} / \mathrm{L}$ TCE at $20 \mathrm{C}$.

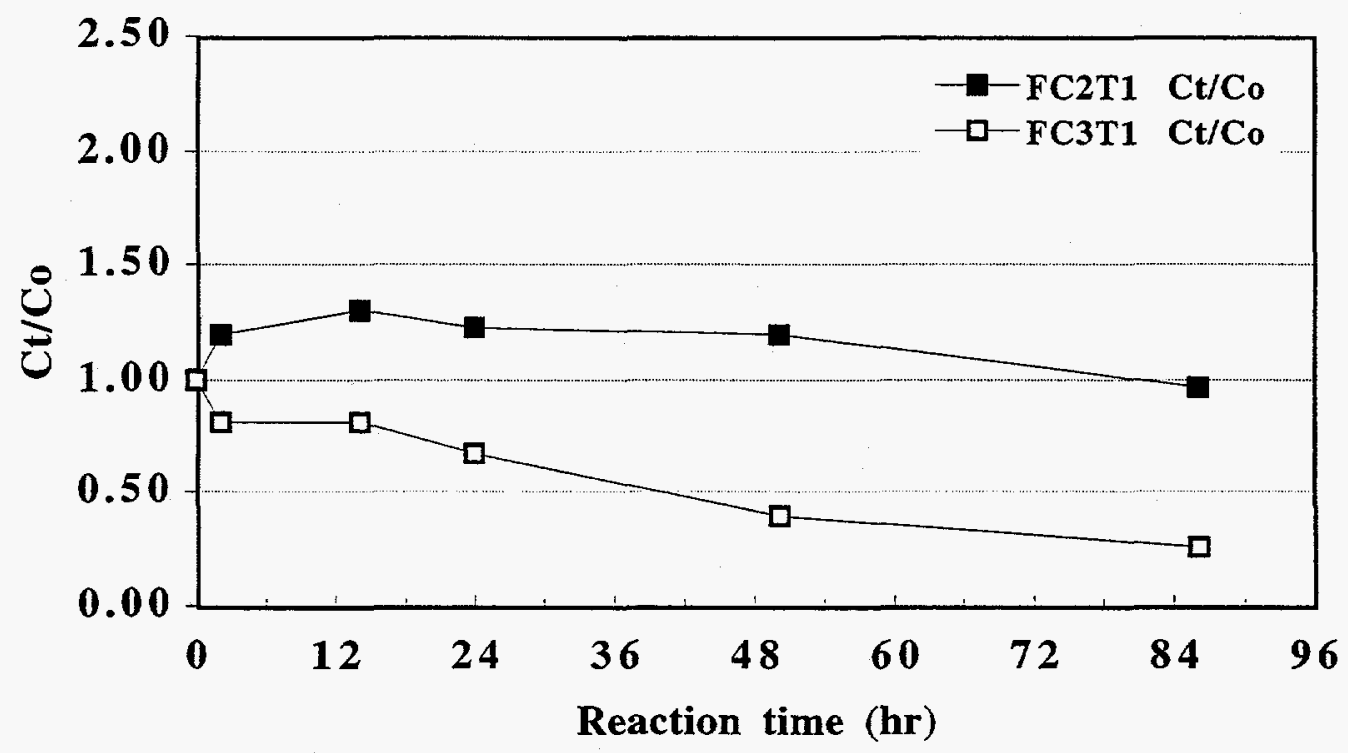

Figure 4.10. TCE degradation with unused iron metal from the same batch that was used for fracture emplacement during September 1996.

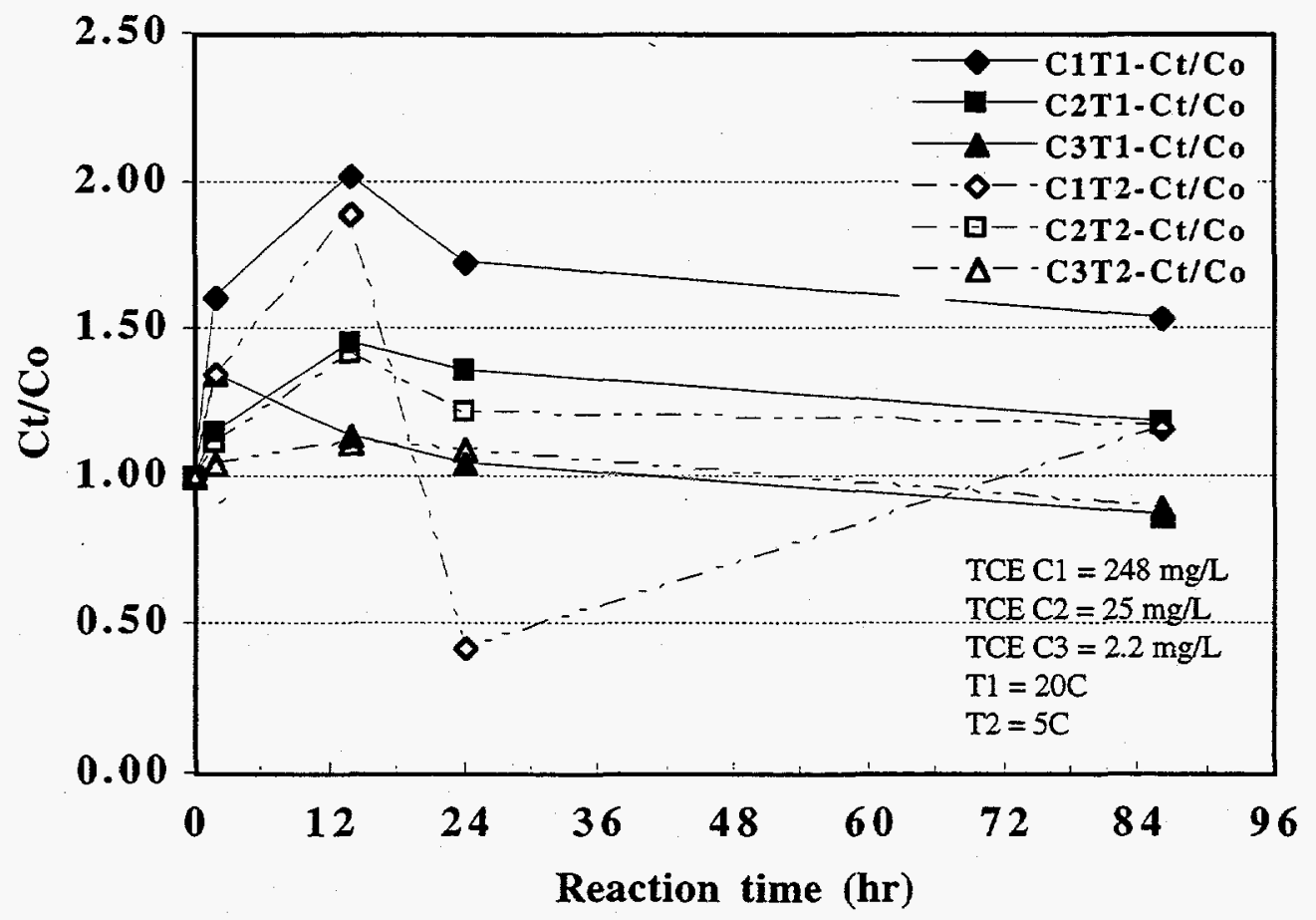


Figure 4.11. Representative soil water content in the iron cell initially and 10 months after emplacement.

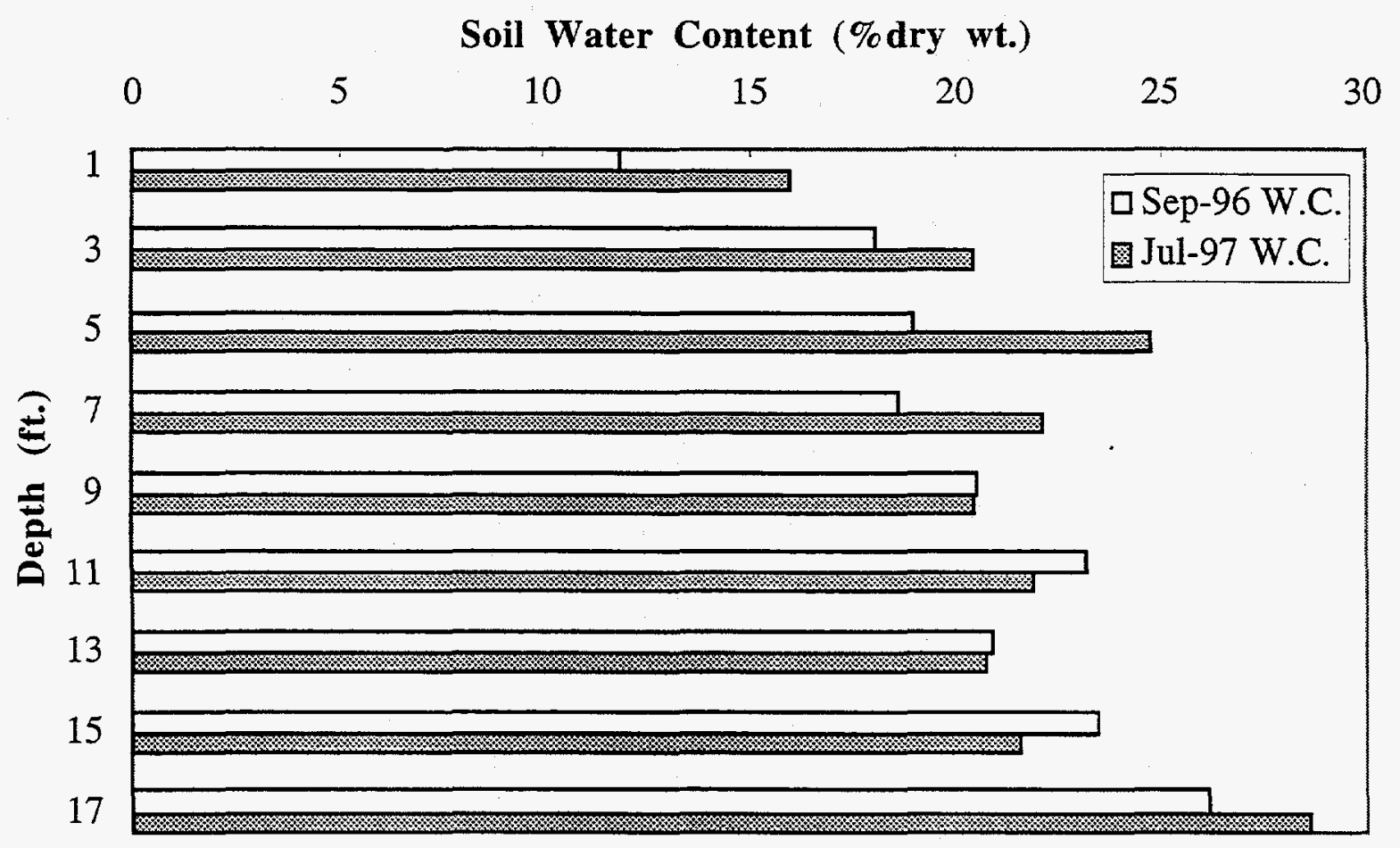

Figure 4.12. Representative soil $\mathrm{pH}$ in the iron cell initially and 10 months after emplacement.

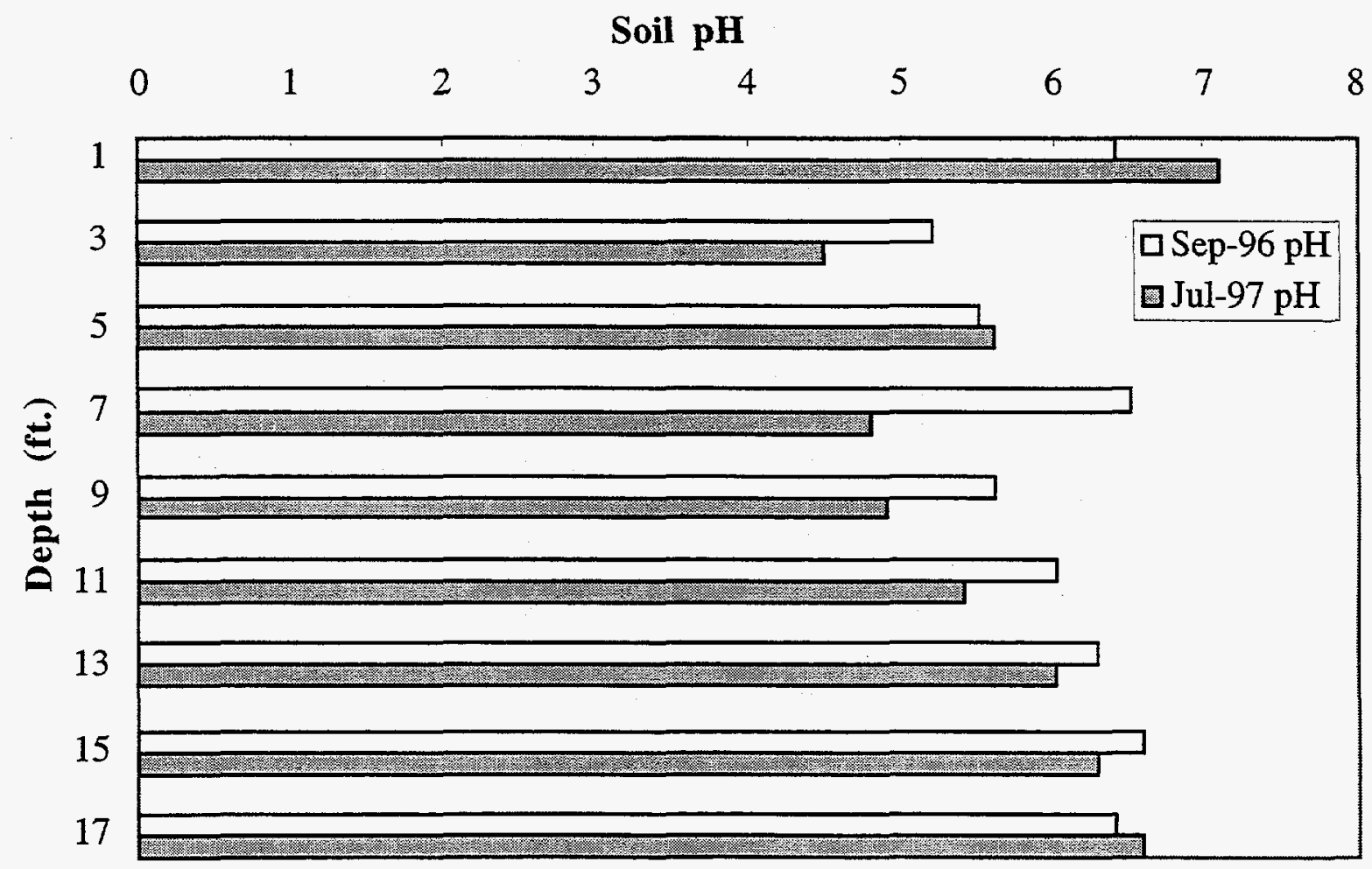


Figure 4.13. Representative soil potassium levels in the iron cell initially and 10 months after emplacement.

\section{Soil Potassum (mg/kg)}

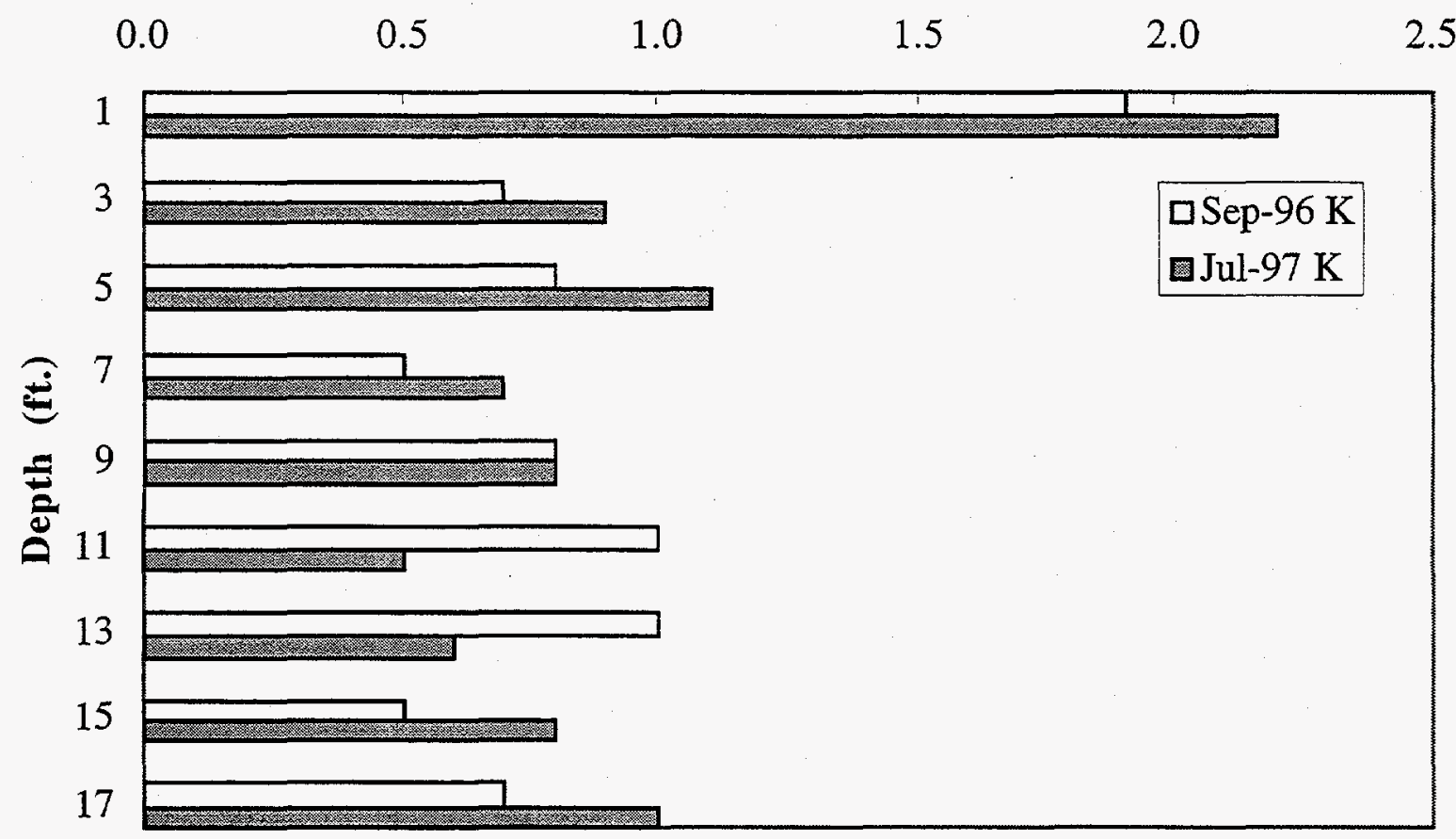

Figure 4.14. Representative soil iron levels in the iron cell initially and 10 months after emplacement.

Soil Iron (mg/kg)

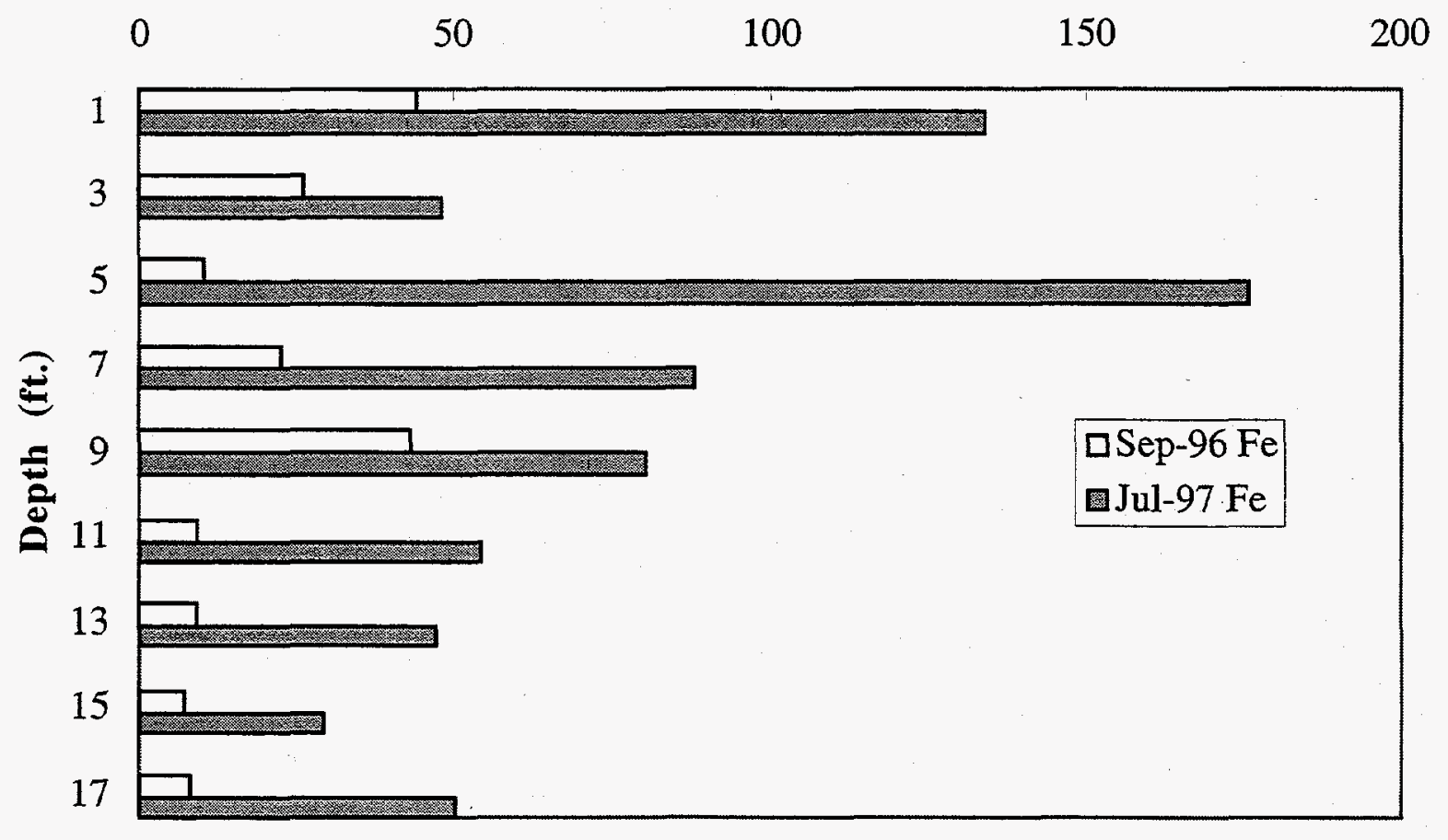


Figure 4.15. Representative soil manganese levels in the iron cell initially and 10 months after emplacement.

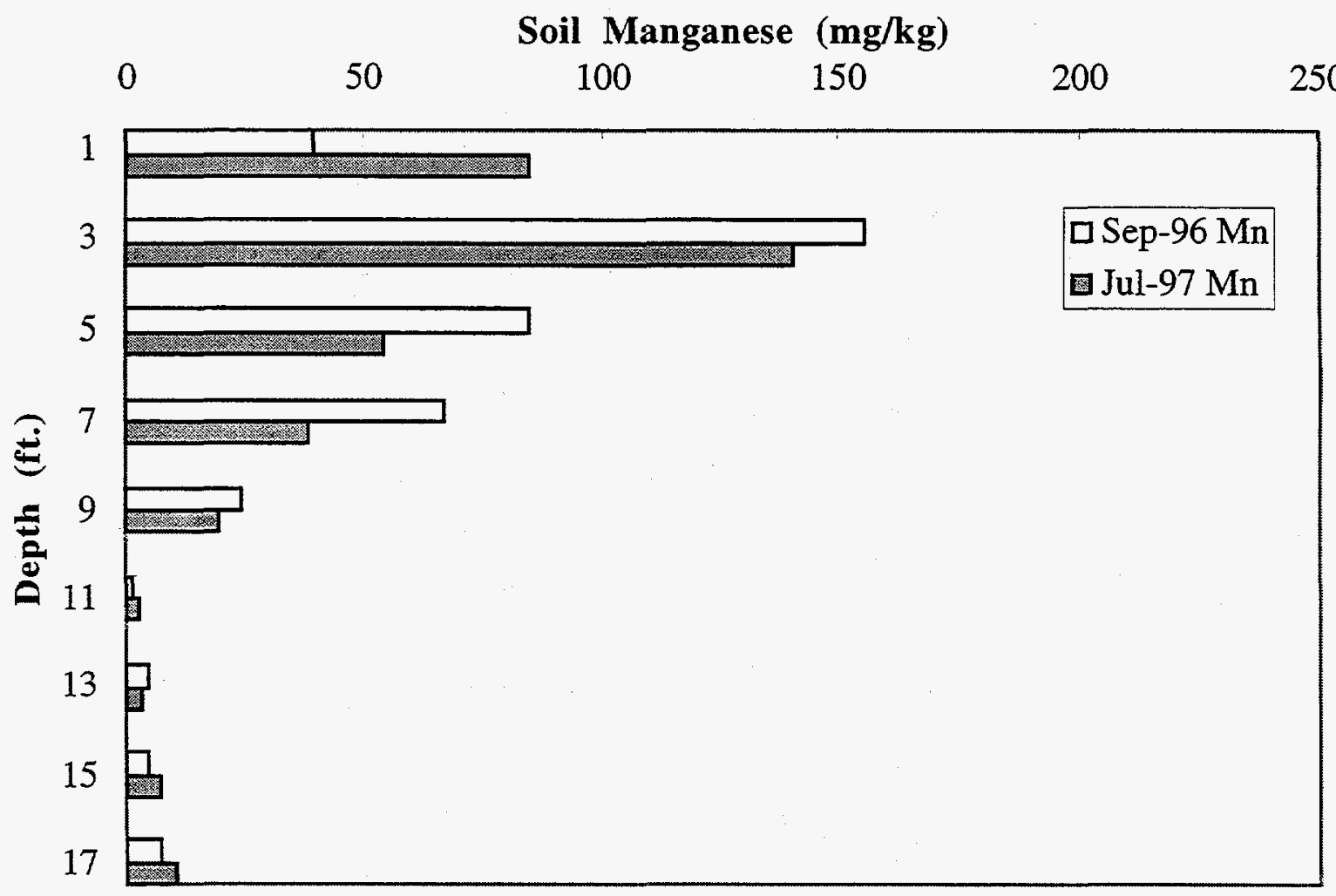

Figure 4.16. Ground water $\mathrm{pH}$ and ion concentrations in piezometer X231A-TCP1 beneath the iron cell.

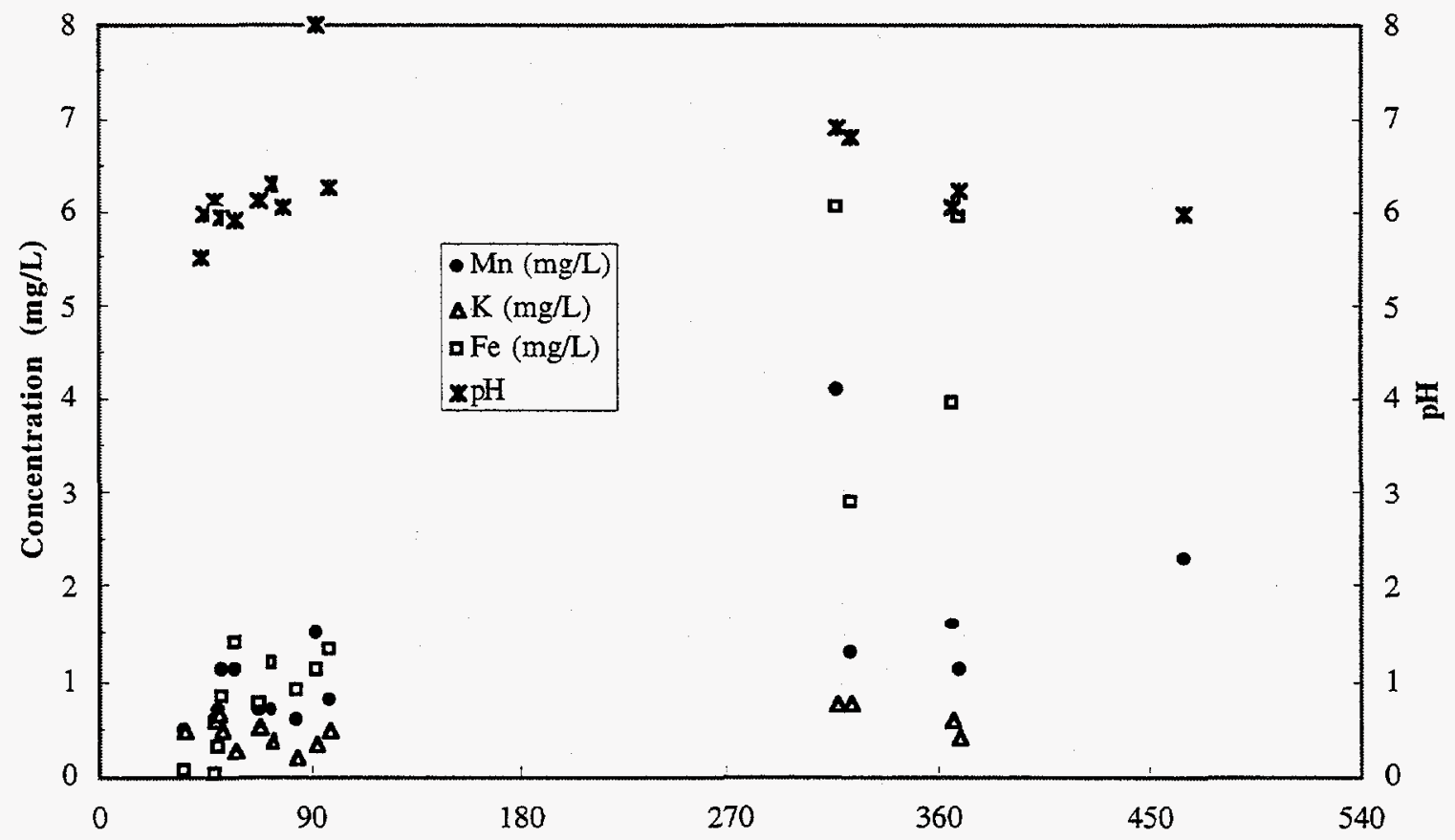


Figure 4.17. Ground water concentrations of DNAPL VOCs beneath the iron cell over time.

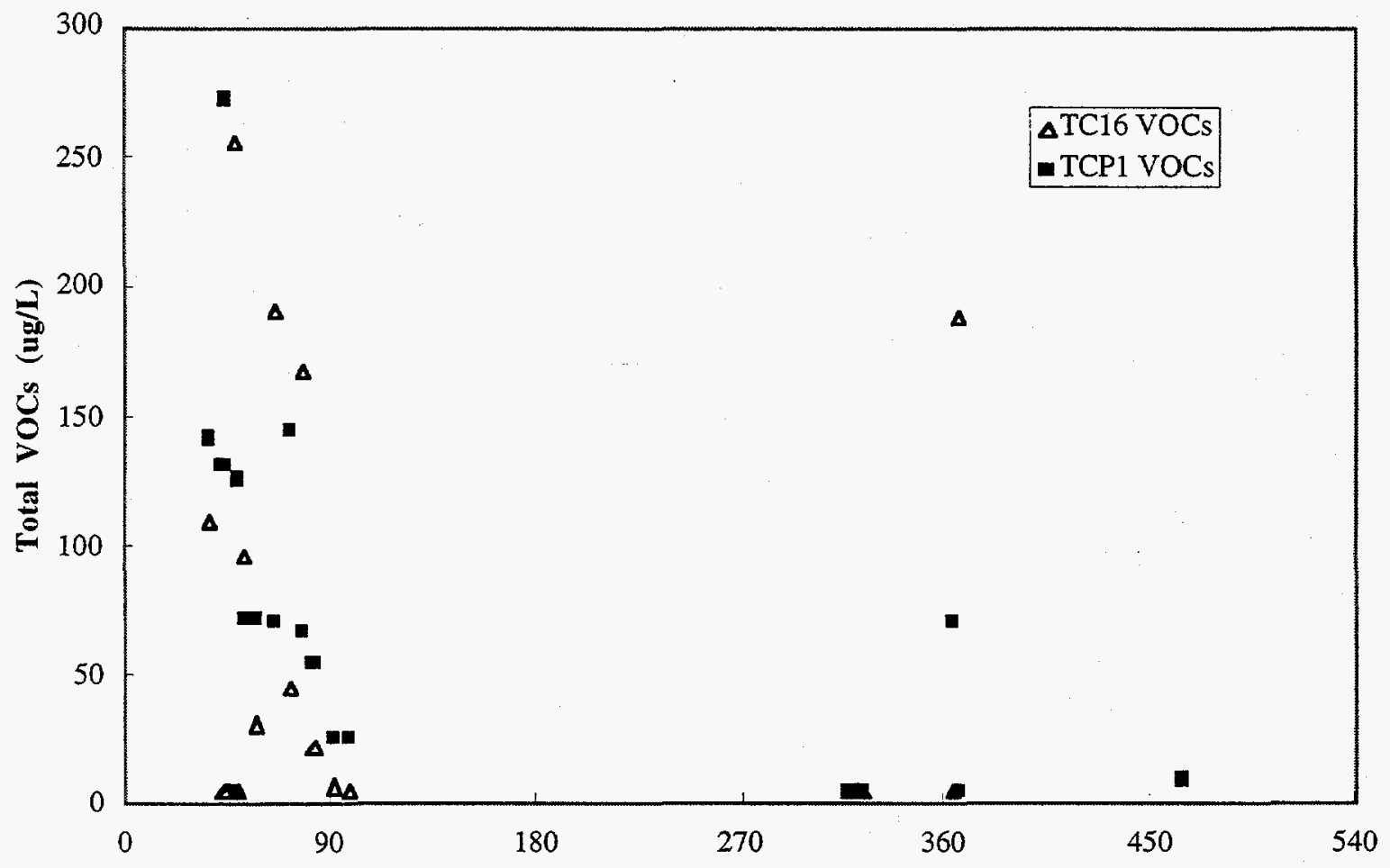


Figure 4.18. Ground water $\mathrm{pH}$ and ion concentrations in piezometers X231A-BGP1 and $\mathrm{X} 231 \mathrm{~A}-\mathrm{BGP} 2$.

(a) Ground water piezometer X231A-BGP1.

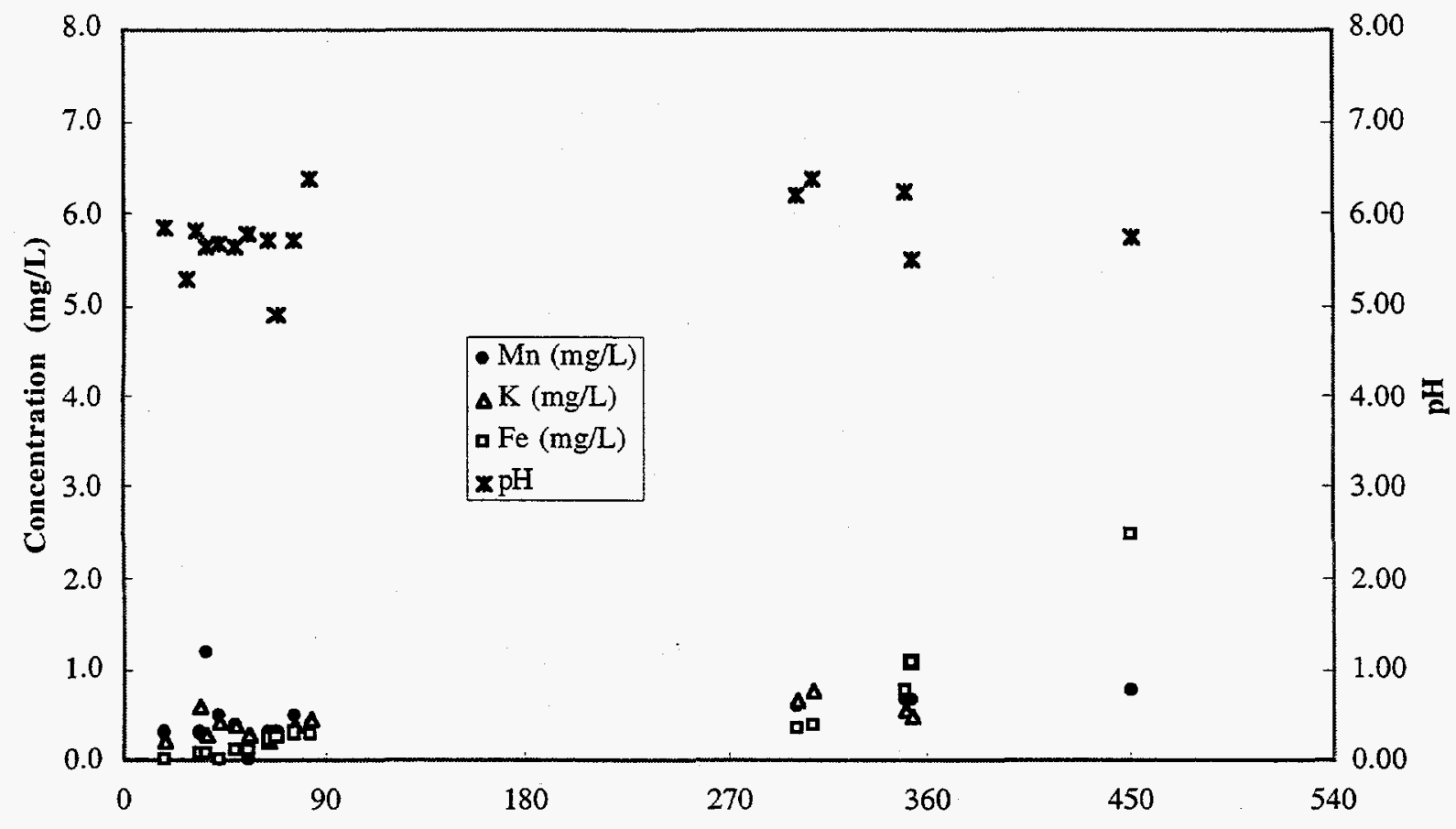

(b) Ground water piezometer X231A-BGP2.

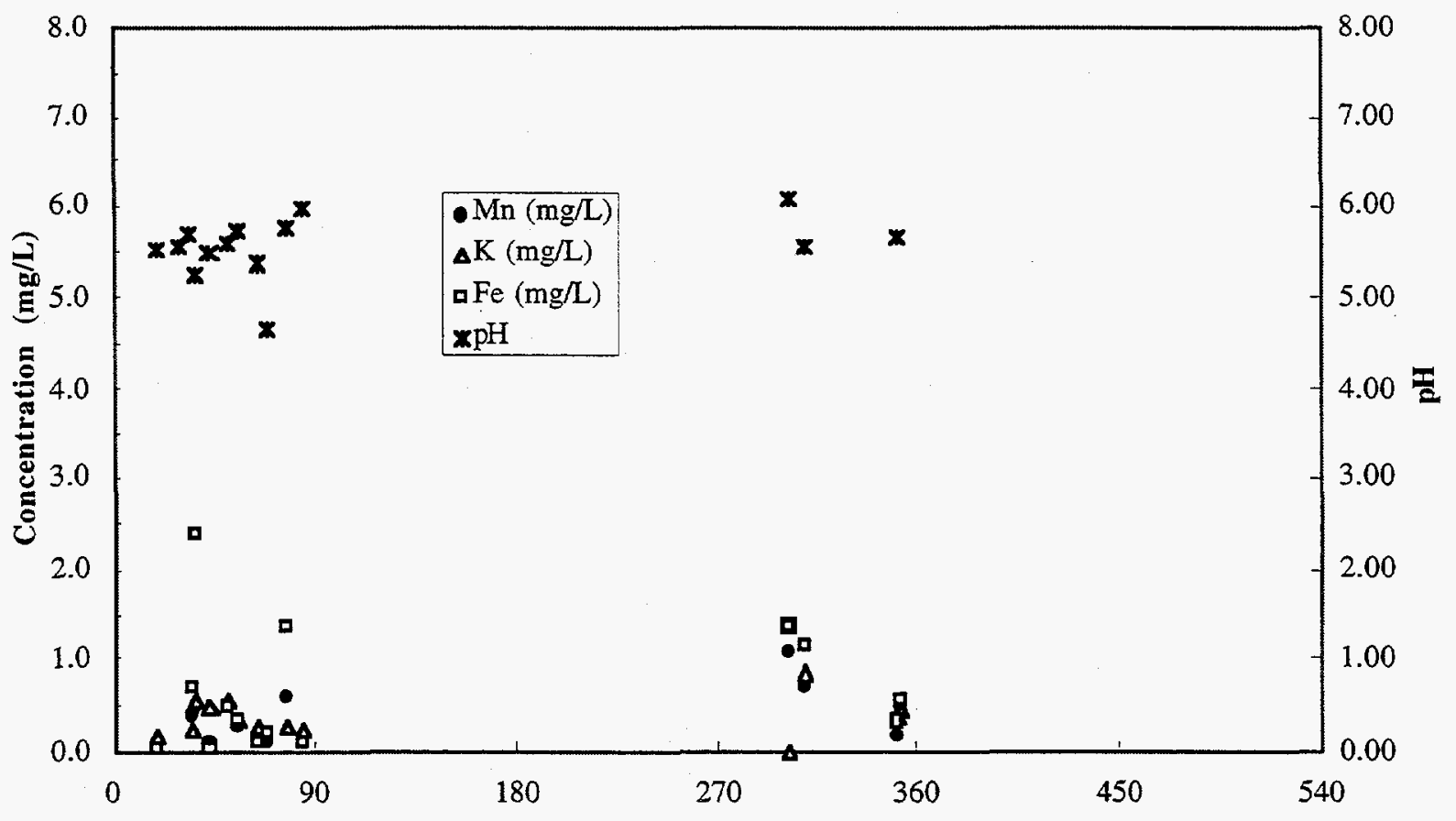


Figure 4.19. Ground water concentrations of DNAPL VOCs in background piezometers.

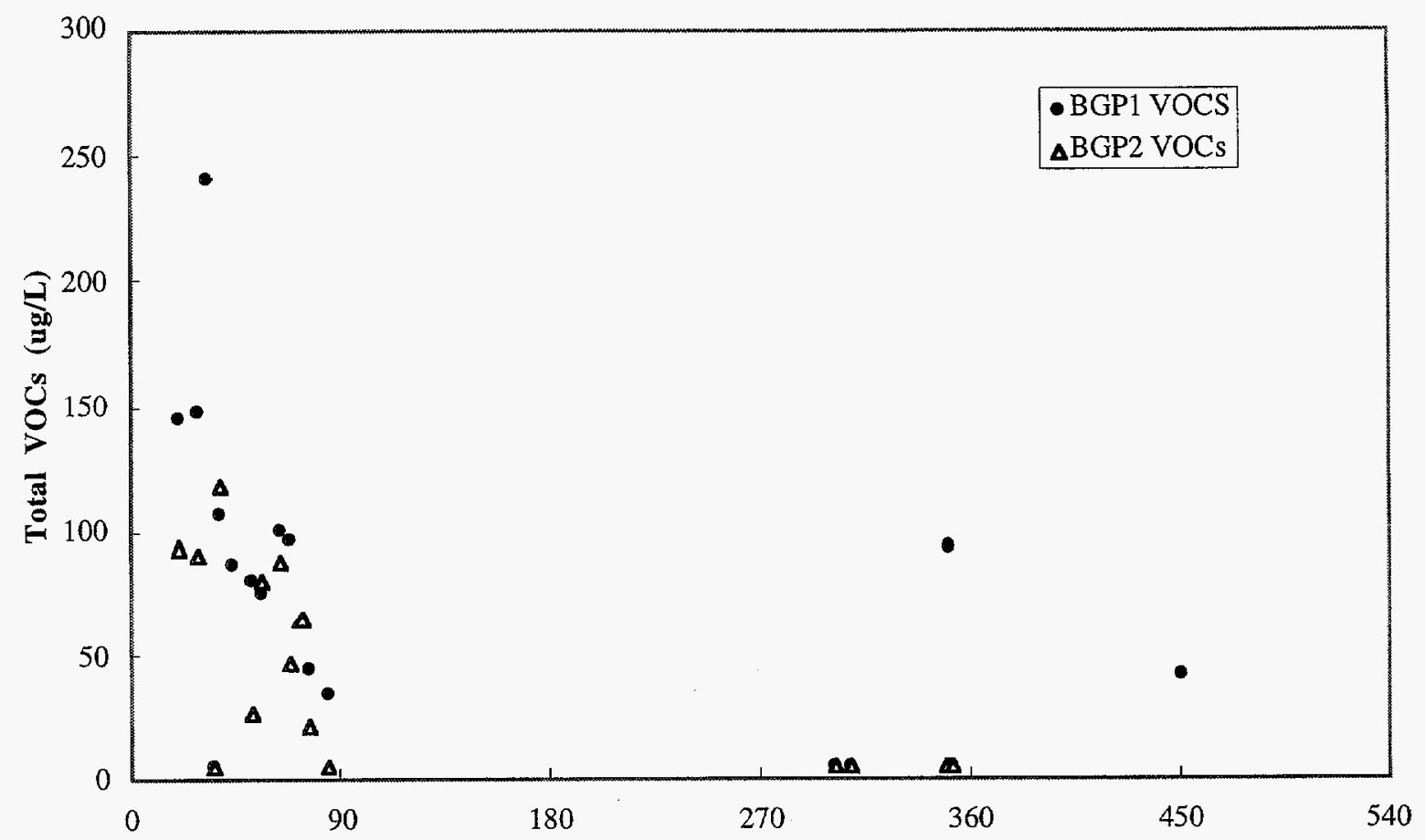


Figure 4.20. Plan view of the horizontal barrier cell created with permanganate grout proppant.

TDB8

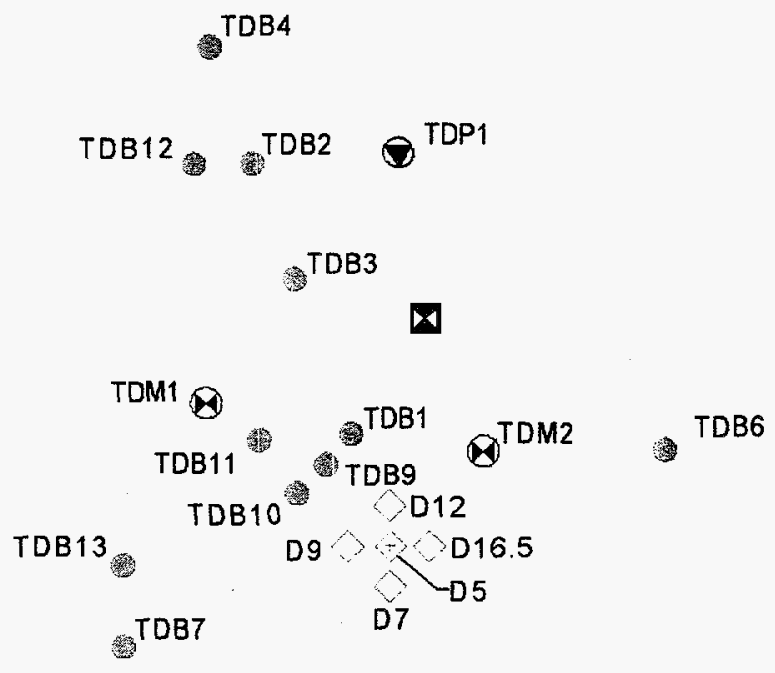

TDB5

TEST CELL D

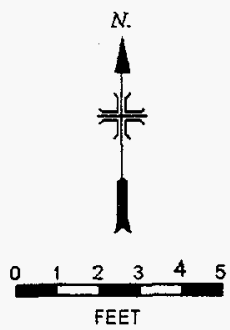

Fracture Access

Soil Sample Borehole

(each with 1/2" dia. PVC wiping thermocouple casing)

Multilevel Instrumented Boring

\ Neutron Probe Casing

D $17 \mathrm{ft}$ Deep Piezometer 


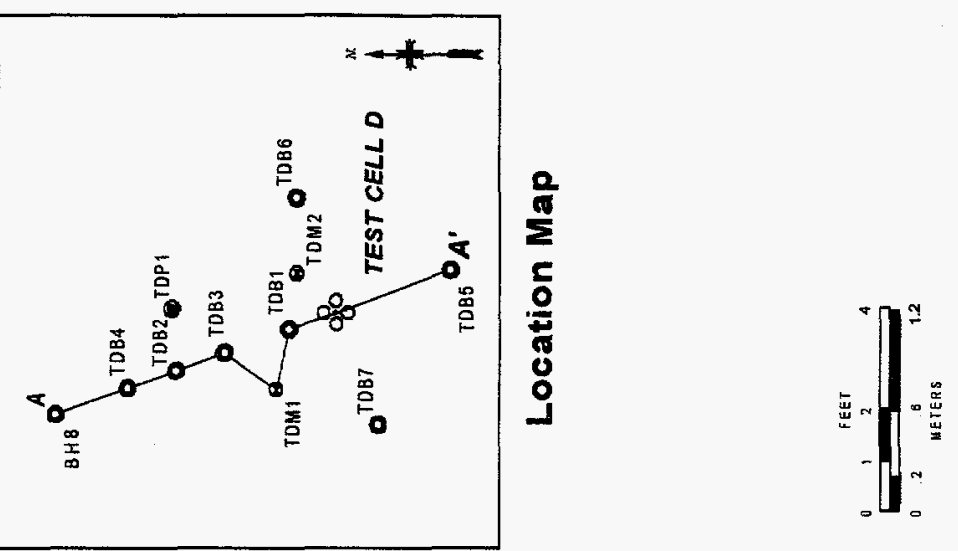

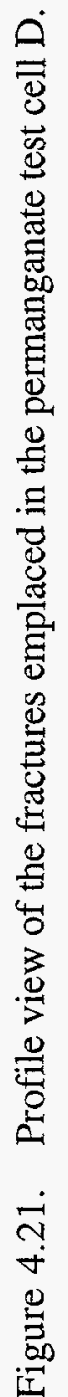

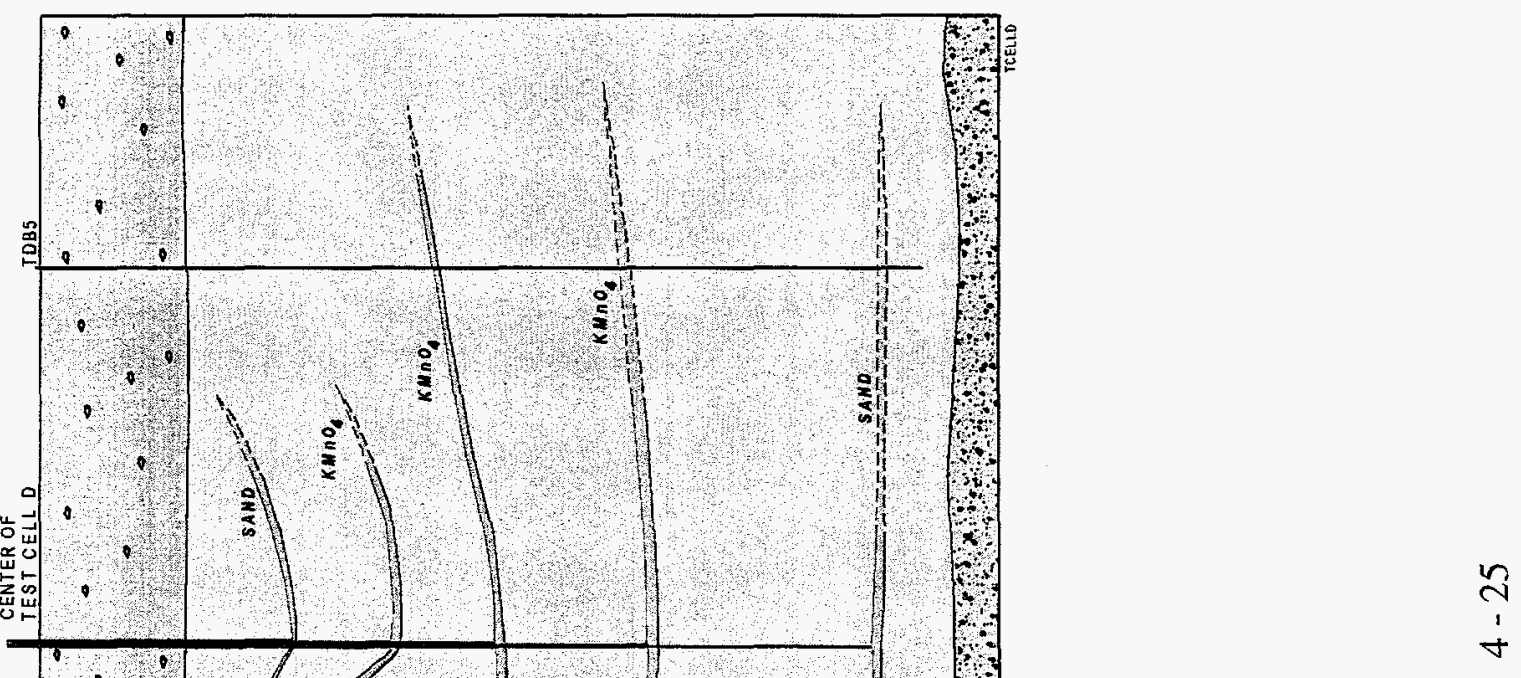

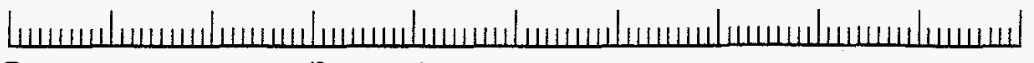

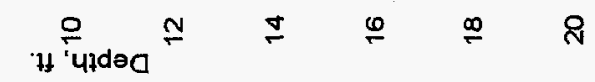


Figure 4.22. Photograph made during December 1996 illustrating the morphology of the permanganate grout fracture and the soil above and below it.
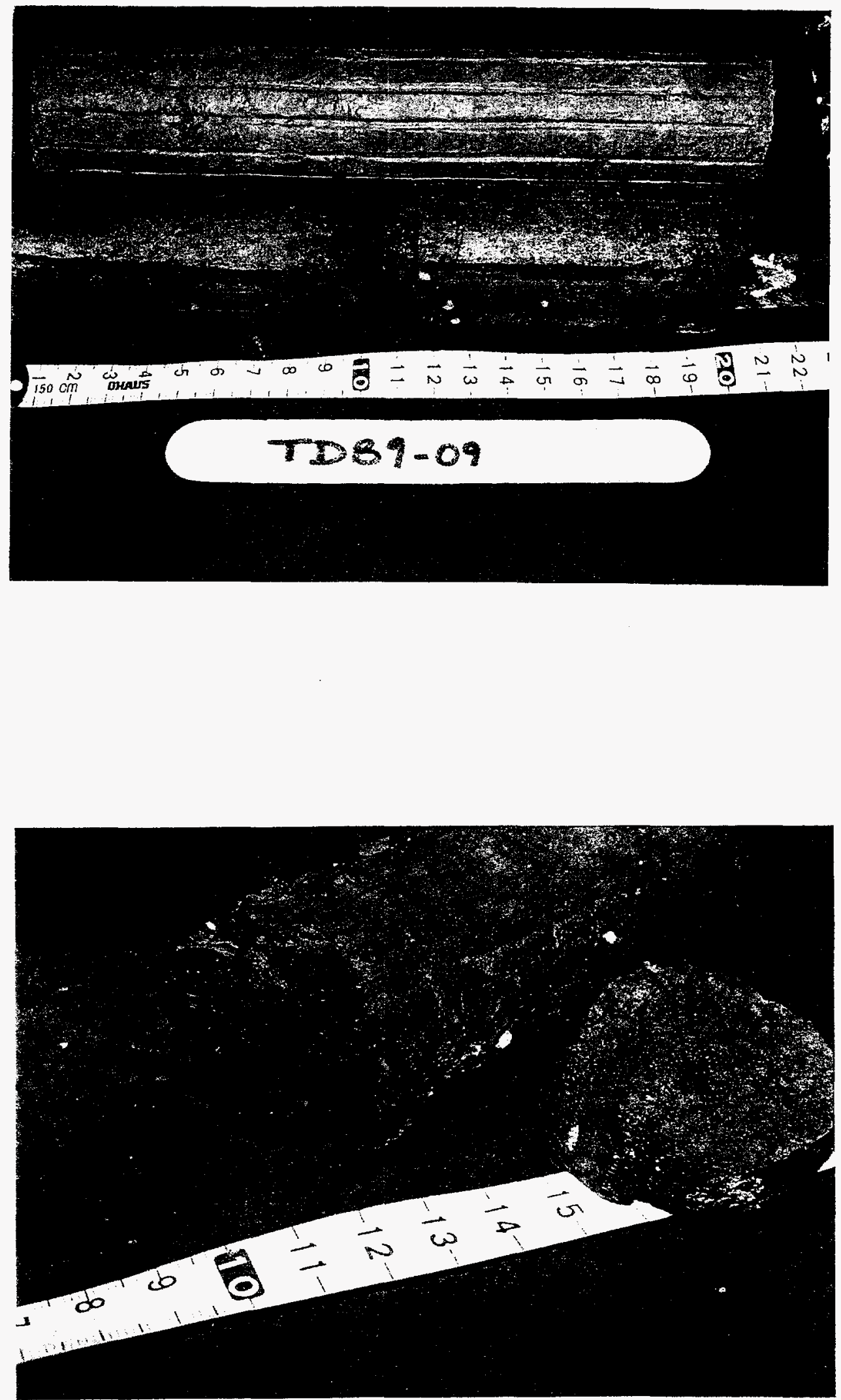
Figure 4.23. Properties in the vicinity of a permanganate filled fracture 3 months after emplacement.
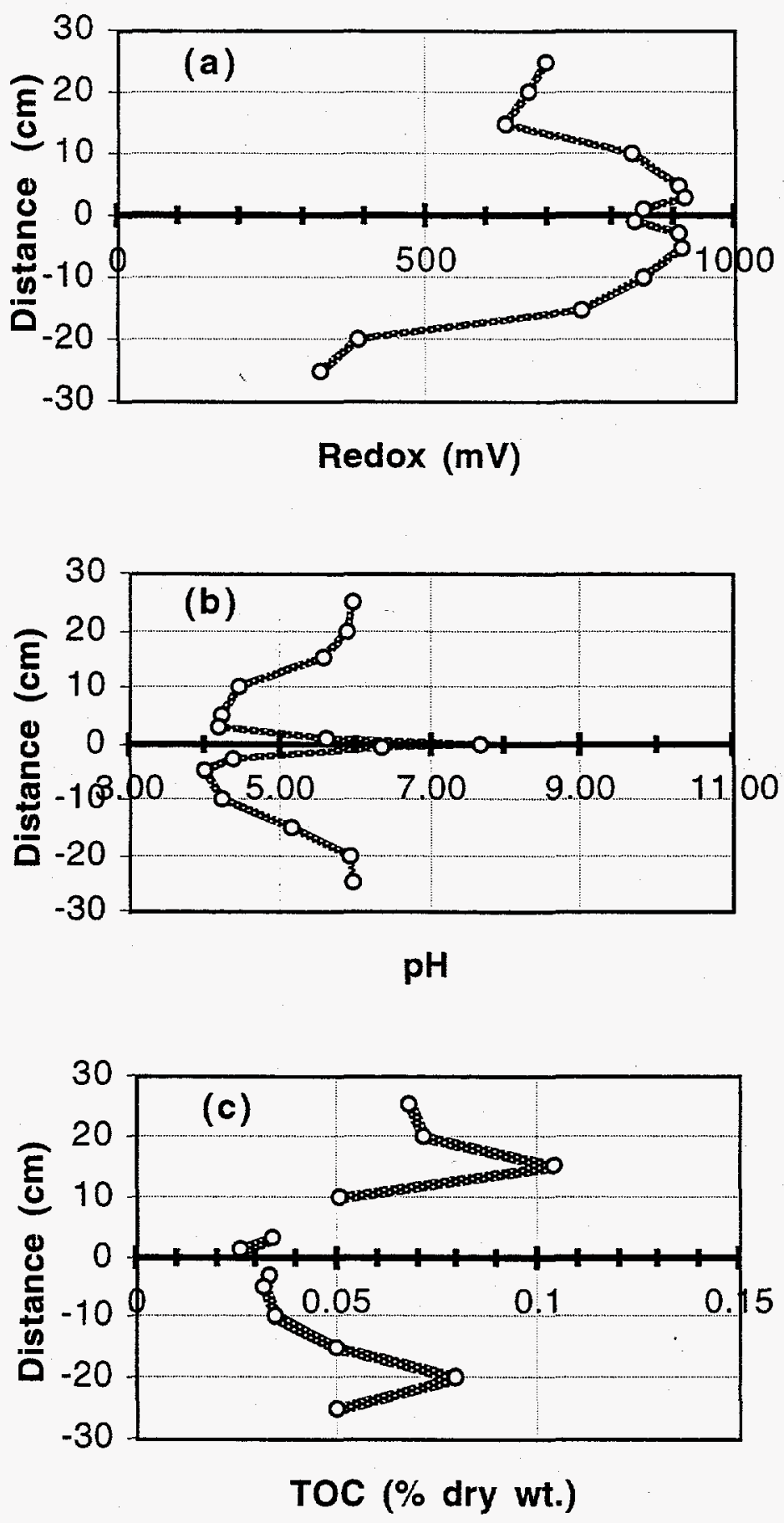
Figure 4.24. Properties in the vicinity of a permanganate filled fracture 10 months after emplacement.
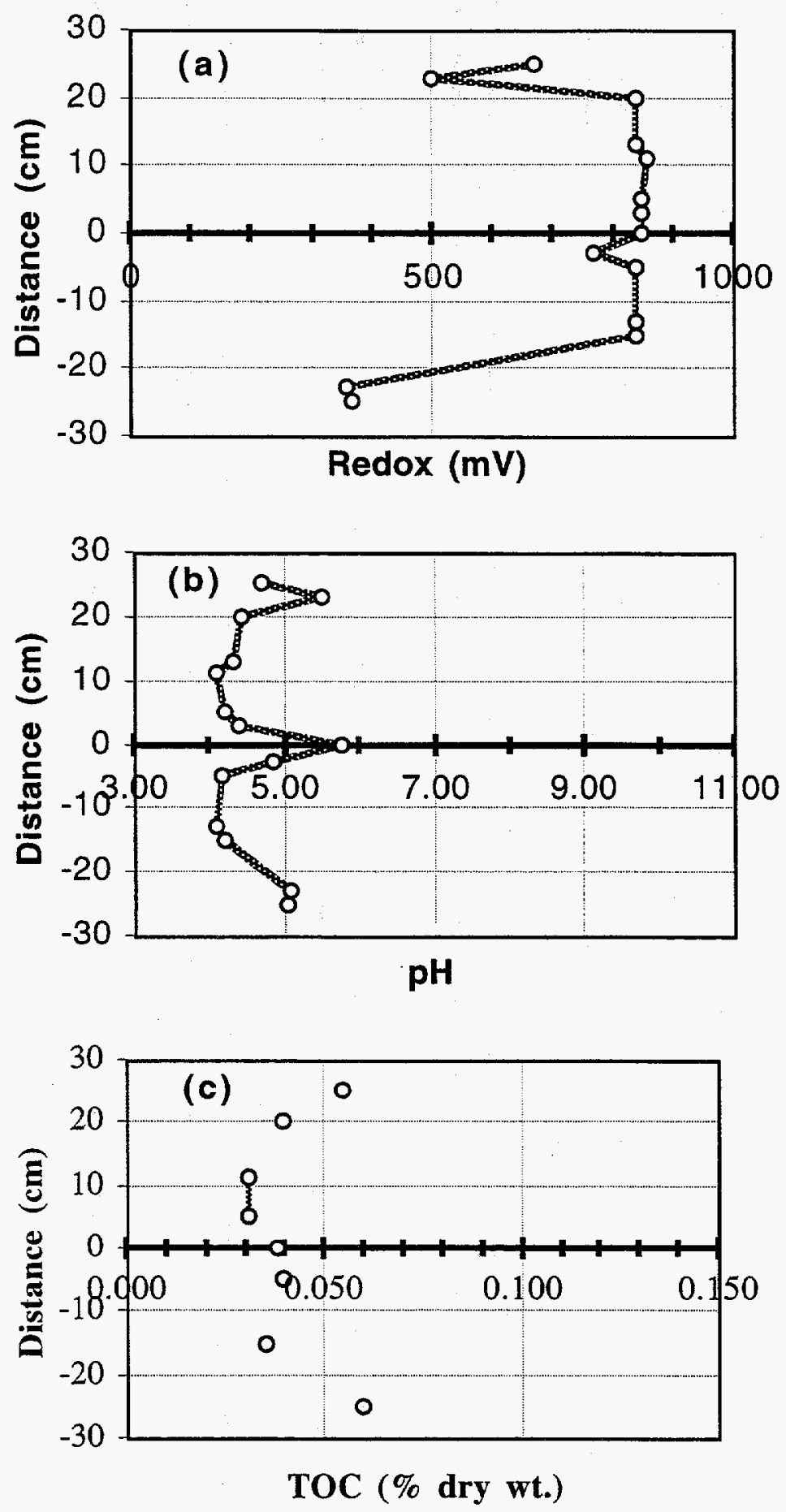
Figure 4.25. TCE degradation in ground water after a 24-hr reaction time versus distance from a permanganate filled fracture 3 months after emplacement. GW initial TCE $=144 \mathrm{mg} / \mathrm{L}$.

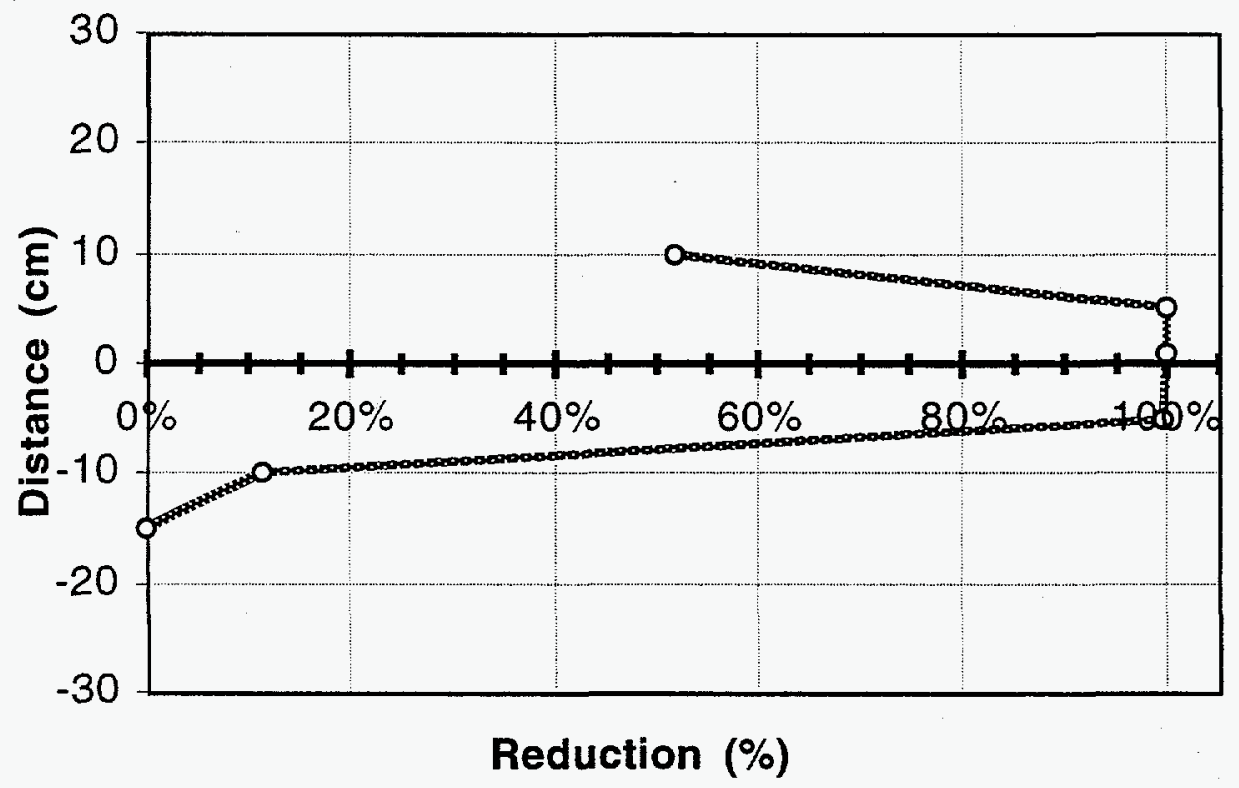


Figure 4.26. TCE degradation in ground water after 2- and 24-hr reaction times versus distance from a permanganate filled fracture 10 months after emplacement. (a) GW1 initial $\mathrm{TCE}=480 \mathrm{mg} / \mathrm{L}$; (b) $\mathrm{GW} 2$ initial $\mathrm{TCE}=54 \mathrm{mg} / \mathrm{L}$.
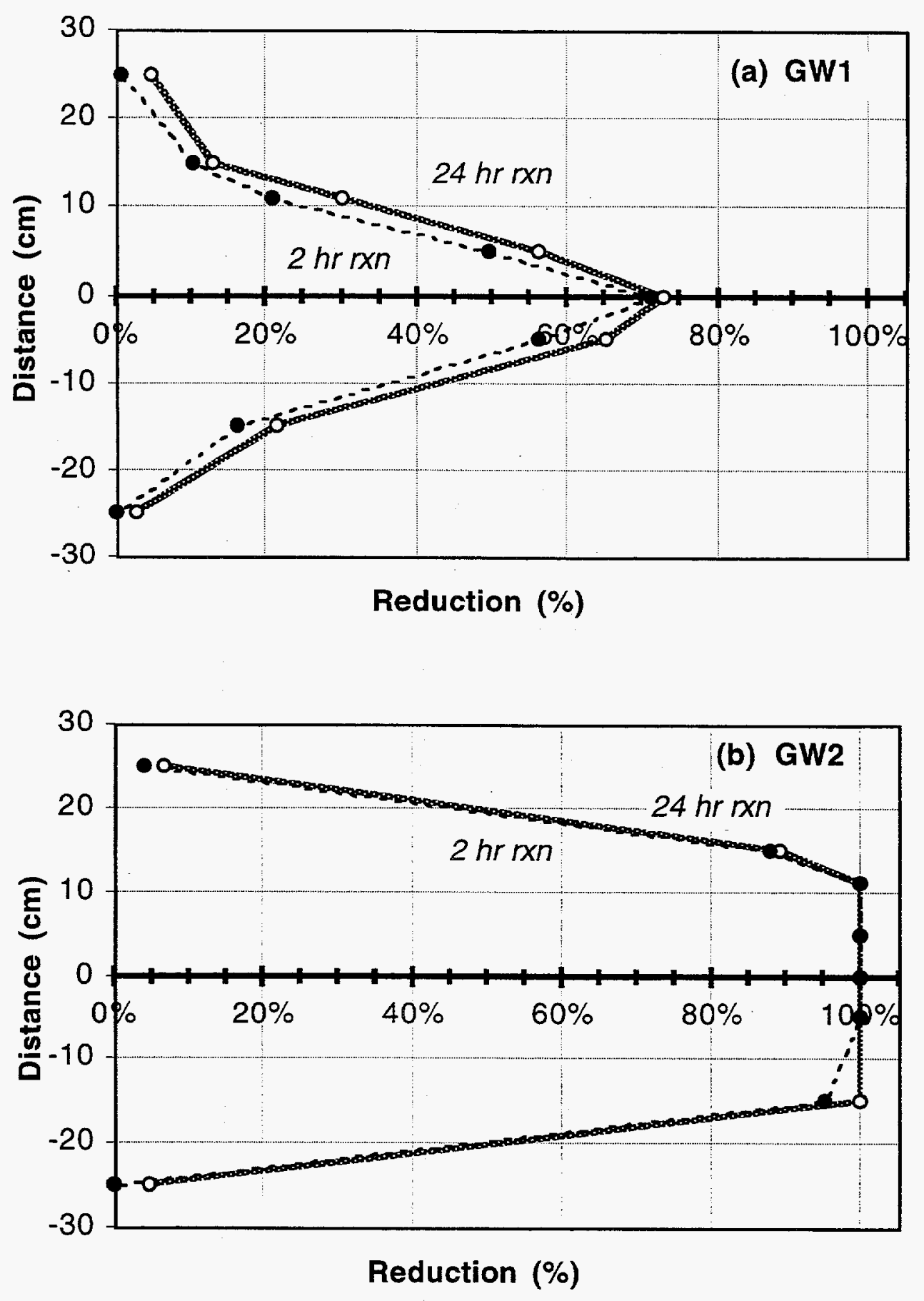
'Figure 4.27. Representative soil water content in the permanganate cell initially and 10 months after emplacement.

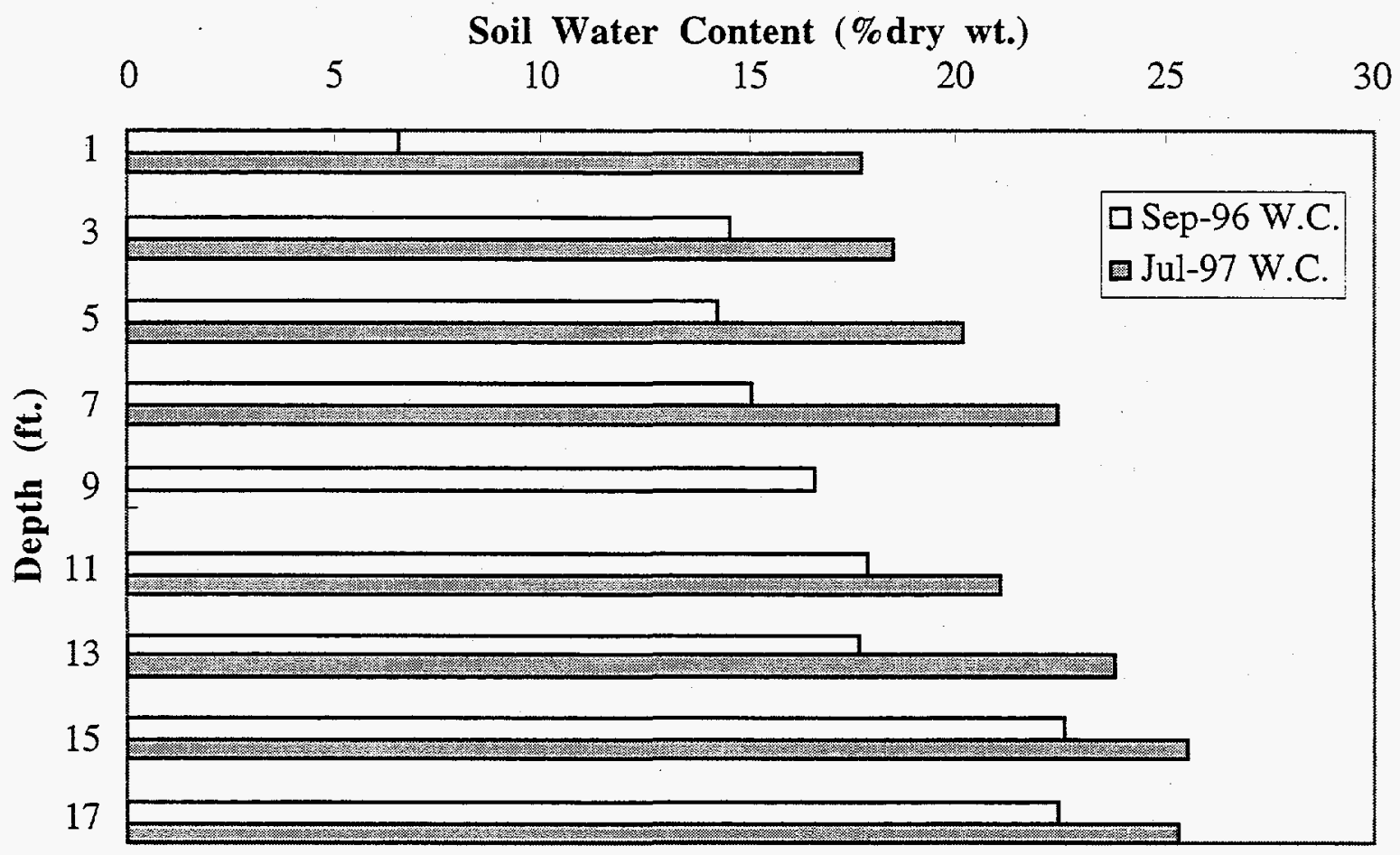

Figure 4.28. Representative soil $\mathrm{pH}$ in the permanganate cell initially and 10 months after emplacement.

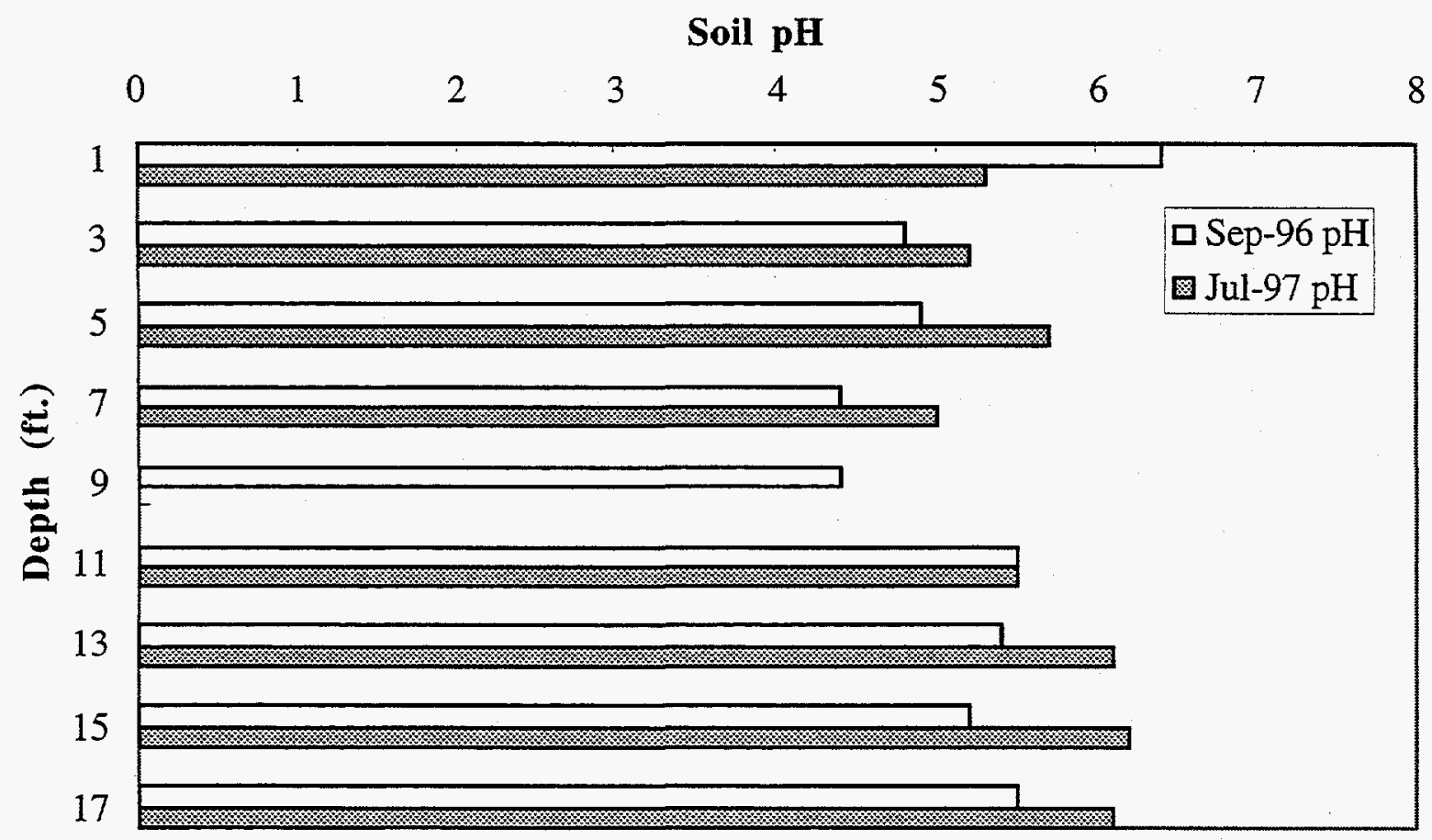

$4-31$ 
Figure 4.29. Representative soil potassium levels in the permanganate cell initially and 10 months after emplacement.

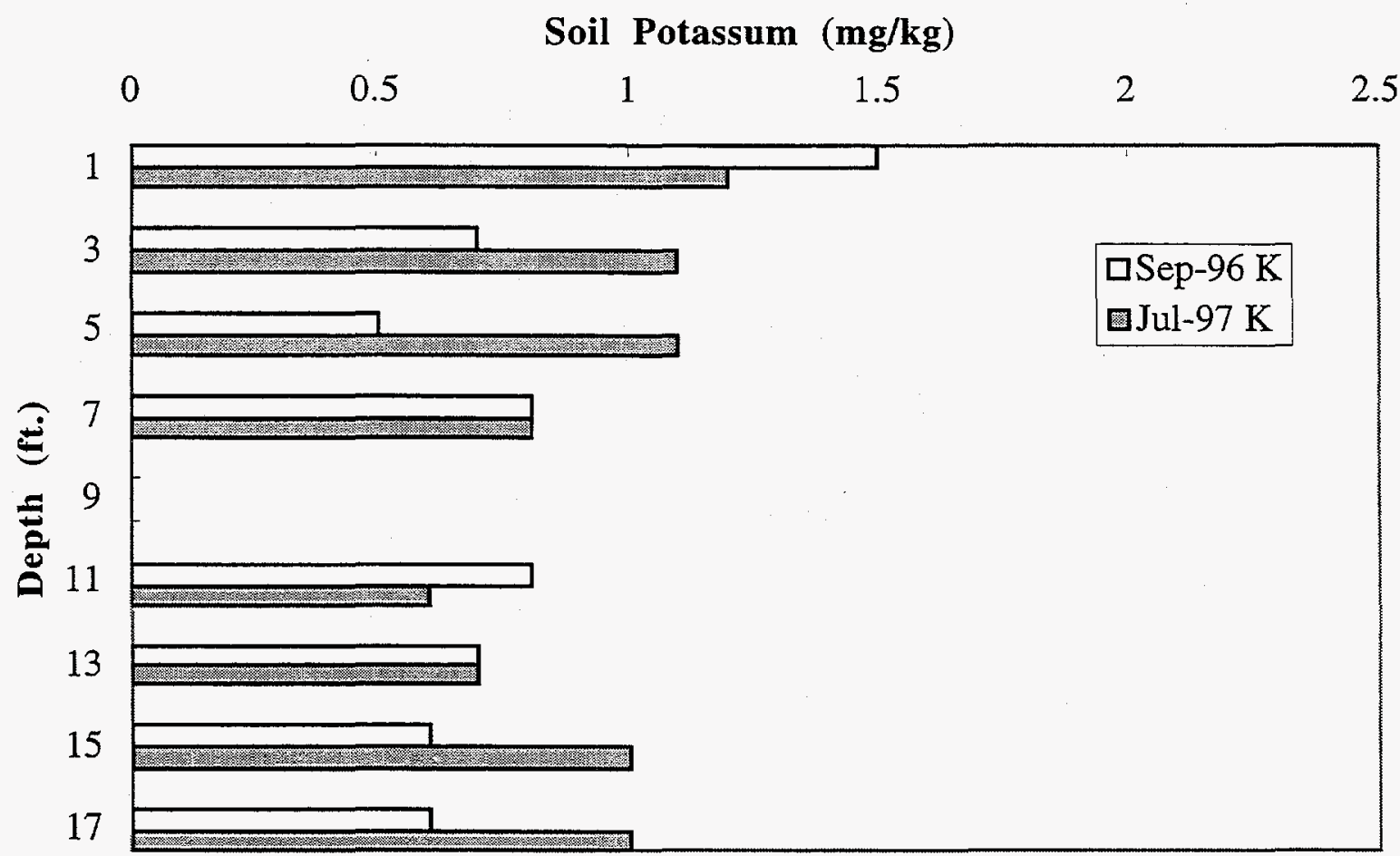

Figure 4.30. Representative soil manganese levels in the permanganate cell initially and 10 months after emplacement.

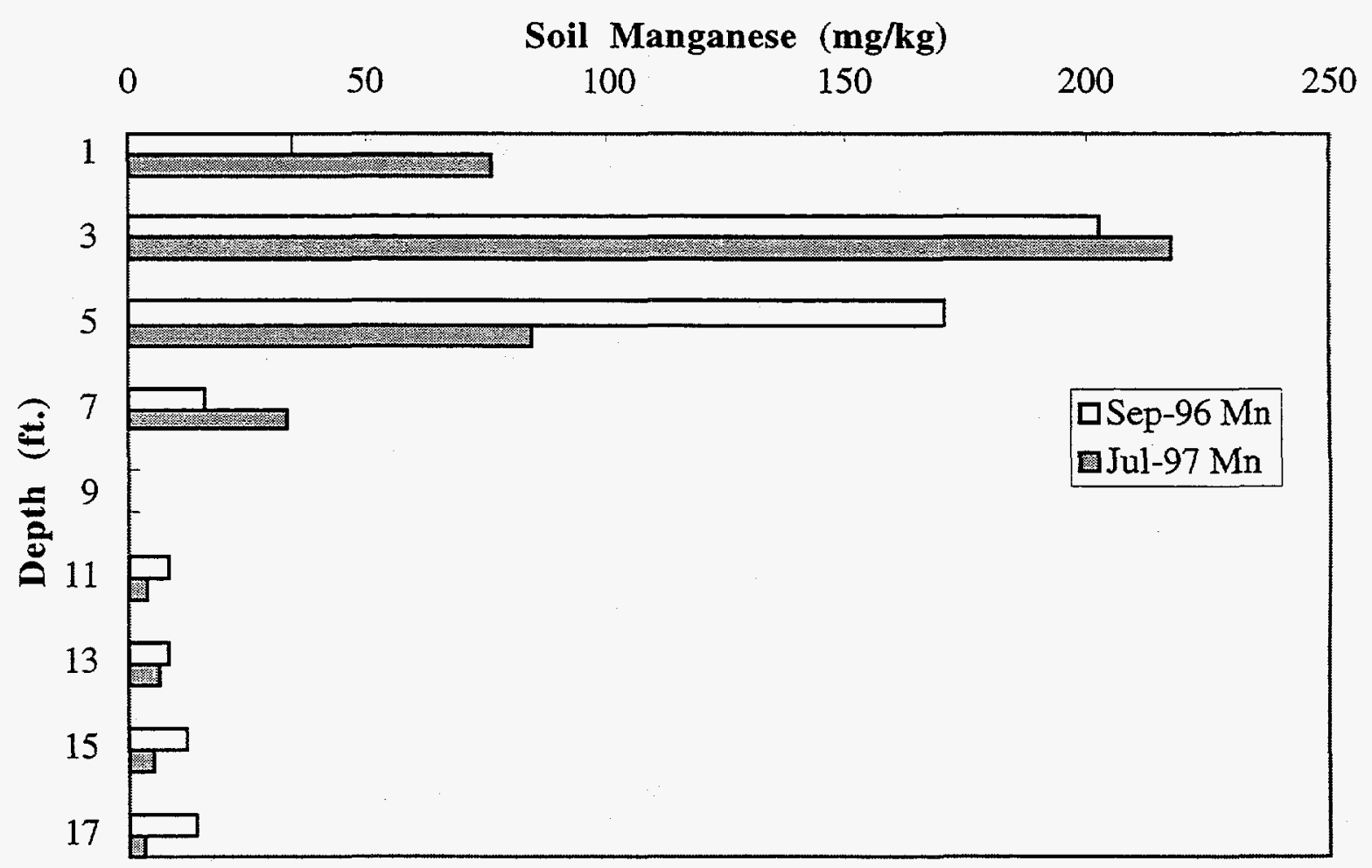


Figure 4.31. Representative soil iron levels in the permanganate cell initially and 10 months after emplacement.

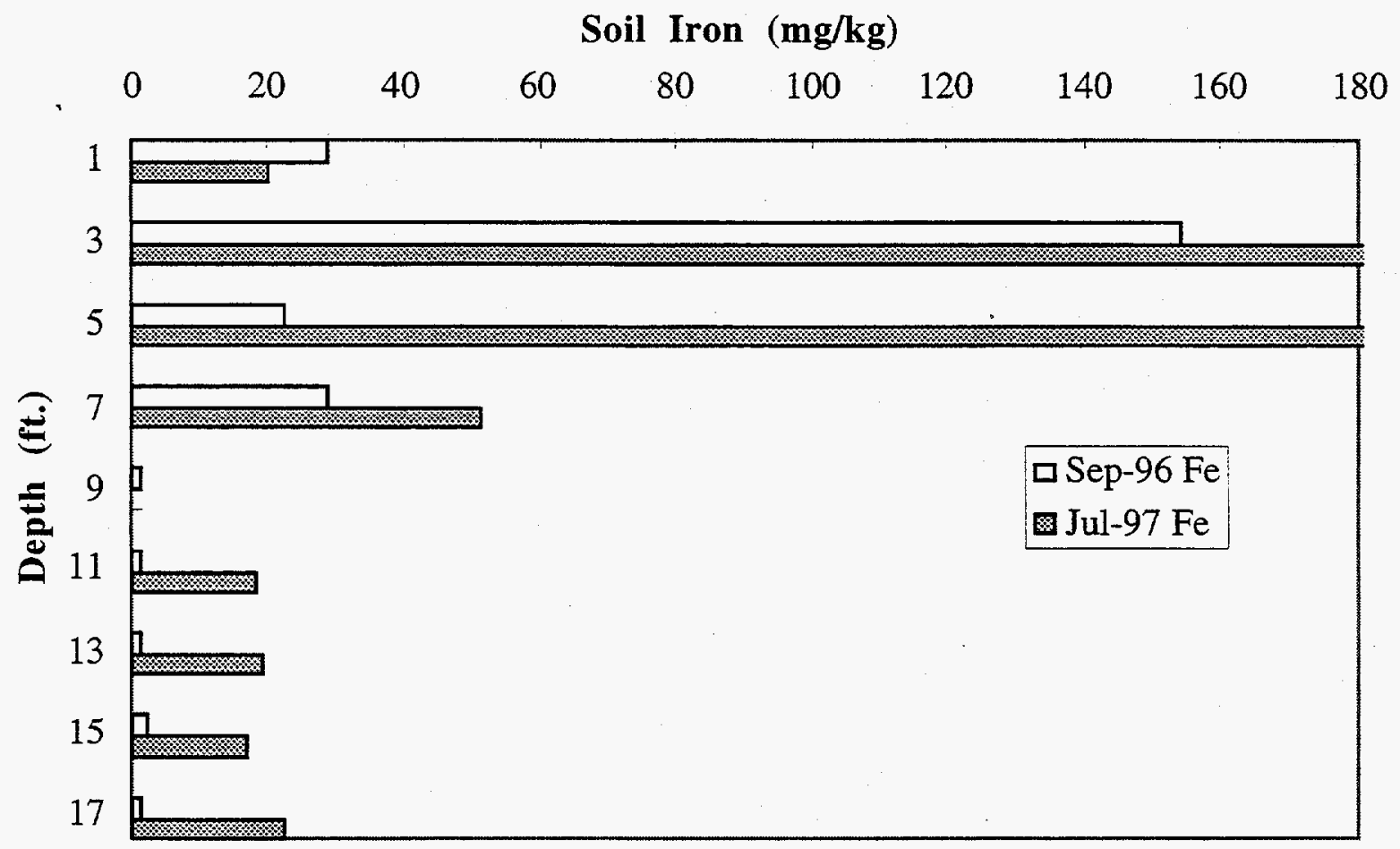

Figure 4.32. Ground water $\mathrm{pH}$ and ion concentrations in piezometer X231A-TDP1 beneath the permanganate cell.

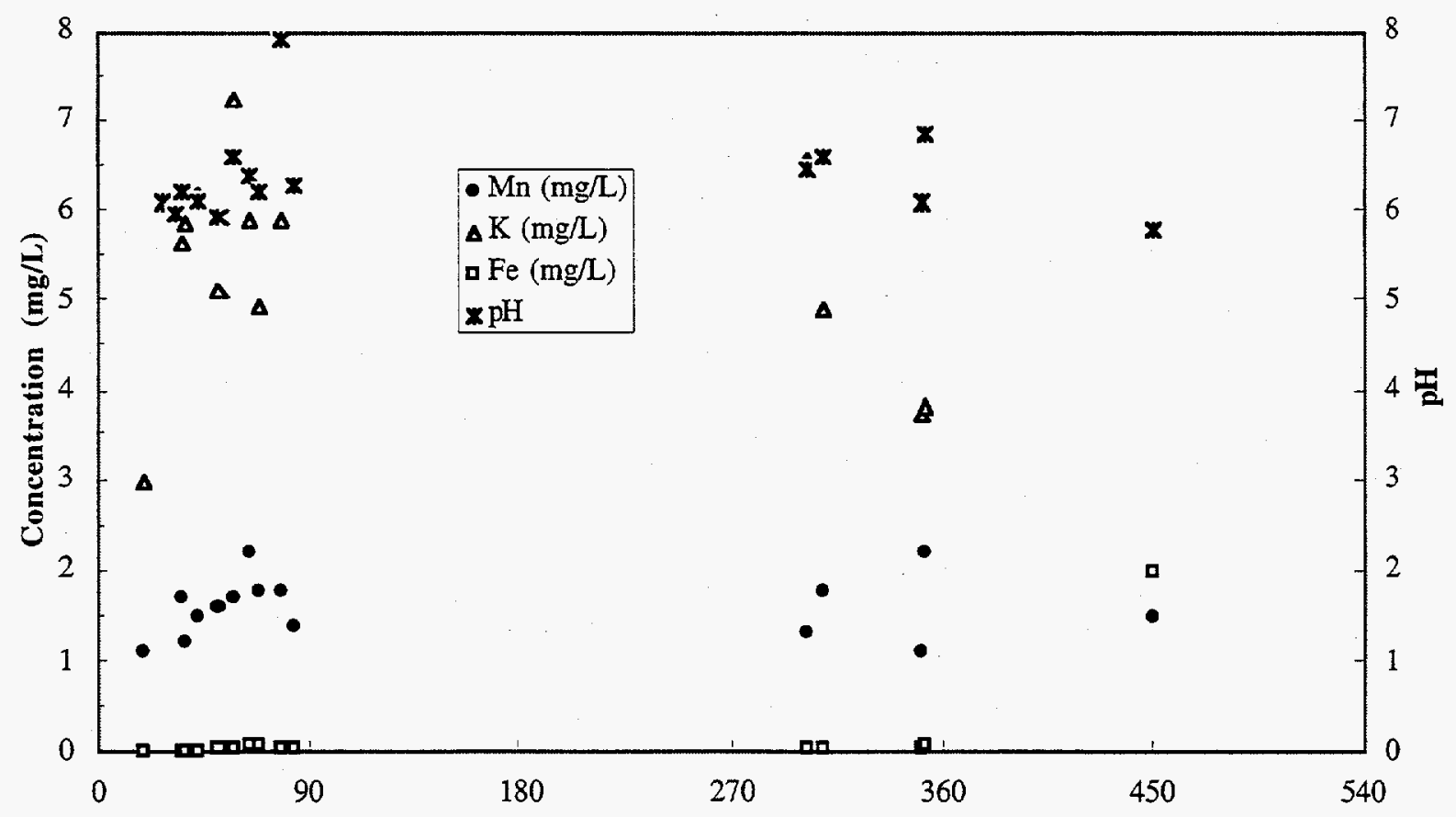


Figure 4.33. Ground water concentrations of DNAPL VOCs beneath the permanganate cell.

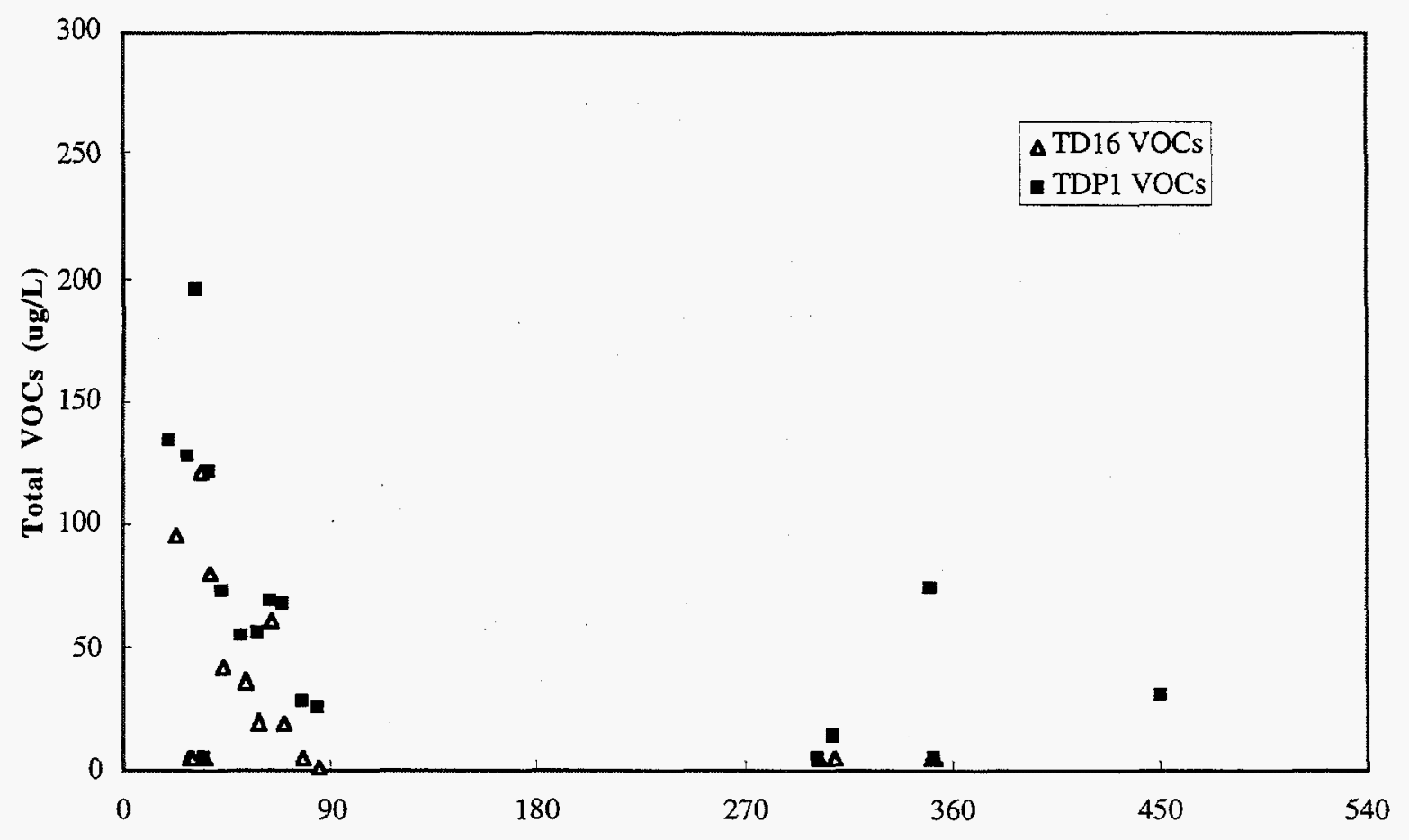


Table 4.1. TCE degradation during batch tests using iron metal collected from the fracture after emplacement as compared to the unused iron used to create the fracture.

\begin{tabular}{|c|c|c|c|c|}
\hline $\begin{array}{c}\text { Emplacement } \\
\text { duration } \\
\text { (months) }\end{array}$ & $\begin{array}{l}\text { Iron metal } \\
\text { source }\end{array}$ & $\begin{array}{c}\text { Initial TCE } \\
(\mathrm{mg} / \mathrm{L}) \\
{[\mathrm{g} \text { TCE } / \mathrm{kg}} \\
\text { media] }\end{array}$ & $\begin{array}{c}\text { Reduction after } \\
\text { 24-hr reaction } \\
(\%)\end{array}$ & $\begin{array}{c}\text { Reduction after } \\
\text { 48-hr reaction } \\
(\%)\end{array}$ \\
\hline 3 & Fracture iron & $\begin{array}{c}144 \\
{[1.2]}\end{array}$ & $28 \%$ & no data \\
\hline 10 & Fracture iron & $\begin{array}{c}54 \\
{[0.5]}\end{array}$ & $36 \%$ & no data \\
\hline 0 & Unused iron & $\begin{array}{c}54 \\
{[0.5]}\end{array}$ & $26 \%$ & $30 \%$ \\
\hline 10 & Fracture iron & $\begin{array}{c}480 \\
{[4.1]}\end{array}$ & $5-10 \%$ & $33 \%$ \\
\hline 0 & Unused iron & $\begin{array}{c}480 \\
{[4.1]}\end{array}$ & $17 \%$ & $17 \%$ \\
\hline
\end{tabular}

Table 4.2. Ground water characteristics beneath the reactive fracture cells as compared to background locations.

\begin{tabular}{|c|c|c|c|c|c|}
\hline Parameter & Units & $\begin{array}{c}\text { X231A-TCP1 } \\
\text { Average } \\
\text { Min - Max } \\
\text { No. }\end{array}$ & $\begin{array}{c}\text { X231A-TDP1 } \\
\text { Average } \\
\text { Min - Max } \\
\text { No. }\end{array}$ & $\begin{array}{c}\text { X231A-BGP1 } \\
\text { Average } \\
\text { Min - Max } \\
\text { No. }\end{array}$ & $\begin{array}{c}\text { X231A-BGP2 } \\
\text { Average } \\
\text { Min - Max } \\
\text { No. }\end{array}$ \\
\hline$\overline{\mathrm{pH}}$ & - & $\begin{array}{c}5.53-7.99 \\
16\end{array}$ & $\begin{array}{c}5.58-7.90 \\
16\end{array}$ & $\begin{array}{c}4.93-6.40 \\
16\end{array}$ & $\begin{array}{c}4.67-6.10 \\
14\end{array}$ \\
\hline Alkalinity & $\mathrm{mgCaCO}_{3} / \mathrm{L}$ & $\begin{array}{c}146 \\
50-245 \\
14\end{array}$ & $\begin{array}{c}137 \\
12-238 \\
13\end{array}$ & $\begin{array}{c}56 \\
14-76 \\
14\end{array}$ & $\begin{array}{c}63 \\
6-146 \\
14\end{array}$ \\
\hline$\overline{\mathrm{TDS}}$ & $\mathrm{mg} / \mathrm{L}$ & $\begin{array}{c}253 \\
158-299 \\
8\end{array}$ & $\begin{array}{c}272 \\
224-306 \\
8\end{array}$ & $\begin{array}{c}175 \\
76-214 \\
8\end{array}$ & $\begin{array}{c}144 \\
91-224 \\
8\end{array}$ \\
\hline$\overline{M n}$ & $\mathrm{mg} / \mathrm{L}$ & $\begin{array}{c}1.25 \\
0.50-4.10 \\
15\end{array}$ & $\begin{array}{c}1.59 \\
1.10-2.20 \\
15\end{array}$ & $\begin{array}{c}0.49 \\
0.0-1.2 \\
15\end{array}$ & $\begin{array}{c}0.38 \\
0.1-1.1 \\
14\end{array}$ \\
\hline$\overline{\mathrm{K}}$ & $\mathrm{mg} / \mathrm{L}$ & $\begin{array}{c}0.50 \\
0.21-0.76 \\
14\end{array}$ & $\begin{array}{c}5.29 \\
3.00-7.25 \\
13\end{array}$ & $\begin{array}{c}0.45 \\
0.21-0.79 \\
13\end{array}$ & $\begin{array}{c}0.38 \\
0.00-0.87 \\
13\end{array}$ \\
\hline $\mathrm{Fe}$ & $\mathrm{mg} / \mathrm{L}$ & $\begin{array}{c}2.86 \\
0.02-16.10 \\
15\end{array}$ & $\begin{array}{c}0.17 \\
0.00-1.97 \\
15\end{array}$ & $\begin{array}{c}0.44 \\
0.01-2.48 \\
15\end{array}$ & $\begin{array}{c}0.66 \\
0.03-2.40 \\
14\end{array}$ \\
\hline $\mathrm{VOCs}^{2}$ & $\mathrm{ug} / \mathrm{L}$ & $\begin{array}{c}73 \\
5-272 \\
18\end{array}$ & $\begin{array}{c}64 \\
5-196 \\
17\end{array}$ & $\begin{array}{c}78 \\
5-242 \\
17\end{array}$ & $\begin{array}{c}61 \\
5-319 \\
16\end{array}$ \\
\hline
\end{tabular}

${ }^{a}$ VOCs $=$ summation of PCE, TCE, $1,1,1-\mathrm{TCA}, \mathrm{c}-\mathrm{DCE}, \mathrm{t}-\mathrm{DCE}$. 
Table 4.3. TCE degradation in the permanganate fracture and the reactivity of the enveloping zone.

\begin{tabular}{cccccc}
\hline $\begin{array}{c}\text { Emplacement } \\
\text { duration } \\
\text { (months) }\end{array}$ & $\begin{array}{c}\text { Initial TCE } \\
(\mathrm{mg} / \mathrm{L}) \\
\text { [g TCE } / \mathrm{kg} \\
\text { media] }\end{array}$ & $\begin{array}{c}\text { Reduction after } \\
\text { 2-hr reaction at } \\
\text { the fracture } \\
(\%)\end{array}$ & $\begin{array}{c}\text { Reduction after } \\
\text { 24-hr reaction at } \\
\text { the fracture } \\
(\%)\end{array}$ & $\begin{array}{c}\text { Reactive zone } \\
\text { thickness } \\
(\mathrm{cm})\end{array}$ & $\begin{array}{c}\text { Highly reactive } \\
\text { zone thickness } \\
\text { (cm) }\end{array}$ \\
3 & $\begin{array}{c}144 \\
{[1.2]}\end{array}$ & no data & $\sim 100 \%$ & 20 & 10 \\
10 & $\begin{array}{c}54 \\
{[0.5]}\end{array}$ & $\sim 100$ & $\sim 100$ & 45 & 25 \\
10 & 480 & $\sim 70$ & $\sim 70$ & 25 & - \\
{$[4.1]$} & & & & \\
\hline
\end{tabular}

Notes: Reactive zone is defined by TCE degradation efficiency $>20 \%$ and the highly reactive zone is defined by TCE degradation efficiency $>90 \%$. 


\section{DISCUSSION}

\subsection{TECHNOLOGY PERFORMANCE}

An assessment of the performance of the different technologies demonstrated at X-231A at the DOE Portsmouth Gaseous Diffusion Plant requires that different factors be considered in an integrated manner. These include remediation technology implementation, operation and maintenance requirements, risk reduction achieved, and cost. Table 5.1 presents a list of several factors and the apparent merits of the different technologies based on the results and experiences gained at X-231A as well as from other relevant work.

With regard to risk reduction achieved by remediation of DNAPL compounds in LPM, it is increasingly recognized that achieving near $100 \%$ efficiency with any available, emerging, or conceivable in situ method is virtually impossible (e.g., Freeze and McKay 1997). Thus, establishment of cleanup goals for TCE and related DNAPL compounds in LPM must be established based on a risk reduction underpinning. For this purpose, consideration must be given not just to total mass removed or destroyed, but also to the reduction in mobile mass and the mobility of any residuals that are not removed or treated. Mobile mass in this context is defined as that mass of contaminant such as TCE that is actively migrating either by advection or diffusion in the liquid or vapor phase. Depending on site conditions, the mobile mass normally can create an unacceptable impact to ground water by leachate migration vertically downward or to the atmosphere by volatilization and vapor migration upwards. In LPM, mobile mass can represent a relatively small percentage of the total mass. This is due in large part to contaminant distribution within the fine-grained matrix during and after the initial contaminant release into the deposit and the diffusion limited mass transfer that occurs thereafter. Understanding of this concept is very important as it affects the degree of remediation efficiency required to actually reduce a posttreatment risk to a desired level.

\subsection{SITE IMPLEMENTATION ISSUES}

When considering remediation technologies for DNAPL compounds in LPM and full-scale application in a production mode at a site like PORTS, there are many issues to be considered as discussed below. While many if not most of these are not only technology specific but site and performance goal specific, some general responses can be given.

\subsubsection{Engineering Issues}

A listing of the engineering issues affecting technology implementation as well as brief responses are given in Table 5.2. Information relevant to the responses may also be gained from Table 5.1. As shown in Table 5.2, the types of issues are diverse and their resolution varies between the different technologies tested. Further definition of the appropriate response for a given issue can be better given if a specific site at PORTS along with application constraints (e.g., time to remediate) and performance goals is identified.

\subsubsection{Waste Management}

The primary waste management issues with the mass recovery and in situ destruction technologies tested are related to type and volume of any generated waste. Prior to implementation of a technology the expected volume of each waste type (sanitary, soil, and water) to be generated must be identified and its appropriate handling planned for. Wastes expected to be generated from 
implementation of the technologies tested (either hot fluid injection/flushing or horizontal reactive barriers) will include drilling spoils associated with the fracture access holes and other monitoring locations, ground water from the site due to dewatering or recirculation, waste water from equipment decontamination, and miscellaneous sanitary trash.

Specific to the PORTS site, all generated solids (i.e., soil) must be containerized in 55-gal drums. The drum filled with drilling spoils must be labeled in accordance with PORTS waste management requirements and stored as designated at an accumulation area. A request for disposal (RFD) must be completed for each drum and submitted to the PORTS waste management department for appropriate disposition. Disposition of the waste and delivery of the drums to the appropriate storage facility must be arranged with waste management. All generated liquids must be also handled in accordance with PORTS waste management requirements. A PORTS water treatment facility must pre-approve any liquid waste sent to that facility that contains chlorinated solvent contamination (e.g., TCE contaminated ground water). All liquid waste needs to meet the acceptance criteria for the pump and treat facility. Additionally, all sanitary waste must be delivered to the local off-site landfill as the site sanitary landfill has been closed effective September 26, 1997.

Any direct sampling of the generated wastes must be obtained as a composite sample. If samples are deemed necessary, sample containers and analytical services may be obtained from the PORTS laboratory.

\subsubsection{Regulatory Issues and Concerns}

Specific permits for this technology depend on site specific application and must be worked out with the appropriate regulators. A subsurface injection permit was required for all subsurface injections at PORTS. Although not required for the X-231A demonstration, an air permit may be required if high concentrations of VOCs are expected to be encountered during vapor extraction which are subsequently released to the air. Additionally, well installation and completion permitting may be required by local and state agencies, CERCLA or RCRA permitting may be required. Finally, at federal facilities, a NEPA review may be required.

\subsubsection{Worker and Environmental Safety}

Potential worker safety risks include those associated with standard construction operations as well as those associated with work at a contaminated site and with potentially hazardous chemicals. All activities must meet DOE guidelines (U.S. DOE 1984) and those applicable in Occupational Safety and Health Administration (OSHA) 29 Code of Federal Regulations (CFR) 1910 and 29 CFR 1926. For the X-231A demonstration a construction safety work permit was not required as all work was conducted under an approved Health and Safety Plan. However, a radiation work permit was also required because $\mathrm{X}-231 \mathrm{~A}$ is also considered an underground radiological contamination control zone.

While there are no severe worker or environmental safety risks associated with the technologies tested, there are notable risks. For hot fluid injection there is risk of exposure to hot surfaces or fluids (e.g., hot air, steam). Worker risk is minimized somewhat by use of down-hole steam and hot air generation. For the horizontal barriers, the risk to workers occurs during handling of reactive proppants (e.g., iron powder, permanganate crystals). Environmental risk is limited however due to the nature of materials used. Once emplaced, worker risk is negligible and the environmental risk is limited because the ground surface is not disturbed by emplacement of the fractures. There is no subsurface soil disruption after installation. 


\section{2 .5 Costs}

The costs of the technologies will vary depending on the scale of the application and the performance goals required. Let us assume that the target site is the $\mathrm{X}-231 \mathrm{~A}$ land treatment unit ( $950 \mathrm{ft}$. by $225 \mathrm{ft}$.) and the region to be treated is the Minford from $\sim 3$ to $18 \mathrm{ft}$. depth ( $15 \mathrm{ft}$. thick) with the performance required being to mitigate any downward migration of TCE to ground water in the Gallia formation. The estimated cost to treat the $118,750 \mathrm{c} . \mathrm{y}$. of soil can be estimated assuming fractures are emplaced at 5, 10 and $15 \mathrm{ft}$. depths with a diameter of $\sim 30 \mathrm{ft}$. and $\sim 10 \%$ overlap between adjacent cells which yields a total of $\sim 325$ cells. The costs for installation of sandpropped fractures including labor and materials is $\sim \$ 6000$ per cell. This amounts to $\$ 1.9$ million or $\sim \$ 16 / c$.y. of soil. Operation costs using thermally enhanced vapor extraction are estimated at $\$ 2500$ per day for resource consumption, routine operation and maintenance, and performance monitoring. Off-gas treatment could increase the operation costs by up to $100 \%$. Assuming an operation period of 1 year, the total operational costs would be $-\$ 1.8$ million or $\sim \$ 14 /$ c.y. Thus an estimated cost per unit volume of soil remediated would be $-\$ 30 /$ c.y. If the treatment time was extended to say 2 years, the cost per yard could increase up to $\$ 60 / c$.y.

The costs for the reactive barrier cells could be similarly estimated. The major differences would be added costs for the reactive media $(\sim 1.6 / \mathrm{lb}$. for permanganate and $\sim \$ 0.38 / \mathrm{lb}$. for iron metal) as compared to standard fracturing sand $(\sim 0.10 / \mathrm{lb}$.) but reduced costs due to lower operational requirements. The costs for media per fracture amounts to roughly $\$ 100$ for sand, $\$ 1000$ for iron, and $\$ 1500$ for permanganate. This increases the installation cost by $\$ 0.9$ million for the iron and $\sim \$ 1.4$ million for the permanganate. However with lower resource consumption (e.g., power), less sampling and analysis (e.g., no off-gas), reduced manpower requirements, and no off-gas treatment costs, the operational costs would be substantially lower; for example in the range of \$0.1 million per year. For a comparable period of 1 year, the cost per c.y. of soil is thus $\$ 24$ and $\$ 28$ for the iron and permanganate systems, respectively. These costs are lower but similar to those of the mass recovery systems. If the operational period exceeds one year, then the barrier systems become increasingly cost competitive.

\subsection{FURTHER DEVELOPMENT OPPORTUNITIES}

The X-231A demonstration was an ambitious effort and substantial information was gathered regarding in situ remediation of DNAPL compounds in LPM at PORTS. However, there are some further development opportunities that evolve directly out of the work completed to date particularly with regard to full-scale deployment at PORTS and elsewhere. These include analysis and development of design information from the existing data as well as generation of new data as outlined below:

- Fracture emplacement methods and equipment need to be optimized for the conditions within the Minford deposit including shallow and deep placement. Information needs to be gathered particularly related to emplacement of reactive media for horizontal treatment barriers.

- Design and implementation protocols need to be developed for horizontal reactive barrier systems including depth and interval of emplacement and reactivity and capacity over time.

o The behavior of horizontal reactive barrier systems under conditions of forced advection needs to be evaluated to understand the benefits/costs of recirculation approaches to in situ treatment and source area mass reduction as opposed to more passive barriers for simple interception and treatment. 
- Application of the horizontal barrier technology to a highly contaminated site needs to be completed. This work should be focused on production level emplacement and general evaluation of process function and performance that would produce engineering feasibility analysis and design data.

- Experimental and modeling evaluations need to be completed to further the understanding of risk reduction as a function of treatment efficiency achieved. This information is critical to establishment of reasonable and achievable cleanup goals. 
Table 5.1. Features and relative merits of individual technologies tested at the X-231A site.

\begin{tabular}{|c|c|c|c|c|}
\hline Feature or merit & Steam mass recovery & Hot air mass recovery & $\begin{array}{l}\text { Iron barrier } \\
\text { degradation }\end{array}$ & $\begin{array}{l}\text { Permanganate barrier } \\
\text { degradation }\end{array}$ \\
\hline Method of installation & Standard fracturing & Standard fracturing & $\begin{array}{l}\text { Standard fracturing } \\
\text { but with iron } \\
\text { proppant }\end{array}$ & $\begin{array}{l}\text { Standard fracturing but } \\
\text { with permanganate } \\
\text { proppant }\end{array}$ \\
\hline Time of installation per fracture & $\sim 2 \mathrm{hr}$ & $\sim 2 \mathrm{hr}$ & -2 to $3 \mathrm{hr}$ & $\sim 2$ to $3 \mathrm{hr}$ \\
\hline Predictability of fracture propagation & Good & Good & Good & Good \\
\hline Applicability to saturated zones & Only with dewatering & Only with dewatering & Yes & Yes \\
\hline Requirement for cap & $\begin{array}{l}\text { Useful but not } \\
\text { required }\end{array}$ & $\begin{array}{l}\text { Useful but not } \\
\text { required }\end{array}$ & $\begin{array}{l}\text { Useful but not } \\
\text { required }\end{array}$ & $\begin{array}{l}\text { Useful but not } \\
\text { required }\end{array}$ \\
\hline Basis of TCE reduction & $\begin{array}{l}\text { Mass transfer and } \\
\text { vapor phase transport }\end{array}$ & $\begin{array}{l}\text { Mass transfer and } \\
\text { vapor phase transport }\end{array}$ & $\begin{array}{l}\text { Interception and } \\
\text { reductive } \\
\text { dechlorination }\end{array}$ & $\begin{array}{l}\text { Interception and } \\
\text { oxidative degradation }\end{array}$ \\
\hline Applicability for non-VOCs & Potential SVOCs & Potentially SVOCs & $\begin{array}{l}\text { Potentially for metals, } \\
\text { nitrates }\end{array}$ & $\begin{array}{l}\text { Potentially for metals, } \\
\text { most organics }\end{array}$ \\
\hline Requirement for off-gas treatment & Yes & Yes & No & No \\
\hline $\begin{array}{l}\text { Potential for ground water impact by } \\
\text { technology itself }\end{array}$ & None & None & Possibly Fe(II) & Possibly Mn (II) \\
\hline $\begin{array}{l}\text { Potential daughter products not } \\
\text { removed }\end{array}$ & None & None & Vinyl chloride & Organic acids \\
\hline Operation facets & $\begin{array}{l}\text { Operation of vacuum } \\
\text { and off-gas system, } \\
\text { dewatering }\end{array}$ & $\begin{array}{l}\text { Operation of vacuum } \\
\text { and off-gas system, } \\
\text { dewatering }\end{array}$ & $\begin{array}{l}\text { None, passive unless } \\
\text { forced injection }\end{array}$ & $\begin{array}{l}\text { None, passive unless } \\
\text { forced injection }\end{array}$ \\
\hline $\begin{array}{l}\text { Resources consumed during } \\
\text { operation }\end{array}$ & Power, water & Power & $\begin{array}{l}\text { None, unless forced } \\
\text { injection }\end{array}$ & $\begin{array}{l}\text { None, unless forced } \\
\text { injection }\end{array}$ \\
\hline Performance monitoring & Off-gas, GW & Off-gas, GW & GW & $\mathrm{GW}$ \\
\hline Installation waste generated & $\begin{array}{l}\text { Borehole spoil, } \\
\text { excess fracture } \\
\text { proppant, washdown, } \\
\text { trash }\end{array}$ & $\begin{array}{l}\text { Borehole spoil, excess } \\
\text { fracture proppant, } \\
\text { washdown, trash }\end{array}$ & $\begin{array}{l}\text { Borehole spoil, } \\
\text { excess fracture } \\
\text { proppant, washdown, } \\
\text { trash }\end{array}$ & $\begin{array}{l}\text { Borehole spoil, excess } \\
\text { fracture proppant, } \\
\text { washdown, trash }\end{array}$ \\
\hline Process waste generated & Off-gas, dewatering & Off-gas, dewatering & None & None \\
\hline Safety risks & Hot surfaces, gases & Hot surfaces, gases & Material handling & Material handling \\
\hline Cost per c.y. & $\$ 30$ to $\$ 90$ & $\$ 30$ to $\$ 90$ & $\$ 30$ & $\$ 30$ \\
\hline
\end{tabular}


Table 5.2. Implementation issues and concerns that need resolution to support full-scale application at PORTS.

Site engineering issues or concerns
General response
1. Effects on natural attenuation used as a follow-on polishing step?
Effects of hot fluids may be to increase biological activity which could provide a bioventing component. If reductive dechlorination were ongoing however, the air flow could induce oxidizing conditions and negate it.

Effects of reactive barriers is in a form a natural attenuation method.

\begin{tabular}{|c|c|}
\hline $\begin{array}{l}\text { 2. Type of characterization data } \\
\text { needed? }\end{array}$ & $\begin{array}{l}\text { Subsurface mechanical properties for fracturing in general } \\
\text { and contaminant distribution for treatment design and } \\
\text { operation. }\end{array}$ \\
\hline $\begin{array}{l}\text { 3. Treatment life, need for periodic } \\
\text { chemical replacement? }\end{array}$ & $\begin{array}{l}\text { Life is on the order of } 1 \text { year or more. Need for chemical } \\
\text { replacement is situation specific. }\end{array}$ \\
\hline 4. Passive vs. active systems? & $\begin{array}{l}\text { Passive system is preferred as barrier but active system } \\
\text { may be better for hot spots and mass reduction quickly. }\end{array}$ \\
\hline $\begin{array}{l}\text { 5. Applicability to the saturated } \\
\text { zone; is dewatering needed? }\end{array}$ & $\begin{array}{l}\text { Vapor phase process need dewatering; barrier techniques } \\
\text { do not. }\end{array}$ \\
\hline $\begin{array}{l}\text { 6. Is a liner required, recommended } \\
\text { or discouraged? }\end{array}$ & Not needed, but can be useful. \\
\hline $\begin{array}{l}\text { 7. What are the geological } \\
\text { limitations? }\end{array}$ & $\begin{array}{l}\text { Fracturing is most suitable for finer grained layered } \\
\text { sediments or those with the correct state of stress. } \\
\text { Applications have been in the Midwest, New England, } \\
\text { and Rocky Mtn, etc. }\end{array}$ \\
\hline 8. What are the safety issues? & $\begin{array}{l}\text { Low pressures are used; chemical handling during } \\
\text { installation of treatment barrier. }\end{array}$ \\
\hline 9. Patent restrictions for use? & Some patents exist or may be sought. Effects uncertain \\
\hline 10. Fracture intervals and overlap? & $\begin{array}{l}\text { Fractures in the Minford appear to be best at } 5 \mathrm{ft} \text {. or below } \\
\text { and with an interval of } 5 \mathrm{ft} \text {. } 10 \% \text { overlap. }\end{array}$ \\
\hline $\begin{array}{l}\text { 11. Expected treatment and } \\
\text { diffusion rates? }\end{array}$ & $\begin{array}{l}\text { Technology, site, and goal specific. Mass recovery } \\
\text { processes will take } 3 \text { months to a year or more while } \\
\text { treatment barriers will last } 1 \text { to several years. }\end{array}$ \\
\hline $\begin{array}{l}\text { 12. Contaminants being treated and } \\
\text { products? }\end{array}$ & $\begin{array}{l}\text { Mass recovery will recover contaminants with v.p. }>10 \\
\text { mm Hg; iron barrier will reduce many oxidized } \\
\text { compounds including } \mathrm{TCE}, \mathrm{NO}_{3} \text { and some metals but } \\
\text { vinyl chloride can be a transient concern; Permanganate } \\
\text { barriers will treat unsaturated halocarbons, aromatics, } \\
\text { phenols, and may precipitate some metals. }\end{array}$ \\
\hline $\begin{array}{l}\text { 13. What are depth limitations of } \\
\text { fractures? }\end{array}$ & None really; $50 \mathrm{ft}$. is max. so far. \\
\hline $\begin{array}{l}\text { 14. Special equipment or expertise } \\
\text { required? }\end{array}$ & $\begin{array}{l}\text { Need design expertise and skilled contractor for } \\
\text { emplacement and operational setup. }\end{array}$ \\
\hline
\end{tabular}




\section{SUMMARY AND CONCLUSIONS}

Chlorocarbons like TCE are classified as dense non-aqueous phase liquid compounds and they are prevalent at contaminated sites in multiple phases. There presence in LPM poses a challenge for assessment of their behavior and risk, and for implementation of effective in situ remediation technologies. As part of a program of activities focused on in situ remediation of DNAPL compounds in LPM, a technology demonstration was completed at the X-231A land treatment unit located at the DOE Portsmouth Gaseous Diffusion Plant in Ohio. This project evaluated hydraulic fracturing as an enabling technology for in situ remediation of TCE by thermally enhanced mass recovery or in place chemical destruction. At the X-231A site, four test cells were established and evaluated between August 1996 and December 1997. Two of the test cells were comprised of a set of horizontal sand-propped fractures that were used for mass recovery of TCE by hot air or steam enhanced soil vapor extraction. Two other cells were comprised of horizontal fractures that were filled with reactive media to yield chemical destruction barriers. The methods and results of the X$231 \mathrm{~A}$ project have been described in this report. Given below are several conclusions that have been drawn based on the field demonstration at X-231A and related work:

- LPM deposits are common across the PORTS site and the DOE Complex and can be expected to vary widely in lithology and their biogeochemical characteristics. Properties such as grain size distributions, particle mineralogies and surface reactivities, subsurface hydrology and microbiology, and structural pore and fracture aperture size, spacing, and continuity are likely quite different and these variations can dramatically impact in situ remediation technology design, operation, and performance.

- DNAPL compounds are also common in the DOE Complex, including DNAPLs in LPM, and their behavior is highly uncertain in many LPM settings. DNAPL compounds that have been distributed in the LPM pore and fracture system and fine-grained matrix during years of exposure and aging, can result in a chromatographic separation of individual compounds. Diffusion-limited mass transfer of compounds that have migrated into the matrix can make it difficult if not impossible to achieve rapid and extensive in situ treatment (e.g., $>90 \%$ removal).

- Soil fracturing of LPM deposits through hydraulic (i.e., use of a liquid) or pneumatic (i.e., use of a gas) methods can be employed to increase the permeability of the subsurface to varying degrees. Existing channels or pathways can be expanded and/or new channels or pathways can be created. Hydraulic methods normally employ an agent or proppant (e.g., sand) to fill and support the fracture opening that was created and thereby prevent fracture closure during natural healing processes in the unconsolidated deposits. Hydraulic methods thus appear more suited to unconsolidated LPM like silt and clay deposits. If the fractures can be spaced closely together and/or be made in a dispersed fashion throughout an LPM deposit, they potentially could be used to (1) enhance the recovery of DNAPL compounds, (2) deliver and distribute treatment agents into the LPM deposit and accomplish destruction in place, or (3) place treatment media as an integral part of the emplaced fracture in which case it could serve as a permeable treatment barrier.

o At the X-231A site, hydraulic fracturing was successfully used to efficiently create over 25 fractures at depths ranging from 4- to 18 -ft bgs and at spacings of as little as 2 to $3 \mathrm{ft}$. The fractures were created using relatively small and uncomplicated trailer-mounted equipment and low pressures. Normal sand proppants were emplaced with typical guar gum gel as well as reactive particle proppants which were emplaced with either guar gum or a mineralbased carrier fluid. Mapping of the fractures through surface lift measurements as well as direct observation via numerous coreholes revealed varied geometries within the subsurface. In general the fractures were initially flat around the point of initiation but then 
gradually climbed toward the ground surface. For the conditions of the Minford at PORTS, fracture placement should probably be at a depth of at least $5 \mathrm{ft}$. or more to avoid venting to the ground surface and the interval between fractures should be $\sim 5 \mathrm{ft}$ to avoid fracture co-mingling. Achievable diameters appear to be on the order of $20 \mathrm{ft}$. at the shallower depths and up to $30 \mathrm{ft}$. at depths near the bottom of the Minford.

o The injection of heat has either hot air or steam into shallow wells followed a similar conceptual model. The temperature increased in the vicinity of the well at early times and the heat added to the formation was approximately 75 percent of the injected heat. With increasing injection, the fraction of injected heat that was lost increased. Heat loss apparently occurred primarily by conduction to the atmosphere as the ground surface warmed, by advection out of the ground surface, and by advection of water and air recovered at wells. The rate of heat loss increased with time until it equaled the rate of heat injection. Thus, there is a maximum amount of heat that can be added to the shallow subsurface by the injection of hot fluids. Injection of hot fluids after that maximum has been reached will have only minor effects.

- The maximum amount of heat that could be injected is roughly proportional to the rate at which heat was injected. When hot air was injected at $14 \mathrm{~kW}$-hr/day, the maximum heat that was added to the ground appears to be $250 \mathrm{~kW}-\mathrm{hr}$. Increasing the rate of heat injection by a factor of five to $70 \mathrm{~kW}$-hr/day caused the maximum amount of heat added to the subsurface to be increased by a factor of four to $1000 \mathrm{~kW}$-hr. This general trend is also recognized during steam injection. During that test, heat was injected at a rate of $120 \mathrm{~kW}$ $\mathrm{hr} / \mathrm{day}$, which is 8.6 times greater than the first air injection test. This resulted in at least $1600 \mathrm{~kW}-\mathrm{hr}$ of heat added to the subsurface, and increase of 6.4 times compared to the initial hot air test. That estimate is a lower limit for the maximum heat that could be injected using steam at Cell $\mathrm{A}$; it is possible that additional heat could have been injected but the data are unavailable to make this assessment.

o Thermally enhanced vapor extraction employing down-hole steam generation was demonstrated during the first 3 weeks of the summer test, when heat was injected as steam at a rate of $160 \mathrm{~kW}-\mathrm{hr} / \mathrm{day}$. This produced temperatures of roughly $100 \mathrm{C}$ at a boring $1 \mathrm{~m}$ from the well in nine days and the heated zone expanded with time. The region significantly heated by steam injection for 3 weeks was $6 \mathrm{~m}$ in maximum dimension and extended from $4 \mathrm{~m}$ depth to the ground surface. The hydraulic fracture into which steam was injected was $6 \mathrm{~m}$ in maximum dimension and it appears that significant heating occurred in the vicinity of the fracture, although minor heating occurred several $\mathrm{m}$ beyond the fraction.

o Steam injection during the Fall 1996 test was minor and had little effect on subsurface temperatures. This occurred because the injection well was clogged by minerals that precipitated from water that splashed from the steam generator. The clogged well caused injection pressures to exceed design specifications for the steam generator, resulting in a variety of mechanical problems during the Fall 1996 test. The steam generator was modified to eliminate splashing and the well remained open during the Summer 1997 test. Consequently, the mechanical problems during the Fall 1996 test were absent from the Summer 1997 test. However, the steam generator did encounter other problems related to an unexpected power outage and an unanticipated disruption of the air source used in the water-level control system in the generator. The down-hole steam generator appears to be a viable approach for heating subsurface formations. However, the implementation of this technique on a widespread basis will require some refinements of the prototype used for these tests to include additional fail-safe mechanisms to improve robustness. 
- Thermally enhanced vapor extraction by down-hole hot air generation and fracture injection proved successful in terms of operational reliability and function. Subsurface temperatures were elevated to a maximum of $70^{\circ} \mathrm{C}$ at an observation point $1 \mathrm{~m}$ from the injection point and air flow rates were increased somewhat following heating. Mass recovery of TCE from the shallower zones of the Minford (e.g., up to $8 \mathrm{ft}$. or so) was quite high as evidenced by changes in off-gas composition and pre- and post-treatment coring (nearly $90 \%$ reduction based on initial levels reduced from an average of $\sim 10$ to $50 \mathrm{mg} / \mathrm{kg}$ to $<1$ $\mathrm{mg} / \mathrm{kg}$, Appendix D). Significant heating occurred several $\mathrm{ft}$ or more below the fracture into which hot air was injected. Recovery of mass was greater than 85 percent above the fracture, and it was less than that at greater depths. The fraction of contaminants removed over the entire thickness of the Minford (18 ft) was 60 percent (Appendix D). Those data are for the fall 1996 test when the heat was injected at a rate of $14 \mathrm{~kW}-\mathrm{hr} /$ day. It is expected that considerably greater fractions of contaminants may have been removed during the summer test when the rate at which heat was injected was increased to $70 \mathrm{~kW}$-hr/day. Data to determine contaminant removal during the summer 1997 test are unavailable.

- Future implementations of this approach should expect significant mass recovery to be occur in the area over the fracture receiving hot fluid injection, a result that was anticipated based on preliminary modeling and confirmed by the field test. The discovery of purephase DNAPL in a piezometer (X231A-BGP3) at $17 \mathrm{ft}$. bgs in the vicinity of test cell B adjacent to the test cell $B$ is consistent with this conclusion. This indicates that the area that can be treated by hot fluid injection will increase by injecting fluids at greater depth. In as much as the contaminants at Cell B were concentrated between 8 and $10 \mathrm{ft}$, it is expected that removal could be increased by injecting hot fluids into the hydraulic fracture created at $12 \mathrm{ft}$ depth.

- Hot air injection was the most viable method of heating subsurface formations during this test. Steam injection was capable of delivering heat to the subsurface at a greater rate, but the hot-air technique was more reliable and required less maintenance.

o The primary assessment of contaminant removal was based on the Fall 1996 tests, however, significantly more heat was injected in both the hot air and the steam cells during the Summer 1997 tests. Data to determine the contaminant removal during the Summer 1997 tests are unavailable due to budget limitations.

- Fractures containing iron particles as the proppant were successfully emplaced at depths of 6,8 , and $12 \mathrm{ft}$ bgs. Based on morphology and geochemical measurements along profiles transecting the fractures, the iron proppant remained reactive but there was little effect on surrounding soil matrix. Concentrations of ambient TCE in the test cell used for these barriers turned out to be too low to simply rely on changes in ambient TCE levels for assessment of treatment efficiency. Thus, degradation efficiency was assessed using intact cores and on-site batch experiments with DNAPL contaminated ground water from the site. These studies confirmed that the reactive zone was confined to the iron metal itself. The degradation efficiency of the iron metal retrieved from the fractures 10 months after initial emplacement was relatively slow, with degradation of TCE with initial concentrations in the range of 50 to $500 \mathrm{mg} / \mathrm{L}$ (equivalent to $\sim 400$ to $4000 \mathrm{mg}$ TCE per $\mathrm{kg}$ reactive solid) equal to only -30 to $40 \%$ during reaction periods of 24 - or 48 -hr. However, assuming firstorder kinetics and normalizing these batch test rates to a solids:solution ratio present within an actual iron-filled fracture, the half-lives are consistent with those previously reported (e.g., $40 \mathrm{~min}$.) and the degradation rates are adequate for treatment of TCE in percolating ground water within an LPM deposit. The iron metal in the proppant did show signs of surface corrosion, but the degradation efficiency was comparable to that of unused iron even after up to 10 months of emplacement in the moist, silty clay subsurface. However, with aging over 15 months, either above-ground or during subsurface emplacement within 
a fracture, the degradation rates appeared to decline and they were generally lower at increasing initial TCE concentrations.

- Fractures containing a new permanganate grout as the fracturing fluid and proppant were successfully emplaced at depths of $\sim 7,9$, and $11 \mathrm{ft}$ bgs. Morphology and geochemical measurements along representative profiles indicate that this process created highly reactive fracture enveloped by zones of reactive soil that continued to grow from approximately $30-$ $\mathrm{cm}$ thick after 3 months to nearly 90 -cm thick after 15 months. Concentrations of ambient TCE in the test cell used for these barriers also turned out to be too low to simply rely on changes in ambient TCE levels for assessment of treatment efficiency. Thus, degradation efficiency was assessed using samples of the fractures and reactive soil obtained from intact cores for on-site batch experiments with DNAPL contaminated ground water from the site. These studies confirmed that there was a reactive zone with high and sustained degradation potential. Dissolved TCE with initial concentrations of in the range of about 50 to 500 $\mathrm{mg} / \mathrm{L}$ (equivalent to $\sim 400$ to $4000 \mathrm{mg}$ TCE to $\mathrm{kg}$ of reactive solid) was completely degraded ( $100 \%$ efficiency) in batch tests using either material from the fractures or reactive soil from the vicinity above and below the fractures. Complete degradation was observed in as little as $2 \mathrm{hr}$. The degradation potential as a function of time and space, was controlled by the mass of permanganate ion that was present in the fracture or the fraction of it that had dissolved/diffused into the soil matrix and had not been previously consumed.

o Vapor phase mass recovery processes coupled with hydraulic fracturing and thermal enhancements appear to be primarily focused on the region overlying fractures receiving hot fluid injection. Significant reductions to complete removal of contaminant mass in the Minford deposit at PORTS were observed above the water table after several months of operation. A highly heterogeneous distribution of contaminant mass, and low levels of contaminants in the vicinity of some test cells, particularly Cell $\mathrm{A}$, preclude a thorough evaluation of the efficiency of contaminant recovery. Performance of this system below the water table was not evaluated during this work and cannot be determined from the available data, although it appears that contaminant mass is not significantly affected below fractures receiving hot fluid injection.

- The hot-fluid injection technologies tested during this work were significantly slower and less extensive, both laterally and with depth, than the aggressive method of mixed region vapor stripping that was demonstrated and employed at the nearby X-231B site at PORTS. However, fracture enhanced technologies were also significantly less disruptive and expensive to implement.

o The performance of the hot fluid injection tests have been used to develop a preliminary estimate of costs to implement across the X-231 site (data cited above). The costs are less than the mixed region process, but could be greater than the reactive barrier process. In view of the preliminary cost estimates, coupled with uncertainties regarding performance of hot fluid injection in areas that were not tested during this program (e.g. below the water table), it appears that the reactive barrier approach holds the greatest potential for a cost effective method of remediation of the Minford deposit at the X-231 site.

o The most viable option for in situ remediation as of this writing involves horizontal barriers that can degrade as well as mitigate downward and upward migration of mobile TCE and other DNAPL compounds. Of the two barrier concepts tested, the oxidative particle grout barrier comprised of potassium permanganate appeared superior to that of the iron metal barrier. This conclusion is based on the diffuse zone of very high reactivity that was achieved and sustained around the permanganate fracture zone. Further work is needed however to fully develop the horizontal reactive barrier technology approach and provide needed design and performance data for full-scale application. 
o The risks of adverse effects to environmental quality or public health are difficult to quantify for DNAPL compounds in LPM. Mass transfer limitations which hinder effective in situ remediation suggest that mobility of residual compounds may be limited and the risks of adverse effects of no consequence. However, there are sites where LPM deposits contaminated by DNAPLs have been a long-term source of ground water contamination well above drinking water standards and even other more risk-based cleanup criteria. Research regarding the mobility of residual untreated DNAPLs in LPM and the concomitant risk associated with them requires further controlled experimentation. 


\section{REFERENCES}

American Petroleum Institute. 1995. Petroleum Contaminated Low Permeability Soil: Hydrocarbon Distribution Processes, Exposure Pathways and In Situ Remediation Technologies. Health and Environmental Sciences Dept. Publication No. 4631. September 1995.

ASI. 1988. Sampling Report for Piketon Oil Biodegradation Plot Project. Prepared By Advanced Sciences, Inc. for Martin Marietta Energy Systems. Piketon, Ohio.

Case, T. 1997. Reactive permanganate grouts for horizontal permeable barriers and in situ treatment of ground water. M.S. thesis, Environmental Science \& Engineering Division, Colorado School of Mines, Golden, CO.

Davenport, D.T., D.J. Georgopoulos, R.L. Siegrist, M.I. Morris, and O.R. West. 1994. Technology Demonstration, Assessment, and Application for a RCRA Closure: Observations and Lessons Learned in the Process. Proc. Spectrum '94, Atlanta, August, 1994.

Dawson, H.E. 1997. Screening Level Tools for Modeling Transport and Fate of Organic Chemicals in Soil and Groundwater (SOILMOD, TRANS1D, NAPLMOB). Software and User's Manual distributed by the Colorado School of Mines, Special Programs and Continuing Education, Golden, CO.

DOE. 1996. In Situ Remediation of DNAPL Compounds in Low Permeability Media: Transport/Fate, In Situ Control Technologies, and Risk Reduction. Joint project report containing 16 focus papers authored by national experts. Oak Ridge National Laboratory Report, ORNL/TM13305, for the U.S. Department of Energy, Office of Technology Development. August, 1996.

Freeze, R.A. and D.B. McKay. 1997. A Framework for Assessing Risk Reduction Due to DNAPL Mass Removal From Low-Permeability Soils. Ground Water. 35(1):111-123.

Gates, D.D. and R.L. Siegrist. 1995. In Situ Chemical Oxidation of Trichloroethylene Using Hydrogen Peroxide. ASCE Journal of Environmental Engineering 121(9): 639-644.

Gierke, J.S., C. Wang, O.R. West, and R.L. Siegrist. 1995. In Situ Mixed Region Vapor Stripping of Low Permeability Media: 3. Modeling of Field Tests. Environ. Science \& Technology. 29(9):2208-2216.

Hill, J.A., R.L. Siegrist, T.J. Phelps, S.M. Pfiffner, and A.V. Palumbo. 1996. Intrinsic Bioremediation Potential in Fractured Low-Permeabihty Media: Literature Review and Conceptual Model Development. Preliminary project report. $107 \mathrm{pp}$.

Huling, S.G. and J.W. Weaver. 1991. Dense Nonaqueous Phase Liquids. Ground Water Issue Paper, EPA/540/4-91-002. Office of Research and Development, Washington, D.C. 20460.

Hunt, J.R., N. Sitar, and K.S. Udell. 1988. Non-aqueous Phase Liquid Transport and Cleanup: Part I. Analysis of Mechanisms, and Part II. Experimental Studies. Water Resources Research. 24(8):1247-1269.

Johnson, R.L., and D. Grady. 1995. Remediation of Tight Soils Using Air Flushing: Summary of 1994 Field Experiments at Sarnia Ontario. Prepared for the American Petroleum Institute by Oregon Graduate Institute Center for Groundwater Research, Beaverton, Oregon. 
Johnson, R., D. Grady, T. Walden, and H. Hopkins. 1995. Remediation of Gasoline Contaminated Low Permeability Media as Evaluated at a Controlled Release Test Site. Invited presentation at the Second International Conference on Challenges and Innovations in the Management of Hazardous Wastes. Air and Waste Management Conference, May, 1995, Washington, D.C.

Korte, N.E., R.L. Siegrist, and P.M. Kearl. 1994. In Situ Treatment of Mixed Contaminants by Process Modules Coupled with Groundwater Recirculation Systems. Proc. I\&EC Special Symposium, American Chemical Society, Atlanta, GA, September.

Labieniec, P.A., D.A. Dzombak, and R.L. Siegrist. 1996. SoilRisk: A Risk Assessment Model for Organic Contaminants in Soil. J. Environmental Engineering. 122(5):388-398.

Liang, L., O.R. West, N.E. Korte, J.D. Goodlaxson, D.A. Pickering, J.L. Zutman, F.J. Anderson, C.A. Welch, M.J. Pelfry, and M.J. Dickery. 1997. The X-625 Groundwater Treatment Facility: A Field-Scale Test of Trichlorotheylene Dechlorination Using Iron Filings for the X-120/X-749 Groundwater Plume. Oak Ridge National Laboratory report, ORNL/TM-13217.

MacDonald, J. A. and M. Kavanaugh. 1994. Restoring Contaminated Groundwater: An Achievable Goal? 1994. Environ. Sci. \& Technol. 28(8): 362A-368A.

Murdoch, L., W. Slack, R. Siegrist, S. Vesper, and T. Meiggs. 1997. Advanced Hydraulic Fracturing Methods to Create In Situ Reactive Barriers. Proc. International Containment Technology Conference and Exhibition. February 9-12, 1997, St. Petersburg, FL. In press.

Murdoch, L., B. Slack, B. Siegrist, S. Vesper, and T. Meiggs. 1997. Hydraulic Fracturing Advances. Civil Engineering. May 1997. pp. 10A-12A.

Pfiffner, S.M., R.L. Siegrist, K.S. Lowe, D.B. Ringleberg, and A.V. Palumbo. 1997. Sarnia: Bioremediation Processes Demonstrated at a Controlled Release Site. Symposium on In Situ and On-Site Bioremediation. April 1997. New Orleans.

Siegrist, R.L., M.I. Morris, O.R. West, D.D. Gates, D.A. Pickering, et al. 1993. Full-scale Demonstration of Physicochemical Processes for In Situ Treatment of Contaminated Soil. Proc. Waste Management '93. Mar. 1993. Tucson, AZ. U.S. Department of Energy.

Siegrist, R.L. and J.J. van Ee. 1994. Measuring and Interpreting VOCs in Soils: State of the Art and Research Needs. EPA/540/R-94/506. Office of Research and Development, Washington, D.C. 20460 .

Siegrist, R. L., D. D. Gates, O. R. West, T. L. Donaldson, L. Liang, O. F. Webb, S. L. Corder, and K. S. Dickerson. 1994. In Situ Physical/Chemical Treatment Technologies for Remediation of Contaminated Sites: Applicability, Development Status, and Research Needs. U.S. Department of Energy, Office of Technology Development, In Situ Remediation Integrated Program. Oak Ridge National Laboratory, Oak Ridge, Tennessee.

Siegrist, R.L., O.R. West, J.S. Gierke, et al. 1995. In Situ Mixed Region Vapor Stripping of Low Permeability Media. 2. Full Scale Field Experiments. Environ. Science \& Technology. 29(9):2198-2207.

Siegrist, R.L. and K.S. Lowe (ed.). 1995. In Situ Remediation of DNAPL Compounds in Low Permeability Media - Interim Report. Interim project report prepared by Oak Ridge National Laboratory with contributions from an ad hoc team of scientists and engineers from DOE national laboratories, academia, and industry. 
Siegrist, R.L., N. E. Korte, M.T. Muck, D.R. Smuin, A.D. Laase, O.R. West, D.T. Davenport, and J. Walker. 1995b. Field Evaluation of Subsurface Manipulation by Fracturing, Multipoint Injection/Dispersal, and Directional Drilling Using Unconfined Test Cells. Invited presentation at the Second International Conference on Challenges and Innovations in the Management of Hazardous Wastes. Air and Waste Management Conference, May, 1995, Washington, D.C.

Siegrist R.L., N.E. Korte, M.T. Muck, D.R. Smuin, A.D. Laase, O.R. West, D.T. Davenport, and J. Walker. 1995c. Field Evaluation of Subsurface Manipulation by Fracturing, Permeation Dispersal, and Horizontal Well Recirculation Using Unconfined Test Cells. Invited presentation at the National Ground Water Association Annual Educational Conference, October, 1995, Indianapolis, IN.

Siegrist, R.L., N.E. Korte, D. Smuin, O.R. West, D.D. Gates, and J.S. Gunderson. 1996. In Situ Treatment of Contaminants in Low Permeability Soils: Biogeochemical Enhancement by Subsurface Manipulation. Invited presentation at First International Conference on Contaminants in the Soil Environment in the Australasia-Pacific Region. February 1996, Adelaide, South Australia.

Smith, L.A. and R.E. Hinchee. 1992. In Situ Thermal Technologies for Site Remediation. Lewis Publishers, Chelsea, MI.

Smuin, D.R., R.L. Siegrist, N.E. Korte, O.R. West, J. Strong-Gunderson, and P.M. Kearl. 1995. Bromide Tracer Evaluation of a Multipoint Injection System for Soil Treatment. Presentation at American Geophysical Union, Fall, 1995 meeting.

U.S. EPA. 1992. Dense Nonaqeuous Phase Liquids -- A workshop Summary. EPA/600/R92/030. Office of Research and Development, Washington, D.C. 20460.

U.S. EPA. 1993. Hydraulic Fracturing Technology - Technology Evaluation Report. EPA/540/R-93/505. Office of Research and Development, Cincinnati, OH.

Walden, T. 1993. Remediation of Low Permeability Soils: An API Research Program. Proc. 1993 Petroleum Hydrocarbons and Organic Chemicals in Groundwater: Prevention, Detection, and Restoration. Houston, TX. National Water Well Assn. pp. 623-629.

West, O.R., R.L. Siegrist, J. S. Gierke, et al. 1995. In Situ Mixed Region Vapor Stripping of Low Permeability Media. 1. Laboratory Experiments. Environ. Science \& Technology. 29(9):2191-2197.

Wust, W., O. Schlicker and A. Dahmke. 1998. Degradation of TCE at Zero-Valent Iron: Chemical Processes Effecting the Design and Performance of Permeable, Reactive Fe(0) Walls. Proceedings NATO/CCMS Workshop on Treatment Walls, Vienna, Austria, February 23-24, 1998. 
APPENDIX A. PRE-DEMONSTRATION RECONNAISSANCE AND TECHNOLOGY TESTING 


\section{A.1 INTRODUCTION}

Prior to establishing the field test cells at the X-231A site and instrumenting them for performance monitoring, preparatory laboratory and field testing was accomplished at two uncontaminated sites available to the project team. The two clean test sites included one located near Cincinnati (i.e., Aber Road site) and another at the DOE Portsmouth Gaseous Diffusion Plant (i.e., Clean Test Site or CTS). This clean site testing was deemed necessary and appropriate since major components of the process equipment and monitoring systems to be employed during the X-231A demonstration had not yet been utilized in conjunction with soil remediation systems enhanced by hydraulic fracturing. For example, in-well units for generating steam and hot air were developed specifically for this project. Thus, the following objectives were pursued during the preparatory testing:

- Conduct field evaluation and equipment development of hot fluid injection into hydraulic fractures at Aber Road,

- Install, operate, and evaluate innovative sidewall sensor systems for measurement of in situ temperature, moisture, and Eh at Aber Road,

- Create hydraulic fractures at the PORTS CTS to prove the feasibility at PORTS,

- Install and operate sensors at PORTS to gain expectation of resultant performance,

- Reconnaissance characterization for selection of an appropriate demonstration site, and

- Development of a specially formualted potassium permanaganate grout for emplacement as a reactive horizontal barrier.

\section{A.2 TESTING OF A DOWN-HOLE STEAM GENERATOR}

\section{A.2.1 Above Ground Testing}

An in-well steam generator was subjected to a two-week above-ground test in a simulated well, which was a vertically mounted section of 6-inch pipe. The generator was built and the testing was conducted by the University of Cincinnati under the auspices of a project funded by the DOD. Results were available to this project as a technical "leverage" of mutual interest.

The generator consisted of an $8 \mathrm{~kW}$ electrically powered heating element, float switches for liquid level control, thermocouples, and a pressure safety relief valve mounted on a custom fabricated steel chassis. Ancillary electrical control and regulated water supply were mounted on the ground surface near the well. The generator relied upon flexible rubber seals to confine the steam in the selected length of casing. These seals, which are known as "k-packers", are finned neoprene sleeves that fit tightly over the outside of 4 inch pipe (the chassis of the generator) and wipe snugly on the inside of 6 -inch pipe (the well casing).

The system operated for 10 days at atmospheric pressure, i.e. with the safety valve removed and no other restriction in its vent to the atmosphere. Control equipment showed an internal temperature of $99^{\circ} \mathrm{C}$, which is consistent with atmospheric boiling and the accuracy of equipment. Average water consumption was about $8.5 \mathrm{~kg} / \mathrm{hr}$. The corresponding power was about $2 / 3$ of the rated $8 \mathrm{~kW}$ of the generator. The remaining $1 / 3$ of the power was probably lost as heat to the atmosphere. Ambient air temperature during the test was not recorded but ranged from $-5{ }^{\circ} \mathrm{C}$ to $10{ }^{\circ} \mathrm{C}$. Calculations utilizing typical heat transfer coefficients for vertical cylinders in air and the temperature difference between the hot pipe and the air are consistent with the observed efficiency.

Subsequently restriction was added to the vent from the steam generator, and pressure and temperature within the generator increased. The system operated successfully at pressures up to 6.5 psi until the last day of the test. During the last day, pressure was increased in increments. 
Upon reaching an internal pressure of $11 \mathrm{psi}$, the generator, which was suspended in the 6-inch pipe by friction, dropped downward until it lodged on a edge in the piping and the upper k-packer vented a significant stream of steam. Pressure was reduced, and the seal recovered sufficiently to permit operation at $3.5 \mathrm{psi}$ until the end of the day. The generator was shut down and removed for inspection and transportation to the Aber Road facility.

In evaluation, a paper-thin coating of scale was observed on all internal surfaces, but the control floats, thermocouples, and heating element showed no sign of deterioration. The fins of the kpackers were deformed and torn. It was therefore noted the that the upper operating temperature for neoprene is approximately the boiling temperature of water. The seals were able to confine steam at ambient pressure for an extended period, but leaked at pressures in excess of 10 psig. The marginal performance of the seals appeared to be the result of softening and loss of strength of the neoprene accompanied by downward movement of the generator, which was held in place by friction, in the 6-inch pipe.

\section{A.2.2 Down-Hole Testing}

In-situ testing of the steam generator was conducted at the Aber Road facility. The Aber Road test site is a 5 acre portion of an inactive industrial waste landfill operated by Browning Ferris Industries (BFI) in eastern Clermont County, Ohio. The site itself is clean, i.e. has not been used for waste disposal. It is approximately 30 miles from Cincinnati and 60 miles from PORTS. The site and other nearby BFI facilites are part of an educational and research facility operated by BFI and sponsored by the State of Ohio. Several research programs funded by the US EPA, the University of Cincinnati, and others have utilized the site for field demonstrations. FRx Inc. enjoys access to the site through cooperative arrangements with the University of Cincinnati.

Geological chacteristics of Aber Road are characteristic of southern Ohio. The terrain is flat with less than $0.5 \%$ slopes. Water table varies with season between 5 and $7 \mathrm{ft}$ bgs, although perched water is often encountered. Soils are silty to clayey glacial tills of low permeability.

Prior to installation in a well at the Aber Road facility, the k-packers were reinforced by insertion of o-rings in between the fins and application of silicone sealant on the heated surfaces - a technique that has extended the pressure capability of k-packers at ambient temperature.

The generator was securely installed in a well such that downward movement would not be possible. A sand-filled hydraulic fracture that was created 5 feet bgs was targeted for steam injection. The water level in the well was approximately 3 feet below surface. During operation, pressure in the generator increased to about $1 \mathrm{psi}$ and the thermocouples showed the commensurate temperature for boiling water. However, the water delivery system did not feed water into the generator. Apparently groundwater was sufficient to keep the heating element submerged.

After 5 days of operation, the heating element failed. The unit was removed from the well for inspection and repair. The element appeared to have ruptured from severe internal pressure. The manufacturer's representative inspected the failed element and pronounced the damage to be consistent with water penetration through the electrical contacts. Prior to installation, the electrical contacts of the heating element, which were not factory-sealed, had been potted in chemically inert cement. Apparently groundwater penetrated fine fissures in the cement and entered the heating element itself, causing failure of the element. A second element was installed with its contacts protected by heat shrinkable tubing and an enclosure around the contacts. The enclosure prevented entry of water from below, but was open to the top of the steam generator. During the course of operation, the casing above the generator (and the space around the electrical contacts) filled with water. Water was introduced into the casing above the generator by a geyser mechanism. A vent tube to the bottom of the steam generator was allowed to discharge to the atmosphere directly 
above the open well. Water inside the vent tube, but within the hot zone of the generator episodically vaporized and ejected slugs of water which fell into the well and onto the steam generator. The element experienced a similar mode of failure after two days of operation.

In summary, the steam generator performed adequately during the above-ground test under relatively dry applications, i.e. without standing water, such as might occur during vadose zone injection. The above-ground test emulated a dry well. Any moisture present at the electrical contacts of the heating element drained downward and away from the element. A steam generator for saturated conditions can not have any exposed electrical connections.

Based on the initial results of the down-hole testing, the generator was redesigned with several improvements. The new design provided a water-tight, mechanical chamber around the electrical contacts and used a threaded connection on the heat element. The redesigned configuration also allowed two heating elements to be installed, potentially doubling the power of the generator. The access conduit that extends from the top of the generator to the space below the generator was expanded from 1/2" diameter to 2" diameter, which allowed use of a greater variety of equipment below the generator. For Aber Road testing, a foot valve was installed on the access conduit to prevent geyser-like activity.

The second prototype, which was designed to remedy various deficiencies above, used the same water control system as the first prototype. It was installed to inject steam into the fracture that was created 5 feet below ground surface. After 1 day of injection, snow above the fracture had melted while 4 inches of snow remained on the surrounding area. During subsequent days, the injected steam displaced groundwater out a vent approximately 5 feet northeast of the well that had been created as a result of the fracturing process. The vent and a second smaller vent about 2 feet northeast of the well eventually eroded to a 6 inch diameter openings. Consequently, injection pressure remained less than $2 \mathrm{psi}(\sim 5 \mathrm{ft}$ of water).

The heating elements on the second prototype burned out after approximately 4 days of operation. It was apparent that the heating elements failed because water was not provided to the boiler. Float switches in the steam chamber were used to sense the water level and control water supply to the generator. Scale and soil particles had caused the polypropylene floats to bind within their housing. Alternative materials were considered for the floats, but examination of the first prototype steam generator revealed that stainless steel floats experienced similar problems.

An alternative water level control was designed, fabricated, and tested. A differential pressure switch sensitive to changes on the order of inches of water is used to monitor the pressure difference between the top and bottom of the generator. The switch was mounted among other control equipment on the ground surface, and a small flow of nitrogen continuously purged the lines that connected each side of the switch to the top or bottom of the steam chamber. The system appeared to control water level satisfactorily, although it is vulnerable to disruptions in the air supply. Several heating elements failed during development, but all of the failures appear to have resulted from a malfunction of the water supply system.

The redesigned prototype isolated the steam chamber from the remainder of the well by means of $\mathrm{k}$-packers reinforced by insertion of o-rings in between the fins and application of silicone sealant on the heated surfaces. The upper k-packer had torn upon removal, a possible result of weakening due to the steam temperatures. An alternate isolation seal was fabricated from silicone rubber and steel plates. The seal system was modeled after the k-packers, i.e. elastomer fins fixed to the chassis of the generator wipe snugly on the inside of the 6-inch pipe. The silicone rubber seal performed satisfactorily for several days at $15 \mathrm{psi}$. 
The silicone rubber seal assembly that isolates the steam chamber from the remainder of the well was used for all testing during February 1996. Despite several trips in and out of the well and sustained exposure to 20 psi steam, the seal elements show minimal wear.

A proven liquid-level control unit provided back-up insurance that the steam generator elements remained submerged. The elements operated continuously for several weeks without failure. Inspection after one week revealed modest scale development and minor corrosion pitting on the element surfaces. A galvanic protection element has been obtained as a preventive measure against corrosion and reputable against scale buildup.

\section{A.3 TESTING OF A DOWN HOLE HOT AIR GENERATOR}

\section{A.3.1 Above Ground Testing}

The air heater consists of an industrial heating element mounted on a custom chassis that will permit placement in a 2-inch well. A light-duty squirrel cage blower was fitted to the heater to provide approximately the airflow that may be experienced in situ. When energized, the element heated to red-yellow, the surrounding housing glowed dull red, and the unit produced air sufficiently hot to ignite paper. The coil on the air heater failed after 6 days during the first tests. The coil appeared to have melted about $3 / 4$ of the way along the heater, at the point where it would be the hottest. It was suspected that radiative heating by reflection off the inner wall of the housing caused the failure--the housing was quite close to the coil. The housing was redesigned to reduce the reflective heating, and a temperature controller was added to the air heater to limit the temperature. An alternative source for elements claimed a longer life but acknowledges that burn out is inevitable, however.

Modifications to enhance the durability of the air heater were incorporated into the prototype. The changes were directed at limiting the temperature of the heating element and thereby extending its expected life. In order to reduce reflected radiation and reduce element temperature, the outer housing of steel was removed and a sheath of mica was installed to direct air flow along the heating element. Some of the radiated heat passed through the mica to be captured by the surrounding well bore. Element temperature was further limited by attenuating the applied power with a switch. A temperature controller, which was driven by a thermocouple positioned downstream of the element, provided on-off protection when the heating elements produced air hotter than the $500{ }^{\circ} \mathrm{C}$ set point.

After meeting the goal of four weeks of uneventful, continuous operation, the test was terminated. The tested equipment consisted of an a squirrel cage blower, an heater element mounted in a cage with mica windows, a control thermocouple positioned down stream of the heater, an on-off controller, and a voltage reducer, which was similar to a residential dimmer switch. The test was restarted briefly to demonstrate the benefits of proportional control of applied power. Under proportional control, the element operated for several hours at medium red with no fluctuation and produced an air stream that varied around the $500{ }^{\circ} \mathrm{C}$ set point by less than a degree. The proportional controller provided smoother operation than the on-off controller when using a fraction of full power.

\section{A.3.2 Down Hole Testing}

A single sand filled hydraulic fracture was created through 2 -inch pipe at $6 \mathrm{ft}$. bgs. It was fairly symmetric and centered and had a diameter of about $25 \mathrm{ft}$. 
A low pressure, high volume air vane-type air compressor was obtained for air injection into fractures. The air compressor had a capacity of $15 \mathrm{cfm}$ open flow and a stall pressure in excess of 15 psi. It connected via flexible hose to the chassis of the hot air heater. The chassis was fitted with a packer composed of neoprene fins mounted on a pipe coupling (a k-packer) and the assembly inserted into the 2 -inch from which the fracture had been created. The assemble was secured in the well to prevent its ejection by the injection pressure.

Hot air was injected at various temperatures for eight weeks. Upon initiation of injection, small air bubbles were observed venting through puddles of standing water across a wide expanse of the ground surface. The extent of venting exceed the limits of the fracture, as determined by uplift, by about 10 feet. The vents were closely spaced at 8 inches. After eight weeks, the pattern of venting had changed substantially. The extent was limited to the $25 \mathrm{ft}$ circle overlying the fracture, the vent spacing increased to the order of feet, and a major vent appeared adjacent to the injection well. Apparently heat and air flow dried the soil along preferential flow paths.

A thermistor wand installed 6 feet from the injection well registered a $15{ }^{\circ} \mathrm{C}$ increase in soil temperature at an interval corresponding to the fracture.

\section{A.4 THERMISTOR DEVELOPMENT}

Prior to development of the thermistors, the methods of making subsurface temperature measurements were reviewed. Arrays of thermocouples or thermistors grouted in place appeared to be the most reliable approach, particularly if multiplexed together in a data acquisition system. The other approaches that use either a wand of thermocouples, a wiping RTD, or an infrared sensor, would be easier to install and provide more detailed data, but cannot assure accurate measurement of formation temperature (heat transfer along the open casing, temperature losses across the casing wall, and equilibrium times all could contribute to errors that are avoided using fixed devices). Also, field implementation of the more sophisticated approaches requires considerably more time and exposes the vulnerability of equipment problems.

Soil temperatures were measured by thermistors fixed on the exterior of wands that are permanently installed in the temperature observation wells. The thermistors were multiplexed to central data acquisition system. The hardware for the data acquisition system was assembled from stock components and developed software to drive the multiplexers, read thermistors, and store data. Two prototype temperature wands were fabricated to demonstrate construction techniques, delineate calibration procedures, and verify performance of the data acquisition system. The protoypes were eventually installed at Aber Road.

Each prototype thermistor wand consisted of a 10-foot long 1-inch PVC pipe that was cut longitudinally to permit installation of thermistors, which are electronic devices that are sensitive to temperature, long its interior. Sixteen thermistors were installed in small holes drilled into, but not quite through, the wall of the PVC pipe. Thermistors were attached to 50-conductor computer ribbon cable that exited the upper end. The two sections of the pipe were reassembled with duct tape wrap to form the cylindrical wand that could be inserted and grouted into a 2-inch borehole.

Subsequently, two additional, 16-foot long wands were built for installation at the CTS. Other than length, the CTS wands were identical to the Aber Road units. Note, wands for X231A were $20 \mathrm{ft}$ long and carried 32 thermistors.

The data acquisition system for the thermistor wands consisted of two 64 channel Campbell Scientific multiplexors, a custom built 8 channel high current multiplexor (to switch the Campbell Scientific units), a DGH thermistor signal processing module and a DGH 16 channel digital output module. The DGH modules communicated with a IBM computer via an RS-232 cable. Custom 
software run on the 286 generation computer instructed the DGH digital module to manipulate the high current multiplexor which in turn drove the multiplexors that switched the thermistors into the signal processing module. In effect the system was a 4096 channel datalogger.

The DAS was installed for eight weeks at Aber Road during the course of testing the hot air injection. It was located adjacent to the low pressure high volume air compressor. Vibrations from the compressor degraded the internal contacts of the signal processing module, and the unit was returned to manufacturer for repair. The DAS was subsequently installed in a more quiet location.

The DAS was transported periodically to PORTS CTS during the summer of 1996 to acquire temeprature data from the wands intalled there. CTS wands operated as required throughout the summer.

\section{A.5 DEMONSTRATION SITE RECONNAISSANCE}

The purpose of the site reconnaissance was to confirm existing historical soil contaminant data and determine if the X-231A site was suitable for the comparative demonstration. Thus, the sampling and analyses served as a go/no go decision point for site selection and the scope of activities was limited.

Soil sampling and installation of two piezometers was conducted at the X-231A unit in 1987 (ASI 1988) (Fig. A.1). Soil sample results indicate low levels of total volatile organic compounds (VOCs) (primarily TCE and 1,1,1-trichloroethane [TCA]) ranging from less than 1 to $282 \mathrm{mg} / \mathrm{kg}$ at the southeast corner of the site. The average reported total VOC concentration was approximately $1 \mathrm{mg} / \mathrm{kg}$. Low concentrations of metals (primarily $\mathrm{Ba}, \mathrm{Cr}, \mathrm{Pb}$, and $\mathrm{Ni}$ ) were detected throughout the unit. Low total beta activities and total $U$ were also detected throughout the unit ranging from 11 to $64 \mathrm{nCi} / \mathrm{kg}$ and 1 to $11 \mathrm{mg} / \mathrm{kg}$, respectively. No PCBs were detected.

The site reconnaissance included sampling six coreholes across the X-231A unit and on site field analyses for VOCs (Fig. A.1). Because the targeted zone for the demonstration was the unsaturated low permeability Minford soils, coring and sample collection was conducted to the top of the Gallia with an effort made to not penetrate the Gallia. Corehole depth ranged from 16 to 20 $\mathrm{ft}$ with the top of the Gallia hit in sample location 2 (Figure A.1, GP02) at $19.5 \mathrm{ft}$.

Soil samples were collected at 2-ft intervals the entire length of the core and analyzed for VOCs (PCE, TCE, and 1,1,1-TCA). At two locations samples were taken at 1 to $2 \mathrm{ft}$., 7 to $8 \mathrm{ft}$., 11 to $12 \mathrm{ft}$., and 15 to $16 \mathrm{ft}$ and analyzed at the PORTS laboratory for PCBs (Aroclor 1254 and 1260), radionuclides (total alpha, total beta, and total uranium), RCRA metals ( $\mathrm{As}, \mathrm{Ba}, \mathrm{Cd}, \mathrm{Cr}, \mathrm{Pb}, \mathrm{Hg}$, $\mathrm{Se}$, and $\mathrm{Ag}$ ), and physical properties ( $\mathrm{pH}$, moisture content, TOC) (Table A.1).

Reconnaissance characterization of the X-231A unit in May 1996 included soil sample collection and analysis to select a site for the comparative field test. Six borings were probed to a depth of 16 to $20 \mathrm{ft}$, soil samples were collected every $2 \mathrm{ft}$ for analyses. Analytical results indicate total VOCs (primarily TCE, TCA, and PCE) range from less than 1 to $56 \mathrm{mg} / \mathrm{kg}$. Four soil samples, two each from borings 4 and 5, were submitted for additional analyses (RCRA metals, Hg, total PCBs, total organic carbon (TOC), $\mathrm{pH}$, radionuclides, and soil moisture) at the PORTs analytical laboratory. Laboratory analytical results confirmed previous data indicating low concentrations of metals $(<20$ $\mu \mathrm{g} / \mathrm{L}$ of $\mathrm{As},<17 \mu \mathrm{g} / \mathrm{L}$ of $\mathrm{Cr}$, and $<19 \mu \mathrm{g} / \mathrm{L}$ of $\mathrm{Pb}$ ) and radionuclides (3.7 to $5.4 \mu \mathrm{g} / \mathrm{g}$ of total $\mathrm{U}, 7$ to $9 \mathrm{pCi} / \mathrm{g}$ total alpha, and $<12$ to $21 \mathrm{pCi} / \mathrm{g}$ total beta). No PCBs were detected. Sample results are presented in Table A.2 and Figure A.2. 


\section{A.6 SOIL FRACTURING AND HOT FLUID TESTING AT THE CTS}

\section{A.6.1 Fracture Emplacement}

Following equipment development and testing at Aber Road, stacked fractures were emplaced at two test cells at the PORTS clean test site (Fig. A.3). Three stacked sand-propped fractures were emplaced at 6,9 and $12 \mathrm{ft}$ bgs. Figures A.4 through A.11 are uplift maps of the individual fractures. This shakedown demonstrated the feasibility of using hydraulic fractures as an enabling technology for the comparative demonstration of in situ remediation of DNAPLs in LPM at PORTS. Additionally, one deep fracture was emplaced at $18 \mathrm{ft}$ bgs just west of the two CTS test cells to conduct dewatering tests and obtain process operation information necessary for dewatering during the comparative demonstration.

Sensors were installed at four monitoring locations at each of the two test cells with the stacked fractures (Fig. A.3). Three monitoring locations (two temperature monitoring locations and one neutron probe monitoring location) were installed using the Geoprobe rig to core a hole to $20 \mathrm{ft}$. Casings (stainless steel tubing for the neutron probe casing and PVC for the temperature casings) were then pushed into the corehole and grouted in place. The fourth monitoring location was drilled to approximately $16 \mathrm{ft}$ using a $71 / 2$ in $\mathrm{OD}$ auger and the Geoprobe rig. This location was instrumented with sidewall sensors (TDRs and piezometers) at discrete locations (10 locations at the first test cell and 7 locations at the second test cell) within the borehole using the innvoative sidewall sampling device developed by FRx, Inc. Following installation of the sidewall sensors, the borehole was filled with grout. Cores collected during instrumentation were visually inspected, but no samples were collected or analzed for biogeochemical properties. No monitoring or measurements were conducted during this phase of field work. However, TDR and piezometer measurements were collected for two months to verify the viability of the sensors and placement techniques.

\section{A.6.2 Down Hole Hot Air Generator Testing}

The hot air generator and associated low pressure compressor were installed at the CTS in mid June 1996, and operated there until the end of August, 1996. Hot air was injected into a fracture created $6 \mathrm{ft}$ bgs at CTS fracture location 1 . The system operated uneventfully except for a spate of ground fault interrupts in late July that were remedied by improvements in wiring.

\section{A.6.3 Process Operations}

In addition to tests of the hot air injection system, an SVE system was installed and operated briefly at the CTS. The system was composed of a 1 HP liquid ring pump, a ring water circulation pump and a ring water reservoir. It was connected via 2" PVC pipe to uppermost fractures at both fracture locations. Operations demonstrated the need for cooling of the ring water and screens to prevent fracture sand from entering the SVE piping.

Dewatering of the lower fractures at the CTS was accomplished by means of aspirators driven by a 2 HP air compressor. The aspriators were mounted on the top of sealed separator pots, which were vertically mounted 4-inch pipes about $3 \mathrm{ft}$ long. Polypropylene float switches inside the seperators detected water levels and provide input to electomechanical logic that periodically cut-off suction and purged the pots of accumulated water. The logic also included cycle counter that provided a direct estimate of the volume of water recovered. These systems operated during the course of the summer of 1996 and recovered water according to Table A.3 (in preparation). 


\section{A.7 LABORATORY TESTING OF CARRIER FLUIDS FOR PERMANGANATE SOLIDS}

Laboratory teasing of optional carrier fluids for delivery of potassium permanganate solids was completed at CSM as described in Case (1997) and highlighted herein. An initial set of experiments investigated the chemical and physical changes that the commonly used guar gel sustained upon mixing and reaction with potassium permanganate. Several different mixtures were created and then examined including (1) potassium permanganate with water, (2) water only, (3) guar gum only, (4) guar gel (guar gum plus Borax cross-linker and enzyme breaker), and (5) guar gel with permanganate. For mixture $5,120 \mathrm{~g}$ of potassium permanganate were added to $100 \mathrm{~mL}$ of the guar gel based on a solids to solution ratio that had been utilized previously for hydraulic fracturing. The viscosity of each mixture is reported in units of time (s) because the method utilized was a measure of the time it took for $50 \mathrm{~mL}$ of the mixture to flow through a $1 \mathrm{~L}$ funnel. The viscosity of the guar gel (mixture 4) was reduced by $99 \%$ upon mixing with potassium permanganate. As expected, the organic-based carrier comprised of guar gum was deemed unsuitable for use as a hydraulic fracturing fluid to deliver permanganate crystals.

Different physical forms of potassium permanganate were then considered as an alternative to crystal $\mathrm{KMnO}_{4}$ for mixing with guar gel. Control solutions were made by mixing equal amounts of the different forms of $\mathrm{KMnO}_{4}$ with water. The estimated viscosities of each control solution were recorded and compared to the viscosities of the mixtures of the different forms of $\mathrm{KMnO}_{4}$ solids that were mixed with guar gel. The guar gel viscosity was reduced significantly for every mixture with the addition of the different forms of $\mathrm{KMnO}_{4}$. The different forms of potassium permanganate solids did not, therefore, mitigate the breakdown of the guar gel upon mixing with $\mathrm{KMnO}_{4}$.

The breakdown of guar gel was then investigated over a range of $\mathrm{KMnO}_{4}$ concentrations to find the minimum concentration of potassium permanganate that significantly decreased the apparent viscosity of the guar gel. $\mathrm{A} \mathrm{KMnO}_{4}$ concentration as low as $1 \mathrm{mg} / \mathrm{L}$ caused a slight breakdown of the viscosity of the guar gel (approximately $26 \%$ estimated viscosity reduction). At a $\mathrm{KMnO}_{4}$ concentration of $50 \mathrm{mg} / \mathrm{L}$, greater than $63 \%$ estimated viscosity reduction of the guar gel was observed. At a concentration of $1000 \mathrm{mg} / \mathrm{L} \mathrm{KMnO}_{4}$, the estimated viscosity of the guar gel was on the same order of magnitude as the viscosity of water (i.e., $\sim 99 \%$ viscosity reduction compared to guar gel alone).

Because food-grade guar gel was adversely affected by potassium permanganate, synthetic gel (Galactasol) was considered as a grout carrier for permanganate solids. The viscosity breakdown of synthetic gel upon mixing with potassium permanganate was comparable to the viscosity breakdown of food-grade guar gel upon mixing with potassium permanganate.

A mineral-based gel was then evaluated as a potential carrier for permanganate solids. Bentonite gel, bentonite gel augmented with Portland cement, and bentonite gel augmented with sodium silicate $\left(\mathrm{Na}_{2} \mathrm{SiO}_{3}\right)$ were all tested for chemical and physical property changes upon mixing with $\mathrm{KMnO}_{4}$. The bentonite gel was prepared with a $5 \%$ by wt. mixture of bentonite powder in $100 \mathrm{~mL}$ of tap water. The four bentonite mixtures that were compared in this set of experiments included: (1) $5 \%$ bentonite gel only, (2) $5 \%$ bentonite gel with $120 \mathrm{~g}$ of $\mathrm{KMnO}_{4}$, (3) $5 \%$ bentonite gel with Portland cement and $120 \mathrm{~g}$ of $\mathrm{KMnO}_{4}$ and (4) $5 \%$ bentonite gel with sodium silicate and $120 \mathrm{~g}$ of $\mathrm{KMnO}_{4}$. The consistency of the $5 \%$ bentonite gel closely resembled that of the food-grade guar gel. The viscosities of all three bentonite gel mixtures increased upon mixing with the $\mathrm{KMnO}_{4}$ solids. The potassium permanganate crystals remained homogeneously mixed and no phase separation or settling was observed. The color of all three mixtures turned very deep purple. The consistency of the bentonite/sodium silicate mixture was slightly less viscous than the other two bentonite slurry mixtures. All four mixtures were allowed to air dry for $24 \mathrm{hr}$ after being poured onto tin foil to form coupons. After $12 \mathrm{hr}$ of drying, the $5 \%$ bentonite gel coupon remained wet on 
the surface with no cracks present. The $5 \%$ bentonite gel mixture with sodium silicate had a few small cracks present, but generally remained wet on the surface with a slightly thicker consistency than it had when it was initially poured to form the coupon. The 5\% bentonite gel mixture with Portland cement and potassium permanganate was more hardened and had fewer small cracks present on the surface than the other three coupons. After $24 \mathrm{hr}$, the bentonite gel coupon had dried with large discontinuous cracks in it. The bentonite gel coupon with permanganate had solidified with relatively smaller cracks and with a homogeneous distribution of the $\mathrm{KMnO}_{4}$ crystals. The bentonite gel with sodium silicate hardened to a brittle state with many small cracks throughout the coupon. The bentonite gel coupon with Portland cement solidified with minimal cracks and homogeneous dispersion of the potassium permanganate crystals. Based on the above results, the $5 \%$ bentonite gel augmented with Portland cement was selected as the carrier to deliver permanganate solids during hydraulic fracturing.

Using the selected carrier fluid, static release rate experiments were completed to measure the rate of release of permanganate ion from the carrier grout under static conditions in tap water. The static release rate was to be determined using the EPA's Uniform Leaching Procedure (ULP). Upon placing a coupon of the reactive grout in the tapwater, the potassium permanganate was released so quickly into solution that the rate was impossible to quantify using this method. Therefore, for applications involving reactive grouts in hydraulic fracturing, the static mass release rate of the permanganate ion will not be not a limiting factor. 
Figure A.1 Location of May 1996 reconnaissance cores and historical borings.

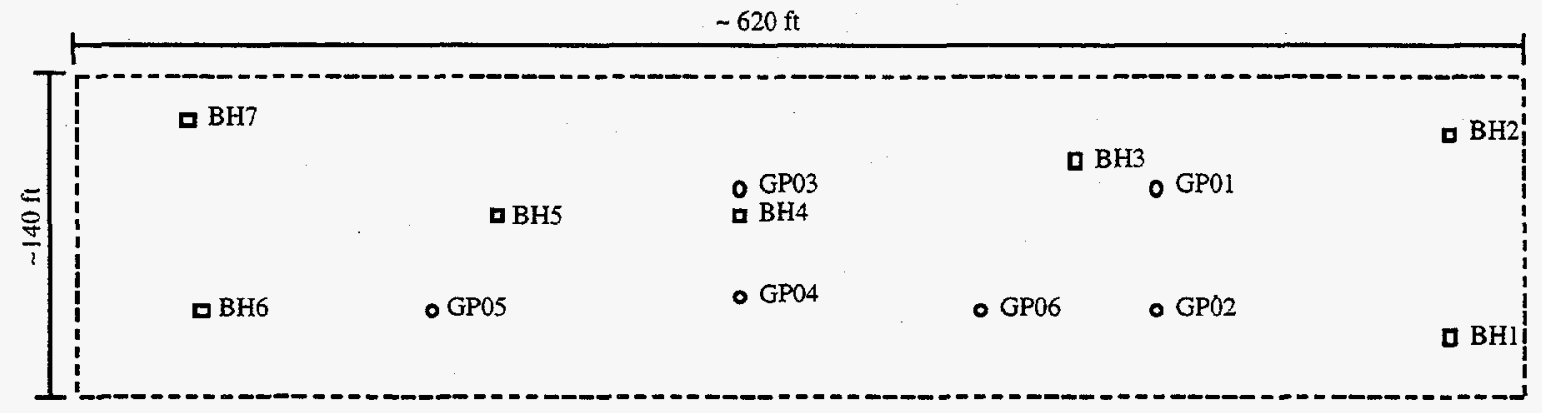

PORTS Perimeter Patrol Road

- 1996 ORNL Geoprobe reconnaissance soil boring location (approximate)

0

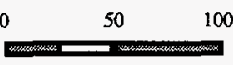

- 1988 ASI soil boring location (approximate)

-- approximate location of the X-231A cap 
Figure A.2 X-231A reconnaissance characterization sample data: (a) TCE, and (b) 1,1,1-TCA.

(a)

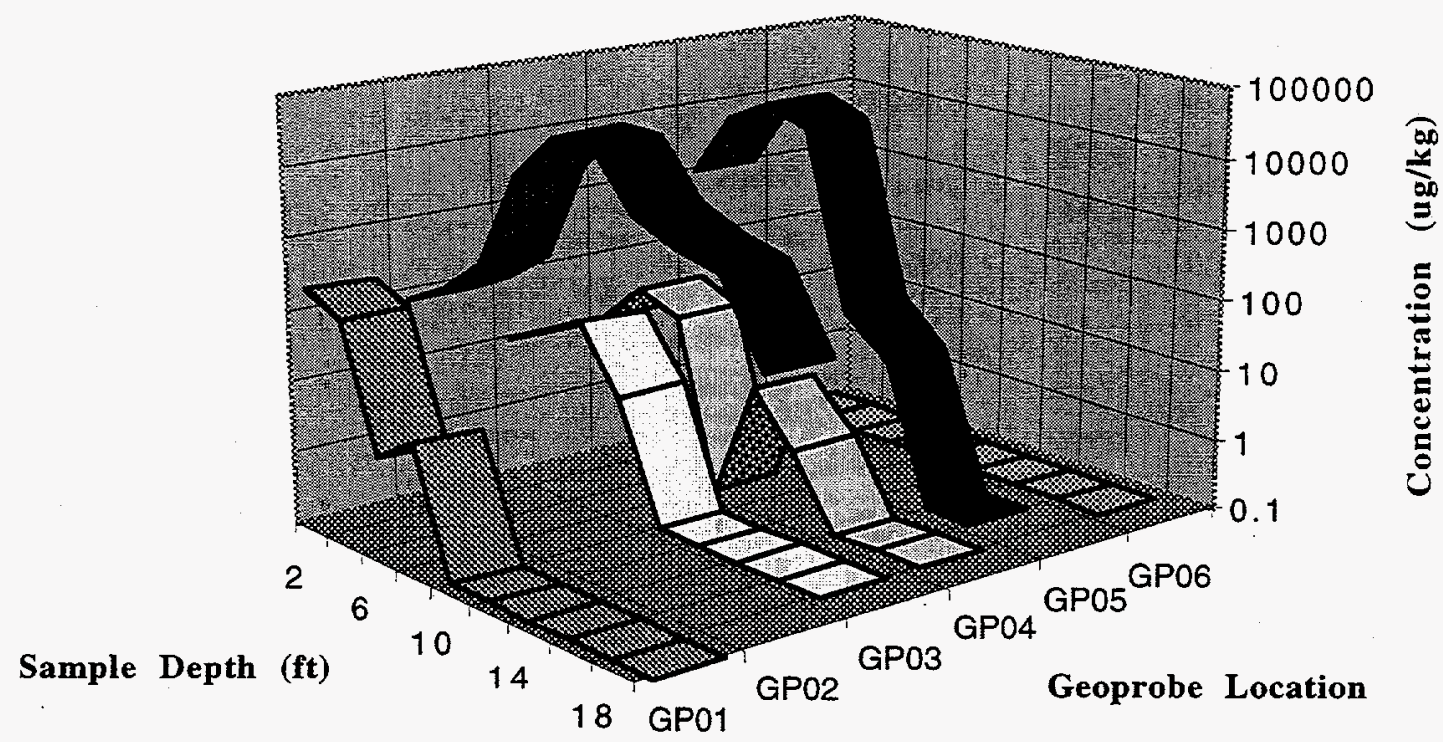

(b)

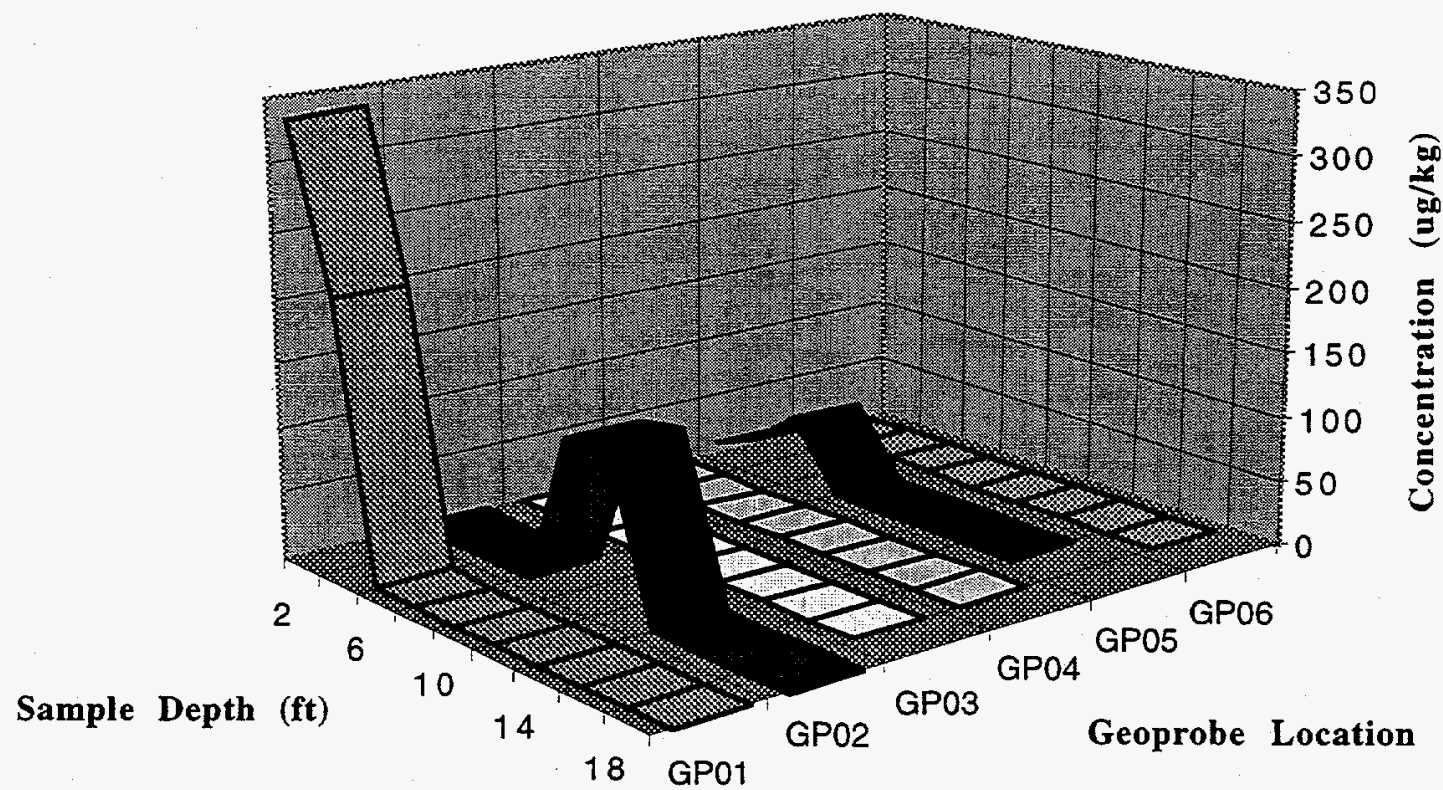

A -11 
Figure A.3 Location of fracture test cells at the CTS.

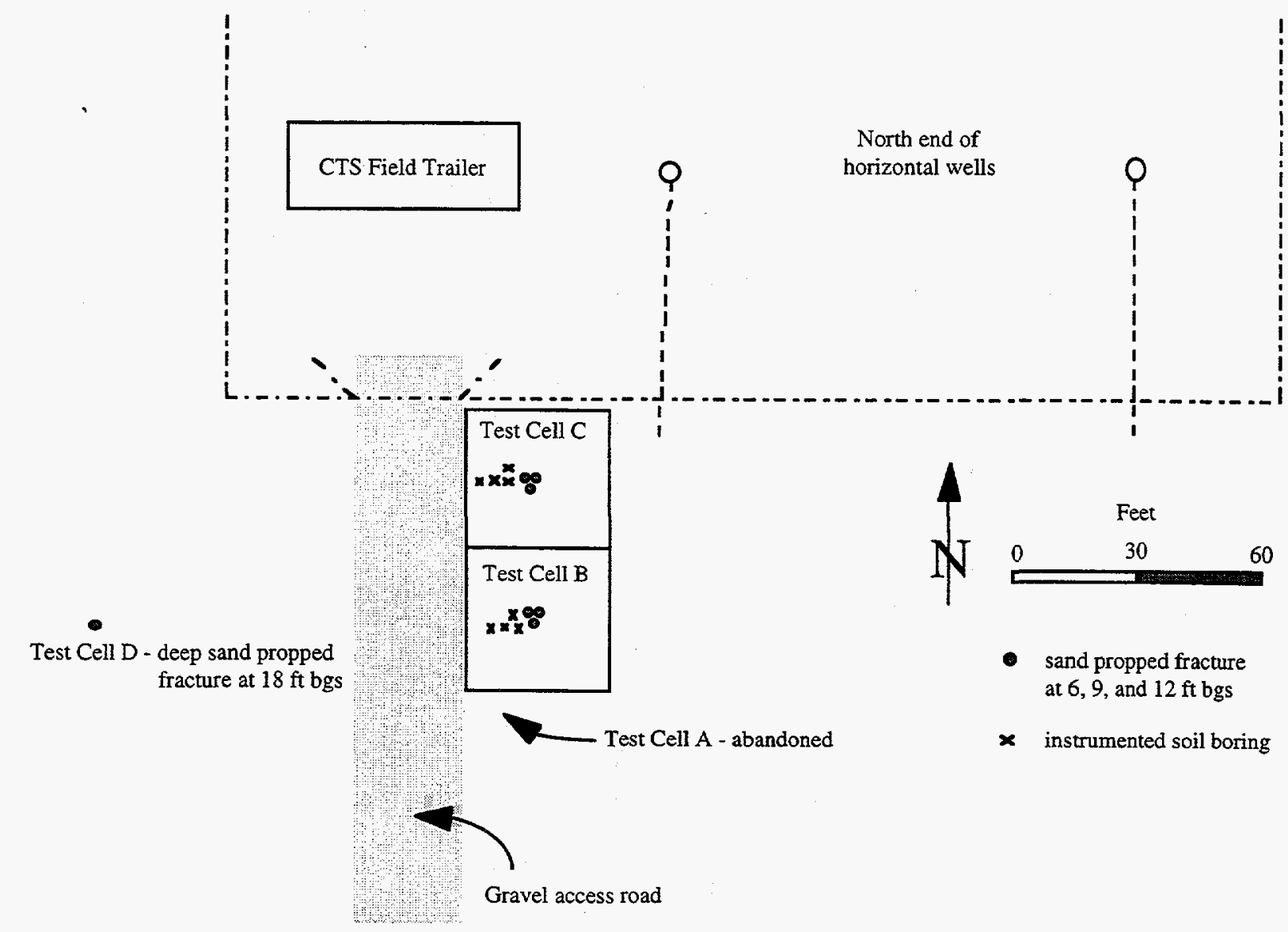


Figure A.4 Hydraulic Fracturing Uplift, Clean Test Site Cell A, 2 m fracture.

\section{Hydraulic Fracturing Uplift}

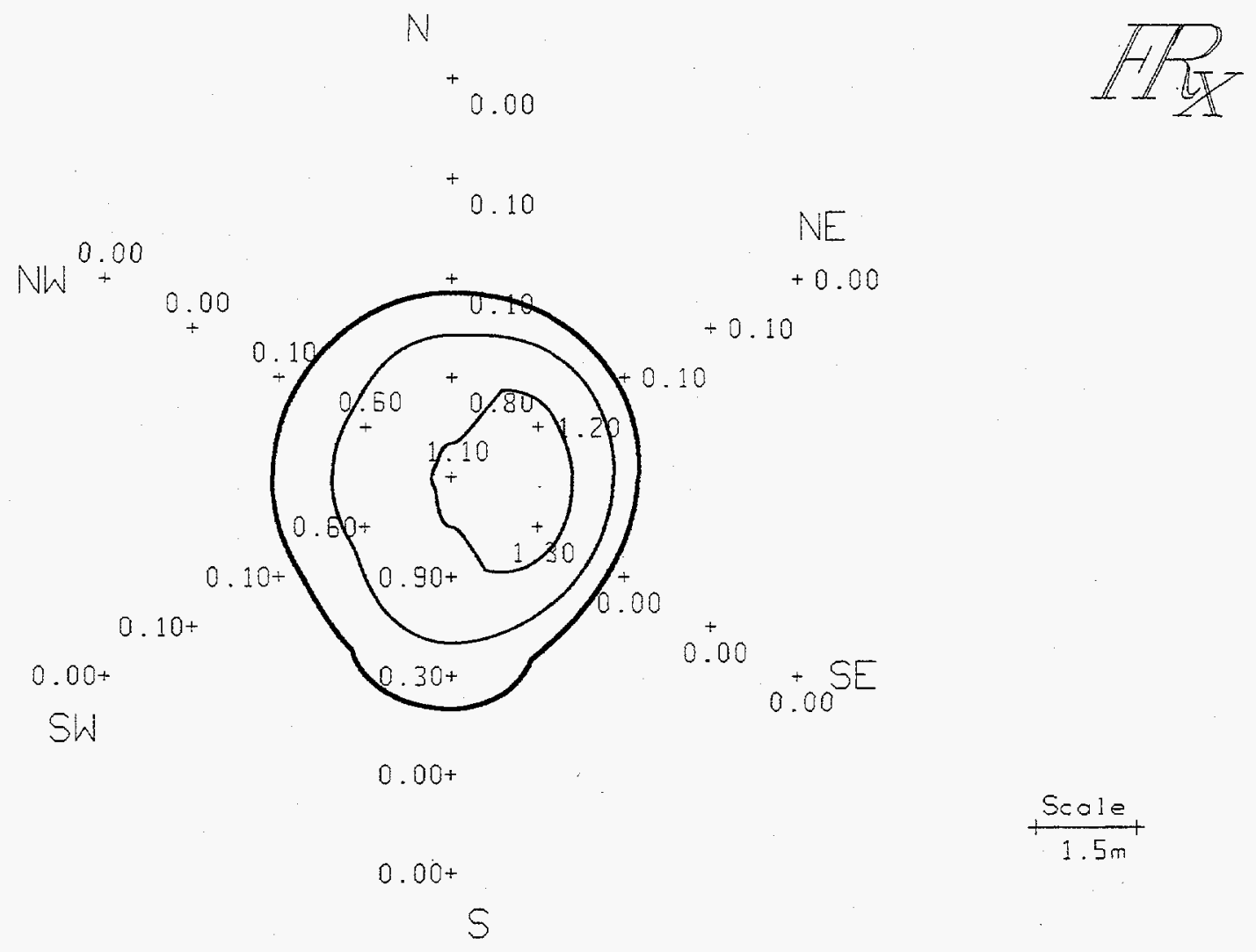

Uplift control points spaced $1.5 \mathrm{~m}$ apart along rays oriented to "plant" north.

Heavy contour is for $2 \mathrm{~mm}$ of uplift, which indicates expected limit of significant sand in the fracture. Lighter contours spaced at $5 \mathrm{~mm}$, starting with $5 \mathrm{~mm}$.

SITE: PORTS Clean Test Site

DATE: 5/8/96

LOCATION: CTS "A"

FRACTURE DEPTH: 6.5

UPLIFT VOLUME: $0.21 \mathrm{~m}^{3}$
FRACTURE ID: CTSA-2

GeL VOLUME: 40 gal.

ProppaNT: \#7 Sand

Proppant CONTENT: $3.5 \mathrm{ft}^{3}$

Ratio, Uplift / Inj Vol: 0.98

NoTes: vent $2 \mathrm{~m} E$ of injection well, possible rodent burrow, abandond location. No $P$ $\log$, transducer not working 
Figure A.5 Hydraulic Fracturing Uplift, Clean Test Site Cell B, $2 \mathrm{~m}$ fracture.

\section{Hydraulic Fracturing Uplift}

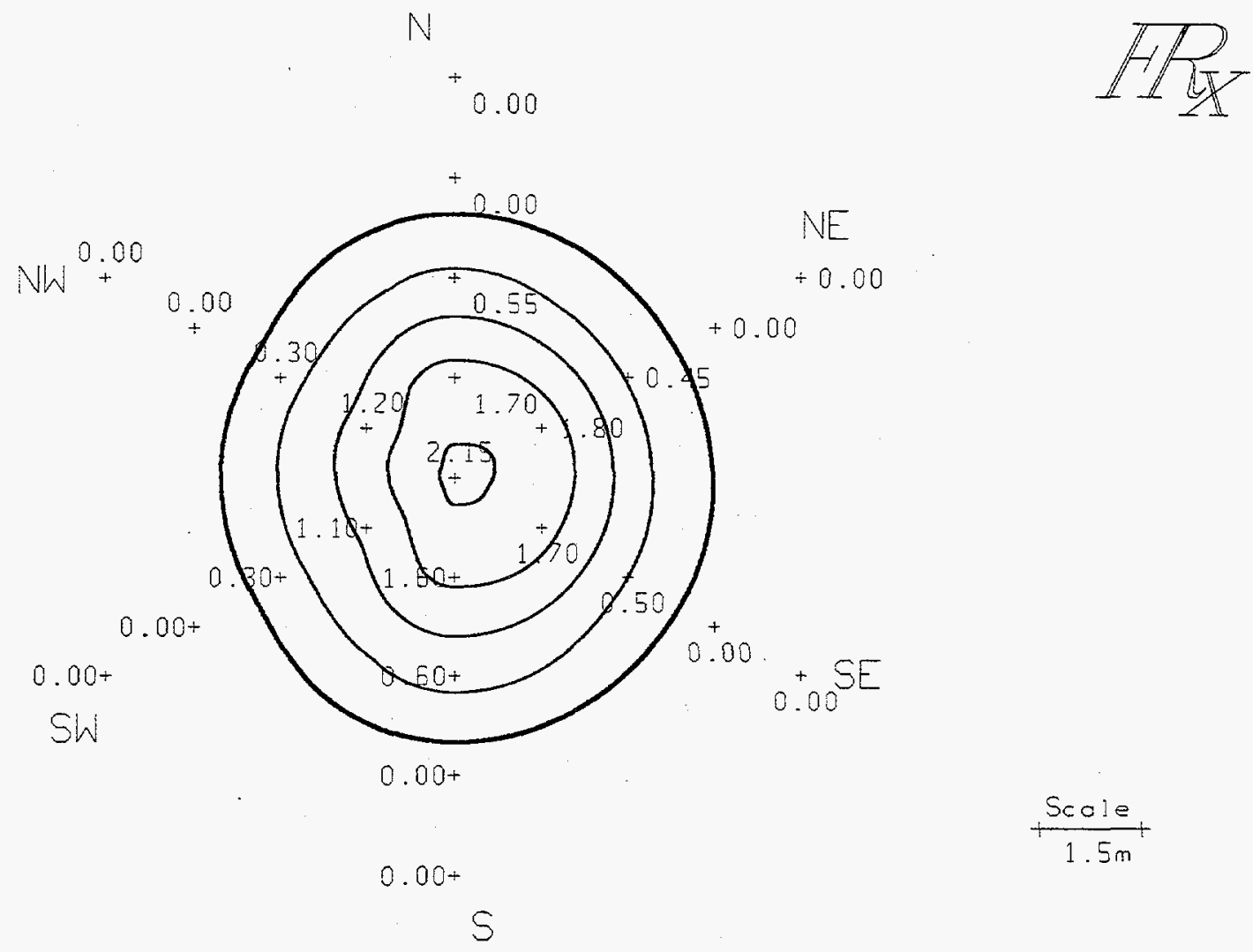

Uplift control points spaced $1.5 \mathrm{~m}$ apart along rays oriented to "plant" north.

Heavy contour is for $2 \mathrm{~mm}$ of uplift, which indicates expected limit of significant sand in the fracture. Lighter contours spaced at $5 \mathrm{~mm}$, starting with $5 \mathrm{~mm}$.

SrTE: PORTS Clean Test Site

DATE: $5 / 8 / 96$

LOCATION: CTS "B"

FRACTURE DEPTH: 6.5

UPLIFT VOLUME: $0.39 \mathrm{~m}^{3}$
FRACTURE ID: CTSB-2

GEL VOLUME: $60 \mathrm{gal}$.

Proppant: \#7 Sand

Proppant Content: $7 \mathrm{ft}^{3}$

Ratio, Uplift / Inj Vol: 1.13

NOTES: 
Figure A.6 Hydraulic Fracturing Uplift, Clean Test Site Cell B, $3 \mathrm{~m}$ fracture.

\section{Hydraulic Fracturing Uplift}

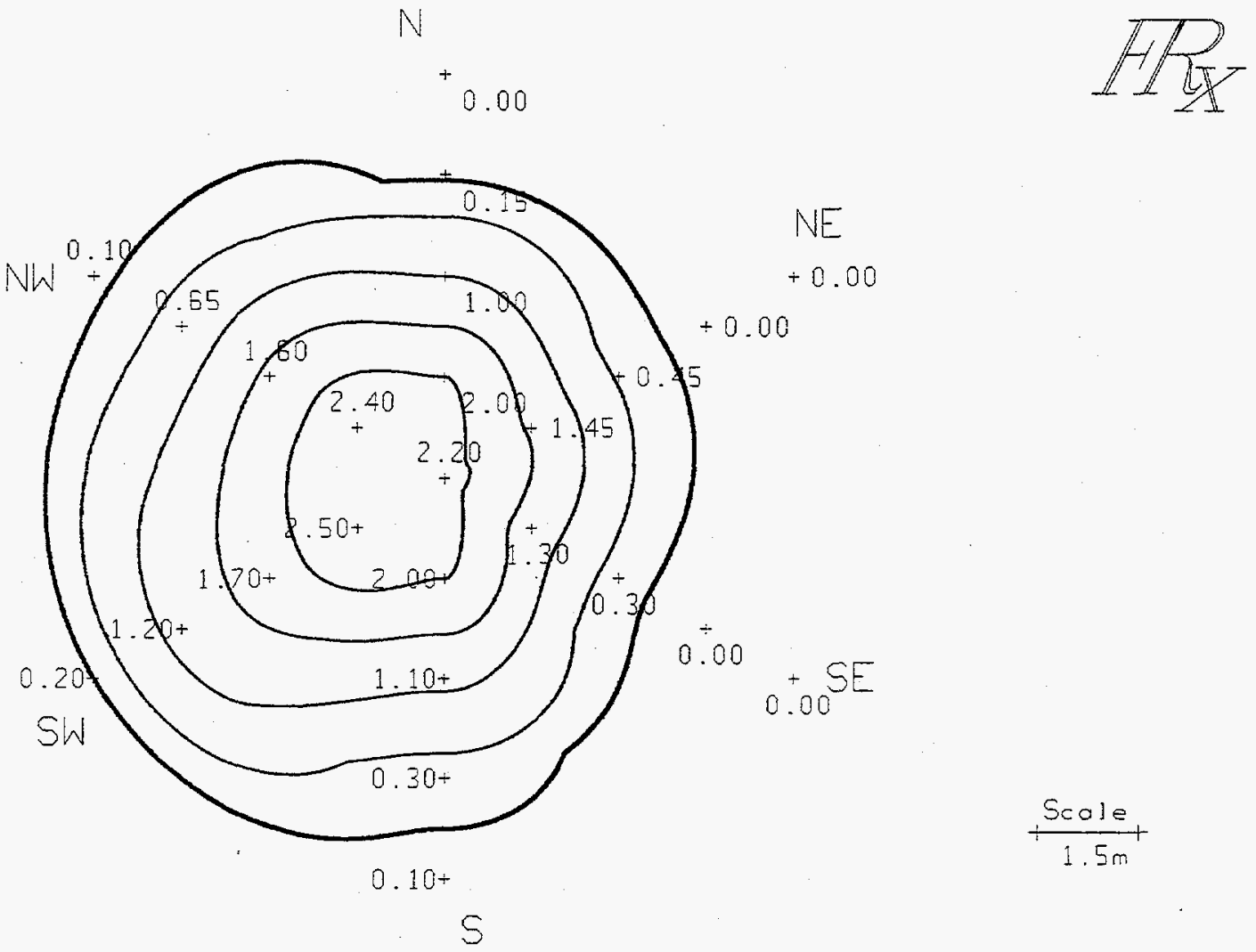

Uplift control points spaced $1.5 \mathrm{~m}$ apart along rays oriented to "plant" north.

Heavy contour is for $2 \mathrm{~mm}$ of uplift, which indicates expected limit of significant sand in the fracture. Lighter contours spaced at $5 \mathrm{~mm}$, starting with $5 \mathrm{~mm}$.

SITE: PORTS Clean Test Site

DATE: $5 / 8 / 96$

LOCATION: CTS "B"

FRACTURE DEPTH: 10

UPLIFT VOLUME: $0.79 \mathrm{~m}^{3}$
FRACTURE ID: CTSB-3

GeL VOLUME: 120 gal.

Proppant: \#5 Sand

Proppant Content: $12 \mathrm{ft}^{3}$

Ratio, Uplift / Inj Vol: 1.2

NoTES: $\mathrm{p}$ log unavailable - coupling mismatch. Ran last $300 \mathrm{lb}$ heavy sd $\gg>12$ ppg 
Figure A.7 Hydraulic Fracturing Uplift, Clean Test Site Cell B, $4 \mathrm{~m}$ fracture.

\section{Hydraulic Fracturing Uplift}

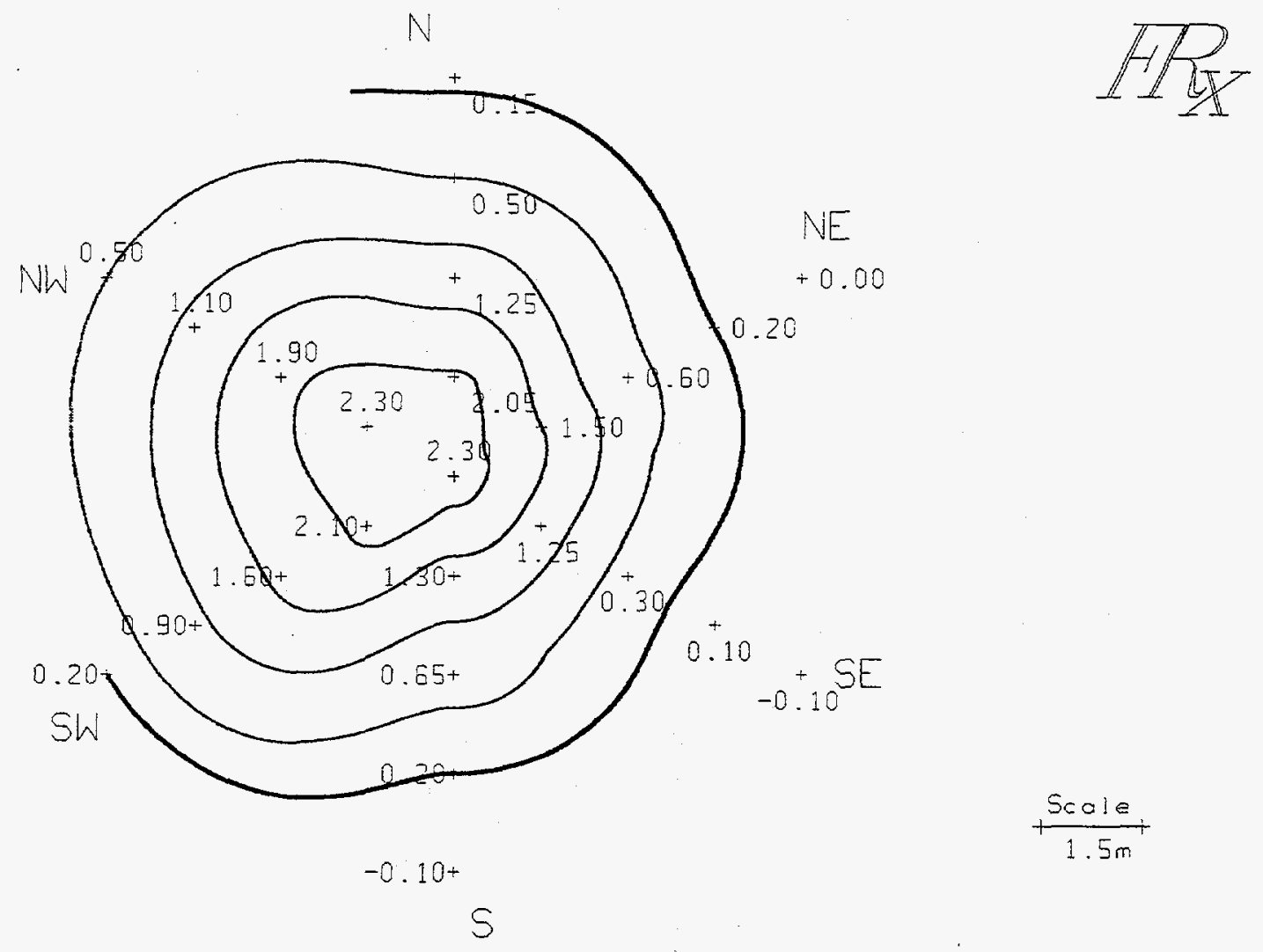

Uplift control points spaced $1.5 \mathrm{~m}$ apart along rays oriented to "plant" north.

Heavy contour is for $2 \mathrm{~mm}$ of uplift, which indicates expected limit of significant sand in the fracture. Lighter contours spaced at $5 \mathrm{~mm}$, starting with $5 \mathrm{~mm}$.

SITE: PORTS Clean Test Site

DATE: $5 / 9 / 96$

LOCATION: CTS "B"

FRACTURE DEPTH: 13

UPLITT VOLUME: $0.84 \mathrm{~m}^{3}$
FRACTURE ID: CTSB-4

GEL VOLUME: $130 \mathrm{gal}$.

Proppant: \#7 Sand

Proppant Content: $16 \mathrm{ft}^{3}$

Ratio, Uplift / Inj Vol: 1.1

\section{NOTES:}


Figure A.8 Hydraulic Fracturing Uplift, Clean Test Site Cell C, $2 \mathrm{~m}$ fracture.

\section{Hydraulic Fracturing Uplift}

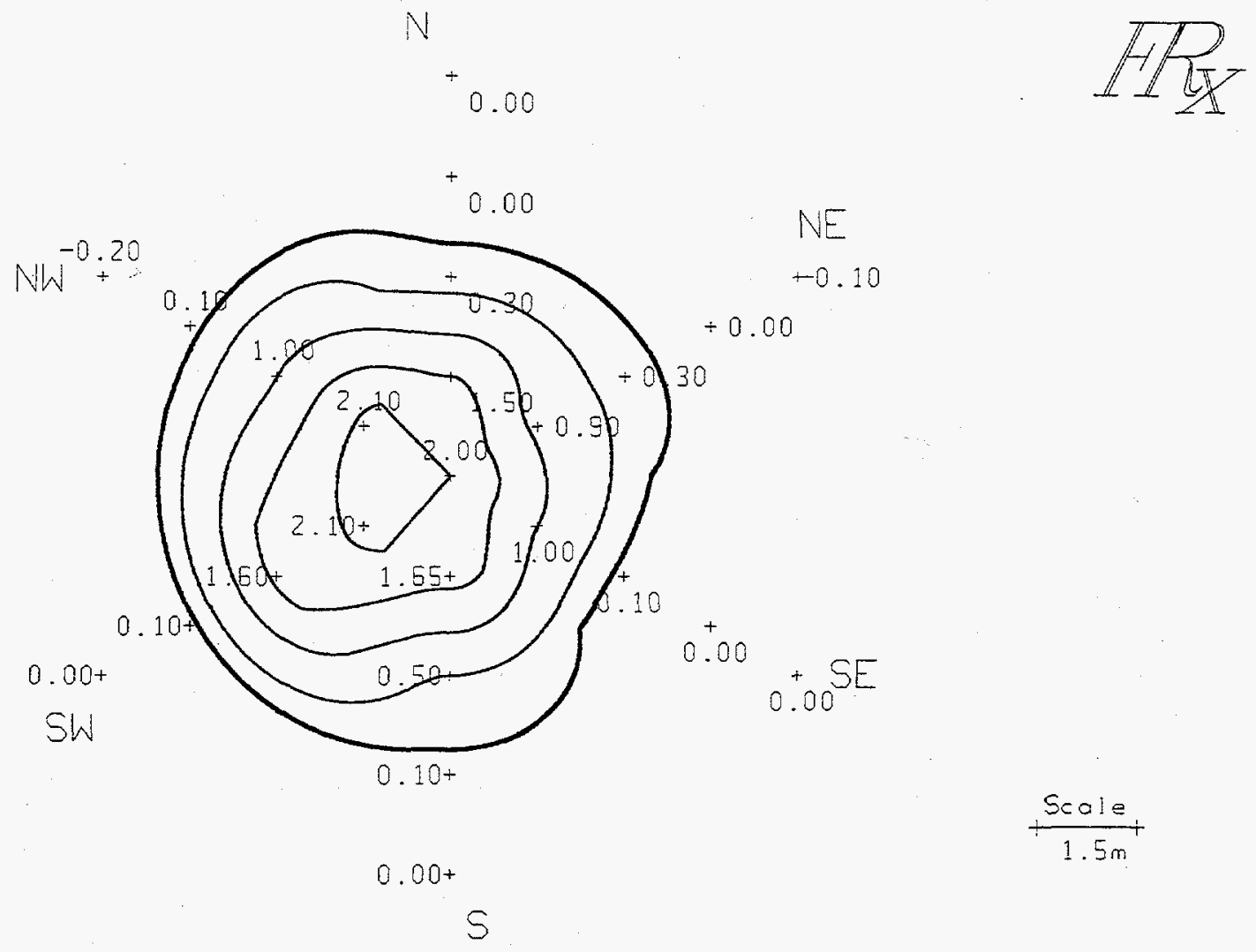

Uplift control points spaced $1.5 \mathrm{~m}$ apart along rays oriented to "plant" north.

Heavy contour is for $2 \mathrm{~mm}$ of uplift, which indicates expected limit of significant sand in the fracture. Lighter contours spaced at $5 \mathrm{~mm}$, starting with $5 \mathrm{~mm}$.

SITE: PORTS Clean Test Site

DATE: $5 / 9 / 96$

LOCATION: CTS "C"

FRACTURE DEPTH: 6.5

UPLIFT VOLUME: $0.46 \mathrm{~m}^{3}$

NoTES: ran last $200 \mathrm{lb} \gg>10 \mathrm{ppg}$
FRACTURE ID: CTSC-2

GeL VOLUME: $60 \mathrm{gal}$.

Proppant: \#7 Sand

Proppant Content: $7 \mathrm{ft}^{3}$

Ratio, Uplift / Inj Vol: 1.33 
Figure A.9 Hydraulic Fracturing Uplift, Clean Test Site Cell C, $3 \mathrm{~m}$ fracture.

\section{Hydraulic Fracturing Uplift}

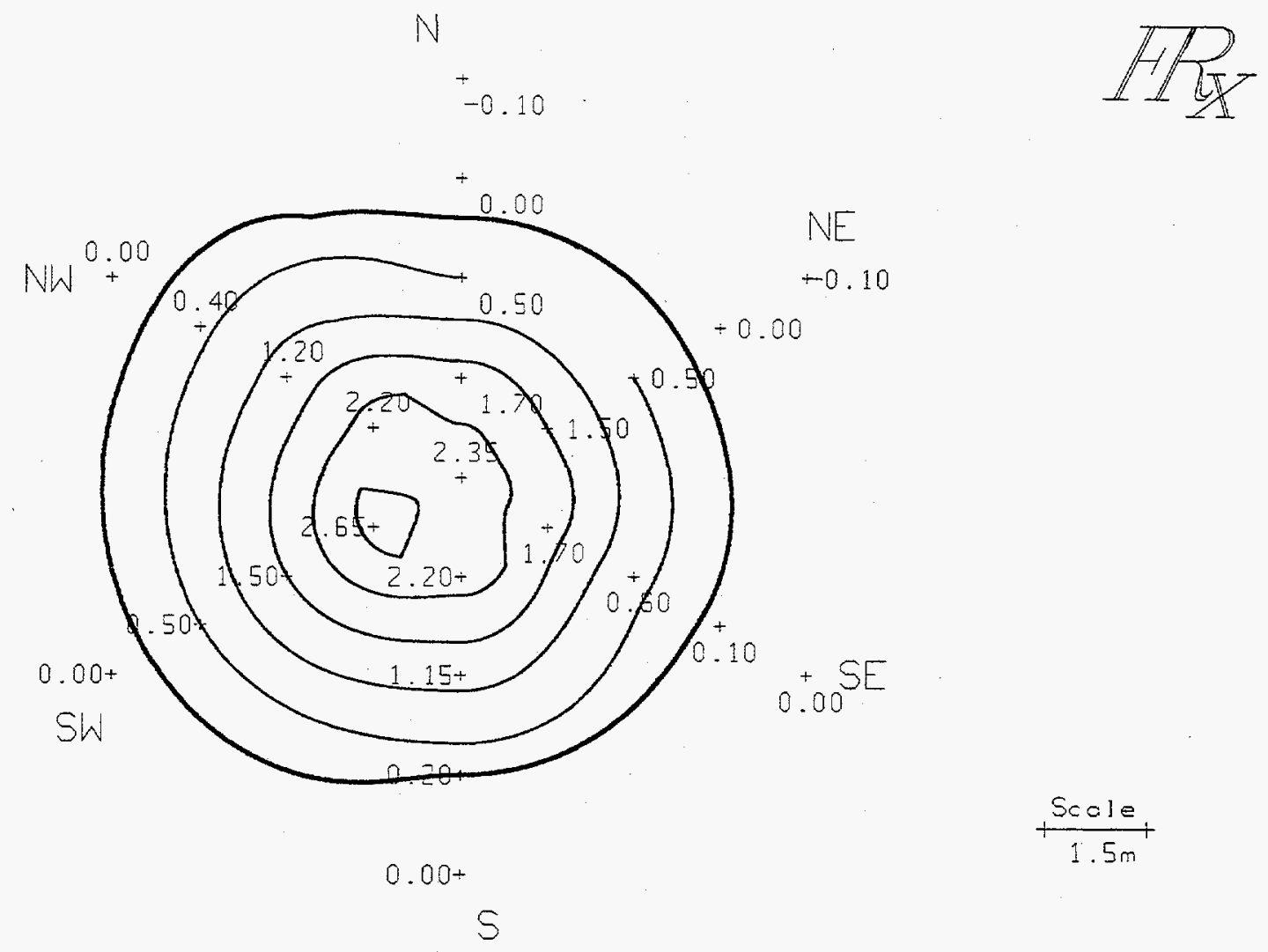

Uplift control points spaced $1.5 \mathrm{~m}$ apart along rays oriented to "plant" north.

Heavy contour is for $2 \mathrm{~mm}$ of uplift, which indicates expected limit of significant sand in the fracture. Lighter contours spaced at $5 \mathrm{~mm}$, starting with $5 \mathrm{~mm}$.

SITE: PORTS Clean Test Site

DATE: $5 / 9 / 96$

LOCATION: CTS "C"

FRACTURE DEPTH: 10

UPLIFT VOLUME: $0.67 \mathrm{~m}^{3}$
FRACTURE ID: CTSC-3

GeL VOLUME: 85 gal.

Proppant: \#5 Sand

Proppant Content: $12 \mathrm{ft}^{3}$

Ratio, Uplift / Inj Vol: 1.28

NoTES: steel drive point, 0 stick-up 
Figure A.10 : Hydraulic Fracturing Uplift, Clean Test Site Cell C, $4 \mathrm{~m}$ fracture.

\section{Hydraulic Fracturing Uplift}

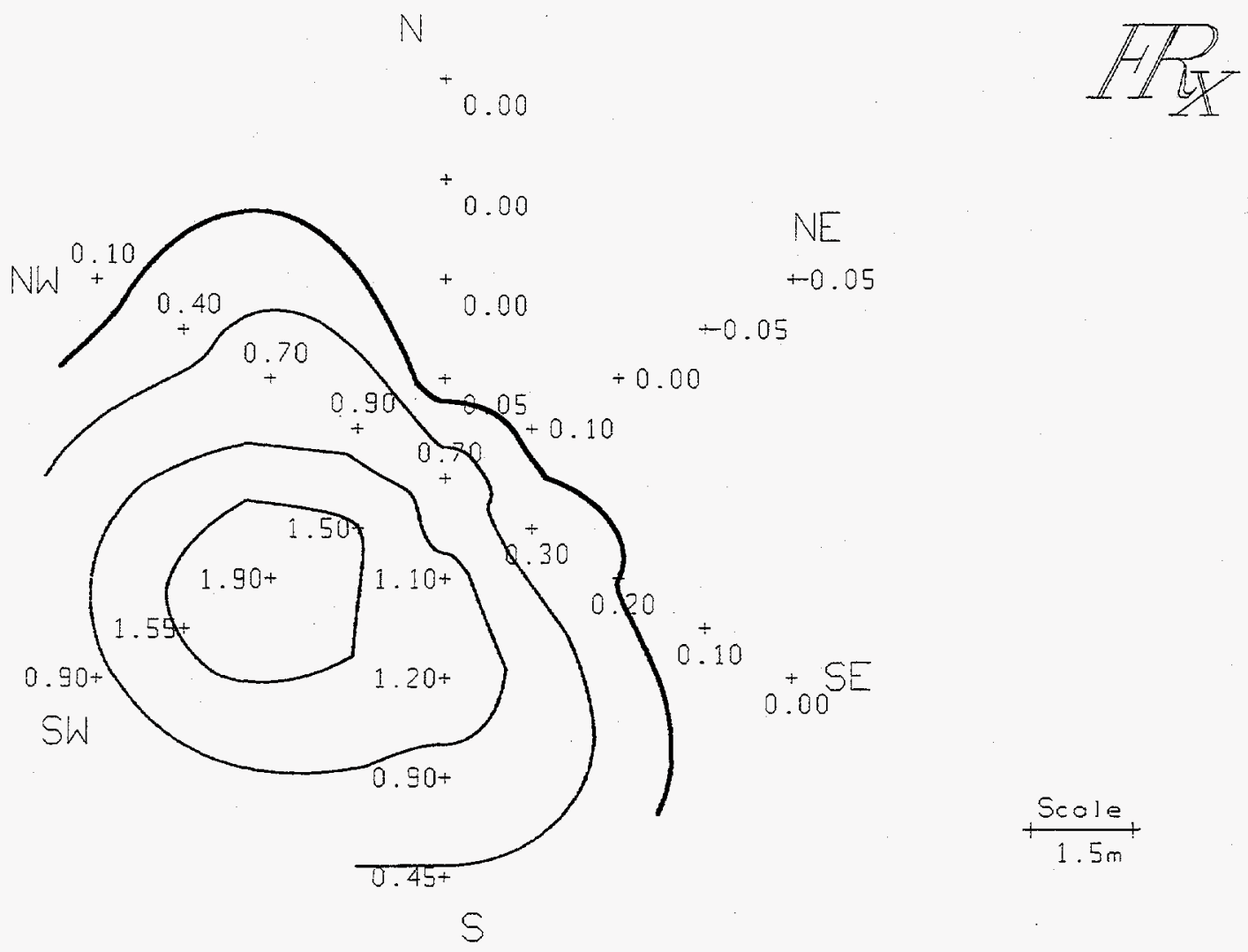

Uplift control points spaced $1.5 \mathrm{~m}$ apart along rays oriented to "plant" north.

Heavy contour is for $2 \mathrm{~mm}$ of uplift, which indicates expected limit of significant sand in the fracture. Lighter contours spaced at $5 \mathrm{~mm}$, starting with $5 \mathrm{~mm}$.

SITE: PORTS Clean Test Site

DATE: $5 / 9 / 96$

LOCATION: CTS "C"

FRACTURE DEPTH: 13

UPLIFT VOLUME: $0.64 \mathrm{~m}^{3}$
FRACTURE ID: CTSC-4

GEL VOLUME: 100 gal.

Proppant: \#7 Sand

Proppant Content: $16 \mathrm{ft}^{3}$

Ratio, Uplift / Inj Vol: 0.98

NOTES: missing first few minutes of $p \log$ 
Figure A.11 Hydraulic Fracturing Uplift, Clean Test Site Cell D, $18 \mathrm{ft}$ fracture.

\section{Hydraulic Fracturing Uplift}

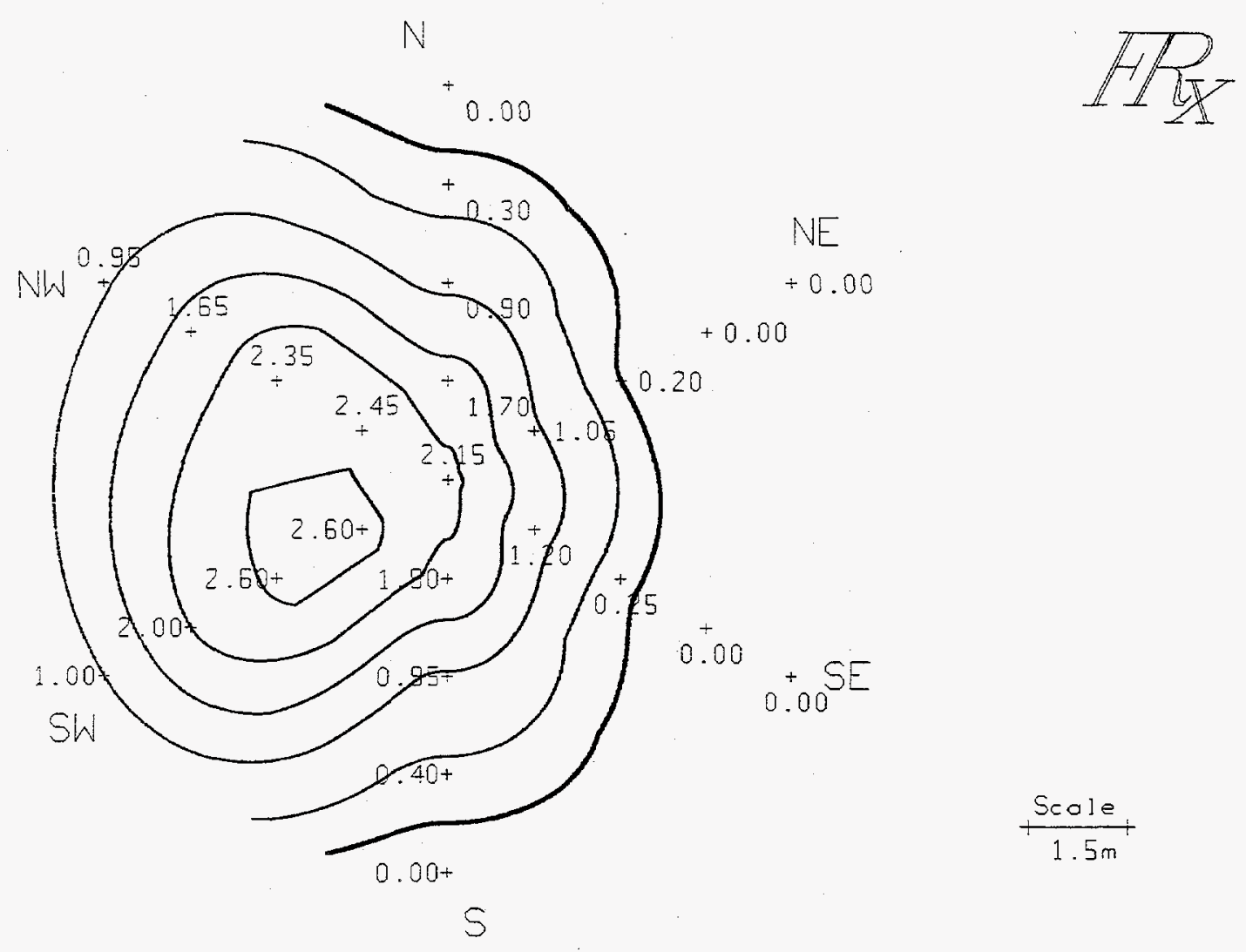

Uplift control points spaced $1.5 \mathrm{~m}$ apart along rays oriented to "plant" north.

Heavy contour is for $2 \mathrm{~mm}$ of uplift, which indicates expected limit of significant sand in the fracture. Lighter contours spaced at $5 \mathrm{~mm}$, starting with $5 \mathrm{~mm}$.

SITE: PORTS Clean Test Site

DATE: $5 / 9 / 96$

LOCATION: CTS "D"

FRACTURE DEPTH: 18

UPLIFT VOLUME: $1.14 \mathrm{~m}^{3}$
FRACTURE ID: CTSD-18

GeL VolUME: $180 \mathrm{gal}$.

Proppant: \#5 \& \#7 Sand

Proppant Content: $28 \mathrm{ft}^{3}$

Ratio, Uplift / Inj Vol: 0.98

\section{NOTES:}


Table A.1 Reconnaissance Sampling Summary.

\begin{tabular}{|c|c|c|c|}
\hline Sample Type & Sample Frequency & $\begin{array}{l}\text { No. of } \\
\text { Samples }\end{array}$ & Analytes ${ }^{2} /$ Laboratory \\
\hline $\begin{array}{l}\text { Soil samples from } \\
\text { X-231A corehole } \\
\text { sampling }\end{array}$ & $\begin{array}{l}9 \text { samples at six } \\
\text { locations }(1-2,3- \\
4,5-6,7-8,9-10 \\
11-12,13-14,15- \\
16,17-18 \mathrm{ft} . \mathrm{bgs})\end{array}$ & 54 samples & VOCs/ORNL Field Lab \\
\hline $\begin{array}{l}\text { Soil samples from } \\
\text { X-231A corehole } \\
\text { sampling }\end{array}$ & $\begin{array}{l}2 \text { samples at } 2 \\
\text { locations ( } 1-2 \text { and } \\
7-8 \mathrm{ft} . \text { bgs at } \\
\text { GP04, } 11-12 \text { and } \\
15-16 \mathrm{ft} \text {. bgs at } \\
\text { GP05) }\end{array}$ & 4 samples & $\begin{array}{l}\text { PCBs/PORTS } \\
\text { Radionuclides/PORTS } \\
\text { RCRA Metals/PORTS }\end{array}$ \\
\hline $\begin{array}{l}\text { QA/QC soil } \\
\text { samples }\end{array}$ & $\begin{array}{l}1 \text { duplicate for } \\
\text { every } 10 \text { VOC } \\
\text { samples }(10 \%)\end{array}$ & 5 samples & VOCs/ORNL Field Lab \\
\hline $\begin{array}{l}\text { QAVQC soil } \\
\text { samples }\end{array}$ & $\begin{array}{l}1 \text { rinsate per } \\
\text { sampling event }\end{array}$ & $\begin{array}{l}1 \text { rinsate } \\
1 \text { rinsate }\end{array}$ & $\begin{array}{l}\text { VOCs/ORNL Field Lab } \\
\text { PCBs/PORTS } \\
\text { Radionuclides/PORTS } \\
\text { RCRA Metals/PORTS }\end{array}$ \\
\hline Field blanks & $\begin{array}{l}1 \text { per decon water } \\
\text { source per task }\end{array}$ & $\begin{array}{l}1 \text { sample } \\
1 \text { sample }\end{array}$ & $\begin{array}{l}\text { VOCs/ORNL Field Lab } \\
\text { PCBs/PORTS } \\
\text { Radionuclides/PORTS } \\
\text { RCRA Metals/PORTS }\end{array}$ \\
\hline
\end{tabular}

Methods for the listed analyses are as follows:

VOCs: hexane extraction and on site field GC for PCE, TCE, 1,1,1-TCA, 1,2-DCE, and 1,1DCE

Radionuclides (gross alpha and beta, total uranium): PORTS TSD-553-240 and 230, respectively

RCRA metals (As, Ba, Cd, Cr, Pb, Hg, Se, and Ag): SW-6010 and SW-7470 (Hg)

PCBs (Aroclor 1254 and 1260): SW-8080

Physical properties: $\mathrm{pH}, \%$ soil moisture, TOC, and bulk density 
Table A.2 VOC and TOC concentrations in soil with depth from reconnaisance sampling, May 1996.

\begin{tabular}{|c|c|c|c|c|c|}
\hline Location & $\begin{array}{c}\text { Depth } \\
\text { (ft bgs) }\end{array}$ & $\begin{array}{c}\text { TCA } \\
(\mu \mathrm{g} / \mathrm{kg})\end{array}$ & $\begin{array}{c}\text { TCE } \\
(\mu \mathrm{g} / \mathrm{kg})\end{array}$ & $\begin{array}{c}\text { PCE } \\
(\mu \mathrm{g} / \mathrm{kg})\end{array}$ & $\begin{array}{c}\text { TOC } \\
(\mathrm{mg} / \mathrm{kg})\end{array}$ \\
\hline \multirow[t]{10}{*}{ GP01 } & 2 & 333 & 186 & 10 & $\mathrm{NA}$ \\
\hline & 4 & 208 & 103 & & NA \\
\hline & 6 & 1 & 2 & & $\mathrm{NA}$ \\
\hline & 8 & & 5 & & NA \\
\hline & 10 & & & & $\mathrm{NA}$ \\
\hline & 12 & & & & NA \\
\hline & 14 & & & & NA \\
\hline & 16 & & & & NA \\
\hline & 18 & & & & NA \\
\hline & 20 & & & & NA \\
\hline \multirow{10}{*}{ GP02 } & 2 & 2 & 73 & & NA \\
\hline & 4 & & 153 & & NA \\
\hline & 6 & & 466 & & NA \\
\hline & 8 & & 10782 & & NA \\
\hline & 10 & 118 & 51517 & 10 & NA \\
\hline & 12 & 125 & 55280 & 10 & NA \\
\hline & 14 & & 9863 & & NA \\
\hline & 16 & & 5565 & & NA \\
\hline & 18 & & 3804 & & NA \\
\hline & 20 & & 319 & & $\mathrm{NA}$ \\
\hline \multirow[t]{9}{*}{ GP03 } & 2 & & 10 & & $\mathrm{NA}$ \\
\hline & 4 & & 18 & & NA \\
\hline & 6 & & 38 & & $\mathrm{NA}$ \\
\hline & 8 & & 5 & & NA \\
\hline & 10 & & & & $\mathrm{NA}$ \\
\hline & 12 & & & & $\mathrm{NA}$ \\
\hline & 14 & & & & NA \\
\hline & 16 & & & & $\mathrm{NA}$ \\
\hline & 18 & & & & $\mathrm{NA}$ \\
\hline \multirow[t]{9}{*}{ GP04 } & 2 & & 10 & & 1000 \\
\hline & 4 & & 42 & & NA \\
\hline & 6 & & 24 & & NA \\
\hline & 8 & & & & 2500 \\
\hline & 10 & & 5 & & $\mathrm{NA}$ \\
\hline & 12 & & 1 & & NA \\
\hline & 14 & & & & NA \\
\hline & 16 & & & & $\mathrm{NA}$ \\
\hline & 18 & & & & NA \\
\hline
\end{tabular}

Blank indicates non-detect.

NA not analyzed 
Table A.2 cont. VOC and TOC concentrations in soil with depth from reconnaisance sampling, May 1996.

\begin{tabular}{|c|c|c|c|c|c|}
\hline Location & $\begin{array}{c}\text { Depth } \\
\text { (ft bgs) }\end{array}$ & $\begin{array}{c}\text { TCA } \\
(\mu \mathrm{g} / \mathrm{kg})\end{array}$ & $\begin{array}{c}\text { TCE } \\
(\mu \mathrm{g} / \mathrm{kg})\end{array}$ & $\begin{array}{c}\mathrm{PCE} \\
(\mu \mathrm{g} / \mathrm{kg})\end{array}$ & $\begin{array}{c}\text { TOC } \\
(\mathrm{mg} / \mathrm{kg})\end{array}$ \\
\hline \multirow[t]{8}{*}{ GP05 } & 2 & 10 & 983 & & NA \\
\hline & 4 & 24 & 8701 & & NA \\
\hline & 6 & 53 & 18090 & & NA \\
\hline & 8 & & 10729 & & NA \\
\hline & 10 & & 32 & & NA \\
\hline & 12 & & 10 & & 1700 \\
\hline & 14 & & & & $\mathrm{NA}$ \\
\hline & 16 & & & & 730 \\
\hline \multirow[t]{9}{*}{ GP06 } & 2 & & & & NA \\
\hline & 4 & & & & $\mathrm{NA}$ \\
\hline & 6 & & & & NA \\
\hline & 8 & & & & $\mathrm{NA}$ \\
\hline & 10 & & & & $\mathrm{NA}$ \\
\hline & 12 & & & & NA \\
\hline & 14 & & & & NA \\
\hline & 16 & & & & NA \\
\hline & 18 & & & & NA \\
\hline
\end{tabular}

Blank indicates non-detect.

NA not analyzed 
Table A.3 Metals concentrations in soil with depth from reconnaisance sampling, May 1996; Portsmouth laboratory analyses.

\begin{tabular}{cccccccccc}
\hline Location & $\begin{array}{c}\text { Depth } \\
(\mathrm{ft} b g \mathrm{~b})\end{array}$ & $\begin{array}{c}\mathrm{As} \\
(\mu \mathrm{g} / \mathrm{L})\end{array}$ & $\begin{array}{c}\mathrm{Ba} \\
(\mu \mathrm{g} / \mathrm{L})\end{array}$ & $\begin{array}{c}\mathrm{Cd} \\
(\mu \mathrm{g} / \mathrm{L})\end{array}$ & $\begin{array}{c}\mathrm{Cr} \\
(\mu \mathrm{g} / \mathrm{L})\end{array}$ & $\begin{array}{c}\mathrm{Pb} \\
(\mu \mathrm{g} / \mathrm{L})\end{array}$ & $\begin{array}{c}\mathrm{Se} \\
(\mu \mathrm{g} / \mathrm{L})\end{array}$ & $\begin{array}{c}\mathrm{Ag} \\
(\mu \mathrm{g} / \mathrm{L})\end{array}$ & $\begin{array}{c}\mathrm{Hg} \\
(\mathrm{mg} / \mathrm{kg})\end{array}$ \\
\hline GP4 & 2 & 11.2 & $64.1 \mathrm{~N}$ & $3.7 \mathrm{~N}$ & 10.5 & 16 & $3.5 \mathrm{UN} \mathrm{N}^{*}$ & $1.9 \mathrm{~N}$ & $0.024 \mathrm{U}$ \\
& 8 & 13.6 & $45.7 \mathrm{~N}$ & $3.3 \mathrm{~N}$ & 12.8 & 13.4 & $3.6 \mathrm{UNJ}$ & $0.49 \mathrm{UN}$ & $0.024 \mathrm{U}$ \\
\hline GP5 & 12 & 19.3 & $47.2 \mathrm{~N}$ & $3.0 \mathrm{~N}$ & 16.9 & 18.7 & $3.6 \mathrm{UNJ}$ & $0.74 \mathrm{~N}$ & $0.024 \mathrm{U}$ \\
& 16 & 19.5 & $48.8 \mathrm{~N}$ & $3.8 \mathrm{~N}$ & 10.1 & 14.1 & $3.5 \mathrm{UNJ}$ & $1.4 \mathrm{~N}$ & $0.024 \mathrm{U}$ \\
\hline
\end{tabular}

* Duplicate analysis is not within control limits.

$\mathrm{J}$ Estimated value

N Spike sample recovery is not within control limits.

$\mathrm{U}$ Compound was analyzed for but not detected. The number is the attainable detection limit for the sample.

UJ Qualify data for the sample as estimated.

Table A.4 Other parameters from reconnaisance sampling, May 1996; Portsmouth laboratory analyses.

\begin{tabular}{cccccccc}
\hline Location & $\begin{array}{c}\text { Depth } \\
\text { (ft bgs) }\end{array}$ & $\begin{array}{c}\text { PCBs } \\
(\mathrm{mg} / \mathrm{kg})\end{array}$ & pH & $\begin{array}{c}\text { Moisture } \\
(\%)\end{array}$ & $\begin{array}{c}\text { Total U } \\
(\mathrm{mg} / \mathrm{kg})\end{array}$ & $\begin{array}{c}\text { Gross alpha } \\
(\mathrm{pCi} / \mathrm{g})\end{array}$ & $\begin{array}{c}\text { Gross beta } \\
(\mathrm{pCi} / \mathrm{g})\end{array}$ \\
\hline GP4 & 2 & $<0.5$ & 7.46 & 14 & 4 & 9 & 16 \\
& 8 & $<0.5$ & 6.46 & 17.9 & 5.4 & 9 & 21 \\
\hline GP5 & 12 & $<0.5$ & 6.33 & 17.9 & 3.8 & 9 & 20 \\
& 16 & $<0.5$ & 5.31 & 19.3 & 3.7 & 7 & $<12$ \\
\hline
\end{tabular}




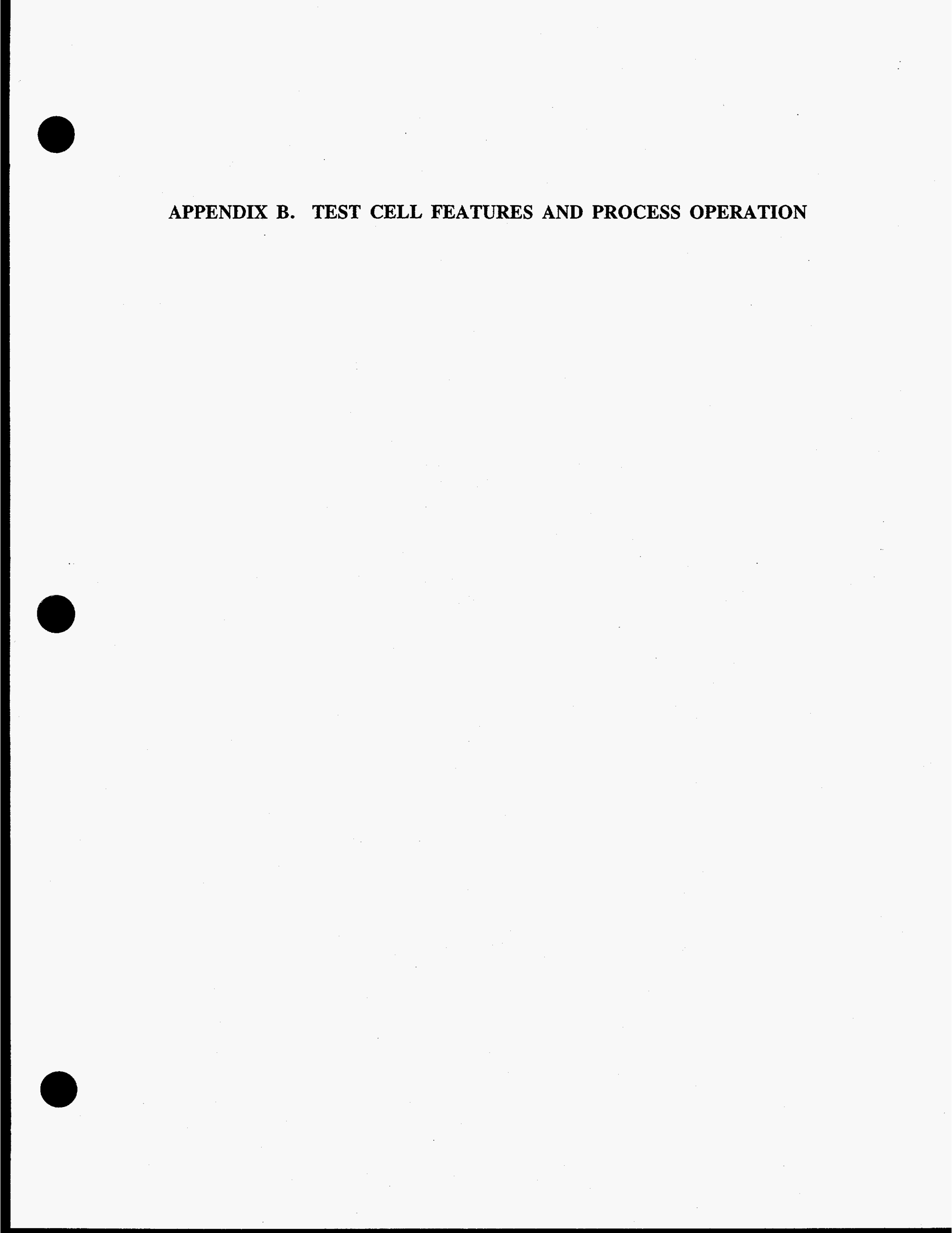


Figure B.1 Hydraulic fracturing uplift, test cell A, $4 \mathrm{ft}$ fracture (8/24/96).

\section{Hydraulic Fracturing Uplift}
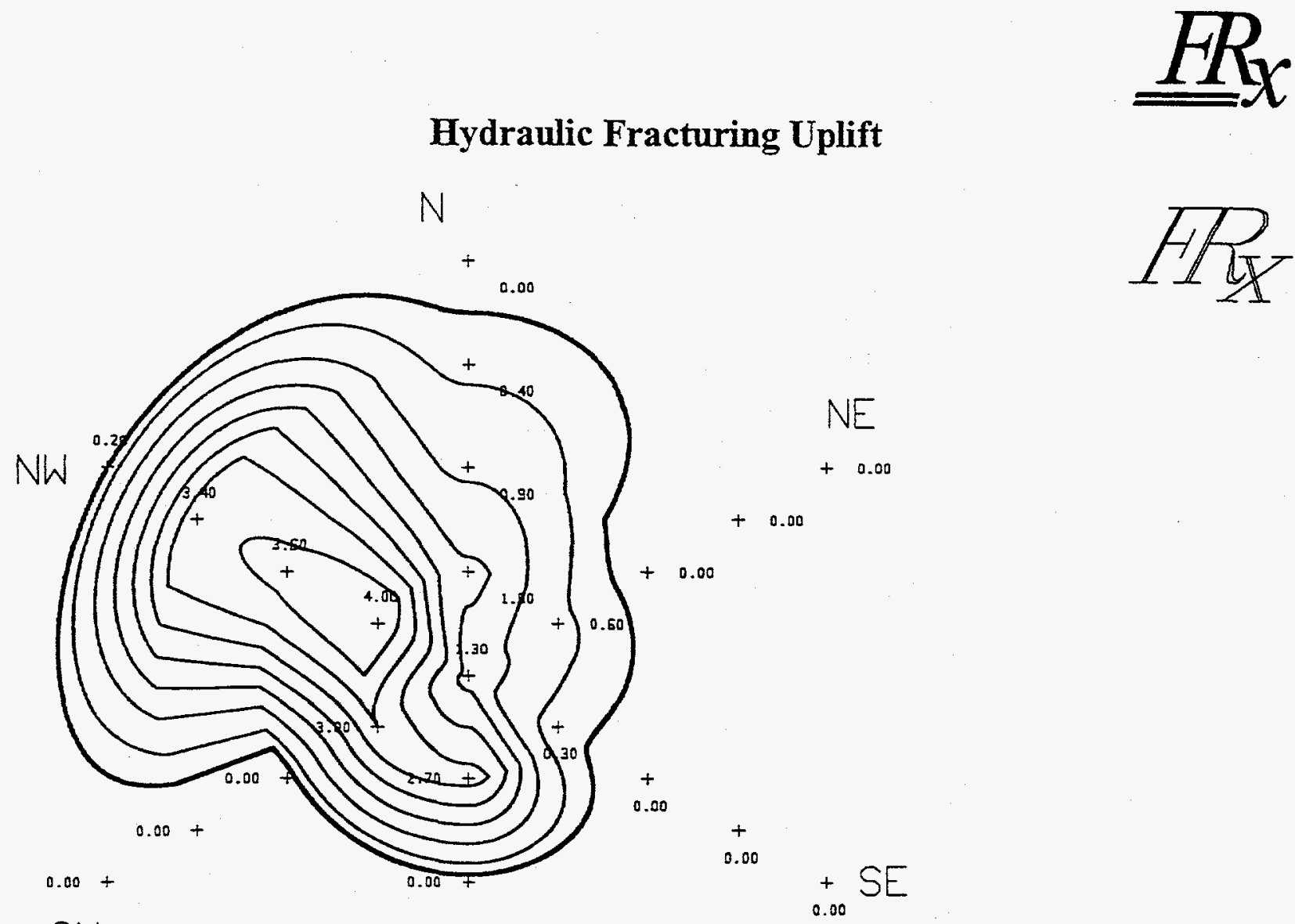

SW

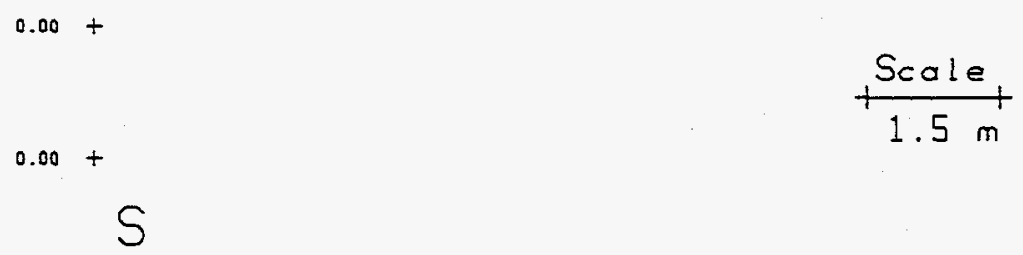

Uplift control points spaced $1.5 \mathrm{~m}$ apart along rays oriented to "plant" north.

Heavy contour is for $2 \mathrm{~mm}$ of uplift, which indicates expected limit of significant sand in the fracture. Lighter contours spaced at $5 \mathrm{~mm}$, starting with $5 \mathrm{~mm}$

SITE: PORTS X231A

DATE: $8 / 24 / 96$

LOCATION: "A" (Steam)

FRACTURE DEPTH: 4

UPLIFT VOLUME: $0.48 \mathrm{~m}^{3}$
FRACTURE ID: X231A-4a

SAND CONTENT: $5(\mathrm{x}) \mathrm{ft}^{3}$

GeL VolUME: 50(x) gal

PROPANT: \#7 Sand

Ratio, Uplift / Inj Vol: 2.91

Notes: (x)- pumped $5 \mathrm{ft} 3$ sand and 50 gal gel on 8/24/96. Pumped addtal $3 \mathrm{ft} 3$ sand and 30 gal gel on $8 / 25 / 96$. 
Figure B.2 Hydraulic Fracturing Uplift, Test Cell A, $4 \mathrm{ft}$ fracture (8/25/96).

\section{Hydraulic Fracturing Uplift}
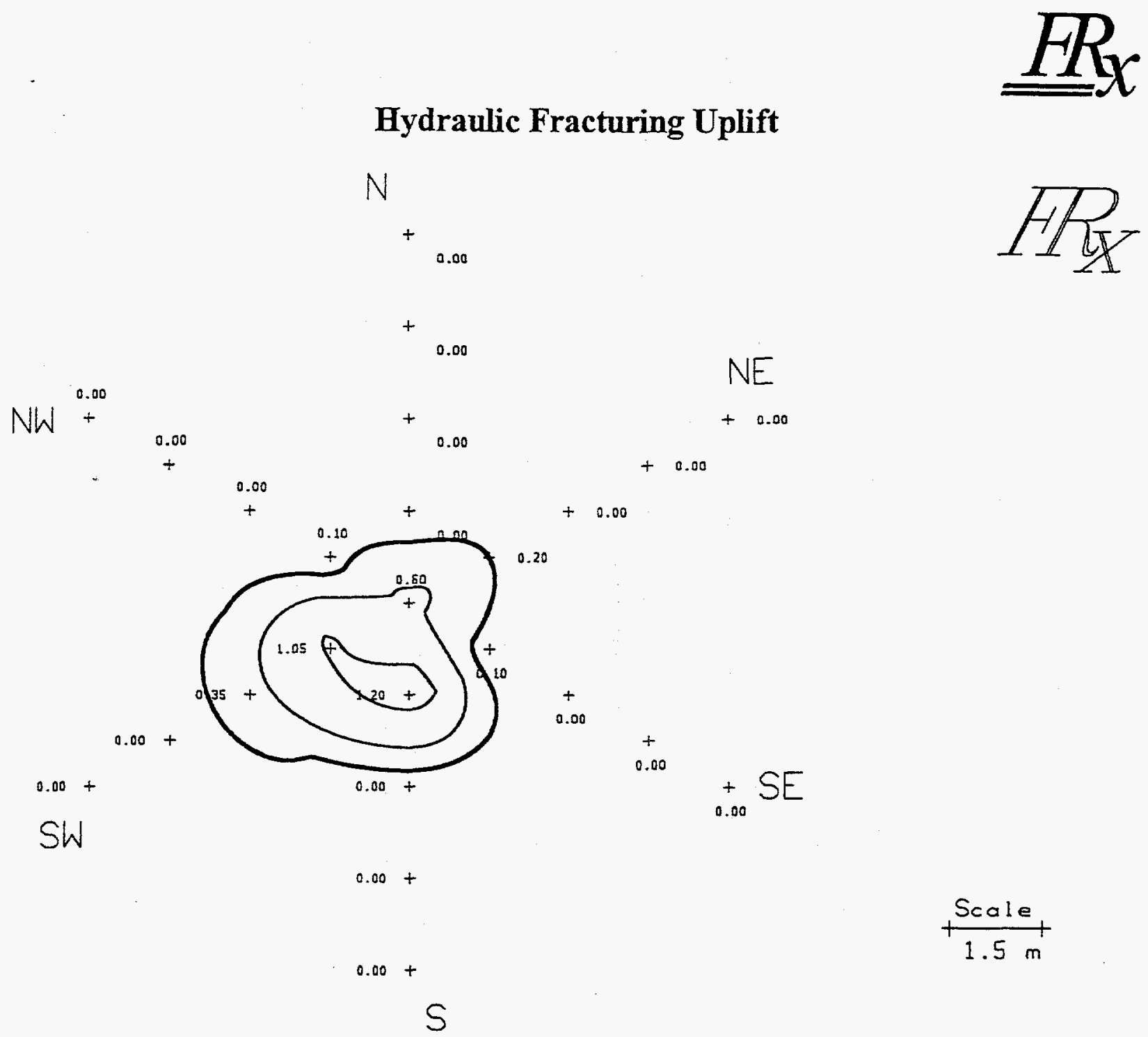

Uplift control points spaced $1.5 \mathrm{~m}$ apart along rays oriented to "plant" north.

Heavy contour is for $2 \mathrm{~mm}$ of uplift, which indicates expected limit of significant sand in the fracture. Lighter contours spaced at $5 \mathrm{~mm}$, starting with $5 \mathrm{~mm}$.

STTE: PORTS X231A

DATE: $8 / 25 / 96$

LOCATION: "A" (Steam)

FRACTURE DEPTH: 4

UPLIFT VOLUME: $0.093 \mathrm{~m}^{3}$.
FRACTURE DD: X231A-4a

SAND CONTENT: $3(\mathrm{x}) \mathrm{ft}^{3}$

GeL VOLUME: 30(x) gal.

PROPANT: \#7 Sand

Ratio, Uplift / Inj Vol: 0.564

Notes: (x)-pumped $5 \mathrm{ft} 3$ sand and 50 gal gel on 8/24/96. Pumped addtal $3 \mathrm{ft} 3$ sand and 30 gal gel on $8 / 25 / 96$. 
Figure B.3 Hydraulic Fracturing Uplift, Test Cell A, $8 \mathrm{ft}$ fracture.

\section{Hydraulic Fracturing Uplift}
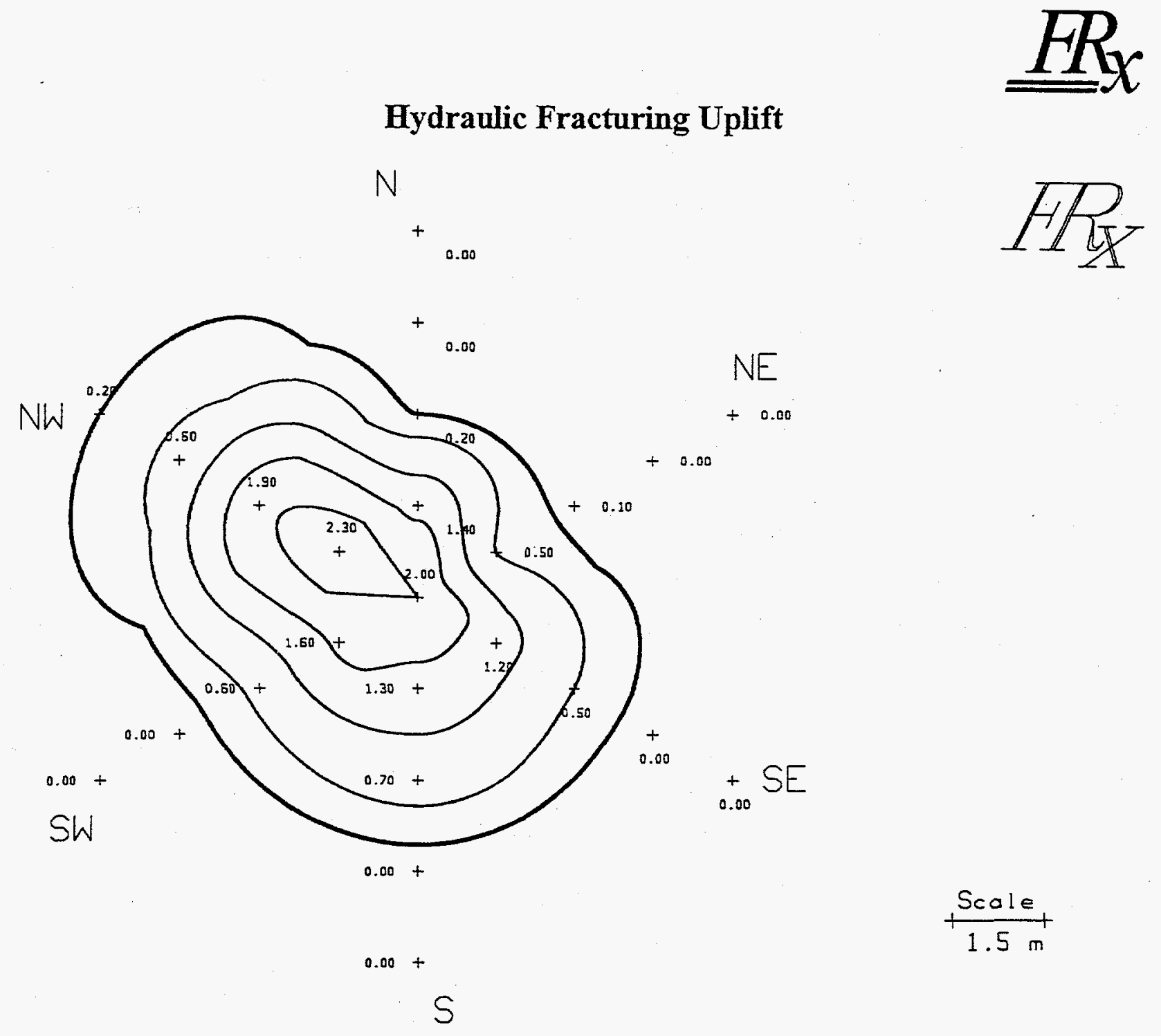

Uplift control points spaced $1.5 \mathrm{~m}$ apart along rays oriented to "plant" north.

Heavy contour is for $2 \mathrm{~mm}$ of uplift, which indicates expected limit of significant sand in the fracture. Lighter contours spaced at $5 \mathrm{~mm}$, starting with $5 \mathrm{~mm}$

STTE: PORTS X231A

DATE: $8 / 24 / 96$

LOCATION: "A" (Steam)

FRACTURE DEPTH: 8

UPLIFT VOLUME: $0.48 \mathrm{~m}^{3}$
Fracture ID: X231A-8

SAND CONTENT: $10 \mathrm{ft}^{3}$

GEL VOLUME: $80 \mathrm{gal}$

PROPANT: \#7 Sand

Ratio, Uplift / Inj Vol: 1.02 
Figure B.4 Hydraulic Fracturing Uplift, Test Cell A, $12 \mathrm{ft}$ fracture.

\section{Hydraulic Fracturing Uplift}

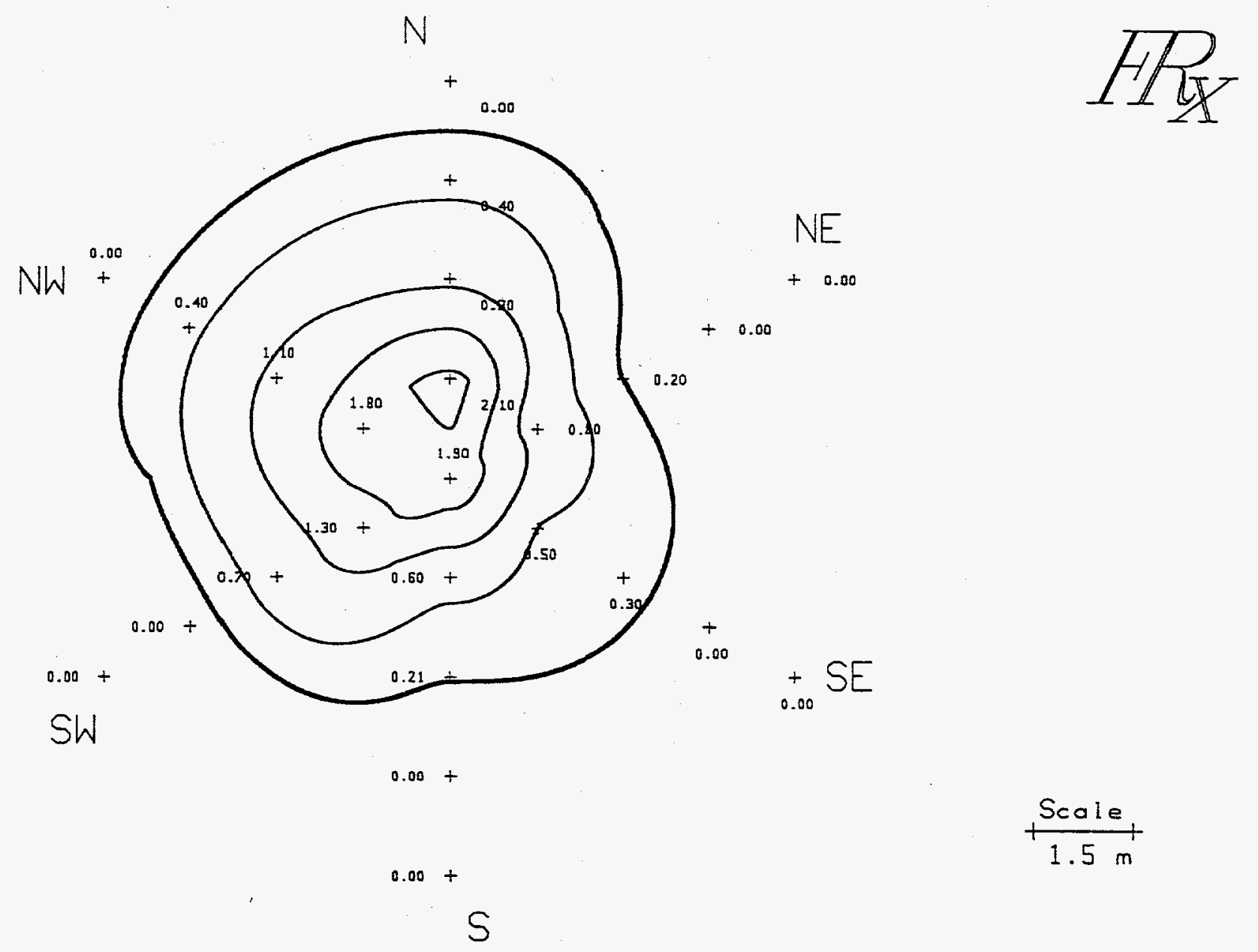

Uplift control points spaced $1.5 \mathrm{~m}$ apart along rays oriented to "plant" north.

Heavy contour is for $2 \mathrm{~mm}$ of uplift, which indicates expected limit of significant sand in the fracture. Lighter contours spaced at $5 \mathrm{~mm}$, starting with $5 \mathrm{~mm}$

SITE: PORTS X231A

DATE: $8 / 24 / 96$

LocATION: "A" (Steam)

FRACTURE DEPTH: 12

UPLIFT VOLUME: $0.43 \mathrm{~m}^{3}$
FRACTURE ID: X231A-12

SAND CONTENT: $13 \mathrm{ft}^{3}$

GeL Volume: $120 \mathrm{gal}$

PROPANT: \#7 Sand

Ratio, Uplift / Inj Vol: 0.643

Notes: 
Figure B.5 Hydraulic Fracturing Uplift, Test Cell A, $18 \mathrm{ft} \mathrm{fracture.}$

\section{Hydraulic Fracturing Uplift}

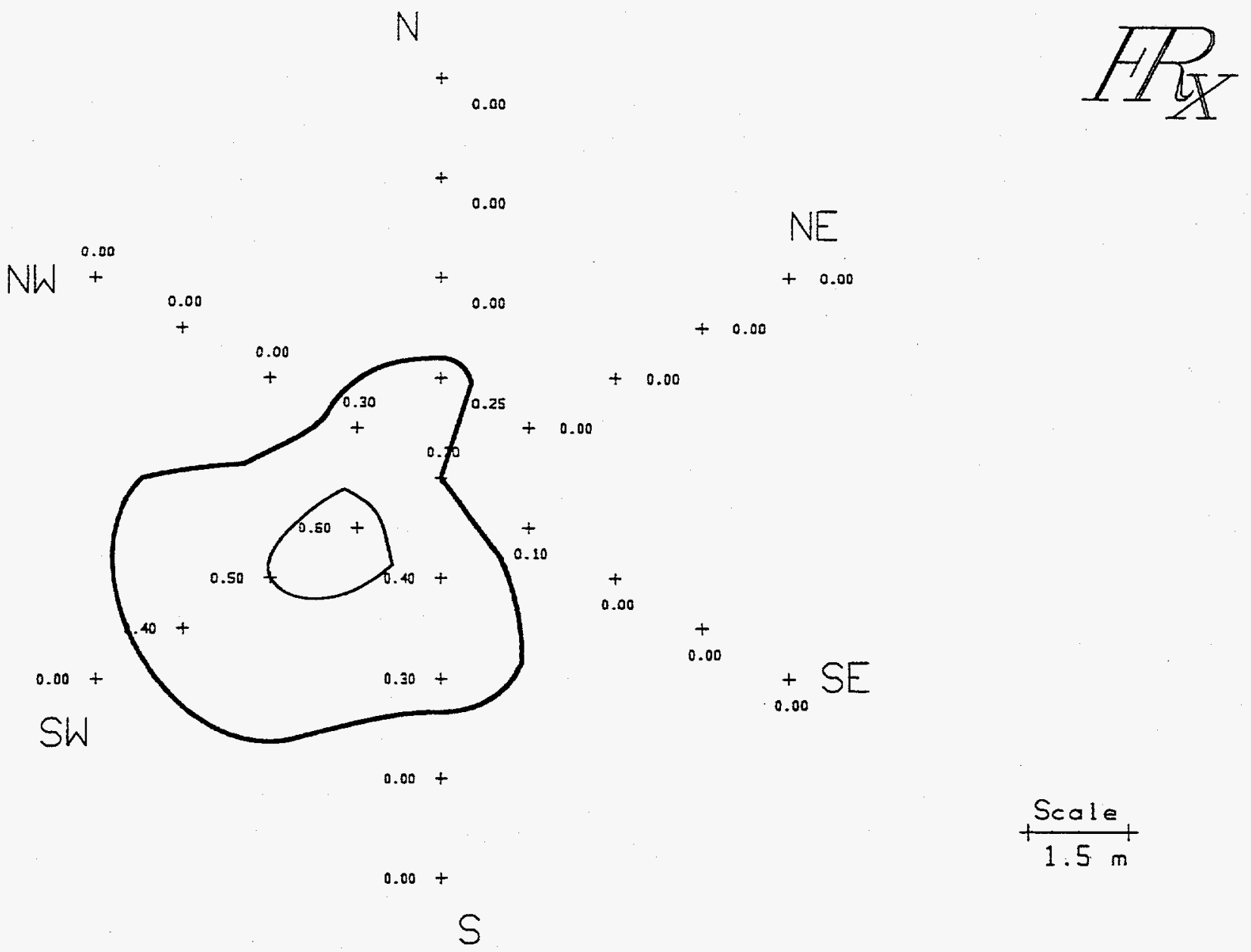

Uplift control points spaced $1.5 \mathrm{~m}$ apart along rays oriented to "plant" north.

Heavy contour is for $2 \mathrm{~mm}$ of uplift, which indicates expected limit of significant sand in the fracture. Lighter contours spaced at $5 \mathrm{~mm}$, starting with $5 \mathrm{~mm}$

SITE: PORTS X231A

DATE: $8 / 25 / 96$

LOCATION: "A" (Steam)

FRACTURE DEPTH: 18

UPLIFT VOLUME: $0.11 \mathrm{~m}^{3}$
FRACTURE ID: X231A-18

SAND CONTENT: $20 \mathrm{ft}^{3}$

GEL VOLUME: $165 \mathrm{gal}$

PROPANT: \#7 Sand

Ratio, Uplift / Inj Vol: 0.113

NoTES: 
Figure B.6 Hydraulic Fracturing Uplift, Test Cell B, $4 \mathrm{ft}$ fracture.

\section{Hydraulic Fracturing Uplift}
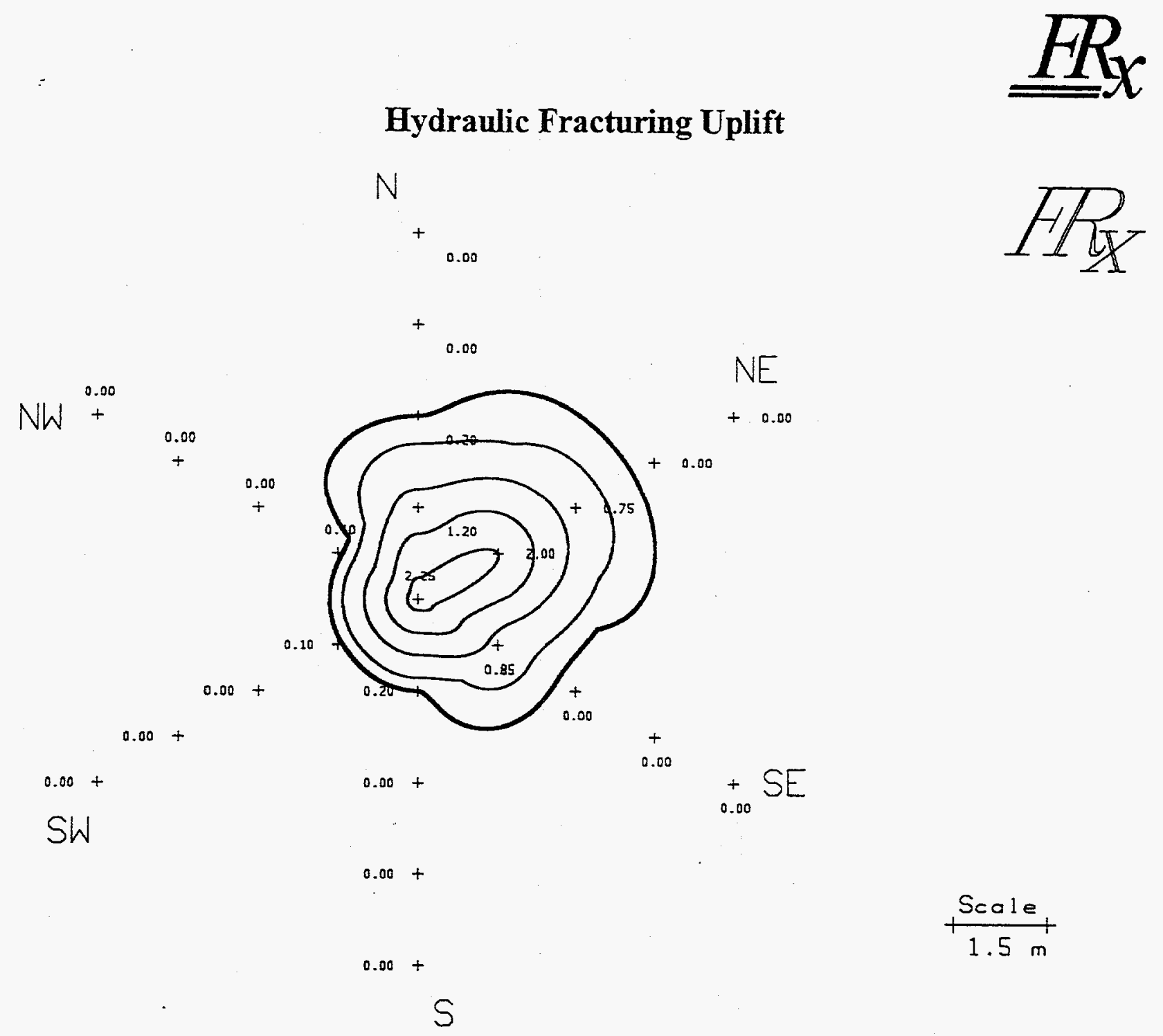

Uplift control points spaced $1.5 \mathrm{~m}$ apart along rays oriented to "plant" north.

Heavy contour is for $2 \mathrm{~mm}$ of uplift, which indicates expected limit of significant sand in the fracture. Lighter contours spaced at $5 \mathrm{~mm}$, starting with $5 \mathrm{~mm}$

SITE: PORTS X231A

DATE: $8 / 25 / 96$

LOCATION: "B" (Hot Air)

FRACTURE DEPTH: 4

UPLIFT VOLUME: $0.20 \mathrm{~m}^{3}$
FRACTURE ID: X231B-4

SAND CONTENT: $5 \mathrm{ft}^{3}$

GEL VOLUME: 50 gal.

PROPANT: \#7 Sand

Ratio, Uplift / Inj Vol: 0.737

NoTES: 
Figure B.7 Hydraulic Fracturing Uplift, Test Cell B, $6 \mathrm{ft}$ fracture.

\section{Hydraulic Fracturing Uplift}
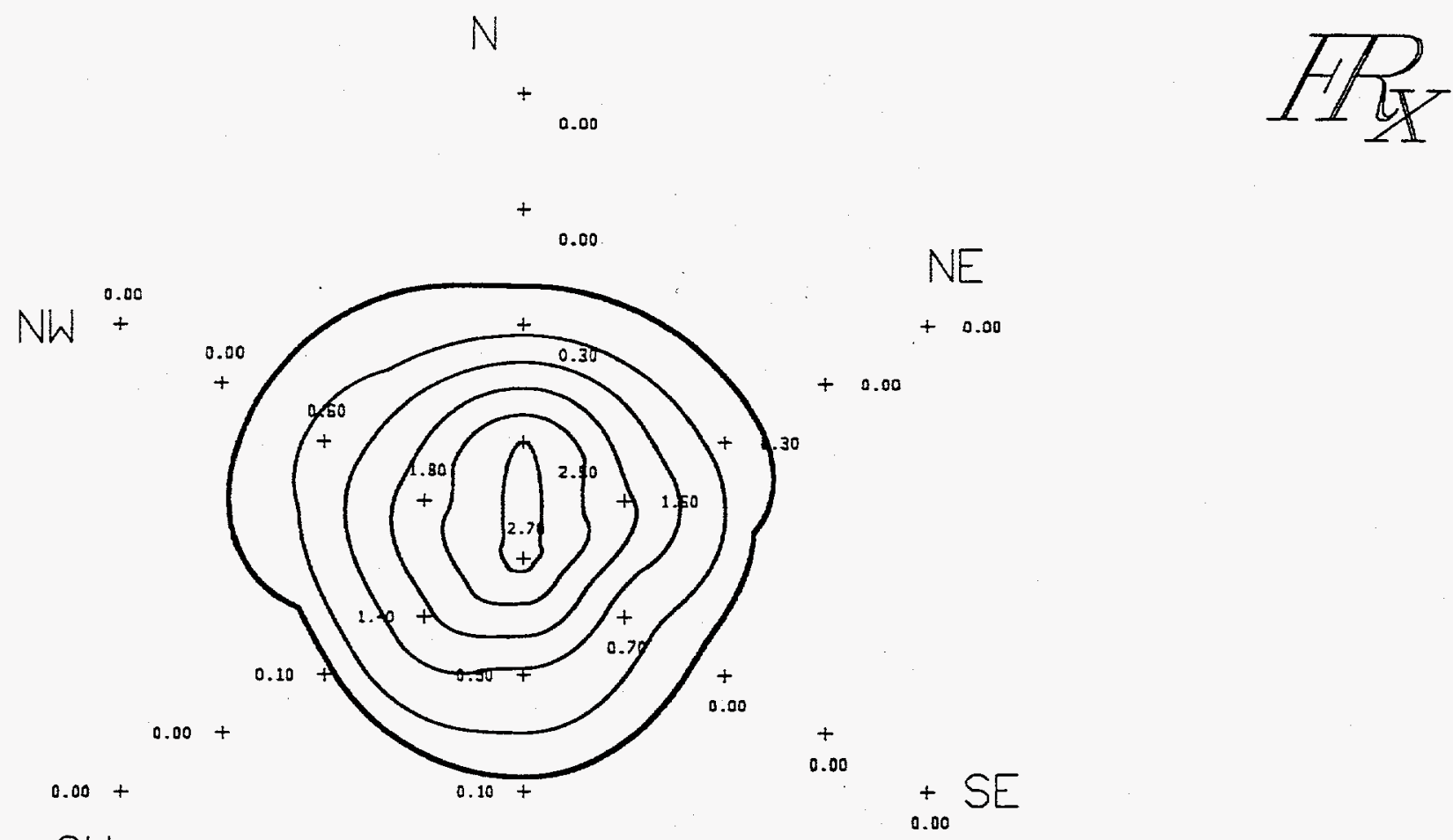

SW

$$
0.00+5 \frac{\text { Scole }}{1.5 \mathrm{~m}}
$$

Uplift control points spaced $1.5 \mathrm{~m}$ apart along rays oriented to "plant" north.

Heavy contour is for $2 \mathrm{~mm}$ of uplift, which indicates expected limit of significant sand in the fracture. Lighter contours spaced at $5 \mathrm{~mm}$, starting with $5 \mathrm{~mm}$.

SITE: PORTS X231A

DATE: $8 / 25 / 96$

LOCATION: "B" (Hot Air)

FRACTURE DEPTH: 6

UPLIFT VOLUME: $0.34 \mathrm{~m}^{3}$
FRACTURE ID: X231B-6

SAND CONTENT: $8 \mathrm{ft}^{3}$

GEL VOLUME: $75 \mathrm{gal}$

PROPANT: \#7 Sand

Ratio, Uplift / Inj Vol: 0.806

NOTES: 
Figure B.8 Hydraulic Fracturing Uplift, Test Cell B, $8 \mathrm{ft}$ fracture.

\section{Hydraulic Fracturing Uplift}
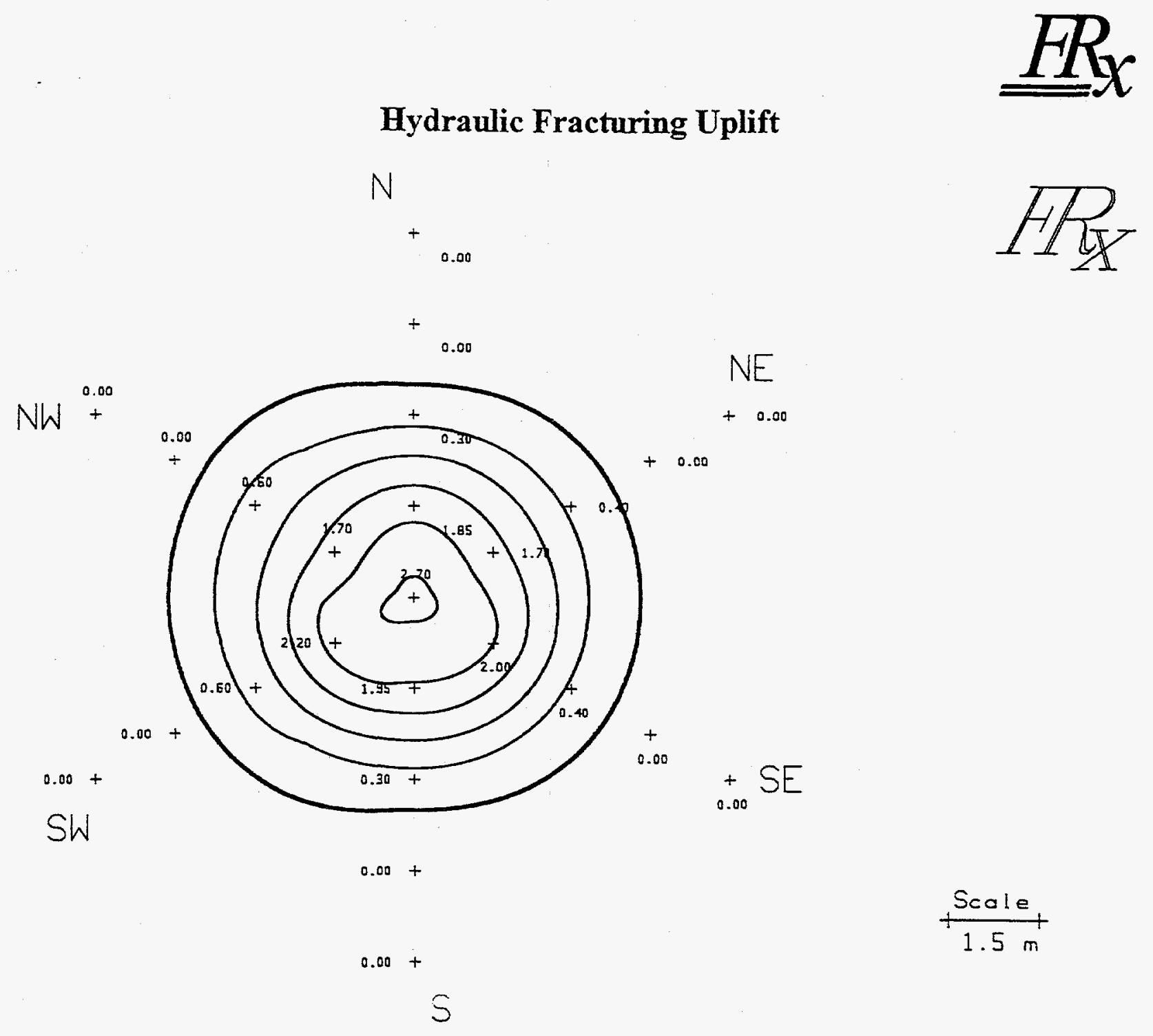

Uplift control points spaced $1.5 \mathrm{~m}$ apart along rays oriented to "plant" north.

Heavy contour is for $2 \mathrm{~mm}$ of uplift, which indicates expected limit of significant sand in the fracture. Lighter contours spaced at $5 \mathrm{~mm}$, starting with $5 \mathrm{~mm}$

SITE: PORTS X231A

DATE: $8 / 25 / 96$

LOCATION: "B" (Hot Air)

FRACTURE DEPTH: 8

UPLIFT VOLUME: $0.45 \mathrm{~m}^{3}$
FRACTURE ID: X231B-8

SAND CONTENT: $12 \mathrm{ft}^{3}$

GEL VOLUME: $110 \mathrm{gal}$.

PRoPANT: \#7 Sand

Ratio, Uplift / Inj Vol: 0.731

NOTES: 
Figure B.9 Hydraulic Fracturing Uplift, Test Cell B, $12 \mathrm{ft}$ fracture.

\section{Hydraulic Fracturing Uplift}
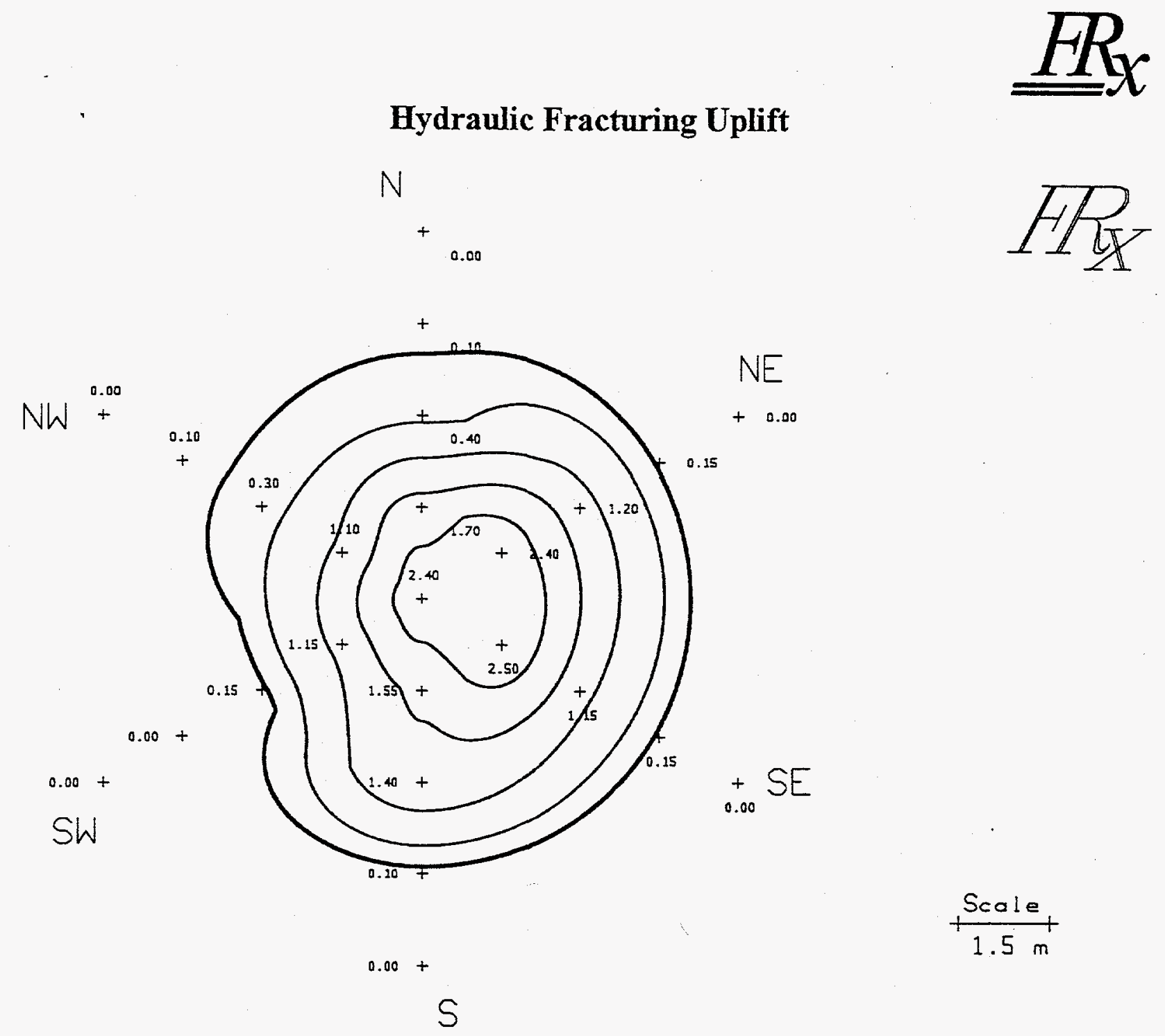

Uplift control points spaced $1.5 \mathrm{~m}$ apart along rays oriented to "plant" north.

Heavy contour is for $2 \mathrm{~mm}$ of uplift, which indicates expected limit of significant sand in the fracture. Lighter contours spaced at $5 \mathrm{~mm}$, starting with $5 \mathrm{~mm}$

SITE: PORTS X231A

DATE: 8/26/96

LOCATION: "B" (Hot Air)

FRACTURE DEPTH: 12

UPLIFT VOLUME: $0.75 \mathrm{~m}^{3}$
FRACTURE ID: X231B-12

SAND CONTENT: $15 \mathrm{ft}^{3}$

GEL VolUME: $130 \mathrm{gal}$.

PRopaNT: \#7 Sand

Ratio, Uplift / Inj Vol: 0.56

NoTES: 
Figure B.10 Hydraulic Fracturing Uplift, Test Cell B, $16.5 \mathrm{ft}$ fracture.

\section{Hydraulic Fracturing Uplift}

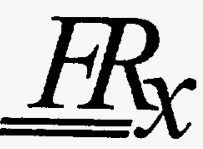

$N$
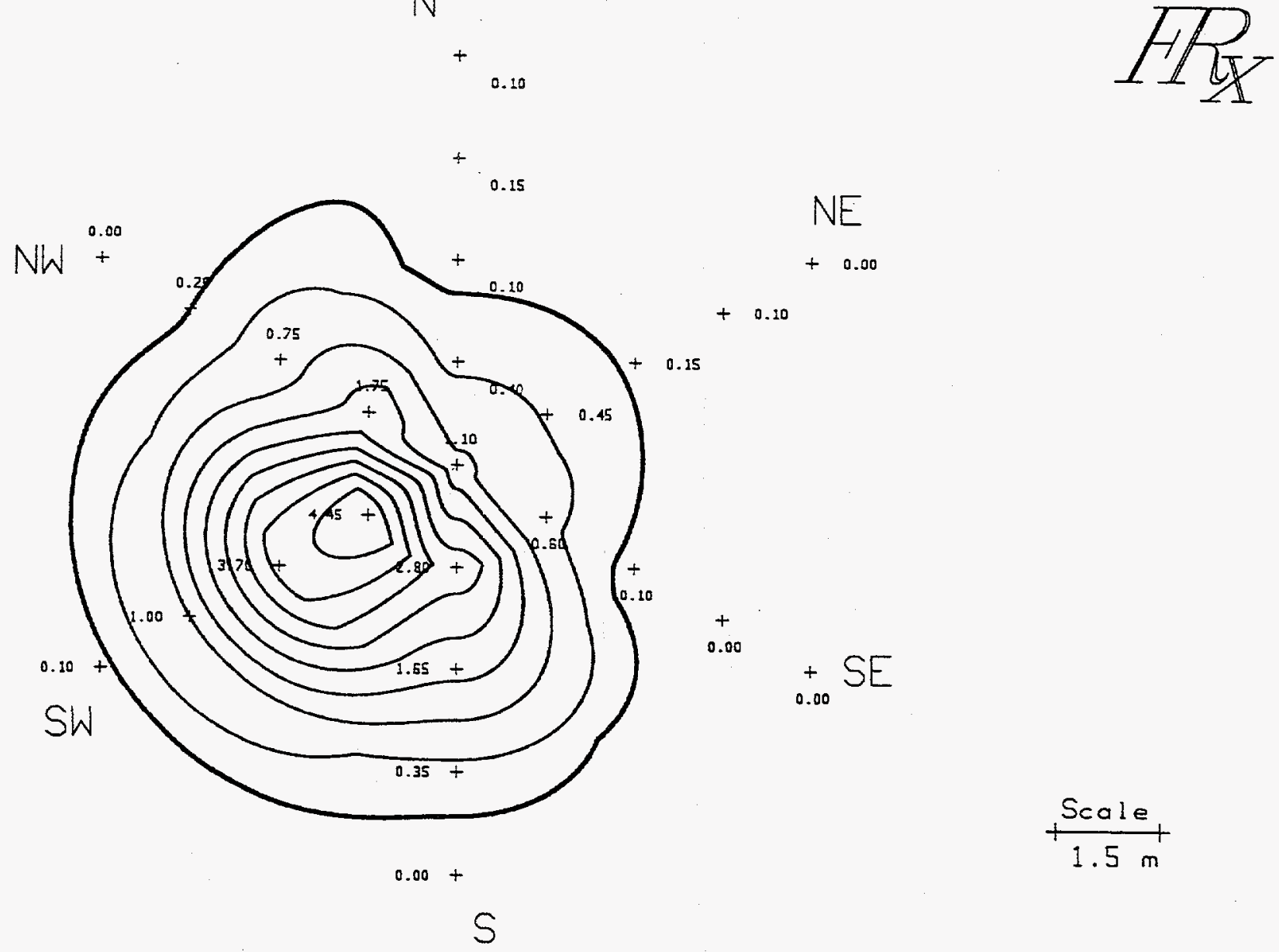

$+\frac{\text { Scale }}{1.5 \mathrm{~m}}$

Uplift control points spaced $1.5 \mathrm{~m}$ apart along rays oriented to "plant" north.

Heavy contour is for $2 \mathrm{~mm}$ of uplift, which indicates expected limit of significant sand in the fracture. Lighter contours spaced at $5 \mathrm{~mm}$, starting with $5 \mathrm{~mm}$

SITE: PORTS X231A

DATE: 8/26/96

Location: "B" (Hot Air)

FRACTURE DEPTH: 16.5

UPLIFT VOLUME: $0.71 \mathrm{~m}^{3}$
FRACTURE ID: X231B-16

SAND CONTENT: $20 \mathrm{ft}^{3}$

GEL VOLUME: $180+20$ H2O gal

PROPANT: \#7 Sand

Ratio, Uplift / Inj Vol: 0.647

NoTES: 
Figure B.11 Hydraulic Fracturing Uplift, Test Cell C, $4 \mathrm{ft}$ fracture.

\section{Hydraulic Fracturing Uplift}
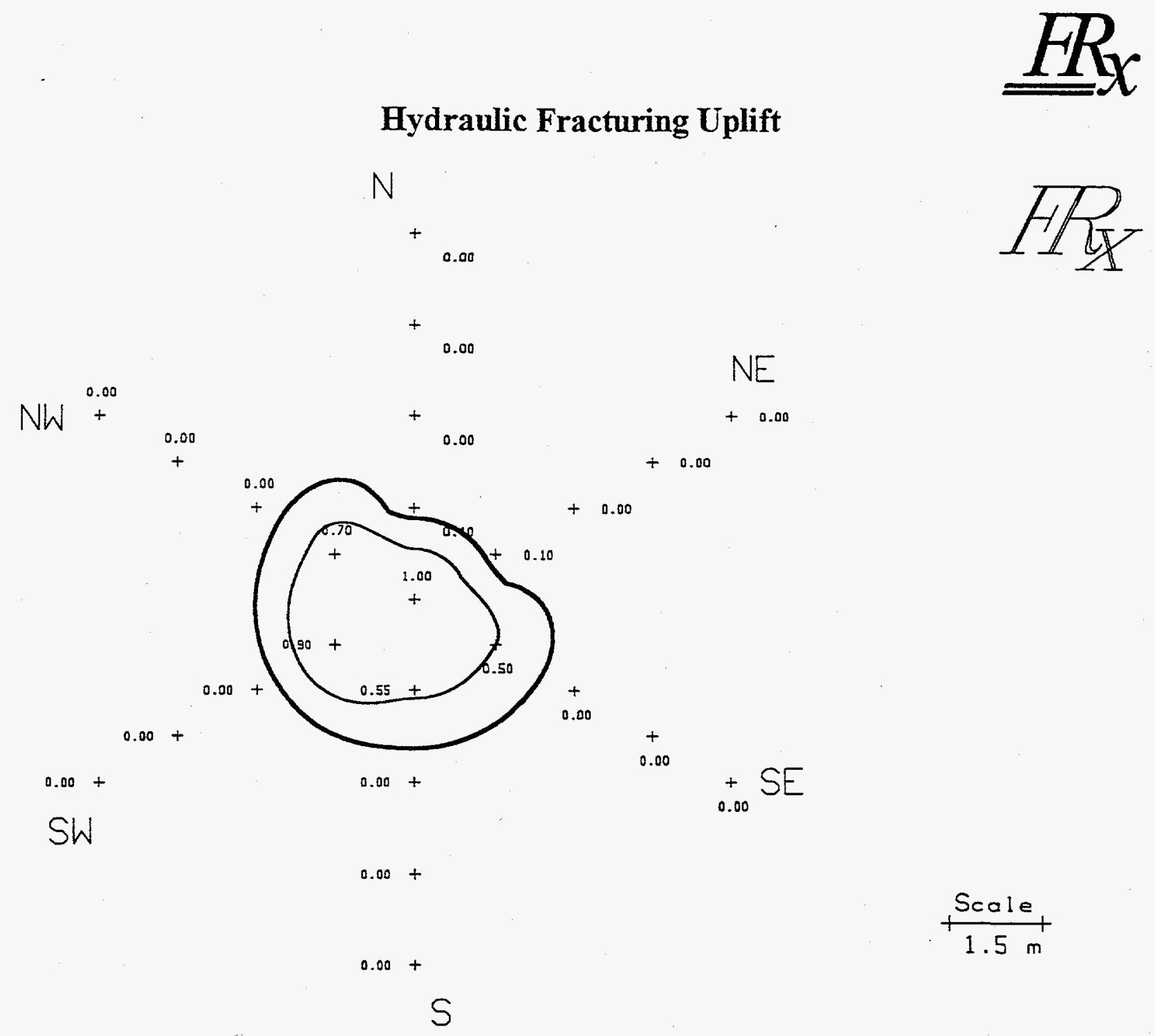

Uplift control points spaced $1.5 \mathrm{~m}$ apart along rays oriented to "plant" north.

Heavy contour is for $2 \mathrm{~mm}$ of uplift, which indicates expected limit of significant sand in the fracture. Lighter contours spaced at $5 \mathrm{~mm}$, starting with $5 \mathrm{~mm}$

SITE: PORTS X231A

DATE: $8 / 27 / 96$

LOCATION: "C" (Iron)

FRACTURE DEPTH: 4

UPLIFT VOLUME: $0.026 \mathrm{~m}^{3}$
FRACTURE ID: X231C-4

SAND CONTENT: $5 \mathrm{ft}^{3}$

GEL VOLUME: $55 \mathrm{gal}$

PROPANT: \#7 Sand

Ratio, Uplift / Inj Vol: 0.088

NoTES: 
Figure B.12 Hydraulic Fracturing Uplift, Test Cell C, $6 \mathrm{ft}$ fracture.

\section{Hydraulic Fracturing Uplift}

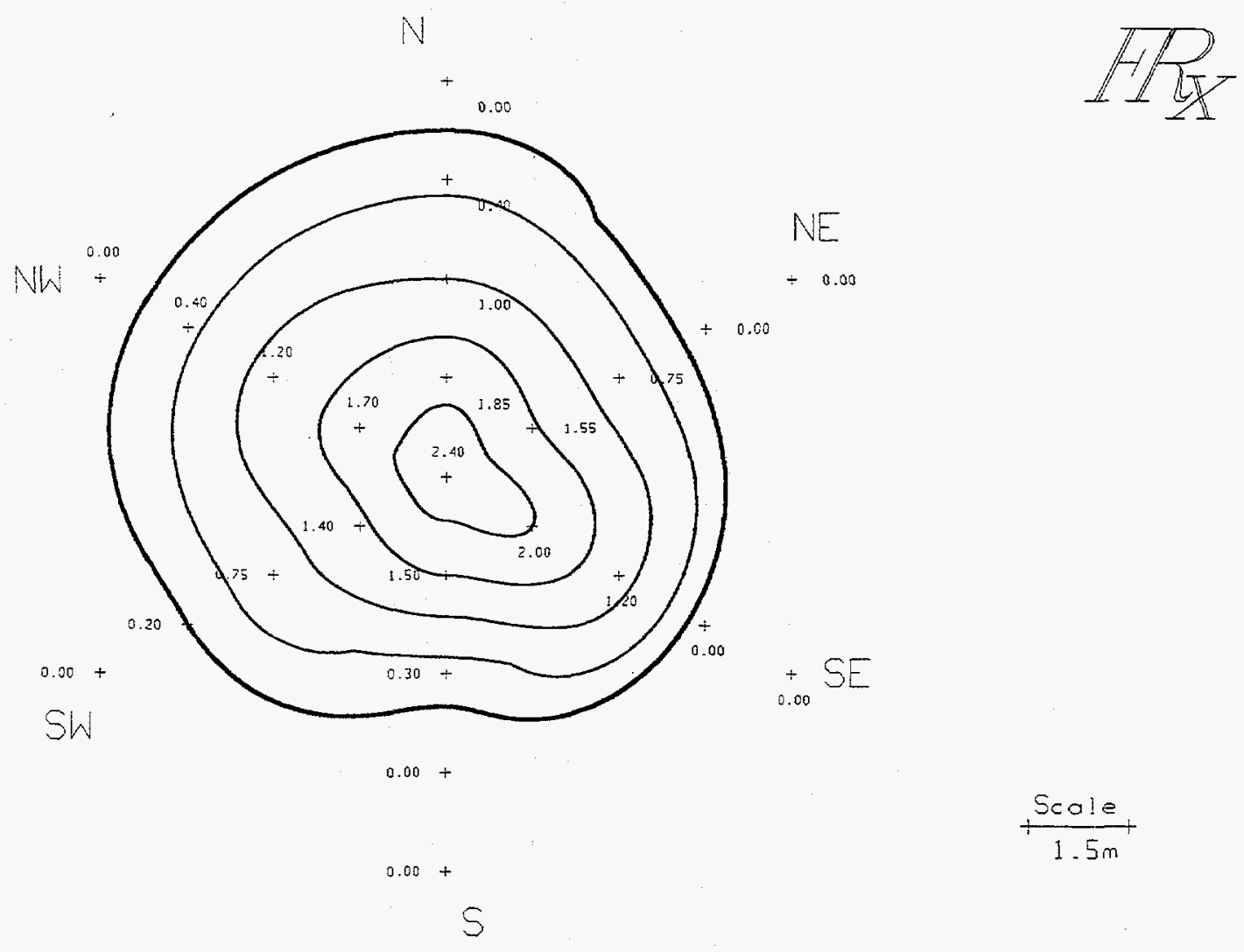

Uplift control points spaced $1.5 \mathrm{~m}$ apart along rays oriented to "plant" north.

Heavy contour is for $2 \mathrm{~mm}$ of uplift, which indicates expected limit of significant sand in the fracture. Lighter contours spaced at $5 \mathrm{~mm}$, starting with $5 \mathrm{~mm}$.

SITE: PORTS X231A

DATE: $8 / 27 / 96$

LOCATION: "C" (Iron)

FRACTURE DEPTH: 6

UPLIFT VOLUME: $0.61 \mathrm{~m}^{3}$
FRACTURE ID: X231C-6

GEL VOLUME: 140 gal.

PROPPANT: Iron

Proppant Content: $10.9 \mathrm{ft}^{3}$

Ratio, Uplift / Inj Vol: 0.979

\section{NoTES:}


Figure B.13 Hydraulic Fracturing Uplift, Test Cell C, $8 \mathrm{ft}$ fracture.

\section{Hydraulic Fracturing Uplift}
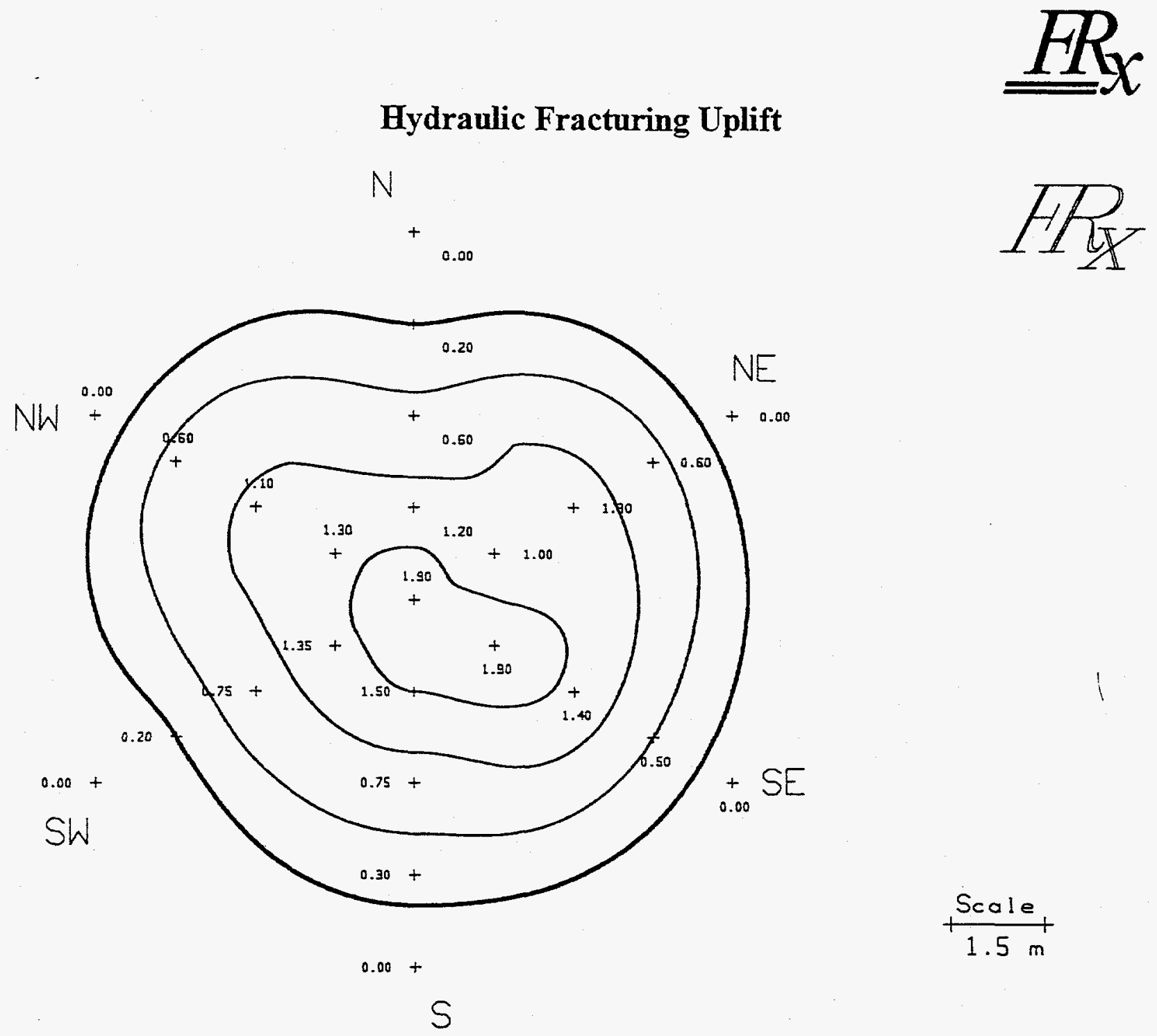

Uplift control points spaced $1.5 \mathrm{~m}$ apart along rays oriented to "plant" north.

Heavy contour is for $2 \mathrm{~mm}$ of uplift, which indicates expected limit of significant sand in the fracture. Lighter contours spaced at $5 \mathrm{~mm}$, starting with $5 \mathrm{~mm}$

SITE: PORTS X231A

DATE: $8 / 27 / 96$

LOCATION: "C" (Iron)

FRACTURE DEPTH: 8

UPLIFT VOLUME: $0.69 \mathrm{~m}^{3}$
FRACTURE ID: X231C-8

SAND CONTENT: $12 \mathrm{ft}^{3}$

GEL VOLUME: $135 \mathrm{gal}$

PROPANT: Iron

Ratio, Uplift / Inj Vol: 1.089

NoTES: 
Figure B.14 Hydraulic Fracturing Uplift, Test Cell C, $12 \mathrm{ft}$ fracture.

\section{Hydraulic Fracturing Uplift}

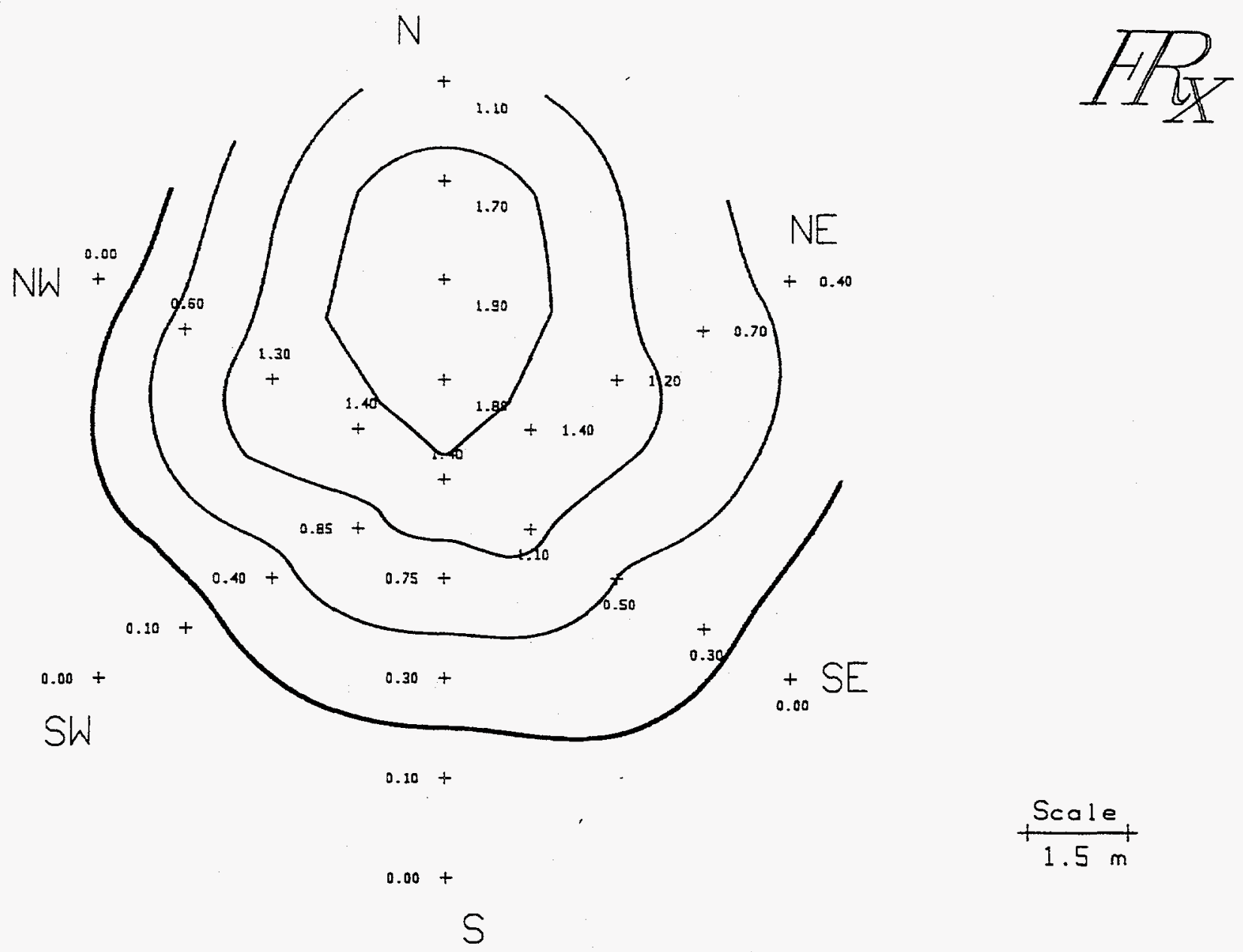

Uplift control points spaced $1.5 \mathrm{~m}$ apart along rays oriented to "plant" north.

Heavy contour is for $2 \mathrm{~mm}$ of uplift, which indicates expected limit of significant sand in the fracture. Lighter contours spaced at $5 \mathrm{~mm}$, starting with $5 \mathrm{~mm}$

SrTE: PORTS X231A

DATE: 8/28/96

LOCATION: "C" (Iron)

FRACTURE DEPTH: 12

UPLIFT VOLUME: $0.78 \mathrm{~m}^{3}$
FRACTURE ID: X231C-12

SAND CONTENT: $24 \mathrm{ft}^{3}$

GEL VolUME: $240 \mathrm{gal}$

PROPANT: Iron

Ratio, Uplift / Inj Vol: 0.678

NOTES: 
Figure B.15 Hydraulic Fracturing Uplift, Test Cell C, $16.5 \mathrm{ft}$ fracture.

\section{Hydraulic Fracturing Uplift}

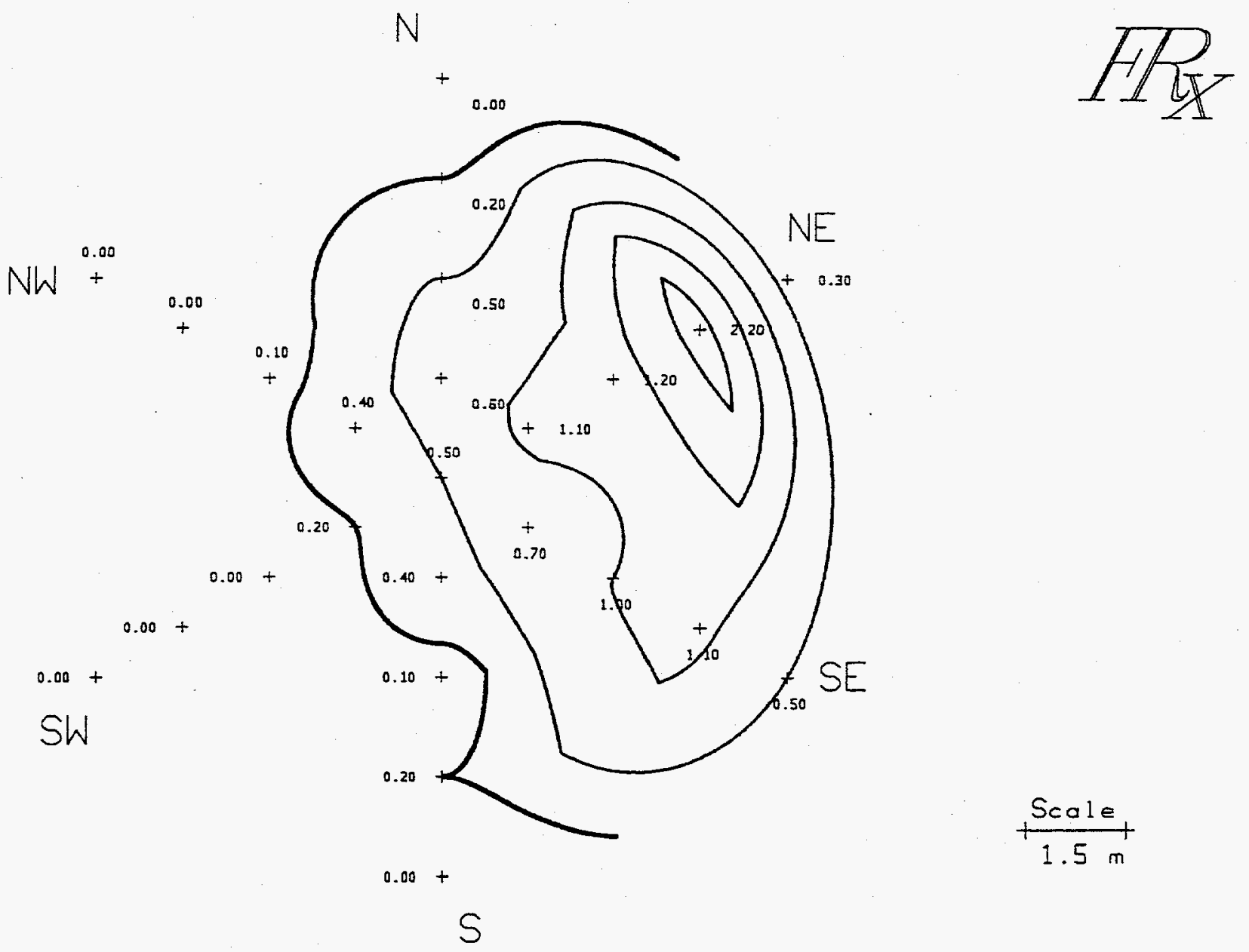

Uplift control points spaced $1.5 \mathrm{~m}$ apart along rays oriented to "plant" north.

Heavy contour is for $2 \mathrm{~mm}$ of uplift, which indicates expected limit of significant sand in the fracture. Lighter contours spaced at $5 \mathrm{~mm}$, starting with $5 \mathrm{~mm}$.

SITE: PORTS X231A

DATE: $8 / 29 / 96$

LOCATION: "C" (Iron)

FRACTURE DEPTH: 16.5

UPLIFT VOLUME: $0.542 \mathrm{~m}^{3}$
FRACTURE ID: X231C-165

SAND CONTENT: $20 \mathrm{ft}^{3}$

GEL VOLUME: 165 gal

PROPANT: \#7 Sand

Ratio, Uplift / Inj Vol: 0.542

NoTES: 
Figure B.16 Hydraulic Fracturing Uplift, Test Cell D, $4 \mathrm{ft}$ fracture.

\section{Hydraulic Fracturing Uplift}

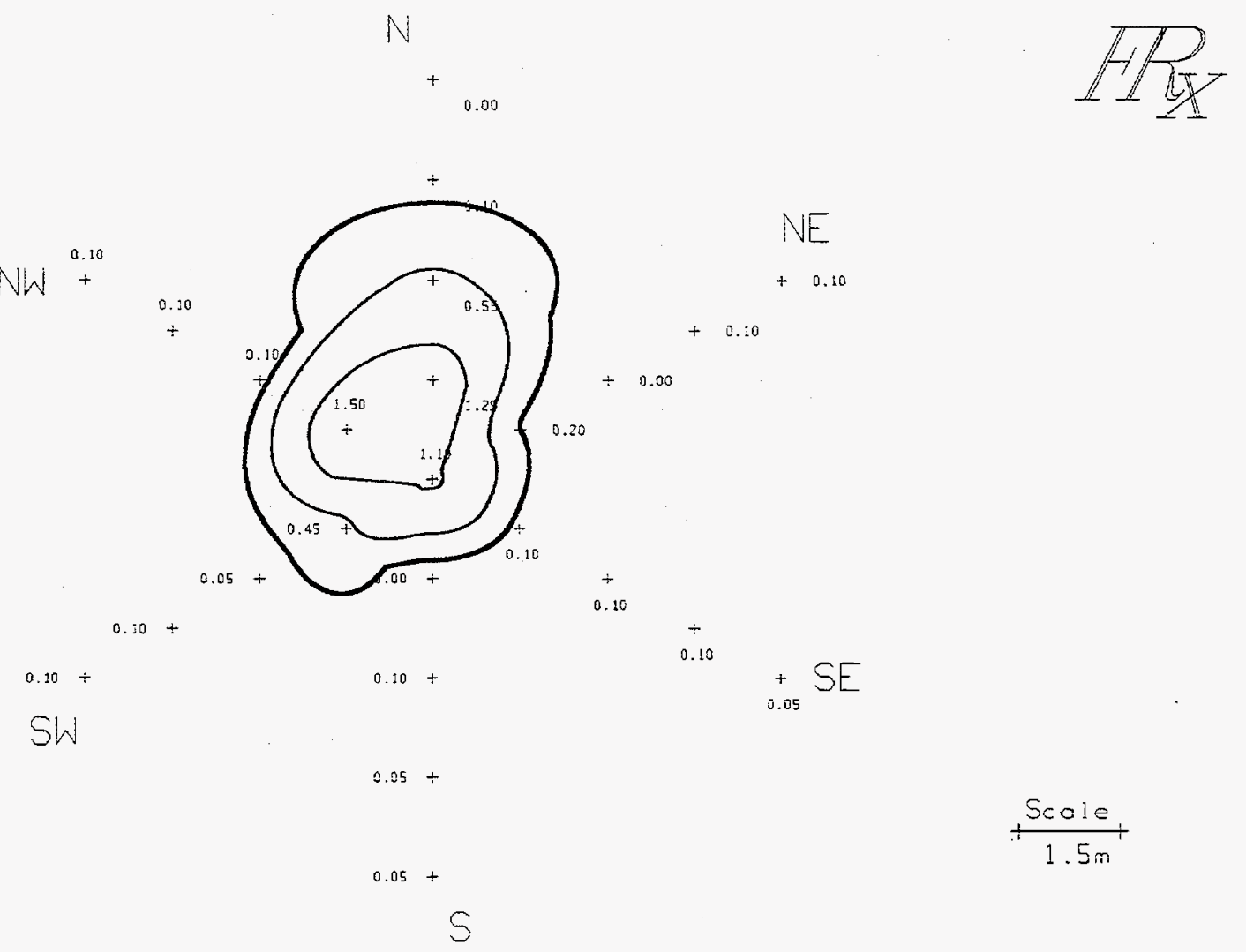

Uplift control points spaced $1.5 \mathrm{~m}$ apart along rays oriented to "plant" north

Heavy contour is for $2 \mathrm{~mm}$ of uplift, which indicates expected limit of significant sand in the fracture. Lighter contours spaced at $5 \mathrm{~mm}$, starting with $5 \mathrm{~mm}$.

SITE: PORTS X231A

DATE: $9 / 17 / 96$

LOCATION: "D" (KMnO4)

FRACTURE DEPTH: 4

UPLIFT VOLUME: $0.206 \mathrm{~m}^{3}$
FRACTURE ID: X231D-4

GEL VOLUME: 60 gal.

Proppant: \#7 Sand

Proppant Content: $5 \mathrm{ft}^{3}$

Ratio, Uplift / Inj Vol: 0.66

NOTES: $\sim 1 \mathrm{~m}$ diameter vent bubble centered $\sim 2.5 \mathrm{~m} \mathrm{~N}$ of injection well 
Figure B.17 Hydraulic Fracturing Uplift, Test Cell D, $7 \mathrm{ft}$ fracture.

\section{Hydraulic Fracturing Uplift}

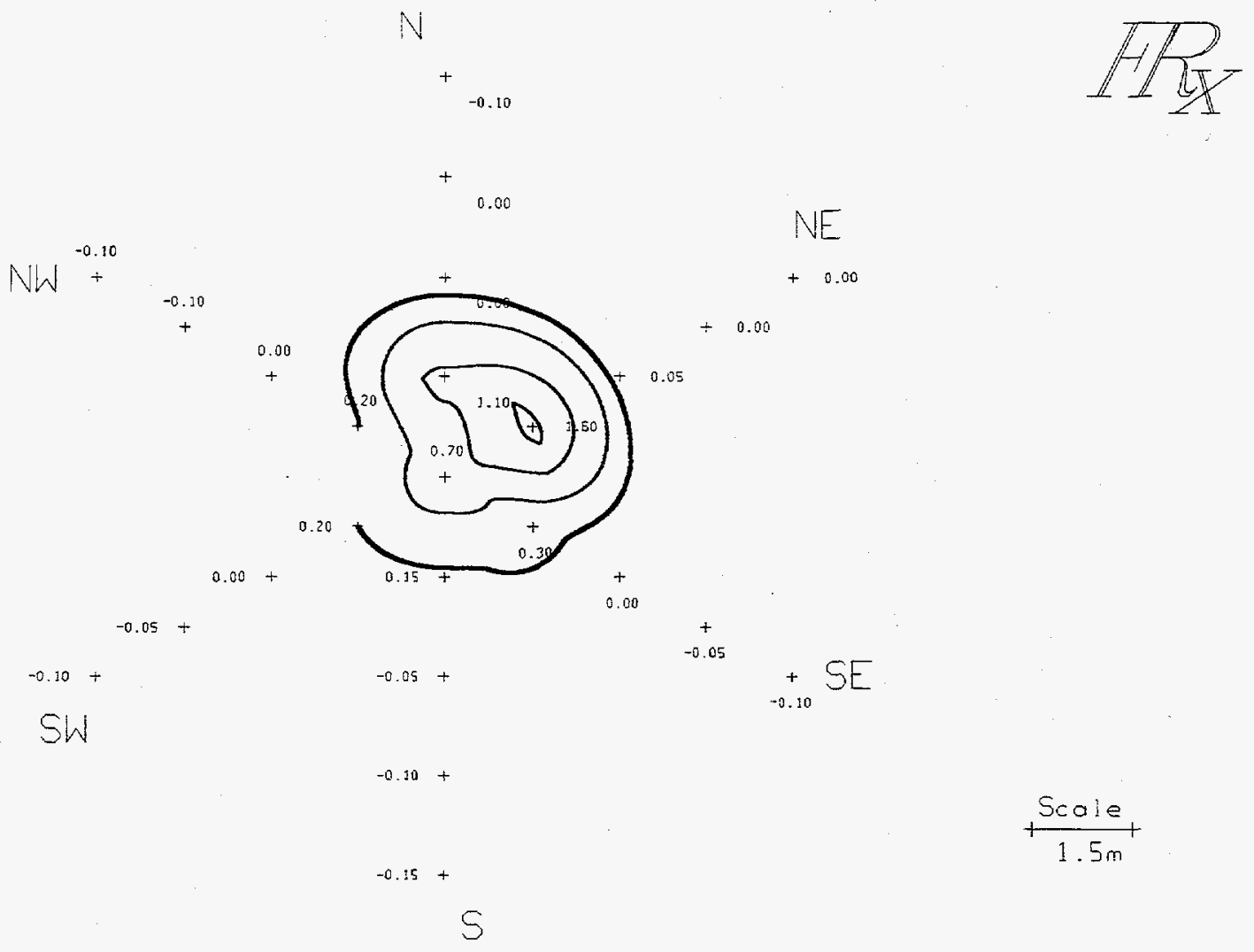

Uplift control points spaced $1.5 \mathrm{~m}$ apart along rays oriented to "plant" north.

Heavy contour is for $2 \mathrm{~mm}$ of uplift, which indicates expected limit of significant sand in the fracture. Lighter contours spaced at $5 \mathrm{~mm}$, starting with $5 \mathrm{~mm}$.

SITE: PORTS X231A

DATE: $9 / 18 / 96$

LOCATION: "D" (KMnO4)

FRACTURE DEPTH: 7

UPLIFT VOLUME: $0.102 \mathrm{~m}^{3}$
FRACTURE ID: X231D-7

GEL VOLUME: 90 gal.

PROPPANT: KMnO4

Proppant Content: $8.8 \mathrm{ft}^{3}$

Ratio, Uplift / Inj Vol: 0.21

NOTES: Grout used in lieu of guar gel. $\sim 2.5 \mathrm{~m}$ diameter centered $\sim 4 \mathrm{~m}$ NNE of injection well 
Figure B.18 Hydraulic Fracturing Uplift, Test Cell D, $9 \mathrm{ft}$ fracture.

\section{Hydraulic Fracturing Uplift}

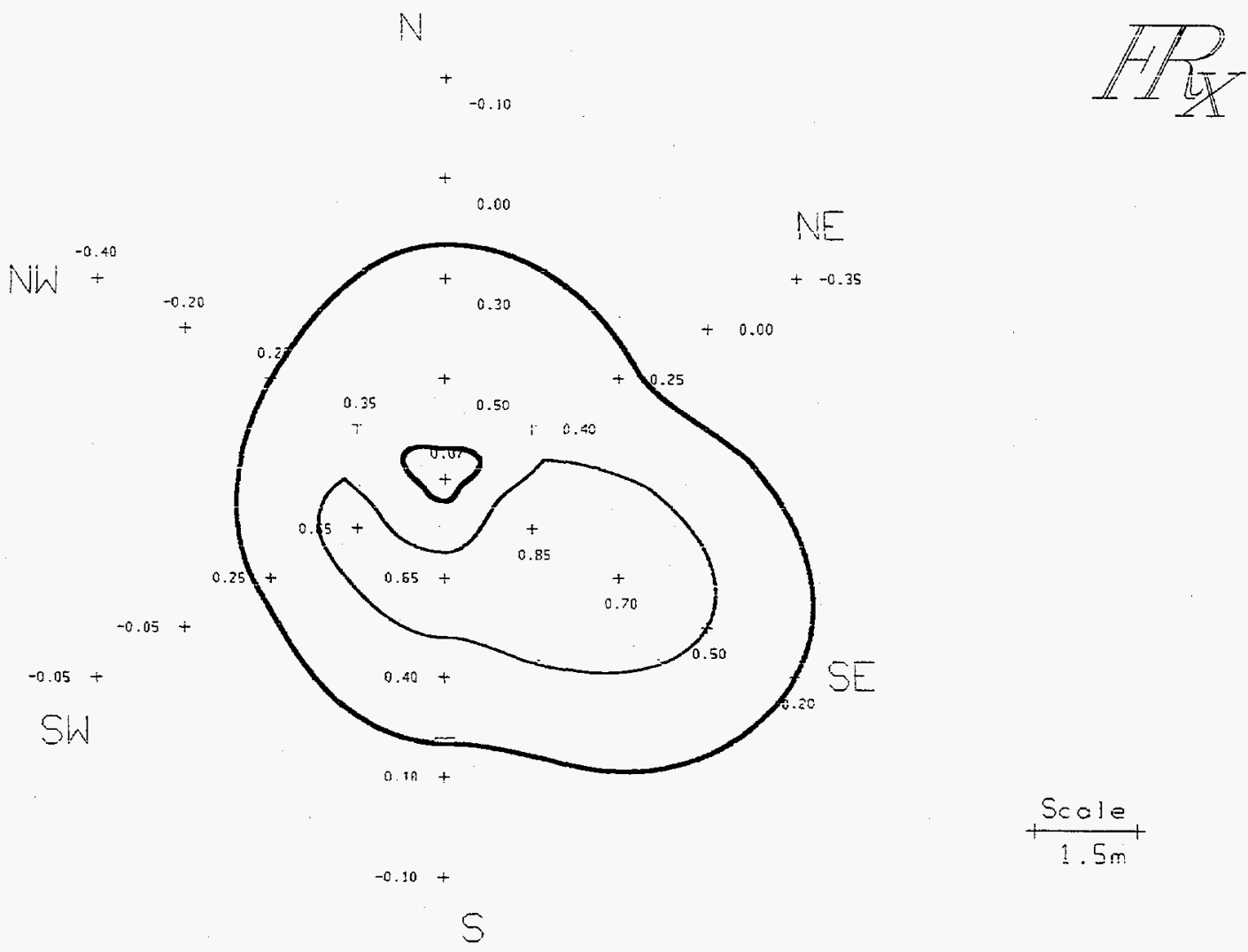

Uplift control points spaced $1.5 \mathrm{~m}$ apart along rays oriented to "plant" north.

Heavy contour is for $2 \mathrm{~mm}$ of uplift, which indicates expected limit of significant sand in the fracture. Lighter contours spaced at $5 \mathrm{~mm}$, starting with $5 \mathrm{~mm}$.

SITE: PORTS X231A

DATE: $9 / 18 / 96$

LOCATION: " $\mathrm{D}$ " (KMnO4)

FRACTURE DEPTH: 9

UTLIFT VOLUME: $0.221 \mathrm{~m}^{3}$
FRACTURE D: X231D-9

GeL VOLUME: 135 gal.

Proppant: KMnO4

Proppant Content: $13.2 \mathrm{ft}^{3}$

Ratio, Uplift / Inj Vol: 0.3

NoTES: Grout used in lieu of guar gel. 
Figure B.19 Hydraulic Fracturing Uplift, Test Cell D, $12 \mathrm{ft}$ fracture.

\section{Hydraulic Fracturing Uplift}

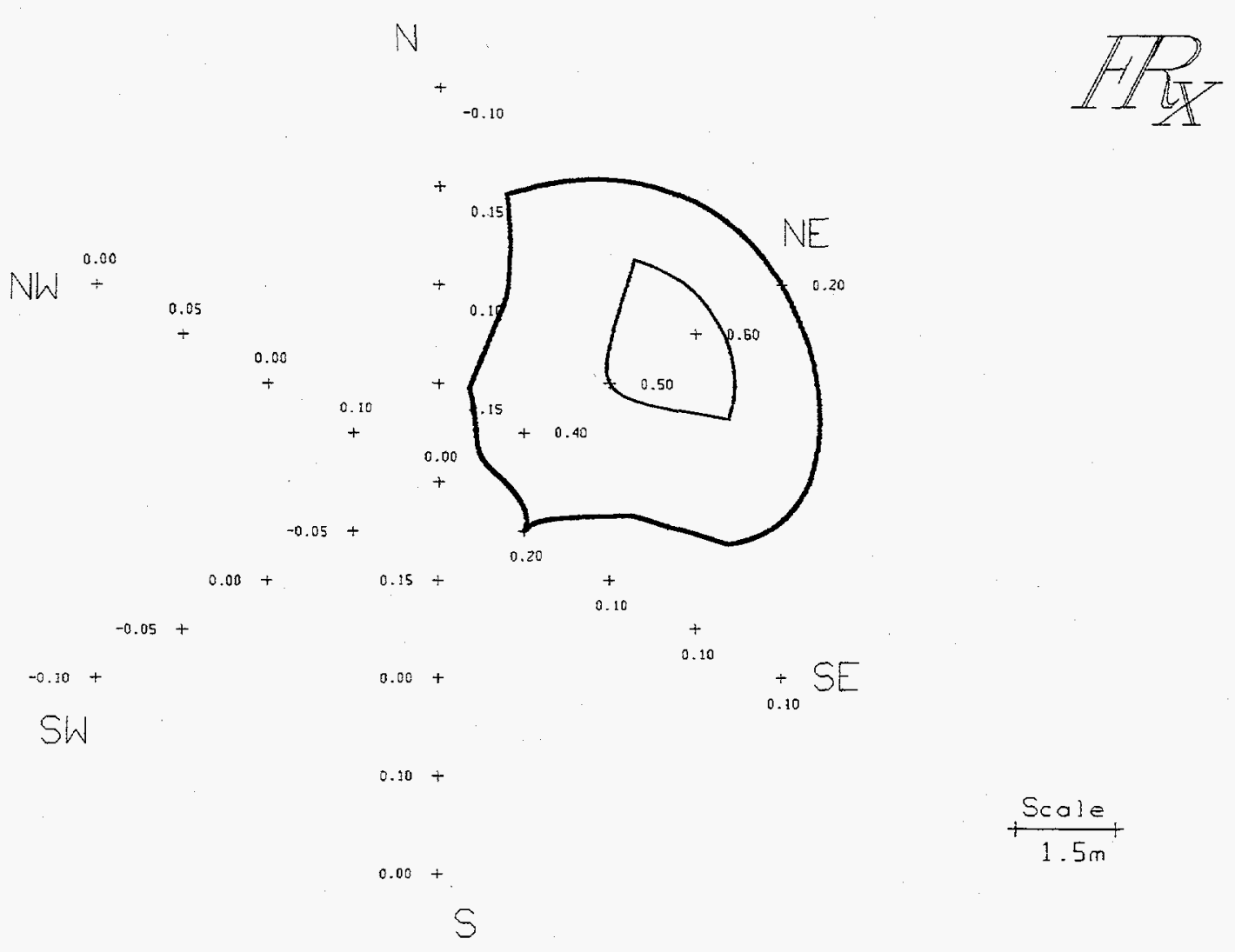

Uplift control points spaced $1.5 \mathrm{~m}$ apart along rays oriented to "plant" north.

Heavy contour is for $2 \mathrm{~mm}$ of uplift, which indicates expected limit of significant sand in the fracture. Lighter contours spaced at $5 \mathrm{~mm}$, starting with $5 \mathrm{~mm}$.

SITE: PORTS X231A

DATE: $9 / 19 / 96$

LOCATION: "D" (KMnO4)

FRACTURE DEPTH: 12

UPLIFT VOLUME: $0.134 \mathrm{~m}^{3}$
FRACTURE ID: X231D-12

GeL VOLUME: $225 \mathrm{gal}$.

PROPPANT: KMnO4

Proppant Content: $22 \mathrm{ft}^{3}$

Ratio, Uplift / Inj Vol: 0.11

NoTES: Grout used in lieu of guar gel. 
Figure B.20 Hydraulic Fracturing Uplift, Test Cell D, $16 \mathrm{ft}$ fracture.

\section{Hydraulic Fracturing Uplift}

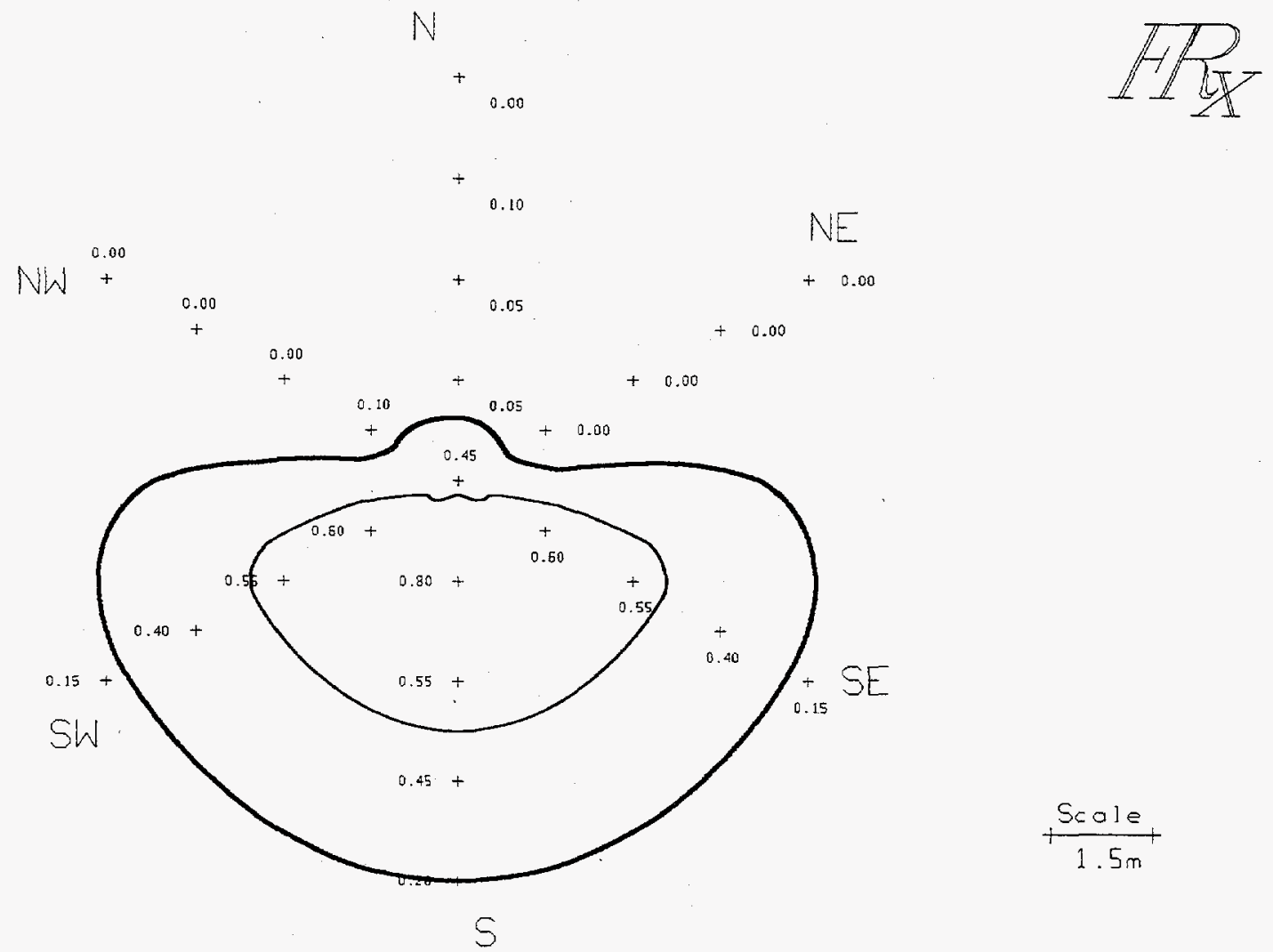

Uplift control points spaced $1.5 \mathrm{~m}$ apart along rays oriented to "plant" north.

Heavy contour is for $2 \mathrm{~mm}$ of uplift, which indicates expected limit of significant sand in the fracture. Lighter contours spaced at $5 \mathrm{~mm}$, starting with $5 \mathrm{~mm}$.

SITE: PORTS X231A

DATE: $9 / 20 / 96$

LOCATION: "D" (KMnO4)

FRACTURE DEPTH: 16

UPLIFT VOLUME: $0.258 \mathrm{~m}^{3}$
FRACTURE ID: X231D-16

GEL VOLUME: 200 gal.

Proppant: \#7 Sand

Proppant Content $20 \mathrm{ft}^{3}$

Ratio, Uplift / Inj Vol: 0.23

NoTES: 
Figure B.21 Rates and volumes injected at Test Cell C and D (summer 1997).

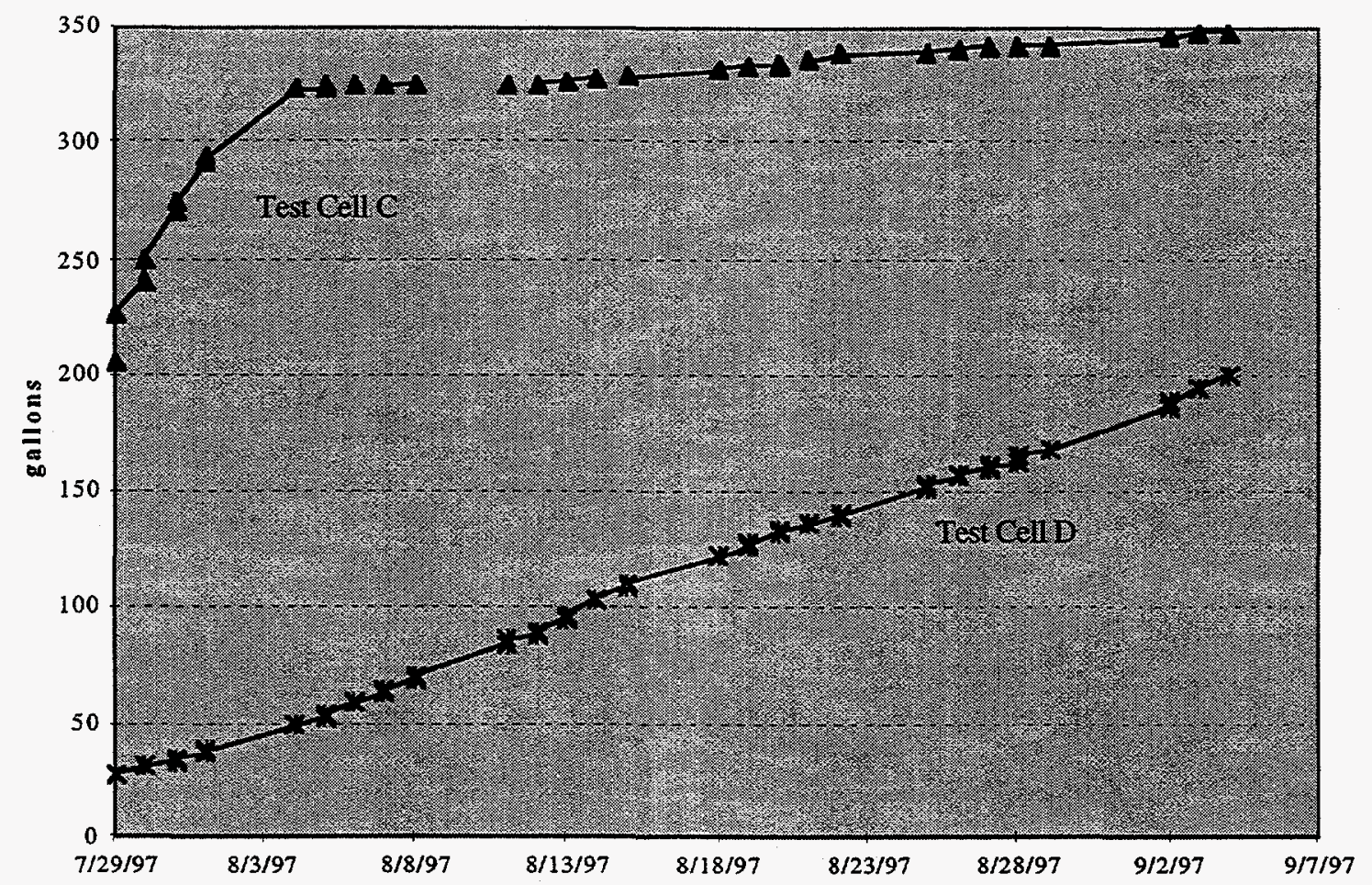


Table B.1 Test cell installation summary.

\begin{tabular}{|c|c|c|c|c|c|}
\hline $\begin{array}{l}\text { Test Cell } \\
\text { Characteristic }\end{array}$ & Units & $\begin{array}{c}\text { Steam } \\
\text { injection with } \\
\text { flushing }\end{array}$ & $\begin{array}{c}\text { Hot air } \\
\text { injection with } \\
\text { flushing }\end{array}$ & Fe Reduction & $\begin{array}{l}\mathrm{KMnO}_{4} \\
\text { Oxidation }\end{array}$ \\
\hline Test cell & - & $\bar{A}$ & $\overline{\mathrm{B}}$ & $\overline{\mathrm{C}}$ & $\overline{\mathrm{D}}$ \\
\hline $\begin{array}{l}\text { Fracture locations - } \\
\text { proppant }\end{array}$ & $\mathrm{ft}$ bgs & $\begin{array}{l}4 \text { - sand } \\
8 \text { - sand } \\
12 \text { - sand } \\
18 \text { - sand }\end{array}$ & $\begin{array}{c}4 \text { - sand } \\
6 \text { - sand } \\
8 \text { - sand } \\
12 \text { - sand } \\
16.5 \text { - sand }\end{array}$ & $\begin{array}{l}4 \text { - sand } \\
6 \text { - iron } \\
8 \text { - iron } \\
12 \text { - iron } \\
16.5 \text { - sand }\end{array}$ & $\begin{array}{c}4-\text { sand } \\
6-\mathrm{KMnO}_{4} \\
8-\mathrm{KMnO}_{4} \\
12-\mathrm{KMnO}_{4} \\
16.5-\text { sand }\end{array}$ \\
\hline $\begin{array}{l}\text { Volume of proppant } \\
\text { injected }\end{array}$ & $\mathrm{cf}$ & & & & \\
\hline $\begin{array}{l}4 \mathrm{ft} \mathrm{fracture} \\
6 \mathrm{ft} \text { fracture } \\
8 \mathrm{ft} \text { fracture } \\
12 \mathrm{ft} \text { fracture } \\
16.5 \mathrm{ft} \text { fracture } \\
18 \mathrm{ft} \text { fracture }\end{array}$ & & $\begin{array}{c}8 \\
- \\
10 \\
13 \\
- \\
20\end{array}$ & $\begin{array}{c}5 \\
8 \\
12 \\
15 \\
20 \\
-\end{array}$ & $\begin{array}{c}5 \\
9 \\
12 \\
24 \\
20 \\
-\end{array}$ & $\begin{array}{c}5 \\
8.8 \\
13.2 \\
22 \\
20 \\
-\end{array}$ \\
\hline Test cell diameter & $\mathrm{ft}$ & 20 & 18 & 20 & 20 \\
\hline $\begin{array}{l}\text { Fracture trend } \\
\text { direction }\end{array}$ & - & NW & NE & SE & NW \\
\hline Test cell depth & $\mathrm{ft}$ & 18 & 16.5 & 16.5 & 16.5 \\
\hline Test cell volume & $\mathrm{cf}$ & 5650 & 4200 & 5180 & 5180 \\
\hline $\begin{array}{l}\text { Treatment process } \\
4 \mathrm{ft} \text { fracture } \\
6 \mathrm{ft} \text { fracture } \\
8 \mathrm{ft} \text { fracture } \\
12 \mathrm{ft} \mathrm{fracture} \\
16.5 \mathrm{ft} \text { fracture } \\
18 \mathrm{ft} \text { fracture }\end{array}$ & & $\begin{array}{c}\text { vapor extraction } \\
- \\
\text { steam injection } \\
\text { vapor extraction } \\
- \\
\text { dewatering }\end{array}$ & $\begin{array}{c}\text { vapor extraction } \\
\text { ambient air inj } \\
\text { hot air injection } \\
\text { vapor extraction } \\
\text { dewatering } \\
\text { - }\end{array}$ & $\begin{array}{l}\text { passive } \\
\text { reduction } \\
\text { reduction } \\
\text { reduction } \\
\text { passive } \\
-\end{array}$ & $\begin{array}{l}\text { passive } \\
\text { oxidation } \\
\text { oxidation } \\
\text { oxidation } \\
\text { passive }\end{array}$ \\
\hline
\end{tabular}


Table B.2 Borehole log summary.

\begin{tabular}{|c|c|c|c|c|}
\hline Borehole ID & $\begin{array}{c}\text { Fracture Depth } \\
\text { (ft bgs) }\end{array}$ & $\begin{array}{l}\text { Apparent Fracture } \\
\text { Dip }\left(^{\circ}\right) \\
\end{array}$ & $\begin{array}{c}\text { Fracture } \\
\text { Thickness (mm) }\end{array}$ & Fracture Type \\
\hline $\begin{array}{l}\text { Test Cell A } \\
\text { TAB } 1\end{array}$ & $\begin{array}{l}6.25 \\
10.6 \\
10.8\end{array}$ & $\begin{array}{c}6-8 \\
10-15 \\
\sim 45\end{array}$ & $\begin{array}{l}3-4 \\
4-5 \\
2 \mathrm{~cm}\end{array}$ & $\begin{array}{l}\text { sand } \\
\text { sand } \\
\text { sand }\end{array}$ \\
\hline TAB2 & $\begin{array}{l}1.33 \\
3.5\end{array}$ & $\begin{array}{c}10 \\
0\end{array}$ & $\begin{array}{l}2-3 \\
2-3\end{array}$ & $\begin{array}{l}\text { sand } \\
\text { sand }\end{array}$ \\
\hline TAB3 & surface & & & sand \\
\hline TAB4 & $\begin{array}{l}\text { no fractures } \\
\text { observed }\end{array}$ & & & \\
\hline TAB5 & 9.0 & 45 & - & sand \\
\hline TAB6 & $\begin{array}{c}\text { no fractures } \\
\text { observed }\end{array}$ & & & \\
\hline TAB7 & $\begin{array}{c}\text { no fractures } \\
\text { observed }\end{array}$ & & & \\
\hline TAB8 & $\begin{array}{c}\text { no fractures } \\
\text { observed }\end{array}$ & & & \\
\hline TAB9 & $\begin{array}{c}3.5 \\
6.5 \\
10.4 \\
11.3 \text { (possible) }\end{array}$ & $\begin{array}{l}- \\
-\end{array}$ & $\begin{array}{l}- \\
- \\
-\end{array}$ & $\begin{array}{l}\text { sand } \\
\text { sand } \\
\text { sand } \\
-\end{array}$ \\
\hline TAM1 & $\begin{array}{c}7.0 \\
11.25 \\
11.67\end{array}$ & $\begin{array}{l}8-10 \\
>45\end{array}$ & $\begin{array}{c}- \\
2.8 \\
1.9 \mathrm{~cm}\end{array}$ & $\begin{array}{l}\text { sand } \\
\text { sand } \\
\text { sand }\end{array}$ \\
\hline TAM2 & $\begin{array}{l}4.42 \\
5.33\end{array}$ & $\begin{array}{c}45-50 \\
-\end{array}$ & $\begin{array}{l}6.3 \\
6.3\end{array}$ & $\begin{array}{l}\text { sand } \\
\text { sand }\end{array}$ \\
\hline TBB1 & $\begin{array}{c}2.17 \\
4.5 \\
10.5 \\
\end{array}$ & $\begin{array}{l}20 \\
10 \\
30 \\
\end{array}$ & $\begin{array}{c}2.54 \mathrm{~cm} \\
2.22 \mathrm{~cm} \\
1.0 \mathrm{~cm}\end{array}$ & $\begin{array}{l}\text { sand } \\
\text { sand } \\
\text { sand }\end{array}$ \\
\hline TBB2 & $\begin{array}{l}\text { no fractures } \\
\text { observed }\end{array}$ & & & \\
\hline TBB3 & $\begin{array}{c}3.0 \\
5.0 \\
10.0\end{array}$ & $\begin{array}{c}20 \\
0 \\
10\end{array}$ & $\begin{array}{l}3-5 \\
2-3 \\
4-7\end{array}$ & $\begin{array}{l}\text { sand } \\
\text { sand } \\
\text { sand }\end{array}$ \\
\hline TBB4 & 6.5 & $10-12$ & 7 & sand \\
\hline TBB5 & $\begin{array}{l}4.67 \\
6.8\end{array}$ & $\begin{array}{c}10 \\
0\end{array}$ & $\begin{array}{l}3 \\
5\end{array}$ & $\begin{array}{l}\text { sand } \\
\text { sand }\end{array}$ \\
\hline TBB6 & $\begin{array}{l}6.08 \\
17.25\end{array}$ & $\begin{array}{c}15 \\
0\end{array}$ & $\begin{array}{c}8 \\
2-3\end{array}$ & $\begin{array}{l}\text { sand } \\
\text { sand }\end{array}$ \\
\hline TBB7 & $\begin{array}{c}\text { no fractures } \\
\text { observed }\end{array}$ & & & \\
\hline
\end{tabular}


Table B. 2 cont. Borehole log summary.

\begin{tabular}{|c|c|c|c|c|}
\hline Borehole ID & $\begin{array}{l}\text { Fracture Depth } \\
\text { (ft bgs) }\end{array}$ & $\begin{array}{c}\text { Apparent Fracture } \\
\text { Dip }\left(^{\circ}\right)\end{array}$ & $\begin{array}{c}\text { Fracture } \\
\text { Thickness (mm) }\end{array}$ & Fracture Type \\
\hline TBB8 & $\begin{array}{c}4.5(5.5 ?) \\
6.8-7.2 \\
10.7 \\
15.5\end{array}$ & $\begin{array}{l}- \\
- \\
-\end{array}$ & $\begin{array}{l}- \\
- \\
-\end{array}$ & $\begin{array}{l}\text { sand } \\
\text { sand } \\
\text { sand } \\
\text { sand }\end{array}$ \\
\hline TBB9 & 10.5 & - & - & sand \\
\hline TBB10 & $\begin{array}{c}\text { no fractures } \\
\text { observed }\end{array}$ & & & \\
\hline TBB11 & $\begin{array}{l}4.0 \\
7.0\end{array}$ & $\overline{-}$ & - & $\begin{array}{l}\text { sand } \\
\text { sand }\end{array}$ \\
\hline TBB12 & 16 (possible) & $=$ & - & sand \\
\hline TBB 13 & $\begin{array}{l}5.5 \\
14.5\end{array}$ & $\begin{array}{l}- \\
-\end{array}$ & $\begin{array}{l}- \\
-\end{array}$ & $\begin{array}{l}\text { sand } \\
\text { sand }\end{array}$ \\
\hline TBM1 & $\begin{array}{c}4.5 \\
8.33 \text { (possible) } \\
13.33\end{array}$ & $\begin{array}{l}0 \\
\overline{0}\end{array}$ & $\begin{array}{l}6.3 \\
- \\
3.2\end{array}$ & $\begin{array}{l}\text { sand } \\
\text { sand }\end{array}$ \\
\hline TBM2 & 7.17 (possible) & - & - & $=$ \\
\hline TCB1 & $\begin{array}{c}5.1 \\
7.6 \\
11.25 \\
\end{array}$ & $\begin{array}{l}- \\
-\end{array}$ & - & $\begin{array}{l}\text { iron } \\
\text { iron } \\
\text { iron }\end{array}$ \\
\hline TCB2 & $\begin{array}{l}6.3 \\
8.5\end{array}$ & - & - & $\begin{array}{c}\text { iron } \\
\text { iron \& sand }\end{array}$ \\
\hline TCB3 & $\begin{array}{l}\text { no fractures } \\
\text { observed }\end{array}$ & & & \\
\hline TCB4 & $\begin{array}{l}\text { no fractures } \\
\text { observed }\end{array}$ & & & \\
\hline TCB5 & $\begin{array}{l}5.0 \\
10.5\end{array}$ & $\begin{array}{l}0 \\
-\end{array}$ & $\begin{array}{l}4 \\
-\end{array}$ & $\begin{array}{l}\text { iron } \\
\text { iron \& sand }\end{array}$ \\
\hline TCB6 & $\begin{array}{l}5.87 \\
10.5\end{array}$ & $\begin{array}{c}0 \\
10-12\end{array}$ & $\begin{array}{l}3-4 \\
2-3\end{array}$ & $\begin{array}{l}\text { iron } \\
\text { iron }\end{array}$ \\
\hline TCB7 & $\begin{array}{c}7 \\
9.5\end{array}$ & $\overline{15}$ & $\overline{2}$ & $\begin{array}{l}\text { iron } \\
\text { iron }\end{array}$ \\
\hline TCB8 & $\begin{array}{l}\text { no fractures } \\
\text { observed }\end{array}$ & & & \\
\hline ТCB9 & $\begin{array}{c}4.8 \\
7.5 \\
11.5 \\
\end{array}$ & $\begin{array}{l}- \\
-\end{array}$ & $\begin{array}{l}- \\
- \\
-\end{array}$ & $\begin{array}{l}\text { iron } \\
\text { iron } \\
\text { iron }\end{array}$ \\
\hline TCB10 & $\begin{array}{c}4.75 \\
7.25 \\
11.75 \\
15.0\end{array}$ & $\begin{array}{l}- \\
- \\
-\end{array}$ & $\begin{array}{l}\text { - } \\
- \\
-\end{array}$ & $\begin{array}{l}\text { iron } \\
\text { iron } \\
\text { iron } \\
\text { sand } \\
\end{array}$ \\
\hline
\end{tabular}


Table B.2 cont. Borehole log summary.

\begin{tabular}{|c|c|c|c|c|}
\hline Borehole ID & $\begin{array}{l}\text { Fracture Depth } \\
(\mathrm{ft} \text { bgs) }\end{array}$ & $\begin{array}{c}\text { Apparent Fracture } \\
\text { Dip }\left(^{\circ}\right)\end{array}$ & $\begin{array}{c}\text { Fracture } \\
\text { Thickness }(\mathrm{mm})\end{array}$ & Fracture Type \\
\hline TCB11 & $\begin{array}{l}6.25 \\
9.66 \\
\end{array}$ & - & - & $\begin{array}{c}\text { iron } \\
\text { iron \& sand }\end{array}$ \\
\hline TCB12 & $\begin{array}{l}7.5 \\
9.66\end{array}$ & - & - & $\begin{array}{c}\text { iron } \\
\text { iron \& sand }\end{array}$ \\
\hline TCB13 & 6.9 & - & - & iron \\
\hline TCMI & $\begin{array}{c}4.5 \\
8.5 \\
11.9\end{array}$ & $\begin{array}{c}0 \\
0 \\
20\end{array}$ & $\begin{array}{c}6 \\
3 \\
3-6\end{array}$ & $\begin{array}{l}\text { iron } \\
\text { iron } \\
\text { iron }\end{array}$ \\
\hline TDB1 & $\begin{array}{l}3 \\
9.1 \\
12\end{array}$ & $\begin{array}{c}15 \\
0 \\
-\end{array}$ & $\begin{array}{c}1 \\
1-2 \\
-\end{array}$ & $\begin{array}{l}\mathrm{KMnO}_{4} \\
\mathrm{KMnO}_{4} \\
\mathrm{KMnO}_{4}\end{array}$ \\
\hline TDB2 & 8.5 & 0 & 1 & $\mathrm{KMnO}_{4}$ \\
\hline TDB3 & $\begin{array}{l}1.75 \\
8.8 \\
\end{array}$ & $\begin{array}{l}0 \\
0 \\
\end{array}$ & $\overline{2}$ & $\begin{array}{l}\mathrm{KMnO}_{4} \\
\mathrm{KMnO}_{4}\end{array}$ \\
\hline TDB4 & 8.0 & - & - & $\mathrm{KMnO}_{4}$ \\
\hline TDB5 & $\begin{array}{c}8.33 \\
10 \text { (possible) } \\
14 \text { (possible) }\end{array}$ & $\begin{array}{l}0 \\
- \\
- \\
\end{array}$ & $\begin{array}{c}4-5 \\
- \\
- \\
\end{array}$ & $\begin{array}{l}\mathrm{KMnO}_{4} \\
\mathrm{KMnO}_{4} \\
\mathrm{KMnO}_{4}\end{array}$ \\
\hline TDB6 & $\begin{array}{l}1-2 \\
8.0 \\
\end{array}$ & $\overline{0}$ & 3 & $\begin{array}{l}\mathrm{KMnO}_{4} \\
\mathrm{KMnO}_{4}\end{array}$ \\
\hline TDB7 & 11.9 & 0 & $4-5$ & $\mathrm{KMnO}_{4}$ \\
\hline TDB8 & $\begin{array}{c}\text { no fractures } \\
\text { observed }\end{array}$ & & 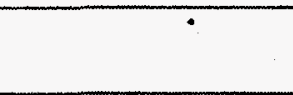 & \\
\hline TDB9 & $\begin{array}{r}4.0 \\
9.0 \\
11.0\end{array}$ & - & - & $\begin{array}{c}\text { sand } \\
\mathrm{KMnO}_{4} \\
\mathrm{KMnO}_{4}\end{array}$ \\
\hline TDB10 & $\begin{array}{c}4.0 \\
9.0 \\
13.5 \text { (possible) }\end{array}$ & $\begin{array}{l}- \\
-\end{array}$ & $\begin{array}{l}- \\
-\end{array}$ & $\begin{array}{c}\text { sand } \\
\mathrm{KMnO}_{4} \\
-\end{array}$ \\
\hline TDB11 & 9.1 & - & - & $\mathrm{KMnO}_{4}$ \\
\hline TDB12 & 11.5 & - & - & $\mathrm{KMnO}_{4}$ \\
\hline TDB13 & 9.0 & - & - & $\mathrm{KMnO}_{4}$ \\
\hline TDM1 & 9.75 & $5-10$ & 6.33 & $\mathrm{KMnO}_{4}$ \\
\hline TDM2 & $\begin{array}{l}3.6 \\
9.75 \\
\end{array}$ & $\begin{array}{l}0 \\
0\end{array}$ & $\begin{array}{l}3.2 \\
3.2 \\
\end{array}$ & $\begin{array}{l}\mathrm{KMnO}_{4} \\
\mathrm{KMnO}_{4}\end{array}$ \\
\hline
\end{tabular}


Table B.3 Process operation monitoring measurements for Test Cell A.

\begin{tabular}{|c|c|c|c|c|c|c|c|c|c|c|}
\hline \multirow[b]{3}{*}{ Date } & \multirow[b]{3}{*}{ Time } & \multirow{3}{*}{$\begin{array}{c}\text { Total Water } \\
\text { Used } \\
\text { gal }\end{array}$} & \multirow{3}{*}{$\begin{array}{l}\text { Genrtr } \\
\text { Temp } \\
{ }^{\circ} \mathrm{F}\end{array}$} & \multicolumn{4}{|c|}{ SVE System } & \multicolumn{3}{|c|}{ Dewatering } \\
\hline & & & & \multicolumn{2}{|c|}{$\begin{array}{c}\text { Extracted Air Flow } \\
\text { Rates (scfh) }\end{array}$} & \multicolumn{2}{|c|}{$\begin{array}{l}\text { Extraction Vacuum } \\
\text { (in. } \mathrm{H}_{2} \mathrm{O} \text { ) }\end{array}$} & \multicolumn{3}{|c|}{$\begin{array}{l}\text { Total Vol Removed } \\
\text { (gal) }\end{array}$} \\
\hline & & & & A-4 & A-12 & A-4 & $\mathrm{A}-12$ & A-4 & $\mathrm{A}-12$ & A-18 \\
\hline $10 / 19 / 96$ & $13: 55$ & & & & & $\overline{0}$ & 27 & 0 & 0 & 0 \\
\hline $10 / 19 / 96$ & $14: 32$ & & & 270 & & 27 & 0 & 0 & 0 & 2.64 \\
\hline $10 / 19 / 96$ & $15: 00$ & & & 252 & & 134 & 134 & 0 & 0 & 2.64 \\
\hline $10 / 19 / 96$ & $17: 01$ & & & 240 & & 54 & 41 & & & \\
\hline $10 / 19 / 96$ & $22: 50$ & & & 300 & & 68 & & 0 & 0 & 27.72 \\
\hline $10 / 20 / 96$ & $8: 08$ & & & 360 & & 54 & & 0 & 0 & 56.76 \\
\hline $10 / 20 / 96$ & $10: 05$ & & & 210 & & 27 & & 0 & 0 & 63.36 \\
\hline $10 / 20 / 96$ & $11: 00$ & & & 402 & & 54 & & & & \\
\hline $10 / 20 / 96$ & $13: 12$ & & & 252 & & 27 & & 0 & 0 & 72.6 \\
\hline $10 / 20 / 96$ & $15: 40$ & & & 300 & & 41 & & 0 & 0 & 79.2 \\
\hline $10 / 21 / 96$ & $9: 20$ & & & 312 & & 41 & & 0 & 0 & 132 \\
\hline $10 / 21 / 96$ & $12: 05$ & & & 324 & & 54 & & 0 & 0 & 138.6 \\
\hline $10 / 21 / 96$ & $16: 00$ & & & 318 & & 54 & & 0 & 0 & 149.16 \\
\hline $10 / 21 / 96$ & $18: 15$ & & & 306 & & 54 & & 0 & 0 & 155.76 \\
\hline $10 / 22 / 96$ & $8: 45$ & & & 366 & & 54 & & 0 & 0 & 196.68 \\
\hline $10 / 22 / 96$ & $13: 25$ & & & 270 & & 68 & & 0 & 0 & 208.56 \\
\hline $10 / 22 / 96$ & $16: 00$ & & & 204 & & 54 & & 0 & 0 & 213.84 \\
\hline $10 / 23 / 96$ & $8: 55$ & & & 384 & & 54 & & 0 & 0 & 241.56 \\
\hline $10 / 23 / 96$ & $14: 50$ & & & 420 & 12 & 54 & & 0 & 0 & 252.12 \\
\hline $10 / 23 / 96$ & $18: 05$ & & & 426 & 6 & 68 & & 0 & 0 & 257.4 \\
\hline $10 / 24 / 96$ & $9: 05$ & & & 426 & 6 & 68 & & 0 & 0 & 274.56 \\
\hline $10 / 24 / 96$ & $16: 45$ & & & 330 & 6 & & & 0 & 0 & 281.16 \\
\hline $10 / 25 / 96$ & $17: 15$ & & & $\overline{372}$ & & 41 & & 0 & 0 & 303.6 \\
\hline
\end{tabular}

Blank indicates no measurement was taken. 
Table B. 3 cont. Process operation monitoring measurements for Test Cell A.

\begin{tabular}{|c|c|c|c|c|c|c|c|c|c|c|c|}
\hline \multirow[b]{3}{*}{ Date } & \multirow[b]{3}{*}{ Time } & \multirow{3}{*}{$\begin{array}{c}\text { Total Water } \\
\text { Used } \\
\text { gal }\end{array}$} & \multirow{3}{*}{$\begin{array}{l}\text { Total Elec. } \\
\text { Used } \\
\text { kWh }\end{array}$} & \multirow{3}{*}{$\begin{array}{l}\text { Genrtr } \\
\text { Temp } \\
{ }^{\circ} \mathrm{F}\end{array}$} & \multicolumn{4}{|c|}{ SVE System } & \multicolumn{3}{|c|}{ Dewatering } \\
\hline & & & & & \multicolumn{2}{|c|}{$\begin{array}{l}\text { Extracted Air Flow } \\
\text { Rates (scfh) }\end{array}$} & \multicolumn{2}{|c|}{$\begin{array}{l}\text { Extraction Vacuum } \\
\text { (in. } \mathrm{H}_{2} \mathrm{O} \text { ) }\end{array}$} & \multicolumn{3}{|c|}{$\begin{array}{c}\text { Total Vol Removed } \\
\text { (gal) }\end{array}$} \\
\hline & & & & & A-4 & A-12 & A-4 & A-12 & $A-4$ & A-12 & A-18 \\
\hline $10 / 26 / 96$ & $9: 10$ & & & & 372 & 18 & 54 & & 0 & 0 & 326.04 \\
\hline $10 / 26 / 96$ & $17: 30$ & & & & & 18 & 106 & & 19.8 & 0 & 333.96 \\
\hline $10 / 27 / 96$ & $8: 50$ & & & & & 36 & 105 & & 35.64 & 27.72 & 364.32 \\
\hline $10 / 27 / 96$ & $15: 30$ & & & & & 18 & 92 & & 35.64 & 33 & 366.96 \\
\hline $10 / 28 / 96$ & $8: 00$ & & & & & 18 & 36 & & 35.64 & 52.8 & 372.24 \\
\hline $10 / 28 / 96$ & $16: 45$ & & & & 180 & 30 & 92 & & 35.64 & 64.68 & 377.52 \\
\hline $10 / 29 / 96$ & $9: 10$ & & & & 204 & 24 & 85 & 116 & 36.96 & 96.36 & 397.32 \\
\hline $10 / 29 / 96$ & $15: 30$ & & & & & & & & & & \\
\hline $10 / 30 / 96$ & $13: 30$ & & & & & & 105 & 112 & 36.96 & 105.6 & 425.04 \\
\hline $10 / 31 / 96$ & $18: 20$ & & & & 330 & & 100 & 100 & 36.96 & 105.6 & 454.08 \\
\hline $11 / 1 / 96$ & $9: 05$ & & & & 180 & & 62 & 98 & & & \\
\hline $11 / 1 / 96$ & $14: 25$ & & & & 246 & & 92 & 135 & 36.96 & 108.24 & 491.04 \\
\hline $11 / 2 / 96$ & $14: 00$ & & & & 180 & & 84 & 100 & 36.96 & 109.56 & 534.6 \\
\hline $11 / 3 / 96$ & $18: 15$ & & & & 150 & & 78 & 100 & 36.96 & 109.56 & 578.16 \\
\hline $11 / 4 / 96$ & $14: 13$ & 13.0 & & & 150 & & 85 & 96 & 36.96 & 109.56 & 587.4 \\
\hline $11 / 4 / 96$ & $16: 50$ & 30.4 & 6 & & 156 & & 82 & & 36.96 & 109.56 & 588.72 \\
\hline $11 / 5 / 96$ & $8: 15$ & 88.8 & 120 & & 150 & & 60 & 98 & 36.96 & 109.56 & 624.36 \\
\hline $11 / 5 / 96$ & $18: 16$ & 115.3 & 179 & & & & 72 & 96 & 36.96 & 109.56 & 641.52 \\
\hline $11 / 6 / 96$ & $7: 50$ & 155.8 & 281 & & & & 94 & 102 & 36.96 & 109.56 & 667.92 \\
\hline $11 / 6 / 96$ & $18: 10$ & 185.1 & 357 & & & & 76 & 104 & 39.6 & 109.56 & 687.72 \\
\hline $11 / 7 / 96$ & $8: 15$ & 229.5 & 462 & & & & 80 & 114 & 40.92 & 109.56 & 714.12 \\
\hline $11 / 7 / 96$ & $18: 00$ & 264.6 & 534 & & 30 & & 70 & 80 & 47.52 & 109.56 & 731.28 \\
\hline $11 / 8 / 96$ & $9: 10$ & 312.1 & 639 & & & & 72 & 80 & 56.76 & 109.56 & 753.72 \\
\hline $11 / 8 / 96$ & $17: 30$ & 345.6 & 709 & & 36 & & 56 & 80 & 58.08 & 109.56 & 772.2 \\
\hline
\end{tabular}

Blank indicates no measurement was taken. 
Table B.3 cont. Process operation monitoring measurements for Test Cell A.

\begin{tabular}{|c|c|c|c|c|c|c|c|c|c|c|c|}
\hline \multirow[b]{3}{*}{ Date } & \multirow[b]{3}{*}{ Time } & \multirow{3}{*}{$\begin{array}{c}\text { Total Water } \\
\text { Used } \\
\text { gal }\end{array}$} & \multirow{3}{*}{$\begin{array}{l}\text { Total Elec. } \\
\text { Used } \\
\text { kWh }\end{array}$} & \multirow{3}{*}{$\begin{array}{l}\text { Genrtr } \\
\text { Temp } \\
{ }^{\circ} \mathrm{F}\end{array}$} & \multicolumn{4}{|c|}{ SVE System } & \multicolumn{3}{|c|}{ Dewatering } \\
\hline & & & & & \multicolumn{2}{|c|}{$\begin{array}{c}\text { Extracted Air Flow } \\
\text { Rates (scfh) }\end{array}$} & \multicolumn{2}{|c|}{$\begin{array}{l}\text { Extraction Vacuum } \\
\left.\text { (in. } \mathrm{H}_{2} \mathrm{O}\right)\end{array}$} & \multicolumn{3}{|c|}{$\begin{array}{c}\text { Total Vol Removed } \\
\text { (gal) }\end{array}$} \\
\hline & & & & & A-4 & A-12 & A-4 & A-12 & $A-4$ & A-12 & A-18 \\
\hline $11 / 9 / 96$ & $9: 30$ & 396.3 & 818 & & 24 & & 42 & 74 & 58.08 & 109.56 & 801.24 \\
\hline $11 / 9 / 96$ & $17: 45$ & 428.0 & 886 & & 42 & 50 & 64 & 59 & 59.4 & 110.88 & 815.76 \\
\hline $11 / 10 / 96$ & $8: 00$ & 479.2 & 990 & & 30 & 22 & 66 & 63 & 59.4 & 112.2 & 863.28 \\
\hline $11 / 10 / 96$ & $19: 00$ & 519.4 & 1071 & & & 20 & 70 & 54 & 59.4 & 112.2 & 900.24 \\
\hline $11 / 11 / 96$ & $9: 32$ & 573.4 & 1177 & & & 30 & 30 & 50 & 59.4 & 112.2 & 946.44 \\
\hline $11 / 11 / 96$ & $11: 30$ & 579.1 & 1191 & & & & 60 & 0 & 59.4 & 113.52 & 950.4 \\
\hline $11 / 11 / 96$ & $17: 05$ & 600.4 & 1232 & & & 40 & 64 & 48 & 60.72 & 121.44 & 960.96 \\
\hline $11 / 12 / 96$ & $9: 10$ & 661.3 & 1349 & & 20 & & 62 & & 60.72 & 133.32 & 988.68 \\
\hline $11 / 12 / 96$ & $13: 15$ & 667.1 & 1358 & & 40 & 30 & 72 & 102 & 60.72 & 137.28 & 993.96 \\
\hline $11 / 12 / 96$ & $17: 40$ & 679.7 & 1390 & & 42 & 48 & 104 & 89 & 62.04 & 141.24 & 999.24 \\
\hline $11 / 13 / 96$ & $8: 00$ & 696.5 & 1424 & & 78 & 90 & 103 & 115 & 62.04 & 157.08 & 1016.4 \\
\hline $11 / 13 / 96$ & $17: 55$ & 703.0 & 1431 & & 90 & 30 & 101 & 130 & 62.04 & 165 & 1021.68 \\
\hline $11 / 14 / 96$ & $9: 50$ & 703.0 & 1431 & & 90 & 102 & 96 & 118 & 63.36 & 252.12 & 1024.32 \\
\hline $11 / 15 / 96$ & $11: 00$ & 710.8 & 1434 & & & & & & 63.36 & 389.4 & 1030.92 \\
\hline $11 / 15 / 96$ & $16: 15$ & & 1463 & & 102 & 40 & 104 & 130 & & & \\
\hline $11 / 16 / 96$ & $14: 00$ & & & & & & & & 63.36 & 419.76 & 1044.12 \\
\hline $11 / 19 / 96$ & $8: 45$ & & 1560 & & & $*$ & & 140 & 63.36 & 561 & 1071.84 \\
\hline $11 / 19 / 96$ & $17: 30$ & & 1561 & & * & $*$ & * & 140 & 63.36 & 605.88 & 1071.84 \\
\hline $11 / 20 / 96$ & $7: 45$ & & 1562 & & 138 & & 148 & 123 & 66 & 693 & 1077.12 \\
\hline $11 / 20 / 96$ & $13: 50$ & & 1570 & & & & & & & & \\
\hline $11 / 20 / 96$ & $17: 05$ & & 1583 & & 132 & 84 & 140 & 118 & 66 & 719.4 & 1081.08 \\
\hline $11 / 21 / 96$ & $7: 50$ & & 1715 & & 132 & 60 & 149 & 136 & 66 & 759 & 1094.28 \\
\hline $11 / 21 / 96$ & $17: 30$ & 714.1 & 1785 & & 96 & 126 & 184 & 132 & 67.32 & 785.4 & 1104.84 \\
\hline
\end{tabular}

Blank indicates no measurement was taken. 
Table B. 3 cont. Process operation monitoring measurements for Test Cell A.

\begin{tabular}{|c|c|c|c|c|c|c|c|c|c|c|c|}
\hline \multirow[b]{3}{*}{ Date } & \multirow[b]{3}{*}{ Time } & \multirow{3}{*}{$\begin{array}{c}\text { Total Water } \\
\text { Used } \\
\text { gal }\end{array}$} & \multirow{3}{*}{$\begin{array}{l}\text { Total Elec. } \\
\text { Used } \\
\text { kWh }\end{array}$} & \multirow{3}{*}{$\begin{array}{l}\text { Genrtr } \\
\text { Temp } \\
{ }^{\circ} \mathrm{F}\end{array}$} & \multicolumn{4}{|c|}{ SVE System } & \multicolumn{3}{|c|}{ Dewatering } \\
\hline & & & & & \multicolumn{2}{|c|}{$\begin{array}{l}\text { Extracted Air Flow } \\
\text { Rates (scfh) }\end{array}$} & \multicolumn{2}{|c|}{$\begin{array}{l}\text { Extraction Vacuum } \\
\left.\quad \text { (in. } \mathrm{H}_{2} \mathrm{O}\right)\end{array}$} & \multicolumn{3}{|c|}{$\begin{array}{c}\text { Total Vol Removed } \\
\text { (gal) }\end{array}$} \\
\hline & & & & & A-4 & A-12 & $\mathrm{A}-4$ & A-12 & $A-4$ & $\mathrm{~A}-12$ & A-18 \\
\hline $11 / 22 / 96$ & $7: 40$ & 764.1 & 1911 & & $\overline{48}$ & 144 & 188 & 138 & 69.96 & 885.72 & 1108.8 \\
\hline $11 / 22 / 96$ & $17: 20$ & 784.1 & 1977 & & 150 & 210 & $>200$ & 146 & 69.96 & 959.64 & 1110.12 \\
\hline $11 / 23 / 96$ & $8: 05$ & 784.1 & 1977 & & 114 & 198 & $>200$ & 152 & 71.28 & 1079.76 & 1110.12 \\
\hline $11 / 23 / 96$ & $17: 40$ & 814.1 & 2029 & & 114 & 198 & $>200$ & 152 & 71.28 & 1153.68 & 1111.44 \\
\hline $11 / 24 / 96$ & $8: 10$ & 854.1 & 2160 & & 108 & 168 & 198 & 137 & 71.28 & 1268.52 & 1114.08 \\
\hline $11 / 24 / 96$ & $17: 25$ & 889.1 & 2243 & & 114 & 210 & 200 & 138 & 71.28 & 1343.76 & 1115.4 \\
\hline $11 / 25 / 96$ & $8: 00$ & 934.1 & 2374 & & 126 & 168 & $>200$ & 146 & 72.6 & 1466.52 & 1118.04 \\
\hline $11 / 25 / 96$ & $17: 35$ & 964.1 & 2458 & & 138 & 240 & $>200$ & 160 & 72.6 & 1545.72 & 1120.68 \\
\hline $11 / 26 / 96$ & $7: 40$ & 1094.1 & 2559 & & 42 & 36 & 75 & 78 & 76.56 & 1554.96 & 1148.4 \\
\hline $11 / 26 / 96$ & $14: 20$ & & & & & & & & 77.88 & 1560.24 & 1158.96 \\
\hline $11 / 26 / 96$ & $17: 10$ & 1114.1 & 2609 & & 48 & 30 & 76 & 80 & 79.2 & 1561.56 & 1162.92 \\
\hline $12 / 2 / 96$ & $8: 45$ & & 3139 & & & & 85 & 90 & 92.4 & 1594.56 & 1218.36 \\
\hline $12 / 2 / 96$ & $17: 30$ & 1424.1 & 3139 & & 30 & 24 & 88 & 83 & 92.4 & 1595.88 & 1219.68 \\
\hline $12 / 3 / 96$ & $8: 25$ & 1434.1 & 3150 & & 36 & 24 & 64 & 58 & 92.4 & 1611.72 & 1236.84 \\
\hline $12 / 3 / 96$ & $16: 45$ & & & & 42 & 30 & 88 & 93 & 92.4 & 1627.56 & 1250.04 \\
\hline $12 / 4 / 96$ & $8: 05$ & & & & 42 & 20 & 81 & 86 & 92.4 & 1650 & 1277.76 \\
\hline $12 / 5 / 96$ & $8: 35$ & & & & 42 & & 81 & 82 & 93.72 & 1689.6 & 1326.6 \\
\hline $12 / 5 / 96$ & $8: 50$ & & & & & & & & & & \\
\hline $12 / 5 / 96$ & $17: 10$ & & & & 54 & 25 & 87 & 94 & 93.72 & 1692.24 & 1330.56 \\
\hline $12 / 6 / 96$ & $8: 00$ & & & & 48 & frozen & 86 & & 93.72 & 1692.24 & 1330.56 \\
\hline $12 / 6 / 96$ & $17: 15$ & & & & & & 79 & 84 & 93.72 & 1698.84 & 1341.12 \\
\hline $12 / 7 / 96$ & $9: 12$ & & & & 60 & 16 & 80 & 82 & 93.72 & 1698.84 & 1341.12 \\
\hline $12 / 7 / 96$ & $17: 00$ & & & & 72 & 144 & 82 & 85 & 93.72 & 1709.4 & 1356.96 \\
\hline
\end{tabular}

Blank indicates no measurement was taken. 
Table B.3 cont. Process operation monitoring measurements for Test Cell A.

\begin{tabular}{|c|c|c|c|c|c|c|c|c|c|c|c|}
\hline \multirow[b]{3}{*}{ Date } & \multirow[b]{3}{*}{ Time } & \multirow{3}{*}{$\begin{array}{l}\text { Total Water } \\
\text { Used } \\
\text { gal }\end{array}$} & \multirow{3}{*}{$\begin{array}{c}\text { Total Elec. } \\
\text { Used } \\
\text { kWh }\end{array}$} & \multirow{3}{*}{$\begin{array}{l}\text { Genrtr } \\
\text { Temp } \\
{ }^{\circ} \mathrm{F}\end{array}$} & \multicolumn{4}{|c|}{ SVE System } & \multicolumn{3}{|c|}{ Dewatering } \\
\hline & & & & & \multicolumn{2}{|c|}{$\begin{array}{l}\text { Extracted Air Flow } \\
\text { Rates (scfh) }\end{array}$} & \multicolumn{2}{|c|}{$\begin{array}{l}\text { Extraction Vacuum } \\
\left.\text { (in. } \mathrm{H}_{2} \mathrm{O}\right)\end{array}$} & \multicolumn{3}{|c|}{$\begin{array}{c}\text { Total Vol Removed } \\
\text { (gal) }\end{array}$} \\
\hline & & & & & A-4 & $A-12$ & A-4 & A-12 & A-4 & A-12 & A-18 \\
\hline $12 / 8 / 96$ & $8: 15$ & & & & $\overline{72}$ & 96 & 82 & 83 & 95.04 & 1734.48 & 1389.96 \\
\hline $12 / 8 / 96$ & $16: 30$ & & & & 78 & 102 & 85 & 86 & 95.04 & 1747.68 & 1407.12 \\
\hline $12 / 9 / 96$ & $9: 00$ & & & & & & 87 & 0 & 95.04 & 1758.24 & 1442.76 \\
\hline $12 / 9 / 96$ & $18: 00$ & & & & 192 & 114 & 78 & 80 & 95.04 & 1771.44 & 1458.6 \\
\hline $12 / 10 / 96$ & $8: 40$ & & & & 330 & 144 & 84 & 0 & 95.04 & 1793.88 & 1482.36 \\
\hline $12 / 10 / 96$ & $18: 20$ & & & & 72 & 108 & 52 & 52 & 95.04 & 1811.04 & 1500.84 \\
\hline $12 / 11 / 96$ & $8: 40$ & & & & 78 & 204 & 70 & 63 & 95.04 & 1820.28 & 1510.08 \\
\hline $12 / 11 / 96$ & $17: 50$ & & & & 36 & 216 & 68 & 68 & 95.04 & 1820.28 & 1510.08 \\
\hline $12 / 12 / 96$ & $8: 50$ & & & & 42 & 204 & 74 & 98 & 95.04 & 1820.28 & 1510.08 \\
\hline $7 / 20 / 97$ & $16: 20$ & & & & 42 & 48 & 110 & 110 & 96.36 & 1820.28 & 1510.08 \\
\hline $7 / 21 / 97$ & $15: 00$ & 177281.5 & 3609 & & & & 0 & 0 & & & \\
\hline $7 / 21 / 97$ & $17: 55$ & 177288.0 & 3622 & & 33 & 26 & 74 & 79 & & 1824.24 & 1519.32 \\
\hline $7 / 24 / 97$ & $17: 00$ & 177376.7 & 3870 & & 15 & 8 & 75 & 81 & 149.16 & 1881 & 1623.6 \\
\hline $7 / 25 / 97$ & $8: 00$ & 177413.6 & 3942 & & 16 & 6 & 77 & 81 & 205.92 & 1899.48 & 1647.36 \\
\hline $7 / 26 / 97$ & $9: 00$ & 177474.7 & 4081 & & & & 0 & 0 & 283.8 & 1899.48 & 1704.12 \\
\hline $7 / 26 / 97$ & $16: 00$ & 177504.6 & 4130 & & 15 & 20 & 76.5 & 82 & & & \\
\hline $7 / 27 / 97$ & $7: 00$ & 177551.5 & 4233 & 233 & 44 & 30 & 110 & 114 & 370.92 & 1899.48 & 1756.92 \\
\hline $7 / 27 / 97$ & $19: 45$ & 177582.8 & 4312 & 234 & & & 102 & 110 & 425.04 & 1899.48 & 1784.64 \\
\hline $7 / 28 / 97$ & $8: 00$ & 177613.5 & 4397 & 234 & & & 114 & 120 & 476.52 & 1899.48 & 1808.4 \\
\hline $7 / 29 / 97$ & $11: 28$ & & & 231 & 0 & 0 & 118 & 121 & 580.8 & 1899.48 & 1841.4 \\
\hline 7/29/97 & $15: 25$ & & & 235 & 0 & 0 & 118 & 120 & 597.96 & 1899.48 & 1846.68 \\
\hline $7 / 30 / 97$ & $8: 05$ & & & 220 & 0 & 0 & 100 & 104 & 681.12 & 1899.48 & 1879.68 \\
\hline 7/30/97 & $15: 43$ & 177733.7 & 4728 & 223 & 0 & 15 & 97 & 102 & 710.16 & 1899.48 & 1894.2 \\
\hline
\end{tabular}

Blank indicates no measurement was taken. 
Table B.3 cont. Process operation monitoring measurements for Test Cell A.

\begin{tabular}{|c|c|c|c|c|c|c|c|c|c|c|c|}
\hline \multirow[b]{3}{*}{ Date } & \multirow[b]{3}{*}{ Time } & \multirow{3}{*}{$\begin{array}{c}\text { Total Water } \\
\text { Used } \\
\text { gal }\end{array}$} & \multirow{3}{*}{$\begin{array}{c}\text { Total Elec. } \\
\text { Used } \\
\text { kWh }\end{array}$} & \multirow{3}{*}{$\begin{array}{l}\text { Genrtr } \\
\text { Temp } \\
{ }^{\circ} \mathrm{F}\end{array}$} & \multicolumn{4}{|c|}{ SVE System } & \multicolumn{3}{|c|}{ Dewátering } \\
\hline & & & & & \multicolumn{2}{|c|}{$\begin{array}{c}\text { Extracted Air Flow } \\
\text { Rates (scfh) }\end{array}$} & \multicolumn{2}{|c|}{$\begin{array}{l}\text { Extraction Vacuum } \\
\left.\text { (in. } \mathrm{H}_{2} \mathrm{O}\right)\end{array}$} & \multicolumn{3}{|c|}{$\begin{array}{l}\text { Total Vol Removed } \\
\text { (gal) }\end{array}$} \\
\hline & & & & & A-4 & A-12 & A-4 & A-12 & A-4 & A-12 & A-18 \\
\hline $7 / 31 / 97$ & $10: 29$ & 177760.8 & 4835 & 234 & 30 & 20 & 102 & 108 & 788.04 & 1899.48 & 1928.52 \\
\hline $7 / 31 / 97$ & $15: 33$ & 177771.8 & 4864 & 235 & 40 & 20 & 100 & 104 & 803.88 & 1899.48 & 1931.16 \\
\hline $8 / 1 / 97$ & $10: 34$ & 177807.6 & 4968 & 235 & 52 & 65 & 98 & 102 & 843.48 & 1899.48 & 1933.8 \\
\hline $8 / 1 / 97$ & $15: 51$ & 177818.5 & 4993 & 235 & 20 & 20 & 100 & 104 & 864.6 & 1900.8 & 1933.8 \\
\hline $8 / 4 / 97$ & $11: 06$ & 177929.6 & 5314 & 202 & 0 & 0 & 0 & 10 & 1020.36 & 1902.12 & 1933.8 \\
\hline $8 / 4 / 97$ & $14: 41$ & 178031.9 & 5315 & 233 & 9 & 8 & 38 & 10 & 1023 & 1902.12 & 1933.8 \\
\hline $8 / 5 / 97$ & $10: 18$ & 177968.9 & 5420 & 230 & 0 & 0 & 92 & 68 & 1111.44 & 1902.12 & 1936.44 \\
\hline $8 / 5 / 97$ & $15: 39$ & 177980.0 & 5456 & 234 & 0 & 60 & 65 & 80 & 1137.84 & 1903.44 & 1936.44 \\
\hline $8 / 6 / 97$ & $11: 07$ & 178016.5 & 5560 & 236 & 15 & 55 & 98 & 105 & 1236.84 & 1904.76 & 1936.44 \\
\hline $8 / 6 / 97$ & $14: 27$ & 178033.4 & 5577 & 228 & 20 & 30 & 95 & 102 & 1251.36 & 1904.76 & 1937.76 \\
\hline $8 / 7 / 97$ & $10: 35$ & 178056.3 & 5676 & 232 & 10 & 40 & 90 & 104 & 1334.52 & 1906.08 & 1937.76 \\
\hline $8 / 7 / 97$ & $15: 44$ & 178065.5 & 5699 & 236 & 25 & 30 & 98 & 108 & 1351.68 & 1906.08 & 1937.76 \\
\hline $8 / 8 / 97$ & $11: 16$ & 178095.5 & & 235 & 20 & 30 & 102 & 110 & 1420.32 & 1906.08 & 1937.76 \\
\hline $8 / 8 / 97$ & $15: 45$ & 178102.5 & 5809 & 232 & 15 & 45 & 95 & 107 & 1436.16 & 1906.08 & 1937.76 \\
\hline $8 / 11 / 97$ & $9: 04$ & 178188.3 & 6060 & 236 & 50 & 55 & 102 & 94 & 1607.76 & 1907.4 & 1937.76 \\
\hline $8 / 11 / 97$ & $15: 21$ & 178203.0 & 6080 & 236 & 35 & 40 & 98 & 105 & 1624.92 & 1907.4 & 1937.76 \\
\hline $8 / 12 / 97$ & $11: 21$ & 178214.4 & 6144 & 226 & 15 & 55 & 90 & 98 & 1677.72 & 1908.72 & 1937.76 \\
\hline $8 / 12 / 97$ & $15: 52$ & 178218.8 & 6157 & 236 & 30 & 60 & 85 & 98 & 1688.28 & 1908.72 & 1937.76 \\
\hline $8 / 13 / 97$ & $12: 00$ & 178242.9 & 6221 & 203 & 30 & 0 & 100 & 110 & 1741.08 & 1912.68 & 1937.76 \\
\hline $8 / 13 / 97$ & $15: 30$ & 178242.9 & 6228 & 187 & 20 & 65 & 94 & 104 & 1751.64 & 1912.68 & 1937.76 \\
\hline $8 / 14 / 97$ & $11: 13$ & 178253.0 & 6228 & 139 & 30 & 150 & 100 & 110 & 1808.4 & 1914 & 1937.76 \\
\hline $8 / 14 / 97$ & $15: 43$ & 178253.0 & 6228 & 139 & 30 & 0 & 98 & 108 & 1820.28 & 1915.32 & 1937.76 \\
\hline $8 / 15 / 97$ & $12: 24$ & 178256.5 & 6231 & 232 & 20 & 30 & 100 & 110 & 1871.76 & 1915.32 & 1937.76 \\
\hline $8 / 15 / 97$ & $14: 50$ & 178258.7 & 6243 & 235 & 10 & 30 & 98 & 110 & 1877.04 & 1915.32 & 1939.08 \\
\hline
\end{tabular}

Blank indicates no measurement was taken. 
Table B.3 cont. Process operation monitoring measurements for Test Cell A.

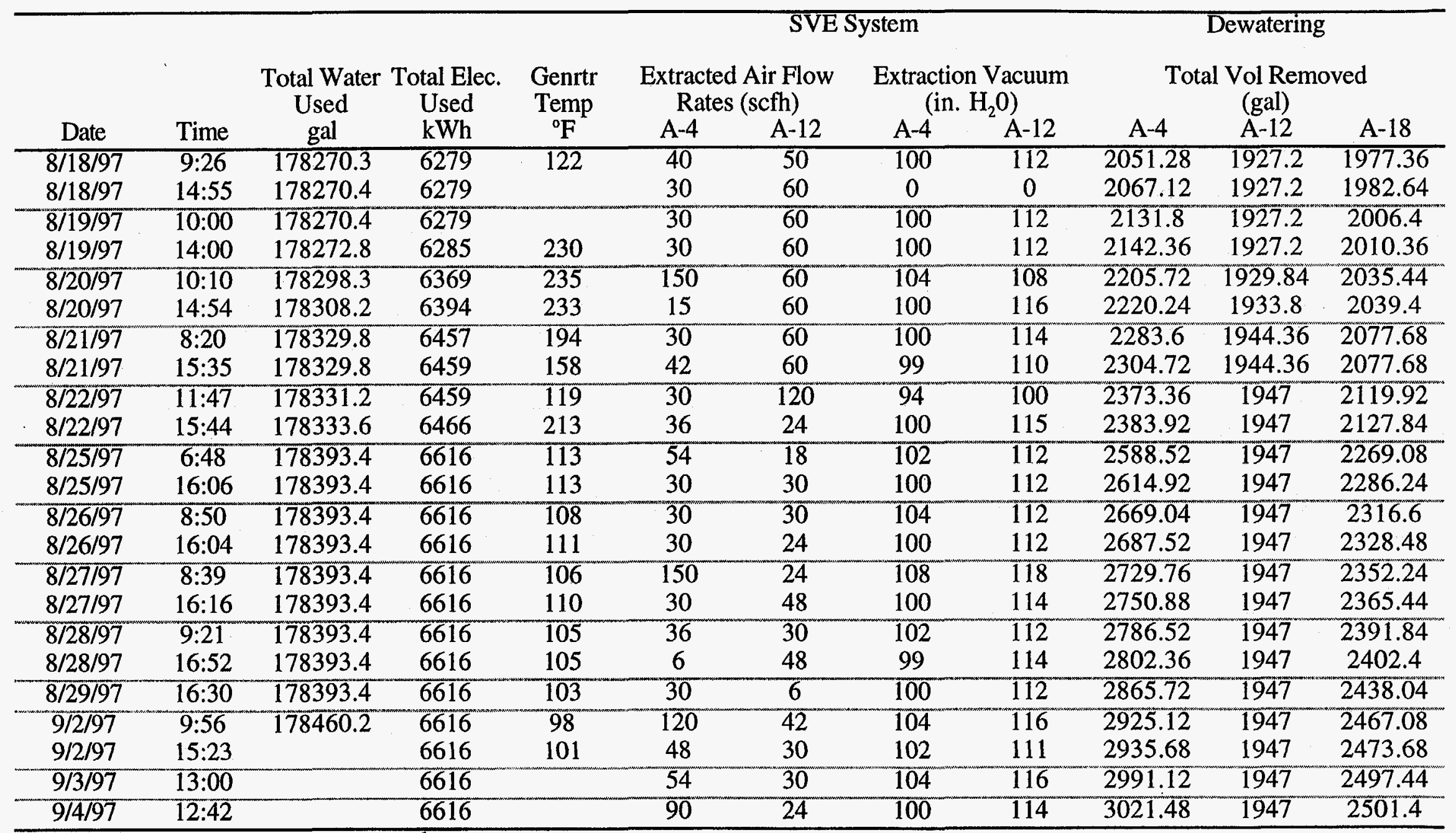

Blank indicates no measurement was taken. 
Table B.4 Process operation monitoring measurements for Test Cell B.

\begin{tabular}{|c|c|c|c|c|c|c|c|c|c|c|c|c|c|}
\hline \multirow[b]{3}{*}{ Date } & \multirow[b]{3}{*}{ Time } & \multicolumn{4}{|c|}{ SVE System } & \multicolumn{4}{|c|}{ Dewatering } & \multirow{3}{*}{$\begin{array}{c}\text { Hot Air } \\
\text { Flow } 8^{\prime} \\
\text { Fracture } \\
\text { cfm }\end{array}$} & \multirow{3}{*}{$\begin{array}{c}\text { Hot Air } \\
\text { Temp } \\
{ }^{\circ} \mathrm{C}\end{array}$} & \multirow{3}{*}{$\begin{array}{c}\text { Ambient } \\
\text { Air Press } \\
\text { 6' Fracture } \\
\text { psi }\end{array}$} & \multirow{3}{*}{$\begin{array}{c}\text { Ambient } \\
\text { Air Flow } \\
\text { 6' Fracture } \\
\mathrm{cfm}\end{array}$} \\
\hline & & \multicolumn{2}{|c|}{$\begin{array}{l}\text { Extracted Air } \\
\text { Flow Rates } \\
\text { (scfh) }\end{array}$} & \multicolumn{2}{|c|}{$\begin{array}{c}\text { Extraction } \\
\text { Vacuum } \\
\text { (in. } \mathrm{H}_{2} \mathrm{O} \text { ) }\end{array}$} & \multicolumn{3}{|c|}{$\begin{array}{l}\text { Total Volume Removed } \\
\text { (gal) }\end{array}$} & \multirow{2}{*}{$\begin{array}{c}\text { Hot Air } \\
\text { Press } 8 \\
\text { Fracture } \\
\text { psi }\end{array}$} & & & & \\
\hline & & B-4 & B12 & $B-4$ & B-12 & $B-4$ & B-12 & B-16.5 & & & & & \\
\hline $10 / 19 / 96$ & $13: 55$ & & & $\overline{0}$ & $\overline{0}$ & 0.0 & 0.0 & 0.0 & & & & & \\
\hline $10 / 19 / 96$ & $14: 32$ & 540 & & 27 & 0 & 0.0 & 0.0 & 0.7 & & & & & \\
\hline $10 / 19 / 96$ & $15: 00$ & 486 & & 68 & 82 & 0.0 & 0.0 & 2.6 & & & & & \\
\hline $10 / 19 / 96$ & $17: 01$ & 320 & & 27 & 41 & & & & & & & & \\
\hline $10 / 19 / 96$ & $22: 50$ & 465 & & 54 & 82 & 1.3 & 0.0 & 15.8 & & & & & \\
\hline $10 / 20 / 96$ & $8: 08$ & 486 & & 41 & 68 & 5.3 & 0.0 & 23.8 & & & & & \\
\hline $10 / 20 / 96$ & $10: 05$ & 264 & & 27 & 27 & 6.6 & 0.0 & 27.7 & & & & & \\
\hline $10 / 20 / 96$ & $11: 00$ & 480 & & 54 & 68 & & & & & & & & \\
\hline $10 / 20 / 96$ & $13: 12$ & 324 & & 27 & 68 & 7.9 & 0.0 & 34.3 & & & & & \\
\hline $10 / 20 / 96$ & $15: 40$ & 186 & & 41 & 41 & 10.6 & 0.0 & 37.0 & & & & & \\
\hline $10 / 21 / 96$ & $9: 20$ & 156 & & 41 & 41 & & & & & & & & \\
\hline $10 / 21 / 96$ & $12: 05$ & 222 & & & & 29.0 & 0.0 & 52.8 & & & & & \\
\hline $10 / 21 / 96$ & $16: 00$ & 216 & 0.6 & & & 29.0 & 0.0 & 60.7 & & & & & \\
\hline $10 / 21 / 96$ & $18: 15$ & 216 & 0.6 & & & 29.0 & 0.0 & 64.7 & & & & & \\
\hline $10 / 22 / 96$ & $8: 45$ & 222 & 0.6 & 68 & & 29.0 & 0.0 & 103.0 & & & & & \\
\hline $10 / 22 / 96$ & $13: 25$ & 288 & 0.8 & 82 & & 29.0 & 0.0 & 114.8 & & & & & \\
\hline $10 / 22 / 96$ & $16: 00$ & 252 & 0.7 & 82 & & 29.0 & 0.0 & 125.4 & & & & & \\
\hline $10 / 23 / 96$ & $8: 55$ & 234 & 0.6 & 54 & & 29.0 & 0.0 & 194.0 & & & & & \\
\hline $10 / 23 / 96$ & $14: 50$ & 270 & 0.7 & 68 & & 29.0 & 0.0 & 217.8 & & & & & \\
\hline $10 / 23 / 96$ & $18: 05$ & 270 & 0.8 & 105 & 105 & 29.0 & 0.0 & 228.4 & & & & & \\
\hline $10 / 24 / 96$ & $9: 05$ & 264 & 0.7 & 100 & 100 & 29.0 & 0.0 & 277.2 & & & & & \\
\hline $10 / 24 / 96$ & $16: 45$ & 255 & & 100 & & 29.0 & 0.0 & 302.3 & & & & & \\
\hline $10 / 25 / 96$ & $17: 15$ & 204 & & 90 & 90 & 29.0 & 0.0 & 367.0 & & & & & \\
\hline $10 / 26 / 96$ & $9: 10$ & 195 & & 95 & 96 & 29.0 & 0.0 & 407.9 & & & & & \\
\hline $10 / 26 / 96$ & $17: 30$ & 180 & & 100 & 94 & 29.0 & 0.0 & 427.7 & & & & & \\
\hline
\end{tabular}

Blank indicates no measurement was taken. 
Table B.4 cont. Process operation monitoring measurements for Test Cell B.

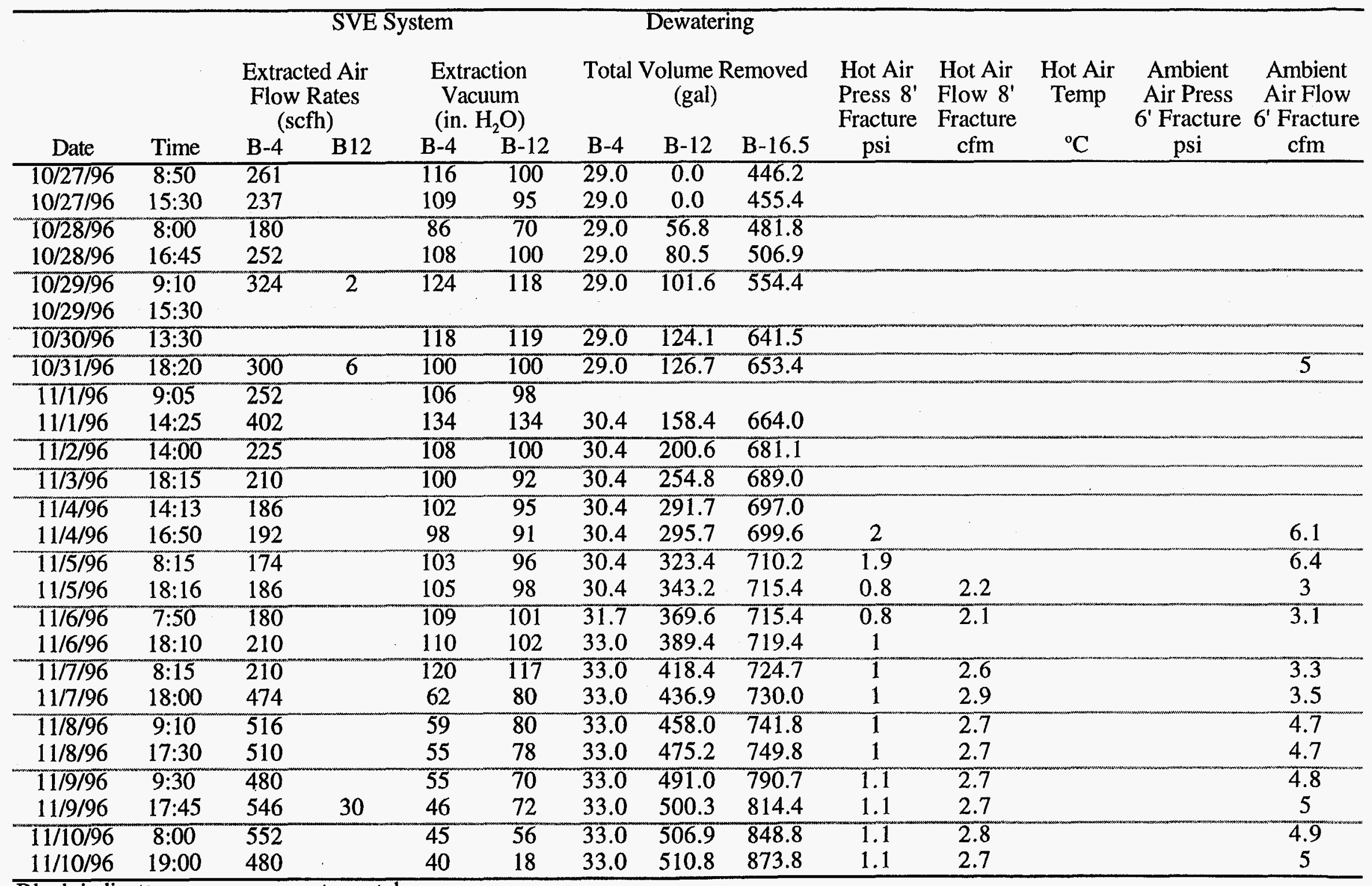

Blank indicates no measurement was taken. 
Table B.4 cont. Process operation monitoring measurements for Test Cell B.

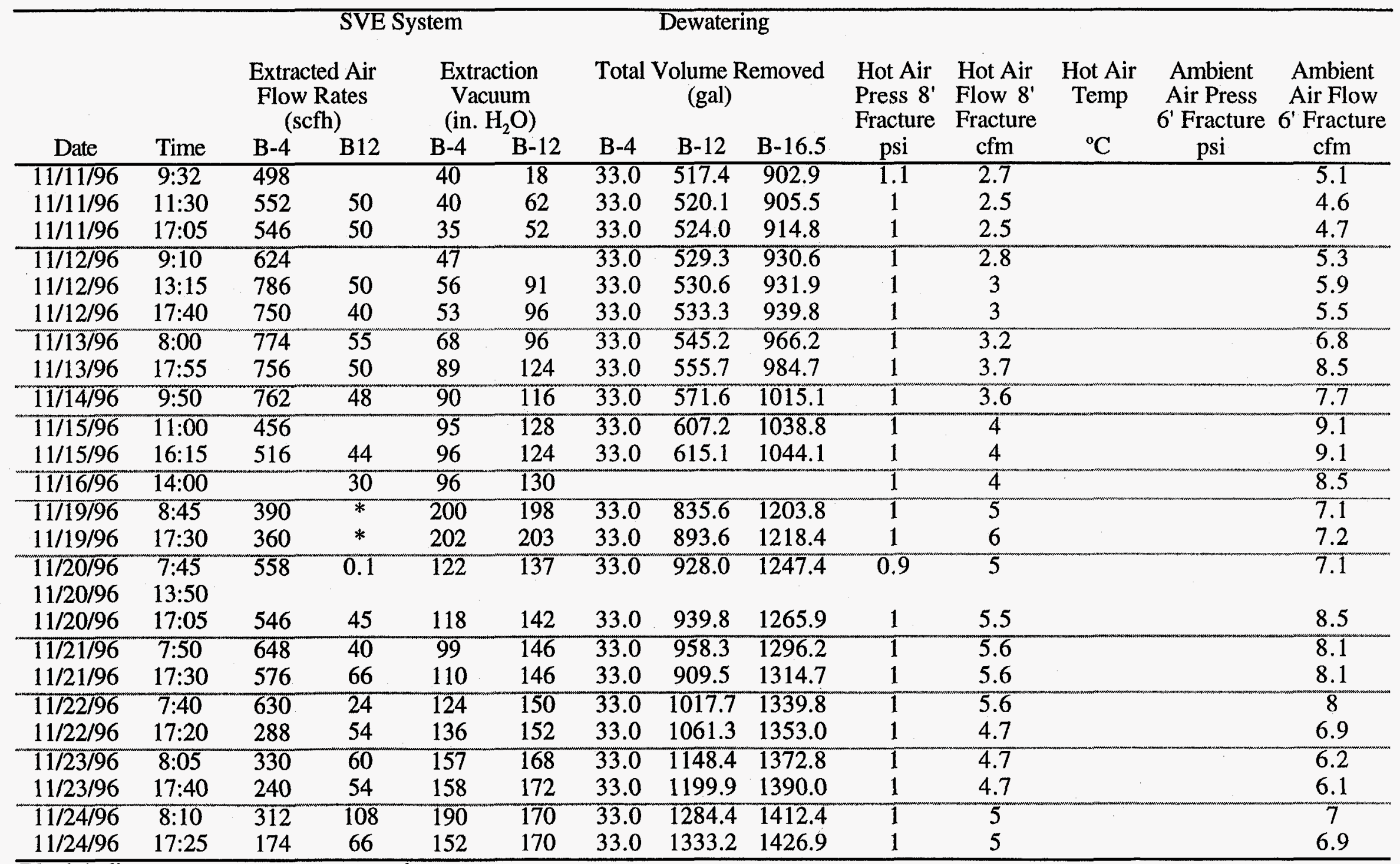

Blank indicates no measurement was taken. 
Table B.4 cont. Process operation monitoring measurements for Test Cell B.

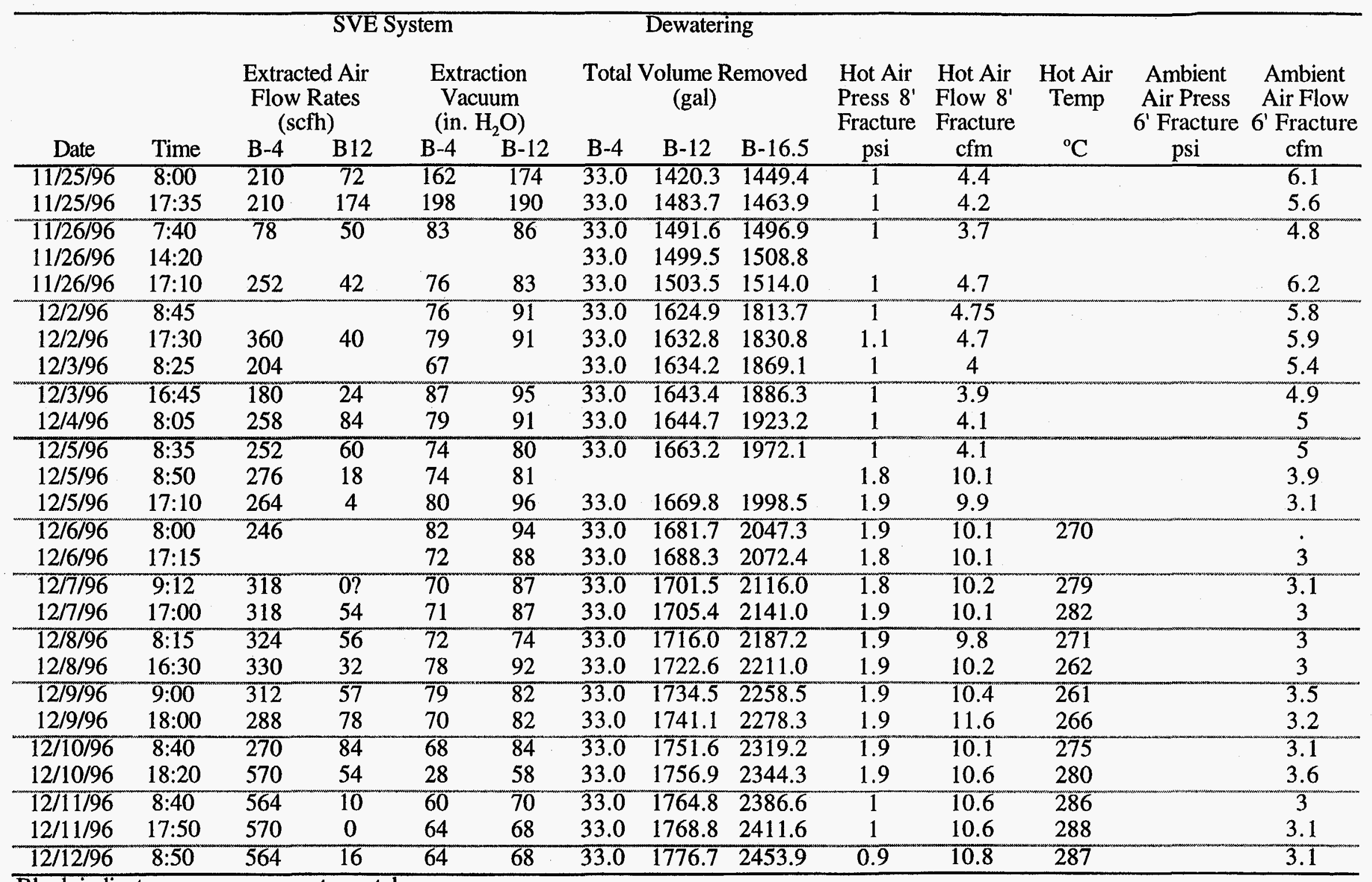

Blank indicates no measurement was taken. 
Table B.4 cont. Process operation monitoring measurments for Test Cell B.

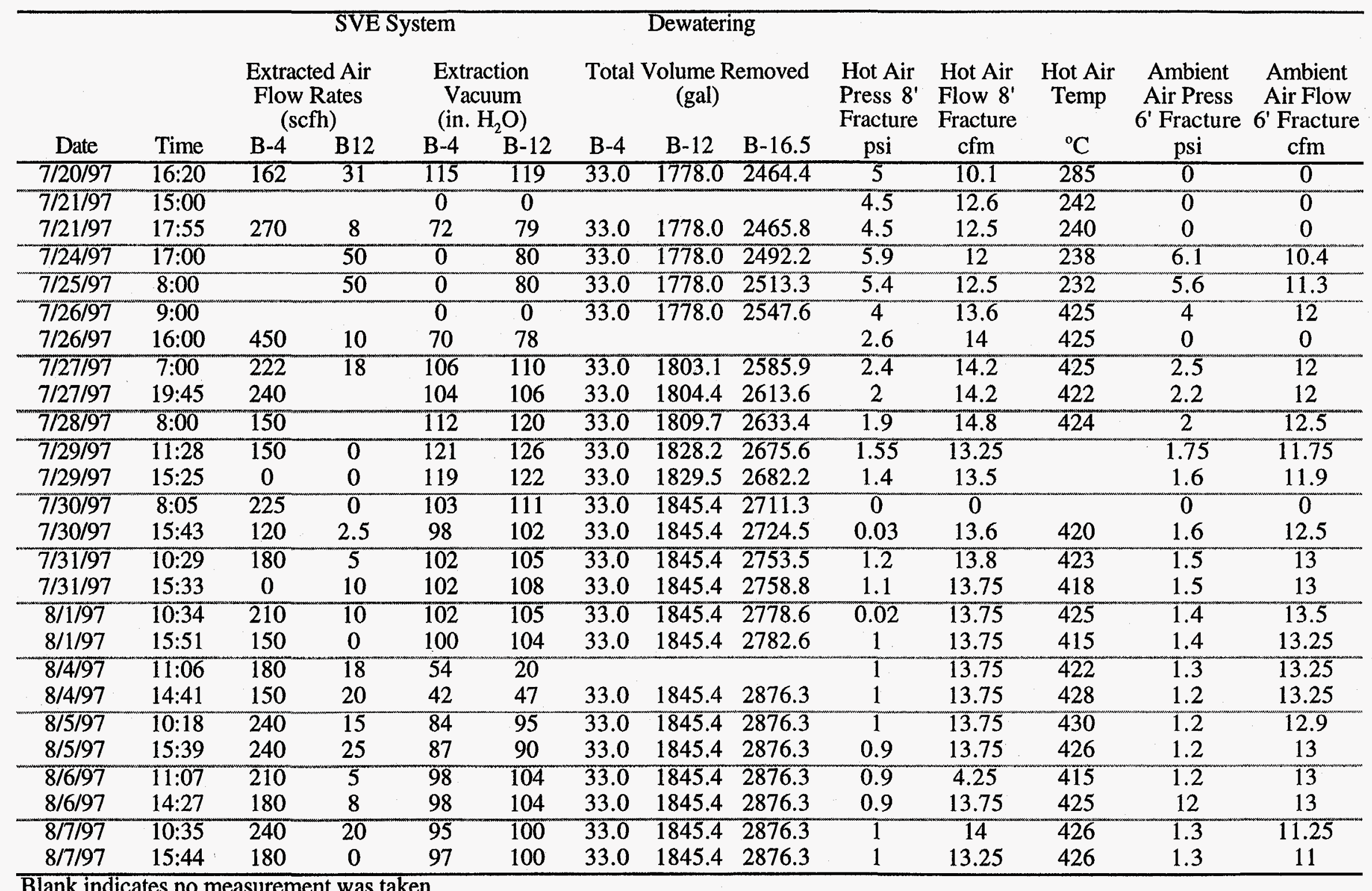


Table B.4 cont. Process operation monitoring measurments for Test Cell B.

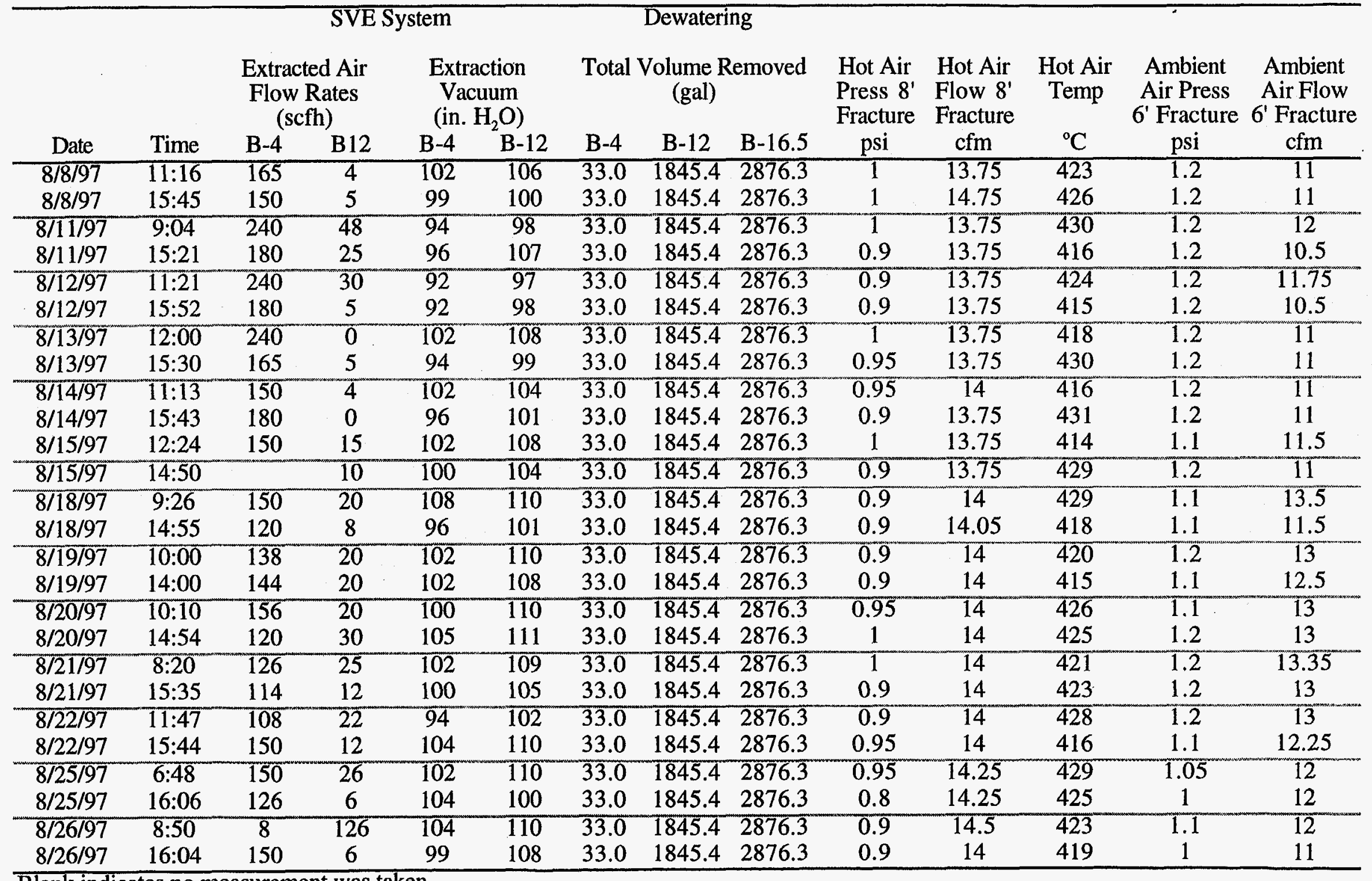

Blank indicates no measurement was taken. 
Table B.4 cont. Process operation monitoring measurments for Test Cell B.

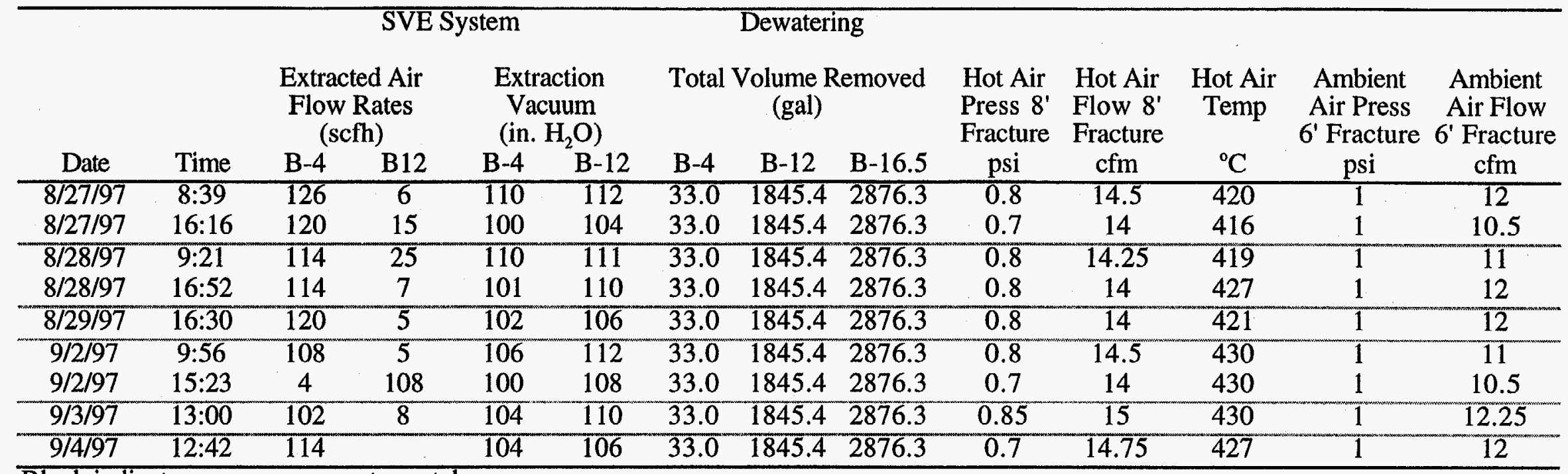

Blank indicates no measurement was taken. 
Table B.5. Rates and volumes of fluid delivery to Test Cells C and D.

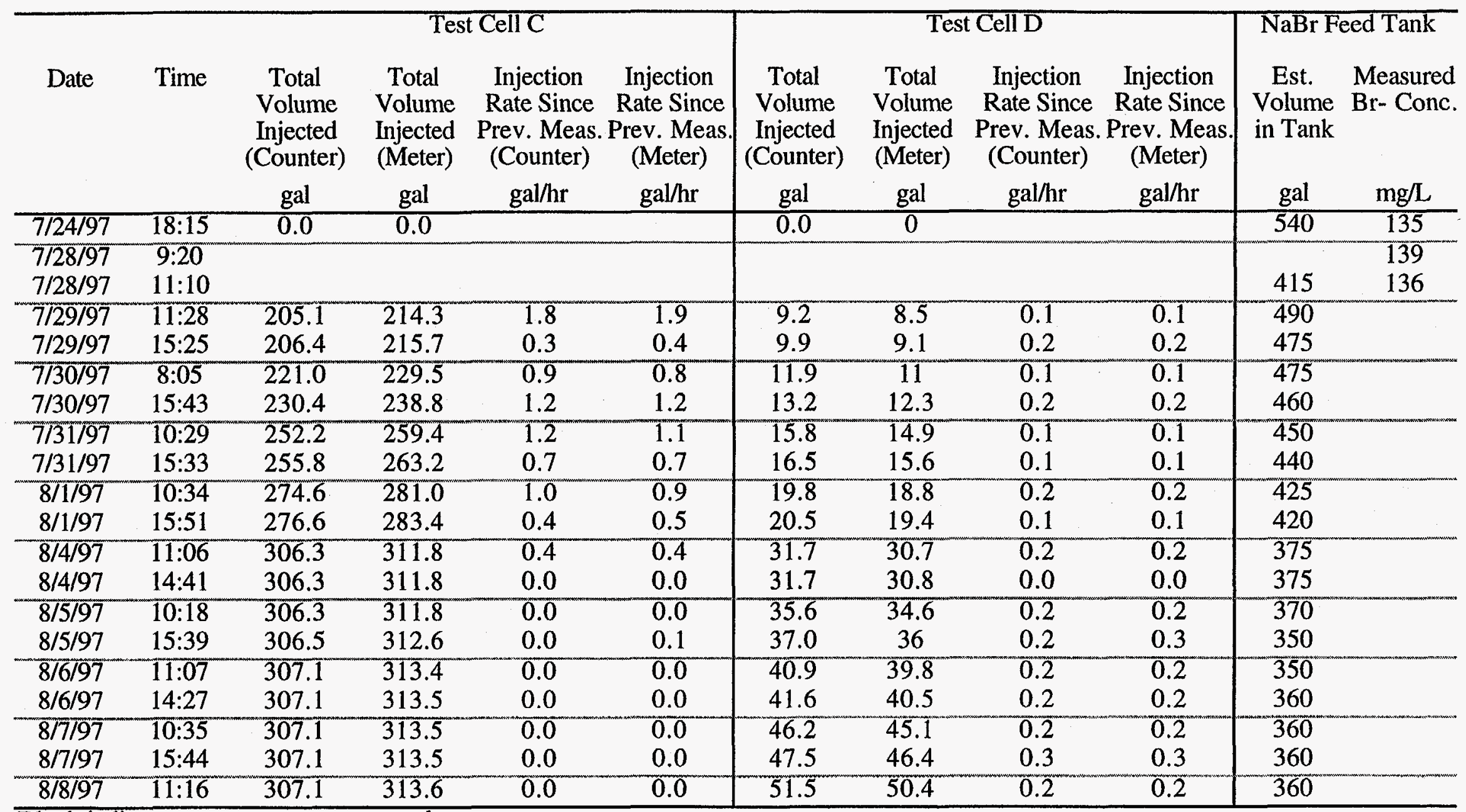

Blank indicates no measurement was taken. 
Table B.5 cont. Rates and volumes of fluid delivery to Test Cells C and D.

\begin{tabular}{|c|c|c|c|c|c|c|c|c|c|c|c|}
\hline \multirow{3}{*}{ Date } & \multirow{3}{*}{ Time } & \multicolumn{4}{|c|}{ Test Cell C } & \multicolumn{4}{|c|}{ Test Cell D } & \multicolumn{2}{|c|}{ NaBr Feed Tank } \\
\hline & & $\begin{array}{c}\text { Total } \\
\text { Volume } \\
\text { Injected } \\
\text { (Counter) }\end{array}$ & $\begin{array}{l}\text { Total } \\
\text { Volume } \\
\text { Injected } \\
\text { (Meter) }\end{array}$ & $\begin{array}{l}\text { Injection } \\
\text { Rate Since } \\
\text { Prev. Meas. } \\
\text { (Counter) }\end{array}$ & $\begin{array}{c}\text { Injection } \\
\text { Rate Since } \\
\text { Prev. Meas. } \\
\text { (Meter) }\end{array}$ & $\begin{array}{c}\text { Total } \\
\text { Volume } \\
\text { Injected } \\
\text { (Counter) }\end{array}$ & $\begin{array}{l}\text { Total } \\
\text { Volume } \\
\text { Injected } \\
\text { (Meter) }\end{array}$ & $\begin{array}{l}\text { Injection } \\
\text { Rate Since } \\
\text { Prev. Meas. } \\
\text { (Counter) }\end{array}$ & $\begin{array}{c}\text { Injection } \\
\text { Rate Since } \\
\text { Prev. Meas. } \\
\text { (Meter) }\end{array}$ & $\begin{array}{c}\text { Est. } \\
\text { Volume } \\
\text { in Tank }\end{array}$ & $\begin{array}{l}\text { Measured } \\
\text { Br- Conc. }\end{array}$ \\
\hline & & gal & gal & $\mathrm{gal} / \mathrm{hr}$ & $\mathrm{gal} / \mathrm{hr}$ & gal & gal & $\mathrm{gal} / \mathrm{hr}$ & $\mathrm{gal} / \mathrm{hr}$ & gal & $\mathrm{mg} / \mathrm{L}$ \\
\hline $8 / 8 / 97$ & $15: 45$ & 307.1 & 313.7 & 0.0 & 0.0 & 52.8 & 52.2 & 0.3 & 0.4 & 310 & \\
\hline $8 / 11 / 97$ & $9: 04$ & 307.3 & 313.8 & 0.0 & 0.0 & 66.7 & 66.1 & 0.2 & 0.2 & 350 & \\
\hline $8 / 11 / 97$ & $15: 21$ & 307.3 & 313.9 & 0.0 & 0.0 & 68.0 & 67.6 & 0.2 & 0.2 & 350 & \\
\hline $8 / 12 / 97$ & $11: 21$ & 307.3 & 313.9 & 0.0 & 0.0 & 70.6 & 70.7 & 0.1 & 0.2 & 350 & \\
\hline $8 / 12 / 97$ & $15: 52$ & 307.3 & 313.9 & 0.0 & 0.0 & 71.9 & 71.5 & 0.3 & 0.2 & 345 & \\
\hline $8 / 13 / 97$ & $12: 00$ & 308.1 & 315.6 & 0.0 & 0.1 & 77.2 & 77.2 & 0.3 & 0.3 & 345 & \\
\hline $8 / 13 / 97$ & $15: 30$ & 308.1 & 315.6 & 0.0 & 0.0 & 78.5 & 78.3 & 0.4 & 0.3 & 340 & \\
\hline $8 / 14 / 97$ & $11: 13$ & 308.9 & 316.8 & 0.0 & 0.1 & 85.1 & 85.1 & 0.3 & 0.3 & 340 & \\
\hline $8 / 14 / 97$ & $15: 43$ & 308.9 & 316.7 & 0.0 & 0.0 & 85.8 & 85.8 & 0.1 & 0.2 & 340 & \\
\hline $8 / 15 / 97$ & $12: 24$ & 309.7 & 317.9 & 0.0 & 0.1 & 91.1 & 91.6 & 0.3 & 0.3 & 325 & \\
\hline $8 / 15 / 97$ & $14: 50$ & 309.7 & 318.0 & 0.0 & 0.0 & 91.1 & 91.7 & 0.0 & 0.0 & 325 & \\
\hline $8 / 18 / 97$ & $9: 26$ & 310.7 & 320.2 & 0.0 & 0.0 & 100.3 & 104.1 & 0.1 & 0.2 & 310 & \\
\hline $8 / 18 / 97$ & $14: 55$ & 311.0 & 320.9 & 0.0 & 0.1 & 101.0 & 104.1 & 0.1 & 0.0 & 310 & \\
\hline $8 / 19 / 97$ & $10: 00$ & 312.0 & 322.3 & 0.1 & 0.1 & 106.3 & 108.5 & 0.3 & 0.2 & 305 & \\
\hline $8 / 19 / 97$ & $14: 00$ & 312.0 & 322.3 & 0.0 & 0.0 & 106.3 & 109.1 & 0.0 & 0.1 & 305 & \\
\hline $8 / 20 / 97$ & $10: 10$ & 312.3 & 322.7 & 0.0 & 0.0 & 110.9 & 113.9 & 0.2 & 0.2 & 305 & \\
\hline $8 / 20 / 97$ & $14: 54$ & 312.5 & 323.4 & 0.1 & 0.1 & 112.2 & 115.4 & 0.3 & 0.3 & 300 & \\
\hline $8 / 21 / 97$ & $8: 20$ & 313.0 & 324.2 & 0.0 & 0.0 & 115.5 & 117.5 & 0.2 & 0.1 & 300 & \\
\hline $8 / 21 / 97$ & $15: 35$ & 313.0 & 324.1 & 0.0 & 0.0 & 116.2 & 118.1 & 0.1 & 0.1 & 300 & \\
\hline $8 / 22 / 97$ & $11: 47$ & 315.1 & 326.5 & 0.1 & 0.1 & 119.5 & 121.4 & 0.2 & 0.2 & 298 & \\
\hline
\end{tabular}


Table B.5 cont. Rates and volumes of fluid delivery to Test Cells C and D.

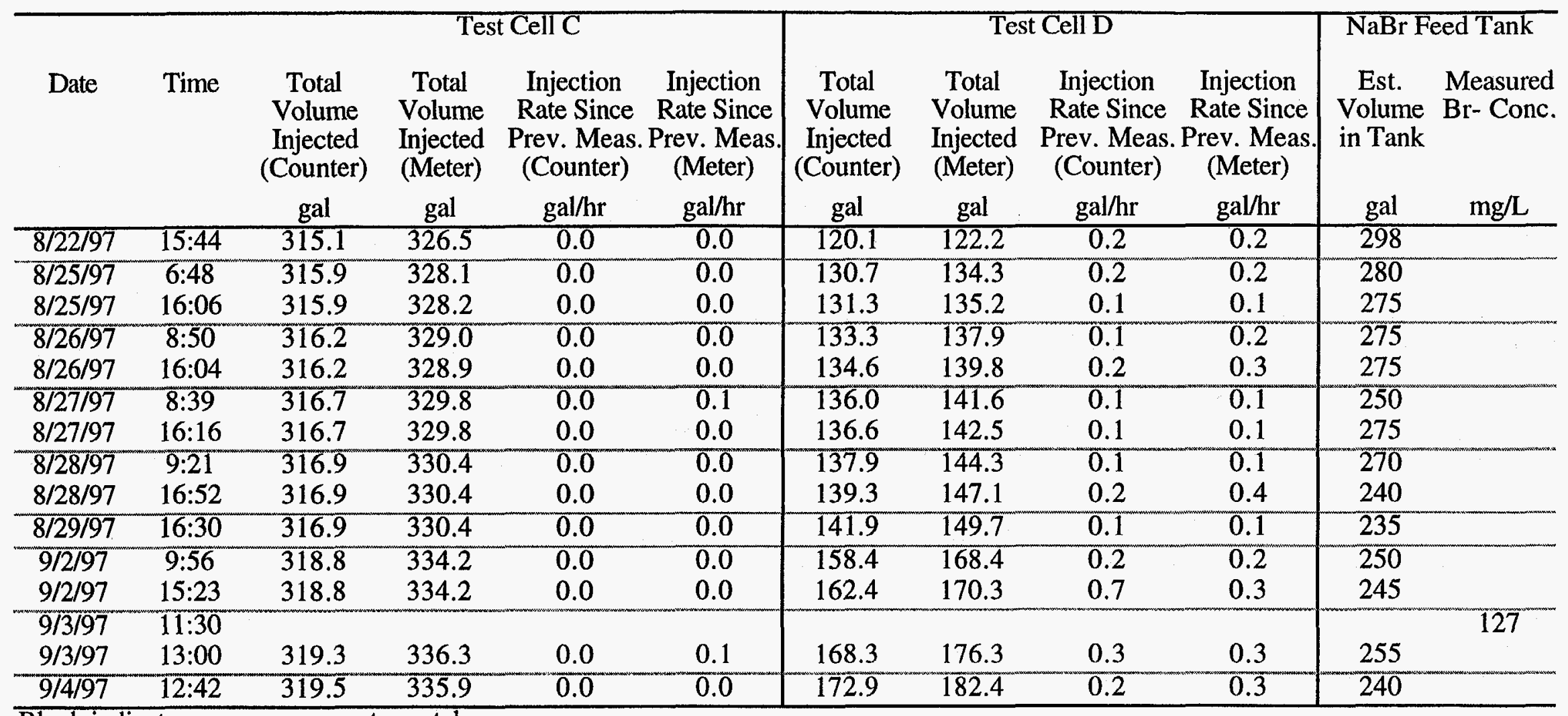

Blank indicates no measurement was taken. 


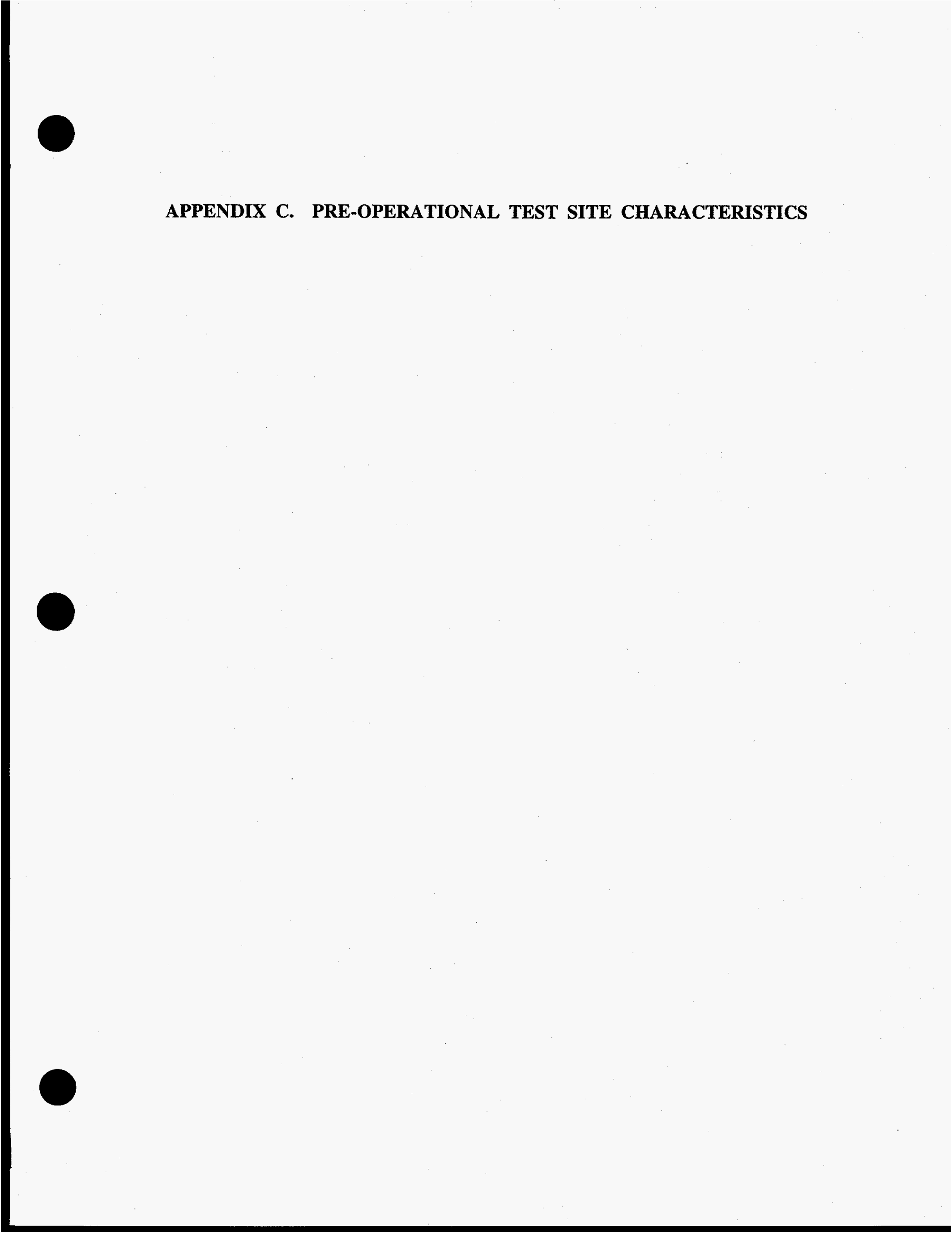


Figure C.1 Test cell A baseline water content profile based on August 1996 soil samples.

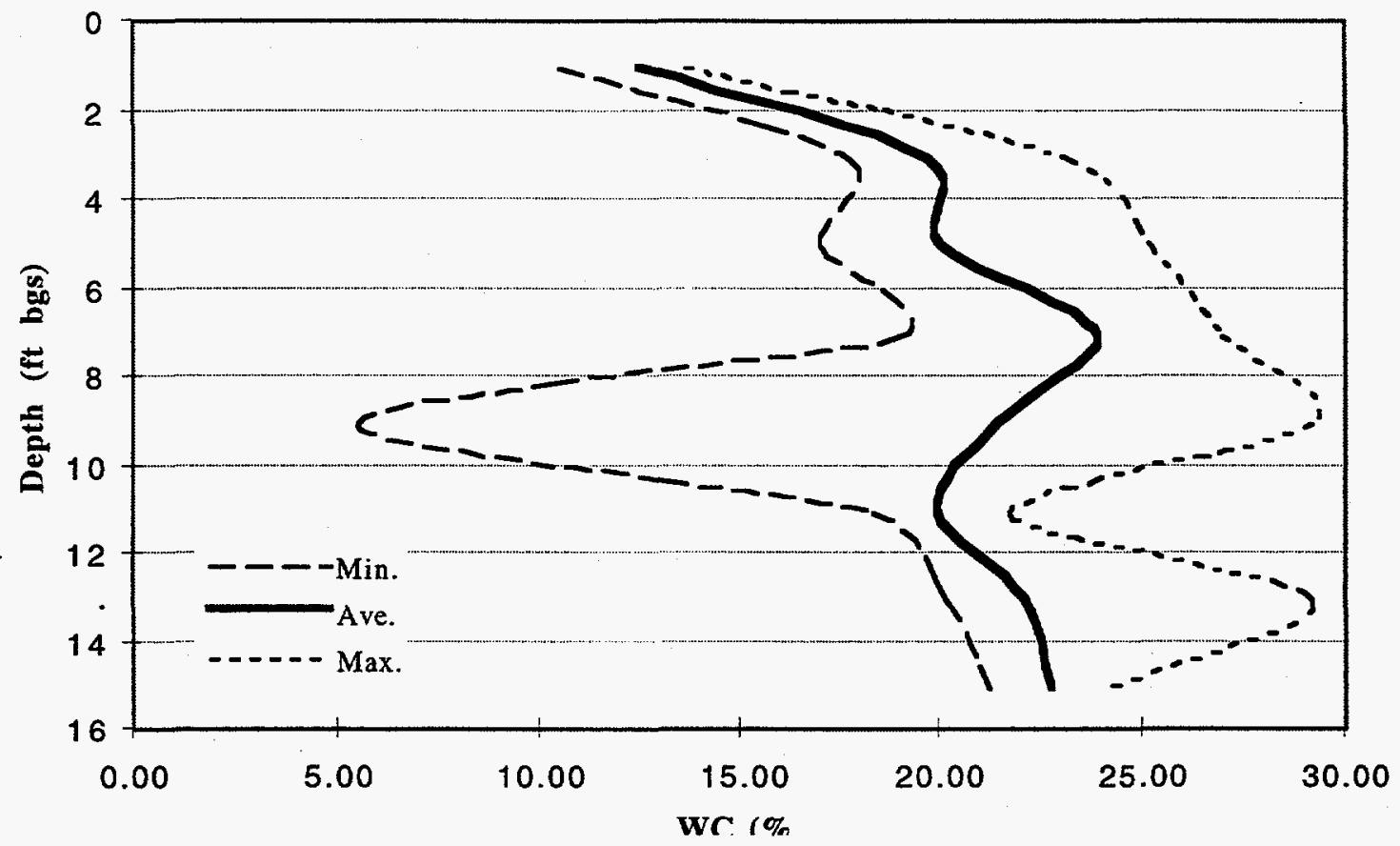

Figure. C.2. Test cell B baseline water content profile based on August 1996 soil samples.

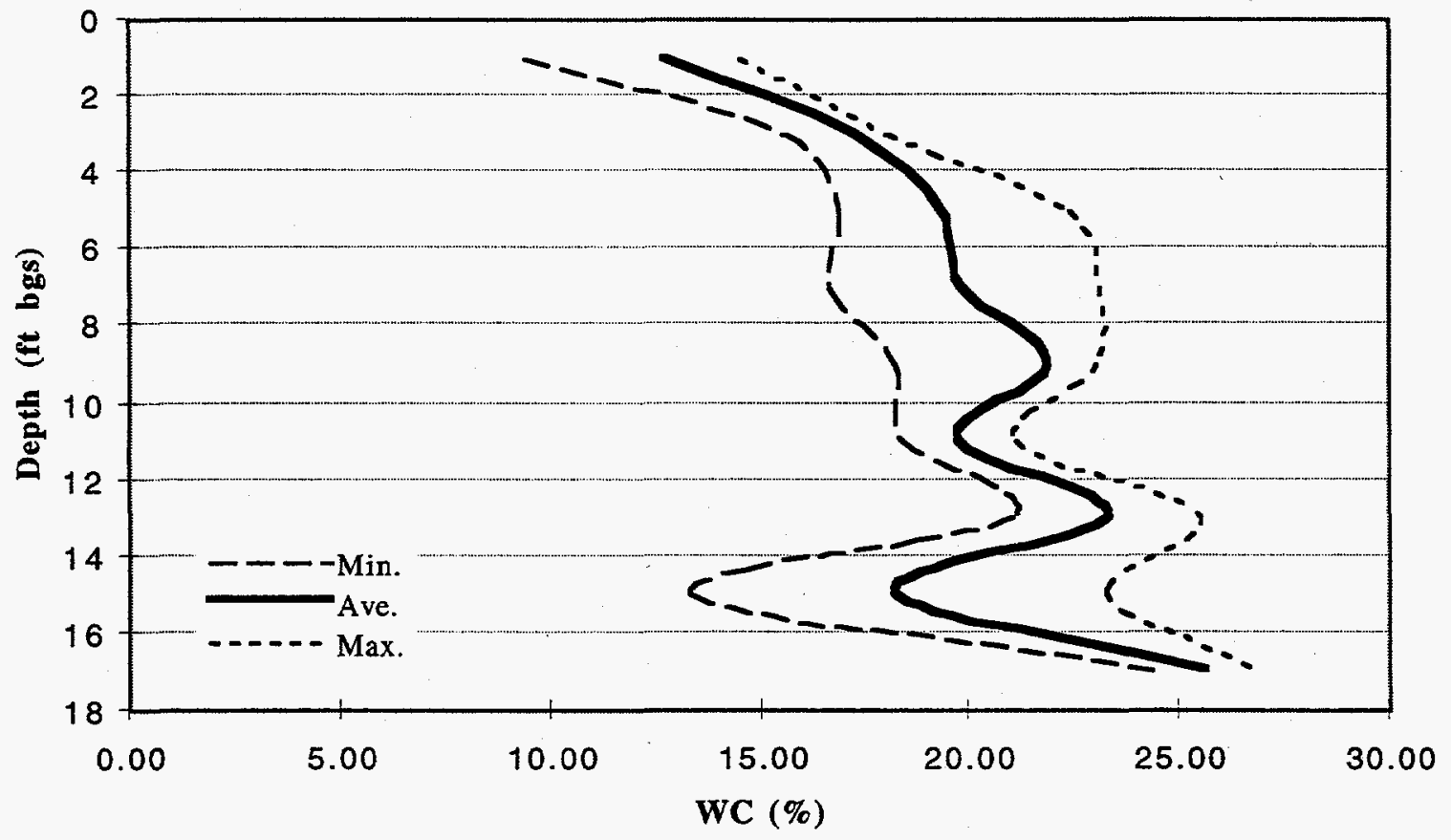

C -1 
Figure C.3 Test cell C baseline water content profile based on August 1996 soil samples.

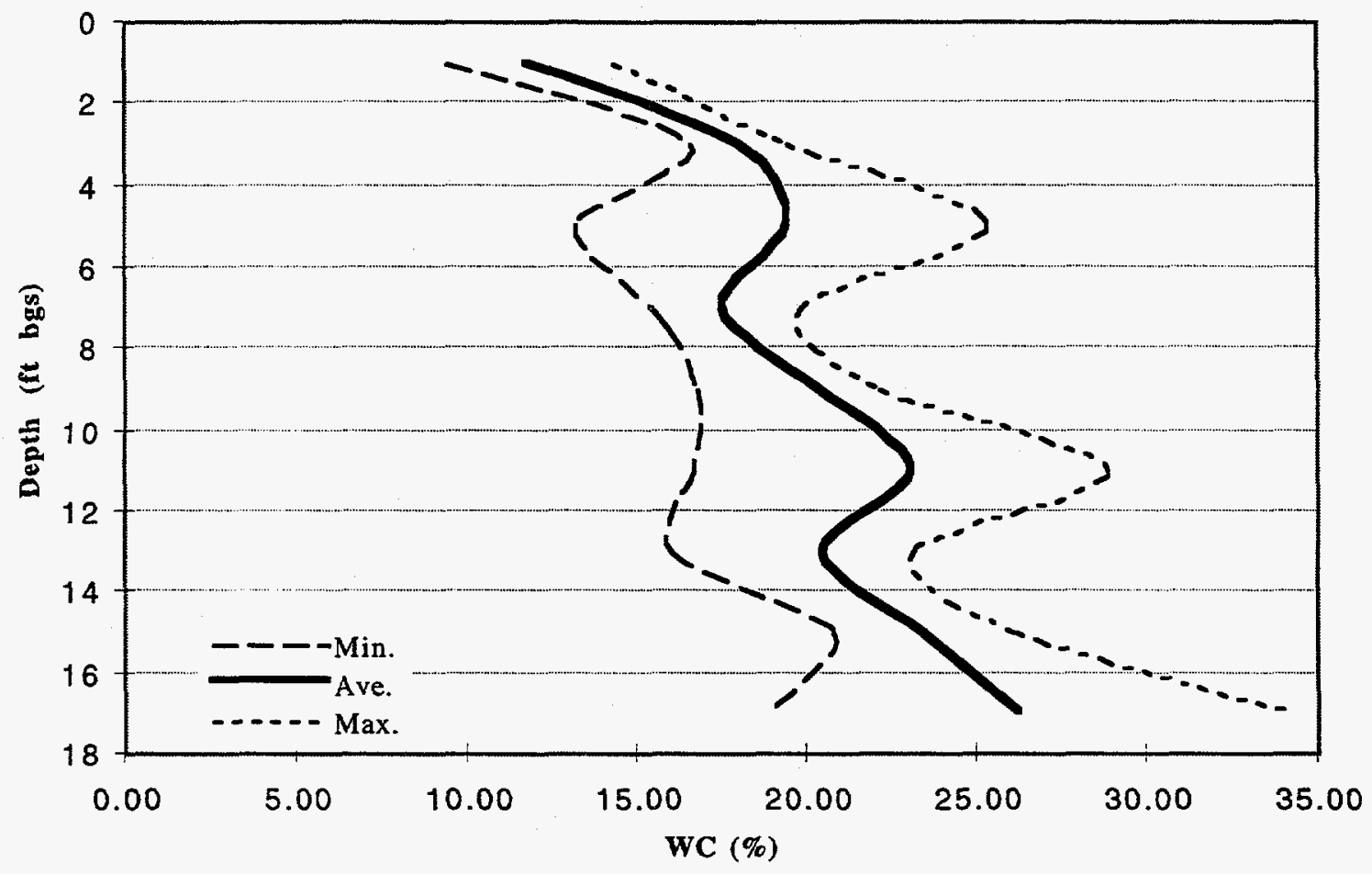

Figure C.4 Test cell D baseline water content profile based on August 1996 soil samples.

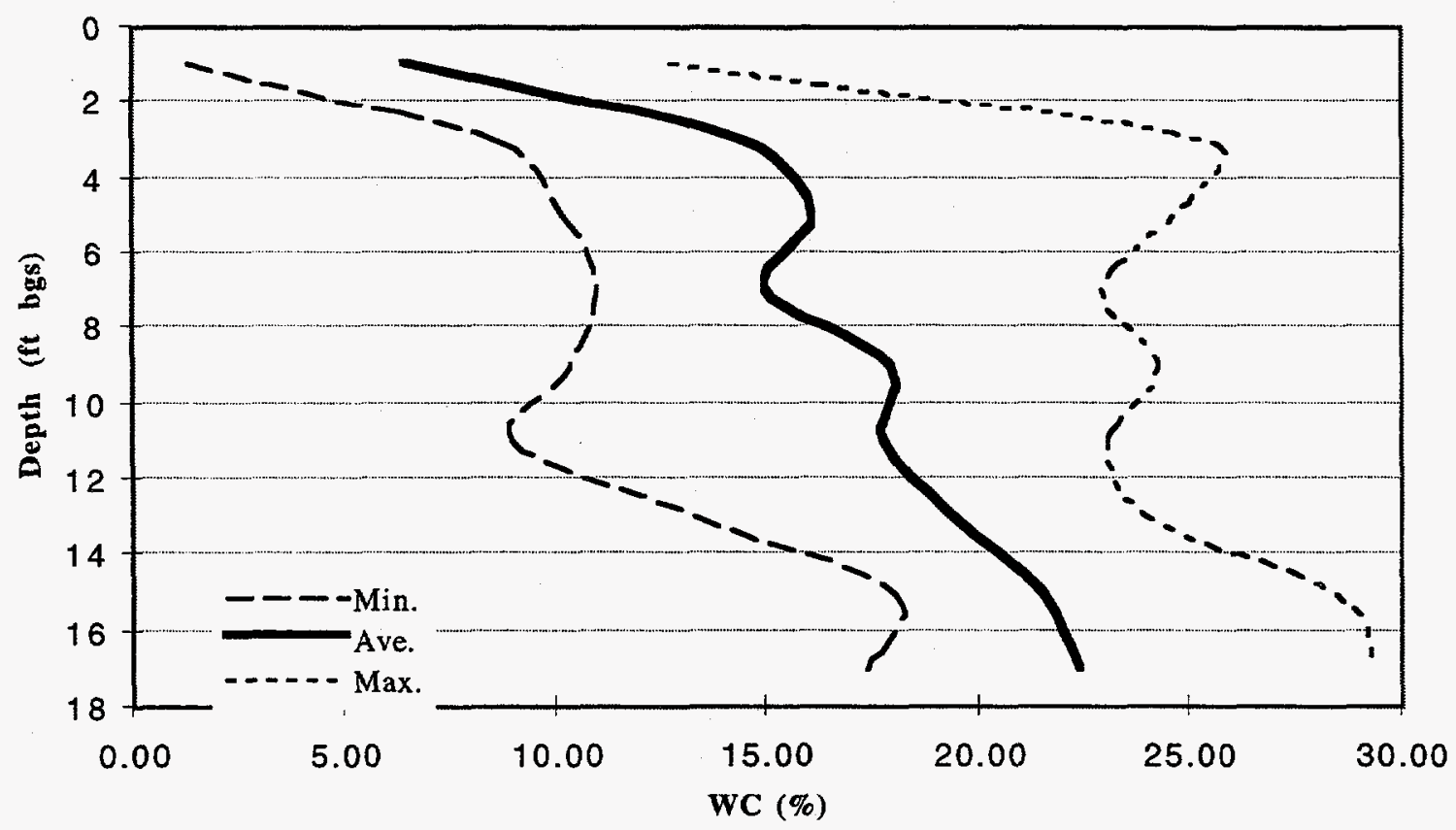

C -2 
Figure C.5 Volumetric moisture content as a function of depth and time in from Background boring. Open symbols are from Fall, 1996, filled symbols from Summer, 1997, measured using TDR. Circles with internal cross measured in lab before testing (Fall 1996).

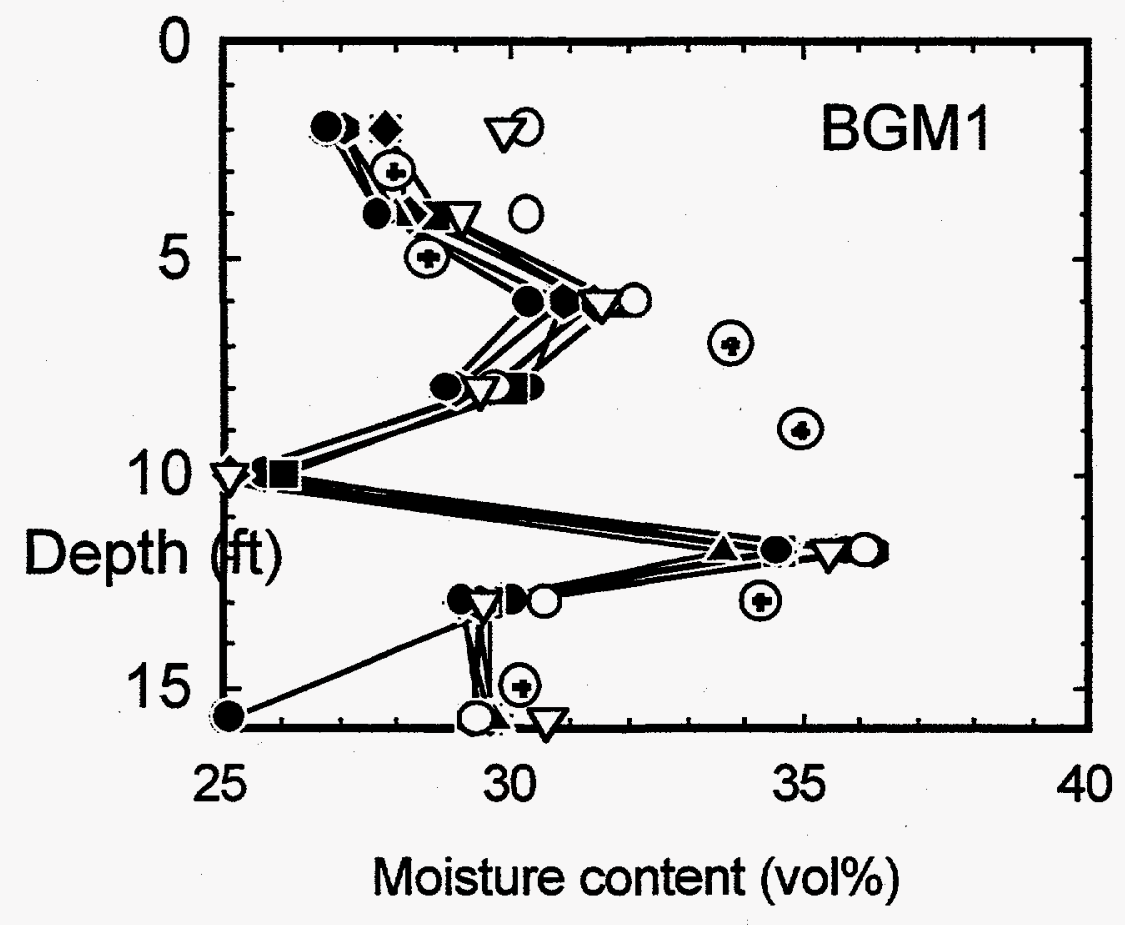

C -3 
Table C.1. Physical/chemical characteristics with depth as observed in a background borehole adjacent to the test cells (August 1996).

\begin{tabular}{cccccc}
\hline Sample ID & $\begin{array}{c}\text { Depth } \\
\text { (ft bgs) }\end{array}$ & $\begin{array}{c}\text { Water content } \\
\text { (dry wt.\%) }\end{array}$ & $\begin{array}{c}\text { Eh } \\
\text { (mV) }\end{array}$ & $\begin{array}{c}\text { Temp } \\
\left({ }^{\circ} \mathrm{F}\right)\end{array}$ & $\begin{array}{c}\text { pH } \\
(1: 1 \text { water ext.) }\end{array}$ \\
\hline BGB2-03 & 3 & 16.2 & 240 & 41 & 4.66 \\
BGB2-05 & 5 & 16.7 & 218 & 40 & 6.21 \\
BGB2-07 & 7 & 20.3 & 78 & NA & 5.89 \\
BGB2-09 & 9 & 21.2 & -22 & NA & 5.79 \\
BGB2-11 & 11 & 25.8 & 15 & NA & 5.91 \\
BGB2-13 & 13 & 20.7 & 165 & NA & 5.49 \\
BGB2-15 & 15 & 17.8 & 280 & NA & 5.64 \\
BGB2-17 & 17 & 20.0 & NA & 53 & 5.74 \\
\hline
\end{tabular}

NA not analyzed

Table C.2. Selected metal content with depth as observed in water extracts made from soil collected from a background borehole adjacent to the test cells (August 1996).

\begin{tabular}{cccccc}
\hline Sample ID & $\begin{array}{c}\text { Depth } \\
\text { (ft bgs) }\end{array}$ & $\begin{array}{c}\mathrm{K}^{+} \\
\text {(ppm) }\end{array}$ & $\begin{array}{c}\text { Total Fe } \\
\text { (ppm) }\end{array}$ & $\begin{array}{c}\text { Mn } \\
(\mathrm{ppm})\end{array}$ & $\begin{array}{c}\mathrm{MnO}_{4} \\
\text { (ppm) }\end{array}$ \\
\hline BGB2-03 & 3 & 103 & 61.5 & 500 & NA \\
BGB2-05 & 5 & 147 & 820 & 1360 & NA \\
BGB2-07 & 7 & 101 & 990 & 4625 & NA \\
BGB2-09 & 9 & 121 & 910 & 144 & NA \\
BGB2-11 & 11 & 161 & 1040 & 350 & NA \\
BGB2-13 & 13 & 87 & 870 & 10 & 1NA \\
BGB2-15 & 15 & 86 & 38.3 & 10 & NA \\
BGB2-17 & 17 & 80 & 22.7 & 20 & NA \\
\hline
\end{tabular}

NA not analyzed 
Table C.3 TDR measurements in the background monitoring location (\% moisture).

\begin{tabular}{cccccccccccccc}
\hline Location & $\begin{array}{c}\text { Depth } \\
\text { (ft bgs) }\end{array}$ & $10 / 10 / 96$ & $10 / 17 / 96$ & $10 / 22 / 96$ & $10 / 29 / 96$ & $11 / 8 / 96$ & $11 / 11 / 96$ & $11 / 15 / 96$ & $11 / 21 / 96$ & $12 / 4 / 96$ & $7 / 19 / 97$ & $7 / 25 / 97$ & $9 / 6 / 97$ \\
\hline BGMI & 2 & 26.8 & 27.8 & 27.8 & 27.8 & 27.1 & 26.8 & 27.1 & 27.1 & 26.8 & 30.3 & 30.3 & 29.9 \\
& 4 & & 28.7 & 28.7 & 28.2 & 28.3 & 27.7 & 28.0 & 27.7 & 27.7 & 30.3 & 29.7 & 31.5 \\
& 6 & 30.9 & 31.3 & 31.8 & 31.4 & & & & 30.9 & 30.3 & 32.1 & 31.8 & 29.4 \\
& 8 & 30.3 & 29.7 & 30.0 & 29.6 & 29.1 & 29.1 & 28.8 & 29.0 & 28.8 & 29.7 & 29.4 & 29.5 \\
10 & 25.7 & 25.1 & 26.0 & 25.1 & 25.4 & 24.8 & 24.2 & 24.2 & 24.2 & 24.8 & 24.5 & 25.1 \\
& 11.8 & 35.8 & 34.7 & 34.6 & 34.6 & 34.2 & 34.6 & 33.6 & 36.2 & 34.6 & 36.1 & 36.1 & 29.1 \\
13 & 30.0 & 29.5 & 29.6 & 29.1 & 29.4 & 29.4 & 29.4 & 29.4 & 29.1 & 30.6 & 30.3 & 35.5 \\
& 15.75 & 25.1 & 29.3 & 29.6 & 29.6 & 29.4 & 29.7 & 29.7 & 29.3 & 29.4 & 29.4 & 30.0 & 30.6 \\
& & & & & & & & & & &
\end{tabular}


Table C.4. VOC concentrations in soil with depth as observed in a background borehole adjacent to the test cells, field laboratory analysis (August 1996).

\begin{tabular}{|c|c|c|c|c|c|c|c|c|c|}
\hline Location & $\begin{array}{l}\text { Depth } \\
\text { (ft bgs) }\end{array}$ & $\begin{array}{l}\mathrm{CH}_{2} \mathrm{Cl}_{2} \\
(\mu \mathrm{g} / \mathrm{kg})\end{array}$ & $\begin{array}{c}\mathrm{t}-1,2- \\
\mathrm{DCE} \\
(\mu \mathrm{g} / \mathrm{kg})\end{array}$ & $\begin{array}{c}\mathrm{c}-1,2- \\
\mathrm{DCE} \\
(\mu \mathrm{g} / \mathrm{kg})\end{array}$ & $\begin{array}{l}1,1-\mathrm{DCE} \\
(\mu \mathrm{g} / \mathrm{kg})\end{array}$ & $\begin{array}{c}1,1,1- \\
\text { TCA } \\
(\mu g / k g)\end{array}$ & $\begin{array}{c}\mathrm{TCE} \\
(\mu \mathrm{g} / \mathrm{kg})\end{array}$ & $\begin{array}{c}\mathrm{PCE} \\
(\mu \mathrm{g} / \mathrm{kg})\end{array}$ & $\begin{array}{c}\text { Total } \\
\text { VOCs } \\
(\mu \mathrm{g} / \mathrm{kg})\end{array}$ \\
\hline$\overline{\mathrm{BGB} 2-01}$ & 1 & & & & & & 9 & & 9 \\
\hline BGB2-02 & 2 & & & & & & 2 & & 2 \\
\hline BGB2-03 & 3 & & & & & & 2 & & 2 \\
\hline BGB2-04 & 4 & & & & & & 4 & & 4 \\
\hline BGB2-05 & 5 & & & & & & 2 & & 2 \\
\hline BGB2-06 & 6 & & & & & 1 & 7 & & 8 \\
\hline BGB2-07 & 7 & & & & & & 2 & & 2 \\
\hline BGB2-08 & 8 & & & & & & 2 & & 2 \\
\hline BGB2-09 & 9 & & & & & & 2 & & 2 \\
\hline BGB2-10 & 10 & & & & & & 3 & & 3 \\
\hline BGB2-11 & 11 & & & & & & 2 & & 2 \\
\hline BGB2-12 & 12 & & & & & & 2 & & 2 \\
\hline BGB2-13 & 13 & & & & & 1 & 2 & & 3 \\
\hline BGB2-14 & 14 & & & & & & 2 & & 2 \\
\hline BGB2-15 & 15 & & & & & & 1 & & 1 \\
\hline BGB2-16 & 16 & & & & & & 2 & & 2 \\
\hline BGB2-17 & 17 & & & & & 1 & 6 & & 8 \\
\hline
\end{tabular}

Blank indicates non-detect. 
Table C.5. Test Cell A physical/chemical characteristics with depth as observed shortly after establishment and before process operation was initiated (August 1996).

\begin{tabular}{cccccc}
\hline Sample ID & $\begin{array}{c}\text { Depth } \\
\text { (ft bgs) }\end{array}$ & $\begin{array}{c}\text { Water content } \\
(\%)\end{array}$ & $\begin{array}{c}\text { Eh } \\
(\mathrm{mV})\end{array}$ & $\begin{array}{c}\text { Temp. } \\
\left({ }^{\circ} \mathrm{F}\right)\end{array}$ & $\begin{array}{c}\text { pH } \\
\text { (extractant) }\end{array}$ \\
\hline TAB01-05 & 5 & 19.9 & 225 & 73 & 6.20 \\
TAB01-09 & 9 & 23 & 140 & 75 & 6.20 \\
TAB01-13 & 13 & 29.2 & 105 & 75 & 6.38 \\
\hline TAB02-01 & 1 & 13.4 & - & - & 6.50 \\
TAB02-02 & 2 & 18.4 & 214 & 75 & 5.88 \\
TAB02-03 & 3 & 17 & 285 & 74 & 6.15 \\
TAB02-04 & 4 & 19 & 140 & 74 & 6.15 \\
TAB02-09 & 9 & 20.7 & 100 & 74 & 6.37 \\
TAB02-11 & 11 & 18.3 & 57 & 73 & 6.38 \\
TAB02-13 & 13 & 20.1 & 52 & 73 & 6.24 \\
TAB02-15 & 15 & 22.8 & 20 & 76 & 6.06 \\
TAB02-17 & 17 & 18.8 & 228 & 76 & 6.01 \\
\hline TAB03-05 & 5 & 25.2 & 160 & 73 & 6.33 \\
TAB03-09 & 9 & 21.3 & 116 & 73 & 6.20 \\
TAB03-13 & 13 & 20.2 & 125 & 72 & 6.39 \\
\hline TAB04-05 & 5 & 21.2 & 160 & 74 & 6.39 \\
TAB04-09 & 9 & 5.5 & 107 & 74 & 6.28 \\
TAB04-13 & 13 & 21 & 72 & 74 & 6.12 \\
\hline TAB05-05 & 5 & 20.7 & 230 & 54 & 6.00 \\
TAB05-09 & 9 & 26.7 & 214 & 51 & 7.26 \\
TAB05-13 & 13 & 22.2 & 100 & 51 & 5.99 \\
\hline TAB06-01 & 1 & 13.7 & - & - & 7.29 \\
TAB06-03 & 3 & 23.2 & 200 & 61 & 5.03 \\
TAB06-05 & 5 & 17.2 & 220 & 54 & 6.14 \\
TAB06-07 & 7 & 25.8 & 235 & 51 & 7.16 \\
TAB06-09 & 9 & 24.3 & 160 & 49 & 6.88 \\
TAB06-13 & 13 & 21.5 & 175 & 49 & 5.83 \\
TAB06-15 & 15 & 24.1 & 90 & 50 & 6.04 \\
TAB06-17 & 17 & 23.6 & 140 & 47 & 5.78 \\
\hline TAB07-05 & 5 & 18.6 & 180 & 49 & 6.72 \\
TAB07-09 & 9 & 29.2 & 137 & 49 & 5.77 \\
TAB07-13 & 13 & 20.3 & 170 & 51 & 5.58 \\
\hline TAB08-01 & 1 & 10.6 & - & - & 7.25 \\
TAB08-03 & 3 & 17.7 & 250 & 56 & 5.44 \\
TAB08-05 & 5 & 20.9 & 310 & 56 & 5.19 \\
TAB08-07 & 7 & 27 & 255 & 54 & 6.73 \\
TAB08-09 & 9 & 20.7 & 190 & 54 & 5.97 \\
TAB08-11 & 11 & 21.7 & 197 & 51 & 5.74 \\
TAB08-13 & 13 & 21.8 & 195 & 49 & 5.95 \\
TAB08-15 & 15 & 21.2 & 153 & 56 & 5.53 \\
TAB08-17 & 17 & 19.2 & 220 & 51 & 5.21 \\
\hline Range & & $10.1-29.2$ & $-13.1-385$ & $42-76$ & $5.19-7.25$ \\
\hline & not & & & & \\
& & & & & \\
\hline
\end{tabular}

C -7 
Table C.6. Test Cell B physical/chemical characteristics with depth as observed shortly after establishment and before process operation was initiated (August 1996).

\begin{tabular}{cccccc}
\hline Sample ID & $\begin{array}{c}\text { Depth } \\
\text { (ft bgs) }\end{array}$ & $\begin{array}{c}\text { Water content } \\
\text { (dry wt.\%) }\end{array}$ & $\begin{array}{c}\text { Eh } \\
(\mathrm{mV})\end{array}$ & $\begin{array}{c}\text { Temp. } \\
\left({ }^{\circ} \mathrm{F}\right)\end{array}$ & $\begin{array}{c}\text { pH } \\
\text { (extractant) }\end{array}$ \\
\hline TBB01-05 & 5 & 19 & 107 & 74 & 5.31 \\
TBB01-09 & 9 & 22.9 & 106 & 75 & 5.90 \\
TBB01-13 & 13 & 21.9 & 300 & 76 & 5.79 \\
\hline TBB02-01 & 1 & 14.5 & - & - & 6.33 \\
TBB02-03 & 3 & 15.6 & 233 & 76 & 5.68 \\
TBB02-05 & 5 & 22.4 & 245 & 74 & 6.08 \\
TBB02-07 & 7 & 23.1 & -38 & 75 & 6.31 \\
TBB02-13 & 13 & 24.3 & 290 & 74 & 6.37 \\
\hline TBB03-09 & 9 & 22.8 & 224 & 74 & 6.21 \\
TBB03-13 & 13 & 24.3 & 227 & 73 & 6.03 \\
\hline TBB05-05 & 5 & 21.0 & 220 & 50 & 4.80 \\
TBB05-09 & 9 & 23.0 & 280 & 51 & 5.24 \\
TBB05-13 & 13 & 23.8 & 310 & 56 & 5.64 \\
\hline TBB06-01 & 1 & 14.4 & - & - & 7.01 \\
TBB06-03 & 3 & 18.1 & 260 & 64 & 5.67 \\
TBB06-05 & 5 & 17.4 & 280 & 60 & 5.10 \\
TBB06-06 & 6 & 16.4 & 200 & 55 & 6.85 \\
TBB06-07 & 7 & 16.6 & 230 & 54 & 6.91 \\
TBB06-09 & 9 & 18.2 & 160 & 54 & 5.96 \\
TBB06-11 & 11 & 18.4 & 260 & 55 & 5.85 \\
TBB06-13 & 13 & 21 & 305 & 54 & 5.48 \\
TBB06-15 & 15 & 13.3 & 307 & 54 & 5.06 \\
TBB06-17 & 17 & 26.8 & 290 & 55 & 5.40 \\
\hline TBB07-01 & 1 & 9.4 & - & - & 6.52 \\
TBB07-03 & 3 & 18 & 300 & 74 & 5.90 \\
TBB07-05 & 5 & 25.26 & 134 & 73 & 6.92 \\
TBB07-05 & 5 & 16.9 & 180 & 56 & 6.51 \\
TBB07-07 & 7 & 19.8 & 190 & 73 & 6.55 \\
TBB07-09 & 9 & 18.4 & 155 & 72 & 6.42 \\
TBB07-09 & 9 & 22.6 & 246 & 55 & 6.12 \\
TBB07-11 & 11 & 21.1 & 287 & 74 & 6.59 \\
TBB07-13 & 13 & 25.5 & 330 & 72 & 6.36 \\
TBB07-13 & 13 & 19.9 & 267 & 45 & 5.32 \\
TBB07-15 & 15 & 23.2 & 303 & 74 & 6.34 \\
TBB07-17 & 17 & 24.5 & 330 & 74 & 6.40 \\
\hline Range & & $9.4-26.8$ & $-38-330$ & $45-76$ & $4.80-7.30$ \\
\hline & not measured & & & & \\
\hline & & & & &
\end{tabular}


Table C.7. Test Cell $\mathrm{C}$ physical/chemical characteristics with depth as observed shortly after establishment and before process operation was initiated (August 1996).

\begin{tabular}{cccccc}
\hline Sample I & $\begin{array}{c}\text { Depth } \\
\text { (ft bgs) }\end{array}$ & $\begin{array}{c}\text { Water content } \\
\text { (dry wt. } \%)\end{array}$ & $\begin{array}{c}\text { Eh } \\
(\mathrm{mV})\end{array}$ & $\begin{array}{c}\text { Temp } \\
\left({ }^{\circ} \mathrm{F}\right)\end{array}$ & $\begin{array}{c}\mathrm{pH} \\
\text { (extractant) }\end{array}$ \\
\hline TCB01-05 & 5 & 24.6 & 154 & 72 & 5.55 \\
TCB01-09 & 9 & 22.2 & 305 & 72 & - \\
TCB01-13 & 13 & 22.2 & 25 & 72 & 6.15 \\
\hline TCB02-01 & 1 & 9.4 & 240 & 74 & 5.80 \\
TCB02-05 & 5 & 23 & 320 & 71 & 5.52 \\
TCB02-09 & 9 & 22.1 & 200 & 70 & 5.57 \\
TCB02-11 & 11 & 23.7 & 295 & 71 & 6.05 \\
TCB02-13 & 13 & 22.2 & 270 & 69 & 6.54 \\
TCB02-15 & 15 & 26.1 & 204 & 70 & 6.60 \\
TCB02-17 & 17 & 34.2 & 211 & 71 & 6.10 \\
\hline TCB03-05 & 5 & 25.3 & 240 & 60 & 5.67 \\
TCB03-09 & 9 & 19.9 & 250 & 60 & 6.02 \\
TCB03-13 & 13 & 23.1 & 235 & 61 & 6.20 \\
\hline TCB04-05 & 5 & 19.1 & 130 & 61 & 5.60 \\
TCB04-09 & 9 & 21.2 & 190 & 58 & 5.87 \\
TCB04-13 & 13 & 19.8 & 205 & 58 & 6.21 \\
\hline TCB05-05 & 5 & 16.3 & 347 & 52 & 5.02 \\
TCB05-09 & 9 & 15.5 & 353 & 55 & 5.55 \\
TCB05-13 & 13 & 21.4 & 125 & 57 & 6.40 \\
\hline TCB06-01 & 1 & 11.8 & - & - & 7.20 \\
TCB06-03 & 3 & 16.6 & 320 & 58 & 4.92 \\
TCB06-05 & 5 & 18.4 & 340 & 56 & 5.12 \\
TCB06-06 & 6 & 15.2 & 338 & 56 & 5.19 \\
TCB06-07 & 7 & 17.2 & 340 & 56 & 7.09 \\
TCB06-09 & 9 & 18.4 & 340 & 56 & 5.49 \\
TCB06-11 & 11 & 16.7 & 355 & 55 & 6.03 \\
TCB06-13 & 13 & 18.7 & 330 & 56 & 6.28 \\
TCB06-15 & 15 & 20.8 & 111 & 56 & 7.11 \\
TCB06-17 & 17 & 18.9 & -56 & 56 & 7.06 \\
\hline TCB07-05 & 5 & 13.2 & 235 & 56 & 5.70 \\
TCB07-09 & 9 & 16.8 & 265 & 56 & 5.59 \\
TCB07-13 & 13 & 16 & 248 & 59 & 5.76 \\
\hline TCB08-01 & 1 & 14.3 & 188 & 67 & 6.23 \\
TCB08-03 & 3 & 19.4 & 171 & 62 & 5.44 \\
TCB08-05 & 5 & 15.29 & 250 & 74 & 5.89 \\
TCB08-07 & 7 & 19.8 & 176 & 76 & 5.85 \\
TCB08-09 & 9 & 21.1 & 325 & 76 & 5.75 \\
TCB08-11 & 11 & 28.9 & 327 & 75 & 5.92 \\
TCB08-13 & 13 & 21.4 & 324 & 75 & 6.18 \\
TCB08-15 & 15 & 23.2 & 205 & 74 & 6.23 \\
TCB08-17 & 17 & 25.5 & 146 & 75 & 6.05 \\
\hline Range & & $9.4-34.2$ & $-56-355$ & $52-76$ & $4.92-7.2$ \\
\hline & not & & & & \\
& & & & & \\
\hline
\end{tabular}


Table C.8. Test Cell D physical/chemical characteristics with depth as observed shortly after establishment and before process operation was initiated (August 1996).

\begin{tabular}{cccccc}
\hline Sample ID & $\begin{array}{c}\text { Depth } \\
\text { (ft bgs) }\end{array}$ & $\begin{array}{c}\text { Water content } \\
\text { (dry wt\%) }\end{array}$ & $\begin{array}{c}\text { Eh } \\
\text { (mV) }\end{array}$ & $\begin{array}{c}\text { Temp. } \\
\left({ }^{\circ} \mathrm{F}\right)\end{array}$ & $\begin{array}{c}\text { pH } \\
\text { (extractant) }\end{array}$ \\
\hline TDB01-05 & 5 & 19.5 & 118 & 53 & 5.05 \\
TDB01-09 & 9 & 22.9 & 820 & 55 & 4.51 \\
TDB01-13 & 13 & 22.8 & 531 & 55 & 5.26 \\
\hline TDB02-01 & 1 & 12.7 & - & - & 6.63 \\
TDB02-03 & 3 & 25.6 & 358 & 58 & 4.81 \\
TDB02-05 & 5 & 20 & 317 & 58 & 4.57 \\
TDB02-07 & 7 & 22.9 & 220 & 56 & 5.47 \\
TDB02-09 & 9 & 24.3 & 440 & 57 & 5.32 \\
TDB02-11 & 11 & 21.3 & 420 & 55 & 5.42 \\
TDB02-13 & 13 & 23.8 & - & - & 6.01 \\
TDB02-15 & 15 & 28.5 & 332 & 58 & 6.07 \\
TDB02-17 & 17 & 29.4 & 354 & 59 & 6.08 \\
\hline TDB03-05 & 5 & 24.6 & 200 & 57 & 5.63 \\
TDB03-09 & 9 & 22.1 & 397 & 58 & 4.22 \\
TDB03-13 & 13 & 22.9 & 356 & 56 & 5.19 \\
\hline TDB04-05 & 5 & 20.9 & 107 & 57 & 5.07 \\
TDB04-09 & 9 & 21.7 & 419 & 56 & 4.53 \\
TDB04-13 & 13 & 24 & 351 & 55 & 5.04 \\
\hline TDB05-05 & 5 & 10.8 & 345 & 70 & 5.13 \\
TDB05-09 & 9 & 17.1 & 453 & 69 & 4.75 \\
TDB05-13 & 13 & 13.3 & 388 & 70 & 5.31 \\
\hline TDB06-01 & 1 & 5.4 & - & - & 6.14 \\
TDB06-03 & 3 & 8.6 & 235 & 70 & 4.34 \\
TDB06-05 & 5 & 10.1 & 204 & 71 & 4.63 \\
TDB06-07 & 7 & 11.1 & 440 & 70 & 3.89 \\
TDB06-09 & 9 & 13.1 & 462 & 70 & 3.74 \\
TDB06-11 & 11 & 23.1 & 410 & 70 & 5.17 \\
TDB06-13 & 13 & 13.6 & 386 & 71 & 4.76 \\
TDB06-15 & 15 & 21.1 & 344 & 71 & 4.71 \\
TDB06-17 & 17 & 20.5 & 344 & 70 & 4.93 \\
\hline TDB07-05 & 5 & 10.1 & 152 & 72 & 4.28 \\
TDB07-09 & 9 & 10.3 & 391 & 71 & 3.82 \\
TDB07-15 & 15 & 18.7 & 353 & 70 & 5.17 \\
\hline TDB08-01 & 1 & 1.27 & - & - & 6.45 \\
TDB08-03 & 3 & 9.2 & -306 & 68 & 5.37 \\
TDB08-05 & 5 & 12.6 & 206 & 3.80 \\
TDB08-07 & 7 & 10.9 & 380 & 68 & 4.05 \\
TDB08-09 & 9 & 12 & 408 & 69 & 5.99 \\
TDB08-11 & 11 & 8.9 & 406 & 72 & 5.38 \\
TDB08-13 & 13 & 15.5 & 388 & 70 & 4.92 \\
TDB08-15 & 15 & 18 & 396 & 70 & 5.41 \\
TDB08-17 & 17 & 17.4 & 397 & 70 & $3.74-6.63$ \\
\hline Range & & $12.7-29.4$ & $107-820$ & $53-72$ & \\
\hline & not measured & & & & \\
\hline
\end{tabular}


Table C.9. Physical/chemical characteristics by depth from selected boreholes as determined by laboratory analysis at Colorado School of Mines (August 1996).

\begin{tabular}{ccccc}
\hline Sample ID & $\begin{array}{c}\text { Depth } \\
\text { (ft bgs) }\end{array}$ & $\begin{array}{c}\text { Bulk Density } \\
\left(\mathrm{g} / \mathrm{cm}^{3}\right)\end{array}$ & $\begin{array}{c}\text { Water Content } \\
(\%)\end{array}$ & $\mathrm{pH}$ \\
\hline TAB8-05 & 5 & 2.722 & 18.46 & 4.31 \\
TAB8-07 & 7 & - & - & - \\
TAB8-09 & 9 & 2.372 & 20.56 & 4.71 \\
TAB8-11 & 11 & - & - & - \\
TAB8-13 & 13 & 1.958 & 21.1 & 5.51 \\
\hline TBB7-05 & 5 & 2.153 & 23.04 & 6.35 \\
TBB7-09 & 9 & 2.413 & 19.21 & 3.84 \\
TBB7-13 & 13 & 1.925 & 25.75 & 3.09 \\
\hline TBB8-05 & 5 & - & 22.32 & 4.75 \\
TBB8-07 & 7 & - & 33.12 & 7.24 \\
TBB8-09 & 9 & - & 37.11 & 5.715 \\
TBB8-13 & 13 & - & 20.95 & 4.945 \\
TBB8-17 & 17 & - & 18.53 & 3.765 \\
TCB8-05 & 5 & 2.782 & 18.44 & 4.39 \\
TCB8-07 & 7 & - & - & - \\
TCB8-09 & 9 & 2.58 & 17.61 & 3.56 \\
TCB8-11 & 11 & - & - & - \\
TCB8-13 & 13 & - & 20.34 & 5.65 \\
\hline TDB8-05 & 5 & 1.92 & 20.09 & 4.16 \\
TDB8-09 & 9 & 2.29 & 20.37 & 4.96 \\
TDB8-13 & 13 & 1.91 & 22.07 & 4.51 \\
TDB9-13 & 13 & - & 18.42 & 7.065 \\
\hline nOt measured & & & & \\
\hline & & & & \\
\hline
\end{tabular}


Table C.10. Selected metal content with depth as observed in water extracts made from soil samples collected from Test Cells A and B, field laboratory analysis

(August 1996).

\begin{tabular}{cccccc}
\hline Sample ID & $\begin{array}{c}\text { Depth } \\
(\mathrm{ft} \mathrm{bgs})\end{array}$ & $\begin{array}{c}\mathrm{K}^{+} \\
(\mathrm{mg} / \mathrm{kg})\end{array}$ & $\begin{array}{c}\text { Total Fe } \\
(\mathrm{mg} / \mathrm{kg})\end{array}$ & $\begin{array}{c}\mathrm{Mn} \\
(\mathrm{mg} / \mathrm{kg})\end{array}$ & $\begin{array}{c}\mathrm{MnO}_{4} \\
(\mathrm{mg} / \mathrm{kg})\end{array}$ \\
\hline TAB2-04 & 4 & 0.99 & 16.7 & 24 & $\mathrm{NA}$ \\
TAB2-09 & 9 & 0.93 & 1252 & 156 & $\mathrm{NA}$ \\
TAB2-13 & 13 & 1.01 & 1206 & 95 & $\mathrm{NA}$ \\
\hline TBB6-05 & 5 & 1.08 & 15.1 & 58 & $\mathrm{NA}$ \\
TBB6-09 & 9 & 1.06 & 150 & 57 & $\mathrm{NA}$ \\
TBB6-13 & 13 & 1.86 & 3.7 & 0 & $\mathrm{NA}$ \\
\hline
\end{tabular}

NA not analyzed

Table C.11. Selected metal content with depth as observed in water extracts made from soil samples collected from Test Cell C, field laboratory analysis.

\begin{tabular}{ccccc}
\hline Sample ID & $\begin{array}{c}\text { Depth } \\
(\mathrm{ft} \mathrm{bgs})\end{array}$ & $\begin{array}{c}\mathrm{K}^{+} \\
(\mathrm{mg} / \mathrm{kg})\end{array}$ & $\begin{array}{c}\text { Total Fe } \\
(\mathrm{mg} / \mathrm{kg})\end{array}$ & $\begin{array}{c}\mathrm{Mn} \\
(\mathrm{mg} / \mathrm{kg})\end{array}$ \\
\hline TCB2-01 & 1 & 3.31 & 51.3 & 8.1 \\
TCB2-05 & 5 & 0.72 & 7.4 & 50 \\
TCB2-09 & 9 & 0.57 & 55.3 & 42 \\
TCB2-11 & 11 & 1.24 & 4.5 & 1.66 \\
TCB2-13 & 13 & 0.80 & 6.2 & 1.07 \\
TCB2-15 & 15 & 0.72 & 5.6 & 4 \\
TCB2-17 & 17 & 0.69 & 7.3 & 5 \\
\hline TCB8-01 & 1 & 0.57 & 37.7 & 69 \\
TCB8-03 & 3 & 0.74 & 26.2 & 155 \\
TCB8-05 & 5 & 0.83 & 12.8 & 119 \\
TCB8-07 & 7 & 0.51 & 21.5 & 66 \\
TCB8-09 & 9 & 0.98 & 30.9 & 7 \\
TCB8-11 & 11 & 0.73 & 13.6 & 1 \\
TCB8-13 & 13 & 1.21 & 11.8 & 1.62 \\
TCB8-15 & 15 & 0.33 & 8.1 & 4 \\
TCB8-17 & 17 & 0.79 & 8.5 & 9 \\
\hline
\end{tabular}


Table C. 11 cont. Selected metal content with depth as observed in water extracts made from soil samples collected from Test Cell $\mathrm{C}$ field laboratory analysis.

\begin{tabular}{|c|c|c|c|c|}
\hline Sample ID & $\begin{array}{l}\text { Depth } \\
\text { (ft bgs) }\end{array}$ & $\begin{array}{c}\mathrm{K}^{+} \\
(\mathrm{mg} / \mathrm{kg})\end{array}$ & $\begin{array}{l}\text { Total Fe } \\
(\mathrm{mg} / \mathrm{kg})\end{array}$ & $\underset{(\mathrm{mg} / \mathrm{kg})}{\mathrm{Mn}}$ \\
\hline TCB9-01 & 1 & NA & 270 & NA \\
\hline TCB9-02 & 2 & NA & 267 & NA \\
\hline TCB9-03 & 3 & $\mathrm{NA}$ & 258 & $\mathrm{NA}$ \\
\hline ТСВ9-04 & 4 & NA & 279 & NA \\
\hline TCB9-05 & 5 & NA & 279 & NA \\
\hline TCB9-06 & 6 & NA & 270 & $\mathrm{NA}$ \\
\hline ТCВ9-07 & 7 & NA & 255 & NA \\
\hline TCB9-08 & 8 & NA & 270 & $\mathrm{NA}$ \\
\hline TCB9-09 & 9 & NA & 73.6 & $\mathrm{NA}$ \\
\hline TCB $9-10$ & 10 & 2.59 & NA & NA \\
\hline TCB9-11 & 11 & 2.09 & NA & $\mathrm{NA}$ \\
\hline TCB9-12 & 12 & 0.88 & NA & NA \\
\hline ТСВ9-13 & 13 & 2.31 & NA & NA \\
\hline TCB9-14 & 14 & 16.02 & NA & NA \\
\hline ТСВ9-15 & 15 & 1.35 & NA & NA \\
\hline TCB10-01 & 1 & 2.13 & 60.4 & 68 \\
\hline TCB $10-03$ & 3 & 1.01 & 51.4 & 106 \\
\hline TCB $10-05$ & 5 & 1.39 & 463 & 43 \\
\hline TCB $10-09$ & 9 & 0.74 & 60 & 15 \\
\hline TCB $10-11$ & 11 & 0.47 & 7 & 1 \\
\hline TCB $10-13$ & 13 & 0.44 & 23 & 3 \\
\hline TCB $10-15$ & 15 & 0.77 & 12 & 13 \\
\hline TCB11-01 & 1 & 2.70 & 62 & 0.99 \\
\hline TCB $11-03$ & 3 & 0.87 & 45 & 175 \\
\hline TCB 11-05 & 5 & 0.64 & 47 & 26 \\
\hline TCB11-07 & 7 & 0.69 & 88 & 38 \\
\hline TCB11-11 & 11 & 0.49 & 63 & 2 \\
\hline TCB11-13 & 13 & 0.48 & 31 & 3 \\
\hline TCB11-15 & 15 & 0.75 & 32 & 8 \\
\hline TCB $11-17$ & 17 & 0.86 & 27 & 3 \\
\hline TCB12-01 & 1 & 1.82 & 281 & 86 \\
\hline TCB12-05 & 5 & 0.80 & 17 & 92 \\
\hline TCB12-09 & 9 & 0.83 & 117 & 23 \\
\hline TCB12-11 & 11 & 0.65 & 92 & 2 \\
\hline TCB12-13 & 13 & 0.72 & 88 & 4 \\
\hline TCB $12-15$ & 15 & 0.74 & 42 & 1 \\
\hline TCB $12-17$ & 17 & 1.07 & 74 & 17 \\
\hline
\end{tabular}

C -13 
Table C.12. Selected metal content with depth as observed in water extracts made from soil samples collected from Test Cell D, field laboratory analysis.

\begin{tabular}{|c|c|c|c|c|c|}
\hline Sample ID & $\begin{array}{c}\text { Depth } \\
\text { (ft bgs) }\end{array}$ & $\begin{array}{c}\mathrm{K}^{+} \\
(\mathrm{mg} / \mathrm{kg})\end{array}$ & $\begin{array}{l}\text { Total Fe } \\
(\mathrm{mg} / \mathrm{kg})\end{array}$ & $\begin{array}{c}\mathrm{Mn} \\
(\mathrm{mg} / \mathrm{kg})\end{array}$ & $\begin{array}{c}\mathrm{MnO}_{4} \\
(\mathrm{mg} / \mathrm{kg})\end{array}$ \\
\hline TDB2-01 & 1 & 1.24 & 42.2 & 7 & $\overline{\mathrm{NA}}$ \\
\hline TDB2-03 & 3 & 0.99 & 306 & 185 & NA \\
\hline TDB2-05 & 5 & 0.49 & 20.5 & NA & NA \\
\hline TDB2-07 & 7 & 0.65 & 56.4 & NA & $\mathrm{NA}$ \\
\hline TDB2-09 & 9 & 1.33 & 1.3 & NA & NA \\
\hline TDB2-11 & 11 & 0.90 & 0.7 & NA & $\mathrm{NA}$ \\
\hline TDB2-13 & 13 & 0.81 & 1 & NA & NA \\
\hline TDB2-15 & 15 & 1.04 & 2.1 & 12 & NA \\
\hline TDB2-17 & 17 & 0.90 & 1.1 & 14 & NA \\
\hline TDB8-01 & 1 & 1.68 & 16.4 & 64 & $\overline{\mathrm{NA}}$ \\
\hline TDB8-03 & 3 & 0.45 & 2.6 & 218 & $\mathrm{NA}$ \\
\hline TDB8-05 & 5 & 0.56 & 23.2 & 170 & NA \\
\hline TDB8-07 & 7 & 0.88 & 2.6 & 16 & $\mathrm{NA}$ \\
\hline TDB8-11 & 11 & 0.70 & 1.6 & 8 & NA \\
\hline TDB8-13 & 13 & 0.49 & 1.1 & 8 & NA \\
\hline TDB8-15 & 15 & 0.22 & 1.1 & 12 & NA \\
\hline TDB8-17 & 17 & 0.23 & 0.9 & 15 & $\mathrm{NA}$ \\
\hline TDB9-01 & 1 & $\overline{\mathrm{NA}}$ & $\overline{\mathrm{NA}}$ & $\overline{\mathrm{NA}}$ & $\overline{\mathrm{NA}}$ \\
\hline TDB9-05 & 5 & $\mathrm{NA}$ & $\mathrm{NA}$ & $\mathrm{NA}$ & $\mathrm{NA}$ \\
\hline TDB9-07 & 7 & NA & $\mathrm{NA}$ & $\mathrm{NA}$ & 1 \\
\hline TDB9-09 & 9 & $\mathrm{NA}$ & $\mathrm{NA}$ & $\mathrm{NA}$ & 1720 \\
\hline TDB9-11 & 11 & NA & $\mathrm{NA}$ & NA & 1600 \\
\hline TDB9-13 & 13 & NA & $\mathrm{NA}$ & $\mathrm{NA}$ & NA \\
\hline TDB9-15 & 15 & NA & NA & $\mathrm{NA}$ & 5 \\
\hline TDB9-17 & 17 & NA & NA & NA & 0.4 \\
\hline TDB11-01 & 1 & $\overline{\mathrm{NA}}$ & 20 & 76 & $\overline{N A}$ \\
\hline TDB 11-03 & 3 & 1.39 & 1380 & 275 & $\mathrm{NA}$ \\
\hline TDB $11-05$ & 5 & NA & 1480 & 147 & NA \\
\hline TDB11-07 & 7 & 0.80 & 28 & 36 & NA \\
\hline TDB11-11 & 11 & 0.60 & 24 & 3 & $\mathrm{NA}$ \\
\hline TDB $11-13$ & 13 & $\mathrm{NA}$ & 14 & 6 & $\mathrm{NA}$ \\
\hline TDB11-15 & 15 & 0.87 & 14 & 7 & $\mathrm{NA}$ \\
\hline TDB $11-17$ & 17 & NA & $\mathrm{NA}$ & NA & NA \\
\hline
\end{tabular}

NA not analyzed 
Table C. 12 cont. Selected metal content with depth as observed in water extracts made from soil samples collected from Test Cell D, field laboratory analysis.

\begin{tabular}{cccccc}
\hline Sample ID & $\begin{array}{c}\text { Depth } \\
\text { (ft bgs) }\end{array}$ & $\begin{array}{c}\mathrm{K}^{+} \\
(\mathrm{mg} / \mathrm{kg})\end{array}$ & $\begin{array}{c}\text { Total Fe } \\
(\mathrm{mg} / \mathrm{kg})\end{array}$ & $\begin{array}{c}\mathrm{Mn} \\
(\mathrm{mg} / \mathrm{kg})\end{array}$ & $\begin{array}{c}\mathrm{MnO}_{4} \\
(\mathrm{mg} / \mathrm{kg})\end{array}$ \\
\hline TDB12-01 & 1 & NA & NA & NA & NA \\
TDB12-03 & 3 & NA & NA & NA & 2 \\
TDB12-05 & 5 & NA & NA & NA & NA \\
TDB12-07 & 7 & 0.82 & NA & NA & NA \\
TDB12-11 & 11 & 0.65 & NA & NA & NA \\
TDB12-13 & 13 & 0.60 & NA & NA & NA \\
TDB12-15 & 15 & 0.72 & NA & NA & 172 \\
TDB12-17 & 17 & 0.66 & NA & NA & 16 \\
\hline TDB13-01 & 1 & 1.18 & NA & NA & NA \\
TDB13-03 & 3 & 0.72 & 52 & 159 & NA \\
TDB13-05 & 5 & 1.14 & 3030 & 20.3 & NA \\
TDB13-07 & 7 & 0.67 & 74 & 30 & NA \\
TDB13-11 & 11 & 0.56 & 12 & 5 & NA \\
TDB13-13 & 13 & 0.83 & 24 & 5 & NA \\
TDB13-15 & 15 & 1.39 & 20 & 3 & NA \\
TDB13-17 & 17 & 1.27 & 22 & 3 & 8 \\
\hline NA & & & &
\end{tabular}

NA not analyzed 
Table C.13. Metal content in soil with depth from selected boreholes, PORTS laboratory analysis (September 1996).

\begin{tabular}{|c|c|c|c|c|c|c|c|c|c|c|}
\hline Location & Depth & $\begin{array}{c}\mathrm{Cl}^{-} \\
(\mathrm{mg} / \mathrm{kg})\end{array}$ & $\begin{array}{c}\mathrm{NO}_{3} \\
(\mathrm{mg} / \mathrm{kg})\end{array}$ & $\begin{array}{c}\mathrm{SO}_{4} \\
(\mathrm{mg} / \mathrm{kg})\end{array}$ & $\begin{array}{c}\mathrm{Ca} \\
(\mathrm{mg} / \mathrm{kg})\end{array}$ & $\begin{array}{c}\mathrm{Fe} \\
(\mathrm{mg} / \mathrm{kg})\end{array}$ & $\begin{array}{c}\mathrm{Mg} \\
(\mathrm{mg} / \mathrm{kg})\end{array}$ & $\begin{array}{c}\mathrm{Mn} \\
(\mathrm{mg} / \mathrm{kg})\end{array}$ & $\begin{array}{c}\bar{K} \\
(\mathrm{mg} / \mathrm{kg})\end{array}$ & $\begin{array}{c}\text { TOC } \\
(\mathrm{mg} / \mathrm{kg})\end{array}$ \\
\hline TAB2-02 & $\overline{2}$ & 121 & 456 & $<300$ & $\overline{1230 \mathrm{~B}}$ & $17800 \mathrm{~J}$ & $1800 \mathrm{~B}$ & $239 B$ & $833 \mathrm{~B}$ & 3300 \\
\hline TAB2-04 & 4 & 65 & 247 & $<300$ & $1530 \mathrm{~B}$ & $21500 \mathrm{~J}$ & 2790B & 385 & 1080B & 630 \\
\hline TAB2-13 & 13 & 109 & $<200$ & $<300$ & $532 B$ & $20100 \mathrm{~J}$ & 1380B & 137B & 492B & 1800 \\
\hline TAB6-06 & 6 & 62.4 & 333 & 394 & $867 \mathrm{~B}$ & 13500 & $846 B$ & 1910 & 411B & 1500 \\
\hline TAB6-09 & 9 & $<60$ & 296 & $<300$ & $1340 \mathrm{~B}$ & 21600 & $1660 \mathrm{~B}$ & 205B & $466 \mathrm{~B}$ & 960 \\
\hline TAB6-13 & 13 & $<60$ & $<200$ & $<300$ & $1130 \mathrm{~B}$ & 14200 & $1280 \mathrm{~B}$ & 897 & 557B & 5100 \\
\hline TAB8-05 & 5 & 74.8 & $<200$ & $<300$ & $1910 \mathrm{~B}$ & $23100 \mathrm{~J}$ & $2740 \mathrm{~B}$ & 424 & $805 B$ & 970 \\
\hline TAB8-09 & 9 & 113 & $<200$ & $<300$ & $831 \mathrm{~B}$ & 23000 & $1530 \mathrm{~B}$ & $166 \mathrm{~B}$ & $576 \mathrm{~B}$ & 6000 \\
\hline TAB8-13 & 13 & 68.1 & $<200$ & 370 & 439B & $12500 \mathrm{~J}$ & 994B & $48.4 \mathrm{BN}$ & $341 B$ & 8200 \\
\hline TBB2-05 & 5 & 188 & 1380 & 558 & $1990 \mathrm{~B}$ & 27200 & $3400 \mathrm{~B}$ & 823 & $1000 \mathrm{~B}$ & 390 \\
\hline TBB2-09 & 9 & 80.6 & 377 & 455 & $373 B$ & 15700 & $1460 B$ & 119B & $722 \mathrm{~B}$ & 4500 \\
\hline TBB2-13 & 13 & 62.5 & $<200$ & $<300$ & $516 \mathrm{~B}$ & 15700 & $1390 \mathrm{~B}$ & $38 \mathrm{~B}$ & $660 \mathrm{~B}$ & 600 \\
\hline TBB6-06 & 6 & $<60$ & 696 & $<300$ & $1830 \mathrm{~B}$ & 27900 & 4210 & 496 & $2070 \mathrm{BN}$ & 1100 \\
\hline TBB6-09 & 9 & $<60$ & $<200$ & $<300$ & $845 B$ & 22100 & 1370B & 197B & 633BN & 630 \\
\hline TBB6-13 & 13 & 78.3 & 350 & $<300$ & $368 \mathrm{~B}$ & 12600 & $840 B$ & $27.8 B$ & $501 B N$ & 380 \\
\hline TBB6-17 & 17 & 67.9 & 245 & $<300$ & 261B & 26700 & 489B & $303 B$ & $559 \mathrm{BN}$ & $<300$ \\
\hline TBB7-05 & 5 & 203 & 299 & $<300$ & $707 \mathrm{~B}$ & $11000 \mathrm{~J}$ & $878 B$ & 194B & $286 \mathrm{BN}$ & 1000 \\
\hline TBB7-09 & 9 & 90.8 & 368 & 397 & 6788 & $14600 \mathrm{~J}$ & 1020B & $96.2 \mathrm{~B}$ & $426 \mathrm{BN}$ & 7600 \\
\hline TBB7-13 & 13 & 64.4 & 210 & 318 & $301 \mathrm{~B}$ & $10100 \mathrm{~J}$ & $615 B$ & $23.4 \mathrm{~B}$ & 283BN & 390 \\
\hline TCB2-05 & 5 & 157 & 227 & 595 & $876 \mathrm{~B}$ & 24200 & $2190 \mathrm{~B}$ & $332 B$ & $707 \mathrm{BN}$ & 1200 \\
\hline TCB2-09 & 9 & 86.6 & 289 & 482 & $538 B$ & 33300 & 1360B & $252 B$ & $703 \mathrm{BN}$ & 950 \\
\hline TCB2-13 & 13 & 86.4 & $<200$ & $<300$ & $262 B$ & 22000 & 667B & 447 & $593 \mathrm{BN}$ & 330 \\
\hline TCB6-06 & 6 & 78 & $<200$ & $<300$ & $1300 \mathrm{~B}$ & $18800 \mathrm{~J}$ & $2070 \mathrm{~B}$ & $122 B$ & 470BN & 350 \\
\hline TCB6-11 & 11 & 110 & 200 & $<300$ & $389 B$ & $27300 \mathrm{~J}$ & $1020 \mathrm{~B}$ & $8309 B$ & $517 \mathrm{~B}$ & 700 \\
\hline TCB6-13 & 13 & $<60$ & $<200$ & $<300$ & $2280 \mathrm{~B}$ & $16400 \mathrm{~J}$ & 1440B & $160 \mathrm{~B}$ & $513 B$ & $<300$ \\
\hline TCB8-13 & 13 & 66.4 & $<200$ & $<300$ & $331 \mathrm{~B}$ & $17600 \mathrm{~J}$ & $719 \mathrm{~B}$ & $206 B$ & 549BN & $<300$ \\
\hline TDB2-05 & 5 & $<60$ & 249 & $<300$ & $382 \mathrm{~B}$ & 24800 & $730 \mathrm{~B}$ & $196 \mathrm{~B}$ & $502 B$ & 680 \\
\hline TDB2-09 & 9 & 87.7 & 324 & $<300$ & 544B & 29400 & $1200 \mathrm{~B}$ & $121 B$ & 787B & 590 \\
\hline TDB2-13 & 13 & $<60$ & $<200$ & $<300$ & 281B & 14600 & $582 \mathrm{~B}$ & $149 B$ & $528 B$ & $<300$ \\
\hline TDB6-05 & 5 & 74.1 & 249 & $<300$ & 349B & 16000 & $745 B$ & $133 B$ & $496 \mathrm{~B}$ & 930 \\
\hline TDB6-09 & 9 & $<60$ & $<200$ & $<300$ & 461B & 25200 & $961 \mathrm{~B}$ & $109 B$ & $483 B$ & 470 \\
\hline TDB6-13 & 13 & $<60$ & $<200$ & $<300$ & $335 B$ & 19400 & $625 B$ & 167B & $524 \mathrm{~B}$ & $<300$ \\
\hline TDB8-05 & 5 & $<60$ & $<200$ & $<300$ & $1390 \mathrm{~B}$ & 20400 & $2410 \mathrm{~B}$ & 455 & 1090BN & 960 \\
\hline TDB8-09 & 9 & $<60$ & $<200$ & $<300$ & $1030 \mathrm{~B}$ & 37000 & $1660 \mathrm{~B}$ & $60.3 B$ & $685 \mathrm{BN}$ & 540 \\
\hline TDB8-13 & 13 & 71.5 & $<200$ & $<300$ & 359B & 19100 & $646 B$ & 553 & $471 B N$ & $<300$ \\
\hline
\end{tabular}

$\mathrm{B}$ Reported value was obtained from a reading that was less than the Contract Required Detection Limit but greater than or equal to the Instrument Detection Limit.

$\mathrm{N}$ Spike sample recovery is not within control limits. 
Table C.14. Radiological content in soil with depth from selected boreholes, PORTS laboratory analysis (December 1997).

\begin{tabular}{lcccccc}
\hline Location & Depth & $\begin{array}{c}\text { Gross alpha } \\
(\mathrm{pCi} / \mathrm{g})\end{array}$ & $\begin{array}{c}\text { Gross beta } \\
(\mathrm{pCi} / \mathrm{g})\end{array}$ & $\begin{array}{c}\text { Technetium } \\
(\mathrm{pCi} / \mathrm{g})\end{array}$ & $\begin{array}{c}\text { Total U } \\
(\mu \mathrm{g} / \mathrm{g})\end{array}$ & $\begin{array}{c}\text { U 235 } \\
\%\end{array}$ \\
\hline TCB14-03 & 3 & $<4$ & 9 & 2.2 & 3.4 & 0.98 \\
TCB14-13 & 13 & 4 & $<8$ & $<0.2$ & 4.1 & 0.96 \\
\hline TCB15-0 & 0 & 5 & 19 & 17.5 & 4.8 & 1.9 \\
TCB15-0d & 0 & 14 & 21 & 7.1 & 0.79 & 13 \\
\hline
\end{tabular}

Table C.15. Microbiological characteristics with depth within the test cells shortly after fracture installation (August 1996).

\begin{tabular}{ccccc}
\hline Sample ID & $\begin{array}{c}\text { Media } \\
\text { type }\end{array}$ & $\begin{array}{c}\text { Depth } \\
\text { (ft) }\end{array}$ & $\begin{array}{c}\text { Total heterotrophs } \\
\text { (org./g) }\end{array}$ & $\begin{array}{c}\text { Iron reducers } \\
\text { (org./g) }\end{array}$ \\
\hline TAB6-05 & Soil & $4-5$ & $100-1000$ & NA \\
TAB6-13 & Soil & $12-13$ & $100-1000$ & NA \\
TAB6-17 & Soil & $16-17$ & $100-1000$ & NA \\
\hline TCB2-05 & Soil & $4-5$ & $1000-10000^{*}$ & NG \\
TCB2-09 & Soil & $8-9$ & $100-1000$ & $1-10$ \\
TCB6-05 & Soil & $4-5$ & $10-100$ & $1-10$ \\
TCB6-09 & Soil & $8-9$ & $100-1000$ & NG \\
TCB6-13 & Soil & $12-13$ & $100-1000$ & NG \\
\hline TDB2-05 & Soil & $4-5$ & $1000-10000^{*}$ & NA \\
TDB2-09 & Soil & $8-9$ & $1000-10000^{*}$ & NA \\
TDB2-13 & Soil & $12-13$ & $100-1000$ & NA \\
\hline
\end{tabular}

NA not analyzed

NG no growth at lowest dilution

* $\quad$ growth observed at highest dilution, so actual value could be higher than that shown 
Table C.16. VOC concentrations in soil with depth within Test Cell A shortly after fracture installation (August 1996).

\begin{tabular}{|c|c|c|c|c|c|c|}
\hline Sample ID & $\begin{array}{c}\text { Depth } \\
\text { (ft bgs) }\end{array}$ & $\begin{array}{l}\text { 1,1-DCE } \\
(\mu \mathrm{g} / \mathrm{kg}) \\
\end{array}$ & $\begin{array}{c}1,1,1-\mathrm{TCA} \\
(\mu \mathrm{g} / \mathrm{kg})\end{array}$ & $\begin{array}{c}\text { TCE } \\
(\mu \mathrm{g} / \mathrm{kg}) \\
\end{array}$ & $\begin{array}{c}\mathrm{PCE} \\
(\mu \mathrm{g} / \mathrm{kg}) \\
\end{array}$ & $\begin{array}{c}\text { Total VOCs } \\
(\mu \mathrm{g} / \mathrm{kg})\end{array}$ \\
\hline ТАВ $1-01$ & 1 & & & 18 & & 18 \\
\hline TAB1-02 & 2 & & & 19 & & 19 \\
\hline TAB1-03 & 3 & & & 16 & & 16 \\
\hline TAB1-04 & 4 & & & 17 & & 17 \\
\hline TAB1-05 & 5 & & & 9 & & 9 \\
\hline TAB1-06 & 6 & & & 10 & & 10 \\
\hline TAB1-07 & 7 & & & 8 & & 8 \\
\hline TAB 1-08 & 8 & & & 6 & & 6 \\
\hline TAB1-09 & 9 & & & 6 & & 6 \\
\hline TAB1-10 & 12 & & & 8 & & 8 \\
\hline TAB1-11 & 11 & & & 9 & & 9 \\
\hline TAB $1-12$ & 12 & & & 8 & & 8 \\
\hline TAB $1-13$ & 13 & & & 10 & & 10 \\
\hline TAB1-14 & 14 & & & & & \\
\hline TAB1-15 & 15 & & & 14 & & 14 \\
\hline TAB1-16 & 16 & & & 8 & & 8 \\
\hline TAB $1-17$ & 17 & & & 6 & & 6 \\
\hline TAB2-01 & 1 & & & 26 & & 26 \\
\hline TAB2-02 & 2 & & & 13 & & 13 \\
\hline TAB2-03 & 3 & & & 10 & & 10 \\
\hline TAB2-04 & 4 & & & 10 & & 10 \\
\hline TAB2-05 & 5 & & & 11 & & 11 \\
\hline TAB2-08 & 8 & & & 11 & & 11 \\
\hline TAB2-09 & 9 & & & 11 & & 11 \\
\hline TAB2-10 & 10 & & & 9 & & 9 \\
\hline TAB2-11 & 11 & & & 9 & & 9 \\
\hline TAB2-12 & 12 & & & 7 & & 7 \\
\hline TAB2-13 & 13 & & & 8 & & 8 \\
\hline TAB2-14 & 14 & & & 13 & & 13 \\
\hline TAB2-15 & 15 & & & 12 & & 12 \\
\hline TAB2-16 & 16 & & & 9 & & 9 \\
\hline TAB2-17 & 17 & & & 10 & & 10 \\
\hline
\end{tabular}

Blank indicates non-detect. 
Table C. 16 cont. VOC concentrations in soil with depth within Test Cell A shortly after fracture installation (August 1996).

\begin{tabular}{|c|c|c|c|c|c|c|}
\hline Sample ID & $\begin{array}{c}\text { Depth } \\
\text { (ft bgs) }\end{array}$ & $\begin{array}{c}1,1-\mathrm{DCE} \\
(\mu \mathrm{g} / \mathrm{kg})\end{array}$ & $\begin{array}{c}1,1,1-\mathrm{TCA} \\
(\mu \mathrm{g} / \mathrm{kg})\end{array}$ & $\begin{array}{c}\text { TCE } \\
(\mu \mathrm{g} / \mathrm{kg})\end{array}$ & $\begin{array}{c}\mathrm{PCE} \\
(\mu \mathrm{g} / \mathrm{kg})\end{array}$ & $\begin{array}{c}\text { Total VoCs } \\
(\mu \mathrm{g} / \mathrm{kg})\end{array}$ \\
\hline TAB3-01 & 1 & & & & & \\
\hline TAB3-02 & 2 & & & & & \\
\hline TAB3-03 & 3 & & & 39 & & 39 \\
\hline TAB3-04 & 4 & & & 9 & & 9 \\
\hline TAB3-05 & 5 & & & 11 & & 11 \\
\hline TAB3-06 & 6 & & & 9 & & 9 \\
\hline TAB3-07 & 7 & & & 12 & & 12 \\
\hline TAB3-08 & 8 & & & 12 & & 12 \\
\hline TAB3-09 & 9 & & & 105 & & 105 \\
\hline TAB3-10 & 10 & & & 11 & & 11 \\
\hline TAB3-11 & 11 & & & 9 & & 9 \\
\hline TAB3-12 & 12 & & & 7 & & 7 \\
\hline TAB3-13 & 13 & & & 9 & & 9 \\
\hline TAB3-14 & 14 & & & & & \\
\hline TAB3-15 & 15 & & & & & \\
\hline TAB3-16 & 16 & & & & & \\
\hline TAB3-17 & 17 & & & & & \\
\hline TAB4-01 & 1 & & & & & \\
\hline TAB4-02 & 2 & & & 8 & & 8 \\
\hline TAB4-03 & 3 & & & 7 & & 7 \\
\hline TAB4-04 & 4 & & & 4 & & 4 \\
\hline TAB4-05 & 5 & & & 5 & & 5 \\
\hline TAB4-06 & 6 & & & & & \\
\hline TAB4-07 & 7 & & & 7 & & 7 \\
\hline TAB4-08 & 8 & & & 8 & & 8 \\
\hline TAB4-09 & 9 & & & & & \\
\hline TAB4-10 & 10 & & & 5 & & 5 \\
\hline TAB4-11 & 11 & & & & & \\
\hline TAB4-12 & 12 & & & & & \\
\hline TAB4-13 & 13 & & & & & \\
\hline TAB4-14 & 14 & & & & & \\
\hline TAB4-15 & 15 & & & & & \\
\hline TAB4-16 & 16 & & & & & \\
\hline TAB4-17 & 17 & & & & & \\
\hline
\end{tabular}

C -19 
Table C. 16 cont. VOC concentrations in soil with depth within Test Cell A shortly after fracture installation (August 1996).

\begin{tabular}{|c|c|c|c|c|c|c|}
\hline Sample ID & $\begin{array}{c}\text { Depth } \\
\text { (ft bgs) }\end{array}$ & $\begin{array}{l}\text { 1,1-DCE } \\
(\mu \mathrm{g} / \mathrm{kg})\end{array}$ & $\begin{array}{c}1,1,1-\mathrm{TCA} \\
(\mu \mathrm{g} / \mathrm{kg})\end{array}$ & $\begin{array}{c}\text { TCE } \\
(\mu \mathrm{g} / \mathrm{kg})\end{array}$ & $\begin{array}{c}\text { PCE } \\
(\mu \mathrm{g} / \mathrm{kg})\end{array}$ & $\begin{array}{c}\text { Total VOCs } \\
(\mu \mathrm{g} / \mathrm{kg})\end{array}$ \\
\hline TAB5-01 & 1 & & & 9 & & 9 \\
\hline TAB5-02 & 2 & & & & & \\
\hline TAB5-03 & 3 & & & & & \\
\hline TAB5-04 & 4 & & & 9 & & 9 \\
\hline TAB5-05 & 5 & & & 6 & & 6 \\
\hline TAB5-06 & 6 & & & & & \\
\hline TAB5-07 & 7 & & & 7 & & 7 \\
\hline TAB5-08 & 8 & & & & & \\
\hline TAB5-09 & 9 & & & 5 & & 5 \\
\hline TAB5-10 & 10 & & & & & \\
\hline TAB5-11 & 11 & & & & & \\
\hline TAB5-12 & 12 & & & & & \\
\hline TAB5-13 & 13 & & & & & \\
\hline TAB5-14 & 14 & & & & & \\
\hline TAB5-15 & 15 & & & & & \\
\hline TAB5-16 & 16 & & & & & \\
\hline TAB5-17 & 17 & & & & & \\
\hline TAB6-01 & 1 & 6 & & 143 & & 149 \\
\hline TAB6-02 & 2 & & & & & \\
\hline TAB6-03 & 3 & & & 186 & & 186 \\
\hline TAB6-04 & 4 & & & 426 & & 426 \\
\hline TAB6-05 & 5 & & 12 & 3,039 & & 3051 \\
\hline TAB6-06 & 6 & & 29 & 7,648 & & 7677 \\
\hline TAB6-07 & 7 & & 43 & 11,240 & & 11283 \\
\hline TAB6-08 & 8 & & 37 & 12,145 & & 12182 \\
\hline TAB6-09 & 9 & & 55 & 15,664 & & 15719 \\
\hline TAB6-12 & 12 & & & 4,059 & & 4059 \\
\hline TAB6-13 & 13 & & & 425 & & 425 \\
\hline TAB6-14 & 14 & & & 82 & & 82 \\
\hline TAB6-15 & 15 & & & 97 & & 97 \\
\hline TAB6-16 & 16 & & & 8 & & 8 \\
\hline TAB6-17 & 17 & & & 9 & & 9 \\
\hline
\end{tabular}

Blank indicates non-detect. 
Table C. 16 cont. VOC concentrations in soil with depth within Test Cell A shortly after fracture installation (August 1996).

\begin{tabular}{|c|c|c|c|c|c|c|}
\hline Sample ID & $\begin{array}{c}\text { Depth } \\
\text { (ft bgs) }\end{array}$ & $\begin{array}{c}\text { 1,1-DCE } \\
(\mu \mathrm{g} / \mathrm{kg})\end{array}$ & $\begin{array}{c}1,1,1-\mathrm{TCA} \\
(\mu \mathrm{g} / \mathrm{kg})\end{array}$ & $\begin{array}{c}\text { TCE } \\
(\mu \mathrm{g} / \mathrm{kg})\end{array}$ & $\begin{array}{c}\mathrm{PCE} \\
(\mu \mathrm{g} / \mathrm{kg})\end{array}$ & $\begin{array}{c}\text { Total VOCs } \\
(\mu \mathrm{g} / \mathrm{kg})\end{array}$ \\
\hline ТAB7-01 & 1 & & & 63 & & 63 \\
\hline TAB7-02 & 2 & & & & & \\
\hline TAB7-03 & 3 & & & 10 & & 10 \\
\hline TAB7-04 & 4 & & & & & \\
\hline TAB7-05 & 5 & & & & & \\
\hline TAB7-06 & 6 & & & 5 & & 5 \\
\hline TAB7-07 & 7 & & & 19 & & 19 \\
\hline TAB7-08 & 8 & & & 13 & & 13 \\
\hline TAB7-09 & 9 & & & & & \\
\hline TAB7-10 & 10 & & & & & \\
\hline TAB7-11 & 11 & & & & & \\
\hline TAB7-12 & 12 & & & & & \\
\hline TAB7-13 & 13 & & & & & \\
\hline TAB7-14 & 14 & & & & & \\
\hline TAB7-15 & 15 & & & & & \\
\hline TAB7-16 & 16 & & & & & \\
\hline TAB7-17 & 17 & & & 23 & & 23 \\
\hline TAB8-01 & 1 & & & 16 & & 16 \\
\hline TAB8-02 & 2 & & & & & \\
\hline TAB8-03 & 3 & & & & & \\
\hline TAB8-04 & 4 & & & & & \\
\hline TAB8-05 & 5 & & & 5 & & 5 \\
\hline TAB8-06 & 6 & & & 5 & & 5 \\
\hline TAB8-07 & 7 & & & 13 & & 13 \\
\hline TAB8-08 & 8 & & & 11 & & 11 \\
\hline TAB8-09 & 9 & & & 10 & & 10 \\
\hline TAB8-10 & 10 & & & 8 & & 8 \\
\hline TAB8-11 & 11 & & & 53 & & 53 \\
\hline TAB8-12 & 12 & & & & & \\
\hline TAB8-13 & 13 & & & & & \\
\hline TAB8-14 & 14 & & & & & \\
\hline TAB8-15 & 15 & & & & & \\
\hline TAB8-16 & 16 & & & & & \\
\hline TAB8-17 & 17 & & & & & \\
\hline
\end{tabular}

C -21 
Table C.17. VOC concentrations in soil with depth within Test Cell B shortly after fracture installation (August 1996).

\begin{tabular}{|c|c|c|c|c|c|c|}
\hline Sample ID & $\begin{array}{l}\text { Depth } \\
\text { (ft bgs) }\end{array}$ & $\begin{array}{c}\text { 1,1-DCE } \\
(\mu \mathrm{g} / \mathrm{kg})\end{array}$ & $\begin{array}{c}1,1,1-\mathrm{TCA} \\
(\mu \mathrm{g} / \mathrm{kg})\end{array}$ & $\begin{array}{c}\text { TCE } \\
(\mu \mathrm{g} / \mathrm{kg})\end{array}$ & $\begin{array}{c}\mathrm{PCE} \\
(\mu \mathrm{g} / \mathrm{kg})\end{array}$ & $\begin{array}{c}\text { Total VOCs } \\
(\mu \mathrm{g} / \mathrm{kg})\end{array}$ \\
\hline TBB1-01 & 1 & & & 12 & & 12 \\
\hline TBB1-02 & 2 & & & 8 & & 8 \\
\hline TBB1-03 & 3 & & & 27 & & 27 \\
\hline TBB1-04 & 4 & & & 61 & & 61 \\
\hline TBB1-05 & 5 & & & 99 & & 99 \\
\hline TBB1-06 & 6 & & & 352 & & 352 \\
\hline TBB1-07 & 7 & & & 624 & & 624 \\
\hline TBB1-08 & 8 & & & 1519 & & 1519 \\
\hline TBB1-09 & 9 & & & 3135 & & 3135 \\
\hline TBB1-10 & 10 & & & 920 & & 920 \\
\hline TBB1-11 & 11 & & & 606 & & 606 \\
\hline TBB1-12 & 12 & & & 120 & & 120 \\
\hline TBB1-13 & 13 & & & 44 & & 44 \\
\hline TBB1-14 & 14 & & & 872 & & 872 \\
\hline TBB1-15 & 15 & & & 10 & & 10 \\
\hline TBB1-16 & 16 & & & 7 & & 7 \\
\hline TBB1-17 & 17 & & & 7 & & 7 \\
\hline TBB2-01 & 1 & & & 8 & & 8 \\
\hline TBB2-02 & 2 & & & 21 & & 21 \\
\hline TBB2-03 & 3 & & & 7 & & 7 \\
\hline TBB2-04 & 4 & & & 7 & & 7 \\
\hline TBB2-05 & 5 & & & & & \\
\hline TBB2-06 & 6 & & & 5 & & 5 \\
\hline TBB2-07 & 7 & & & 9 & & 9 \\
\hline TBB2-08 & 8 & & & 15 & & 15 \\
\hline TBB2-09 & 9 & & & 8 & & 8 \\
\hline TBB2-10 & 10 & & & 10 & & 10 \\
\hline TBB2-11 & 11 & & & & & \\
\hline TBB2-12 & 12 & & & & & \\
\hline TBB2-13 & 13 & & & 7 & & 7 \\
\hline TBB2-14 & 14 & & 3 & 5 & & 8 \\
\hline TBB2-15 & 15 & & 5 & 10 & & 1015 \\
\hline TBB2-16 & 16 & & & & & \\
\hline TBB2-17 & 17 & & 3 & 5 & & 58 \\
\hline
\end{tabular}

Blank indicates non-detect. 
Table C. 17 cont. VOC concentrations in soil with depth within Test Cell B shortly after fracture installation (August 1996).

\begin{tabular}{|c|c|c|c|c|c|c|}
\hline Sample ID & $\begin{array}{c}\text { Depth } \\
\text { (ft bgs) }\end{array}$ & $\begin{array}{c}\text { 1,1-DCE } \\
(\mu \mathrm{g} / \mathrm{kg})\end{array}$ & $\begin{array}{c}1,1,1-\mathrm{TCA} \\
(\mu \mathrm{g} / \mathrm{kg})\end{array}$ & $\begin{array}{c}\text { TCE } \\
(\mu \mathrm{g} / \mathrm{kg})\end{array}$ & $\begin{array}{c}\text { PCE } \\
(\mu \mathrm{g} / \mathrm{kg})\end{array}$ & $\begin{array}{c}\text { Total VOCs } \\
(\mu \mathrm{g} / \mathrm{kg})\end{array}$ \\
\hline TBB3-01 & 1 & & & 5 & & 5 \\
\hline TBB3-02 & 2 & & & & & \\
\hline TBB3-03 & 3 & & & 11 & & 11 \\
\hline TBB3-04 & 4 & & & 11 & & 11 \\
\hline TBB3-05 & 5 & & & 13 & & 13 \\
\hline TBB3-06 & 6 & & & 40 & & 40 \\
\hline TBB3-07 & 7 & & & 180 & & 180 \\
\hline TBB3-08 & 8 & & & 331 & & 331 \\
\hline TBB3-09 & 9 & & & 310 & & 310 \\
\hline TBB3-10 & 10 & & & 122 & & 122 \\
\hline TBB3-11 & 11 & & & 32 & & 32 \\
\hline TBB3-12 & 12 & & & 9 & & 9 \\
\hline TBB3-13 & 13 & & & 23 & & 23 \\
\hline TBB3-14 & 14 & & & 22 & & 22 \\
\hline TBB3-15 & 15 & & & 24 & & 24 \\
\hline TBB3-16 & 16 & & & 300 & & 300 \\
\hline TBB3-17 & 17 & & & 10 & & 10 \\
\hline TBB4-01 & 1 & & & 104 & & 104 \\
\hline TBB4-02 & 2 & & & 29 & & 29 \\
\hline TBB4-03 & 3 & & & 65 & & 65 \\
\hline TBB4-04 & 4 & & & 69 & & 69 \\
\hline TBB4-05 & 5 & & & 186 & & 186 \\
\hline TBB4-06 & 6 & & & 912 & & 912 \\
\hline TBB4-07 & 7 & & & 1166 & & 1166 \\
\hline TBB4-08 & 8 & & & 2573 & & 2573 \\
\hline TBB4-09 & 9 & & & 2106 & & 2106 \\
\hline TBB4-10 & 10 & & & 1675 & & 1675 \\
\hline TBB4-11 & 11 & & & 68 & & 68 \\
\hline TBB4-12 & 12 & & & 31 & & 31 \\
\hline TBB4-13 & 13 & & & 7 & & 7 \\
\hline TBB4-14 & 14 & & & & & \\
\hline TBB4-15 & 15 & & & 5 & & 5 \\
\hline TBB4-16 & 16 & & & 12 & & 12 \\
\hline TBB4-17 & 17 & & & 16 & & 16 \\
\hline
\end{tabular}

Blank indicates non-detect. 
Table C.17 cont. VOC concentrations in soil with depth within Test Cell B shortly after fracture installation (August 1996).

\begin{tabular}{|c|c|c|c|c|c|c|}
\hline Sample ID & $\begin{array}{r}\text { Depth } \\
\text { (ft bgs) }\end{array}$ & $\begin{array}{c}1,1-\mathrm{DCE} \\
(\mu \mathrm{g} / \mathrm{kg})\end{array}$ & $\begin{array}{c}1,1,1-\mathrm{TCA} \\
(\mu \mathrm{g} / \mathrm{kg})\end{array}$ & $\begin{array}{c}\text { TCE } \\
(\mu \mathrm{g} / \mathrm{kg})\end{array}$ & $\begin{array}{c}\mathrm{PCE} \\
(\mu \mathrm{g} / \mathrm{kg})\end{array}$ & $\begin{array}{c}\text { Total VOCs } \\
(\mu \mathrm{g} / \mathrm{kg})\end{array}$ \\
\hline TBB5-01 & 1 & & & 51 & & 51 \\
\hline TBB5-02 & 2 & & & 21 & & 21 \\
\hline TBB5-03 & 3 & & & 51 & & 51 \\
\hline TBB5-04 & 4 & & & 83 & & 83 \\
\hline TBB5-05 & 5 & & & 184 & & 184 \\
\hline TBB5-06 & 6 & & & 491 & & 491 \\
\hline TBB5-07 & 7 & & & 703 & & 703 \\
\hline TBB5-08 & 8 & & & 3169 & & 3169 \\
\hline TBB5-09 & 9 & & & 3749 & & 3749 \\
\hline TBB5-10 & 10 & & & 2400 & & 2400 \\
\hline TBB5-11 & 11 & & & 1222 & & 1222 \\
\hline TBB5-12 & 12 & & & 344 & & 344 \\
\hline TBB5-13 & 13 & & & 114 & & 114 \\
\hline TBB5-14 & 14 & & & 40 & & 40 \\
\hline TBB5-15 & 15 & & & 171 & & 171 \\
\hline TBB5-16 & 16 & & & 7 & & 7 \\
\hline TBB5-17 & 17 & & & 5 & & 5 \\
\hline TBB6-01 & 1 & & & 50 & & 50 \\
\hline TBB6-02 & 2 & & & 773 & & 773 \\
\hline TBB6-03 & 3 & & & 705 & & 705 \\
\hline TBB6-04 & 4 & & & 2221 & & 2221 \\
\hline TBB6-05 & 5 & & & 4566 & & 4566 \\
\hline TBB6-06 & 6 & & & 10666 & & 10666 \\
\hline TBB6-07 & 7 & & & 20205 & 10 & 20215 \\
\hline TBB6-08 & 8 & & 31 & 32136 & 24 & 32191 \\
\hline TBB6-09 & 9 & & 12 & 20055 & 7 & 20074 \\
\hline TBB6-10 & 10 & & & 23839 & 11 & 23850 \\
\hline TBB6-11 & 11 & & & 8553 & & 8553 \\
\hline TBB6-12 & 12 & & & 3853 & & 3853 \\
\hline TBB6-13 & 13 & & & 1776 & & 1776 \\
\hline TBB6-14 & 14 & & & 609 & & 609 \\
\hline TBB6-15 & 15 & & & 135 & & 135 \\
\hline TBB6-16 & 16 & & 4 & 42 & & 46 \\
\hline TBB6-17 & 17 & & 4 & 39 & & 43 \\
\hline
\end{tabular}

Blank indicates non-detect. 
Table C.17 cont. VOC concentrations in soil with depth within Test Cell B shortly after fracture installation (August 1996).

\begin{tabular}{ccccccc}
\hline Sample ID & $\begin{array}{c}\text { Depth } \\
(\mathrm{ft} \text { bgs })\end{array}$ & $\begin{array}{c}1,1-\mathrm{DCE} \\
(\mu \mathrm{g} / \mathrm{kg})\end{array}$ & $\begin{array}{c}1,1,1-\mathrm{TCA} \\
(\mu \mathrm{g} / \mathrm{kg})\end{array}$ & $\begin{array}{c}\text { TCE } \\
(\mu \mathrm{g} / \mathrm{kg})\end{array}$ & $\begin{array}{c}\text { PCE } \\
(\mu \mathrm{g} / \mathrm{kg})\end{array}$ & $\begin{array}{c}\text { Total VOCs } \\
(\mu \mathrm{g} / \mathrm{kg})\end{array}$ \\
\hline TBB7-01 & 1 & & & & \\
TBB7-02 & 2 & & 12 & & 12 \\
TBB7-03 & 3 & & & & \\
TBB7-04 & 4 & & 4 & & \\
TBB7-05 & 5 & & & & \\
TBB7-06 & 6 & & & & \\
TBB7-07 & 7 & & & & \\
TBB7-08 & 8 & & & \\
TBB7-09 & 9 & & & \\
TBB7-10 & 10 & & & \\
TBB7-11 & 11 & & 7 & \\
TBB7-12 & 12 & & 130 & \\
TBB7-13 & 13 & & 97 & 7 \\
TBB7-14 & 14 & & 7 & \\
TBB7-15 & 15 & & & \\
TBB7-16 & 16 & & & \\
TBB7-17 & 17 & & & \\
\hline
\end{tabular}

Blank indicates non-detect. 
Table C.18. VOC concentrations in soil with depth within Test Cell C shortly after fracture installation (August 1996).

\begin{tabular}{|c|c|c|c|c|c|c|}
\hline Sample ID & $\begin{array}{c}\text { Depth } \\
\text { (ft bgs) }\end{array}$ & $\begin{array}{c}1,1-\overline{D C E} \\
(\mu \mathrm{g} / \mathrm{kg})\end{array}$ & $\begin{array}{c}1,1,1-\mathrm{TCA} \\
(\mu \mathrm{g} / \mathrm{kg})\end{array}$ & $\begin{array}{c}\text { TCE } \\
(\mu \mathrm{g} / \mathrm{kg})\end{array}$ & $\begin{array}{c}\mathrm{PCE} \\
(\mu \mathrm{g} / \mathrm{kg})\end{array}$ & $\begin{array}{c}\text { Total VOCs } \\
(\mu \mathrm{g} / \mathrm{kg})\end{array}$ \\
\hline TCB1-01 & 1 & & & & & \\
\hline TCB 1-02 & 2 & & & & & \\
\hline TCB 1-03 & 3 & & & & & \\
\hline TCB1-04 & 4 & & & 4 & & 4 \\
\hline TCB1-05 & 5 & & & 7 & & 7 \\
\hline TCB1-06 & 6 & & & & & \\
\hline TCB 1-07 & 7 & & & & & \\
\hline TCB 1-08 & 8 & & & & & \\
\hline TCB 1-09 & 9 & & & & & \\
\hline ТCB $1-10$ & 10 & & & & & \\
\hline TCB $1-11$ & 11 & & & & & \\
\hline TCB $1-12$ & 12 & & & & & \\
\hline ТСВ1-13 & 13 & & & & & \\
\hline TCB1-14 & 14 & & & & & \\
\hline TCB $1-15$ & 15 & & & & & \\
\hline TCB $1-16$ & 16 & & & & & \\
\hline ТCB $1-17$ & 17 & & & & & \\
\hline TCB2-01 & 1 & & & & & \\
\hline TCB2-02 & 2 & & & & & \\
\hline TCB2-03 & 3 & & & & & \\
\hline TCB2-04 & 4 & & & & & \\
\hline TCB2-05 & 5 & & & & & \\
\hline TCB2-06 & 6 & & & 50 & & 50 \\
\hline TCB2-07 & 7 & & & & & \\
\hline TCB2-08 & 8 & & & & & \\
\hline TCB2-09 & 9 & & & & & \\
\hline TCB2-10 & 10 & & & & & \\
\hline TCB2-11 & 11 & & & & & \\
\hline TCB2-12 & 12 & & & & & \\
\hline TCB2-13 & 13 & & & & & \\
\hline TCB2-14 & 14 & & & & & \\
\hline TCB2-15 & 15 & & & & & \\
\hline TCB2-16 & 16 & & & & & \\
\hline TCB2-17 & 17 & & & & & \\
\hline
\end{tabular}

Blank indicates non-detect. 
Table C.18 cont. VOC concentrations in soil with depth within Test Cell C shortly after fracture installation (August 1996).

\begin{tabular}{|c|c|c|c|c|c|c|}
\hline Sample ID & $\begin{array}{l}\text { Depth } \\
\text { (ft bgs) }\end{array}$ & $\begin{array}{c}\text { 1,1-DCE } \\
(\mu \mathrm{g} / \mathrm{kg})\end{array}$ & $\begin{array}{c}1,1,1-\mathrm{TCA} \\
(\mu \mathrm{g} / \mathrm{kg})\end{array}$ & $\begin{array}{c}\text { TCE } \\
(\mu \mathrm{g} / \mathrm{kg})\end{array}$ & $\begin{array}{c}\mathrm{PCE} \\
(\mu \mathrm{g} / \mathrm{kg})\end{array}$ & $\begin{array}{c}\text { Total VOCs } \\
(\mu \mathrm{g} / \mathrm{kg})\end{array}$ \\
\hline TCB3-01 & 1 & & & 8 & & 8 \\
\hline TCB3-02 & 2 & & & 7 & & 7 \\
\hline TCB3-03 & 3 & & & 11 & & 11 \\
\hline TCB3-04 & 4 & & & 10 & & 10 \\
\hline TCB3-05 & 5 & & & & & \\
\hline TCB3-06 & 6 & & & 6 & & 6 \\
\hline TCB3-07 & 7 & & & 8 & & 8 \\
\hline TCB3-08 & 8 & & & 9 & & 9 \\
\hline ТCB3-09 & 9 & & & 8 & & 8 \\
\hline TCB3-10 & 10 & & & 8 & & 8 \\
\hline TCB3-11 & 11 & & & & & \\
\hline TCB3-12 & 12 & & & 7 & & 7 \\
\hline TCB3-13 & 13 & & & 4 & & 4 \\
\hline TCB3-14 & 14 & & & 6 & & 6 \\
\hline TCB3-15 & 15 & & & 7 & & 7 \\
\hline TCB3-16 & 16 & & & 13 & & 13 \\
\hline TCB3-17 & 17 & & & 35 & & 35 \\
\hline TCB4-01 & 1 & & & 5 & & 5 \\
\hline TCB4-02 & 2 & & & & & \\
\hline TCB4-03 & 3 & & & 9 & & 9 \\
\hline TCB4-04 & 4 & & & & & \\
\hline TCB4-05 & 5 & & & 6 & & 6 \\
\hline TCB4-06 & 6 & & & 5 & & 5 \\
\hline TCB4-07 & 7 & & & 8 & & 8 \\
\hline TCB4-08 & 8 & & & 8 & & 8 \\
\hline TCB4-09 & 9 & & & 5 & & 5 \\
\hline TCB4-10 & 10 & & & & & \\
\hline TCB4-11 & 11 & & & & & \\
\hline TCB4-12 & 12 & & & 6 & & 6 \\
\hline TCB4-13 & 13 & & & 4 & & 4 \\
\hline TCB4-14 & 14 & & & 5 & & 5 \\
\hline TCB4-15 & 15 & & & 11 & & 11 \\
\hline TCB4-16 & 16 & & & 19 & & 19 \\
\hline TCB4-17 & 17 & & 4 & 36 & & 40 \\
\hline
\end{tabular}

Blank indicates non-detect. 
Table C.18 cont. VOC concentrations in soil with depth within Test Cell C shortly after fracture installation (August 1996).

\begin{tabular}{|c|c|c|c|c|c|c|}
\hline Sample ID & $\begin{array}{c}\text { Depth } \\
\text { (ft bgs) }\end{array}$ & $\begin{array}{l}\text { 1,1-DCE } \\
(\mu \mathrm{g} / \mathrm{kg})\end{array}$ & $\begin{array}{c}1,1,1-\mathrm{TCA} \\
(\mu \mathrm{g} / \mathrm{kg})\end{array}$ & $\begin{array}{c}\mathrm{TCE} \\
(\mu \mathrm{g} / \mathrm{kg})\end{array}$ & $\begin{array}{c}\mathrm{PCE} \\
(\mu \mathrm{g} / \mathrm{kg}) \\
\end{array}$ & $\begin{array}{c}\text { Total VOCs } \\
(\mu \mathrm{g} / \mathrm{kg})\end{array}$ \\
\hline TCB5-01 & 1 & & & & & \\
\hline TCB5-02 & 2 & & & & & \\
\hline TCB5-03 & 3 & & & & & \\
\hline TCB5-04 & 4 & & & & & \\
\hline TCB5-05 & 5 & & & & & \\
\hline TCB5-06 & 6 & & & & & \\
\hline TCB5-07 & 7 & & & & & \\
\hline TCB5-08 & 8 & & & & & \\
\hline TCB5-09 & 9 & & & & & \\
\hline TCB5-10 & 10 & & & & & \\
\hline TCB5-11 & 11 & & & & & \\
\hline TCB5-12 & 12 & & & & & \\
\hline TCB5-13 & 13 & & & & & \\
\hline TCB5-14 & 14 & & & & & \\
\hline TCB6-01 & 1 & & & & & \\
\hline ТCB6-02 & 2 & & & & & \\
\hline TCB6-03 & 3 & & & & & \\
\hline TCB6-04 & 4 & & & & & \\
\hline ТCB6-05 & 5 & & & & & \\
\hline TCB6-06 & 6 & & & & & \\
\hline TCB6-07 & 7 & & & & & \\
\hline TCB6-08 & 8 & & & & & \\
\hline ТCB6-09 & 9 & & & & & \\
\hline TCB6-10 & 10 & & & & & \\
\hline TCB6-11 & 11 & & & & & \\
\hline TCB6-12 & 12 & & & & & \\
\hline TCB6-13 & 13 & & & & & \\
\hline TCB6-14 & 14 & & & & & \\
\hline TCB6-15 & 15 & & & & & \\
\hline TCB6-16 & 16 & & & & & \\
\hline TCB6-17 & 17 & & & & & \\
\hline
\end{tabular}


Table C.18 cont. VOC concentrations in soil with depth within Test Cell C shortly after fracture installation (August 1996).

\begin{tabular}{|c|c|c|c|c|c|c|}
\hline Sample ID & $\begin{array}{c}\text { Depth } \\
\text { (ft bgs) }\end{array}$ & $\begin{array}{c}1,1-\mathrm{DCE} \\
(\mu \mathrm{g} / \mathrm{kg})\end{array}$ & $\begin{array}{c}1,1,1-\mathrm{TCA} \\
(\mu \mathrm{g} / \mathrm{kg})\end{array}$ & $\begin{array}{c}\text { TCE } \\
(\mu \mathrm{g} / \mathrm{kg})\end{array}$ & $\begin{array}{c}\mathrm{PCE} \\
(\mu \mathrm{g} / \mathrm{kg})\end{array}$ & $\begin{array}{c}\text { Total VOCs } \\
(\mu \mathrm{g} / \mathrm{kg})\end{array}$ \\
\hline TCB7-01 & 1 & & & & & \\
\hline TCB7-02 & 2 & & & 8 & & 8 \\
\hline TCB7-03 & 3 & & & & & \\
\hline TCB7-05 & 5 & & & & & \\
\hline TCB7-06 & 6 & & & & & \\
\hline TCB7-07 & 7 & & & & & \\
\hline TCB7-08 & 8 & & & & & \\
\hline ТСB7-09 & 9 & & & & & \\
\hline TCB7-10 & 10 & & & & & \\
\hline TCB7-11 & 11 & & & & & \\
\hline TCB 7-12 & 12 & & & & & \\
\hline TCB7-13 & 13 & & & & & \\
\hline TCB7-14 & 14 & & & & & \\
\hline TCB7-15 & 15 & & & & & \\
\hline TCB7-16 & 16 & & & & & \\
\hline TCB $7-17$ & 17 & & & 7 & & 7 \\
\hline TCB8-01 & 1 & & & 7 & & 7 \\
\hline TCB8-02 & 2 & & & 7 & & 7 \\
\hline TCB8-03 & 3 & & & 6 & & 6 \\
\hline TCB8-04 & 4 & & & & & \\
\hline TCB8-05 & 5 & & & & & \\
\hline TCB8-06 & 6 & & & 6 & & 6 \\
\hline TCB8-07 & 7 & & 6 & 4 & & 10 \\
\hline TCB8-08 & 8 & & 7 & 7 & & 14 \\
\hline TCB8-09 & 9 & & 5 & 9 & & 16 \\
\hline TCB8-10 & 10 & & 5 & 4 & & 9 \\
\hline TCB8-11 & 11 & & & 5 & & 5 \\
\hline TCB8-12 & 12 & & & & & \\
\hline TCB8-13 & 13 & & & & & \\
\hline TCB8-14 & 14 & & & 5 & & 5 \\
\hline TCB8-15 & 15 & & & 8 & & 8 \\
\hline TCB8-16 & 16 & & 4 & 21 & & 25 \\
\hline TCB8-17 & 17 & & 5 & 41 & & 46 \\
\hline
\end{tabular}

Blank indicates non-detect. 
Table C.19. VOC concentrations in soil with depth within Test Cell D shortly after fracture installation (August 1996).

\begin{tabular}{|c|c|c|c|c|c|c|}
\hline Sample ID & $\begin{array}{r}\text { Depth } \\
\text { (ft bgs) }\end{array}$ & $\begin{array}{l}1,1-\mathrm{DCE} \\
(\mu \mathrm{g} / \mathrm{kg})\end{array}$ & $\begin{array}{c}1,1,1-\mathrm{TCA} \\
(\mu \mathrm{g} / \mathrm{kg}) \\
\end{array}$ & $\begin{array}{c}\mathrm{TCE} \\
(\mu \mathrm{g} / \mathrm{kg})\end{array}$ & $\begin{array}{c}\mathrm{PCE} \\
(\mu \mathrm{g} / \mathrm{kg})\end{array}$ & $\begin{array}{c}\text { Total VOCs } \\
(\mu \mathrm{g} / \mathrm{kg})\end{array}$ \\
\hline TDB1-01 & 1 & & & & & \\
\hline TDB1-02 & 2 & & & & & \\
\hline TDB1-03 & 3 & & & & & \\
\hline TDB1-04 & 4 & & & & & \\
\hline TDB1-05 & 5 & & 4 & & & 4 \\
\hline TDB1-06 & 6 & & & & & \\
\hline TDB1-07 & 7 & & & & & \\
\hline TDB1-08 & 8 & & & & & \\
\hline TDB1-09 & 9 & & & & & \\
\hline TDB1-10 & 10 & & & & & \\
\hline TDB1-11 & 11 & & & & & \\
\hline TDB1-12 & 12 & & & & & \\
\hline TDB1-13 & 13 & & & & & \\
\hline TDB1-14 & 14 & & & & & \\
\hline TDB1-15 & 15 & & & & & \\
\hline TDB1-16 & 16 & & & 4 & & 4 \\
\hline TDB1-17 & 17 & & & 11 & & 11 \\
\hline TDB2-01 & 1 & & & & & \\
\hline TDB2-02 & 2 & & & & & \\
\hline TDB2-03 & 3 & & & & & \\
\hline TDB2-04 & 4 & & & & & \\
\hline TDB2-05 & 5 & & & & & \\
\hline TDB2-06 & 6 & & & & & \\
\hline TDB2-07 & 7 & & & & & \\
\hline TDB2-08 & 8 & & & & & \\
\hline TDB2-09 & 9 & & & & & \\
\hline TDB2-10 & 10 & & & & & \\
\hline TDB2-11 & 11 & & & & & \\
\hline TDB2-12 & 12 & & & & & \\
\hline TDB2-13 & 13 & & & & & \\
\hline TDB2-14 & 14 & & & & & \\
\hline TDB2-15 & 15 & & & 4 & & 4 \\
\hline TDB2-16 & 16 & & & 7 & & 7 \\
\hline TDB2-17 & 17 & & & 6 & & 6 \\
\hline
\end{tabular}

Blank indicates non-detect. 
Table C.19 cont. VOC concentrations in soil with depth within Test Cell D shortly after fracture installation (August 1996).

\begin{tabular}{|c|c|c|c|c|c|c|}
\hline Sample ID & $\begin{array}{c}\text { Depth } \\
\text { (ft bgs) }\end{array}$ & $\begin{array}{c}1,1-\mathrm{DCE} \\
(\mu \mathrm{g} / \mathrm{kg})\end{array}$ & $\begin{array}{c}1,1,1-\mathrm{TCA} \\
(\mu \mathrm{g} / \mathrm{kg})\end{array}$ & $\begin{array}{c}\text { TCE } \\
(\mu \mathrm{g} / \mathrm{kg})\end{array}$ & $\begin{array}{c}\text { PCE } \\
(\mu \mathrm{g} / \mathrm{kg})\end{array}$ & $\begin{array}{c}\text { Total VOCs } \\
(\mu \mathrm{g} / \mathrm{kg})\end{array}$ \\
\hline TDB3-01 & 1 & & & & & \\
\hline TDB3-02 & 2 & & & & & \\
\hline TDB3-03 & 3 & & & & & \\
\hline TDB3-04 & 4 & & & & & \\
\hline TDB3-05 & 5 & & & & & \\
\hline TDB3-06 & 6 & & & & & \\
\hline TDB3-07 & 7 & & & & & \\
\hline TDB3-08 & 8 & & & & & \\
\hline TDB3-09 & 9 & & & & & \\
\hline TDB3-10 & 10 & & & & & \\
\hline TDB3-11 & 11 & & & & & \\
\hline TDB3-12 & 12 & & & & & \\
\hline TDB3-13 & 13 & & & & & \\
\hline TDB3-14 & 14 & & & & & \\
\hline TDB3-15 & 15 & & & 5 & & 5 \\
\hline TDB3-16 & 16 & & & 4 & & 4 \\
\hline TDB3-17 & 17 & & & 7 & & 7 \\
\hline TDB4-01 & 1 & & & & & \\
\hline TDB4-02 & 2 & & & & & \\
\hline TDB4-03 & 3 & & & & & \\
\hline TDB4-04 & 4 & & & & & \\
\hline TDB4-05 & 5 & & & & & \\
\hline TDB4-06 & 6 & & & & & \\
\hline TDB4-07 & 7 & & & & & \\
\hline TDB4-08 & 8 & & & & & \\
\hline TDB4-09 & 9 & & & & & \\
\hline TDB4-10 & 10 & & & & & \\
\hline TDB4-11 & 11 & & & & & \\
\hline TDB4-12 & 12 & & & & & \\
\hline TDB4-13 & 13 & & & & & \\
\hline TDB4-14 & 14 & & & & & \\
\hline TDB4-15 & 15 & & & 6 & & 6 \\
\hline TDB4-16 & 16 & & & 10 & & 10 \\
\hline TDB4-17 & 17 & & & 22 & & 22 \\
\hline
\end{tabular}

Blank indicates non-detect. 
Table C.19 cont. VOC concentrations in soil with depth within Test Cell D shortly after fracture installation (August 1996).

\begin{tabular}{|c|c|c|c|c|c|c|}
\hline Sample ID & $\begin{array}{c}\text { Depth } \\
(\mathrm{ft} \text { bgs) }\end{array}$ & $\begin{array}{c}1,1-\mathrm{DCE} \\
(\mu \mathrm{g} / \mathrm{kg})\end{array}$ & $\begin{array}{c}1,1,1-\mathrm{TCA} \\
(\mu \mathrm{g} / \mathrm{kg})\end{array}$ & $\begin{array}{c}\text { TCE } \\
(\mu \mathrm{g} / \mathrm{kg})\end{array}$ & $\begin{array}{c}\overline{P C E} \\
(\mu \mathrm{g} / \mathrm{kg})\end{array}$ & $\begin{array}{c}\text { Total VOCs } \\
(\mu \mathrm{g} / \mathrm{kg})\end{array}$ \\
\hline TDB5-01 & 1 & & & & & \\
\hline TDB5-02 & 2 & & & & & \\
\hline TDB5-03 & 3 & & & & & \\
\hline TDB5-04 & 4 & & & & & \\
\hline TDB5-05 & 5 & & & & & \\
\hline TDB5-06 & 6 & & & & & \\
\hline TDB5-07 & 7 & & & & & \\
\hline TDB5-08 & 8 & & & & & \\
\hline TDB5-09 & 9 & & & & & \\
\hline TDB5-10 & 10 & & & & & \\
\hline TDB5-11 & 11 & & & & & \\
\hline TDB5-12 & 12 & & & & & \\
\hline TDB5-13 & 13 & & & & & \\
\hline TDB5-14 & 14 & & & & & \\
\hline TDB5-15 & 15 & & & 12 & & 12 \\
\hline TDB5-16 & 16 & & & 18 & & 18 \\
\hline TDB5-17 & 17 & & & 17 & & 17 \\
\hline TDB6-01 & 1 & & & & & \\
\hline TDB6-02 & 2 & & & & & \\
\hline TDB6-03 & 3 & & & & & \\
\hline TDB6-04 & 4 & & & & & \\
\hline TDB6-05 & 5 & & & & & \\
\hline TDB6-06 & 6 & & & & & \\
\hline TDB6-07 & 7 & & & & & \\
\hline TDB6-08 & 8 & & & & & \\
\hline TDB6-09 & 9 & & & & & \\
\hline TDB6-10 & 10 & & & & & \\
\hline TDB6-11 & 11 & & & & & \\
\hline TDB6-12 & 12 & & & & & \\
\hline TDB6-13 & 13 & & & & & \\
\hline TDB6-14 & 14 & & & & & \\
\hline TDB6-15 & 15 & & & 12 & & 12 \\
\hline TDB6-16 & 16 & & & 17 & & 17 \\
\hline TDB6-17 & 17 & & & 11 & & 11 \\
\hline
\end{tabular}

Blank indicates non-detect. 
Table C. 19 cont. VOC concentrations in soil with depth within Test Cell D shortly after fracture installation (August 1996).

\begin{tabular}{|c|c|c|c|c|c|c|}
\hline Sample ID & $\begin{array}{c}\text { Depth } \\
\text { (ft bgs) }\end{array}$ & $\begin{array}{l}\text { 1,1-DCE } \\
(\mu \mathrm{g} / \mathrm{kg})\end{array}$ & $\begin{array}{c}1,1,1-\mathrm{TCA} \\
(\mu \mathrm{g} / \mathrm{kg})\end{array}$ & $\begin{array}{c}\text { TCE } \\
(\mu \mathrm{g} / \mathrm{kg})\end{array}$ & $\begin{array}{c}\mathrm{PCE} \\
(\mu \mathrm{g} / \mathrm{kg})\end{array}$ & $\begin{array}{c}\text { Total VOCs } \\
(\mu \mathrm{g} / \mathrm{kg})\end{array}$ \\
\hline TDB7-01 & 1 & & & & & \\
\hline TDB7-02 & 2 & & & & & \\
\hline TDB7-03 & 3 & & & & & \\
\hline TDB7-04 & 4 & & & & & \\
\hline TDB7-05 & 5 & & & & & \\
\hline TDB7-06 & 6 & & & & & \\
\hline TDB7-07 & 7 & & & & & \\
\hline TDB7-08 & 8 & & & & & \\
\hline TDB7-09 & 9 & & & & & \\
\hline TDB7-10 & 10 & & & & & \\
\hline TDB7-15 & 15 & & & 13 & & 13 \\
\hline TDB7-16 & 16 & & & 18 & & 18 \\
\hline TDB7-17 & 17 & & & 19 & & 19 \\
\hline TDB8-01 & 1 & & & & & \\
\hline TDB8-02 & 2 & & & & & \\
\hline TDB8-03 & 3 & & & & & \\
\hline TDB8-04 & 4 & & & & & \\
\hline TDB8-05 & 5 & & & & & \\
\hline TDB8-06 & 6 & & & & & \\
\hline TDB8-07 & 7 & & & & & \\
\hline TDB8-08 & 8 & & & & & \\
\hline TDB8-09 & 9 & & & & & 、 \\
\hline TDB8-10 & 10 & & & & & \\
\hline TDB8-11 & 11 & & & & & \\
\hline TDB8-12 & 12 & & & & & \\
\hline TDB8-13 & 13 & & & & & \\
\hline TDB8-14 & 14 & & & & & \\
\hline TDB8-15 & 15 & & & 8 & & 8 \\
\hline TDB8-16 & 16 & & & 6 & & 6 \\
\hline TDB8-17 & 17 & & & 14 & & 14 \\
\hline
\end{tabular}

Blank indicates non-detect. 
Table C.20 In situ Eh measurements at background location (in $\mathrm{mV}$ ).

\begin{tabular}{|c|c|c|c|c|c|c|c|c|c|c|c|c|}
\hline Location & $\begin{array}{c}\text { Depth } \\
\text { (ft bgs) }\end{array}$ & $10 / 20 / 96$ & $10 / 27 / 96$ & $11 / 11 / 96$ & $11 / 24 / 96$ & $12 / 6 / 96$ & $\begin{array}{c}\text { Date } \\
7 / 17 / 97\end{array}$ & $7 / 18 / 97$ & $7 / 24 / 97$ & $9 / 3 / 97$ & 9/5/97 & $12 / 12 / 97$ \\
\hline \multirow[t]{7}{*}{ BGMI } & 1.75 & -107.3 & -54.5 & -48.2 & -28.6 & -62.2 & -473.0 & -461.7 & -470.0 & -474.1 & -465.7 & -510.4 \\
\hline & 3.75 & 194.6 & 179.2 & 172.7 & 237.3 & 219.7 & -536.0 & -538.2 & -547.0 & -569.8 & -509.6 & -581.7 \\
\hline & 5.75 & -519.8 & -444.7 & -464.1 & -426.6 & -361.1 & -532.0 & -534.0 & -529.0 & -582.9 & -576.8 & -502.5 \\
\hline & 7.50 & -739.8 & -727.7 & -713.1 & -718.9 & -713.1 & -666.0 & -664.4 & -665.0 & -676.3 & -669.2 & -693.5 \\
\hline & 11.50 & -282.1 & -486.0 & -479.9 & -505.4 & -277.8 & -580.0 & -581.1 & -598.0 & -603.4 & -604.0 & -542.9 \\
\hline & 13.25 & -664.3 & -461.6 & -451.4 & -200.9 & -221.1 & -611.0 & -615.9 & -621.0 & -690.2 & -716.2 & -379.2 \\
\hline & 15.75 & -293.3 & -296.7 & -333.9 & -383.2 & -386.8 & -503.0 & -503.6 & -500.0 & -509.3 & -506.3 & -425.6 \\
\hline
\end{tabular}

Table C.21 Wiping thermocouple measurements at background location $\left({ }^{\circ} \mathrm{C}\right)$.

\begin{tabular}{cccc}
\hline Location & Depth & \multicolumn{2}{c}{ Date } \\
& (ft bgs) & $7 / 26 / 97$ & $9 / 6 / 97$ \\
\hline BGM1 & 1 & 33.6 & 28.6 \\
& 3 & 29.7 & 29.8 \\
& 5 & 25.9 & 28.7 \\
& 7 & 23.8 & 27.4 \\
& 9 & 22.3 & 26.0 \\
& 11 & 21.1 & 23.9 \\
& 13 & 20.6 & 22.7 \\
& 15 & 20.4 & \\
& 17 & 20.4 & \\
\hline
\end{tabular}


Table C.22 VOC concentrations with depth from selected boreholes in Test Cell A shortly after fracture installation. PORTS laboratory analysis using a soil sample preserved in methanol.

\begin{tabular}{ccccccccc}
\hline & $\begin{array}{c}\text { Depth } \\
\text { (ft bgs) }\end{array}$ & $\begin{array}{c}\text { CH2Cl2 } \\
(\mathrm{ug} / \mathrm{kg})\end{array}$ & $\begin{array}{c}\mathrm{t}-1,2- \\
\text { DCE } \\
(\mathrm{ug} / \mathrm{kg})\end{array}$ & $\begin{array}{c}\mathrm{c-1,2-} \\
\mathrm{DCE} \\
(\mathrm{ug} / \mathrm{kg})\end{array}$ & $\begin{array}{c}1,1-\mathrm{DCA} \\
(\mathrm{ug} / \mathrm{kg})\end{array}$ & $\begin{array}{c}1,1-\mathrm{DCE} \\
(\mathrm{ug} / \mathrm{kg})\end{array}$ & $\begin{array}{c}1,1,1- \\
\text { TCA } \\
(\mathrm{ug} / \mathrm{kg})\end{array}$ & $\begin{array}{c}\text { TCE } \\
(\mathrm{ug} / \mathrm{kg})\end{array}$ \\
\hline TAB2-02 & 2 & $400 \mathrm{U}$ & $400 \mathrm{U}$ & $400 \mathrm{U}$ & $400 \mathrm{U}$ & $400 \mathrm{U}$ & $400 \mathrm{U}$ & $400 \mathrm{U}$ \\
TAB2-04 & 4 & $400 \mathrm{U}$ & $400 \mathrm{U}$ & $400 \mathrm{U}$ & $400 \mathrm{U}$ & $400 \mathrm{U}$ & $400 \mathrm{U}$ & $400 \mathrm{U}$ \\
TAB2-13 & 13 & $400 \mathrm{U}$ & $400 \mathrm{U}$ & $400 \mathrm{U}$ & $400 \mathrm{U}$ & $400 \mathrm{U}$ & $400 \mathrm{U}$ & $400 \mathrm{U}$ \\
\hline TAB6-05 & 5 & $400 \mathrm{U}$ & $400 \mathrm{U}$ & $400 \mathrm{U}$ & $400 \mathrm{U}$ & $400 \mathrm{U}$ & $400 \mathrm{U}$ & 3900 \\
TAB6-06 & 6 & $400 \mathrm{U}$ & $400 \mathrm{U}$ & $400 \mathrm{U}$ & $400 \mathrm{U}$ & $400 \mathrm{U}$ & $400 \mathrm{U}$ & $400 \mathrm{U}$ \\
TAB6-09 & 9 & $400 \mathrm{U}$ & $400 \mathrm{U}$ & $400 \mathrm{U}$ & $400 \mathrm{U}$ & $400 \mathrm{U}$ & $400 \mathrm{U}$ & 17000 \\
TAB6-13 & 13 & $400 \mathrm{U}$ & $400 \mathrm{U}$ & $400 \mathrm{U}$ & $400 \mathrm{U}$ & $400 \mathrm{U}$ & $400 \mathrm{U}$ & 1300 \\
\hline TAB8-05 & 5 & $400 \mathrm{U}$ & $400 \mathrm{U}$ & $400 \mathrm{U}$ & $400 \mathrm{U}$ & $400 \mathrm{U}$ & $400 \mathrm{U}$ & $400 \mathrm{U}$ \\
TAB8-09 & 9 & $400 \mathrm{U}$ & $400 \mathrm{U}$ & $400 \mathrm{U}$ & $400 \mathrm{U}$ & $400 \mathrm{U}$ & $400 \mathrm{U}$ & 8800 \\
TAB8-13 & 13 & $400 \mathrm{U}$ & $400 \mathrm{U}$ & $400 \mathrm{U}$ & $400 \mathrm{U}$ & $400 \mathrm{U}$ & $400 \mathrm{U}$ & $400 \mathrm{U}$ \\
\hline
\end{tabular}

$\mathrm{U}$ - Compound was analyzed for but not detected. Value reported is the attainable detection limit.

Table C.23 VOC concentrations with depth from selected boreholes in Test Cell A shortly after fracture installation. PORTS laboratory analysis using a standard EPA soil analysis method.

\begin{tabular}{|c|c|c|c|c|c|c|c|c|}
\hline Sample ID & $\begin{array}{c}\text { Depth } \\
\text { (ft bgs) }\end{array}$ & $\begin{array}{c}\mathrm{CH} 2 \mathrm{Cl} 2 \\
\text { (ug/kg) }\end{array}$ & $\begin{array}{c}\mathrm{t}-1,2- \\
\mathrm{DCE} \\
(\mathrm{ug} / \mathrm{kg})\end{array}$ & $\begin{array}{c}\mathrm{c}-1,2- \\
\mathrm{DCE} \\
(\mathrm{ug} / \mathrm{kg})\end{array}$ & $\begin{array}{c}1,1-\mathrm{DCA} \\
(\mathrm{ug} / \mathrm{kg})\end{array}$ & $\begin{array}{l}1,1-\mathrm{DCE} \\
(\mathrm{ug} / \mathrm{kg})\end{array}$ & $\begin{array}{c}1,1,1- \\
\text { TCA } \\
(u g / k g)\end{array}$ & $\begin{array}{c}\mathrm{TCE} \\
(\mathrm{ug} / \mathrm{kg})\end{array}$ \\
\hline TAB2-02 & 2 & $20 \mathrm{U}$ & $20 \mathrm{U}$ & $20 \mathrm{U}$ & $20 \mathrm{U}$ & $\overline{20 U}$ & $400 \mathrm{U}$ & $20 \mathrm{U}$ \\
\hline TAB2-04 & 4 & $20 U$ & $20 U$ & $20 U$ & $20 U$ & $20 U$ & $400 \mathrm{U}$ & $20 \mathrm{U}$ \\
\hline TAB2-13 & 13 & $20 \mathrm{U}$ & $20 U$ & $20 \mathrm{U}$ & $20 \mathrm{U}$ & $20 \mathrm{U}$ & $400 U$ & $20 U$ \\
\hline TAB6-05 & 5 & $20 \mathrm{U}$ & $20 \mathrm{U}$ & $20 \mathrm{U}$ & $20 \mathrm{U}$ & $20 \mathrm{U}$ & $400 U$ & 350 \\
\hline TAB6-06 & 6 & $20 U$ & $20 U$ & 48 & $20 \mathrm{U}$ & $20 U$ & $400 U$ & $3400 \mathrm{E}$ \\
\hline TAB6-09 & 9 & $20 \mathrm{U}$ & $20 \mathrm{U}$ & 26 & $20 \mathrm{U}$ & 20 & $400 U$ & $5800 \mathrm{E}$ \\
\hline TAB6-13 & 13 & $20 \mathrm{U}$ & $20 U$ & 220 & $20 \mathrm{U}$ & $20 \mathrm{U}$ & $400 \mathrm{U}$ & 110 \\
\hline TAB8-05 & 5 & $20 \mathrm{U}$ & $20 \mathrm{U}$ & $20 \mathrm{U}$ & $20 \mathrm{U}$ & $20 \mathrm{U}$ & $20 \mathrm{U}$ & $20 \mathrm{U}$ \\
\hline TAB8-09 & 9 & $20 U$ & $20 U$ & $20 \mathrm{U}$ & $20 U$ & $20 U$ & $400 U$ & $20 U$ \\
\hline TAB8-13 & 13 & $20 \mathrm{U}$ & $20 U$ & $20 U$ & $20 \mathrm{U}$ & $20 U$ & $400 U$ & $20 U$ \\
\hline
\end{tabular}

$\mathrm{U}$ - Compound was analyzed for but not detected. Value reported is the attainable detection limit. E - Estimated value. 
Table C.24 VOC concentrations with depth from selected boreholes in Test Cell B shortly after fracture installation. PORTS laboratory analysis using a soil sample preserved in methanol.

\begin{tabular}{|c|c|c|c|c|c|c|c|c|}
\hline Sample ID & $\begin{array}{c}\text { Depth } \\
\text { (ft bgs) }\end{array}$ & $\begin{array}{l}\mathrm{CH} 2 \mathrm{Cl} 2 \\
\text { (ug/kg) }\end{array}$ & $\begin{array}{l}\mathrm{t}-1,2- \\
\text { DCE } \\
\text { (ug/kg) }\end{array}$ & $\begin{array}{l}c-1,2- \\
\text { DCE } \\
(\mathrm{ug} / \mathrm{kg})\end{array}$ & $\begin{array}{c}1,1-\mathrm{DCA} \\
(\mathrm{ug} / \mathrm{kg})\end{array}$ & $\begin{array}{l}1,1-\mathrm{DCE} \\
(\mathrm{ug} / \mathrm{kg})\end{array}$ & $\begin{array}{c}1,1,1- \\
\text { TCA } \\
\text { (ug/kg) }\end{array}$ & $\begin{array}{c}\text { TCE } \\
\text { (ug/kg) }\end{array}$ \\
\hline TBB2-05 & 5 & $400 \mathrm{U}$ & $400 \mathrm{U}$ & $400 \mathrm{U}$ & $400 U$ & $400 \mathrm{U}$ & $400 \mathrm{U}$ & $400 \mathrm{U}$ \\
\hline TBB2-09 & 9 & $400 \mathrm{U}$ & $400 U$ & $400 \mathrm{U}$ & $400 U$ & $400 \mathrm{U}$ & $400 U$ & $400 \mathrm{U}$ \\
\hline TBB2-13 & 13 & $400 \mathrm{U}$ & $400 \mathrm{U}$ & $400 \mathrm{U}$ & $400 U$ & $400 \mathrm{U}$ & $400 U$ & $400 \mathrm{U}$ \\
\hline TBB6-13 & 13 & $400 \mathrm{U}$ & $400 \mathrm{U}$ & $400 \mathrm{U}$ & $400 \mathrm{U}$ & $400 \mathrm{U}$ & $400 \mathrm{U}$ & 3000 \\
\hline ТВB6-17 & 17 & $400 \mathrm{U}$ & $400 \mathrm{U}$ & $400 \mathrm{U}$ & $400 \mathrm{U}$ & $400 \mathrm{U}$ & $400 U$ & $400 U$ \\
\hline TBB7-05 & 5 & $400 \mathrm{U}$ & $400 \mathrm{U}$ & $400 \mathrm{U}$ & $400 \mathrm{U}$ & $400 \mathrm{U}$ & $400 \mathrm{U}$ & $400 \mathrm{U}$ \\
\hline TBB7-09 & 9 & $400 \mathrm{U}$ & $400 \mathrm{U}$ & $400 \mathrm{U}$ & $400 \mathrm{U}$ & $400 \mathrm{U}$ & $400 \mathrm{U}$ & $400 U$ \\
\hline TBB7-13 & 13 & $400 \mathrm{U}$ & $400 \mathrm{U}$ & $400 \mathrm{U}$ & $400 \mathrm{U}$ & $400 \mathrm{U}$ & $400 \mathrm{U}$ & $400 U$ \\
\hline
\end{tabular}

$\mathrm{U}$ - Compound was analyzed for but not detected. Value reported is the attainable detection limit.

Table C.25 VOC concentrations with depth from selected boreholes in Test Cell B shortly after fracture installation. PORTS laboratory analysis using a standard EPA soil analysis method.

\begin{tabular}{ccccccccc}
\hline & $\begin{array}{c}\text { Depth } \\
\text { Cample ID } \\
\text { (ft bgs) }\end{array}$ & $\begin{array}{c}\mathrm{t}-1,2- \\
\text { (ug/kg) }\end{array}$ & $\begin{array}{c}\text { DCE } \\
\text { (ug/kg) }\end{array}$ & $\begin{array}{c}\text { C-1,2- } \\
\text { (ug/kg) }\end{array}$ & $\begin{array}{c}1,1-\mathrm{DCA} \\
\text { (ug/kg) }\end{array}$ & $\begin{array}{c}1,1-\mathrm{DCE} \\
(\mathrm{ug} / \mathrm{kg})\end{array}$ & $\begin{array}{c}1,1,1- \\
\text { TCA } \\
(\mathrm{ug} / \mathrm{kg})\end{array}$ & $\begin{array}{c}\text { TCE } \\
(\mathrm{ug} / \mathrm{kg})\end{array}$ \\
\hline TBB2-05 & 5 & $4 \mathrm{UJ}$ & $4 \mathrm{UJ}$ & $4 \mathrm{UJ}$ & $4 \mathrm{UJ}$ & $4 \mathrm{UJ}$ & $400 \mathrm{U}$ & $4 \mathrm{UJ}$ \\
TBB2-09 & 9 & $2 \mathrm{U}$ & $2 \mathrm{U}$ & $2 \mathrm{U}$ & $2 \mathrm{U}$ & $2 \mathrm{U}$ & $400 \mathrm{U}$ & $2 \mathrm{U}$ \\
TBB2-13 & 13 & $4 \mathrm{U}$ & $4 \mathrm{U}$ & $4 \mathrm{U}$ & $4 \mathrm{U}$ & $4 \mathrm{U}$ & $400 \mathrm{U}$ & $4 \mathrm{U}$ \\
\hline TBB6-13 & 13 & $20 \mathrm{U}$ & $20 \mathrm{U}$ & $20 \mathrm{U}$ & $20 \mathrm{U}$ & $20 \mathrm{U}$ & $400 \mathrm{U}$ & $20 \mathrm{U}$ \\
TBB6-17 & 17 & $20 \mathrm{U}$ & $20 \mathrm{U}$ & $20 \mathrm{U}$ & $20 \mathrm{U}$ & $20 \mathrm{U}$ & $400 \mathrm{U}$ & $20 \mathrm{U}$ \\
\hline TBB7-05 & 5 & $4 \mathrm{U}$ & $4 \mathrm{U}$ & $4 \mathrm{U}$ & $4 \mathrm{U}$ & $4 \mathrm{U}$ & $400 \mathrm{U}$ & $4 \mathrm{U}$ \\
TBB7-09 & 9 & 2 & $2 \mathrm{U}$ & $2 \mathrm{U}$ & $2 \mathrm{U}$ & $2 \mathrm{U}$ & $400 \mathrm{U}$ & $2 \mathrm{U}$ \\
TBB7-13 & 13 & $10 \mathrm{UJ}$ & $10 \mathrm{UJ}$ & $10 \mathrm{UJ}$ & $10 \mathrm{UJ}$ & $10 \mathrm{UJ}$ & $400 \mathrm{U}$ & $10 \mathrm{UJ}$
\end{tabular}

$\mathrm{U}$ - Compound was analyzed for but not detected. Value reported is the attainable detection limit. $\mathrm{UJ}=$ Qualify data for the sample as estimated. 
Table C.26 VOC concentrations with depth from selected boreholes in Test Cell C shortly after fracture installation. PORTS laboratory analysis using a soil sample preserved in methanol.

\begin{tabular}{lcccccccc}
\hline & $\begin{array}{c}\text { Depth } \\
\text { Sample ID }\end{array}$ & $\begin{array}{c}\text { (ft bgs }) \\
(\mathrm{ug} / \mathrm{kg})\end{array}$ & $\begin{array}{c}\mathrm{t}-1,2- \\
\text { DCE } \\
(\mathrm{ug} / \mathrm{kg})\end{array}$ & $\begin{array}{c}\mathrm{c}-1,2- \\
\text { DCE } \\
(\mathrm{ug} / \mathrm{kg})\end{array}$ & $\begin{array}{c}1,1-\mathrm{DCA} \\
(\mathrm{ug} / \mathrm{kg})\end{array}$ & $\begin{array}{c}1,1-\mathrm{DCE} \\
(\mathrm{ug} / \mathrm{kg})\end{array}$ & $\begin{array}{c}1,1,1- \\
\text { TCA } \\
(\mathrm{ug} / \mathrm{kg})\end{array}$ & $\begin{array}{c}\text { TCE } \\
(\mathrm{ug} / \mathrm{kg})\end{array}$ \\
\hline TCB2-05 & 5 & $400 \mathrm{U}$ & $400 \mathrm{U}$ & $400 \mathrm{U}$ & $400 \mathrm{U}$ & $400 \mathrm{U}$ & $400 \mathrm{U}$ & $400 \mathrm{U}$ \\
TCB2-09 & 9 & $400 \mathrm{U}$ & $400 \mathrm{U}$ & $400 \mathrm{U}$ & $400 \mathrm{U}$ & $400 \mathrm{U}$ & $400 \mathrm{U}$ & $400 \mathrm{U}$ \\
TCB2-13 & 13 & $400 \mathrm{U}$ & $400 \mathrm{U}$ & $400 \mathrm{U}$ & $400 \mathrm{U}$ & $400 \mathrm{U}$ & $400 \mathrm{U}$ & $400 \mathrm{U}$ \\
\hline TCB6-06 & 6 & $400 \mathrm{U}$ & $400 \mathrm{U}$ & $400 \mathrm{U}$ & $400 \mathrm{U}$ & $400 \mathrm{U}$ & $400 \mathrm{U}$ & $400 \mathrm{U}$ \\
TCB6-11 & 11 & $400 \mathrm{U}$ & $400 \mathrm{U}$ & $400 \mathrm{U}$ & $400 \mathrm{U}$ & $400 \mathrm{U}$ & $400 \mathrm{U}$ & $400 \mathrm{U}$ \\
TCB6-13 & 13 & $400 \mathrm{U}$ & $400 \mathrm{U}$ & $400 \mathrm{U}$ & $400 \mathrm{U}$ & $400 \mathrm{U}$ & $400 \mathrm{U}$ & $400 \mathrm{U}$ \\
\hline TCB8-05 & 5 & $400 \mathrm{U}$ & $400 \mathrm{U}$ & $400 \mathrm{U}$ & $400 \mathrm{U}$ & $400 \mathrm{U}$ & $400 \mathrm{U}$ & $400 \mathrm{U}$ \\
TCB8-09 & 9 & $400 \mathrm{U}$ & $400 \mathrm{U}$ & $400 \mathrm{U}$ & $400 \mathrm{U}$ & $400 \mathrm{U}$ & $400 \mathrm{U}$ & $400 \mathrm{U}$ \\
TCB8-13 & 13 & $400 \mathrm{U}$ & $400 \mathrm{U}$ & $400 \mathrm{U}$ & $400 \mathrm{U}$ & $400 \mathrm{U}$ & $400 \mathrm{U}$ & $400 \mathrm{U}$ \\
\hline
\end{tabular}

U - Compound was analyzed for but not detected. Value reported is the attainable detection limit.

Table C.27 VOC concentrations with depth from selected boreholes in Test Cell C shortly after fracture installation. PORTS laboratory analysis using a standard EPA soil analysis method.

\begin{tabular}{|c|c|c|c|c|c|c|c|c|}
\hline Sample ID & $\begin{array}{c}\text { Depth } \\
\text { (ft bgs) }\end{array}$ & $\begin{array}{l}\mathrm{CH} 2 \mathrm{Cl} 2 \\
(\mathrm{ug} / \mathrm{kg})\end{array}$ & $\begin{array}{c}\mathrm{t}-1,2- \\
\mathrm{DCE} \\
(\mathrm{ug} / \mathrm{kg})\end{array}$ & $\begin{array}{c}\mathrm{c}-1,2- \\
\mathrm{DCE} \\
(\mathrm{ug} / \mathrm{kg})\end{array}$ & $\begin{array}{r}1,1-\mathrm{DCA} \\
(\mathrm{ug} / \mathrm{kg})\end{array}$ & $\begin{array}{c}1,1-\mathrm{DCE} \\
(\mathrm{ug} / \mathrm{kg})\end{array}$ & $\begin{array}{c}1,1,1- \\
\text { TCA } \\
(\mathrm{ug} / \mathrm{kg})\end{array}$ & $\begin{array}{c}\mathrm{TCE} \\
\text { (ug/kg) }\end{array}$ \\
\hline TCB2-05 & 5 & $20 \mathrm{U}$ & $20 \mathrm{U}$ & $20 \mathrm{U}$ & $20 \mathrm{U}$ & $20 \mathrm{U}$ & $400 \mathrm{U}$ & $20 \mathrm{U}$ \\
\hline TCB2-09 & 9 & $2 U$ & $2 \mathrm{U}$ & $2 \mathrm{U}$ & $2 U$ & $2 \mathrm{U}$ & $400 U$ & $2 \mathrm{U}$ \\
\hline TCB2-13 & 13 & $2 U$ & $2 \mathrm{U}$ & $2 \mathrm{U}$ & $2 \mathrm{U}$ & $2 \mathrm{U}$ & $400 U$ & 7 \\
\hline TCB6-06 & 6 & $20 \mathrm{U}$ & $20 \mathrm{U}$ & $20 \mathrm{U}$ & $20 \mathrm{U}$ & $20 \mathrm{U}$ & $400 \mathrm{U}$ & $20 \mathrm{U}$ \\
\hline ТCB6-11 & 11 & $20 U$ & $20 U$ & $20 U$ & $20 U$ & $20 \mathrm{U}$ & $400 U$ & $20 \mathrm{U}$ \\
\hline TCB6-13 & 13 & $20 U$ & $20 U$ & $20 U$ & $20 U$ & $20 \mathrm{U}$ & $400 U$ & $20 \mathrm{U}$ \\
\hline TCB8-05 & 5 & $2 \mathrm{U}$ & $2 \mathrm{U}$ & $\overline{2 \mathrm{U}}$ & $2 \mathrm{U}$ & $2 \mathrm{U}$ & $400 \mathrm{U}$ & $\overline{2 U}$ \\
\hline ТCB8-09 & 9 & $4 U$ & $4 U$ & $4 U$ & $4 U$ & $4 U$ & $400 \mathrm{U}$ & $4 U$ \\
\hline ТCB8-13 & 13 & $2 \mathrm{U}$ & $2 \mathrm{U}$ & $2 \mathrm{U}$ & $2 \mathrm{U}$ & $2 \mathrm{U}$ & $400 \mathrm{U}$ & $2 U$ \\
\hline
\end{tabular}

$\mathrm{U}$ - Compound was analyzed for but not detected. Value reported is the attainable detection limit. 
Table C.28 VOC concentrations with depth from selected boreholes in Test Cell D shortly after fracture installation. PORTS laboratory analysis using a soil sample preserved in methanol.

\begin{tabular}{|c|c|c|c|c|c|c|c|c|}
\hline Sample ID & $\begin{array}{c}\text { Depth } \\
\text { (ft bgs) }\end{array}$ & $\begin{array}{l}\mathrm{CH} 2 \mathrm{Cl} 2 \\
\text { (ug/kg) }\end{array}$ & $\begin{array}{c}\mathrm{t}-1,2- \\
\mathrm{DCE} \\
\text { (ug/kg) }\end{array}$ & $\begin{array}{c}\mathrm{c}-1,2- \\
\mathrm{DCE} \\
(\mathrm{ug} / \mathrm{kg})\end{array}$ & $\begin{array}{c}1,1-\mathrm{DCA} \\
(\mathrm{ug} / \mathrm{kg})\end{array}$ & $\begin{array}{c}1,1-\mathrm{DCE} \\
(\mathrm{ug} / \mathrm{kg})\end{array}$ & $\begin{array}{c}1,1,1- \\
\text { TCA } \\
(\mathrm{ug} / \mathrm{kg})\end{array}$ & $\begin{array}{c}\text { TCE } \\
\text { (ug/kg) }\end{array}$ \\
\hline TDB2-05 & 5 & $400 U$ & $400 \mathrm{U}$ & $400 \mathrm{U}$ & $400 \mathrm{U}$ & $400 \mathrm{U}$ & $400 \mathrm{U}$ & $400 \mathrm{U}$ \\
\hline TDB2-09 & 9 & $400 \mathrm{U}$ & $400 \mathrm{U}$ & $400 \mathrm{U}$ & $400 \mathrm{U}$ & $400 \mathrm{U}$ & $400 \mathrm{U}$ & $400 U$ \\
\hline TDB2-13 & 13 & $400 \mathrm{U}$ & $400 \mathrm{U}$ & $400 \mathrm{U}$ & $400 \mathrm{U}$ & $400 \mathrm{U}$ & $400 \mathrm{U}$ & $400 U$ \\
\hline TDB6-09 & 9 & $400 \mathrm{U}$ & $400 \mathrm{U}$ & $\overline{400 U}$ & $400 \mathrm{U}$ & $400 \mathrm{U}$ & $400 \mathrm{U}$ & $400 \mathrm{U}$ \\
\hline TDB6-13 & 13 & $400 U$ & $400 \mathrm{U}$ & $400 \mathrm{U}$ & $400 \mathrm{U}$ & $400 \mathrm{U}$ & $400 \mathrm{U}$ & $400 \mathrm{U}$ \\
\hline TDB8-05 & 5 & $400 \mathrm{U}$ & $400 \mathrm{U}$ & $400 \mathrm{U}$ & $\overline{400 U}$ & $400 \mathrm{U}$ & $\overline{400 U}$ & $400 \mathrm{U}$ \\
\hline TDB8-09 & 9 & $400 U$ & $400 \mathrm{U}$ & $400 \mathrm{U}$ & $400 \mathrm{U}$ & $400 \mathrm{U}$ & $400 \mathrm{U}$ & $400 U$ \\
\hline TDB8-13 & 13 & $400 \mathrm{U}$ & $400 \mathrm{U}$ & $400 \mathrm{U}$ & $400 \mathrm{U}$ & $400 U$ & $400 \mathrm{U}$ & $400 \mathrm{U}$ \\
\hline
\end{tabular}

U-Compound was analyzed for but not detected. Value reported is the attainable detection limit.

Table C.29 VOC concentrations with depth from selected boreholes in Test Cell D shortly after fracture installation. PORTS laboratory analysis using a standard EPA soil analysis method.

\begin{tabular}{|c|c|c|c|c|c|c|c|c|}
\hline Sample ID & $\begin{array}{c}\text { Depth } \\
\text { (ft bgs) }\end{array}$ & $\begin{array}{l}\text { CH2Cl2 } \\
(\mathrm{ug} / \mathrm{kg})\end{array}$ & $\begin{array}{c}\mathrm{t}-1,2- \\
\mathrm{DCE} \\
(\mathrm{ug} / \mathrm{kg})\end{array}$ & $\begin{array}{c}\mathrm{c}-1,2- \\
\mathrm{DCE} \\
(\mathrm{ug} / \mathrm{kg})\end{array}$ & $\begin{array}{c}\text { 1,1-DCA } \\
(\mathrm{ug} / \mathrm{kg})\end{array}$ & $\begin{array}{l}1,1-\mathrm{DCE} \\
(\mathrm{ug} / \mathrm{kg})\end{array}$ & $\begin{array}{c}1,1,1- \\
\text { TCA } \\
(\mathrm{ug} / \mathrm{kg})\end{array}$ & $\begin{array}{c}\text { TCE } \\
(\mathrm{ug} / \mathrm{kg})\end{array}$ \\
\hline TDB2-05 & 5 & $20 \mathrm{U}$ & 200 & 200 & $20 \mathrm{U}$ & $20 \mathrm{U}$ & $400 \mathrm{U}$ & $20 \mathrm{U}$ \\
\hline TDB2-09 & 9 & $20 \mathrm{U}$ & $20 U$ & $20 U$ & $20 U$ & $20 U$ & $400 \mathrm{U}$ & $20 U$ \\
\hline TDB2-13 & 13 & $20 \mathrm{U}$ & $20 \mathrm{U}$ & $20 \mathrm{U}$ & $20 \mathrm{U}$ & $20 \mathrm{U}$ & $400 \mathrm{U}$ & $20 U$ \\
\hline TDB6-05 & 5 & $20 \mathrm{U}$ & $20 \mathrm{U}$ & $20 \mathrm{U}$ & $20 \bar{U}$ & $20 \mathrm{U}$ & & $20 \mathrm{U}$ \\
\hline TDB6-09 & 9 & $20 \mathrm{U}$ & $20 \mathrm{U}$ & $20 \mathrm{U}$ & $20 U$ & $20 \mathrm{U}$ & $400 \mathrm{U}$ & $20 \mathrm{U}$ \\
\hline TDB6-13 & 13 & $20 \mathrm{U}$ & $20 \mathrm{U}$ & 200 & $20 \mathrm{U}$ & $20 \mathrm{U}$ & $400 \mathrm{U}$ & $20 \mathrm{U}$ \\
\hline TDB8-05 & 5 & $20 \mathrm{U}$ & $20 \mathrm{U}$ & 200 & $20 \mathrm{U}$ & $20 \mathrm{U}$ & $400 \mathrm{U}$ & $20 \mathrm{U}$ \\
\hline TDB8-09 & 9 & $20 \mathrm{U}$ & $20 \mathrm{U}$ & $20 U$ & $20 U$ & $20 U$ & $400 \mathrm{U}$ & $20 \mathrm{U}$ \\
\hline TDB8-13 & 13 & $20 \mathrm{U}$ & $20 \mathrm{U}$ & $20 \mathrm{U}$ & $20 \mathrm{U}$ & $20 \mathrm{U}$ & $400 \mathrm{U}$ & $20 \mathrm{U}$ \\
\hline
\end{tabular}

U - Compound was analyzed for but not detected. Value reported is the attainable detection limit. 
APPENDIX D. OPERATIONAL AND POST-TREATMENT HOT FLUID CELL CHARACTERISTICS 
Table D.1 Test Cell A physical/chemical characteristics with depth as observed in the field following treatment (December 9, 1996).

\begin{tabular}{lccccc}
\hline Sample ID & $\begin{array}{c}\text { Depth } \\
\text { (ft bgs) }\end{array}$ & $\begin{array}{c}\text { Water } \\
\text { Content } \\
\text { (dry wt\%) }\end{array}$ & $\begin{array}{c}\text { Eh } \\
(\mathrm{mV})\end{array}$ & $\begin{array}{c}\text { Temp } \\
\left({ }^{\circ} \mathrm{F}\right)\end{array}$ & $\begin{array}{c}\mathrm{pH} \\
\text { (extract) }\end{array}$ \\
\hline TAB9-01 & 1 & 22.11 & 202.9 & 41.7 & \\
TAB9-03 & 3 & 19.16 & 358.5 & 48.9 & \\
TAB9-05 & 5 & 17.55 & 262.5 & 47.7 & \\
TAB9-07 & 7 & 24.57 & 219.4 & 56.2 & \\
TAB9-09 & 9 & 23.43 & 66.7 & 53.2 & \\
TAB9-11 & 11 & 23.99 & 30.9 & 50.8 & \\
TAB9-13 & 13 & 19.97 & 37.2 & 56.2 & \\
TAB9-15 & 15 & 26.41 & -13.1 & 55.4 & \\
TAB9-17 & 17 & 19.44 & 70.5 & 47.7 & \\
\hline
\end{tabular}

Blank table entry indicated measurement not taken. 
Table D.2 Test Cell B physical/chemical characteristics with depth as observed in the field following treatment (December 10-11, 1996).

\begin{tabular}{|c|c|c|c|c|c|}
\hline Sample ID & $\begin{array}{c}\text { Depth } \\
\text { (ft bgs) }\end{array}$ & $\begin{array}{l}\text { Water Content } \\
\text { (dry wt } \%)\end{array}$ & $\begin{array}{c}\mathrm{Eh} \\
(\mathrm{mV})\end{array}$ & $\begin{array}{l}\text { Temp } \\
\left({ }^{\circ} \mathrm{F}\right)\end{array}$ & $\frac{\mathrm{pH}}{\text { (extract) }}$ \\
\hline TBB8-03 & 3 & 22.08 & 252.8 & 53.8 & 5.22 \\
\hline TBB8-05 & 5 & 19.14 & 302.8 & 55.6 & 6.92 \\
\hline TBB8-07 & 7 & 22.54 & 241.5 & 59.6 & 7.30 \\
\hline TBB8-09 & 9 & 20.25 & 68.3 & 66.7 & 6.62 \\
\hline TBB8-11 & 11 & 21.05 & 261.8 & 57 & 5.47 \\
\hline TBB8-13 & 13 & 25.89 & 292.3 & 63.7 & 5.51 \\
\hline TBB8-15 & 15 & 24.27 & 323.1 & 60.3 & 5.62 \\
\hline TBB8-17 & 17 & 21.55 & 299.0 & 62.6 & 5.70 \\
\hline TBB9-03 & 3 & 21.37 & 354.4 & 59.3 & 4.70 \\
\hline TBB9-05 & 5 & 22.75 & 363.1 & 63.5 & 6.44 \\
\hline TBB9-07 & 7 & 25.00 & 266.2 & 64.9 & 7.23 \\
\hline TBB9-09 & 9 & 18.81 & 191.6 & 67.5 & 5.89 \\
\hline TBB9-11 & 11 & 18.87 & 221.9 & 66.8 & 5.49 \\
\hline TBB9-13 & 13 & 24.50 & 317.1 & 65.8 & 5.51 \\
\hline TBB9-15 & 15 & 24.59 & 391.5 & 61.9 & 5.29 \\
\hline TBB9-17 & 17 & 24.48 & 333.6 & 64.7 & 5.75 \\
\hline TBB10-03 & 3 & 22.79 & 232.1 & 54.1 & 6.06 \\
\hline TBB $10-05$ & 5 & 20.78 & 231.4 & 57.2 & 6.55 \\
\hline TBB10-07 & 7 & 20.75 & & & 7.06 \\
\hline ТВВ $10-09$ & 9 & 22.52 & 122.9 & 61.7 & 6.00 \\
\hline TBB10-11 & 11 & 19.71 & 200.6 & 59 & 5.46 \\
\hline TBB $10-13$ & 13 & 30.59 & 295.1 & 60.8 & 5.43 \\
\hline TBB10-15 & 15 & 25.80 & 292.8 & 63 & 5.75 \\
\hline TBB10-17 & 17 & 29.08 & 277.4 & 63.3 & 5.80 \\
\hline TBB11-03 & $\overline{3}$ & 18.96 & 277.5 & 58.3 & 6.04 \\
\hline TBB11-05 & 5 & 20.49 & 143.6 & 60.9 & 6.64 \\
\hline TBB11-07 & 7 & 26.22 & 130.5 & 64.3 & 6.79 \\
\hline TBB11-09 & 9 & 21.04 & 252.0 & 64.8 & 5.12 \\
\hline TBB11-11 & 11 & 19.97 & & & 5.54 \\
\hline TBB $11-13$ & 13 & 26.56 & 342.6 & 67.5 & 5.71 \\
\hline TBB $11-15$ & 15 & 28.83 & 391.6 & 66.6 & 5.74 \\
\hline TBB $11-17$ & 17 & 24.13 & 315.9 & 66 & 5.80 \\
\hline TBB12-03 & 3 & 21.86 & 326.1 & 57.4 & 5.14 \\
\hline TBB12-05 & 5 & 26.09 & 286.6 & 60.9 & 7.14 \\
\hline TBB12-07 & 7 & 20.28 & 261.0 & 64.3 & 5.85 \\
\hline TBB 12-09 & 9 & 21.45 & 175.8 & 65.3 & 6.68 \\
\hline TBB12-11 & 11 & 20.08 & 44.9 & 63 & 6.35 \\
\hline TBB12-13 & 13 & 25.71 & 295.8 & 64 & 5.35 \\
\hline TBB12-15 & 15 & 22.37 & 302.2 & 63.9 & 5.29 \\
\hline TBB12-17 & 17 & 26.76 & 306.0 & 63.5 & 5.24 \\
\hline TBB13-03 & 3 & 21.01 & 301.2 & 57.5 & 5.06 \\
\hline TBB13-05 & 5 & 18.11 & 321.2 & 61.8 & 6.11 \\
\hline TBB13-07 & 7 & 24.96 & 288.9 & 63.7 & 6.87 \\
\hline TBB13-09 & 9 & 21.08 & 127.0 & 63.2 & 6.17 \\
\hline TBB13-11 & 11 & 18.73 & 170.1 & 61.7 & 5.76 \\
\hline TBB13-13 & 13 & 23.04 & 293.1 & 63.5 & 5.55 \\
\hline TBB13-15 & 15 & 25.64 & 362.6 & 60.4 & 5.34 \\
\hline TBB13-17 & 17 & 27.18 & 322.5 & 60.8 & 5.27 \\
\hline
\end{tabular}

Blank table entry indicates measurement not taken. 
Table D.3 VOC concentration in soil with depth within Test Cell A following treatment (December 1996).

\begin{tabular}{|c|c|c|c|c|c|c|}
\hline Sample ID & $\begin{array}{r}\text { Depth } \\
\text { (ft bgs) }\end{array}$ & $\begin{array}{c}\text { cis-1,2-DCE } \\
(\mathrm{ug} / \mathrm{kg})\end{array}$ & $\begin{array}{c}1,1,1-\mathrm{TCA} \\
\text { (ug/kg) }\end{array}$ & $\begin{array}{c}\text { TCE } \\
\text { (ug/kg) }\end{array}$ & $\begin{array}{c}\mathrm{PCE} \\
\text { (ug/kg) } \\
\end{array}$ & $\begin{array}{c}\text { Total VOCs } \\
\text { (ug/kg) }\end{array}$ \\
\hline ТАВ $9-01$ & 1 & & & 6 & & 6 \\
\hline TAB9-02 & 2 & & & 6 & & 6 \\
\hline TAB9-03 & 3 & & & 3 & & 3 \\
\hline TAB9-04 & 4 & & 1 & 2 & & 3 \\
\hline TAB9-05 & 5 & & 1 & 4 & & 5 \\
\hline TAB9-06 & 6 & & & 2 & & 2 \\
\hline TAB9-07 & 7 & & & 1 & & 1 \\
\hline TAB9-08 & 8 & & 1 & 1 & & 2 \\
\hline TAB9-09 & 9 & & & 2 & & 2 \\
\hline TAB9-10 & 10 & & 1 & 8 & & 9 \\
\hline ТАВ9-11 & 11 & & & 1 & & 1 \\
\hline TAB9-12 & 12 & & 1 & 1 & & 2 \\
\hline TAB9-13 & 13 & & & 3 & & 3 \\
\hline TAB9-14 & 14 & & & 1 & & 1 \\
\hline TAB9-15 & 15 & & & 1 & & 1 \\
\hline TAB9-16 & 16 & & & 2 & & 2 \\
\hline TAB9-17 & 17 & & 1 & 20 & & 21 \\
\hline
\end{tabular}

Blank table entry is a non detect. 
Table D.4 VOC concentrations in soil with depth in Test Cell B following treatment (December 1996).

\begin{tabular}{|c|c|c|c|c|c|c|}
\hline Sample ID & $\begin{array}{c}\text { Depth } \\
\text { (ft bgs) }\end{array}$ & $\begin{array}{c}\text { cis } 1,2-D C E \\
\text { (ug/kg) }\end{array}$ & $\begin{array}{c}1,1,1-\mathrm{TCA} \\
(\mathrm{ug} / \mathrm{kg})\end{array}$ & $\begin{array}{c}\text { TCE } \\
(\mathrm{ug} / \mathrm{kg})\end{array}$ & $\begin{array}{c}\mathrm{PCE} \\
\text { (ug/kg) }\end{array}$ & $\begin{array}{c}\text { Total VOCs } \\
(\mathrm{ug} / \mathrm{kg})\end{array}$ \\
\hline TBB8-01 & 1 & & & 8 & & 8 \\
\hline TBB8-02 & 2 & & & 2 & & 2 \\
\hline TBB8-03 & 3 & & 1 & 8 & & 9 \\
\hline TBB8-04 & 4 & & & 2 & & 2 \\
\hline TBB8-05 & 5 & & & 69 & & 69 \\
\hline TBB8-06 & 6 & & & 99 & & 99 \\
\hline TBB8-07 & 7 & & 1 & 90 & & 91 \\
\hline TBB8-08 & 8 & & & 1423 & & 1423 \\
\hline TBB8-09 & 9 & 695 & & 253 & & 948 \\
\hline TBB8-10 & 10 & & & 75 & & 75 \\
\hline TBB8-11 & 11 & & & 91 & & 91 \\
\hline TBB8-12 & 12 & & & 102 & & 102 \\
\hline TBB8-13 & 13 & & & 25 & & 25 \\
\hline TBB8-14 & 14 & & & 26 & & 26 \\
\hline TBB8-15 & 15 & & 1 & 11 & & 12 \\
\hline TBB8-16 & 16 & & & 5 & & 5 \\
\hline TBB8-17 & 17 & & & 3 & & 3 \\
\hline TBB9-01 & 1 & & & 7 & & 7 \\
\hline ТВB9-02 & 2 & & & & & \\
\hline TBB9-03 & 3 & & & & & \\
\hline TBB9-04 & 4 & & & & & \\
\hline TBB9-05 & 5 & & & 2 & & 2 \\
\hline TBB9-06 & 6 & & & 16 & & 16 \\
\hline TBB9-07 & 7 & & & 22 & & 22 \\
\hline TBB9-08 & 8 & & & 5 & & 5 \\
\hline ТВB9-09 & 9 & & & 15 & & 15 \\
\hline TBB9-10 & 10 & & 1 & 41 & & 42 \\
\hline TBB9-11 & 11 & & & 9 & & 9 \\
\hline TBB9-12 & 12 & & & 1 & & 1 \\
\hline TBB9-13 & 13 & & & 1 & & 1 \\
\hline TBB9-14 & 14 & & 2 & 4 & & 6 \\
\hline TBB9-15 & 15 & & & 1 & & 1 \\
\hline TBB9-16 & 16 & & & 2 & & 2 \\
\hline TBB9-17 & 17 & & & 1 & & 1 \\
\hline
\end{tabular}


Table D.4 cont. VOC concentrations in soil with depth in Test Cell B following treatment (December 1996).

\begin{tabular}{|c|c|c|c|c|c|c|}
\hline Sample ID & $\begin{array}{c}\text { Depth } \\
\text { (ft bgs) }\end{array}$ & $\begin{array}{c}\text { cis 1,2-DCE } \\
\text { (ug/kg) }\end{array}$ & $\begin{array}{c}1,1,1-\mathrm{TCA} \\
\text { (ug/kg) }\end{array}$ & $\begin{array}{c}\text { TCE } \\
\text { (ug/kg) }\end{array}$ & $\begin{array}{c}\text { PCE } \\
\text { (ug/kg) }\end{array}$ & $\begin{array}{c}\text { Total VOCs } \\
\text { (ug/kg) }\end{array}$ \\
\hline TBB10-01 & 1 & & & 3 & & 3 \\
\hline TBB10-02 & 2 & & & 1 & & 1 \\
\hline TBB10-03 & 3 & & & & & \\
\hline TBB10-04 & 4 & & & & & \\
\hline TBB10-05 & 5 & & 2 & 3 & & 3 \\
\hline TBB10-06 & 6 & & & & & \\
\hline TBB10-07 & 7 & & & 4 & & 2 \\
\hline TBB10-08 & 8 & & & 9 & & 5 \\
\hline TBB10-09 & 9 & & & 3 & & 3 \\
\hline TBB10-10 & 10 & & & 1 & & 1 \\
\hline TBB10-11 & 11 & & & & & \\
\hline TBB10-12 & 12 & & & & & \\
\hline TBB10-13 & 13 & & & 2 & & 1 \\
\hline TBB10-14 & 14 & & & 3 & & 3 \\
\hline TBB10-15 & 15 & & & 1 & & 1 \\
\hline TBB10-16 & 16 & 11 & & 1 & & 16 \\
\hline TBB10-17 & 17 & & & & & \\
\hline TBB11-01 & 1 & 64 & & 11 & & 75 \\
\hline TBB11-02 & 2 & & & 1 & & 1 \\
\hline TBB11-03 & 3 & & 1 & 1 & & 2 \\
\hline TBB11-04 & 4 & & 1 & & & 1 \\
\hline TBB11-05 & 5 & & & 195 & & 195 \\
\hline TBB11-06 & 6 & & & 304 & & 304 \\
\hline TBB11-07 & 7 & & 1 & 479 & & 480 \\
\hline TBB11-08 & 8 & 96 & 1 & 270 & & 367 \\
\hline TBB11-09 & 9 & 106 & 1 & 81 & & 188 \\
\hline TBB $11-10$ & 10 & 96 & 1 & 210 & & 307 \\
\hline TBB11-11 & 11 & & 1 & 628 & & 629 \\
\hline TBB11-12 & 12 & & 1 & 158 & & 159 \\
\hline TBB11-13 & 13 & & 1 & 48 & & 49 \\
\hline TBB11-14 & 14 & & & 10 & & 10 \\
\hline TBB11-15 & 15 & & & 3 & & 3 \\
\hline TBB11-16 & 13 & & & 1 & & 1 \\
\hline TBB 11-17 & 17 & & & 3 & & 3 \\
\hline
\end{tabular}

D - 5 
Table D.4 cont. VOC concentrations in soil with depth in Test Cell B following treatment (December 1996).

\begin{tabular}{|c|c|c|c|c|c|c|}
\hline Sample ID & $\begin{array}{r}\text { Depth } \\
\text { (ft bgs) } \\
\end{array}$ & $\begin{array}{c}\text { cis 1,2-DCE } \\
\text { (ug/kg) }\end{array}$ & $\begin{array}{c}1,1,1-\mathrm{TCA} \\
(\mathrm{ug} / \mathrm{kg})\end{array}$ & $\begin{array}{c}\text { TCE } \\
\text { (ug/kg) }\end{array}$ & $\begin{array}{c}\mathrm{PCE} \\
\text { (ug/kg) }\end{array}$ & $\begin{array}{l}\text { Total VOCs } \\
\text { (ug/kg) }\end{array}$ \\
\hline TBB12-01 & 1 & & & 1 & & 1 \\
\hline TBB12-02 & 2 & & & 1 & & 1 \\
\hline TBB12-03 & 3 & & & 5 & & 5 \\
\hline TBB12-04 & 4 & & & 4 & & 4 \\
\hline TBB12-05 & 5 & & & 22 & & 22 \\
\hline TBB12-06 & 6 & & & 162 & & 162 \\
\hline TBB12-07 & 7 & & 1 & 304 & & 305 \\
\hline TBB12-08 & 8 & & & 488 & & 488 \\
\hline ТВB12-09 & 9 & & 1 & 460 & & 461 \\
\hline TBB12-10 & 10 & & & 429 & & 429 \\
\hline TBB12-11 & 11 & & & 2 & & 2 \\
\hline TBB12-12 & 12 & & & 3 & & 3 \\
\hline TBB12-13 & 13 & & & 5 & & 5 \\
\hline TBB12-14 & 14 & & & 4 & & 4 \\
\hline TBB12-15 & 15 & & & 3 & & 3 \\
\hline TBB12-16 & 16 & & & 8 & & 8 \\
\hline TBB12-17 & 17 & & 1 & 16 & & 17 \\
\hline TBB13-01 & 1 & & & 5 & & 5 \\
\hline TBB13-02 & 2 & & & 62 & & 62 \\
\hline TBB13-03 & 3 & & & 50 & & 50 \\
\hline TBB13-04 & 4 & & & 180 & & 180 \\
\hline TBB13-05 & 5 & & & & & \\
\hline TBB13-06 & 6 & & 1 & 7983 & & 7984 \\
\hline TBB13-07 & 7 & 38 & 7 & 27519 & 8 & 27553 \\
\hline TBB13-08 & 8 & 32 & 9 & 27716 & 16 & 27773 \\
\hline TBB13-09 & 9 & & 6 & 31669 & 18 & 31693 \\
\hline TBB13-10 & 10 & & & 38140 & 22 & 38162 \\
\hline TBB13-11 & 11 & & & 9006 & 1 & 9006 \\
\hline TBB13-12 & 12 & & & 4349 & & 4349 \\
\hline TBB13-13 & 13 & 28 & & 2928 & & 2956 \\
\hline TBB13-14 & 14 & & & 912 & & 912 \\
\hline TBB13-15 & 15 & & 2 & 469 & & 471 \\
\hline TBB13-16 & 16 & & 4 & 54 & & 58 \\
\hline TBB 13-17 & 17 & & 3 & 47 & & 50 \\
\hline
\end{tabular}

Blank table entry is a non detect. 
Table D.5 Total VOC \% reduction in soil, test cell A, fall 1996.

\begin{tabular}{cccc}
\hline & \multicolumn{2}{c}{ Total VOCs in ug/kg } & \% Reduction \\
Depth & TAB1 & TBA9 & TAB1/TAB9 \\
\hline 1 & 18.34 & 5.65 & $69.19 \%$ \\
\hline 2 & 19.27 & 5.70 & $70.41 \%$ \\
\hline 3 & 16.46 & 3.09 & $81.24 \%$ \\
\hline 4 & 17.11 & 3.49 & $79.61 \%$ \\
\hline 5 & 9.35 & 4.99 & $46.63 \%$ \\
\hline 6 & 9.62 & 2.26 & $76.52 \%$ \\
\hline 7 & 7.84 & 0.73 & $90.73 \%$ \\
\hline 8 & 6.36 & 1.80 & $71.70 \%$ \\
\hline 9 & 5.76 & 2.32 & $59.73 \%$ \\
\hline 10 & 8.24 & 9.86 & $-19.69 \%$ \\
\hline 11 & 8.73 & 0.73 & $91.65 \%$ \\
\hline 12 & 7.54 & 1.72 & $77.26 \%$ \\
\hline 13 & 9.72 & 3.06 & $68.53 \%$ \\
\hline 14 & - & 0.72 & ND \\
\hline 15 & 13.56 & 1.44 & $89.37 \%$ \\
\hline 16 & 7.88 & 1.97 & $75.05 \%$ \\
\hline 17 & 6.44 & 20.97 & $-225.66 \%$ \\
\hline
\end{tabular}

ND - not determined, no pre-test soil sample collected and analyzed.

Notes: \% Reduction in VOC determined from pre-test soil concentrations and post-test soil concentrations. Only one post location was sampled at test cell A. 
Table D.6 Total VOC \% reduction in soil, test cell B, fall 1996.

\begin{tabular}{ccccccc}
\hline $\begin{array}{c}\text { depth } \\
\text { (ft bgs) }\end{array}$ & \multicolumn{7}{c}{ \% Reduction in Soil VOCs (total) } \\
\cline { 2 - 7 } & $\begin{array}{c}\text { TBB1/ } \\
\text { TBB8 }\end{array}$ & $\begin{array}{c}\text { TBB2/ } \\
\text { TBB10 }\end{array}$ & $\begin{array}{c}\text { TBB3/ } \\
\text { TBB9 }\end{array}$ & $\begin{array}{c}\text { TBB4/ } \\
\text { TBB12 }\end{array}$ & $\begin{array}{c}\text { TBB5/ } \\
\text { TBB11 }\end{array}$ & $\begin{array}{c}\text { TBB6/ } \\
\text { TBB13 }\end{array}$ \\
\hline 1 & 31.85 & 60.79 & -44.32 & 98.77 & -47.58 & 89.13 \\
\hline 2 & 73.23 & 94.32 & ND & 95.43 & 95.00 & 91.98 \\
\hline 3 & 65.86 & 100.00 & 100.00 & 93.05 & 95.96 & 92.97 \\
\hline 4 & 96.15 & 100.00 & 100.00 & 94.90 & 98.55 & 91.88 \\
\hline 5 & 30.34 & ND & 83.66 & 88.31 & -6.10 & ND \\
\hline 6 & 71.97 & 100.00 & 60.28 & 82.24 & 38.18 & 25.13 \\
\hline 7 & 85.40 & 55.47 & 87.61 & 73.85 & 31.76 & -36.39 \\
\hline 8 & 6.36 & 41.34 & 98.44 & 80.98 & 88.43 & 13.72 \\
\hline 9 & 69.79 & 60.28 & 95.21 & ND & 94.98 & -57.88 \\
\hline 10 & 91.83 & 85.78 & 65.12 & ND & 87.18 & -60.02 \\
\hline 11 & 84.93 & ND & 70.73 & 96.32 & -48.50 & -5.31 \\
\hline 12 & 15.27 & ND & 87.79 & 90.67 & 53.73 & -12.85 \\
\hline 13 & 43.00 & 75.62 & 93.76 & 29.70 & 56.61 & -66.47 \\
\hline 14 & 97.00 & 68.76 & 75.38 & ND & 74.08 & -49.78 \\
\hline 15 & -19.34 & 92.94 & 95.63 & 35.69 & 98.04 & -249.84 \\
\hline 16 & 34.29 & ND & 99.43 & 37.08 & 85.48 & -26.91 \\
\hline 17 & 63.92 & 100.00 & 90.35 & -3.30 & 44.65 & -16.79 \\
\hline
\end{tabular}

ND - not determined, no pre- or post-test soil sample collected and analyzed.

Notes: \% Reduction in VOC determined from 1996 pre-test soil concentrations and post-test soil concentrations. Column headings indcate pre/post soil sample locations. The negative $\%$ reductions (i.e, increase in concentration) at TBB6/TBB13 from 13 to $15 \mathrm{ft}$ bgs are attributed to ground water contamination and the proximity of the sample locations to the free phase observed in piezometer (BGP3) located nearby to the southwest. 
Table D.7 Test Cell A, off-gas monitoring at A4 (4 ft fracture).

\begin{tabular}{|c|c|c|c|c|c|c|c|c|}
\hline Date & $\begin{array}{c}\text { Time of } \\
\text { day }\end{array}$ & $\begin{array}{c}\text { Elapsed } \\
\text { time (hrs) }\end{array}$ & $\begin{array}{c}\text { DAS } \\
\text { (ppmv) }\end{array}$ & $\begin{array}{c}\text { FID } \\
\text { (ppmv) }\end{array}$ & $\begin{array}{l}\mathrm{CH}_{4} \\
(\%)\end{array}$ & $\begin{array}{l}\mathrm{CO}_{2} \\
(\%)\end{array}$ & $\begin{array}{l}\mathrm{O}_{2} \\
(\%)\end{array}$ & $\begin{array}{l}\text { Pressure } \\
\text { (in. } \mathrm{H}_{2} \mathrm{O} \text { ) } \\
\end{array}$ \\
\hline \multirow[t]{4}{*}{$10 / 19 / 96$} & $14: 30$ & $\overline{0}$ & & 4040 & & & & \\
\hline & $15: 30$ & 1 & 3500 & 3510 & & & & \\
\hline & $17: 30$ & 3 & 5090 & 5090 & & & & \\
\hline & 23:00 & 9 & 2650 & 2630 & 0 & 8.4 & 15.1 & 986 \\
\hline \multirow[t]{2}{*}{$10 / 20 / 96$} & $9: 00$ & 19 & 770 & 750 & 0.1 & 7.1 & 16.8 & $\overline{989}$ \\
\hline & $17: 00$ & 27 & & & & & & \\
\hline $10 / 22 / 96$ & $14: 30$ & 72 & 127.6 & 290 & & & & \\
\hline \multirow[t]{2}{*}{$10 / 23 / 96$} & $10: 15$ & 92 & 185.5 & 470 & & & & \\
\hline & $16: 30$ & 98 & 193 & 490 & 0 & 3.3 & 15.6 & \\
\hline \multirow[t]{2}{*}{$10 / 24 / 96$} & $9: 15$ & 115 & 440 & 450 & 0 & 3 & 16.2 & \\
\hline & $16: 30$ & 122 & 330 & 350 & 0 & 3.1 & 16.2 & 400 \\
\hline \multirow[t]{2}{*}{$10 / 25 / 96$} & $9: 00$ & 139 & 181.2 & 200 & 0 & 3.2 & 16.2 & $\overline{402}$ \\
\hline & $18: 00$ & 148 & 120.4 & 120 & & & & \\
\hline \multirow[t]{2}{*}{$10 / 26 / 96$} & $9: 00$ & 163 & 150.9 & 140 & 0 & 2 & 18.8 & 401 \\
\hline & $17: 30$ & 171 & 109.8 & 100 & & & & \\
\hline \multirow[t]{2}{*}{$10 / 27 / 96$} & $9: 30$ & 187 & & & & & & \\
\hline & $17: 30$ & 195 & 133.6 & 120 & & & & \\
\hline \multirow[t]{2}{*}{$10 / 28 / 96$} & $7: 30$ & 209 & 148.9 & 140 & 0 & 2.3 & 17.2 & 399 \\
\hline & $17: 30$ & 219 & 210.6 & 200 & 0 & 2.3 & 17.5 & 398 \\
\hline $10 / 29 / 96$ & $19: 15$ & 245 & 402 & 380 & $\overline{0}$ & 2.5 & 16.6 & 395 \\
\hline \multirow[t]{2}{*}{$10 / 30 / 96$} & $8: 00$ & 258 & 159.4 & 160 & 0 & 2.6 & 17 & $\overline{393}$ \\
\hline & $17: 45$ & 268 & 152.1 & 140 & & & & \\
\hline \multirow[t]{2}{*}{$10 / 31 / 96$} & $7: 45$ & 282 & 139.2 & 130 & 0 & 2.7 & 16.7 & 400 \\
\hline & $18: 30$ & 292 & 129.8 & 120 & 0 & 2.5 & 17.4 & 398 \\
\hline $11 / 1 / 96$ & $7: 45$ & 305 & 114.5 & 110 & 0 & 2.5 & 17.2 & 398 \\
\hline \multirow[t]{2}{*}{$11 / 4 / 96$} & $9: 00$ & 378 & 88.1 & 110 & 0 & 1.9 & 17.5 & 402 \\
\hline & $16: 30$ & 385 & 122.7 & 120 & 0 & 2 & 17.3 & 400 \\
\hline $11 / 5 / 96$ & $9: 00$ & 402 & 137.5 & 140 & 1.3 & 2 & 17.5 & 400 \\
\hline $11 / 6 / 96$ & $8: 00$ & 426 & & & 0.7 & 2.2 & 16.6 & 434 \\
\hline $11 / 7 / 96$ & $8: 30$ & 450 & & & 0 & 1.4 & 18.5 & 415 \\
\hline $11 / 8 / 96$ & $8: 00$ & 474 & & & 0 & 1.7 & 16.7 & 418 \\
\hline $11 / 8 / 96$ & $18: 45$ & 484 & 138.4 & 120 & 0 & 2 & 15.6 & 395 \\
\hline \multirow[t]{2}{*}{$11 / 9 / 96$} & $8: 30$ & 498 & 175.2 & 170 & 0.7 & 2 & 15.5 & 396 \\
\hline & $18: 15$ & 508 & 551 & 560 & 0.1 & 2 & 16.3 & 398 \\
\hline \multirow[t]{2}{*}{$11 / 10 / 96$} & $8: 15$ & 522 & 304.6 & 290 & 0 & 1.9 & 16.6 & 399 \\
\hline & $17: 30$ & 531 & 255.8 & 270 & 0 & 1.9 & 16.5 & 400 \\
\hline
\end{tabular}


Table D.7 cont. Test Cell A, off-gas monitoring at A4 (4 ft fracture).

\begin{tabular}{|c|c|c|c|c|c|c|c|c|}
\hline$\overline{\text { Date }}$ & $\begin{array}{c}\text { Time of } \\
\text { day }\end{array}$ & $\begin{array}{c}\text { Elapsed } \\
\text { time (hrs) }\end{array}$ & $\begin{array}{c}\text { DAS } \\
\text { (ppmv) }\end{array}$ & $\begin{array}{c}\text { FID } \\
\text { (ppmv) }\end{array}$ & $\begin{array}{l}\mathrm{CH}_{4} \\
(\%)\end{array}$ & $\begin{array}{l}\mathrm{CO}_{2} \\
(\%)\end{array}$ & $\begin{array}{l}\mathrm{O}_{2} \\
(\%)\end{array}$ & $\begin{array}{l}\text { Pressure } \\
\left(\text { in. } \mathrm{H}_{2} \mathrm{O} \text { ) }\right.\end{array}$ \\
\hline \multirow[t]{2}{*}{$11 / 11 / 96$} & $10: 00$ & 548 & 150.3 & 150 & $\overline{0}$ & 1.6 & 17.1 & 403 \\
\hline & $16: 30$ & 554 & 117.5 & 120 & 0.8 & 1.7 & 17.2 & 403 \\
\hline \multirow[t]{2}{*}{$11 / 12 / 96$} & $8: 30$ & 570 & 142.1 & 140 & 0 & 2.3 & 15.9 & 406 \\
\hline & $17: 15$ & 579 & 69.2 & 70 & 0 & 1.7 & 17.8 & 406 \\
\hline \multirow[t]{2}{*}{$11 / 13 / 96$} & $8: 30$ & 594 & & & 0 & 1.8 & 18.4 & 406 \\
\hline & $18: 15$ & 604 & & & 0 & 1.4 & 18.9 & 405 \\
\hline \multirow[t]{2}{*}{$11 / 14 / 96$} & $9: 45$ & 619 & & & 0 & 1.4 & 18.8 & 406 \\
\hline & $18: 45$ & 628 & & & 0.4 & 1.4 & 19.4 & 406 \\
\hline $11 / 19 / 96$ & $17: 00$ & 747 & 13.7 & 10 & 0 & 0 & 20.4 & 399 \\
\hline \multirow{2}{*}{$11 / 20 / 96$} & $8: 30$ & 760 & 30.4 & 40 & 0 & 1.6 & 19.3 & 398 \\
\hline & $14: 30$ & 766 & 30.7 & 40 & 0 & 1.6 & 18.9 & 398 \\
\hline \multirow[t]{2}{*}{$11 / 21 / 96$} & $8: 00$ & 782 & 33.2 & 40 & 0 & 1.6 & 18.7 & 397 \\
\hline & $17: 30$ & 791 & 22.7 & 30 & 0 & 1.4 & 18.7 & 398 \\
\hline \multirow[t]{2}{*}{$11 / 22 / 96$} & $8: 00$ & 806 & 51.3 & 30 & 0.1 & 1.3 & 19.1 & 402 \\
\hline & $17: 00$ & 815 & 17.3 & 30 & 0 & 1.2 & 19.4 & 401 \\
\hline \multirow[t]{2}{*}{$11 / 23 / 96$} & $8: 00$ & 830 & 24.6 & 40 & 0 & 1.1 & 19.8 & 400 \\
\hline & $18: 00$ & 840 & 23.6 & 30 & 0 & 1.1 & 19.4 & 398 \\
\hline \multirow[t]{2}{*}{$11 / 24 / 96$} & $8: 00$ & 854 & 21.2 & 30 & 0 & 1.1 & 19.7 & 399 \\
\hline & $16: 30$ & 862 & 25.5 & 30 & 0 & 1.1 & 19.6 & 398 \\
\hline \multirow{2}{*}{$11 / 25 / 96$} & $8: 00$ & 878 & 39.3 & 40 & 0 & 1.1 & 19.8 & 398 \\
\hline & $17: 30$ & 887 & 14.8 & 20 & 0 & 1.1 & 19.3 & 394 \\
\hline \multirow[t]{2}{*}{$11 / 26 / 96$} & $7: 30$ & 901 & 28.5 & 30 & 0 & 1.3 & 18.9 & 398 \\
\hline & $17: 30$ & 911 & 29.7 & 30 & 0 & 1.2 & 18.9 & 402 \\
\hline \multirow{2}{*}{$12 / 2 / 96$} & $11: 00$ & 1049 & 34.7 & 30 & 0 & 1.5 & 18.4 & 398 \\
\hline & $18: 00$ & 1056 & 33.7 & 30 & 0.1 & 1.6 & 18.2 & 398 \\
\hline \multirow[t]{2}{*}{$12 / 3 / 96$} & $8: 30$ & 1070 & 57.7 & 50 & 0.4 & 1.6 & 18.1 & 398 \\
\hline & $16: 30$ & 1078 & 17.1 & 40 & 1 & 0 & 20.5 & 398 \\
\hline \multirow[t]{2}{*}{$12 / 4 / 96$} & $8: 00$ & 1092 & 44.4 & 40 & 0 & 1.5 & 19.1 & 402 \\
\hline & $17: 00$ & 1101 & 30.6 & 30 & 0.1 & 1.5 & 18.9 & 402 \\
\hline \multirow[t]{2}{*}{$12 / 5 / 96$} & $8: 30$ & 1116 & 45.2 & 40 & 0.8 & 1.4 & 18.7 & 398 \\
\hline & $16: 00$ & 1124 & 41.6 & 40 & 0 & 1.4 & 18.9 & 392 \\
\hline $12 / 6 / 96$ & $9: 00$ & 1141 & 36.4 & 30 & 0 & 1.3 & 19 & 396 \\
\hline \multirow[t]{2}{*}{$12 / 7 / 96$} & $7: 30$ & 1163 & 45.1 & 40 & 0 & 1.3 & 18.7 & 394 \\
\hline & $18: 00$ & 1174 & 34.4 & 30 & 0 & 1.3 & 19.1 & 395 \\
\hline \multirow{2}{*}{$12 / 8 / 96$} & $8: 30$ & 1188 & 0 & 30 & 0 & 1.2 & 19 & 394 \\
\hline & $16: 30$ & 1196 & 32.8 & 30 & 0.1 & 1.3 & 18.7 & 396 \\
\hline
\end{tabular}


Table D.7 cont. Test Cell A, off-gas monitoring at A4 (4 ft fracture).

\begin{tabular}{ccccccccr}
\hline Date & $\begin{array}{c}\text { Time of } \\
\text { day }\end{array}$ & $\begin{array}{c}\text { Elapsed } \\
\text { time (hrs) }\end{array}$ & $\begin{array}{c}\text { DAS } \\
(\mathrm{ppmv})\end{array}$ & $\begin{array}{c}\mathrm{FID} \\
(\mathrm{ppmv})\end{array}$ & $\begin{array}{c}\mathrm{CH}_{4} \\
(\%)\end{array}$ & $\begin{array}{c}\mathrm{CO}_{2} \\
(\%)\end{array}$ & $\begin{array}{c}\mathrm{O}_{2} \\
(\%)\end{array}$ & $\begin{array}{c}\text { Pressure } \\
\left(\text { (in. } \mathrm{H}_{2} \mathrm{O}\right)\end{array}$ \\
\hline $12 / 9 / 96$ & $8: 00$ & 1212 & 19 & 20 & 0 & 1.3 & 18.7 & 399 \\
& $18: 00$ & 1222 & & & & & & \\
\hline $12 / 10 / 96$ & $8: 30$ & 1238 & 31.6 & 30 & 0 & 1.1 & 20.1 & 396 \\
& $17: 00$ & 1247 & 16.1 & 30 & & & & \\
\hline $12 / 11 / 96$ & $8: 00$ & 1262 & 45 & 50 & 0 & 1.3 & 19.3 & 394 \\
& $18: 00$ & 1272 & 17.9 & 50 & 0 & 1.2 & 18.8 & 394 \\
\hline
\end{tabular}

Blank table entry indicates measurement not taken.

Table D.8 Test Cell A, off-gas monitoring at A12 (12 ft fracture).

\begin{tabular}{ccccccccc}
\hline Date & $\begin{array}{c}\text { Time of } \\
\text { day }\end{array}$ & $\begin{array}{c}\text { Elapsed } \\
\text { time (hrs) }\end{array}$ & $\begin{array}{c}\text { DAS } \\
(\mathrm{ppmv})\end{array}$ & $\begin{array}{c}\mathrm{FID} \\
(\mathrm{ppmv})\end{array}$ & $\begin{array}{c}\mathrm{CH}_{4} \\
(\%)\end{array}$ & $\begin{array}{c}\mathrm{CO}_{2} \\
(\%)\end{array}$ & $\begin{array}{c}\mathrm{O}_{2} \\
(\%)\end{array}$ & $\begin{array}{c}\text { Pressure } \\
\left(\text { in. } \mathrm{H}_{2} \mathrm{O}\right)\end{array}$ \\
\hline $10 / 19 / 96$ & $14: 30$ & 0 & & 10000 & & & & \\
& $15: 30$ & 1 & 15770 & 10000 & & & & \\
& $17: 30$ & 3 & 29250 & 10000 & & & & \\
& $23: 00$ & 9 & 21020 & 10000 & 0.3 & 4.2 & 20.2 & 986 \\
\hline $10 / 20 / 96$ & $9: 00$ & 19 & 12090 & 10000 & 0.1 & 2.1 & 24.2 & 989 \\
& $17: 00$ & & & & & & & \\
\hline $10 / 22 / 96$ & $14: 30$ & 72 & & 10000 & & & & \\
\hline $10 / 23 / 96$ & $10: 15$ & 92 & 4236 & $\mathrm{NM}$ & & & 21.1 & \\
& $16: 30$ & 98 & 35 & $\mathrm{NM}$ & & & & \\
\hline $10 / 24 / 96$ & $9: 15$ & 115 & 14.5 & $\mathrm{NM}$ & & & 21.1 & \\
& $16: 30$ & 122 & 0 & 4200 & 0 & 0.5 & 20.4 & 398 \\
\hline $10 / 25 / 96$ & $9: 00$ & 139 & 4280 & 4730 & 0.2 & 1.6 & 20.3 & 400 \\
& $18: 00$ & 148 & 4740.1 & 2320 & & & & \\
\hline $10 / 26 / 96$ & $9: 00$ & 163 & 2325 & 7880 & 1 & 2.4 & 19.3 & 401 \\
& $17: 30$ & 171 & 7976.9 & 5240 & 0.4 & 1 & 19.8 & 401 \\
\hline $10 / 27 / 96$ & $9: 30$ & 187 & 5263.4 & 3700 & 0.2 & 1.8 & 17.9 & 402 \\
& $17: 30$ & 195 & 3704.3 & 2820 & & & & \\
\hline $10 / 28 / 96$ & $7: 30$ & 209 & 822 & 2340 & 0 & 0.8 & 20.8 & 399 \\
& $17: 30$ & 219 & 2369.6 & 230 & 0 & 0 & 21.2 & 398 \\
\hline $10 / 29 / 96$ & $19: 15$ & 245 & 214.4 & 9730 & 0.6 & 1.5 & 19.9 & 394 \\
\hline $10 / 30 / 96$ & $8: 00$ & 258 & 9683.2 & 9890 & 1.2 & 3.6 & 16.6 & 393 \\
& $17: 45$ & 268 & 9885.9 & 8210 & & & & \\
\hline
\end{tabular}


Table D.8 cont. Test Cell A, off-gas monitoring at A12 (12 ft fracture).

\begin{tabular}{|c|c|c|c|c|c|c|c|c|}
\hline Date & $\begin{array}{c}\text { Time of } \\
\text { day }\end{array}$ & $\begin{array}{c}\text { Elapsed } \\
\text { time (hrs) }\end{array}$ & $\begin{array}{c}\text { DAS } \\
\text { (ppmv) }\end{array}$ & $\begin{array}{c}\text { FiD } \\
\text { (ppmv) }\end{array}$ & $\begin{array}{l}\mathrm{CH}_{4} \\
(\%)\end{array}$ & $\begin{array}{l}\mathrm{CO}_{2} \\
(\%)^{2}\end{array}$ & $\begin{array}{c}\mathrm{O}_{2} \\
(\%)\end{array}$ & $\begin{array}{l}\text { Pressure } \\
\left.\text { (in. } \mathrm{H}_{2} \mathrm{O}\right)\end{array}$ \\
\hline \multirow{2}{*}{$10 / 31 / 96$} & $7: 45$ & 282 & 8290.1 & 5030 & 0.4 & 3.6 & 16.5 & 399 \\
\hline & $18: 30$ & 292 & 5145.3 & 4530 & 0.2 & 2.8 & 17 & 398 \\
\hline $11 / 1 / 96$ & $7: 45$ & 305 & 4541.2 & 5280 & 0.2 & 2.9 & 17.3 & 398 \\
\hline \multirow[t]{2}{*}{$11 / 4 / 96$} & $9: 00$ & 378 & 5279.6 & 9910 & 1 & 4.1 & 14.4 & 402 \\
\hline & $16: 30$ & 385 & 9883.5 & 100 & 1.3 & 0.8 & 19.8 & 400 \\
\hline $11 / 6 / 96$ & $8: 00$ & 426 & 99.1 & & 0 & 1.5 & 17.5 & 441 \\
\hline $11 / 7 / 96$ & $8: 30$ & 450 & & & 0 & 0 & 20.6 & 397 \\
\hline \multirow[t]{2}{*}{$11 / 8 / 96$} & $8: 00$ & 474 & & 10 & 0 & 0.3 & 19.5 & 434 \\
\hline & $18: 45$ & 484 & 0 & & 0 & 0.7 & 19 & 395 \\
\hline \multirow[t]{2}{*}{$11 / 9 / 96$} & $8: 30$ & 498 & 5.8 & 10 & 1.2 & 0 & 20 & 395 \\
\hline & $18: 15$ & 508 & 3.4 & 10 & 0 & 0 & 20.3 & 397 \\
\hline \multirow[t]{2}{*}{$11 / 10 / 96$} & $8: 15$ & 522 & 142.6 & 120 & 0 & 0.1 & 20.5 & 398 \\
\hline & $17: 30$ & 531 & 444.3 & 380 & 0 & 1.2 & 19.1 & 399 \\
\hline \multirow{2}{*}{$11 / 11 / 96$} & $10: 00$ & 548 & 41.8 & 50 & 0 & 0.1 & 19.9 & 403 \\
\hline & $16: 30$ & 554 & 1431.6 & 1350 & 1.8 & 1.4 & 18.3 & 403 \\
\hline \multirow[t]{2}{*}{$11 / 12 / 96$} & $8: 30$ & 570 & 264.3 & 280 & 0 & 0 & 20.6 & 406 \\
\hline & $17: 15$ & 579 & 1578.6 & 1560 & 0.1 & 1.8 & 18.2 & 405 \\
\hline $11 / 13 / 96$ & $8: 30$ & 594 & & 1160 & 0 & 1.7 & 18.8 & 406 \\
\hline \multirow[t]{2}{*}{$11 / 14 / 96$} & $9: 45$ & 619 & & 350 & 0.3 & 2.2 & 18.2 & 406 \\
\hline & $18: 45$ & 628 & & 960 & 1.2 & 1.8 & 18.9 & 406 \\
\hline $11 / 19 / 96$ & $17: 00$ & 747 & & & & & & \\
\hline \multirow{2}{*}{$11 / 20 / 96$} & $8: 30$ & 760 & & & & & & \\
\hline & $14: 30$ & 766 & 144.7 & 140 & 0 & 0 & 21 & 397 \\
\hline $11 / 21 / 96$ & $\begin{array}{c}8: 00 \\
17: 30\end{array}$ & $\begin{array}{l}782 \\
791\end{array}$ & 236.6 & 240 & 0 & 1 & 19.9 & 397 \\
\hline \multirow[t]{2}{*}{$11 / 22 / 96$} & $8: 00$ & 806 & & & & & & \\
\hline & $17: 00$ & 815 & & & 0 & 0 & 20.8 & 401 \\
\hline \multirow[t]{2}{*}{$11 / 23 / 96$} & $8: 00$ & 830 & & & 0 & 1.2 & 19.7 & 400 \\
\hline & $18: 00$ & 840 & 71.3 & 40 & 0 & 0.2 & 20.8 & 398 \\
\hline \multirow[t]{2}{*}{$11 / 24 / 96$} & $8: 00$ & 854 & & & 0 & 1 & 20.9 & 399 \\
\hline & $16: 30$ & 862 & 299.3 & 30 & 0 & 1.2 & 19.7 & 398 \\
\hline \multirow[t]{2}{*}{$11 / 25 / 96$} & $8: 00$ & 878 & 418.3 & 420 & 0 & 1.3 & 19.4 & 398 \\
\hline & $17: 30$ & 887 & 78.7 & 80 & 0 & 1.1 & 20 & 394 \\
\hline \multirow[t]{2}{*}{$11 / 26 / 96$} & $7: 30$ & 901 & 82 & 110 & 0 & 0.8 & 20.9 & 398 \\
\hline & $17: 30$ & 911 & 280.4 & 240 & 0 & 1.2 & 19.2 & 402 \\
\hline
\end{tabular}


Table D.8 cont. Test Cell A, off-gas monitoring at A12 (12 ft fracture).

\begin{tabular}{ccccccccc}
\hline Date & $\begin{array}{c}\text { Time of } \\
\text { day }\end{array}$ & $\begin{array}{c}\text { Elapsed } \\
\text { time (hrs) }\end{array}$ & $\begin{array}{c}\text { DAS } \\
(\mathrm{ppmv})\end{array}$ & $\begin{array}{c}\mathrm{FID} \\
(\mathrm{ppmv})\end{array}$ & $\begin{array}{c}\mathrm{CH}_{4} \\
(\%)\end{array}$ & $\begin{array}{c}\mathrm{CO}_{2} \\
(\%)\end{array}$ & $\begin{array}{c}\mathrm{O}_{2} \\
(\%)\end{array}$ & $\begin{array}{c}\text { Pressure } \\
\left(\text { in. } \mathrm{H}_{2} \mathrm{O}\right)\end{array}$ \\
\hline $12 / 2 / 96$ & $11: 00$ & 1049 & 54.2 & 50 & 0 & 0 & 21.1 & 398 \\
& $18: 00$ & 1056 & 269.8 & 240 & 0.1 & 0.9 & 19.7 & 398 \\
\hline $12 / 3 / 96$ & $8: 30$ & 1070 & 310.3 & 310 & 0.7 & 1.3 & 19 & 397 \\
& $16: 30$ & 1078 & 863 & 860 & 1.9 & 0 & 20.6 & 398 \\
\hline $12 / 4 / 96$ & $8: 00$ & 1092 & 604 & 610 & 0.1 & 1.9 & 18.8 & 402 \\
& $17: 00$ & 1101 & 812.9 & 790 & 0.2 & 1.9 & 18.6 & 401 \\
\hline $12 / 5 / 96$ & $8: 30$ & 1116 & 833.7 & 770 & 1.6 & 0 & 21.2 & 396 \\
& $16: 00$ & 1124 & 19.9 & 10 & 0 & 0 & 20.9 & 392 \\
\hline $12 / 6 / 96$ & $9: 00$ & 1141 & 0 & 0 & 0 & 0 & 20.9 & 396 \\
\hline $12 / 7 / 96$ & $7: 30$ & 1163 & 47.7 & 40 & 0 & 0 & 20.8 & 395 \\
& $18: 00$ & 1174 & 1020.9 & 1000 & 0 & 1.9 & 18.2 & 395 \\
\hline $12 / 8 / 96$ & $8: 30$ & 1188 & 698.7 & 720 & 0 & 1.9 & 18.3 & 395 \\
& $16: 30$ & 1196 & 583 & 590 & 0.2 & 1.9 & 17.9 & 396 \\
\hline $12 / 9 / 96$ & $8: 00$ & 1212 & 822.5 & 860 & 0.1 & 2.3 & 17.6 & 400 \\
& $18: 00$ & 1222 & $\mathrm{NM}$ & $\mathrm{NM}$ & $\mathrm{NM}$ & $\mathrm{NM}$ & $\mathrm{NM}$ & $\mathrm{NM}$ \\
\hline $12 / 10 / 96$ & $8: 30$ & 1238 & 321.7 & 330 & 0 & 0.5 & 20.7 & 396 \\
& $17: 00$ & 1247 & 241.5 & 240 & 0 & 0.5 & 20.7 & 394 \\
\hline $12 / 11 / 96$ & $8: 00$ & 1262 & 43 & 50 & 0 & 0 & 21.5 & 393 \\
& $18: 00$ & 1272 & 5.8 & 30 & 0 & 0 & 21 & 394 \\
\hline
\end{tabular}

Blank table entry indicates measurement not taken.

Table D.9 Test Cell B, off-gas monitoring at B4 (4 ft fracture).

\begin{tabular}{cccrrrrrr}
\hline Date & $\begin{array}{c}\text { Time of } \\
\text { day }\end{array}$ & $\begin{array}{c}\text { Elapsed } \\
\text { time (hrs) }\end{array}$ & $\begin{array}{c}\text { DAS } \\
(\mathrm{ppmv})\end{array}$ & $\begin{array}{c}\text { FID } \\
(\mathrm{ppmv})\end{array}$ & $\begin{array}{c}\mathrm{CH}_{4} \\
(\%)\end{array}$ & $\begin{array}{c}\mathrm{CO}_{2} \\
(\%)\end{array}$ & $\begin{array}{c}\mathrm{O}_{2} \\
(\%)\end{array}$ & $\begin{array}{c}\text { Pressure } \\
\left(\text { in. } \mathrm{H}_{2} \mathrm{O}\right)\end{array}$ \\
\hline $10 / 19 / 96$ & $14: 30$ & 0 & 3850 & 3830 & & & & \\
& $15: 30$ & 1 & 2550 & 2530 & & & & \\
& $17: 30$ & 3 & 3140 & 3130 & & & & \\
& $23: 00$ & 9 & 2940 & 2920 & 0 & 3.9 & 19.6 & 986 \\
\hline $10 / 20 / 96$ & $9: 00$ & 19 & 13900 & 13600 & 0.1 & 3.5 & 21.2 & 989 \\
& $17: 00$ & 27 & 1080 & 1050 & 0 & 3.6 & 21.1 & 987 \\
\hline $10 / 22 / 96$ & $14: 30$ & 72 & 392 & 1180 & & & & \\
\hline $10 / 23 / 96$ & $10: 15$ & 92 & 364 & 1070 & & & & \\
& $16: 30$ & 98 & 343 & 1000 & 0 & 1.9 & 18.4 & \\
\hline
\end{tabular}


Table D.9 cont. Test Cell B, off-gas monitoring at B4 (4 ft fracture).

\begin{tabular}{|c|c|c|c|c|c|c|c|c|}
\hline Date & $\begin{array}{c}\text { Time of } \\
\text { day }\end{array}$ & $\begin{array}{c}\text { Elapsed } \\
\text { time (hrs) }\end{array}$ & $\begin{array}{c}\text { DAS } \\
\text { (ppmv) }\end{array}$ & $\begin{array}{c}\text { FID } \\
\text { (ppmv) }\end{array}$ & $\begin{array}{l}\mathrm{CH}_{4} \\
(\%)\end{array}$ & $\begin{array}{l}\mathrm{CO}_{2} \\
(\%)^{2}\end{array}$ & $\begin{array}{l}\mathrm{O}_{2} \\
(\%)\end{array}$ & $\begin{array}{l}\text { Pressure } \\
\text { (in. } \mathrm{H}_{2} \mathrm{O} \text { ) }\end{array}$ \\
\hline \multirow[t]{2}{*}{$10 / 24 / 96$} & $9: 15$ & 115 & 800 & 820 & 0 & 1.7 & 18.6 & \\
\hline & $16: 30$ & 122 & 700 & 720 & 0 & 1.7 & 18.8 & 400 \\
\hline \multirow[t]{2}{*}{$10 / 25 / 96$} & $9: 00$ & 139 & 268.6 & 280 & 0 & 1.6 & 19.5 & 401 \\
\hline & $18: 00$ & 148 & 265.2 & 270 & & & & \\
\hline \multirow[t]{2}{*}{$10 / 26 / 96$} & $9: 00$ & 163 & 199.4 & 200 & 0 & 1.7 & 19.4 & 401 \\
\hline & $17: 30$ & 171 & 272.8 & 280 & 0 & 1.5 & 19 & 402 \\
\hline \multirow[t]{2}{*}{$10 / 27 / 96$} & $9: 30$ & 187 & 262.7 & 280 & 0 & 1.5 & 18.9 & $\overline{402}$ \\
\hline & $17: 30$ & 195 & & & & & & \\
\hline \multirow[t]{2}{*}{$10 / 28 / 96$} & $7: 30$ & 209 & 270.1 & 260 & 0 & 1.5 & 19 & 399 \\
\hline & $17: 30$ & 219 & 267.1 & 250 & 0 & 1.5 & 19.2 & 398 \\
\hline $10 / 29 / 96$ & $19: 15$ & 245 & 218.4 & 220 & & & & \\
\hline \multirow[t]{2}{*}{$10 / 30 / 96$} & $8: 00$ & 258 & 195.4 & 190 & $\overline{0}$ & 1.5 & 19.1 & $\overline{392}$ \\
\hline & $17: 45$ & 268 & 157.9 & 150 & & & & \\
\hline \multirow[t]{2}{*}{$10 / 31 / 96$} & $7: 45$ & 282 & 143.6 & 140 & 0 & 1.2 & 19 & 399 \\
\hline & $18: 30$ & 292 & 131.2 & 120 & 0 & 1 & 19.7 & 398 \\
\hline $11 / 1 / 96$ & $7: 45$ & 305 & 121.6 & 110 & 0 & 1 & 19.8 & 398 \\
\hline \multirow[t]{2}{*}{$11 / 4 / 96$} & $9: 00$ & 378 & 76.6 & 90 & 0 & 1 & 19.1 & 402 \\
\hline & $16: 30$ & 385 & 12.2 & 10 & 0.3 & 0.1 & 20.8 & 400 \\
\hline $11 / 5 / 96$ & $9: 00$ & 402 & 1.9 & 10 & & & & \\
\hline $11 / 6 / 96$ & $8: 00$ & 426 & & & 0 & 0 & 20.1 & 438 \\
\hline $11 / 7 / 96$ & $8: 30$ & 450 & & & 0 & 0 & 20.5 & 430 \\
\hline $11 / 8 / 96$ & $8: 00$ & 474 & & & 0 & 0.1 & 19.9 & 420 \\
\hline $11 / 8 / 96$ & $18: 45$ & 484 & $\overline{0}$ & 0 & 0 & 0.1 & 20.1 & 395 \\
\hline \multirow[t]{2}{*}{$11 / 9 / 96$} & $8: 30$ & 498 & 8.2 & 10 & 1 & 0.1 & 19.8 & 396 \\
\hline & $18: 15$ & 508 & 5.6 & 10 & 0 & 0.1 & 20 & 398 \\
\hline \multirow[t]{2}{*}{$11 / 10 / 96$} & $8: 15$ & 522 & 0 & 10 & 0 & 0.1 & 20.4 & 398 \\
\hline & $17: 30$ & 531 & 25.7 & 20 & 0 & 0.2 & 20.2 & 399 \\
\hline \multirow[t]{2}{*}{$11 / 11 / 96$} & $10: 00$ & 548 & 2 & 10 & 0 & 0.2 & 20.1 & 402 \\
\hline & $16: 30$ & 554 & 34 & 30 & 1.2 & 0.2 & 19.8 & 403 \\
\hline \multirow[t]{2}{*}{$11 / 12 / 96$} & $8: 30$ & 570 & 14.2 & 10 & 0 & 0.3 & 20.1 & 406 \\
\hline & $17: 15$ & 579 & 6.8 & 20 & 0 & 0.1 & 20.6 & 405 \\
\hline \multirow[t]{2}{*}{$11 / 13 / 96$} & $8: 30$ & 594 & & & 0 & 0 & 20.7 & 406 \\
\hline & $18: 15$ & 604 & & & 0 & 0 & 20.8 & 405 \\
\hline \multirow[t]{2}{*}{$11 / 14 / 96$} & $9: 45$ & 619 & & & $\overline{0}$ & 0 & 20.6 & 405 \\
\hline & $18: 45$ & 628 & & & 0.6 & 0 & 20.7 & 406 \\
\hline $11 / 19 / 96$ & $17: 00$ & 747 & 10 & 0 & 0 & 0 & 21 & 397 \\
\hline
\end{tabular}


Table D.9 cont. Test Cell B, off-gas monitoring at B4 (4 ft fracture).

\begin{tabular}{|c|c|c|c|c|c|c|c|c|}
\hline$\overline{\text { Date }}$ & $\begin{array}{c}\text { Time of } \\
\text { day }\end{array}$ & $\begin{array}{c}\text { Elapsed } \\
\text { time (hrs) }\end{array}$ & $\begin{array}{c}\text { DAS } \\
\text { (ppmv) }\end{array}$ & $\begin{array}{c}\text { FID } \\
\text { (ppmv) }\end{array}$ & $\begin{array}{l}\overline{\mathrm{CH}_{4}} \\
(\%)\end{array}$ & $\begin{array}{l}\mathrm{CO}_{2} \\
(\%)\end{array}$ & $\begin{array}{l}\mathrm{O}_{2} \\
(\%)\end{array}$ & $\begin{array}{l}\text { Pressure } \\
\text { (in. } \mathrm{H}_{2} \mathrm{O} \text { ) }\end{array}$ \\
\hline \multirow[t]{2}{*}{$11 / 20 / 96$} & $8: 30$ & 760 & 1.9 & 10 & 0 & $\overline{0}$ & 21 & 398 \\
\hline & $14: 30$ & 766 & 2.3 & 10 & 0 & 0 & 21 & 397 \\
\hline \multirow[t]{2}{*}{$11 / 21 / 96$} & $8: 00$ & 782 & 0 & 0 & 0 & 0 & 20.7 & 397 \\
\hline & $17: 30$ & 791 & 0 & 0 & 0 & 0 & 20.6 & 398 \\
\hline \multirow[t]{2}{*}{$11 / 22 / 96$} & $8: 00$ & 806 & 1 & 0 & 0 & 0 & 20.7 & 402 \\
\hline & $17: 00$ & 815 & 0 & 0 & & & & \\
\hline \multirow[t]{2}{*}{$11 / 23 / 96$} & $8: 00$ & 830 & 0.1 & 10 & 0 & 0 & 21 & 399 \\
\hline & $18: 00$ & 840 & 0 & 0 & 0 & 0 & 20.8 & 398 \\
\hline \multirow[t]{2}{*}{$11 / 24 / 96$} & $8: 00$ & 854 & 0.8 & 0 & 0 & 0 & 20.9 & 399 \\
\hline & $16: 30$ & 862 & 0.4 & 0 & 0 & 0 & 20.9 & 398 \\
\hline \multirow[t]{2}{*}{$11 / 25 / 96$} & $8: 00$ & 878 & 0 & 0 & 0 & 0 & 21.1 & 398 \\
\hline & $17: 30$ & 887 & 1.6 & 0 & 0 & 0 & 20.7 & 394 \\
\hline \multirow{2}{*}{$11 / 26 / 96$} & $7: 30$ & 901 & 0 & 0 & 0 & 0 & 20.9 & 398 \\
\hline & $17: 30$ & 911 & 0 & 0 & 0 & 0 & 20.8 & 402 \\
\hline \multirow[t]{2}{*}{$12 / 2 / 96$} & $11: 00$ & 1049 & 0 & 0 & 0 & 0 & 20.9 & 398 \\
\hline & $18: 00$ & 1056 & 0 & 0 & 0.1 & 0 & 20.6 & 398 \\
\hline \multirow{2}{*}{$12 / 3 / 96$} & $8: 30$ & 1070 & 9.8 & 0 & 0.5 & 0 & 20.5 & 397 \\
\hline & $16: 30$ & 1078 & 0 & 0 & 1.3 & 0 & 20.6 & 398 \\
\hline \multirow[t]{2}{*}{$12 / 4 / 96$} & $8: 00$ & 1092 & $\overline{0}$ & 0 & 0 & $\overline{0}$ & 20.8 & 402 \\
\hline & $17: 00$ & 1101 & 0 & 10 & 0 & 0 & 20.6 & 402 \\
\hline \multirow[t]{2}{*}{$12 / 5 / 96$} & $8: 30$ & 1116 & 37.8 & 10 & 1 & 1.9 & 18.5 & 397 \\
\hline & $16: 00$ & 1124 & 7.5 & 10 & 0 & 0 & 20.9 & 393 \\
\hline $12 / 6 / 96$ & $9: 00$ & 1141 & 6 & 0 & 0 & 0 & 20.6 & 396 \\
\hline \multirow[t]{2}{*}{$12 / 7 / 96$} & $7: 30$ & 1163 & 1.2 & 10 & 0 & $\overline{0}$ & 20.7 & 395 \\
\hline & $18: 00$ & 1174 & 0 & 0 & 0 & 0 & 20.7 & 395 \\
\hline \multirow[t]{2}{*}{$12 / 8 / 96$} & $8: 30$ & 1188 & 11.5 & 10 & 0 & $\overline{0}$ & 20.4 & 394 \\
\hline & $16: 30$ & 1196 & 0 & 10 & 0.1 & 0 & 19.9 & 396 \\
\hline \multirow{2}{*}{$12 / 9 / 96$} & $8: 00$ & 1212 & 6.2 & 10 & $\overline{0}$ & $\overline{0}$ & 19.9 & 400 \\
\hline & $18: 00$ & 1222 & 0 & 0 & 0 & 0 & 20.5 & 400 \\
\hline \multirow[t]{2}{*}{$12 / 10 / 96$} & $8: 30$ & 1238 & 8.3 & 10 & 0 & 0 & 21.4 & 396 \\
\hline & $17: 00$ & 1247 & 14.4 & 0 & 0 & 0 & 21.4 & 394 \\
\hline \multirow[t]{2}{*}{$12 / 11 / 96$} & $8: 00$ & 1262 & 15 & 0 & 0 & $\overline{0}$ & 21.4 & 394 \\
\hline & $18: 00$ & 1272 & 0 & 0 & 0 & 0 & 21.4 & 394 \\
\hline
\end{tabular}

Blank table entry indicates measurement not taken. 
Table D.10 Test Cell B, off-gas monitoring at B12 (12 ft fracture).

\begin{tabular}{|c|c|c|c|c|c|c|c|c|}
\hline Date & $\begin{array}{l}\text { Time of } \\
\text { day }\end{array}$ & $\begin{array}{c}\text { Elapsed } \\
\text { time (hrs) }\end{array}$ & $\begin{array}{c}\text { DAS } \\
\text { (ppmv) }\end{array}$ & $\begin{array}{c}\text { FDD } \\
(\mathrm{ppmv})\end{array}$ & $\begin{array}{l}\mathrm{CH}_{4} \\
(\%)\end{array}$ & $\begin{array}{l}\mathrm{CO}_{2} \\
(\%)\end{array}$ & $\begin{array}{l}\mathrm{O}_{2} \\
(\%)\end{array}$ & $\begin{array}{l}\text { Pressure } \\
\left(\text { in. } \mathrm{H}_{2} \mathrm{O}\right)\end{array}$ \\
\hline \multirow[t]{4}{*}{$10 / 19 / 96$} & $14: 30$ & 0 & 101160 & 10000 & & & & \\
\hline & $15: 30$ & 1 & 101160 & 10000 & & & & \\
\hline & $17: 30$ & 3 & 101600 & 10000 & & & & \\
\hline & 23:00 & 9 & 101160 & 10000 & 15.6 & 28.7 & 5.5 & 986 \\
\hline \multirow{2}{*}{$10 / 20 / 96$} & $9: 00$ & 19 & 61130 & 10000 & 13.4 & 26.1 & 6.9 & 988 \\
\hline & $17: 00$ & 27 & 61160 & 10000 & 1.9 & 5.6 & 14.9 & 988 \\
\hline $10 / 22 / 96$ & $14: 30$ & 72 & 4013 & 10000 & & & & \\
\hline \multirow[t]{2}{*}{$10 / 23 / 96$} & $10: 15$ & 92 & 9184 & 10000 & & & & \\
\hline & $16: 30$ & 98 & 9189 & 10000 & 13.8 & 24.5 & 3.3 & \\
\hline \multirow{2}{*}{$10 / 24 / 96$} & $9: 15$ & 115 & 26340 & 10000 & 9.4 & 21 & 6.5 & \\
\hline & $16: 30$ & 122 & 26340 & 10000 & & & & \\
\hline \multirow[t]{2}{*}{$10 / 25 / 96$} & $9: 00$ & 139 & 9900 & 9893.5 & 6.9 & 15.6 & 9.1 & $\overline{399}$ \\
\hline & $18: 00$ & 148 & 157.4 & 160 & & & & \\
\hline \multirow[t]{2}{*}{$10 / 26 / 96$} & $9: 00$ & 163 & 3971.8 & 4010 & 2.9 & 6 & 18 & 401 \\
\hline & $17: 30$ & 171 & 9901 & 9900 & & & & \\
\hline \multirow[t]{2}{*}{$10 / 27 / 96$} & $9: 30$ & 187 & 6885.4 & 6820 & 0.8 & 1.9 & 19.7 & 402 \\
\hline & $17: 30$ & 195 & 9908.5 & 9910 & & & & \\
\hline \multirow[t]{2}{*}{$10 / 28 / 96$} & $7: 30$ & 209 & 964.7 & 930 & 0 & 0.4 & 21 & 399 \\
\hline & $17: 30$ & 219 & 15 & 0 & 0 & 0 & 21.3 & 398 \\
\hline $10 / 29 / 96$ & $19: 15$ & 245 & 9910 & 9910 & 5.2 & 8.6 & 14.4 & $\overline{392}$ \\
\hline \multirow[t]{2}{*}{$10 / 30 / 96$} & $8: 00$ & 258 & 9885.2 & 9890 & 3.5 & 7.1 & 15.7 & $\overline{393}$ \\
\hline & $17: 45$ & 268 & 9889.7 & 9890 & & & & \\
\hline \multirow[t]{2}{*}{$10 / 31 / 96$} & $7: 45$ & 282 & 9893.6 & 9890 & 5.9 & 14.8 & 8.6 & 400 \\
\hline & $18: 30$ & 292 & 9904.2 & 9910 & 8.3 & 16.2 & 7.9 & 398 \\
\hline $11 / 1 / 96$ & $7: 45$ & 305 & 9880.3 & 9880 & 6 & 13.8 & 8.9 & 398 \\
\hline \multirow[t]{2}{*}{$11 / 4 / 96$} & $9: 00$ & 378 & 9902.8 & 9910 & 3.2 & 13.3 & 7.5 & $\overline{401}$ \\
\hline & $16: 30$ & 385 & 9904.9 & 9910 & 3.7 & 12.3 & 8.8 & 400 \\
\hline $11 / 5 / 96$ & $9: 00$ & 402 & & & 5 & 11.2 & 9.7 & $\overline{422}$ \\
\hline $11 / 6 / 96$ & $8: 00$ & 426 & & & 2.2 & 10.6 & 9.2 & 444 \\
\hline $11 / 7 / 96$ & $8: 30$ & 450 & & & 2.1 & 10.9 & 9.2 & 429 \\
\hline $11 / 8 / 96$ & $8: 00$ & 474 & & & 1.5 & 9.2 & 10.4 & 440 \\
\hline $11 / 8 / 96$ & $18: 45$ & 484 & 14652.4 & 10000 & 1.6 & 9.2 & 10.8 & 395 \\
\hline \multirow[t]{2}{*}{$11 / 9 / 96$} & $8: 30$ & 498 & 13779.8 & 10000 & 4.3 & 9.5 & 10.5 & 395 \\
\hline & $18: 15$ & 508 & 12501.5 & 10000 & 1.3 & 8.3 & 11.8 & 397 \\
\hline
\end{tabular}


Table D.10 cont. Test Cell B, off-gas monitoring at B12 (12 ft fracture).

\begin{tabular}{ccccccccr}
\hline Date & $\begin{array}{c}\text { Time of } \\
\text { day }\end{array}$ & $\begin{array}{c}\text { Elapsed } \\
\text { time (hrs) }\end{array}$ & $\begin{array}{c}\text { DAS } \\
\text { (ppmv) }\end{array}$ & $\begin{array}{c}\text { FID } \\
\text { (ppmv) }\end{array}$ & $\begin{array}{c}\mathrm{CH}_{4} \\
(\%)\end{array}$ & $\begin{array}{c}\mathrm{CO}_{2} \\
(\%)\end{array}$ & $\begin{array}{c}\mathrm{O}_{2} \\
(\%)\end{array}$ & $\begin{array}{c}\text { Pressure } \\
\left.\text { (in. } \mathrm{H}_{2} \mathrm{O}\right)\end{array}$ \\
\hline $11 / 10 / 96$ & $8: 15$ & 522 & 11638.3 & 10000 & 1.1 & 8 & 12.5 & 398 \\
& $17: 30$ & 531 & 12838.4 & 10000 & 1.3 & 8.5 & 11.6 & 399 \\
\hline $11 / 11 / 96$ & $10: 00$ & 548 & 1437.7 & 10000 & 2.4 & 9.9 & 10 & 402 \\
& $16: 30$ & 554 & 13954.8 & 10000 & 4.8 & 9.3 & 10.2 & 402 \\
$11 / 12 / 96$ & $8: 30$ & 570 & 2251.8 & 2260 & 0 & 2.7 & 18.7 & 406 \\
& $17: 15$ & 579 & 14432.5 & 10000 & 1.3 & 9.3 & 10.5 & 406 \\
\hline $11 / 13 / 96$ & $8: 30$ & 594 & & 10000 & 1.4 & 8.3 & 11.5 & 406 \\
& $18: 15$ & 604 & & 10000 & 1.6 & 8.9 & 10.8 & 405 \\
\hline $11 / 14 / 96$ & $9: 45$ & 619 & & 10000 & 1.8 & 9.5 & 10 & 406 \\
& $18: 45$ & 628 & & 10000 & 3.8 & 8.4 & 11 & 406 \\
\hline $11 / 19 / 96$ & $17: 00$ & 747 & 4888 & 4910 & & & & \\
\hline $11 / 20 / 96$ & $8: 30$ & 760 & 6399.8 & 6390 & 0.6 & 6.2 & 14.1 & 398 \\
& $14: 30$ & 766 & 5695 & 5680 & 0.6 & 5 & 15 & 397 \\
\hline $11 / 21 / 96$ & $8: 00$ & 782 & 7393.5 & 7200 & 0.7 & 6.2 & 13.4 & 396 \\
& $17: 30$ & 791 & 7754.4 & 7740 & 0.8 & 6.4 & 12.8 & 398 \\
\hline $11 / 22 / 96$ & $8: 00$ & 806 & 7346.5 & 7510 & 0.8 & 7 & 11.8 & 402 \\
& $17: 00$ & 815 & 8846.8 & 8860 & 1.1 & 8.6 & 10.4 & 401 \\
\hline $11 / 23 / 96$ & $8: 00$ & 830 & 7723.1 & 7750 & 0.9 & 8 & 11.5 & 399 \\
& $18: 00$ & 840 & 7799.8 & 7620 & 0.9 & 7.9 & 11 & 398 \\
\hline $11 / 24 / 96$ & $8: 00$ & 854 & 4241.8 & 4210 & 0.9 & 7.4 & 12.5 & 399 \\
& $16: 30$ & 862 & 7346.2 & 7390 & 0.8 & 7.2 & 12.1 & 398 \\
\hline $11 / 25 / 96$ & $8: 00$ & 878 & 7743.1 & 7670 & 0.7 & 6.6 & 12.6 & 398 \\
& $17: 30$ & 887 & 5122 & 5120 & 0.6 & 5.2 & 14.6 & 394 \\
\hline $11 / 26 / 96$ & $7: 30$ & 901 & 7025.3 & 7000 & 0.7 & 6.5 & 12 & 399 \\
& $17: 30$ & 911 & 7660.6 & 7660 & 0.7 & 6.6 & 11.9 & 403 \\
\hline $12 / 2 / 96$ & $11: 00$ & 1049 & 8390.6 & 8410 & 0.9 & 5.9 & 13 & 398 \\
& $18: 00$ & 1056 & 3582.4 & 3550 & 0.6 & 4 & 17 & 398 \\
\hline $12 / 3 / 96$ & $8: 30$ & 1070 & 1859.2 & 1860 & 1 & 3 & 16.7 & 397 \\
& $16: 30$ & 1078 & 7062.3 & 7020 & 2.4 & 0 & 20.8 & 398 \\
\hline $12 / 4 / 96$ & $8: 00$ & 1092 & 1752 & 1750 & 0.2 & 3.4 & 15.4 & 402 \\
& $17: 00$ & 1101 & 6628.5 & 6660 & 1 & 5.5 & 13 & 401 \\
\hline $12 / 5 / 96$ & $8: 30$ & 1116 & 5007.4 & 4970 & & & & \\
& $16: 00$ & 1124 & 4300.5 & 4290 & 0.5 & 4 & 15.8 & 393 \\
\hline $12 / 6 / 96$ & $9: 00$ & 1141 & 6401.5 & 6380 & 0.5 & 4.4 & 15.3 & 396 \\
\hline & & & & & & & & \\
\hline
\end{tabular}


Table D.10 cont. Test Cell B, off-gas monitoring at B12 (12 ft fracture).

\begin{tabular}{ccccccccr}
\hline Date & $\begin{array}{c}\text { Time of } \\
\text { day }\end{array}$ & $\begin{array}{c}\text { Elapsed } \\
\text { time (hrs) }\end{array}$ & $\begin{array}{c}\text { DAS } \\
(\mathrm{ppmv})\end{array}$ & $\begin{array}{c}\mathrm{FID} \\
(\mathrm{ppmv})\end{array}$ & $\begin{array}{c}\mathrm{CH}_{4} \\
(\%)\end{array}$ & $\begin{array}{c}\mathrm{CO}_{2} \\
(\%)\end{array}$ & $\begin{array}{c}\mathrm{O}_{2} \\
(\%)\end{array}$ & $\begin{array}{c}\text { Pressure } \\
\left(\text { in. } \mathrm{H}_{2} \mathrm{O}\right)\end{array}$ \\
\hline $12 / 7 / 96$ & $7: 30$ & 1163 & 5222 & 5230 & 0.4 & 3.8 & 16.2 & 395 \\
& $18: 00$ & 1174 & 3680.6 & 3680 & 0.4 & 3.4 & 16.6 & 395 \\
\hline $12 / 8 / 96$ & $8: 30$ & 1188 & 4219.3 & 4210 & 0.3 & 3.5 & 16.5 & 395 \\
& $16: 30$ & 1196 & 6815.9 & 6800 & 0.7 & 4.5 & 14.8 & 396 \\
\hline $12 / 9 / 96$ & $8: 00$ & 1212 & 8622.3 & 8630 & 0.8 & 5.3 & 13.1 & \\
& $18: 00$ & 1222 & 7291.6 & 7290 & 0.6 & 4.5 & 14.9 & 400 \\
\hline $12 / 10 / 96$ & $8: 30$ & 1238 & 7781.7 & 7810 & 0.6 & 4.5 & 15.5 & 396 \\
& $17: 00$ & 1247 & 2703.9 & 2710 & 0.1 & 1.8 & 19.4 & 394 \\
\hline $12 / 11 / 96$ & $8: 00$ & 1262 & 2599.9 & 2590 & 0.1 & 1.9 & 19.1 & 394 \\
& $18: 00$ & 1272 & 2096.2 & 2100 & 0.1 & 1.8 & 19.4 & 394 \\
\hline
\end{tabular}

Blank table entry indicates measurement not taken. 
Table D.11 Test Cell A, A4 (4 ft fracture) off-gas GC results.

\begin{tabular}{|c|c|c|c|c|c|c|c|c|c|}
\hline Date & $\begin{array}{l}\mathrm{CH}_{2} \mathrm{Cl}_{2} \\
\text { (ppmv) }\end{array}$ & $\begin{array}{c}\mathrm{t}-1,2- \\
\mathrm{DCE} \\
\text { (ppmv) }\end{array}$ & $\begin{array}{c}\mathrm{c}-1,2- \\
\text { DCE } \\
\text { (ppmv) }\end{array}$ & $\begin{array}{l}1,1-\mathrm{DCA} \\
\text { (ppmv) }\end{array}$ & $\begin{array}{l}1,1-\mathrm{DCE} \\
\text { (ppmv) }\end{array}$ & $\begin{array}{c}1,1,1- \\
\text { TCA } \\
\text { (ppmv) }\end{array}$ & $\begin{array}{c}\text { TCE } \\
\text { (ppmv) }\end{array}$ & $\begin{array}{c}\text { PCE } \\
\text { (ppmv) }\end{array}$ & $\begin{array}{l}\text { Total } \\
\text { (ppmv) }\end{array}$ \\
\hline $10 / 19 / 96$ & & & 10 & & 380 & 0 & 16 & & 406 \\
\hline $10 / 19 / 96$ & & & 10 & & 371 & 0 & 18 & & 399 \\
\hline $10 / 20 / 96$ & & 0 & 11 & 0 & 227 & 0 & 46 & 0 & 285 \\
\hline $10 / 21 / 96$ & & 28 & 977 & 113 & 31968 & 50 & 145 & 1 & 33282 \\
\hline $10 / 22 / 96$ & & 29 & 851 & 105 & 29153 & 60 & 157 & 0 & 30355 \\
\hline $10 / 26 / 96$ & & & 668 & 259 & & 262 & 839 & 1 & 2029 \\
\hline $10 / 28 / 96$ & & & 535 & 385 & & 224 & 1486 & & 2630 \\
\hline $10 / 29 / 96$ & & & & & & 446 & 2150 & 11 & 2607 \\
\hline $10 / 30 / 96$ & & & 461 & 354 & & 293 & 1505 & 5 & 2618 \\
\hline $11 / 1 / 96$ & 28 & & 530 & 748 & & 518 & 2315 & 18 & 4157 \\
\hline $11 / 5 / 96$ & & & 740 & 296 & & 346 & 1617 & 3 & 3002 \\
\hline $11 / 6 / 96$ & & & 683 & 411 & & 385 & 1689 & 2 & 3170 \\
\hline $11 / 7 / 96$ & & & 613 & & & 49 & 1199 & 1 & 1862 \\
\hline $11 / 8 / 96$ & & & 676 & & & 64 & 1659 & 1 & 2400 \\
\hline $11 / 9 / 96$ & 10 & 48 & 691 & 170 & & 203 & 2734 & 2 & 3858 \\
\hline $11 / 10 / 96$ & & & 838 & 151 & & 166 & 2571 & 2 & 3728 \\
\hline $11 / 11 / 96$ & & & 1149 & 174 & & 136 & 2382 & 1 & 3842 \\
\hline $11 / 12 / 96$ & & & 535 & 114 & & 175 & 2480 & 1 & 3305 \\
\hline $11 / 13 / 96$ & & & 358 & 433 & & 201 & 2070 & 1 & 3063 \\
\hline $11 / 14 / 96$ & & & 407 & 224 & & 145 & 2753 & 1 & 3530 \\
\hline $11 / 20 / 96$ & 12 & 25 & 381 & 262 & & 241 & 2260 & 1 & 3182 \\
\hline $11 / 21 / 96$ & & 20 & 417 & 317 & & 250 & 1917 & 1 & 2922 \\
\hline $11 / 22 / 96$ & 11 & 26 & 411 & 123 & & 117 & 1852 & 1 & 2541 \\
\hline $11 / 23 / 96$ & & & 554 & 133 & & 136 & 1759 & 3 & 2585 \\
\hline $11 / 24 / 96$ & & & 410 & 119 & & 206 & 2278 & & 3013 \\
\hline $11 / 25 / 96$ & 17 & & 356 & 51 & & 96 & 1811 & & 2331 \\
\hline $11 / 26 / 96$ & & & 395 & 63 & & 57 & 1396 & & 1911 \\
\hline $12 / 3 / 96$ & & & 660 & & & 151 & 1318 & & 2129 \\
\hline $12 / 4 / 96$ & & & 433 & 172 & & 201 & 1637 & & 2443 \\
\hline $12 / 5 / 96$ & & & 417 & 257 & & 235 & 2021 & & 2930 \\
\hline $12 / 6 / 96$ & 4 & 26 & 373 & 163 & & 134 & 1450 & & 2150 \\
\hline $12 / 7 / 96$ & & & 457 & 105 & & 119 & 1406 & & 2087 \\
\hline $12 / 8 / 96$ & & & 287 & 84 & & 77 & 1108 & & 1556 \\
\hline $12 / 9 / 96$ & & & 367 & 163 & & 137 & 1227 & & 1894 \\
\hline $12 / 10 / 96$ & 2 & 10 & 283 & 98 & & 151 & 1338 & & 1882 \\
\hline $12 / 11 / 96$ & & & 781 & 262 & & 189 & 1239 & & 2471 \\
\hline
\end{tabular}

Blank table entry is a non detect. 
Table D.12 Test Cell A, A12 (12 ft fracture) off-gas GC results.

\begin{tabular}{|c|c|c|c|c|c|c|c|c|c|}
\hline Date & $\begin{array}{l}\mathrm{CH}_{2} \mathrm{Cl}_{2} \\
\text { (ppmv) }\end{array}$ & $\begin{array}{c}\mathrm{t}-1,2- \\
\mathrm{DCE} \\
\text { (ppmv) }\end{array}$ & $\begin{array}{c}\text { C-1,2- } \\
\text { DCE } \\
\text { (ppmv) }\end{array}$ & $\begin{array}{l}1,1-\mathrm{DCA} \\
\text { (ppmv) }\end{array}$ & $\begin{array}{l}1,1-\overline{D C E} \\
\text { (ppmv) }\end{array}$ & $\begin{array}{c}1,1,1- \\
\text { TCA } \\
\text { (ppmv) }\end{array}$ & $\begin{array}{c}\mathrm{TCE} \\
(\mathrm{ppmv})\end{array}$ & $\begin{array}{c}\mathrm{PCE} \\
\text { (ppmv) }\end{array}$ & $\begin{array}{l}\text { Total } \\
\text { (ppmv) }\end{array}$ \\
\hline $10 / 19 / 96$ & & & 25 & & 38 & & 7 & & 70 \\
\hline $10 / 19 / 96$ & & & 22 & & 17 & & 10 & & 49 \\
\hline $10 / 20 / 96$ & & & 1 & & 3 & & 2 & & 6 \\
\hline $10 / 21 / 96$ & & & 101 & 14 & 643 & 1 & 45 & 1 & 805 \\
\hline $10 / 22 / 96$ & & & 56 & & 2122 & 1 & 299 & 1 & 2478 \\
\hline $10 / 26 / 96$ & 198 & 690 & 677 & 120 & & 166 & 26833 & 653 & 29337 \\
\hline $10 / 27 / 96$ & & 456 & 142 & 18 & 173 & 41 & 5002 & 549 & 6381 \\
\hline $10 / 28 / 96$ & & & & & & 3 & 332 & & 335 \\
\hline $10 / 29 / 96$ & & & & & & & 1498 & 19 & 1517 \\
\hline $10 / 30 / 96$ & & & & & 310 & 2 & 846 & 3 & 1161 \\
\hline $11 / 1 / 96$ & & & & & 417 & 9 & 891 & 6 & 1323 \\
\hline $11 / 5 / 96$ & & & & & & 88 & 823 & 4 & 915 \\
\hline $11 / 6 / 96$ & 128 & & 390 & 232 & & 261 & 2431 & 2 & 3444 \\
\hline $11 / 7 / 96$ & & & & & & 1 & 963 & 1 & 965 \\
\hline $11 / 8 / 96$ & & & & & & 15 & 671 & 1 & 687 \\
\hline $11 / 9 / 96$ & & 19 & & & & 2 & 930 & 1 & 952 \\
\hline $11 / 10 / 96$ & & & & & & 1 & 708 & 1 & 710 \\
\hline $11 / 11 / 96$ & & & & & & 3 & 1316 & 1 & 1320 \\
\hline $11 / 12 / 96$ & & & & & & 2 & 1142 & 1 & 1145 \\
\hline $11 / 13 / 96$ & & & & & & 37 & 1362 & 1 & 1400 \\
\hline $11 / 14 / 96$ & & 35 & & 495 & 494 & 158 & 3207 & 1 & 4390 \\
\hline $11 / 20 / 96$ & 28 & 34 & 54 & 87 & & 46 & 1323 & 1 & 1573 \\
\hline $11 / 21 / 96$ & & & 59 & 64 & & 26 & 820 & & 969 \\
\hline $11 / 26 / 96$ & & & & 210 & & 219 & 1183 & & 1612 \\
\hline $12 / 3 / 96$ & & & & 151 & & 106 & 1102 & & 1359 \\
\hline $12 / 4 / 96$ & & & & 250 & & 198 & 1681 & & 2129 \\
\hline $12 / 5 / 96$ & & & & 289 & & 278 & 2332 & & 2899 \\
\hline $12 / 6 / 96$ & & & & & 1 & 1 & 488 & & 490 \\
\hline $12 / 7 / 96$ & & & & & & & 117 & & 117 \\
\hline $12 / 8 / 96$ & & & & 219 & & 162 & 1974 & & 2355 \\
\hline $12 / 9 / 96$ & & & 10 & 258 & & 198 & 2878 & & 3344 \\
\hline $12 / 10 / 96$ & & & & 25 & & 16 & 1027 & & 1068 \\
\hline $12 / 11 / 96$ & & & & & 556 & 3 & 940 & & 1499 \\
\hline
\end{tabular}

Blank table entry is a non detect. 
Table D.13 Test Cell B, B4 (4 ft fracture) off-gas GC results.

\begin{tabular}{|c|c|c|c|c|c|c|c|c|c|}
\hline Date & $\begin{array}{c}\mathrm{CH}_{2} \mathrm{Cl}_{2} \\
\text { (ppmv) }\end{array}$ & $\begin{array}{c}\mathrm{t}-1,2- \\
\mathrm{DCE} \\
\text { (ppmv) }\end{array}$ & $\begin{array}{c}\mathrm{c}-1,2- \\
\mathrm{DCE} \\
(\mathrm{ppmv})\end{array}$ & $\begin{array}{r}\text { 1,1-DCA } \\
\text { (ppmv) }\end{array}$ & $\begin{array}{c}1,1-\mathrm{DCE} \\
\text { (ppmv) }\end{array}$ & $\begin{array}{c}1,1,1- \\
\text { TCA } \\
\text { (ppmv) }\end{array}$ & $\begin{array}{c}\text { TCE } \\
\text { (ppmv) }\end{array}$ & $\begin{array}{c}\text { PCE } \\
\text { (ppmv) }\end{array}$ & $\begin{array}{l}\text { Total } \\
\text { (ppmv) }\end{array}$ \\
\hline $10 / 19 / 96$ & & 1 & 131 & & 899 & & 345 & & 1376 \\
\hline $10 / 19 / 96$ & & & 117 & & 705 & & 251 & & 1073 \\
\hline $10 / 20 / 96$ & & & 74 & & 436 & & 173 & & 683 \\
\hline $10 / 21 / 96$ & & & 4838 & & 72589 & 31 & 3316 & 24 & 80798 \\
\hline $10 / 22 / 96$ & & 32 & 3482 & 29 & 60845 & 29 & 2154 & 1 & 66572 \\
\hline $10 / 26 / 96$ & & & 1315 & 116 & & 133 & 6016 & 2 & 7582 \\
\hline $10 / 27 / 96$ & 45 & 262 & 1656 & 43 & & 40 & 23368 & 702 & 26116 \\
\hline $10 / 28 / 96$ & & & 1642 & & & 20 & 24061 & 2 & 25725 \\
\hline $10 / 29 / 96$ & & & 1538 & & & 27 & 22768 & 20 & 24353 \\
\hline $10 / 30 / 96$ & & & 1286 & & & 18 & 14561 & 6 & 15871 \\
\hline $11 / 1 / 96$ & & & 1116 & & & 16 & 12661 & 20 & 13813 \\
\hline $11 / 6 / 96$ & & & & & & 2 & 774 & 2 & 778 \\
\hline $11 / 7 / 96$ & & & & & & 2 & 813 & 1 & 816 \\
\hline $11 / 8 / 96$ & & & & & & 2 & 1593 & 1 & 1596 \\
\hline $11 / 9 / 96$ & & & & & & 2 & 1637 & 1 & 1640 \\
\hline $11 / 10 / 96$ & & & & & & 2 & 1677 & 1 & 1680 \\
\hline $11 / 11 / 96$ & & & & & & 2 & 1331 & 1 & 1334 \\
\hline $11 / 12 / 96$ & & & & & & 8 & 1644 & 1 & 1653 \\
\hline $11 / 13 / 96$ & & & & & & 2 & 1142 & 1 & 1145 \\
\hline $11 / 14 / 96$ & & & & & & 1 & 1221 & 1 & 1223 \\
\hline $11 / 20 / 96$ & & & & & & 1 & 1091 & 1 & 1093 \\
\hline $11 / 21 / 96$ & & & & & & 1 & 809 & 1 & 811 \\
\hline $11 / 22 / 96$ & 6 & 24 & 840 & 1 & & 1 & 840 & 1 & 1713 \\
\hline $11 / 23 / 96$ & & & & & & & 803 & 3 & 806 \\
\hline $11 / 24 / 96$ & & & & & & & 686 & 1 & 687 \\
\hline $11 / 25 / 96$ & & & & & & & 626 & & 626 \\
\hline $11 / 26 / 96$ & & & & & & & 1232 & & 1232 \\
\hline $12 / 3 / 96$ & & & & & 1 & & 624 & & 625 \\
\hline $12 / 4 / 96$ & & & & & & & 584 & & 584 \\
\hline $12 / 5 / 96$ & & & & & & & 396 & & 396 \\
\hline $12 / 6 / 96$ & & & & & & 1 & 1226 & & 1227 \\
\hline $12 / 7 / 96$ & & & & & & & 365 & & 365 \\
\hline $12 / 8 / 96$ & & & & & & & 650 & & 650 \\
\hline $12 / 9 / 96$ & & & & & 1 & & 560 & & 561 \\
\hline $12 / 10 / 96$ & 1 & & & & & & 365 & & 366 \\
\hline $12 / 11 / 96$ & & & & 1 & & & 523 & & 524 \\
\hline
\end{tabular}

Blank table entry is a non detect. 
Table D.14 Test Cell B, B12 (12 ft fracture) off-gas GC results.

\begin{tabular}{|c|c|c|c|c|c|c|c|c|c|}
\hline Date & $\begin{array}{l}\mathrm{CH}_{2} \mathrm{Cl}_{2} \\
\text { (ppmv) }\end{array}$ & $\begin{array}{c}\mathrm{t}-1,2- \\
\mathrm{DCE} \\
(\mathrm{ppmv})\end{array}$ & $\begin{array}{c}\mathrm{C}-1,2- \\
\text { DCE } \\
(\mathrm{ppmv})\end{array}$ & $\begin{array}{l}1,1-\mathrm{DCA} \\
\text { (ppmv) }\end{array}$ & $\begin{array}{c}\text { 1,1-DCE } \\
\text { (ppmv) }\end{array}$ & $\begin{array}{c}1,1,1- \\
\text { TCA } \\
\text { (ppmv) }\end{array}$ & $\begin{array}{c}\text { TCE } \\
\text { (ppmv) }\end{array}$ & $\begin{array}{c}\text { PCE } \\
\text { (ppmv) }\end{array}$ & $\begin{array}{c}\text { Total } \\
\text { (ppmv) }\end{array}$ \\
\hline $10 / 19 / 96$ & & & 230 & & 14705 & 1 & 3118 & $\overline{3}$ & 18056 \\
\hline $10 / 19 / 96$ & & & 466 & 2 & 31536 & 1 & 4890 & 2 & 36897 \\
\hline $10 / 20 / 96$ & & & 368 & 3 & 15279 & 1 & 1890 & 2 & 17543 \\
\hline $10 / 21 / 96$ & & & 24974 & 659 & 712 & 172 & 716830 & 308 & 743655 \\
\hline $10 / 21 / 96$ & & & 19863 & 394 & 4418004 & 79 & 71898 & 31 & 4510269 \\
\hline $10 / 22 / 96$ & & & 39 & & 442 & 1 & 37 & & 519 \\
\hline $10 / 26 / 96$ & 602 & 1418 & 1906 & 1014 & & 97 & 118341 & 528 & 123906 \\
\hline $10 / 27 / 96$ & & & 14590 & 2104 & & 206 & 939715 & 1527 & 958142 \\
\hline $10 / 28 / 96$ & & & & & & 1 & 186 & & 187 \\
\hline $10 / 29 / 96$ & & & 14860 & & & 1444 & 445066 & 307 & 461677 \\
\hline $10 / 30 / 96$ & & & 58879 & 8100 & & 4328 & 782463 & 826 & 854596 \\
\hline $11 / 1 / 96$ & & & 67376 & & & 8774 & 765285 & 855 & 842290 \\
\hline $11 / 5 / 96$ & 55519 & & 156468 & 3563 & & 26236 & 883744 & 1094 & 1126624 \\
\hline $11 / 6 / 96$ & 95833 & & 210453 & 5974 & & 36212 & 950006 & 1511 & 1299989 \\
\hline $11 / 7 / 96$ & & & 165286 & 3999 & & 26370 & 867879 & 993 & 1064527 \\
\hline $11 / 8 / 96$ & & & 73701 & 812 & & 12314 & 1425134 & 235 & 1512196 \\
\hline $11 / 9 / 96$ & & 456 & 102680 & 1303 & & 17079 & 1673499 & 280 & 1795297 \\
\hline $11 / 10 / 96$ & & & 110023 & 1763 & & 16736 & 1847705 & 308 & 1976535 \\
\hline $11 / 11 / 96$ & & & 157587 & 3262 & & 31126 & 3113341 & 543 & 3305859 \\
\hline $11 / 12 / 96$ & & & 35904 & 494 & & 2776 & 508421 & 133 & 547728 \\
\hline $11 / 13 / 96$ & & & 140833 & 2012 & & 23114 & 2506540 & 442 & 2672941 \\
\hline $11 / 14 / 96$ & & & 131556 & 4839 & & 26394 & 2511750 & 408 & 2674947 \\
\hline $11 / 20 / 96$ & & & 94491 & 1754 & & 16089 & 754462 & 629 & 867425 \\
\hline $11 / 21 / 96$ & & & 60717 & 1134 & & 8547 & 1040805 & 432 & 1111635 \\
\hline $11 / 22 / 96$ & & & 114693 & 1852 & & 18023 & 1252194 & 519 & 1387281 \\
\hline $11 / 23 / 96$ & & & 100179 & 1731 & & 15109 & 1953195 & 683 & 2070897 \\
\hline $11 / 24 / 96$ & & & 125690 & 2474 & & 18986 & 2539211 & 750 & 2687111 \\
\hline $11 / 25 / 96$ & & & 79755 & 2249 & & 11298 & 1253228 & 168 & 1346698 \\
\hline $11 / 26 / 96$ & & & 94956 & 1291 & & 14758 & 1889209 & 500 & 2000714 \\
\hline $12 / 3 / 96$ & & & 15185 & & & 2142 & 307790 & 21 & 325138 \\
\hline $12 / 4 / 96$ & & & 21900 & & & & 521181 & 32 & 543113 \\
\hline $12 / 5 / 96$ & & & 64011 & 959 & & 9748 & 841583 & 553 & 916854 \\
\hline $12 / 6 / 96$ & & & 33829 & 632 & & 5788 & 691285 & 329 & 731863 \\
\hline $12 / 7 / 96$ & & & 29319 & 615 & & 5460 & 704987 & 396 & 740777 \\
\hline $12 / 8 / 96$ & & & 48780 & 1412 & & 11540 & 1352073 & 623 & 1414428 \\
\hline $12 / 9 / 96$ & & & 50100 & 1254 & & 10871 & 1147860 & 149 & 1210234 \\
\hline $12 / 10 / 96$ & & 343 & 27536 & 598 & & 8730 & 885089 & 1032 & 923328 \\
\hline $12 / 11 / 96$ & & & 19082 & 461 & & 3807 & 465966 & 61 & 489377 \\
\hline
\end{tabular}

Blank table entry is a non detect. 
Table D.15 Test Cell A, in situ Eh measurements (in mV).

\begin{tabular}{|c|c|c|c|c|c|c|c|c|c|c|}
\hline Location & $\begin{array}{c}\text { Depth } \\
\text { (ft bgs) }\end{array}$ & $10 / 20 / 96$ & $10 / 27 / 96$ & $11 / 11 / 96$ & $11 / 24 / 96$ & $\begin{array}{c}\text { Date } \\
12 / 6 / 96\end{array}$ & $7 / 18 / 97$ & $9 / 3 / 97$ & $9 / 5 / 97$ & $12 / 12 / 97$ \\
\hline \multirow[t]{9}{*}{ TAM1 } & 2.8 & -171.6 & -185.3 & -264.2 & -71.5 & -8.0 & -683.3 & -647.2 & -651.9 & -784.6 \\
\hline & 4.6 & -155.7 & -566.4 & -386.6 & -381.1 & -341.8 & -586.7 & -583.7 & -586.4 & -546.8 \\
\hline & 5.1 & -652.2 & -664.6 & -804.8 & -811.1 & -826.9 & -662.4 & -691.4 & -688.0 & -578.1 \\
\hline & 5.6 & -151.3 & -164.4 & -173.6 & -175.3 & -152.7 & -801.6 & -757.5 & -776.1 & -593.8 \\
\hline & 6.3 & -899.4 & -905.1 & -798.7 & -474.7 & -455.0 & -645.1 & -762.6 & -756.0 & -582.1 \\
\hline & 6.8 & -622.8 & -288.3 & -165.6 & -163.4 & -141.6 & -422.2 & -670.5 & -681.3 & -543.6 \\
\hline & 7.5 & -962.1 & -950.6 & -445.0 & -176.7 & -146.2 & -625.0 & -683.9 & -693.3 & -593.3 \\
\hline & 10.0 & -470.8 & -490.7 & -496.2 & -508.3 & -486.6 & -621.5 & -611.3 & -625.3 & -607.5 \\
\hline & 12.0 & -457.6 & -449.3 & -497.3 & -513.2 & -486.2 & -566.2 & -627.7 & -629.4 & -617.4 \\
\hline
\end{tabular}

Table D.16 Test Cell B, in situ Eh measurements (in $\mathrm{mV}$ ).

\begin{tabular}{|c|c|c|c|c|c|c|c|c|c|c|}
\hline Location & $\begin{array}{c}\text { Depth } \\
\text { (ft bgs) }\end{array}$ & $10 / 20 / 96$ & $10 / 27 / 96$ & $11 / 11 / 96$ & $11 / 24 / 96$ & $\begin{array}{c}\text { Date } \\
12 / 6 / 96\end{array}$ & $7 / 18 / 97$ & $9 / 3 / 97$ & $9 / 5 / 97$ & $12 / 12 / 97$ \\
\hline \multirow[t]{7}{*}{ TBM1 } & 2.9 & -182.8 & -136.7 & -23.7 & -2.5 & 10.5 & -501.8 & -8.2 & -15.4 & -154.2 \\
\hline & 4.5 & -136.1 & -92.1 & 325.2 & 105.1 & 120.0 & -620.3 & -23.3 & -36.0 & 4.4 \\
\hline & 5.2 & -690.0 & -750.5 & -904.8 & -909.4 & -898.8 & -815.9 & -680.7 & -619.0 & -103.2 \\
\hline & 7.5 & -626.5 & -622.0 & -640.7 & -647.8 & -680.6 & -801.0 & -265.1 & -236.5 & -71.7 \\
\hline & 8.3 & -469.6 & -425.7 & & & -488.5 & -615.9 & -584.4 & -577.9 & -521.0 \\
\hline & 8.8 & -332.1 & -467.0 & 421.7 & -456.3 & -503.9 & -654.5 & -664.4 & -652.1 & -644.5 \\
\hline & 11.8 & -304.4 & -322.2 & -343.5 & -367.5 & -324.2 & -413.8 & -564.0 & -563.6 & -607.6 \\
\hline \multirow[t]{3}{*}{ TBM2 } & 5.8 & -537.9 & -560.9 & -511.2 & -560.1 & -568.9 & -618.6 & -669.9 & -671.1 & -279. \\
\hline & 7.0 & -469.2 & -415.2 & -415.0 & -360.1 & -447.0 & -623.5 & -670.3 & -663.4 & -547.9 \\
\hline & 7.8 & -377.2 & -422.0 & -439.7 & -447.9 & -458.2 & -500.3 & -625.4 & -615.7 & -239.3 \\
\hline
\end{tabular}

Blank table entry indicates measurement not taken. 
Table D.17 Wiping thermocouple measurements in Test Cell A $\left({ }^{\circ} \mathrm{C}\right)$.

\begin{tabular}{|c|c|c|c|c|c|}
\hline \multirow[b]{2}{*}{ Location } & \multirow[b]{2}{*}{$\begin{array}{l}\text { Depth } \\
\text { (ft bgs) }\end{array}$} & \multicolumn{4}{|c|}{ Date } \\
\hline & & $7 / 18 / 97$ & $7 / 24 / 97$ & $9 / 3 / 97$ & $9 / 6 / 97$ \\
\hline \multirow[t]{7}{*}{ TABI } & 1.0 & 32.5 & 29.9 & 35.7 & 32.0 \\
\hline & 3.0 & 29.5 & 31.8 & 40.9 & 38.0 \\
\hline & 5.0 & 24.8 & 33.1 & 44.3 & 40.9 \\
\hline & 7.0 & 22.6 & 36.9 & 47.2 & 43.3 \\
\hline & 9.0 & 20.4 & 32.5 & 48.2 & 42.2 \\
\hline & 11.0 & 19.1 & 22.8 & 43.6 & 38.9 \\
\hline & 12.5 & 18.7 & 21.7 & 39.1 & 35.6 \\
\hline \multirow[t]{6}{*}{ TAB2 } & 1.0 & 32.9 & 29.1 & 32.8 & 27.0 \\
\hline & 3.0 & 29.9 & 30.0 & 34.0 & 30.6 \\
\hline & 5.0 & 26.6 & 28.4 & 34.3 & 32.0 \\
\hline & 7.0 & 24.1 & 26.2 & 34.0 & 32.0 \\
\hline & 9.0 & 22.2 & 24.2 & 32.9 & 30.8 \\
\hline & 10.0 & 20.5 & 21.5 & 31.6 & 29.3 \\
\hline \multirow[t]{7}{*}{ TAB3 } & 1.0 & 30.4 & 29.1 & 33.3 & 28.4 \\
\hline & 3.0 & 28.4 & 29.5 & 33.3 & 29.6 \\
\hline & 5.0 & 25.6 & 28.1 & 32.5 & 29.7 \\
\hline & 7.0 & 23.1 & 25.6 & & 28.9 \\
\hline & 9.0 & 21.2 & 23.6 & & 27.7 \\
\hline & 11.0 & 20.1 & 21.6 & & 26.3 \\
\hline & 13.0 & 19.4 & 20.8 & & 24.9 \\
\hline \multirow[t]{6}{*}{ TAB5 } & 1.0 & 32.3 & 28.7 & 31.7 & 28.5 \\
\hline & 3.0 & 30.6 & 28.8 & 34.4 & 31.5 \\
\hline & 5.0 & 27.4 & 28.0 & 35.5 & 32.5 \\
\hline & 7.0 & 24.7 & 26.0 & 35.8 & 32.5 \\
\hline & 9.0 & 22.2 & 24.1 & 34.6 & 31.6 \\
\hline & 11.0 & 20.0 & 21.1 & 32.0 & 29.7 \\
\hline \multirow[t]{8}{*}{ ТAB6 } & 1.0 & 31.7 & 29.2 & 33.5 & 27.9 \\
\hline & 3.0 & 30.3 & 29.8 & 34.6 & 31.2 \\
\hline & 5.0 & 26.8 & 27.9 & 34.6 & 32.4 \\
\hline & 7.0 & 24.0 & 25.9 & 34.0 & 32.8 \\
\hline & 9.0 & 22.0 & 24.0 & 32.7 & 31.9 \\
\hline & 11.0 & 20.1 & 22.5 & 30.8 & 30.3 \\
\hline & 13.0 & 19.1 & 21.3 & 28.5 & 28.1 \\
\hline & 15.0 & 18.7 & 20.2 & 26.3 & 26.2 \\
\hline
\end{tabular}


Table D.17 cont. Wiping thermocouple measurements in Test Cell A $\left({ }^{\circ} \mathrm{C}\right)$.

\begin{tabular}{|c|c|c|c|c|c|}
\hline \multirow[b]{2}{*}{ Location } & \multirow[b]{2}{*}{$\begin{array}{l}\text { Depth } \\
\text { (ft bgs) }\end{array}$} & \multicolumn{4}{|c|}{ Date } \\
\hline & & $7 / 18 / 97$ & $7 / 24 / 97$ & $9 / 3 / 97$ & $9 / 6 / 97$ \\
\hline \multirow[t]{6}{*}{ TAB7 } & 1.0 & 33.9 & 27.5 & 32.4 & 29.0 \\
\hline & 3.0 & 30.7 & 28.8 & 33.0 & 31.8 \\
\hline & 5.0 & 27.0 & 27.3 & 32.6 & 31.8 \\
\hline & 7.0 & 24.2 & 25.7 & 31.9 & 31.3 \\
\hline & 9.0 & 22.1 & 24.1 & 30.3 & 30.1 \\
\hline & 10.5 & 20.1 & 21.0 & 28.0 & 28.1 \\
\hline \multirow{7}{*}{ TAMI } & 1.0 & & & & 28.7 \\
\hline & 3.0 & & & & 35.5 \\
\hline & 5.0 & & & & 37.7 \\
\hline & 7.0 & & & & 41.1 \\
\hline & 9.0 & & & & 42.8 \\
\hline & 11.0 & & & & 40.3 \\
\hline & 13.0 & & & & 34.9 \\
\hline \multirow[t]{7}{*}{ TAM2 } & 1.0 & & & & 29.8 \\
\hline & 3.0 & & & & 33.1 \\
\hline & 5.0 & & & & 33.4 \\
\hline & 7.0 & & & & 34.0 \\
\hline & 9.0 & & & & 32.7 \\
\hline & 11.0 & & & & 30.7 \\
\hline & 12.0 & & & & 29.5 \\
\hline
\end{tabular}

Blank table entry indicates measurement not taken.

D -25 
Table D.18 Wiping thermocouple measurements in Test Cell B $\left({ }^{\circ} \mathrm{C}\right)$.

\begin{tabular}{|c|c|c|c|c|c|c|}
\hline \multirow[b]{2}{*}{ Location } & \multirow[b]{2}{*}{$\begin{array}{c}\text { Depth } \\
\text { (ft bgs) }\end{array}$} & \multicolumn{5}{|c|}{ Date } \\
\hline & & $7 / 18 / 97$ & $7 / 24 / 97$ & $7 / 26 / 97$ & $9 / 3 / 97$ & 9/6/97 \\
\hline \multirow[t]{8}{*}{ TBB1 } & 1.0 & 32.5 & 33.0 & 38.1 & 40.0 & \\
\hline & 3.0 & 31.1 & 33.5 & 36.4 & 47.2 & \\
\hline & 5.0 & 27.7 & 36.8 & 36.7 & 57.3 & \\
\hline & 7.0 & 24.5 & 39.0 & 36.3 & 87.7 & \\
\hline & 9.0 & 22.5 & 32.1 & 30.9 & 57.0 & \\
\hline & 11.0 & 21.1 & 23.6 & 24.7 & 43.3 & \\
\hline & 13.0 & 20.1 & 21.2 & 21.4 & 36.6 & \\
\hline & 15.0 & 19.4 & 20.0 & 19.3 & 31.6 & \\
\hline \multirow[t]{6}{*}{ TBB2 } & 1.0 & 32.5 & 30.4 & & 34.6 & 28.4 \\
\hline & 3.0 & 31.6 & 31.6 & & & 28.3 \\
\hline & 5.0 & 27.9 & 28.4 & & & 27.8 \\
\hline & 7.0 & 24.6 & 24.9 & & & 26.7 \\
\hline & 9.0 & 22.7 & 22.3 & & & 25.7 \\
\hline & 11.0 & 20.5 & 20.2 & & & 24.8 \\
\hline \multirow{8}{*}{ TBB3 } & 1.0 & 31.2 & 28.6 & 34.9 & 34.0 & 31.1 \\
\hline & 3.0 & 30.2 & 30.5 & 30.0 & 36.4 & 32.5 \\
\hline & 5.0 & 27.4 & 28.2 & 28.5 & 37.7 & 32.4 \\
\hline & 7.0 & 24.7 & 25.3 & 25.8 & 38.0 & 30.8 \\
\hline & 9.0 & 22.7 & 23.4 & 23.6 & 36.3 & 29.2 \\
\hline & 11.0 & 21.3 & 21.0 & 22.2 & 33.3 & 27.7 \\
\hline & 13.0 & 20.2 & 20.1 & 21.1 & 30.8 & 25.5 \\
\hline & 15.0 & 19.5 & 19.4 & 20.4 & 28.4 & 23.1 \\
\hline \multirow[t]{8}{*}{ TBB4 } & 1.0 & 35.0 & 31.3 & & & 30.5 \\
\hline & 3.0 & 32.5 & 31.8 & & & 31.0 \\
\hline & 5.0 & 28.5 & 29.1 & & & 30.7 \\
\hline & 7.0 & 25.5 & 26.0 & & & 29.9 \\
\hline & 9.0 & 23.8 & 23.0 & & & 28.5 \\
\hline & 11.0 & 22.8 & 21.3 & & & 26.3 \\
\hline & 13.0 & 21.7 & 20.0 & & & 24.1 \\
\hline & 15.0 & 21.0 & 19.3 & & & 22.0 \\
\hline \multirow{6}{*}{ TBB5 } & 1.0 & 33.3 & 30.9 & & 32.6 & 26.5 \\
\hline & 3.0 & 31.5 & 31.0 & & 33.3 & 29.2 \\
\hline & 5.0 & 28.3 & 28.4 & & 33.1 & 30.2 \\
\hline & 7.0 & 25.6 & 25.7 & & 32.2 & 29.6 \\
\hline & 9.0 & 23.5 & 23.9 & & & \\
\hline & 11.0 & 22.1 & 22.4 & & & \\
\hline
\end{tabular}


Table D.18 cont. Wiping thermocouple measurements in Test Cell B $\left({ }^{\circ} \mathrm{C}\right)$.

\begin{tabular}{|c|c|c|c|c|c|c|}
\hline \multirow[b]{2}{*}{ Location } & \multirow[b]{2}{*}{$\begin{array}{c}\text { Depth } \\
\text { (ft bgs) }\end{array}$} & \multicolumn{5}{|c|}{ Date } \\
\hline & & 7/18/97 & $7 / 24 / 97$ & $7 / 26 / 97$ & 9/3/97 & 9/6/97 \\
\hline \multirow[t]{5}{*}{ TBB6 } & 1.0 & 33.9 & 27.0 & & 38.8 & 32.8 \\
\hline & 3.0 & 32.8 & 26.6 & & 37.7 & 33.2 \\
\hline & 5.0 & 29.3 & 27.2 & & 36.1 & 32.0 \\
\hline & 7.0 & 26.3 & 27.0 & & 34.6 & 31.0 \\
\hline & 9.0 & 24.0 & 23.5 & & 32.0 & 28.3 \\
\hline \multirow[t]{10}{*}{ TBB7 } & 1.0 & & & & 32.5 & 27.4 \\
\hline & 3.0 & & & & 34.0 & 27.3 \\
\hline & 5.0 & & & & 32.6 & 26.0 \\
\hline & 7.0 & & & & 30.8 & 24.5 \\
\hline & 8.0 & & & & 30.1 & 23.9 \\
\hline & 9.0 & & & & & 23.2 \\
\hline & 11.0 & & & & & 22.3 \\
\hline & 13.0 & & & & & 21.2 \\
\hline & 15.0 & & & & & 20.6 \\
\hline & 17.0 & & & & & 20.7 \\
\hline \multirow{8}{*}{ TBM1" } & 1.0 & & & & 37.8 & 31.8 \\
\hline & 3.0 & & & & 36.6 & 39.5 \\
\hline & 5.0 & & & & 38.5 & 54.8 \\
\hline & 7.0 & & & & 38.3 & 61.2 \\
\hline & 9.0 & & & & 36.4 & 54.9 \\
\hline & 11.0 & & & & 28.0 & 43.3 \\
\hline & 13.0 & & & & 24.9 & 34.5 \\
\hline & 14.3 & & & & 23.2 & 29.8 \\
\hline \multirow{8}{*}{ TBM2 } & 1.0 & & & & 33.3 & 29.9 \\
\hline & 3.0 & & & & 29.6 & 32.5 \\
\hline & 5.0 & & & & 27.4 & 34.2 \\
\hline & 7.0 & & & & 24.9 & 33.8 \\
\hline & 9.0 & & & & 23.6 & 32.6 \\
\hline & 11.0 & & & & 22.2 & 29.0 \\
\hline & 13.0 & & & & 21.8 & 25.6 \\
\hline & 14.3 & & & & 21.0 & 24.1 \\
\hline
\end{tabular}

Blank table entry indicates measurement not taken. 
Table D.19 TDR measurements in Test Cell A monitoring location (\% moisture).

\begin{tabular}{|c|c|c|c|c|c|c|c|c|c|c|c|c|c|}
\hline \multirow[t]{2}{*}{ Location } & \multirow{2}{*}{$\begin{array}{c}\text { Depth } \\
\text { (ft bgs) }\end{array}$} & \multicolumn{12}{|c|}{ Date } \\
\hline & & $10 / 8 / 96$ & $10 / 17 / 96$ & $10 / 21 / 96$ & $11 / 8 / 96$ & $11 / 11 / 96$ & $11 / 15 / 96$ & $11 / 21 / 96$ & $11 / 26 / 96$ & $12 / 4 / 96$ & $7 / 18 / 97$ & $7 / 25 / 97$ & $9 / 5 /$ \\
\hline \multirow[t]{10}{*}{ TAM1 } & 3 & 25.7 & 25.5 & 25.1 & 24.8 & 24.8 & 24.8 & 24.5 & 25.1 & 25.7 & 30.3 & 30.6 & 31 . \\
\hline & 4 & 27.4 & 26.5 & 26.0 & 26.2 & 26.1 & 26.5 & 26.2 & 25.9 & 26.2 & 29.4 & 28.3 & 29. \\
\hline & 6 & 30.0 & 30.1 & 29.6 & 29.7 & 30.0 & 29.7 & 29.4 & 30.6 & 29.7 & 30.6 & 31.8 & 34. \\
\hline & 7 & 30.3 & 30.0 & 30.0 & 29.1 & 29.1 & 29.4 & 28.8 & 30.8 & 29.1 & 30.3 & 30.9 & 33. \\
\hline & 8 & 34.9 & 34.0 & 33.7 & & & & 34.2 & 35.5 & 34.2 & 33.9 & 34.6 & 36. \\
\hline & 10 & & & & & & & 29.7 & 30.0 & 30.3 & 30.3 & 31.8 & 31. \\
\hline & 11 & 30.9 & 30.5 & 30.0 & 30.3 & 29.4 & 30.6 & 30.3 & 30.0 & 30.3 & 30.6 & 30.6 & 31. \\
\hline & 11.5 & 41.1 & 39.8 & 39.8 & 39.5 & 40.5 & 40.5 & 39.5 & 39.9 & 38.9 & 38.6 & 39.2 & 44 . \\
\hline & 12 & 39.5 & 37.1 & 36.5 & 36.1 & 36.7 & 36.7 & 35.9 & 35.8 & 35.5 & 36.4 & 35.2 & 43. \\
\hline & 14 & 28.8 & 30.0 & 29.6 & 29.4 & 24.8 & 29.7 & 28.6 & 29.4 & 29.4 & 30.0 & 30.3 & 29 . \\
\hline \multirow[t]{10}{*}{ TAM2" } & 3 & 27.1 & 27.2 & 26.9 & 26.5 & 26.8 & 27.7 & 26.5 & 27.4 & 27.1 & 29.1 & 28.6 & 28. \\
\hline & 4.8 & 10.9 & 11.0 & 10.0 & 9.9 & 9.9 & 9.2 & 23.8 & 9.6 & 9.2 & 23.9 & 23.7 & 23 . \\
\hline & 5.3 & 28.8 & 27.5 & 27.8 & 27.1 & 26.8 & 26.8 & 26.8 & 27.1 & 26.8 & 29.1 & 28.3 & 28 . \\
\hline & 5.8 & 31.5 & 33.0 & 32.8 & 32.4 & 32.1 & 31.8 & 32.1 & 31.5 & 32.1 & 33.6 & 33.0 & 34. \\
\hline & 6.5 & -114.3 & -124.0 & -124.0 & -144.8 & -148.1 & 47.4 & -155.2 & 31.5 & 31.4 & -20.7 & -119.1 & -78 \\
\hline & 7 & 37.0 & 36.1 & 36.0 & 35.5 & 35.5 & 36.2 & 35.8 & 36.4 & 36.1 & 37.2 & 36.4 & 39. \\
\hline & 7.5 & 36.4 & 36.5 & 36.0 & & & & 35.8 & 35.8 & 35.3 & 37.3 & 37.0 & 41 . \\
\hline & 8 & 34.2 & 34.4 & 34.6 & & & & 34.2 & 33.6 & 34.9 & 34.9 & 34.6 & 35 . \\
\hline & 10 & 28.8 & 28.9 & 28.7 & 24.5 & 28.8 & 28.7 & 28.6 & 28.4 & 28.6 & 28.3 & 28.8 & 29. \\
\hline & 12 & 35.2 & 33.8 & 33.2 & 31.8 & 31.8 & & 31.5 & 31.2 & 30.6 & 30.6 & 31.5 & 31. \\
\hline
\end{tabular}

Blank table entry indicates measurement not taken. 
Table D.20 TDR measurements in Test Cell B monitoring location (\% moisture).

\begin{tabular}{|c|c|c|c|c|c|c|c|c|c|c|c|c|c|}
\hline \multirow[t]{2}{*}{ Location } & \multirow{2}{*}{$\begin{array}{c}\text { Depth } \\
\text { (ft bgs) }\end{array}$} & \multicolumn{12}{|c|}{$\overline{\text { Date }}$} \\
\hline & & $10 / 8 / 96$ & $10 / 17 / 96$ & $10 / 22 / 96$ & $11 / 8 / 96$ & $11 / 11 / 96$ & $11 / 15 / 96$ & $11 / 21 / 96$ & $11 / 26 / 96$ & $12 / 4 / 96$ & $7 / 18 / 97$ & $7 / 25 / 97$ & $9 / 5 / 9^{\prime}$ \\
\hline \multirow[t]{7}{*}{ TBM1 } & 3 & 29.7 & 29.4 & 30.0 & 30.6 & 26.7 & 29.7 & 30.0 & 30.0 & 30.0 & 33.9 & 32.7 & $\overline{33.9}$ \\
\hline & 4.5 & & & & & & & & & & & & \\
\hline & 5.3 & 27.7 & 28.9 & 29.1 & 28.6 & 28.8 & 28.8 & 29.1 & 29.4 & 29.1 & 30.6 & 30.9 & 26.2 \\
\hline & 7.5 & 31.8 & 31.7 & & 19.7 & 18.3 & 17.2 & 17.7 & 18.9 & 17.2 & 32.1 & 21.4 & 18.1 \\
\hline & 8.3 & 30.9 & 29.8 & 30.5 & 30.0 & 30.0 & 30.0 & 30.0 & 30.3 & 30.3 & 31.5 & 30.0 & 30.6 \\
\hline & 9 & 30.9 & 30.3 & 30.5 & 29.7 & 30.0 & 30.0 & 30.0 & 30.3 & 30.3 & 32.1 & 32.1 & 32.6 \\
\hline & 12 & 28.8 & 28.2 & 28.7 & 27.4 & 27.4 & 27.7 & 27.4 & 28.0 & 28.0 & 30.6 & 30.0 & 29.3 \\
\hline \multirow[t]{3}{*}{ TBM2 } & 6 & 36.7 & 36.4 & 37.0 & 36.1 & 36.1 & 36.1 & 35.5 & 36.4 & 36.1 & 37.3 & 37.6 & 38.0 \\
\hline & 7.2 & 32.7 & 32.1 & 21.2 & 32.1 & 31.5 & 32.1 & 31.1 & 31.8 & 31.5 & 33.3 & 32.4 & 33.2 \\
\hline & 8 & 32.1 & 31.7 & 31.8 & 31.2 & 31.2 & 31.5 & 30.9 & 31.2 & 31.5 & 33.0 & 32.7 & 34.1 \\
\hline
\end{tabular}


Table D.21 Helium tracer test, injection in fracture B-8, Test Cell B, October 27, 1996.

\begin{tabular}{cccccc}
\hline Date & $\begin{array}{c}\text { Injection } \\
\text { Point }\end{array}$ & Time & $\begin{array}{c}\text { Elapsed } \\
\text { Time } \\
(\mathrm{min})\end{array}$ & $\begin{array}{c}\text { Monitor } \\
\text { Point }\end{array}$ & He Conc. Comments \\
$(\%)$
\end{tabular}


Table D.21 cont. Helium tracer test, injection in fracture B-8, Test Cell B, October 27, 1996.

\begin{tabular}{|c|c|c|c|c|c|c|}
\hline Date & $\begin{array}{c}\text { Injection } \\
\text { Point }\end{array}$ & Time & $\begin{array}{c}\text { Elapsed } \\
\text { Time } \\
\text { (hr:m) }\end{array}$ & $\begin{array}{c}\text { Monitor } \\
\text { Point }\end{array}$ & $\begin{array}{c}\text { He Conc } \\
(\%)\end{array}$ & Comments \\
\hline \multirow[t]{14}{*}{$10 / 27 / 96$} & $\overline{B-8}$ & $16: 49$ & $1: 09$ & $\overline{\mathrm{B}-4}$ & & Inadequate flow \\
\hline & & $16: 51$ & $1: 11$ & & & Inadequate flow \\
\hline & & $16: 59$ & $1: 19$ & & & Too much flow \\
\hline & & $17: 02$ & $1: 22$ & & & Too much flow \\
\hline & & $17: 05$ & $1: 25$ & & 2.20 & \\
\hline & & $17: 06$ & $1: 26$ & & 2.10 & \\
\hline & & $17: 07$ & $1: 27$ & & & Detector powered down \\
\hline & & $17: 15$ & $1: 35$ & & 1.80 & \\
\hline & & $17: 16$ & $1: 36$ & & 1.90 & \\
\hline & & $17: 22$ & $1: 42$ & $\mathrm{~B}-8$ & $52.00^{\circ}$ & Inj. mix measured $3 \mathrm{ft} b \mathrm{gs}$ \\
\hline & & $17: 32$ & $1: 52$ & $\mathrm{~B}-4$ & 2.50 & \\
\hline & & $18: 20$ & $2: 40$ & $\mathrm{~B}-8$ & 93.00 & Inj. mix measured $3 \mathrm{ft} b g s$ \\
\hline & & $18: 28$ & $2: 48$ & $\mathrm{~B}-12$ & 3.60 & \\
\hline & & $19: 05$ & $3: 25$ & $\mathrm{~B}-4$ & 5.20 & Injection flow stopped \\
\hline
\end{tabular}


Table D.22 Helium tracer test, injection in fracture B-8, Test Cell B, October 28, 1996.

\begin{tabular}{|c|c|c|c|c|c|c|}
\hline Date & $\begin{array}{c}\text { Injection } \\
\text { Point }\end{array}$ & Time & $\begin{array}{l}\text { Elapsed } \\
\text { Time } \\
\text { (hr:m) }\end{array}$ & $\begin{array}{l}\text { Monitor } \\
\text { Point }\end{array}$ & $\begin{array}{c}\mathrm{He} \\
\text { Conc. } \\
(\%)\end{array}$ & Comments \\
\hline \multirow[t]{32}{*}{$10 / 28 / 96$} & & $10: 55$ & & Cell B & 0.00 & B4 outflow rate $=4 \mathrm{scfm}$ \\
\hline & & & & & & B12 gauge not operting \\
\hline & & 10:58 & & B-4 & 0.00 & B-4, pre-injection fracture gas \\
\hline & & 10:59 & & Cell B & 0.00 & Ambient air at cell B \\
\hline & & $11: 00$ & & B-8 & 0.00 & Inj. mix measured $3 \mathrm{ft}$ bgs \\
\hline & & & & & & $\begin{array}{l}3.0 \mathrm{scfh} \text { air flow into } \mathrm{B}-8 \text { prior to } \\
\text { injection }\end{array}$ \\
\hline & B-8 & $11: 07$ & & & & $\begin{array}{l}\text { Inj. start, } \mathrm{He}=2.0 \mathrm{scfh} \text { (as air) } \\
\text { indicated }\end{array}$ \\
\hline & & $11: 08$ & $0: 01$ & B-4 & 0.00 & \\
\hline & & 11:09 & 0:02 & & 0.00 & \\
\hline & & 11:10 & $0: 03$ & & 0.00 & $\begin{array}{l}\text { He flow }=2.0 \mathrm{scfh} \text { (as air) at } \\
\text { cylinder. } 325 \mathrm{scfh} \text { total ini at B-8 }\end{array}$ \\
\hline & & 11:11 & 0:04 & & 0.00 & \\
\hline & & 11:12 & 0:05 & & 0.12 & \\
\hline & & 11:13 & 0:06 & & 0.46 & $\begin{array}{l}\text { He inj. had stopped, restarted at } 2.0 \\
\text { scfh }\end{array}$ \\
\hline & & 11:14 & $0: 07$ & & 0.51 & \\
\hline & & $11: 15$ & $0: 08$ & & 0.56 & \\
\hline & & $11: 16$ & $0: 09$ & & 0.59 & \\
\hline & & 11:17 & $0: 10$ & & 0.61 & \\
\hline & & $11: 18$ & $0: 11$ & & 0.63 & \\
\hline & & $11: 19$ & $0: 12$ & & 0.72 & \\
\hline & & $11: 20$ & $0: 13$ & & 0.74 & \\
\hline & & $11: 21$ & $0: 14$ & & 0.75 & He flow adj. back up to $2.0 \mathrm{scfh}$ \\
\hline & & $11: 23$ & $0: 16$ & & 0.83 & \\
\hline & & $11: 24$ & $0: 17$ & & 0.84 & \\
\hline & & $11: 25$ & $0: 18$ & B-12 & 0.09 & \\
\hline & & $11: 26$ & $0: 19$ & & 0.11 & \\
\hline & & $11: 28$ & $0: 21$ & & 0.12 & \\
\hline & & $11: 33$ & $0: 26$ & & 0.27 & \\
\hline & & $11: 34$ & $0: 27$ & $\mathrm{~B}-4$ & 0.85 & \\
\hline & & $11: 35$ & $0: 28$ & & 0.82 & \\
\hline & & $11: 37$ & $0: 30$ & & 0.76 & \\
\hline & & $11: 38$ & $0: 31$ & & 0.77 & \\
\hline & & $11: 40$ & $0: 33$ & $\mathrm{~B}-8$ & 36.00 & $\begin{array}{l}\text { Inj. mix measured } 3 \mathrm{ft} b g s \text {, total flow } \\
=3.25 \mathrm{scfh}\end{array}$ \\
\hline
\end{tabular}


Table D.22 cont. Helium tracer test, injection in fracture B-8, Test Cell B, October 28, 1996.

\begin{tabular}{|c|c|c|c|c|c|c|}
\hline Date & $\begin{array}{l}\text { Injection } \\
\text { Point }\end{array}$ & Time & $\begin{array}{c}\text { Elapsed } \\
\text { Time } \\
\text { (hr:m) }\end{array}$ & $\begin{array}{l}\text { Monitor } \\
\text { Point }\end{array}$ & $\begin{array}{c}\mathrm{He} \\
\text { Conc. } \\
(\%)\end{array}$ & Comments \\
\hline \multirow[t]{29}{*}{$10 / 28 / 96$} & $\overline{\mathrm{B}-8}$ & $11: 42$ & $0: 35$ & $\overline{\mathrm{B}-4}$ & 0.89 & \\
\hline & & $11: 44$ & $0: 37$ & & 0.84 & \\
\hline & & $11: 45$ & $0: 38$ & & 0.82 & \\
\hline & & $11: 46$ & $0: 39$ & & 0.80 & \\
\hline & & $11: 48$ & $0: 41$ & & 0.84 & \\
\hline & & $11: 53$ & $0: 46$ & & 0.94 & \\
\hline & & $11: 57$ & $0: 50$ & & 0.90 & \\
\hline & & $11: 59$ & $0: 52$ & $\mathrm{~B}-12$ & 0.04 & \\
\hline & & $12: 02$ & $0: 55$ & & 0.04 & \\
\hline & & $12: 04$ & $0: 57$ & & 0.39 & Inj. flow stable at $2.0 \mathrm{scfh}$ \\
\hline & & $12: 12$ & 1:05 & & 0.33 & \\
\hline & & $12: 13$ & $1: 06$ & $\mathrm{~B}-4$ & 1.00 & \\
\hline & & $12: 14$ & 1:07 & & 1.10 & \\
\hline & & $12: 20$ & $1: 13$ & & 1.10 & \\
\hline & & $12: 22$ & $1: 15$ & B-8 & 40.00 & Inj. mix measured $3 \mathrm{ft}$ bgs \\
\hline & & $12: 25$ & $1: 18$ & $\mathrm{~B}-4$ & 0.97 & \\
\hline & & $12: 29$ & $1: 22$ & & 0.95 & \\
\hline & & $12: 32$ & $1: 25$ & & 1.00 & \\
\hline & & $12: 35$ & $1: 28$ & $\mathrm{~B}-12$ & 0.04 & \\
\hline & & $12: 43$ & $1: 36$ & & 0.14 & \\
\hline & & $12: 47$ & $1: 40$ & & 0.27 & \\
\hline & & $12: 50$ & $1: 43$ & & 0.23 & \\
\hline & & $12: 51$ & $1: 44$ & $\mathrm{~B}-4$ & 1.20 & \\
\hline & & $13: 00$ & $1: 53$ & & 1.30 & \\
\hline & & $13: 15$ & $2: 08$ & & 1.00 & \\
\hline & & $14: 00$ & $2: 53$ & & 0.71 & \\
\hline & & $14: 01$ & $2: 54$ & $\mathrm{~B}-12$ & 0.05 & \\
\hline & & $14: 02$ & $2: 55$ & & 0.04 & \\
\hline & & $14: 05$ & $2: 58$ & & & Stopped $\mathrm{He}$ injection \\
\hline
\end{tabular}


Table D.23 Helium tracer test, injection in mini-soil piezometer NW-2, Test Cell A, November 22, 1996.

\begin{tabular}{|c|c|c|c|c|c|c|}
\hline Date & $\begin{array}{l}\text { Injection } \\
\text { Point }\end{array}$ & Time & $\begin{array}{l}\text { Elapsed } \\
\text { Time } \\
\text { (hr:m) }\end{array}$ & $\begin{array}{l}\text { Monitor } \\
\text { Point }\end{array}$ & $\begin{array}{c}\mathrm{He} \\
\text { Conc. } \\
(\%)\end{array}$ & Comments \\
\hline $11 / 22 / 96$ & & $15: 00$ & & $\overline{\mathrm{A}-4}$ & 0.00 & A-4, pre-injection fracture gas \\
\hline & $\mathrm{NW}-2 *$ & $15: 02$ & & \multirow{6}{*}{$A-4$} & & \multirow{6}{*}{$\begin{array}{l}\text { Started He flow into NW2, free flow } \\
\text { at } 0.4 \text { scfh (as air) }\end{array}$} \\
\hline & & $15: 04$ & $0: 02$ & & 0.00 & \\
\hline & & $15: 06$ & 0:04 & & 0.00 & \\
\hline & & $15: 08$ & $0: 06$ & & 0.00 & \\
\hline & & $15: 10$ & $0: 08$ & & 0.00 & \\
\hline & & $15: 13$ & $0: 11$ & & 0.00 & \\
\hline & & $15: 13$ & $0: 11$ & \multirow[t]{3}{*}{$\mathrm{A}-12$} & 0.18 & \\
\hline & & $15: 15$ & $0: 13$ & & 0.16 & \\
\hline & & $15: 16$ & $0: 14$ & & 0.06 & \\
\hline & & $15: 18$ & $0: 16$ & \multirow[t]{3}{*}{$\mathrm{A}-4$} & 0.00 & \\
\hline & & $15: 20$ & $0: 18$ & & 0.00 & \\
\hline & & $15: 25$ & $0: 23$ & & 0.00 & \\
\hline & & $15: 30$ & $0: 28$ & $A-12$ & 0.04 & \\
\hline & & $15: 33$ & $0: 31$ & \multirow[t]{2}{*}{$\mathrm{A}-4$} & 0.00 & \multirow[t]{2}{*}{$\begin{array}{l}\text { Problem w/He detector, also water in } \\
\text { A-4 and A-12 sample lines }\end{array}$} \\
\hline & & $16: 05$ & $1: 03$ & & 0.00 & \\
\hline & & $16: 06$ & $1: 04$ & \multirow[t]{2}{*}{$A-12$} & 0.21 & \\
\hline & & $16: 07$ & $1: 05$ & & 0.33 & \\
\hline & & $16: 09$ & $1: 07$ & $\mathrm{~A}-4$ & $0.00^{\circ}$ & \\
\hline & & $16: 12$ & $1: 10$ & $\mathrm{~A}-12$ & 0.23 & $\begin{array}{l}\text { Water in drop-out pot, as water } \\
\text { enters the sample line the conc. of He } \\
\text { drops - the transport of He in the } \\
\text { sample line may be inhibited by the } \\
\text { moisture. }\end{array}$ \\
\hline
\end{tabular}

* Mini-piezometer NW-2 was $6 \mathrm{ft}$ northwest of the center of Test Cell A.

Note: A previous test injecting helium into the $8 \mathrm{ft}$ fracture at Test Cell A failed. The helium caused the steam generator to malfunction. 
Table D.24 Helium tracer test, injection in B-6 fracture at high flow rate, Test Cell B November 23, 1996.

\begin{tabular}{|c|c|c|c|c|c|c|}
\hline Date & $\begin{array}{l}\text { Injection } \\
\text { Point }\end{array}$ & Time & $\begin{array}{l}\text { Elapsed } \\
\text { Time } \\
\text { (hr:m) }\end{array}$ & $\begin{array}{l}\text { Monitor } \\
\text { Point }\end{array}$ & $\begin{array}{c}\mathrm{He} \\
\text { Conc. } \\
(\%)\end{array}$ & Comments \\
\hline \multirow[t]{2}{*}{$11 / 23 / 96$} & & $11: 10$ & & $\overline{\mathrm{B}-4}$ & 0.00 & Air flow into $6 \mathrm{ft}$ fracture $=6 \mathrm{scfm}$ \\
\hline & & $11: 10$ & & B-12 & 0.00 & \\
\hline & B-6 & $11: 19$ & & & & Inj. start, He inj. @ 1.0 scfm \\
\hline & & $11: 20$ & 0:01 & B-4 & 31.00 & \\
\hline & & $11: 22$ & $0: 03$ & $\mathrm{~B}-12$ & 0.00 & Water entering drop-out pot \\
\hline & & $11: 23$ & $0: 04$ & & 0.02 & \\
\hline & & $11: 24$ & 0:05 & & 0.21 & \\
\hline & & $11: 25$ & $0: 06$ & B-4 & 32.00 & \\
\hline & & $11: 33$ & $0: 14$ & $\mathrm{~B}-12$ & 0.39 & \\
\hline & & $11: 34$ & $0: 15$ & & 0.45 & \\
\hline & & $11: 35$ & $0: 16$ & & 0.59 & \\
\hline & & $11: 36$ & $0: 17$ & & 0.62 & \\
\hline & & $11: 37$ & $0: 18$ & B-4 & 32.00 & \\
\hline & & $11: 43$ & $0: 24$ & B-12 & 1.60 & \\
\hline & & $11: 44$ & $0: 25$ & & 0.84 & \\
\hline & & $11: 45$ & $0: 26$ & & 0.73 & \\
\hline & & $11: 46$ & 0:27 & & & $\begin{array}{l}\text { Stopped He flow. Used over half of } \\
\text { an "A" size cylinder of helium. }\end{array}$ \\
\hline
\end{tabular}


Table D.25 Helium tracer test, injection in mini-soil piezometer BN-1, Test Cell B, November 24, 1996.

\begin{tabular}{|c|c|c|c|c|c|c|}
\hline Date & $\begin{array}{l}\text { Injection } \\
\text { Point }\end{array}$ & Time & $\begin{array}{l}\text { Elapsed } \\
\text { Time } \\
\text { (hr:m) }\end{array}$ & $\begin{array}{l}\text { Monitor } \\
\text { Point }\end{array}$ & $\begin{array}{c}\mathrm{He} \\
\text { Conc. } \\
(\%)\end{array}$ & Comments \\
\hline \multirow[t]{23}{*}{$11 / 24 / 96$} & & $14: 34$ & & Cell B & 0.00 & Ambient air \\
\hline & & & & B-4 & 0.00 & B-4, pre-inj. fracture gas \\
\hline & & & & B-12 & 0.00 & B-12, pre-inj. fracture gas \\
\hline & $\mathrm{BN}-1{ }^{*}$ & & & & & $\begin{array}{l}\text { He inj. into mini-piezo. Non- } \\
\text { pressurized inj., piezo. is open to } \\
\text { atmosphere. }\end{array}$ \\
\hline & & $14: 51$ & & & & He inj. start \\
\hline & & $14: 53$ & $0: 02$ & B-4 & 0.00 & \\
\hline & & $14: 55$ & $0: 04$ & & 0.00 & \\
\hline & & $14: 57$ & 0:06 & & 0.00 & \\
\hline & & $14: 58$ & $0: 07$ & B-12 & 0.00 & \\
\hline & & $15: 00$ & $0: 09$ & & 0.00 & \\
\hline & & 15:01 & 0:10 & & 0.00 & \\
\hline & & $15: 02$ & $0: 11$ & $\mathrm{~B}-4$ & 0.17 & \\
\hline & & $15: 03$ & $0: 12$ & & 0.56 & $\begin{array}{l}\text { He detector did not return to zero in } \\
\text { ambient air (dropped to } 0.5 \text { ). May } \\
\text { not be accurate values. }\end{array}$ \\
\hline & & $15: 04$ & $0: 13$ & & 0.61 & \\
\hline & & $15: 07$ & $0: 16$ & B-12 & 0.00 & Water arriving in sample lines \\
\hline & & $15: 10$ & $0: 19$ & $\mathrm{~B}-4$ & 0.26 & \\
\hline & & $15: 12$ & $0: 21$ & & 0.27 & \\
\hline & & $15: 13$ & $0: 22$ & & 0.29 & \\
\hline & & $15: 15$ & $0: 24$ & & 0.30 & \\
\hline & & $15: 17$ & $0: 26$ & $\mathrm{BN}-1$ & 30.00 & $\begin{array}{l}\text { He measured } 4 \text { " into casing of BN- } \\
1\end{array}$ \\
\hline & & $15: 20$ & $0: 29$ & $\mathrm{~B}-4$ & 0.00 & $\begin{array}{l}\text { Flushed water droplets out of sample } \\
\text { lines. }\end{array}$ \\
\hline & & $15: 25$ & $0: 34$ & & 0.00 & No other changes to system. Do not \\
\hline & & $15: 30$ & $0: 39$ & & 0.00 & Stopped injection. \\
\hline
\end{tabular}

* BN-1 is a mini-piezometer 30 " deep installed $4 \mathrm{ft}$ north-northwest of the center of Test Cell B. 
Table D.26 Helium tracer test, injection in fracture B-6, Test Cell B, December 9, 1996.

\begin{tabular}{|c|c|c|c|c|c|c|}
\hline Date & $\begin{array}{c}\text { Injection } \\
\text { Point }\end{array}$ & Time & $\begin{array}{l}\text { Elapsed } \\
\text { Time } \\
(\mathrm{hr}: \mathrm{m})\end{array}$ & $\begin{array}{l}\text { Monitor } \\
\text { Point }\end{array}$ & $\begin{array}{c}\text { He Conc. } \\
(\%)\end{array}$ & Comments \\
\hline \multirow[t]{31}{*}{$12 / 9 / 96$} & & $13: 52$ & & Trailer & 0.00 & Ambient air in trailer \\
\hline & & 13:54 & & B-4 & 0.00 & B-4, pre-injection fracture gas \\
\hline & & & & B-12 & 0.00 & B-12, pre-injection fracture gas \\
\hline & $\mathrm{B}-6$ & $14: 16$ & & & & $\begin{array}{l}\text { Injection start, He pres. }=12 \text { psi, } \\
\text { flow }=1.7 \mathrm{~L} / \mathrm{min}(\text { as Helium })\end{array}$ \\
\hline & & $14: 17$ & $0: 01$ & B-4 & 0.14 & \\
\hline & & $14: 18$ & $0: 02$ & & 0.20 & \\
\hline & & 14:19 & $0: 03$ & $\mathrm{~B}-12$ & 0.00 & \\
\hline & & $14: 21$ & $0: 05$ & & 0.00 & Flow stable@1.7 L/min \\
\hline & & $14: 22$ & $0: 06$ & B-4 & 0.69 & \\
\hline & & $14: 23$ & $0: 07$ & & 0.62 & \\
\hline & & $14: 24$ & $0: 08$ & & 0.63 & \\
\hline & & $14: 25$ & $0: 09$ & & 0.64 & \\
\hline & & $14: 27$ & $0: 11$ & & 0.65 & \\
\hline & & $14: 28$ & $0: 12$ & B-12 & 0.00 & \\
\hline & & $14: 29$ & $0: 13$ & & 0.00 & \\
\hline & & $14: 30$ & $0: 14$ & B-4 & 0.79 & \\
\hline & & $14: 31$ & $0: 15$ & & 0.85 & \\
\hline & & $14: 33$ & $0: 17$ & & 0.86 & \\
\hline & & $14: 35$ & $0: 19$ & & 0.87 & Flow stable at $1.7 \mathrm{~L} / \mathrm{min}$ \\
\hline & & 14:37 & $0: 21$ & & 0.89 & \\
\hline & & $14: 39$ & $0: 23$ & B-12 & 0.00 & \\
\hline & & $14: 41$ & $0: 25$ & & 0.00 & \\
\hline & & $14: 43$ & $0: 27$ & $\mathrm{~B}-4$ & 0.89 & \\
\hline & & $14: 45$ & $0: 29$ & & 0.91 & \\
\hline & & $14: 50$ & $0: 34$ & B-12 & 0.00 & \\
\hline & & 14:54 & $0: 38$ & & 0.00 & \\
\hline & & $14: 57$ & $0: 41$ & & 0.00 & \\
\hline & & 14:57 & $0: 41$ & B-4 & 0.63 & \\
\hline & & $15: 10$ & $0: 54$ & & 0.66 & \\
\hline & & $15: 12$ & $0: 56$ & $\mathrm{~B}-12$ & 0.00 & \\
\hline & & $15: 17$ & $1: 01$ & B-4 & 0.67 & Injection stopped \\
\hline
\end{tabular}


Table D.27 Helium tracer test, injection in fracture B-8, Test Cell B, December 9, 1996.

\begin{tabular}{|c|c|c|c|c|c|c|}
\hline Date & $\begin{array}{c}\text { Injection } \\
\text { Point }\end{array}$ & Time & $\begin{array}{l}\text { Elapsed } \\
\text { Time } \\
\text { (hr:m) }\end{array}$ & $\begin{array}{l}\text { Monitor } \\
\text { Point }\end{array}$ & $\begin{array}{l}\text { He Conc. } \\
(\%)\end{array}$ & Comments \\
\hline \multirow[t]{32}{*}{$12 / 9 / 96$} & & $\overline{15: 53}$ & & $\overline{B-4}$ & 0.00 & $\mathrm{~B}-4$, pre-injection fracture gas \\
\hline & & $16: 00$ & & B-12 & 0.00 & B-12, pre-injection fracture gas \\
\hline & & 16:04 & & B-4 & 0.00 & B-4, pre-injection fracture gas \\
\hline & B-8 & $16: 06$ & & & & $\begin{array}{l}\text { Injection start, He flow }=1.7 \mathrm{~L} / \mathrm{min} \\
\text { (as He), pres = } 14 \text { psi (needed to } \\
\text { overcome hot air inj. pressure. }\end{array}$ \\
\hline & & 16:07 & 0:01 & B-12 & 0.04 & \\
\hline & & $16: 08$ & $0: 02$ & & 0.14 & \\
\hline & & 16:09 & $0: 03$ & & 0.18 & \\
\hline & & $16: 10$ & $0: 04$ & & 0.20 & \\
\hline & & $16: 11$ & $0: 05$ & & 0.24 & \\
\hline & & $16: 13$ & $0: 07$ & & 0.25 & \\
\hline & & $16: 16$ & $0: 10$ & $\mathrm{~B}-4$ & 0.62 & \\
\hline & & $16: 18$ & $0: 12$ & & 0.63 & \\
\hline & & $16: 20$ & $0: 14$ & & 0.60 & \\
\hline & & $16: 22$ & $0: 16$ & $\mathrm{~B}-12$ & 0.06 & He flow stable @ $1.7 \mathrm{~L} / \mathrm{min}$ \\
\hline & & $16: 25$ & $0: 19$ & & 0.05 & \\
\hline & & $16: 29$ & $0: 23$ & $\mathrm{~B}-4$ & 0.77 & \\
\hline & & $16: 33$ & $0: 27$ & & 0.63 & \\
\hline & & $16: 34$ & $0: 28$ & & 0.62 & \\
\hline & & $16: 35$ & $0: 29$ & B-12 & 0.14 & \\
\hline & & $16: 36$ & $0: 30$ & & 0.07 & \\
\hline & & $16: 38$ & $0: 32$ & & 0.04 & \\
\hline & & $16: 40$ & $0: 34$ & & 0.04 & \\
\hline & & $16: 41$ & $0: 35$ & $B-4$ & 0.68 & \\
\hline & & $16: 44$ & $0: 38$ & & 0.71 & \\
\hline & & $16: 49$ & $0: 43$ & & 0.63 & \\
\hline & & $16: 55$ & $0: 49$ & $\mathrm{~B}-12$ & 0.06 & \\
\hline & & $16: 56$ & $0: 50$ & & & Stopped He flow \\
\hline & & $16: 57$ & $0: 51$ & B-12 & 0.00 & \\
\hline & & $16: 59$ & $0: 53$ & $\mathrm{~B}-4$ & 0.19 & \\
\hline & & $17: 00$ & $0: 54$ & & 0.19 & \\
\hline & & $17: 08$ & 1:02 & & 0.00 & \\
\hline & & 17:12 & $1: 06$ & $\mathrm{~B}-12$ & 0.00 & \\
\hline
\end{tabular}


Table D.28 Helium tracer test, injection in A-8 fracture, Test Cell A, December 12, 1996.

\begin{tabular}{|c|c|c|c|c|c|c|}
\hline Date & $\begin{array}{c}\text { Injection } \\
\text { Point }\end{array}$ & Time & $\begin{array}{l}\text { Elapsed } \\
\text { Time } \\
(\mathrm{hr}: \mathrm{m})\end{array}$ & $\begin{array}{l}\text { Monitor } \\
\text { Point }\end{array}$ & $\begin{array}{l}\text { He Conc } \\
(\%)\end{array}$ & Comments \\
\hline \multirow[t]{21}{*}{$12 / 12 / 96$} & & $8: 38$ & & Trlr & 0.00 & Ambient air in trailer \\
\hline & & & & A-4 & 0.00 & A-4, pre-injection fracture gas \\
\hline & & & & A-12 & 0.00 & A-12, pre-injection fracture gas \\
\hline & $A-8$ & $8: 44$ & & & & Injection start, He flow @ $2.2 \mathrm{~L} / \mathrm{min}$ \\
\hline & & $8: 46$ & $0: 02$ & A-12 & 0.00 & \\
\hline & & $8: 48$ & $0: 04$ & $A-4$ & 0.00 & \\
\hline & & $8: 51$ & $0: 07$ & & 0.00 & \\
\hline & & $8: 53$ & $0: 09$ & $A-12$ & 0.00 & He connection broke, test stopped \\
\hline & $\bar{A}-8$ & $8: 57$ & & & & Restart injection @ $2.2 \mathrm{~L} / \mathrm{min}$ \\
\hline & & $8: 58$ & $0: 01$ & A-12 & 0.00 & \\
\hline & & $8: 59$ & $0: 02$ & $A-4$ & 0.00 & \\
\hline & & 9:00 & 0:03 & & 0.00 & $\begin{array}{l}\text { Flow dropping, incr. pres to } 25 \text { psi, } \\
\text { flow @ } 2.2 \mathrm{~L} / \mathrm{min} \text {. Flow cannot be } \\
\text { sustained. }\end{array}$ \\
\hline & & 9:02 & $0: 05$ & & 0.13 & \\
\hline & & $9: 03$ & $0: 06$ & & & Boosted flow to $2.2 \mathrm{~L} / \mathrm{min}$ \\
\hline & & 9:04 & $0: 07$ & & 0.14 & \\
\hline & & 9:05 & 0:08 & & 0.00 & \\
\hline & & 9:06 & 0:09 & & 0.00 & \\
\hline & & 9:07" & $0: 10$ & $\mathrm{~A}-12$ & 0.00 & Calibrated detector \\
\hline & & $9: 20$ & $0: 23$ & $A-4$ & 0.00 & \\
\hline & & $9: 22$ & $0: 25$ & $\mathrm{~A}-12$ & 0.14 & \\
\hline & & $9: 25$ & $0: 28$ & $A-4$ & 0.00 & Stopped test \\
\hline
\end{tabular}


APPENDIX E. OPERATIONAL AND POST TREATMENT BARRIER CELL CHARACTERISTICS 
Figure E.1 Test Cell D, Representative Eh Profile (location TDM2).

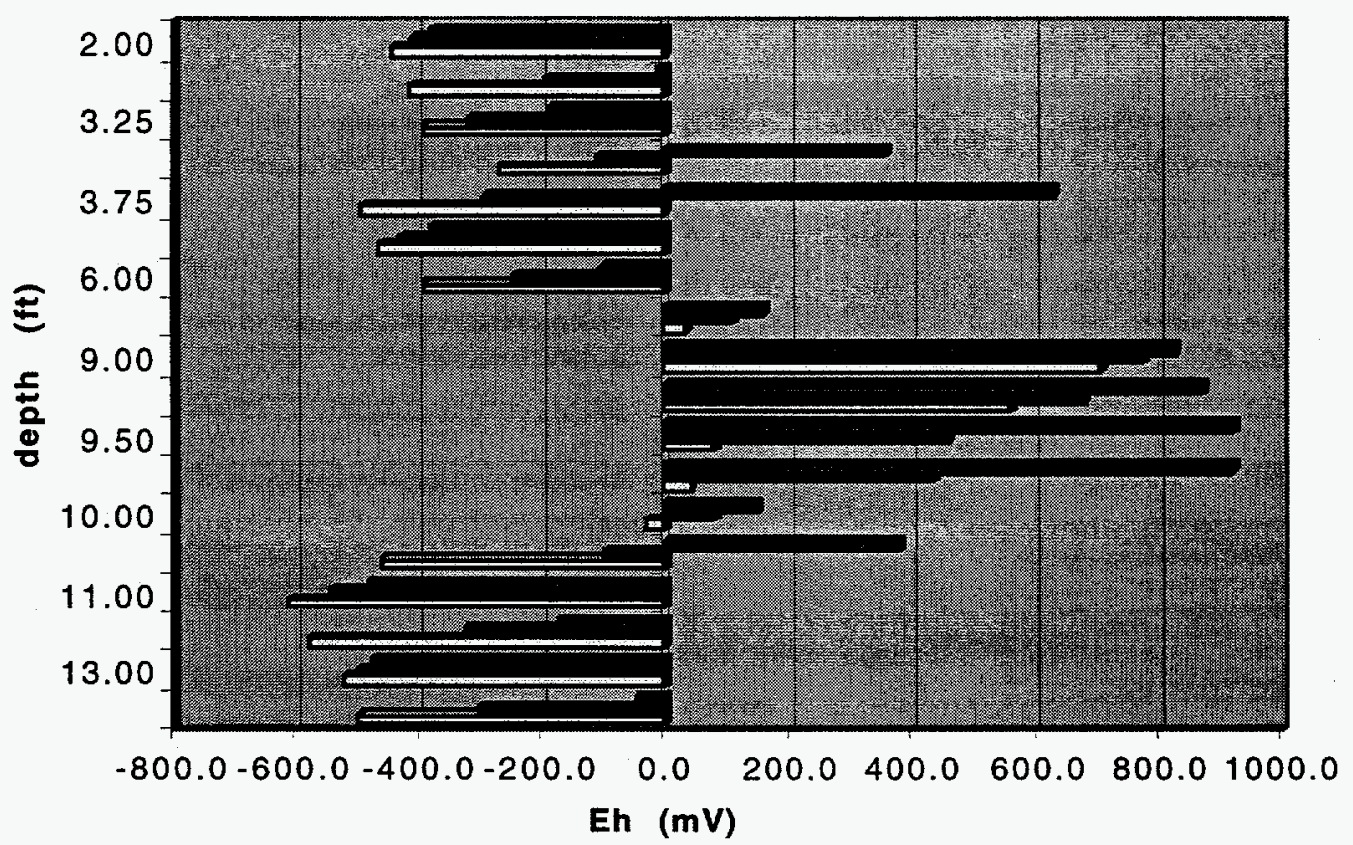

Min

- Ave

Max

E - 1 
Figure E.2 Volumetric moisture content as a function of depth and time in Cells C \& D.

Cell D (upper) and C (lower). Open symbols are from Fall, 1996, filled symbols from Summer, 1997, measured using TDR. Circles with internal cross measured in lab before testing (Fall 1996), squares with internal cross measured in lab after testing (Fall, 1997).
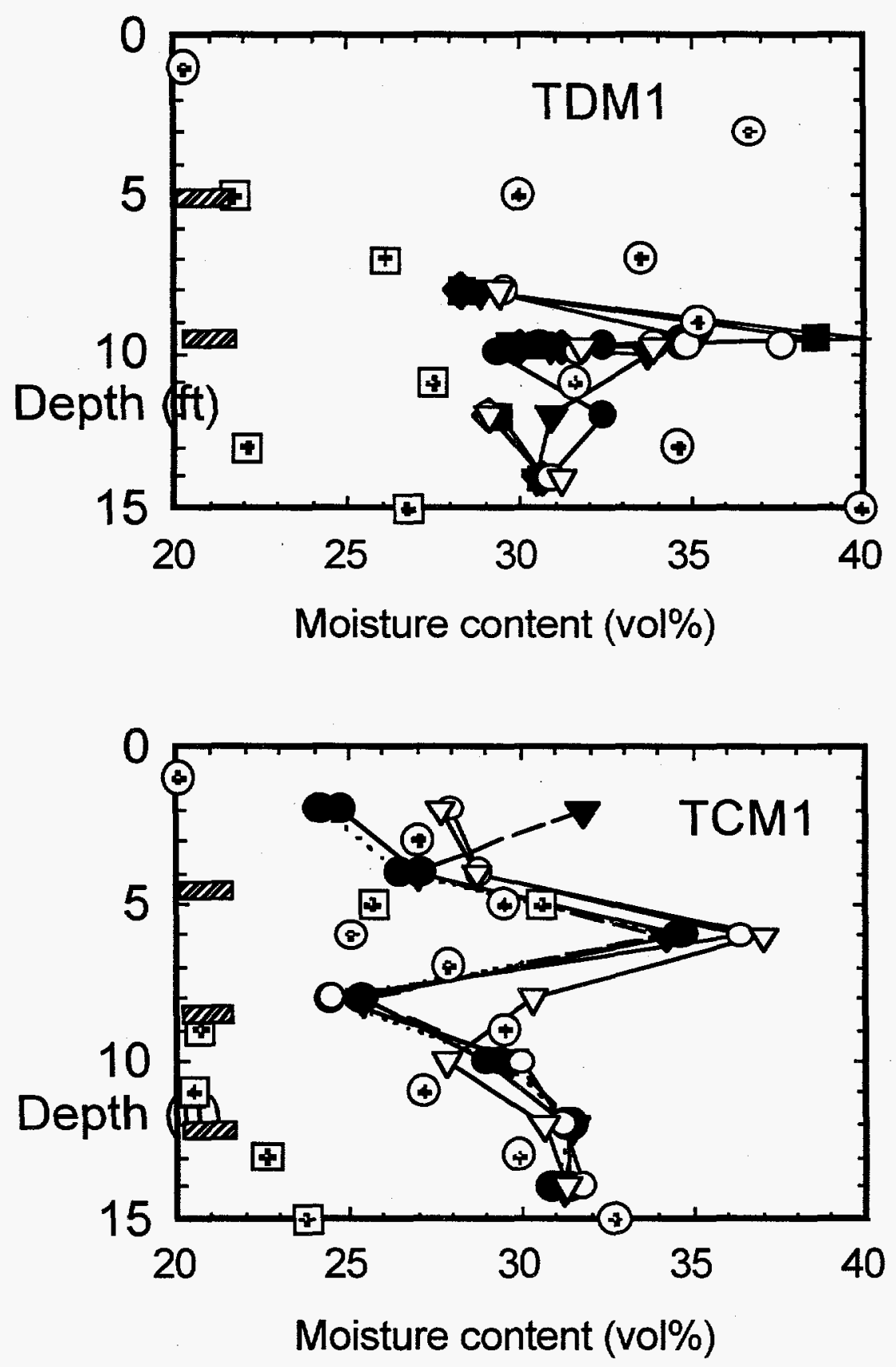

$\mathrm{E}-2$ 
Table E.1 Test Cell C physical/chemical characteristics with depth as observed in the field at $-3,10$ and 15 months after fracture emplacement.

\begin{tabular}{|c|c|c|c|c|c|c|}
\hline Sample ID & $\begin{array}{c}\text { Depth } \\
\text { (ft bgs) }\end{array}$ & $\begin{array}{c}\text { Date } \\
\text { Sampled }\end{array}$ & $\begin{array}{c}\text { Water } \\
\text { Content } \\
(\text { dry wt \%) }\end{array}$ & $\begin{array}{c}\text { Eh } \\
(\mathrm{mV})\end{array}$ & $\begin{array}{c}\text { Temp } \\
\left({ }^{\circ} \mathrm{F}\right)\end{array}$ & $\begin{array}{c}\mathrm{pH} \\
\text { (extract) }\end{array}$ \\
\hline TCB9-01 & 1 & $12 / 12 / 96$ & & 164.9 & 57.1 & 7.27 \\
\hline TCB9-03 & 3 & & & 274.1 & 56.5 & 5.33 \\
\hline TCB9-05 & 5 & & & 320.0 & 58.6 & 6.02 \\
\hline ТCB9-07 & 7 & & & 208.9 & 61.2 & 6.42 \\
\hline ТCB9-09 & 9 & & & 327.1 & 64.6 & 5.79 \\
\hline TCB9-11 & 11 & & & & & 6.00 \\
\hline ТСB9-13 & 13 & & & 348.6 & 66.7 & 6.34 \\
\hline TCB9-15 & 15 & & 25.27 & 342.0 & 64.9 & 6.62 \\
\hline TCB9-17 & 17 & & 26.05 & 321.2 & 63.9 & 6.49 \\
\hline TCB10-01 & 1 & $07 / 19 / 97$ & 16.85 & & & 6.89 \\
\hline TCB $10-03$ & 3 & & 20.87 & & & 4.47 \\
\hline TCB $10-05$ & 5 & & 22.15 & & & 6.55 \\
\hline ТCB 10-09 & 9 & & 20.50 & & & \\
\hline TCB $10-11$ & 11 & & 24.40 & & & 5.46 \\
\hline TCB $10-13$ & 13 & & 19.75 & & & 5.77 \\
\hline TCB $10-15$ & 15 & & 21.97 & & & 6.48 \\
\hline TCB11-01 & 1 & $07 / 19 / 97$ & 14.29 & & & 7.40 \\
\hline TCB $11-03$ & 3 & & 19.93 & & & 4.53 \\
\hline TCB $11-05$ & 5 & & 25.38 & & & 5.07 \\
\hline ТCB $11-07$ & 7 & & 21.95 & & & 4.77 \\
\hline TCB11-11 & 11 & & 21.41 & & & 5.60 \\
\hline TCB11-13 & 13 & & 21.62 & & & 6.11 \\
\hline TCB $11-15$ & 15 & & 20.88 & & & 6.79 \\
\hline TCB11-17 & 17 & & 29.86 & & & 6.71 \\
\hline TCB12-01 & 1 & $07 / 19 / 97$ & 16.77 & & & 7.07 \\
\hline TCB $12-05$ & 5 & & 26.66 & & & 5.09 \\
\hline TCB $12-05$ & 5 & & 23.94 & & & 6.10 \\
\hline TCB 12-09 & 9 & & 20.23 & & & 4.91 \\
\hline TCB 12-11 & 11 & & 19.61 & & & 5.28 \\
\hline TCB $12-13$ & 13 & & 20.66 & & & 5.99 \\
\hline TCB $12-15$ & 15 & & 21.68 & & & 5.69 \\
\hline ТСB $12-17$ & 17 & & 27.34 & & & 6.42 \\
\hline TCB14-01 & 1 & $12 / 09 / 97$ & 24.55 & 166.5 & & 7.08 \\
\hline TCB14-03 & 3 & & 18.12 & 196.8 & & 6.02 \\
\hline TCB14-05 & 5 & & 25.50 & 173.9 & & 6.08 \\
\hline TCB14-09 & 9 & & 21.58 & 237.1 & & 5.58 \\
\hline TCB14-13 & 13 & & 22.15 & 156.3 & & 6.69 \\
\hline TCB $14-15$ & 15 & & 22.90 & 25.0 & & 6.79 \\
\hline
\end{tabular}

Blank table entry indicates measurement not taken. 
Table E.2 Test Cell D physical/chemical characteristics with depth as observed in the field at $\sim 3,10$ and 15 months after fracture emplacement.

\begin{tabular}{|c|c|c|c|c|c|c|}
\hline Sample ID & $\begin{array}{c}\text { Depth } \\
\text { (ft bgs) }\end{array}$ & $\begin{array}{c}\text { Date } \\
\text { Sampled }\end{array}$ & $\begin{array}{c}\text { Water } \\
\text { Content } \\
(\text { dry wt \%) }\end{array}$ & $\begin{array}{c}\text { Eh } \\
(\mathrm{mV})\end{array}$ & $\begin{array}{l}\text { Temp } \\
\left({ }^{\circ} \mathrm{F}\right)\end{array}$ & $\begin{array}{c}\mathrm{pH} \\
\text { (extract) }\end{array}$ \\
\hline TDB9-01 & $T$ & $12 / 12 / 96$ & 10.85 & 377.6 & 59.6 & 6.64 \\
\hline TDB9-05 & 5 & & 20.52 & 171.1 & 59.1 & 6.03 \\
\hline TDB9-07 & 7 & & 18.32 & 321.8 & 60.8 & 5.89 \\
\hline TDB9-09 & 9 & & 22.19 & 839.8 & 61.4 & 4.86 \\
\hline TDB9-11 & 11 & & 21.03 & 838.3 & 61.7 & 5.64 \\
\hline TDB9-13 & 13 & & 23.30 & 808.0 & 64.8 & 6.40 \\
\hline TDB9-15 & 15 & & 26.28 & 659.5 & 60.1 & 6.36 \\
\hline TDB9-17 & 17 & & 30.20 & 599.9 & 59.7 & 6.37 \\
\hline TDB11-01 & 1 & $07 / 20 / 97$ & 17.84 & & & 4.61 \\
\hline TDB11-03 & 3 & & 18.35 & & & 5.36 \\
\hline TDB11-05 & 5 & & 20.91 & & & 5.41 \\
\hline TDB11-07 & 7 & & 23.91 & & & 5.07 \\
\hline TDB11-11 & 11 & & 21.42 & & & 5.39 \\
\hline TDB11-13 & 13 & & 24.69 & & & 6.07 \\
\hline TDB11-15 & 15 & & 24.27 & & & 6.16 \\
\hline TDB11-17 & 17 & & 21.00 & & & 6.12 \\
\hline TDB12-01 & 1 & $07 / 20 / 97$ & 20.17 & & & 6.27 \\
\hline TDB12-03 & 3 & & 20.60 & & & 5.26 \\
\hline TDB12-05 & 5 & & 19.81 & & & 5.90 \\
\hline TDB 12-07 & 7 & & 22.39 & & & 5.14 \\
\hline TDB12-11 & 11 & & 21.29 & & & 5.61 \\
\hline TDB12-13 & 13 & & 22.02 & & & 6.16 \\
\hline TDB12-15 & 15 & & 23.15 & & & 6.18 \\
\hline TDB $12-17$ & 17 & & 27.51 & & & 6.26 \\
\hline TDB13-01 & 1 & $07 / 20 / 97$ & 14.96 & & & 4.91 \\
\hline TDB13-03 & 3 & & 16.62 & & & 5.03 \\
\hline TDB13-05 & 5 & & 19.62 & & & 5.71 \\
\hline TDB13-07 & 7 & & 21.00 & & & 4.93 \\
\hline TDB13-11 & 11 & & 20.22 & & & 5.38 \\
\hline TDB13-13 & 13 & & 24.72 & & & 6.06 \\
\hline TDB13-15 & 15 & & 29.22 & & & 6.18 \\
\hline TDB13-17 & 17 & & 27.53 & & & 6.03 \\
\hline
\end{tabular}

Blank table entry indicates measurement not taken. 
Table E.3 Selected metal content with depth as observed in sample extracts made from soil samples collected from Test Cell C, field laboratory analysis.

\begin{tabular}{|c|c|c|c|c|c|c|}
\hline Sample ID & $\begin{array}{c}\text { Depth } \\
\text { (ft bgs) }\end{array}$ & Date & $\begin{array}{c}\mathrm{K}^{+} \\
(\mathrm{mg} / \mathrm{kg})\end{array}$ & $\begin{array}{l}\text { Total Fe } \\
(\mathrm{mg} / \mathrm{kg})\end{array}$ & $\begin{array}{c}\mathrm{Mn} \\
(\mathrm{mg} / \mathrm{kg})\end{array}$ & $\begin{array}{c}\mathrm{MnO}_{4} \\
(\mathrm{mg} / \mathrm{kg})\end{array}$ \\
\hline TCB9-01 & 1 & $12 / 12 / 96$ & & 270 & & \\
\hline TCB9-02 & 2 & & & 267 & & \\
\hline TCB9-03 & 3 & & & 258 & & \\
\hline TCB9-04 & 4 & & & 279 & & \\
\hline TCB9-05 & 5 & & & 279 & & \\
\hline TCB9-06 & 6 & & & 270 & & \\
\hline TCB9-07 & 7 & & & 255 & & \\
\hline ТСB9-08 & 8 & & & 270 & & \\
\hline ТСВ9-09 & 9 & & & 73.6 & & \\
\hline TCB9-10 & 10 & & 2.59 & & & \\
\hline TCB9-11 & 11 & & 2.09 & & & 152.9 \\
\hline ТCB $9-12$ & 12 & & 0.88 & & & 25.5 \\
\hline ТСВ9-13 & 13 & & 2.31 & & & 43843.2 \\
\hline ТСВ9-14 & 14 & & 16.02 & & & 40784.4 \\
\hline TCB9-15 & 15 & & 1.35 & & & \\
\hline TCB10-01 & 1 & $07 / 19 / 97$ & 2.13 & 60.4 & 68 & \\
\hline TCB10-03 & 3 & & 1.01 & 51.4 & 106 & 11.0 \\
\hline TCB10-05 & 5 & & 1.39 & 463 & 43 & 0.8 \\
\hline TCB $10-09$ & 9 & & 0.74 & 60 & 15 & \\
\hline TCB $10-11$ & 11 & & 0.47 & 7 & 1 & \\
\hline TCB $10-13$ & 13 & & 0.44 & 23 & 3 & \\
\hline TCB $10-15$ & 15 & & 0.77 & 12 & 13 & \\
\hline TCB11-01 & 1 & $07 / 19 / 97$ & 2.70 & 62 & 99 & \\
\hline TCB11-03 & 3 & & 0.87 & 45 & 175 & \\
\hline TCB11-05 & 5 & & 0.64 & 47 & 26 & \\
\hline TCB11-07 & 7 & & 0.69 & 88 & 38 & 0.8 \\
\hline TCB11-11 & 11 & & 0.49 & 63 & 2 & \\
\hline TCB $11-13$ & 13 & & 0.48 & 31 & 3 & \\
\hline TCB11-15 & 15 & & 0.75 & 32 & 8 & \\
\hline TCB $11-17$ & 17 & & 0.86 & 27 & 3 & \\
\hline ТCB12-01 & 1 & $07 / 19 / 97$ & 1.82 & 281 & 86 & 11.2 \\
\hline TCB12-05 & 5 & & 0.80 & 17 & 92 & \\
\hline TCB $12-05$ & 5 & & 1.15 & 1040 & 129 & \\
\hline TCB 12-09 & 9 & & 0.83 & 117 & 23 & \\
\hline TCB12-11 & 11 & & 0.65 & 92 & 2 & \\
\hline TCB12-13 & 13 & & 0.72 & 88 & 4 & \\
\hline TCB12-15 & 15 & & 0.74 & 42 & 1 & \\
\hline TCB12-17 & 17 & & 1.07 & 74 & 17 & \\
\hline
\end{tabular}

Blank table entry indicates not analyzed. 
Table E.4 Selected metal content with depth as observed in sample extracts made from soil samples collected from Test Cell D, field laboratory analysis.

\begin{tabular}{|c|c|c|c|c|c|c|}
\hline Sample ID & $\begin{array}{c}\text { Depth } \\
\text { (ft bgs) }\end{array}$ & Date & $\begin{array}{c}\mathrm{K}^{+} \\
(\mathrm{mg} / \mathrm{kg})\end{array}$ & $\begin{array}{l}\text { Total Fe } \\
(\mathrm{mg} / \mathrm{kg})\end{array}$ & $\begin{array}{c}\mathrm{Mn} \\
(\mathrm{mg} / \mathrm{kg})\end{array}$ & $\begin{array}{c}\mathrm{MnO}_{4} \\
(\mathrm{mg} / \mathrm{kg})\end{array}$ \\
\hline TDB9-15 & 15 & $12 / 12 / 96$ & 0.50 & & & 127.5 \\
\hline TDB9-17 & 17 & & 0.66 & & & 10.2 \\
\hline TDB11-01 & 1 & $07 / 20 / 97$ & & 20 & 76 & \\
\hline TDB11-03 & 3 & & 1.39 & 1380 & 275 & \\
\hline TDB11-05 & 5 & & & 1480 & 147 & \\
\hline TDB11-07 & 7 & & 0.80 & 28 & 36 & \\
\hline TDB11-11 & 11 & & 0.60 & 24 & 3 & \\
\hline TDB11-13 & 13 & & & 14 & 6 & \\
\hline TDB11-15 & 15 & & 0.87 & 14 & 7 & \\
\hline TDB $11-17$ & 17 & & & & & \\
\hline TDB12-01 & 1 & $07 / 20 / 97$ & & & & \\
\hline TDB 12-03 & 3 & & & & & 1.6 \\
\hline TDB12-05 & 5 & 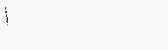 & & & & \\
\hline TDB12-07 & 7 & & 0.82 & & & \\
\hline TDB12-11 & 11 & & 0.65 & & & \\
\hline TDB12-13 & 13 & & 0.60 & & & \\
\hline TDB12-15 & 15 & & 0.72 & & & 172.1 \\
\hline TDB12-17 & 17 & & 0.66 & & & 15.5 \\
\hline TDB13-01 & 1 & $07 / 20 / 97$ & 1.18 & & & \\
\hline TDB13-03 & 3 & & 0.72 & 52 & 159 & \\
\hline TDB13-05 & 5 & & 1.14 & 3030 & 20.3 & \\
\hline TDB13-07 & 7 & & 0.67 & 74 & 30 & \\
\hline TDB13-11 & 11 & & 0.56 & 12 & 5 & \\
\hline TDB13-13 & 13 & & 0.83 & 24 & 5 & \\
\hline TDB13-15 & 15 & & 1.39 & 20 & 3 & \\
\hline TDB13-17 & 17 & & 1.27 & 22 & 3 & 7.6 \\
\hline
\end{tabular}

Blank table entry indicates not analyzed. 
Table E.5 VOC concentrations in soil with depth within Test Cell C following treatment (December 1996/July 1997).

\begin{tabular}{|c|c|c|c|c|c|c|}
\hline Sample ID & $\begin{array}{c}\text { Depth } \\
\text { (ft bgs) }\end{array}$ & $\begin{array}{c}\text { cis 1,2-DCE } \\
\text { (ug/kg) }\end{array}$ & $\begin{array}{c}1,1,1-\mathrm{TCA} \\
\text { (ug/kg) }\end{array}$ & $\begin{array}{c}\text { TCE } \\
\text { (ug/kg) }\end{array}$ & $\begin{array}{c}\mathrm{PCE} \\
\text { (ug/kg) }\end{array}$ & $\begin{array}{c}\text { Total VOCs } \\
\text { (ug/kg) }\end{array}$ \\
\hline TCB9-01 & 1 & & & $\overline{2}$ & & 2 \\
\hline TCB9-02 & 2 & & & & & \\
\hline TCB9-03 & 3 & & & & & \\
\hline TCB9-04 & 4 & & & & & \\
\hline ТCB9-05 & 5 & & & & & \\
\hline TCB9-06 & 6 & & ، & & & \\
\hline TCB9-07 & 7 & & & & & \\
\hline TCB9-08 & 8 & & & & & \\
\hline ТCB9-09 & 9 & & & & & \\
\hline TCB9-10 & 10 & & & & & \\
\hline ТCВ9-11 & 11 & & & & & \\
\hline TCB9-12 & 12 & & & & & \\
\hline TCB9-13 & 13 & 7 & & & & 7 \\
\hline TCB9-14 & 14 & & & & & \\
\hline TCB9-15 & 15 & & & & & \\
\hline TCB9-16 & 16 & & & 1 & & 1 \\
\hline TCB9-17 & 17 & & & 3 & & 3 \\
\hline TCB10-01 & 1 & & & & & \\
\hline TCB $10-03$ & 3 & & & & & \\
\hline TCB $10-05$ & 5 & & & & & \\
\hline ТCB $10-09$ & 9 & & & & & \\
\hline TCB10-11 & 11 & & & & & \\
\hline TCB $10-13$ & 13 & & & & & \\
\hline TCB $10-15$ & 15 & & & & & \\
\hline TCB11-01 & 1 & & & & & \\
\hline ТCB11-03 & 3 & & & & & \\
\hline TCB11-05 & 5 & & & & & \\
\hline ТСВ11-07 & 7 & & & & & \\
\hline TCB11-11 & 11 & & & & & \\
\hline TCB11-13 & 13 & & & & & \\
\hline ТCB11-15 & 15 & & & & & \\
\hline ТСB $11-17$ & 17 & & & & & \\
\hline
\end{tabular}


Table E.5 cont. VOC concentrations in soil with depth within Test Cell C following treatment (December 1996/July 1997).

\begin{tabular}{|c|c|c|c|c|c|c|}
\hline Sample ID & $\begin{array}{c}\text { Depth } \\
\text { (ft bgs) }\end{array}$ & $\begin{array}{c}\text { cis 1,2-DCE } \\
(\mathrm{ug} / \mathrm{kg})\end{array}$ & $\begin{array}{c}1,1,1-\mathrm{TCA} \\
(\mathrm{ug} / \mathrm{kg})\end{array}$ & $\begin{array}{c}\text { TCE } \\
\text { (ug/kg) }\end{array}$ & $\begin{array}{c}\mathrm{PCE} \\
(\mathrm{ug} / \mathrm{kg})\end{array}$ & $\begin{array}{c}\text { Total VOCs } \\
\text { (ug/kg) }\end{array}$ \\
\hline TCB12-01 & 1 & & & & & \\
\hline TCB 12-03 & 2 & & & & & \\
\hline TCB12-05 & 5 & & & & & \\
\hline TCB12-05 & 5 & & & & & \\
\hline TCB12-09 & 9 & & & & & \\
\hline TCB12-11 & 11 & & & & & \\
\hline TCB 12-13 & 13 & & & & & \\
\hline TCB12-15 & 15 & & & & & \\
\hline TCB12-17 & 17 & & & & & \\
\hline ТCB 14-01' & 1 & & & & & \\
\hline ТCB 14-03 & 3 & & & & & \\
\hline TCB $14-05$ & 5 & & & & & \\
\hline ТСВ 14-09 & 9 & & & & & \\
\hline TCB 14-13 & 13 & & & & & \\
\hline TCB $14-15$ & 15 & & & & & \\
\hline
\end{tabular}

Blank table entry is a non detect

Note: Borehole 9 sampled after $\sim 3$ months passive operation

Boreholes 10-12 sampled after $\sim 10$ months passive operation

Borehole 14 sampled after $\sim 15$ months passive operation 
Table E.6 VOC concentrations in soil with depth within Test Cell D following treatment (December 1996/ July 1997).

\begin{tabular}{|c|c|c|c|c|c|c|}
\hline Sample ID & $\begin{array}{c}\text { Depth } \\
\text { (ft bgs) }\end{array}$ & $\begin{array}{c}\text { cis } 1,2-\mathrm{DCE} \\
\text { (ug/kg) }\end{array}$ & $\begin{array}{c}1,1,1-\mathrm{TCA} \\
\text { (ug/kg) }\end{array}$ & $\begin{array}{c}\mathrm{TCE} \\
(\mathrm{ug} / \mathrm{kg})\end{array}$ & $\begin{array}{c}\mathrm{PCE} \\
(\mathrm{ug} / \mathrm{kg})\end{array}$ & $\begin{array}{c}\text { Total VOCs } \\
\text { (ug/kg) }\end{array}$ \\
\hline TDB9-01 & 1 & 42 & & 5 & & 47 \\
\hline TDB9-03 & 3 & 85 & & 19 & & 104 \\
\hline TDB9-04 & 4 & & & & & \\
\hline TDB9-05 & 5 & & & & & \\
\hline TDB9-06 & 6 & & & & & \\
\hline TDB9-07 & 7 & & & & & \\
\hline TDB9-08 & 8 & & & & & \\
\hline TDB9-09 & 9 & & & & & \\
\hline TDB9-10 & 10 & & & & & \\
\hline TDB9-11 & 11 & & & & & \\
\hline TDB9-12 & 12 & 436 & 6 & 30 & 11 & 483 \\
\hline TDB9-13 & 13 & & & & & \\
\hline TDB9-14 & 14 & & & 1 & & 1 \\
\hline TDB9-15 & 15 & & & 4 & & 4 \\
\hline TDB9-16 & 16 & & & 12 & & 12 \\
\hline TDB9-17 & 17 & & & 9 & & 9 \\
\hline TDB11-01 & 1 & & & & & \\
\hline TDB11-03 & 3 & & & & & \\
\hline TDB11-05 & 5 & & & & & \\
\hline TDB11-07 & 7 & & & & & \\
\hline TDB11-11 & 11 & & & & & \\
\hline TDB11-13 & 13 & & & & & \\
\hline TDB11-15 & 15 & & & & & \\
\hline TDB1 1-17 & 17 & & & & & \\
\hline TDB12-01 & 1 & & & & & \\
\hline TDB12-03 & 3 & & & & & \\
\hline TDB12-05 & 5 & & & & & \\
\hline TDB12-07 & 7 & & & & & \\
\hline TDB12-11 & 11 & & & & & \\
\hline TDB12-13 & 13 & & & & & \\
\hline TDB12-15 & 15 & & & & & \\
\hline TDB12-17 & 17 & & & & & \\
\hline
\end{tabular}

E - 9 
Table E.6 cont. $\quad$ VOC concentrations in soil with depth within Test Cell D following treatment (December 1996 / July 1997).

\begin{tabular}{ccccccc}
\hline Sample ID & $\begin{array}{c}\text { Depth } \\
\text { (ft bgs) }\end{array}$ & $\begin{array}{c}\text { cis 1,2-DCE } \\
\text { (ug/kg) }\end{array}$ & $\begin{array}{c}1,1,1-\mathrm{TCA} \\
\text { (ug/kg) }\end{array}$ & $\begin{array}{c}\text { TCE } \\
(\mathrm{ug} / \mathrm{kg})\end{array}$ & $\begin{array}{c}\text { PCE } \\
\text { (ug/kg) }\end{array}$ & $\begin{array}{c}\text { Total VOCs } \\
\text { (ug/kg) }\end{array}$ \\
\hline TDB13-01 & 1 & & & & & \\
TDB13-03 & 3 & & & & \\
TDB13-05 & 5 & & & & \\
TDB13-07 & 7 & & & & \\
TDB13-11 & 11 & & 7 & \\
TDB13-13 & 13 & & 16 & \\
TDB13-15 & 15 & & & & \\
TDB13-17 & 17 & & & & \\
\hline
\end{tabular}

Blank table entry is a non detect

Note: Boreholes 9-10 sampled after $\sim 3$ months passive operation

Boreholes 11-13 sampled after $\sim 10$ months passive operation 
Table E.7 Test Cell C, in situ Eh measurements (in $\mathrm{mV}$ ).

\begin{tabular}{|c|c|c|c|c|c|c|c|c|c|c|c|}
\hline Location & $\begin{array}{c}\text { Depth } \\
\text { (ft bgs) }\end{array}$ & $10 / 20 / 96$ & $10 / 27 / 96$ & $11 / 11 / 96$ & $11 / 24 / 96$ & $\begin{array}{c}\text { Date } \\
12 / 6 / 96\end{array}$ & $7 / 17 / 97$ & $7 / 24 / 97$ & 9/3/97 & $9 / 5 / 97$ & $12 / 12 / 97$ \\
\hline \multirow[t]{21}{*}{ TCM1 } & 2.00 & 138.0 & 120.7 & 129.2 & 169.0 & 150.2 & -498.0 & -490.0 & -180.5 & -142.6 & -140.8 \\
\hline & 4.00 & -397.4 & -376.2 & -399.6 & -372.3 & -409.1 & -500.0 & -514.0 & -494.4 & -494.9 & -479.8 \\
\hline & 4.25 & & -424.0 & -416.1 & -383.0 & -394.4 & -496.0 & -451.0 & -490.4 & -478.1 & -447.2 \\
\hline & 4.50 & -375.4 & -401.5 & -433.8 & -409.8 & -453.6 & -479.0 & -482.0 & -542.6 & -541.1 & -530.3 \\
\hline & 4.75 & -276.1 & -348.4 & -402.1 & -374.0 & -460.2 & -452.0 & -482.0 & -465.6 & -516.8 & -463.0 \\
\hline & 5.00 & -367.0 & -436.7 & -451.8 & -456.8 & -481.7 & -480.0 & -516.0 & -550.7 & -535.6 & -577.4 \\
\hline & 6.00 & -479.2 & -514.9 & -464.5 & -465.0 & -491.5 & -463.0 & -543.0 & -655.3 & -645.3 & -517.1 \\
\hline & 7.00 & -498.1 & -503.1 & -476.5 & -474.0 & -494.7 & -540.0 & -546.0 & -651.7 & -650.2 & -515.1 \\
\hline & 8.00 & -457.7 & -473.9 & -490.6 & -508.6 & -499.7 & -483.0 & -473.0 & -551.2 & -557.4 & -640.2 \\
\hline & 8.25 & -342.9 & -342.0 & -383.2 & -400.0 & -470.9 & -504.0 & -460.0 & -531.3 & -546.0 & -537.9 \\
\hline & 8.50 & -356.5 & -354.8 & -363.0 & -362.8 & -395.1 & -376.0 & -376.0 & -196.1 & -198.1 & -253.7 \\
\hline & 8.75 & -503.8 & -514.0 & -628.1 & -537.6 & -593.9 & -580.0 & -529.0 & -626.4 & -624.4 & -620.1 \\
\hline & 9.00 & -469.2 & -333.9 & -489.6 & 502.7 & -524.1 & -366.0 & -557.0 & -501.9 & -503.7 & -189.0 \\
\hline & 10.00 & -316.2 & -362.9 & -367.8 & -404.8 & -453.9 & -557.0 & -556.0 & -597.1 & -596.7 & -581.9 \\
\hline & 11.00 & -664.5 & -658.0 & -701.1 & -700.9 & -725.8 & -780.0 & -780.0 & -815.2 & -837.9 & -814.4 \\
\hline & 11.50 & -439.1 & -447.0 & -427.1 & -446.0 & -499.7 & -580.0 & -558.0 & -527.3 & -516.3 & -543.6 \\
\hline & 11.75 & -487.1 & -504.4 & -542.9 & -447.4 & -590.0 & -972.0 & -960.0 & -1020.4 & -1014.3 & -997.2 \\
\hline & 12.00 & -442.3 & -445.2 & -418.1 & -396.1 & -454.1 & -160.0 & -188.0 & -278.2 & -287.9 & -501.3 \\
\hline & 12.25 & -431.5 & -434.8 & -448.3 & -490.9 & -557.3 & -573.0 & -591.0 & -642.1 & -638.0 & -591.7 \\
\hline & 13.00 & & -344.0 & -426.6 & -364.9 & -425.3 & -272.0 & -318.0 & -317.2 & -256.9 & -314.8 \\
\hline & 14.00 & & -438.5 & -450.9 & -466.3 & -493.2 & -196.0 & -172.0 & -204.8 & -250.6 & -267.4 \\
\hline Ref 1D & & -125.8 & -466.4 & -480.6 & -476.8 & & -503.0 & -504.0 & -614.3 & & \\
\hline Ref 1 & & -144.5 & -486.4 & -498.0 & & & -567.0 & -439.0 & -627.1 & -605.6 & \\
\hline
\end{tabular}

Blank table entry indicates measurement not taken. 
Table E.8 Test Cell D, in situ Eh measurements (in $\mathrm{mV}$ ).

\begin{tabular}{|c|c|c|c|c|c|c|c|c|c|c|c|}
\hline Location & $\begin{array}{c}\text { Depth } \\
\text { (ft bgs) }\end{array}$ & $10 / 20 / 96$ & $10 / 27 / 96$ & $11 / 11 / 96$ & $11 / 23 / 96$ & $\begin{array}{c}\text { Date } \\
12 / 6 / 96\end{array}$ & $7 / 17 / 97$ & $7 / 24 / 97$ & 9/3/97 & $9 / 5 / 97$ & $12 / 12 / 97$ \\
\hline \multirow[t]{9}{*}{ TDM1 } & 8.00 & -410.9 & 452.7 & -402.9 & -391.6 & -385.2 & 302.0 & 288.0 & 265.9 & 460.0 & 250.1 \\
\hline & 9.25 & 857.8 & 845.2 & 770.3 & 678.1 & 671.1 & 823.0 & 812.0 & 780.1 & 777.9 & 753.6 \\
\hline & 9.50 & 92.8 & 456.0 & 828.7 & 830.1 & 814.3 & 838.0 & 830.0 & 822.2 & 808.9 & 826.5 \\
\hline & 9.75 & 259.4 & 478.3 & 213.9 & 191.1 & 178.4 & 943.0 & 937.0 & 930.0 & 929.2 & 898.6 \\
\hline & 10.00 & -68.4 & 335.2 & 1.0 & 25.1 & 38.8 & 192.0 & 180.0 & 749.9 & 850.7 & 889.4 \\
\hline & 10.25 & -506.3 & -514.6 & -505.3 & -489.2 & -444.0 & -148.0 & -157.0 & -113.0 & -114.2 & 39.9 \\
\hline & 11.00 & -467.2 & -474.2 & -483.7 & -475.2 & -467.5 & -236.0 & 18.0 & 48.5 & 98.9 & 93.2 \\
\hline & 12.00 & -611.2 & -612.8 & -553.6 & -529.1 & -520.0 & -445.0 & -4.5 & -469.1 & -481.6 & -480.3 \\
\hline & 14.00 & -629.8 & -605.8 & -617.6 & -572.9 & -584.5 & -232.0 & -33.0 & -390.7 & -384.2 & -340.1 \\
\hline Ref 02 & & -102.7 & -85.2 & -104.4 & -112.1 & & -378.0 & -327.0 & -253.4 & -79.4 & \\
\hline \multirow[t]{18}{*}{ TDM2 } & 2.00 & -422.5 & -411.2 & -432.2 & -441.4 & -446.3 & -402.0 & -405.0 & -379.4 & -383.0 & -371.0 \\
\hline & 3.00 & -388.2 & -347.8 & -415.6 & -394.8 & -72.2 & -52.0 & -44.0 & -30.2 & -14.0 & 45.1 \\
\hline & 3.25 & -342.5 & -276.8 & -305.4 & -190.0 & -211.1 & -364.0 & -390.0 & -394.8 & -395.6 & -385.3 \\
\hline & 3.50 & -270.8 & -105.7 & -252.8 & -168.1 & -137.2 & -255.0 & -217.0 & 355.1 & 84.4 & -382.2 \\
\hline & 3.75 & -490.4 & -493.5 & -487.0 & -490.2 & -473.7 & -373.0 & -379.0 & 628.5 & -91.7 & -350.1 \\
\hline & 4.00 & -380.0 & -431.2 & -461.1 & -460.0 & -466.1 & -408.0 & -440.0 & -385.3 & -454.6 & -430.4 \\
\hline & 6.00 & -197.6 & -152.4 & -104.3 & -181.2 & -395.0 & -315.0 & -335.0 & -227.6 & -307.6 & -242.6 \\
\hline & 8.00 & 32.6 & 53.9 & 78.5 & 108.4 & 113.2 & 155.0 & 143.0 & 131.1 & 128.8 & 219.7 \\
\hline & 9.00 & 823.6 & 758.7 & 778.9 & 793.2 & 793.6 & 827.0 & 715.0 & 705.7 & 772.2 & 658.9 \\
\hline & 9.25 & 719.1 & 621.5 & 578.9 & 558.7 & 559.9 & 817.0 & 870.0 & 626.8 & 770.7 & 705.9 \\
\hline & 9.50 & 102.0 & 207.1 & 75.4 & 114.7 & 123.1 & 921.0 & 909.0 & 852.8 & 819.8 & 847.7 \\
\hline & 9.75 & 53.5 & 62.3 & 51.1 & 95.7 & 40.4 & 920.0 & 911.0 & 868.1 & 907.0 & 843.3 \\
\hline & 10.00 & -29.5 & 8.2 & 35.9 & 63.6 & 57.7 & 140.0 & 133.0 & 128.9 & 148.7 & -8.1 \\
\hline & 10.25 & -462.2 & -460.0 & -413.2 & -57.2 & -72.4 & 197.0 & 119.0 & 375.7 & & 315.1 \\
\hline & 11.00 & -556.4 & -557.9 & -485.8 & -611.0 & -494.4 & -538.0 & -540.0 & -552.6 & -548.6 & -586.0 \\
\hline & 12.00 & -579.0 & -542.3 & -360.3 & -254.0 & -251.6 & -202.0 & -289.0 & -288.9 & -174.9 & -248.9 \\
\hline & 13.00 & -475.8 & -478.9 & -514.8 & -516.8 & -521.3 & -487.0 & -498.0 & -508.1 & & -485.4 \\
\hline & 14.00 & -265.0 & -291.9 & -322.4 & -335.8 & -327.5 & -456.0 & -50.0 & -498.4 & -173.5 & -453.7 \\
\hline
\end{tabular}

Blank table entry indicates measurement not taken.

$$
E-12
$$


Table E.9 Wiping thermocouple measurements in Test Cell C $\left({ }^{\circ} \mathrm{C}\right)$.

\begin{tabular}{|c|c|c|c|c|}
\hline Location & $\begin{array}{c}\text { Depth } \\
\text { (ft bgs) }\end{array}$ & $7 / 18 / 97$ & $\begin{array}{c}\text { Date } \\
7 / 24 / 97\end{array}$ & $9 / 3 / 97$ \\
\hline \multirow[t]{8}{*}{ TCB1 } & 1.00 & 36.3 & 28.7 & 31.6 \\
\hline & 3.00 & 32.7 & 29.6 & 30.5 \\
\hline & 5.00 & 28.8 & 27.7 & 29.2 \\
\hline & 7.00 & 25.6 & 24.8 & 27.7 \\
\hline & 9.00 & 23.1 & 22.5 & 26.4 \\
\hline & 11.00 & 21.6 & 21.0 & 25.2 \\
\hline & 13.00 & 20.1 & 19.7 & 23.9 \\
\hline & 14.00 & 19.6 & 18.6 & 21.9 \\
\hline \multirow[t]{9}{*}{ TCB2 } & $1.00^{\circ}$ & 33.3 & 28.4 & 29.6 \\
\hline & 3.00 & 31.2 & 28.5 & \\
\hline & 5.00 & 28.2 & 26.9 & \\
\hline & 7.00 & 25.5 & 24.3 & \\
\hline & 8.00 & 24.3 & & \\
\hline & 9.00 & & 22.4 & \\
\hline & 11.00 & & 20.9 & \\
\hline & 13.00 & & 19.9 & \\
\hline & 15.00 & & 18.8 & \\
\hline \multirow{10}{*}{ TCB3 } & 1.00 & 33.5 & 29.0 & 30.0 \\
\hline & 3.00 & 31.9 & 29.7 & \\
\hline & 5.00 & 28.9 & 27.5 & \\
\hline & 7.00 & 26.3 & 24.9 & \\
\hline & 9.00 & 24.2 & 22.8 & \\
\hline & 11.00 & 22.9 & 21.0 & \\
\hline & 13.00 & 21.7 & 19.8 & \\
\hline & 15.00 & 20.8 & 18.9 & \\
\hline & 17.00 & 20.2 & 18.4 & \\
\hline & 18.00 & 19.2 & 17.8 & \\
\hline \multirow[t]{10}{*}{ "TCB4" } & 1.00 & 35.2 & 29.1 & 29.9 \\
\hline & 3.00 & 33.1 & 29.3 & 30.1 \\
\hline & 5.00 & 30.1 & 27.7 & 29.2 \\
\hline & 7.00 & 26.8 & 24.9 & 28.0 \\
\hline & 9.00 & 24.6 & 22.9 & 26.8 \\
\hline & 11.00 & 22.8 & 21.4 & 25.4 \\
\hline & 13.00 & 21.8 & 20.1 & 24.2 \\
\hline & 15.00 & 21.0 & 19.2 & 23.1 \\
\hline & 17.00 & 20.4 & 18.6 & 22.2 \\
\hline & 18.00 & 19.9 & 17.9 & 20.8 \\
\hline
\end{tabular}

E - 13 
Table E. 9 cont. Wiping thermocouple measurements in Test Cell C $\left({ }^{\circ} \mathrm{C}\right)$.

\begin{tabular}{|c|c|c|c|c|}
\hline Location & $\begin{array}{c}\text { Depth } \\
\text { (ft bgs) }\end{array}$ & $7 / 18 / 97$ & $\begin{array}{c}\text { Date } \\
7 / 24 / 97\end{array}$ & $9 / 3 / 97$ \\
\hline \multirow[t]{5}{*}{ TCB5 } & 1.00 & 35.5 & 28.6 & 28.4 \\
\hline & 3.00 & 33.1 & 29.5 & \\
\hline & 5.00 & 29.7 & 27.7 & \\
\hline & 7.00 & 26.6 & 24.6 & \\
\hline & 9.00 & 24.5 & 22.5 & 25.7 \\
\hline \multirow[t]{10}{*}{ TCB6 } & $1.00^{\circ}$ & 34.1 & 29.0 & \\
\hline & 3.00 & 32.4 & 30.3 & \\
\hline & 5.00 & 29.4 & 27.9 & \\
\hline & 7.00 & 26.4 & 24.7 & \\
\hline & 9.00 & 24.2 & 22.5 & \\
\hline & 11.00 & 22.6 & 21.0 & \\
\hline & 13.00 & 21.1 & 19.9 & \\
\hline & 15.00 & 20.2 & 19.1 & \\
\hline & 17.00 & 19.5 & 18.7 & \\
\hline & 18.00 & 19.2 & 18.0 & \\
\hline \multirow[t]{9}{*}{ TCB7 } & $1.00^{\circ}$ & 33.9 & 29.7 & 32.3 \\
\hline & 3.00 & 31.8 & 30.1 & 31.5 \\
\hline & 5.00 & 28.7 & 27.7 & 30.0 \\
\hline & 7.00 & 25.8 & 24.8 & 28.3 \\
\hline & 9.00 & 23.2 & 22.6 & \\
\hline & 11.00 & 21.9 & 21.0 & \\
\hline & 13.00 & 20.6 & 19.9 & \\
\hline & 15.00 & 20.1 & 19.2 & \\
\hline & 17.00 & 19.7 & 18.7 & \\
\hline \multirow[t]{10}{*}{ TCB8 } & 1.00 & 32.0 & 28.5 & 30.2 \\
\hline & 3.00 & 31.4 & 29.7 & 30.4 \\
\hline & 5.00 & 29.3 & 27.7 & 29.4 \\
\hline & 7.00 & 27.0 & 25.0 & 27.8 \\
\hline & 9.00 & 25.0 & 22.8 & 26.6 \\
\hline & 11.00 & 23.4 & 21.0 & 24.9 \\
\hline & 13.00 & 22.5 & 19.8 & \\
\hline & 15.00 & 21.9 & 19.0 & \\
\hline & 17.00 & 21.5 & 18.4 & \\
\hline & 18.00 & 20.9 & 17.8 & 21.1 \\
\hline
\end{tabular}

Blank table entry indicates measurement not taken. 
Table E.10 Wiping thermocouple measurements in Test Cell D $\left({ }^{\circ} \mathrm{C}\right)$.

\begin{tabular}{|c|c|c|c|c|}
\hline Location & $\begin{array}{c}\text { Depth } \\
\text { (ft bgs) }\end{array}$ & $7 / 18 / 97$ & $\begin{array}{c}\text { Date } \\
7 / 24 / 97\end{array}$ & 9/4/97 \\
\hline \multirow[t]{9}{*}{ TDB1 } & 1.00 & 38.2 & 29.4 & 30.6 \\
\hline & 3.00 & 35.3 & 30.1 & \\
\hline & 5.00 & 31.2 & 28.3 & \\
\hline & 7.00 & 28.6 & 25.8 & \\
\hline & 9.00 & 26.2 & 23.7 & \\
\hline & 11.00 & 23.6 & 21.9 & \\
\hline & 13.00 & 21.8 & 20.7 & \\
\hline & 15.00 & 21.2 & 19.8 & \\
\hline & 17.00 & 20.4 & 18.9 & \\
\hline \multirow[t]{10}{*}{ TDB2 2} & 1.00 & 34.1 & 28.5 & $1 / 29 / 00$ \\
\hline & 3.00 & 32.9 & 29.7 & \\
\hline & 5.00 & 30.0 & 27.8 & \\
\hline & 7.00 & 27.6 & 25.7 & \\
\hline & 9.00 & 25.3 & 23.5 & \\
\hline & 11.00 & 23.5 & 21.8 & \\
\hline & 13.00 & 22.2 & 20.7 & \\
\hline & 15.0 & 21.5 & 19.7 & \\
\hline & 17.0 & 20.8 & 18.9 & \\
\hline & 18.0 & 20.3 & 18.6 & \\
\hline \multirow[t]{10}{*}{ TDB3 } & 1.00 & 34.6 & 29.7 & 30.7 \\
\hline & 3.00 & 32.3 & 30.9 & \\
\hline & 5.00 & 30.0 & 28.9 & \\
\hline & 7.00 & 27.7 & 26.3 & \\
\hline & 9.00 & 25.6 & 24.1 & \\
\hline & 11.00 & 23.7 & 22.2 & \\
\hline & 13.00 & 22.6 & 20.9 & \\
\hline & 15.00 & 21.6 & 19.9 & \\
\hline & 17.00 & 21.1 & 19.1 & \\
\hline & 18.00 & 20.6 & 18.7 & \\
\hline \multirow[t]{9}{*}{ TDB4 } & 1.0 & 35.2 & 29.3 & 30.0 \\
\hline & 3.0 & 33.1 & 29.5 & \\
\hline & 5.0 & 29.9 & 28.0 & \\
\hline & 7.0 & 27.6 & 25.9 & \\
\hline & 9.0 & 25.1 & 23.8 & \\
\hline & 11.0 & 23.2 & 21.9 & \\
\hline & 13.0 & 21.4 & 20.8 & \\
\hline & 15.0 & 20.7 & 19.7 & \\
\hline & 17.0 & 20.0 & 19.0 & \\
\hline
\end{tabular}


Table E.10 cont. Wiping thermocouple measurements in Test Cell D $\left({ }^{\circ} \mathrm{C}\right)$.

\begin{tabular}{|c|c|c|c|c|}
\hline Location & $\begin{array}{l}\text { Depth } \\
\text { (ft bgs) }\end{array}$ & $7 / 18 / 97$ & $\begin{array}{c}\text { Date } \\
7 / 24 / 97\end{array}$ & 9/4/97 \\
\hline \multirow[t]{10}{*}{ TDB5 } & 1.00 & 35.7 & 28.0 & 26.2 \\
\hline & 3.00 & 33.9 & 29.2 & \\
\hline & 5.00 & 31.2 & 28.4 & \\
\hline & 7.00 & 28.5 & 26.7 & \\
\hline & 9.00 & 26.3 & 24.6 & \\
\hline & 11.00 & 24.3 & 23.2 & \\
\hline & 13.00 & 22.7 & 22.0 & \\
\hline & 15.00 & 21.7 & 20.9 & \\
\hline & 17.00 & 20.7 & 19.9 & \\
\hline & 19.00 & 19.8 & 18.6 & \\
\hline \multirow[t]{10}{*}{ TDB6 } & 1.00 & 33.4 & 28.6 & 26.4 \\
\hline & 3.00 & 32.7 & 30.0 & \\
\hline & 5.00 & 28.8 & 29.0 & \\
\hline & 7.00 & 26.1 & 27.1 & \\
\hline & 9.00 & 24.9 & 25.0 & \\
\hline & 11.00 & 22.2 & 22.2 & \\
\hline & 13.00 & 21.5 & 21.2 & \\
\hline & 15.00 & 20.5 & 20.1 & \\
\hline & 17.00 & 19.9 & 19.4 & \\
\hline & 18.00 & 19.3 & & \\
\hline \multirow[t]{10}{*}{ TDB7 } & 1.0 & 35.8 & 29.7 & 31.4 \\
\hline & 3.0 & 33.7 & 30.3 & 31.0 \\
\hline & 5.0 & 30.5 & 28.9 & 29.5 \\
\hline & 7.0 & 28.0 & 27.3 & 28.3 \\
\hline & 9.0 & 25.6 & 25.6 & 26.9 \\
\hline & 11.0 & 23.7 & 23.5 & 25.4 \\
\hline & 13.0 & 22.7 & 22.2 & 24.2 \\
\hline & 15.00 & 21.8 & 21.0 & 23.1 \\
\hline & 17.00 & 21.0 & 20.2 & 22.3 \\
\hline & 18.00 & 20.8 & 18.7 & 21.0 \\
\hline \multirow[t]{10}{*}{ TDB8 } & 1.0 & 34.4 & 28.5 & 32.6 \\
\hline & 3.0 & 32.9 & 29.7 & \\
\hline & 5.0 & 29.9 & 28.1 & \\
\hline & 7.0 & 27.5 & 25.4 & \\
\hline & 9.0 & 25.2 & 23.5 & \\
\hline & 11.0 & 23.5 & 21.5 & \\
\hline & 13.0 & 22.2 & 20.4 & \\
\hline & 15.0 & 21.3 & 19.5 & \\
\hline & 17.0 & 20.6 & 18.9 & \\
\hline & 18.0 & 20.2 & 18.5 & \\
\hline
\end{tabular}

Blank table entry indicates measurement not taken. 
Table E.11 TDR measurements in Test Cell C monitoring locations (\% moisture).

\begin{tabular}{ccccccccc}
\hline Location & Depth & \multicolumn{7}{c}{ Date } \\
& (ft bgs) & $10 / 8 / 96$ & $10 / 21 / 96$ & $11 / 21 / 96$ & $12 / 4 / 96$ & $7 / 19 / 97$ & $7 / 25 / 97$ & $9 / 5 / 97$ \\
\hline TCM1 & 2 & 26.2 & 24.8 & 24.2 & 31.8 & 28.0 & 27.4 & 27.7 \\
& 4 & 29.4 & 27.1 & 26.5 & 27.0 & 28.8 & 28.3 & 28.7 \\
& 6 & 34.7 & 34.7 & 34.6 & 34.2 & 36.4 & 36.4 & 37.0 \\
& 8 & 26.5 & 25.4 & 24.5 & 25.4 & 24.5 & 29.6 & 30.3 \\
& 10 & 28.7 & 29.0 & 29.4 & 29.7 & 30.0 & 29.4 & 27.8 \\
& 12 & 31.2 & 31.3 & 31.5 & 31.5 & 31.2 & 31.2 & 30.6 \\
& 14 & 31.7 & 31.4 & 30.9 & 31.2 & 31.8 & 31.2 & 31.3 \\
\hline
\end{tabular}

Table E.12 TDR measurements in Test Cell D monitoring locations (\% moisture).

\begin{tabular}{|c|c|c|c|c|c|c|c|c|c|}
\hline \multirow[t]{2}{*}{ Location } & \multirow{2}{*}{$\begin{array}{c}\text { Depth } \\
\text { (ft bgs) }\end{array}$} & \multicolumn{8}{|c|}{ Date } \\
\hline & & $10 / 8 / 96$ & $10 / 21 / 96$ & $11 / 21 / 96$ & $12 / 4 / 96$ & $7 / 19 / 97$ & $7 / 25 / 97$ & 9/5/97 & $9 / 6 / 97$ \\
\hline \multirow[t]{8}{*}{ TDM1 } & 8 & & $\overline{28.9}$ & 28.3 & $\overline{28.3}$ & 29.1 & 29.4 & & 29.6 \\
\hline & 9.5 & 34.7 & 35.1 & 38.6 & 40.2 & 89.1 & 74.1 & 32.7 & 18.9 \\
\hline & $9.75 \mathrm{a}$ & 32.4 & 33.7 & 30.6 & & & & & 37.6 \\
\hline & $9.75 b$ & 34.7 & 31.8 & & & & & & 33.9 \\
\hline & $9.75 \mathrm{c}$ & 30.6 & 30.9 & & 31.2 & 33.9 & 33.9 & 32.4 & 34.9 \\
\hline & 10 & 29.4 & 30.0 & 29.7 & 30.0 & 31.8 & 31.8 & 32.7 & 31.7 \\
\hline & 12 & 32.4 & 30.9 & 29.4 & 29.1 & 29.1 & 29.1 & 27.2 & 29.1 \\
\hline & 14 & 30.9 & 30.5 & 30.6 & 30.6 & 31.2 & 31.2 & 33.0 & 30.9 \\
\hline \multirow[t]{9}{*}{ TDM22 } & 2 & & & 28.8 & 28.6 & 30.9 & 30.9 & & 31.1 \\
\hline & 4 & & 29.1 & 28.8 & 28.8 & 29.7 & 29.7 & & 29.4 \\
\hline & 6 & & 29.1 & 28.6 & 28.3 & 30.0 & 30.3 & & 30.0 \\
\hline & 8 & & & 29.3 & 28.8 & 31.5 & 30.6 & & 30.0 \\
\hline & 9.5 & & 30.0 & 30.6 & 30.0 & 33.0 & 32.7 & & \\
\hline & 9.75 & & 30.0 & 29.9 & 29.7 & 31.8 & 31.7 & & \\
\hline & 10 & & 30.5 & 30.9 & 30.0 & 31.5 & 31.2 & & \\
\hline & 12 & & 30.0 & 28.8 & 28.8 & 28.0 & 28.3 & & \\
\hline & 14 & & 33.2 & 33.0 & 32.7 & 34.2 & 33.6 & & \\
\hline
\end{tabular}

Blank table entry indicates measurement not taken. 


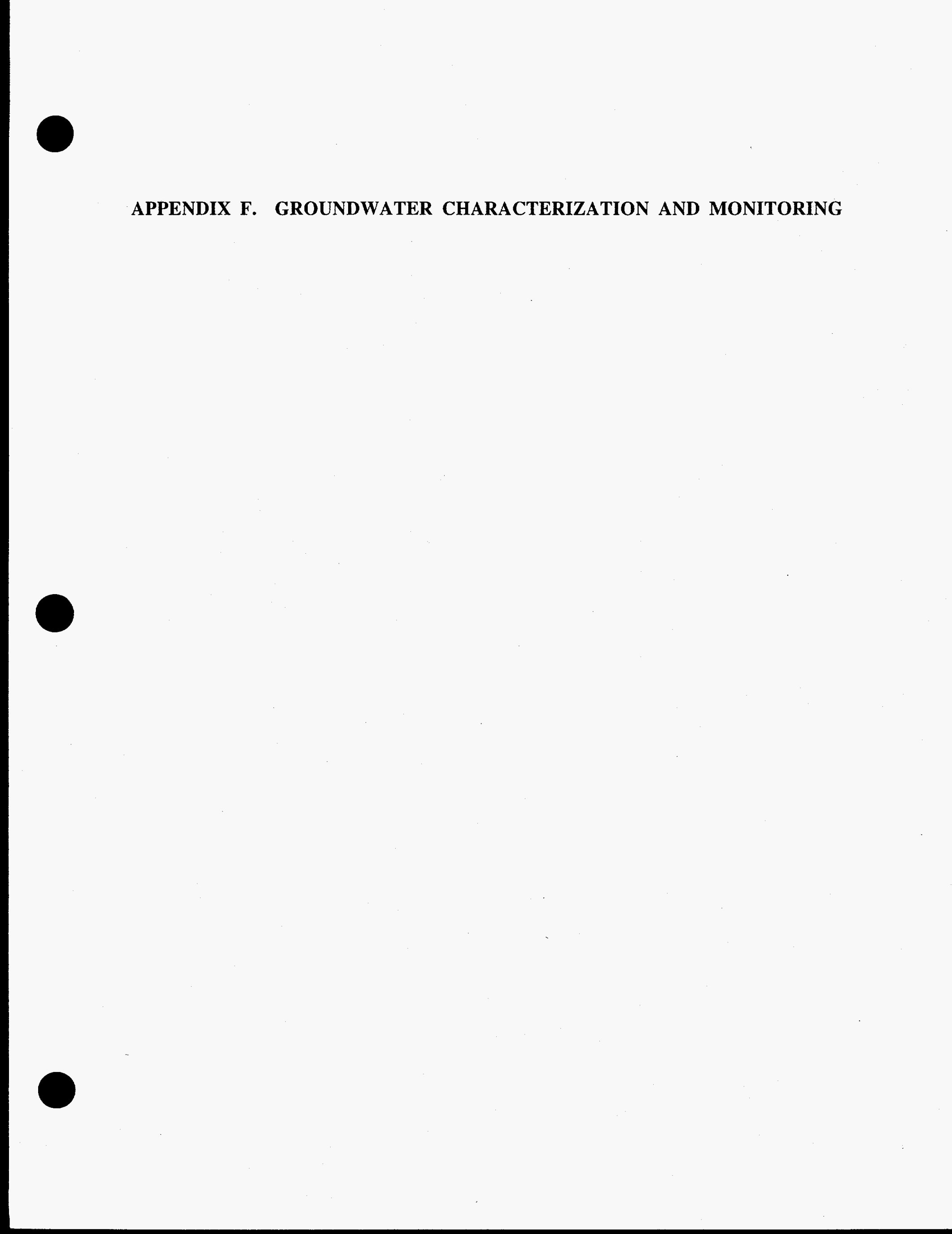


Figure F.1 Groundwater Iron Concentrations at Test Cell C.

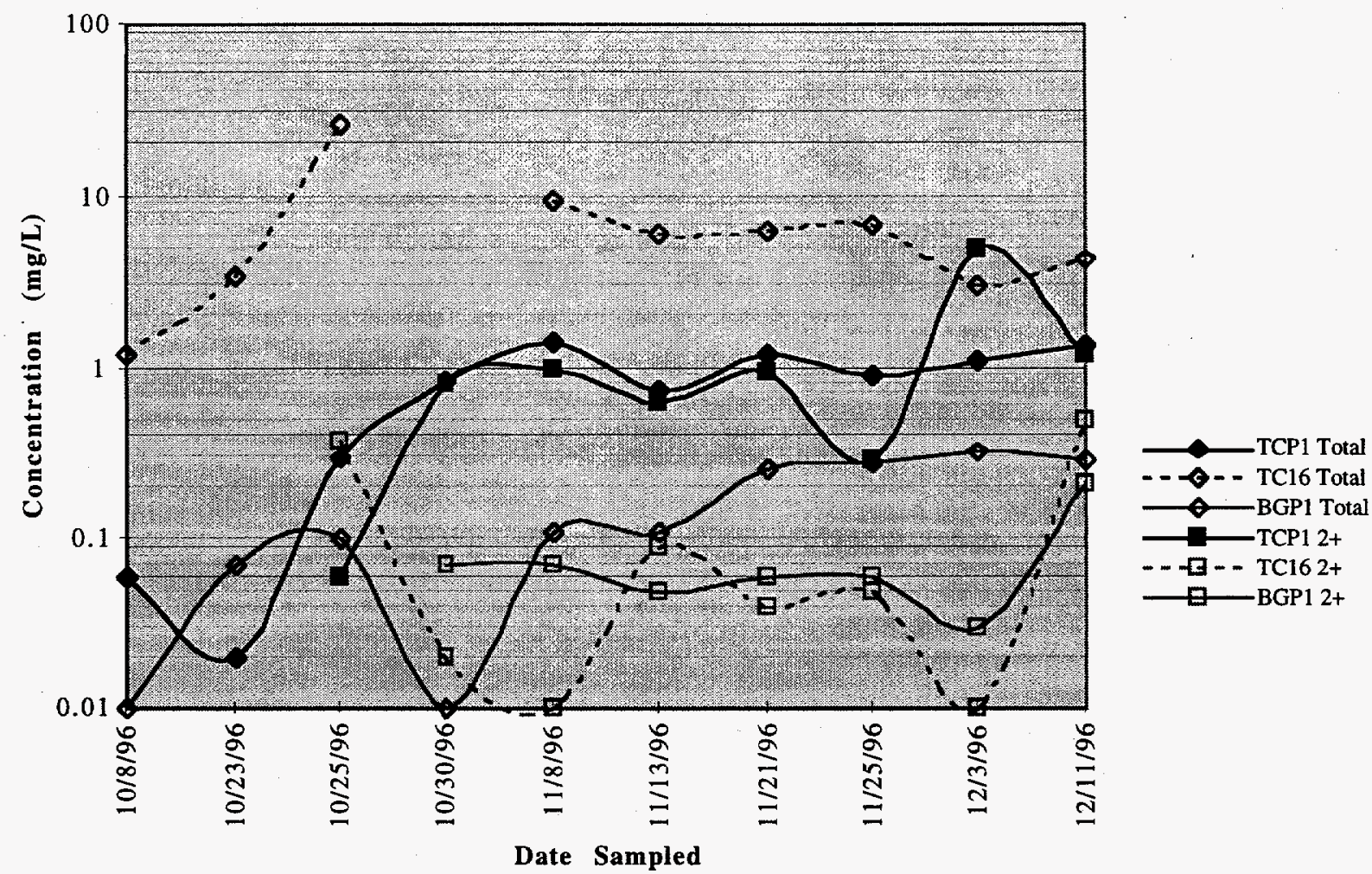

Figure F.2 Groundwater Mn Concentrations at Test Cell D.

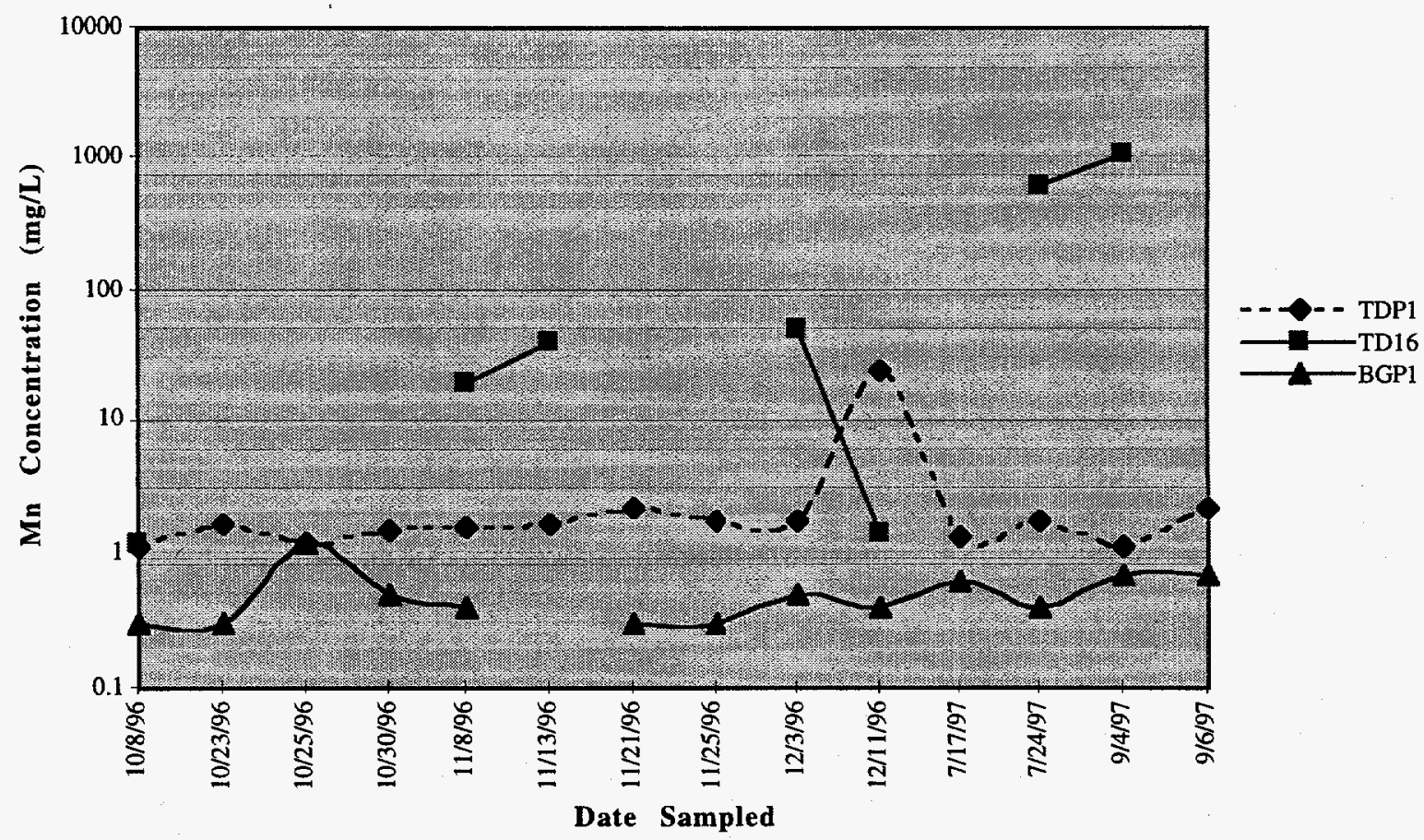




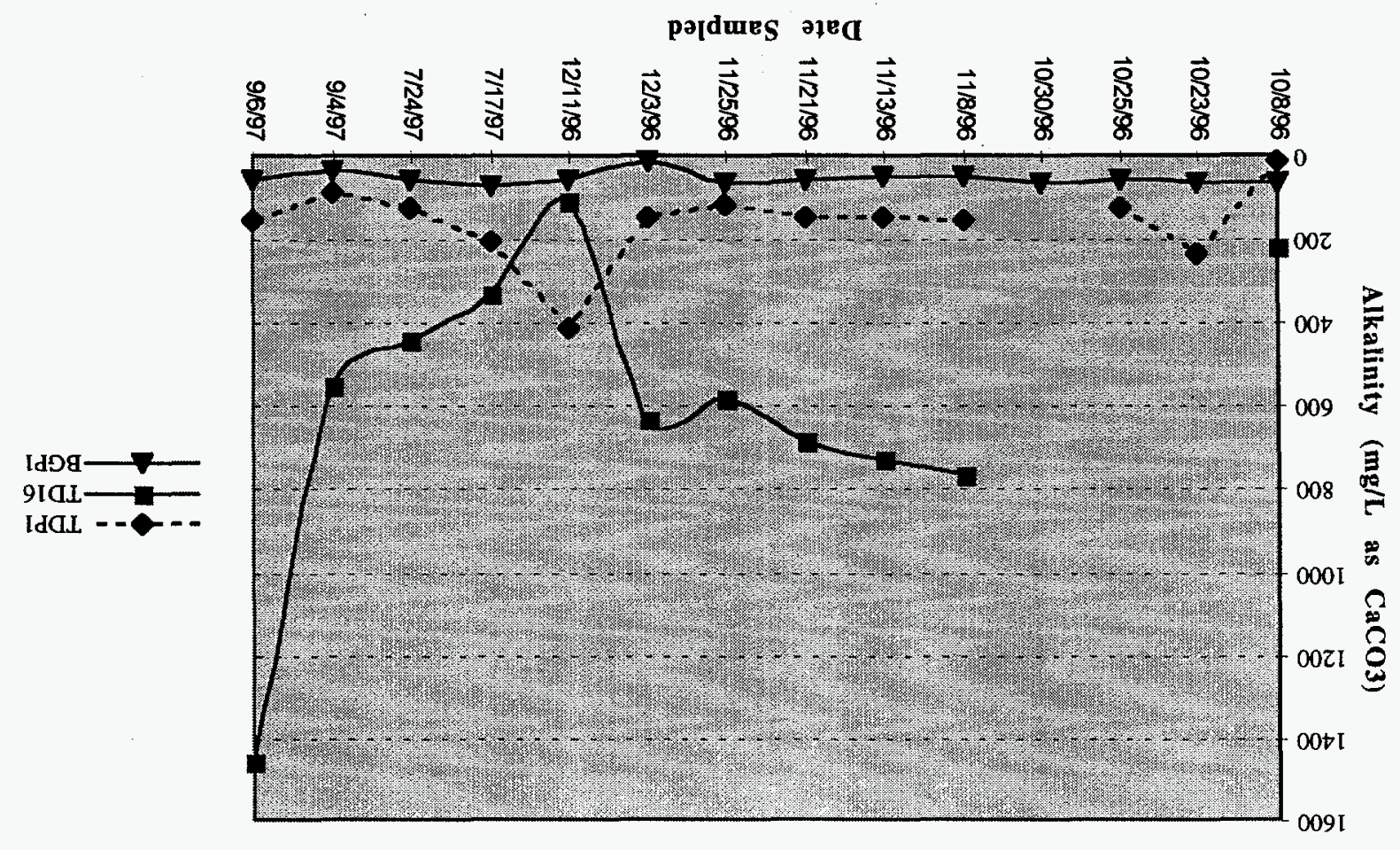

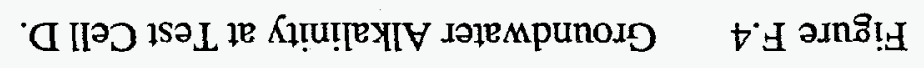

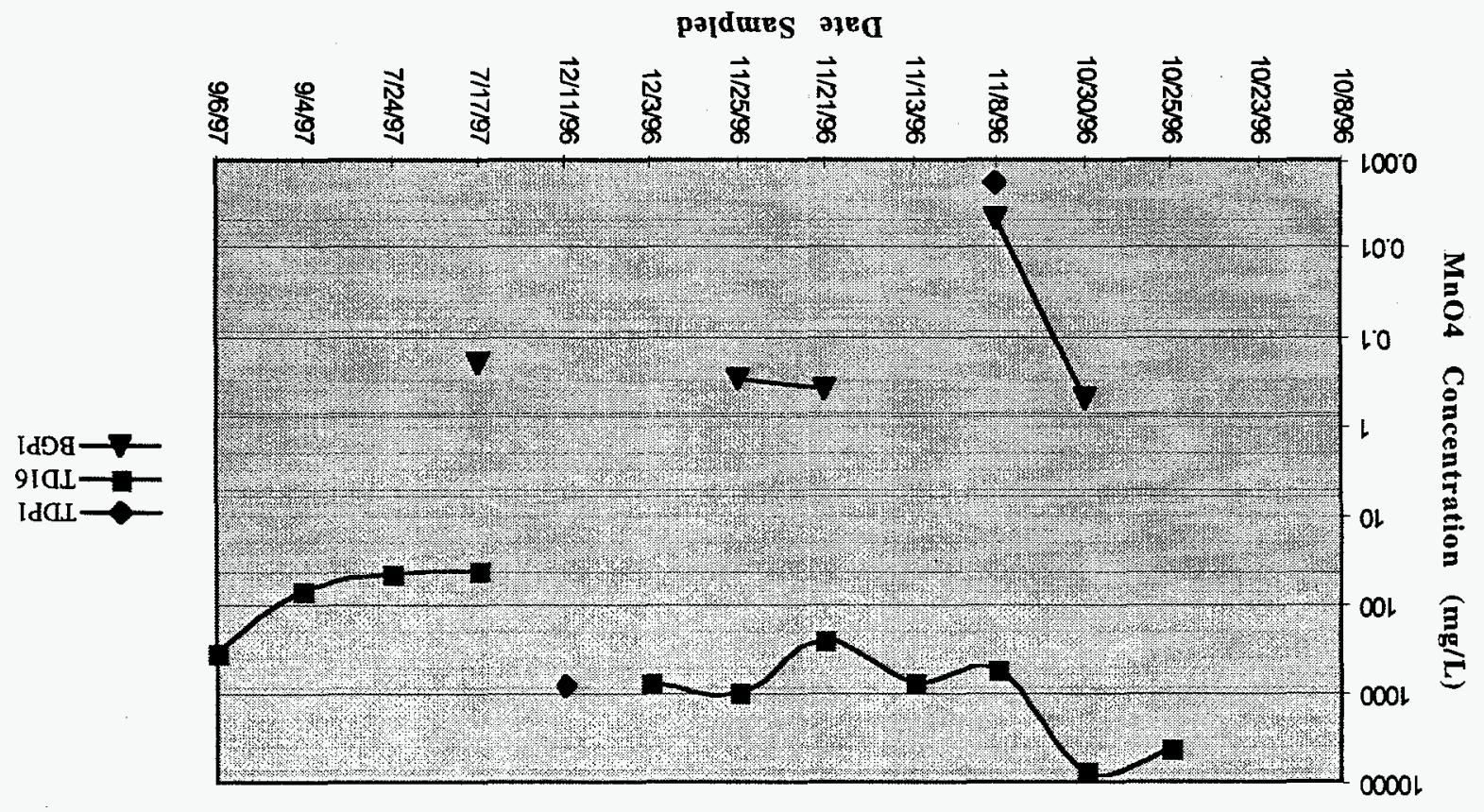

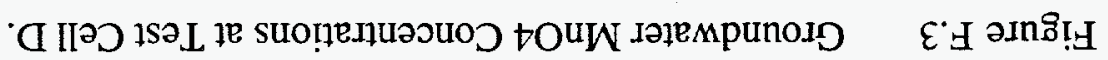


Figure F.5 Test Cell A (TAP1) Groundwater Quality Parameters.

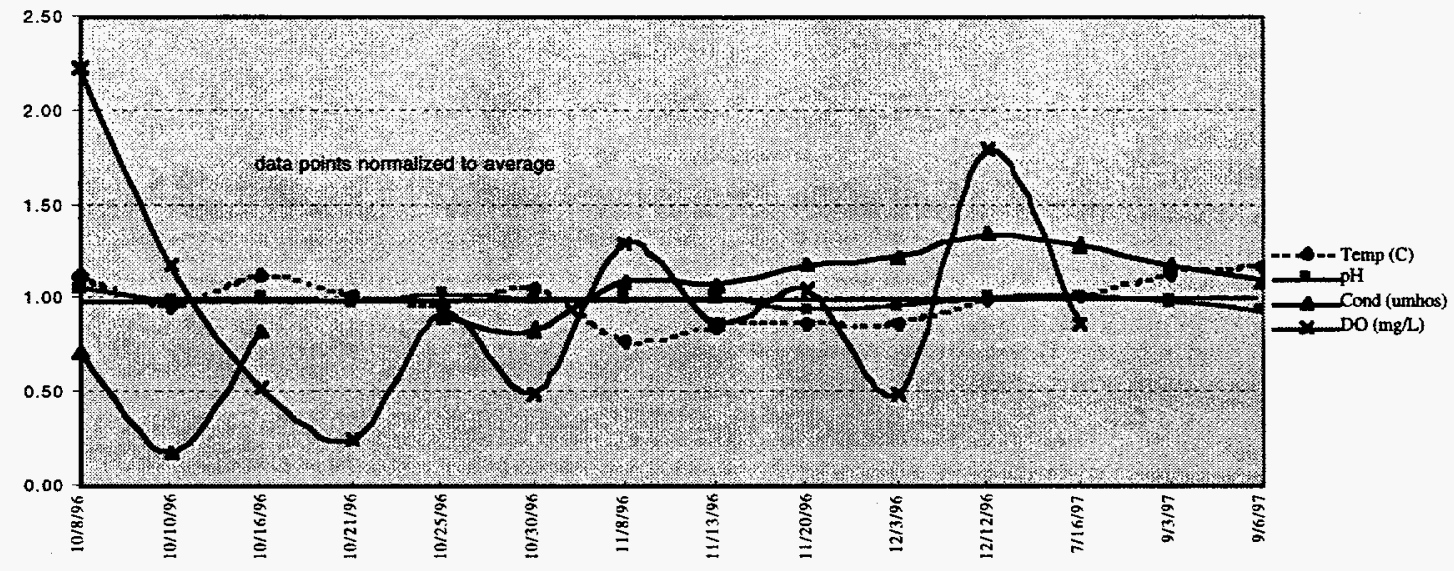

Figure F.6 Test Cell B (TBP1) Groundwater Quality Parameters.

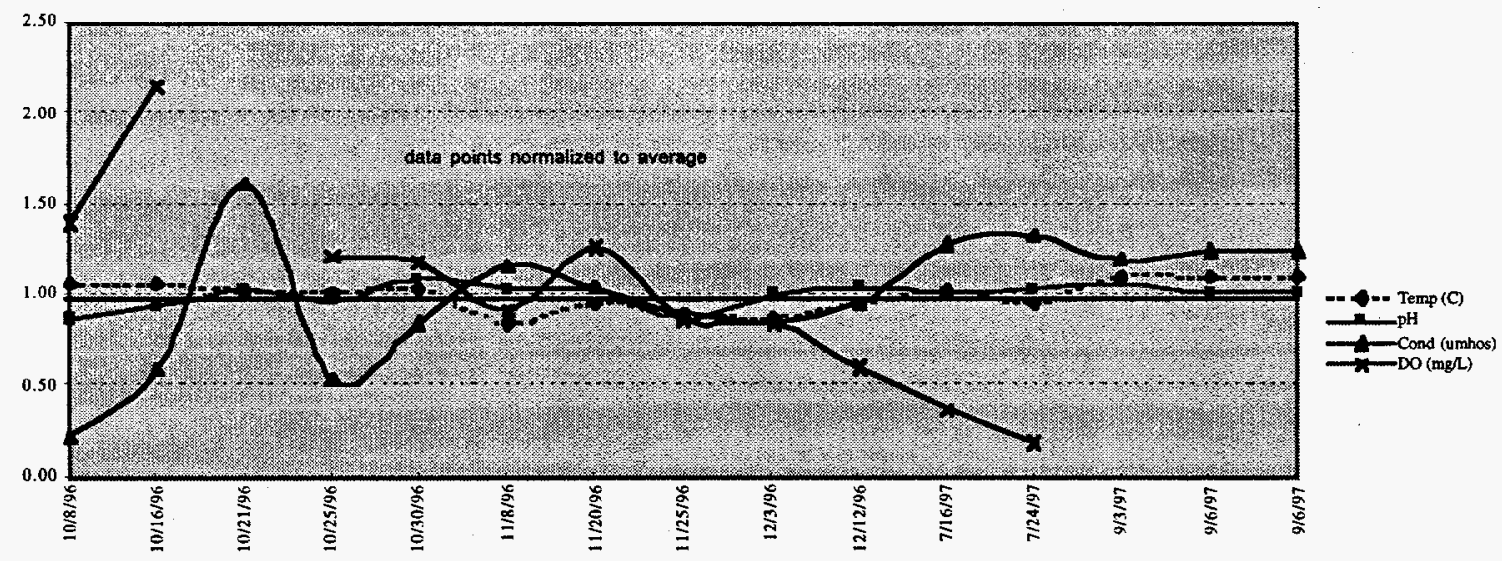


Figure F.7 Test Cell C (TCP1) Groundwater Quality Parameters.

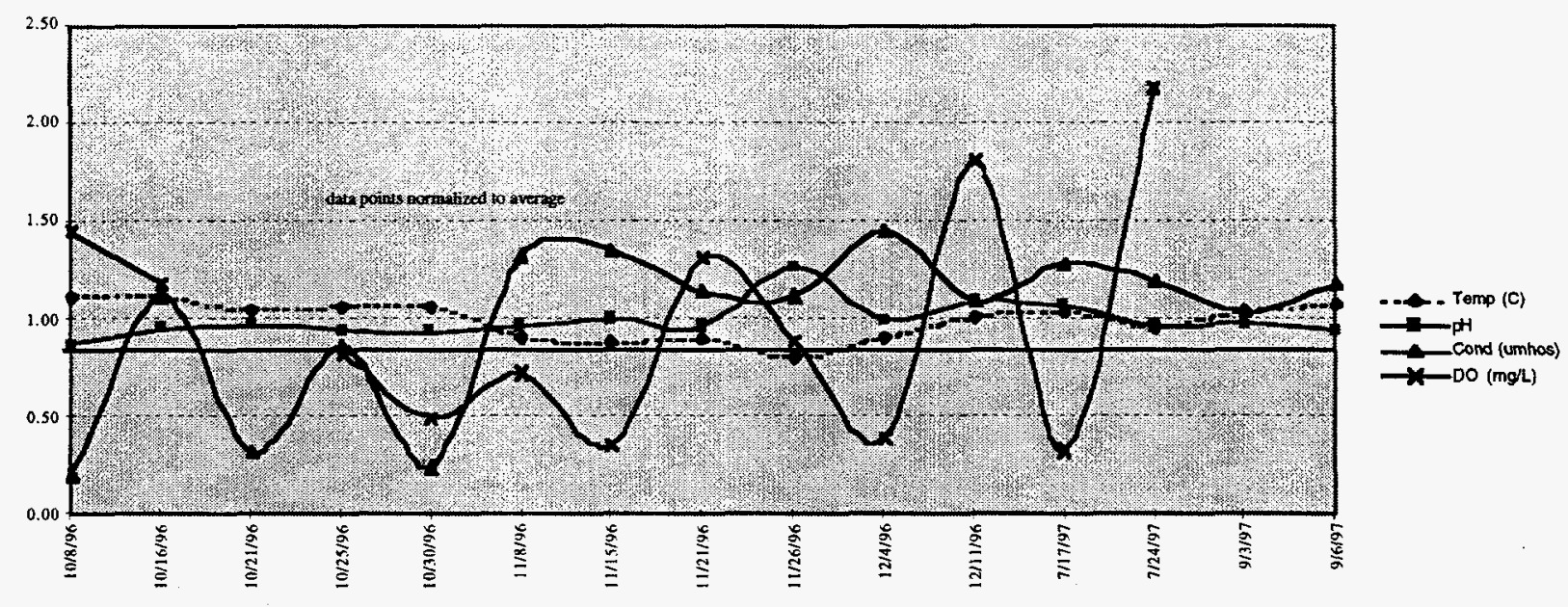

Figure F.8 Test Cell D (TDP1) Groundwater Quality Parameters.

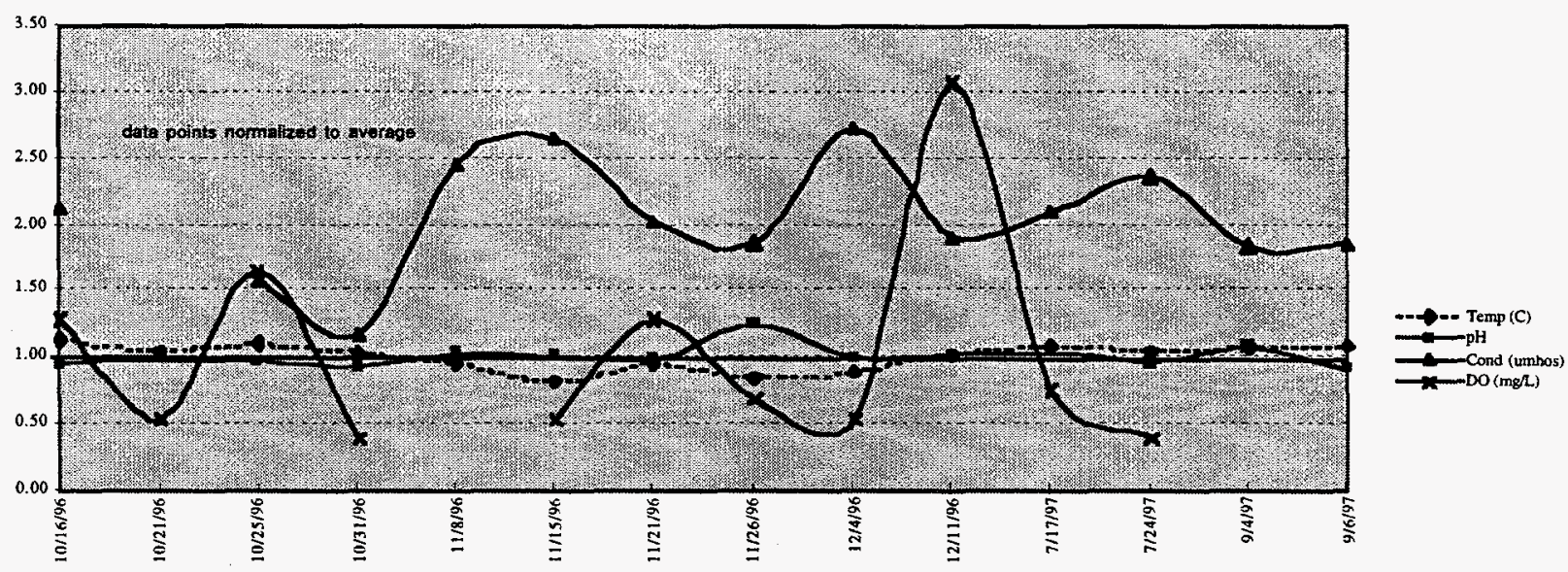


Table F.1 VOC concentrations in background monitoring locations, field laboratory analysis.

\begin{tabular}{|c|c|c|c|c|c|c|c|c|c|c|}
\hline Location & Date & $\begin{array}{c}\mathrm{CH} 2 \mathrm{Cl} 2 \\
(\mathrm{ug} / \mathrm{L})\end{array}$ & $\begin{array}{l}\mathrm{t}-1,2- \\
\mathrm{DCE} \\
(\mathrm{ug} / \mathrm{L})\end{array}$ & $\begin{array}{l}c-1,2- \\
D C E \\
(\mathrm{ug} / \mathrm{L})\end{array}$ & $\begin{array}{c}1,1- \\
\mathrm{DCE} \\
(\mathrm{ug} / \mathrm{L})\end{array}$ & $\begin{array}{c}1,2- \\
\mathrm{DCA} \\
(\mathrm{ug} / \mathrm{L})\end{array}$ & $\begin{array}{c}1,1,1- \\
\text { TCA } \\
\text { (ug/L) }\end{array}$ & $\begin{array}{c}\text { TCE } \\
(\mathrm{ug} / \mathrm{L})\end{array}$ & $\begin{array}{l}\text { PCE } \\
(\mathrm{ug} / \mathrm{L})\end{array}$ & $\begin{array}{l}\text { Total } \\
\text { VOCs } \\
\text { (ug/L) }\end{array}$ \\
\hline \multirow[t]{2}{*}{$\overline{X 600-01 G}$} & $10 / 10 / 96$ & 59 & & & 22 & & 1 & 47 & & 129 \\
\hline & $12 / 11 / 96$ & & & & & & 1 & 21 & & 22 \\
\hline \multirow[t]{2}{*}{$X 600-02 G$} & $11 / 23 / 96$ & & & & & & 2 & 62 & & 64 \\
\hline & $12 / 11 / 96$ & & & & & & 2 & 32 & & 34 \\
\hline$X 600-04 G$ & $10 / 10 / 96$ & 57 & & & 200 & & 82 & 698 & & $1037 "$ \\
\hline$\times 600-05 G$ & $10 / 10 / 96$ & 60 & & & 53 & & 11 & $220^{\circ}$ & & 344 \\
\hline \multirow[t]{17}{*}{ BGPI } & $10 / 8 / 96$ & 50 & & & 29 & & 2 & 64 & & 145 \\
\hline & $10 / 17 / 96$ & 56 & & & 30 & & 2 & 60 & & 148 \\
\hline & $10 / 21 / 96$ & 29 & & & 22 & & 2 & 189 & & 242 \\
\hline & $10 / 23 / 96$ & & & & & & & & & \\
\hline & $10 / 25 / 96$ & 28 & & & & & 2 & 77 & & 107 \\
\hline & $10 / 31 / 96$ & & & & & & 3 & 84 & & 87 \\
\hline & $11 / 8 / 96$ & & & 18 & & & 3 & 60 & & 81 \\
\hline & $11 / 13 / 96$ & & & & & & 3 & 73 & & 76 \\
\hline & $11 / 21 / 96$ & & & 9 & & & 2 & 90 & & 101 \\
\hline & $11 / 25 / 96$ & & & & & & 1 & 96 & & 97 \\
\hline & $12 / 3 / 96$ & & & & & & 1 & 44 & & 45 \\
\hline & $12 / 11 / 96$ & & & & & & 1 & 34 & & 35 \\
\hline & $7 / 17 / 97$ & & & & & & & & & \\
\hline & $7 / 24 / 97$ & & & & & & & 6 & & 6 \\
\hline & $9 / 4 / 97$ & & & & & 94 & & & & 94 \\
\hline & $9 / 6 / 97$ & & & & & & & $1 \mathrm{~J}$ & & \\
\hline & $12 / 12 / 97$ & & & & & & & 42 & & 42 \\
\hline \multirow[t]{17}{*}{ BGP2 } & $10 / 8 / 96$ & 50 & & & 16 & & & 28 & & 94 \\
\hline & $10 / 8 / 96$ & 52 & & & 17 & & & 26 & & 95 \\
\hline & $10 / 17 / 96$ & 57 & & & 17 & & 17 & & & 91 \\
\hline & $10 / 21 / 96$ & 28 & & & 28 & & 0 & 263 & & 319 \\
\hline & $10 / 23 / 96$ & & & & & & & & & \\
\hline & $10 / 25 / 96$ & 39 & & & & & & 79 & & 118 \\
\hline & $10 / 30 / 96$ & & & & & & & 65 & & 65 \\
\hline & $11 / 8 / 96$ & & & & & & & 27 & & 27 \\
\hline & $11 / 13 / 96$ & & & & & & 2 & 78 & & 80 \\
\hline & $11 / 21 / 96$ & & & & & & & 89 & & 89 \\
\hline & $11 / 25 / 96$ & & & & & & & 47 & & 47 \\
\hline & $12 / 3 / 96$ & & & & & & & 22 & & 22 \\
\hline & $12 / 11 / 96$ & & & & & & & 1 & & 1 \\
\hline & $7 / 17 / 97$ & & & & & & & & & \\
\hline & $7 / 24 / 97$ & & & & & & & & & \\
\hline & $9 / 3 / 97$ & & & & & & & & & \\
\hline & $9 / 6 / 97$ & & & & & & & & & \\
\hline
\end{tabular}


Table F.1. cont. VOC concentrations in background monitoring locations, field laboratory analysis.

\begin{tabular}{|c|c|c|c|c|c|c|c|c|c|c|}
\hline Location & Date & $\begin{array}{r}\mathrm{CH} 2 \mathrm{Cl} 2 \\
(\mathrm{ug} / \mathrm{L})\end{array}$ & $\begin{array}{l}t-1,2- \\
\text { DCE } \\
(\mathrm{ug} / \mathrm{L}) \\
\end{array}$ & $\begin{array}{l}c-1,2- \\
\text { DCE } \\
\text { (ug/L) }\end{array}$ & $\begin{array}{c}1,1- \\
\text { DCE } \\
\text { (ug/L) }\end{array}$ & $\begin{array}{c}1,2- \\
\text { DCA } \\
(\mathrm{ug} / \mathrm{L})\end{array}$ & $\begin{array}{c}1,1,1- \\
\text { TCA } \\
(\mathrm{ug} / \mathrm{L})\end{array}$ & $\begin{array}{c}\mathrm{TCE} \\
(\mathrm{ug} / \mathrm{L})\end{array}$ & $\begin{array}{l}\mathrm{PCE} \\
\text { (ug/L) } \\
\end{array}$ & $\begin{array}{c}\text { Total } \\
\text { VOCs } \\
\text { (ug/L) }\end{array}$ \\
\hline \multirow[t]{19}{*}{$\overline{\text { BGP3 }}$} & $10 / 10 / 96$ & 205 & & 1509 & 43886 & 694 & 3990 & 320510 & 140 & 370934 \\
\hline & $10 / 17 / 96$ & 111 & & 1795 & 69273 & 323 & 4649 & 344320 & 193 & 420664 \\
\hline & $10 / 17 / 96$ & & & & & & & & & \\
\hline & $10 / 21 / 96$ & 58 & & 572 & 36501 & 95 & 4107 & 333461 & 189 & 374983 \\
\hline & $10 / 23 / 96$ & & & & & & & & & \\
\hline & $10 / 25 / 96$ & 498 & & & & & 5912 & 515226 & 180 & 521816 \\
\hline & $10 / 30 / 96$ & 41 & & 347 & & 498 & 7353 & 437655 & 126 & 446020 \\
\hline & $11 / 9 / 96$ & 61 & & 525 & & 375 & 11871 & 340522 & 227 & 353581 \\
\hline & $11 / 9 / 96$ & & & 6770 & 934 & & 10383 & 540017 & 228 & 558332 \\
\hline & $11 / 13 / 96$ & & & & & & 9022 & 509356 & 201 & 518579 \\
\hline & $11 / 20 / 96$ & 160 & & 732 & & & 4430 & 569013 & 245 & 574580 \\
\hline & $11 / 25 / 96$ & 791 & & 1934 & & & 3932 & 426184 & 73 & 432914 \\
\hline & $12 / 3 / 96$ & 77 & & 695 & & 473 & 4932 & 311165 & 207 & 317549 \\
\hline & $12 / 12 / 96$ & & & 1034 & & & 4417 & 491052 & 144 & 496647 \\
\hline & $7 / 16 / 97$ & & & 3214 & & & & 528000 & & 531214 \\
\hline & $7 / 24 / 97$ & & & & & & & 606344 & & 606344 \\
\hline & $9 / 4 / 97$ & & & & & 10800 & & 693000 & & 703800 \\
\hline & 9/4/97 & & & & & & & 528000 & & 528000 \\
\hline & $9 / 6 / 97$ & & & & & & & 351084 & & 351084 \\
\hline
\end{tabular}

Blank entries are non detect 
Table F.2. VOC concentrations in Test Cell A monitoring locations, field laboratory analysis.

\begin{tabular}{|c|c|c|c|c|c|c|c|c|c|c|}
\hline Location & Date & $\begin{array}{l}\mathrm{CH} 2 \mathrm{Cl} 2 \\
\text { (ug/L) }\end{array}$ & $\begin{array}{l}\mathrm{t}-1,2- \\
\mathrm{DCE} \\
\text { (ug/L) }\end{array}$ & $\begin{array}{l}\text { c-1,2- } \\
\text { DCE } \\
\text { (ug/L) }\end{array}$ & $\begin{array}{c}1,1- \\
\text { DCE } \\
\text { (ug/L) }\end{array}$ & $\begin{array}{c}1,2- \\
\text { DCA } \\
(\mathrm{ug} / \mathrm{L})\end{array}$ & $\begin{array}{c}\text { 1,1,1- } \\
\text { TCA } \\
\text { (ug/L) }\end{array}$ & $\begin{array}{c}\text { TCE } \\
(\mathrm{ug} / \mathrm{L})\end{array}$ & $\begin{array}{l}\text { PCE } \\
(\mathrm{ug} / \mathrm{L})\end{array}$ & $\begin{array}{c}\text { Total } \\
\text { VOCs } \\
(\mathrm{ug} / \mathrm{L})\end{array}$ \\
\hline TA12 & $11 / 23 / 96$ & & & & & & & & & \\
\hline \multirow[t]{16}{*}{ TA18 } & $10 / 10 / 96$ & 5 & & & 17 & & & 43 & & 65 \\
\hline & $10 / 17 / 96$ & & & & & & & & & \\
\hline & $10 / 18 / 96$ & & & & & & & & & \\
\hline & $10 / 22 / 96$ & 40 & & & 27 & & 5 & 162 & & 234 \\
\hline & $10 / 23 / 96$ & & & & & & & & & \\
\hline & $10 / 25 / 96$ & 35 & & & & & 1 & 64 & & 100 \\
\hline & $10 / 30 / 96$ & & & & & & 7 & 151 & & 158 \\
\hline & $11 / 9 / 96$ & & & & & & 9 & 706 & & 715 \\
\hline & $11 / 13 / 96$ & & & & 16 & & 7 & 69 & & 92 \\
\hline & $11 / 20 / 96$ & & & 21 & 44 & & 17 & 206 & & 288 \\
\hline & $12 / 3 / 96$ & & & & 11 & & 3 & 87 & & 101 \\
\hline & $12 / 12 / 96$ & & & & 5 & & 3 & 61 & & 69 \\
\hline & $7 / 16 / 97$ & & & & & & & & & \\
\hline & $7 / 24 / 97$ & & & & & & & 58 & & 58 \\
\hline & $9 / 3 / 97$ & & & & & 26 & & 1 & & 26 \\
\hline & $9 / 6 / 97$ & & & & & & & & & \\
\hline \multirow[t]{16}{*}{ TAP1 } & $10 / 10 / 96$ & 48 & & & 35 & & 2 & 62 & & 147 \\
\hline & $10 / 16 / 96$ & 58 & & & 37 & & 1 & 66 & & 162 \\
\hline & $10 / 21 / 96$ & 25 & & & 32 & & 5 & 287 & & 349 \\
\hline & $10 / 23 / 96$ & & & & & & & & & \\
\hline & $10 / 25 / 96$ & 44 & & & 37 & & 8 & 149 & & 238 \\
\hline & $10 / 30 / 96$ & & & & 14 & & 7 & 205 & & 226 \\
\hline & $11 / 8 / 96$ & & & 20 & 23 & & 5 & 129 & & 177 \\
\hline & $11 / 13 / 96$ & & & & 20 & & 5 & 83 & & 108 \\
\hline & $11 / 20 / 96$ & & & 13 & 26 & & 6 & 140 & & 185 \\
\hline & $11 / 25 / 96$ & & & & & & 6 & 119 & & 125 \\
\hline & $12 / 3 / 96$ & & & & 14 & & 4 & 96 & & 114 \\
\hline & $12 / 12 / 96$ & & & & 17 & & 5 & 92 & & 114 \\
\hline & $7 / 16 / 97$ & & & & & & & 4 & & \\
\hline & $7 / 24 / 97$ & & & & & & & 57 & & 57 \\
\hline & $9 / 3 / 97$ & & & & & 1 & & 74 & & 74 \\
\hline & $9 / 6 / 97$ & & & & & 940 & & 22 & & 962 \\
\hline
\end{tabular}

Blank entries are non detect 
Table F.3. VOC concentrations in Test Cell B monitoring locations, field laboratory analysis.

\begin{tabular}{|c|c|c|c|c|c|c|c|c|c|c|}
\hline Location & Date & $\begin{array}{c}\mathrm{CH} 2 \mathrm{Cl} 2 \\
(\mathrm{ug} / \mathrm{L})\end{array}$ & $\begin{array}{c}\mathrm{t}-1,2- \\
\mathrm{DCE} \\
(\mathrm{ug} / \mathrm{L}) \\
\end{array}$ & $\begin{array}{c}\mathrm{c}-1,2- \\
\mathrm{DCE} \\
(\mathrm{ug} / \mathrm{L})\end{array}$ & $\begin{array}{c}1,1- \\
\text { DCE } \\
(\mathrm{ug} / \mathrm{L}) \\
\end{array}$ & $\begin{array}{c}1,2- \\
\text { DCA } \\
(\mathrm{ug} / \mathrm{L}) \\
\end{array}$ & $\begin{array}{c}1,1,1- \\
\text { TCA } \\
(\mathrm{ug} / \mathrm{L})\end{array}$ & $\begin{array}{c}\text { TCE } \\
\text { (ug/L) } \\
\end{array}$ & $\begin{array}{l}\text { PCE } \\
\text { (ug/L) } \\
\end{array}$ & $\begin{array}{l}\text { Total } \\
\text { VOCs } \\
\text { (ug/L) } \\
\end{array}$ \\
\hline \multirow[t]{17}{*}{ TB16 } & $10 / 10 / 96$ & 57 & & & 25 & & 0 & 375 & & 457 \\
\hline & $10 / 17 / 96$ & & & & & & & & & \\
\hline & $10 / 18 / 96$ & & & & & & & & & \\
\hline & $10 / 22 / 96$ & & & & & & 6 & 2769 & & 2775 \\
\hline & $10 / 23 / 96$ & & & & & & & & & \\
\hline & $10 / 25 / 96$ & 25 & & 38 & 24 & & 18 & 4619 & 1 & 4725 \\
\hline & $10 / 31 / 96$ & & & 64 & 32 & & 35 & 4275 & 2 & 4408 \\
\hline & $11 / 10 / 96$ & 23 & & 168 & 26 & & 59 & 6422 & 2 & 6700 \\
\hline & $11 / 13 / 96$ & & & 177 & 38 & & 47 & 5000 & & 5262 \\
\hline & $11 / 20 / 96$ & & & 207 & 26 & & 33 & 7272 & 1 & 7539 \\
\hline & $11 / 25 / 96$ & 37 & & 252 & 34 & & 61 & 11966 & 2 & 12352 \\
\hline & $12 / 3 / 96$ & & & 108 & 22 & & 41 & 7376 & 2 & 7549 \\
\hline & $12 / 12 / 96$ & & & 81 & 32 & & 49 & 8373 & 2 & 8537 \\
\hline & $7 / 16 / 97$ & & & & & & & & & \\
\hline & $7 / 24 / 97$ & & & 1241 & & & & 428 & & 1669 \\
\hline & $9 / 3 / 97$ & & & 1003 & & & & 7272 & & 8275 \\
\hline & $9 / 6 / 97$ & & & 2927 & & 520 & & 1067 & & \\
\hline \multirow[t]{17}{*}{ TBP1 } & $10 / 8 / 96$ & 56 & & & 23 & & & 24 & & 103 \\
\hline & $10 / 16 / 96$ & 60 & & & 46 & & & 27 & & 133 \\
\hline & $10 / 21 / 96$ & 30 & & & 34 & & 1 & 263 & & 328 \\
\hline & $10 / 23 / 96$ & & & & & & & & & \\
\hline & $10 / 25 / 96$ & 35 & & & & & 1 & 162 & & 198 \\
\hline & $10 / 30 / 96$ & & & & & & & 50 & & 50 \\
\hline & $11 / 8 / 96$ & & & 18 & & & & 37 & & 55 \\
\hline & $11 / 13 / 96$ & & & & & & 5 & 368 & & 373 \\
\hline & $11 / 20 / 96$ & & & & & & & 42 & & 42 \\
\hline & $11 / 25 / 96$ & & & & & & & 17 & & 17 \\
\hline & $12 / 3 / 96$ & & & & & & & 17 & & 17 \\
\hline & $12 / 12 / 96$ & & & & & & & 4 & & 4 \\
\hline & $7 / 16 / 97$ & & & & & & & & & \\
\hline & $7 / 24 / 97$ & & & & & 7 & & 103 & & 103 \\
\hline & $9 / 3 / 97$ & & & & & 19 & & 90 & & 109 \\
\hline & 9/6/97 & & & & & & & 3 & . & \\
\hline & $9 / 6 / 97$ & & & & & & & 3 & & \\
\hline
\end{tabular}

Blank entries are non detect 
Table F.4. VOC concentrations in Test Cell C monitoring locations, field laboratory analysis.

\begin{tabular}{|c|c|c|c|c|c|c|c|c|c|c|}
\hline Location & Date & $\begin{array}{c}\mathrm{CH} 2 \mathrm{Cl2} \\
(\mathrm{ug} / \mathrm{L})\end{array}$ & $\begin{array}{c}\mathrm{t}-1,2- \\
\mathrm{DCE} \\
(\mathrm{ug} / \mathrm{L}) \\
\end{array}$ & $\begin{array}{l}c-1,2- \\
\text { DCE } \\
\text { (ug/L) }\end{array}$ & $\begin{array}{c}1,1- \\
\text { DCE } \\
(\mathrm{ug} / \mathrm{L})\end{array}$ & $\begin{array}{c}1,2- \\
\mathrm{DCA} \\
(\mathrm{ug} / \mathrm{L}) \\
\end{array}$ & $\begin{array}{c}1,1,1- \\
\text { TCA } \\
\text { (ug/L) } \\
\end{array}$ & $\begin{array}{r}\text { TCE } \\
\text { (ug/L) } \\
\end{array}$ & $\begin{array}{r}\mathrm{PCE} \\
(\mathrm{ug} / \mathrm{L}) \\
\end{array}$ & $\begin{array}{l}\text { Total } \\
\text { VOCs } \\
(\mathrm{ug} / \mathrm{L}) \\
\end{array}$ \\
\hline \multirow{17}{*}{ TC16 } & $10 / 10 / 96$ & 60 & & & 26 & & & 24 & & 110 \\
\hline & $10 / 17 / 96$ & & & & & & & & & \\
\hline & $10 / 18 / 96$ & & & & & & & & & \\
\hline & $10 / 22 / 96$ & 41 & & & & & & 215 & & 256 \\
\hline & $10 / 23 / 96$ & & & & & & & & & \\
\hline & $10 / 25 / 96$ & 40 & & & & & & 57 & & 97 \\
\hline & $10 / 31 / 96$ & & & & & & & 31 & & 31 \\
\hline & $11 / 9 / 96$ & & & & & & 3 & 189 & & 192 \\
\hline & $11 / 15 / 96$ & & & & & & & 45 & & 45 \\
\hline & $11 / 21 / 96$ & & & & & & 1 & 167 & & 168 \\
\hline & $11 / 26 / 96$ & & & & & & & 22 & & 22 \\
\hline & $12 / 4 / 96$ & & & & & & & 7 & & 7 \\
\hline & $12 / 11 / 96$ & & & & & & & 2 & & 2 \\
\hline & $7 / 17 / 97$ & & & & & & & & & \\
\hline & $7 / 24 / 97$ & & & & & & & & & \\
\hline & $9 / 3 / 97$ & & & & & & & & & \\
\hline & $9 / 6 / 97$ & & & & & 189 & & 1 & & 189 \\
\hline \multirow[t]{18}{*}{ TCP1 } & $10 / 8 / 96$ & 54 & & & 27 & & 1 & $60^{\circ}$ & & $142^{\prime}$ \\
\hline & $10 / 16 / 96$ & 57 & & & 31 & & 1 & 43 & & 132 \\
\hline & $10 / 21 / 96$ & 29 & & & 20 & & 1 & 222 & & 272 \\
\hline & $10 / 23 / 96$ & & & & & & & & & \\
\hline & $10 / 25 / 96$ & 46 & & & 9 & & 2 & 69 & & 126 \\
\hline & $10 / 30 / 96$ & & & & & & 2 & 70 & & 72 \\
\hline & $11 / 8 / 96$ & & & 25 & & & 2 & 45 & & 72 \\
\hline & $11 / 15 / 96$ & & & & & & 2 & 69 & & 71 \\
\hline & $11 / 21 / 96$ & & & 11 & & & 2 & 132 & & 145 \\
\hline & $11 / 21 / 96$ & & & 8 & & & 1 & 58 & & 67 \\
\hline & $11 / 26 / 96$ & & & & & & 1 & 54 & & 55 \\
\hline & $12 / 4 / 96$ & & & & & & 1 & 25 & & 26 \\
\hline & $12 / 11 / 96$ & & & & & & 1 & 24 & & 25 \\
\hline & $7 / 17 / 97$ & & & & & & & & & \\
\hline & $7 / 24 / 97$ & & & & & & & & & \\
\hline & 9/3/97 & & & & & 71 & & & & 71 \\
\hline & $9 / 6 / 97$ & & & & & & & & & \\
\hline & $12 / 12 / 97$ & & & & & & & 9 & & 9 \\
\hline
\end{tabular}

Blank entries are non detect 
Table F.5 VOC concentrations in Test Cell D monitoring locations, field laboratory analysis.

\begin{tabular}{|c|c|c|c|c|c|c|c|c|c|c|}
\hline Location & Date & $\begin{array}{l}\mathrm{CH} 2 \mathrm{Cl} 2 \\
(\mathrm{ug} / \mathrm{L}) \\
\end{array}$ & $\begin{array}{c}\mathrm{t}-1,2- \\
\mathrm{DCE} \\
\text { (ug/L) }\end{array}$ & $\begin{array}{c}\mathrm{c}-1,2- \\
\mathrm{DCE} \\
\text { (ug/L) }\end{array}$ & $\begin{array}{c}1,1- \\
\mathrm{DCE} \\
(\mathrm{ug} / \mathrm{L}) \\
\end{array}$ & $\begin{array}{c}1,2- \\
\text { DCA } \\
(\mathrm{ug} / \mathrm{L})\end{array}$ & $\begin{array}{c}1,1,1- \\
\text { TCA } \\
\text { (ug/L) }\end{array}$ & $\begin{array}{c}\text { TCE } \\
(\mathrm{ug} / \mathrm{L}) \\
\end{array}$ & $\begin{array}{c}\text { PCE } \\
(\mathrm{ug} / \mathrm{L}) \\
\end{array}$ & $\begin{array}{l}\text { Total } \\
\text { VOCs } \\
\text { (ug/L) } \\
\end{array}$ \\
\hline \multirow[t]{14}{*}{ TD16 } & $\begin{array}{l}10 / 10 / 96 \\
10 / 17 / 96 \\
10 / 18 / 96\end{array}$ & 60 & & & 16 & & & 20 & & 96 \\
\hline & $\begin{array}{l}10 / 22 / 96 \\
10 / 23 / 96\end{array}$ & 41 & & & & & 1 & 80 & & 122 \\
\hline & $10 / 25 / 96$ & 41 & & & & & 1 & 38 & & 80 \\
\hline & $10 / 31 / 96$ & & & & & & 2 & 40 & & 42 \\
\hline & $11 / 10 / 96$ & & & 29 & & & 1 & 7 & & 37 \\
\hline & $11 / 15 / 96$ & & & & & & 2 & 18 & & 20 \\
\hline & $11 / 21 / 96$ & & & 6 & & & 1 & 55 & & 62 \\
\hline & $11 / 26 / 96$ & & & & & & 1 & 18 & & 19 \\
\hline & $12 / 4 / 96$ & & & & & & 1 & 4 & & 5 \\
\hline & $12 / 11 / 96$ & & & & & & 1 & 1 & & 2 \\
\hline & $7 / 17 / 97$ & & & & & & & & & \\
\hline & $7 / 24 / 97$ & & & & & & & & & \\
\hline & $9 / 4 / 97$ & & & & & & & & & \\
\hline & 9/6/97 & & & & & & & & & \\
\hline \multirow[t]{17}{*}{ TDP1 } & $10 / 8 / 96$ & 55 & & & 37 & & 1 & 41 & & 134 \\
\hline & $10 / 16 / 96$ & 58 & & & 29 & & 1 & 40 & & 128 \\
\hline & $10 / 21 / 96$ & 30 & & & 20 & & 1 & 145 & & 196 \\
\hline & $10 / 23 / 96$ & & & & & & & & & \\
\hline & $10 / 25 / 96$ & 37 & & & & & 2 & 82 & & 121 \\
\hline & $10 / 31 / 96$ & & & & & & 2 & 71 & & 73 \\
\hline & $11 / 8 / 96$ & & & 16 & & & 2 & 37 & & 55 \\
\hline & $11 / 15 / 96$ & & & & & & 2 & 55 & & 57 \\
\hline & $11 / 21 / 96$ & & & 14 & & & 2 & 53 & & 69 \\
\hline & $11 / 26 / 96$ & & & & & & 1 & 67 & & 68 \\
\hline & $12 / 4 / 96$ & & & & & & 1 & 28 & & 29 \\
\hline & $12 / 11 / 96$ & & & & & & 1 & 25 & & 26 \\
\hline & $7 / 17 / 97$ & & & & & & & & & \\
\hline & $7 / 24 / 97$ & & & & & & & 14 & & 14 \\
\hline & 9/4/97 & & & & & 74 & & & & 74 \\
\hline & 9/6/97 & & & & & & & 2 & & \\
\hline & $12 / 12 / 97$ & & & & & & & 31 & & 31 \\
\hline
\end{tabular}

Blank entries are non detect 
Table F.6. VOC concentrations in background monitoring locations, PORTS laboratory analysis.

\begin{tabular}{|c|c|c|c|c|c|c|c|c|}
\hline Location & Date & $\begin{array}{c}\mathrm{CH} 2 \mathrm{Cl} 2 \\
(\mathrm{ug} / \mathrm{L})\end{array}$ & $\begin{array}{c}\mathrm{t}-1,2-\mathrm{DCE} \\
(\mathrm{ug} / \mathrm{L})\end{array}$ & $\begin{array}{c}\mathrm{c}-1,2- \\
\mathrm{DCE} \\
\text { (ug/L) }\end{array}$ & $\begin{array}{c}\text { 1,1-DCE } \\
\text { (ug/L) }\end{array}$ & $\begin{array}{c}1,1-\mathrm{DCA} \\
(\mathrm{ug} / \mathrm{L})\end{array}$ & $\begin{array}{c}1,1,1- \\
\text { TCA } \\
\text { (ug/L) }\end{array}$ & $\begin{array}{r}\text { TCE } \\
\text { (ug/L) } \\
\end{array}$ \\
\hline$\overline{X 600-01 G}$ & $10 / 10 / 96$ & $2 \mathrm{U}$ & $2 \mathrm{U}$ & $2 U$ & 3 & $2 \mathrm{U}$ & $2 \mathrm{U}$ & 22 \\
\hline$X 600-04 G$ & $10 / 10 / 96$ & $200 U$ & $200{ }^{2}$ & 2000 & $200 \mathrm{U}$ & $200 \mathrm{U}$ & 2000 & 630 \\
\hline$\times 600-05 G$ & $10 / 10 / 96$ & 20 & $2 \mathrm{U}$ & 13 & 26 & $2 U$ & 8 & $190 \mathrm{E}$ \\
\hline BGP1 & $10 / 8 / 96$ & 20 & $2 \mathrm{U}$ & 2 & 8 & 20 & $2 \mathrm{U}$ & 50 \\
\hline BGP1 & $10 / 17 / 96$ & $20 \mathrm{U}$ & $20 \mathrm{U}$ & $20 \mathrm{U}$ & $20 U$ & $20 \mathrm{U}$ & $20 \mathrm{U}$ & 38 \\
\hline BGP1 & $11 / 13 / 96$ & $4 \mathrm{U}$ & $4 U$ & $4 U$ & 5 & $4 U$ & $4 U$ & 35 \\
\hline BGP1 & $12 / 11 / 96$ & $4 U$ & $4 U$ & 5 & 11 & $4 \mathrm{U}$ & $4 U$ & 72 \\
\hline BGP2 & $10 / 8 / 96$ & $2 \mathrm{U}$ & $2 \mathrm{U}$ & $2 U$ & $2 \mathrm{U}$ & $2 \mathrm{U}$ & $2 \mathrm{U}$ & $2 \mathrm{U}$ \\
\hline BGP2 & $10 / 17 / 96$ & $20 \mathrm{U}$ & $20 \mathrm{U}$ & $20 \mathrm{U}$ & $20 U$ & $20 \mathrm{U}$ & $20 \mathrm{U}$ & $20 \mathrm{U}$ \\
\hline BGP2 & $11 / 21 / 96$ & $2 \mathrm{U}$ & $2 \mathrm{U}$ & $2 \mathrm{U}$ & $2 \mathrm{U}$ & $2 \mathrm{U}$ & $2 \mathrm{U}$ & $2 \mathrm{U}$ \\
\hline BGP2 & $12 / 11 / 96$ & $2 U$ & $2 \mathrm{U}$ & $2 \mathrm{U}$ & $2 \mathrm{U}$ & $2 \mathrm{U}$ & $2 U$ & $2 U$ \\
\hline BGP3 & $10 / 10 / 96$ & $10000 \mathrm{U}$ & $10000 \mathrm{U}$ & $10000 \mathrm{U}$ & $10000 U$ & $10000 \mathrm{U}$ & 100000 & 400000 \\
\hline BG & & $10000 \mathrm{U}$ & $10000 \mathrm{U}$ & $10000 \mathrm{U}$ & $10000 \mathrm{U}$ & $10000 \mathrm{U}$ & $10000 \mathrm{U}$ & $600000 \mathrm{E}$ \\
\hline BGP3 & $10 / 17 / 96$ & $10000 \mathrm{U}$ & $10000 \mathrm{U}$ & $10000 \mathrm{U}$ & $10000 \mathrm{U}$ & $10000 \mathrm{U}$ & $10000 \mathrm{U}$ & 490000 \\
\hline BGP3 & $10 / 21 / 96$ & $10000 \mathrm{U}$ & $10000 \mathrm{U}$ & $10000 U$ & $10000 \mathrm{U}$ & $10000 \mathrm{U}$ & $10000 \mathrm{U}$ & 470000 \\
\hline BGP3 & $11 / 20 / 96$ & $10000 \mathrm{U}$ & $10000 \mathrm{U}$ & $10000 \mathrm{U}$ & $10000 \mathrm{U}$ & $10000 \mathrm{U}$ & $10000 \mathrm{U}$ & 460000 \\
\hline BGP3 & $12 / 12 / 96$ & $10000 \mathrm{U}$ & $10000 \mathrm{U}$ & $10000 \mathrm{U}$ & $10000 \mathrm{U}$ & $10000 \mathrm{U}$ & $10000 U$ & 460000 \\
\hline
\end{tabular}

$\mathrm{U}=$ Compound was analyzed for but not detected. The number is the attainable detection limit for the sample. 
Table F.7. VOC concentrations in Test Cells A, B, C, and D monitoring locations, PORTS laboratory analysis.

\begin{tabular}{|c|c|c|c|c|c|c|c|c|}
\hline Location & Date & $\begin{array}{c}\mathrm{CH} 2 \mathrm{Cl} 2 \\
\mathrm{ug} / \mathrm{L}\end{array}$ & $\begin{array}{l}\mathrm{t}-1,2- \\
\mathrm{DCE} \\
\mathrm{ug} / \mathrm{L}\end{array}$ & $\begin{array}{c}c-1,2-\mathrm{DCE} \\
u g / L\end{array}$ & $\begin{array}{c}1,1-\mathrm{DCE} \\
\mathrm{ug} / \mathrm{L}\end{array}$ & $\begin{array}{c}\text { 1,1-DCA } \\
\mathrm{ug} / \mathrm{L}\end{array}$ & $\begin{array}{c}1,1,1-\mathrm{TCA} \\
\mathrm{ug} / \mathrm{L} \\
\end{array}$ & $\begin{array}{l}\text { TCE } \\
\text { ug/L }\end{array}$ \\
\hline TA18 & $10 / 10 / 96$ & $2 \mathrm{U}$ & $2 \mathrm{U}$ & $\overline{2 U}$ & 3 & $\overline{2 U}$ & $2 \mathrm{U}$ & $\overline{14}$ \\
\hline TA18 & $11 / 20 / 96$ & $10 \mathrm{U}$ & $10 U$ & $10 \mathrm{U}$ & 57 & $10 \mathrm{U}$ & 16 & 160 \\
\hline TA18 & $12 / 12 / 96$ & $2 \mathrm{U}$ & $2 \mathrm{U}$ & 11 & 28 & 8 & 4 & 78 \\
\hline TAP1 & $10 / 10 / 96$ & $2 \mathrm{U}$ & $2 U$ & 4 & 14 & 3 & 2 & 46 \\
\hline TAP1 & $10 / 16 / 96$ & $2 \mathrm{U}$ & $2 \mathrm{U}$ & 6 & $2 \mathrm{U}$ & 4 & $2 \mathrm{U}$ & 38 \\
\hline TAP1 & $11 / 20 / 96$ & $2 \mathrm{U}$ & $2 \mathrm{U}$ & $5 \mathrm{D}$ & $32 \mathrm{D}$ & $6 \mathrm{D}$ & $7 \mathrm{D}$ & $100 \mathrm{D}$ \\
\hline TAP1 & $12 / 3 / 96$ & $2 \mathrm{U}$ & $2 \mathrm{U}$ & 6 & 27 & 8 & 4 & 94 \\
\hline TAP1 & $12 / 12 / 96$ & $4 U$ & $4 U$ & 5 & 26 & 7 & 5 & 100 \\
\hline TB 16 & $10 / 10 / 96$ & $200 \mathrm{UJ}$ & $200 \mathrm{UJ}$ & $200 \mathrm{UJJ}$ & $200 \mathrm{UJ}$ & $200 \mathrm{UJ}$ & $200 \mathrm{UJJ}$ & $370 \mathrm{~J}$ \\
\hline TB16 & $10 / 31 / 96$ & $200 \mathrm{U}$ & $200 \mathrm{U}$ & $200 \mathrm{U}$ & $200 \mathrm{U}$ & $200 U$ & $200 U$ & 4100 \\
\hline TB16 & $11 / 20 / 96$ & $200 U$ & $200 U$ & 350 & $200 U$ & $200 U$ & $200 \mathrm{U}$ & 7800 \\
\hline TB 16 & $12 / 3 / 96$ & $200 \mathrm{U}$ & $200 U$ & 210 & $200 \mathrm{U}$ & $200 U$ & $200 \mathrm{U}$ & 7400 \\
\hline TB16 & $12 / 12 / 96$ & $200 U$ & $200 \mathrm{U}$ & $200 U$ & $200 \mathrm{U}$ & $200 U$ & $200 U$ & 8600 \\
\hline TBP1 & $10 / 8 / 96$ & $2 \mathrm{U}$ & $2 \mathrm{U}$ & 3 & $2 \mathrm{U}$ & $2 \mathrm{U}$ & $2 \mathrm{U}$ & 6 \\
\hline TBP1 & $10 / 16 / 96$ & $2 \mathrm{U}$ & $2 \mathrm{U}$ & 4 & $2 \mathrm{U}$ & $2 \mathrm{U}$ & $2 U$ & 5 \\
\hline TBP1 & $11 / 20 / 96$ & $2 \mathrm{U}$ & $2 \mathrm{U}$ & 3 & $2 \mathrm{U}$ & $2 \mathrm{U}$ & $2 \mathrm{U}$ & 7 \\
\hline TBP1 & $12 / 12 / 96$ & $2 \mathrm{U}$ & $2 \mathrm{U}$ & 2 & $2 \mathrm{U}$ & $2 \mathrm{U}$ & $2 \mathrm{U}$ & 5 \\
\hline TC16" & $10 / 10 / 96$ & 2000 & $200 \mathrm{U}$ & $200 \mathrm{U}$ & $200 \mathrm{U}$ & $200 \mathrm{U}$ & $200 \mathrm{U}$ & $200 \mathrm{U}$ \\
\hline TC16 & $11 / 21 / 96$ & $10 \mathrm{U}$ & $10 \mathrm{U}$ & $10 \mathrm{U}$ & $10 \mathrm{U}$ & $10 \mathrm{U}$ & $10 \mathrm{U}$ & $10 \mathrm{U}$ \\
\hline TC16 & $12 / 11 / 96$ & $2 \mathrm{U}$ & $2 \mathrm{U}$ & $2 \mathrm{U}$ & $2 \mathrm{U}$ & $2 \mathrm{U}$ & $2 \mathrm{U}$ & $2 \mathrm{U}$ \\
\hline TCP1 & $10 / 8 / 96$ & $2 U$ & $2 \mathrm{U}$ & $2 \mathrm{U}$ & 5 & $2 \mathrm{U}$ & 20 & 28 \\
\hline TCP1 & $10 / 16 / 96$ & $2 \mathrm{U}$ & $2 \mathrm{U}$ & $2 \mathrm{U}$ & 4 & $2 \mathrm{U}$ & $2 \mathrm{U}$ & 22 \\
\hline TCP1 & $11 / 8 / 96$ & $2 \mathrm{U}$ & $2 \mathrm{U}$ & 4 & 5 & $2 \mathrm{U}$ & $2 \mathrm{U}$ & 21 \\
\hline TCP1 & $11 / 21 / 96$ & $10 \mathrm{U}$ & $10 \mathrm{U}$ & $10 \mathrm{U}$ & $10 \mathrm{U}$ & $10 \mathrm{U}$ & $10 \mathrm{U}$ & 24 \\
\hline TCP1 & $11 / 21 / 96$ & $10 \mathrm{U}$ & $10 \mathrm{U}$ & $10 \mathrm{U}$ & $10 \mathrm{U}$ & $10 \mathrm{U}$ & $10 \mathrm{U}$ & 23 \\
\hline TCP1 & $12 / 11 / 96$ & $2 \mathrm{U}$ & $2 \mathrm{U}$ & 3 & 5 & $2 \mathrm{U}$ & $2 \mathrm{U}$ & 23 \\
\hline TD16" & $10 / 10 / 96$ & $200 \mathrm{U}$ & $200 \mathrm{U}$ & $200 \mathrm{U}$ & $200 \mathrm{U}$ & $200 \mathrm{U}$ & $200 \mathrm{U}$ & $200 \mathrm{U}$ \\
\hline TD16 & $11 / 21 / 96$ & $2 \mathrm{U}$ & $2 \mathrm{U}$ & $2 \mathrm{U}$ & $2 \mathrm{U}$ & $2 \mathrm{U}$ & $2 \mathrm{U}$ & $2 \mathrm{U}$ \\
\hline TD16 & $12 / 11 / 96$ & $2 \mathrm{U}$ & $2 \mathrm{U}$ & 3 & 3 & $2 \mathrm{U}$ & $2 \mathrm{U}$ & 27 \\
\hline TDP1 & $10 / 8 / 96$ & $2 \mathrm{U}$ & 20 & $2 \mathrm{U}$ & 3 & "2U' & $2 \mathrm{U}$ & 29 \\
\hline TDP1 & $10 / 16 / 96$ & $2 \mathrm{U}$ & $2 \mathrm{U}$ & $2 \mathrm{U}$ & 2 & $2 \mathrm{U}$ & $2 \mathrm{U}$ & 21 \\
\hline TDP1 & $11 / 21 / 96$ & $10 \mathrm{U}$ & $10 U$ & $10 \mathrm{U}$ & $10 \mathrm{U}$ & $10 \mathrm{U}$ & $10 \mathrm{U}$ & 28 \\
\hline TDP1 & $12 / 11 / 96$ & $2 U$ & $2 \mathrm{U}$ & $2 \mathrm{U}$ & $2 \mathrm{U}$ & $2 \mathrm{U}$ & $2 \mathrm{U}$ & $2 \mathrm{U}$ \\
\hline
\end{tabular}

$\mathrm{J}=$ Estimated value

$\mathrm{U}=\mathrm{Compound}$ was analyzed for but not detected. Value reported is the attainable instrument detection limit.

$\mathrm{UJ}=$ Qualify data for the sample as estimated. 
Table F.8 Inorganics concentrations in background monitoring locations, field laboratory analysis.

\begin{tabular}{|c|c|c|c|c|c|c|c|c|}
\hline Location & Date & $\begin{array}{c}\text { Alkalinity } \\
\text { as CaCO3 } \\
(\mathrm{mg} / \mathrm{L})\end{array}$ & $\begin{array}{c}\mathrm{K}+ \\
(\mathrm{mg} / \mathrm{L})\end{array}$ & $\begin{array}{c}\text { Total } \\
\text { Fe } \\
(\mathrm{mg} / \mathrm{L})\end{array}$ & $\begin{array}{l}\mathrm{Fe} 2+ \\
(\mathrm{mg} / \mathrm{L})\end{array}$ & $\underset{(\mathrm{mg} / \mathrm{L})}{\mathrm{Mn}}$ & $\underset{(\mathrm{MnO} 4 / \mathrm{L})}{\mathrm{Mn}}$ & $\begin{array}{c}\mathrm{Br}- \\
(\mathrm{mg} / \mathrm{L})\end{array}$ \\
\hline \multirow[t]{2}{*}{$\mathrm{X} 600-01 \mathrm{G}$} & $10 / 10 / 96$ & 17 & & 0.01 & & 0.1 & & \\
\hline & $12 / 11 / 96$ & 14 & 8.78 & 0.18 & 0.00 & 4.4 & 0.1 & \\
\hline \multirow[t]{2}{*}{$\times 600-02 G$} & $11 / 23 / 96$ & 34 & & 1.79 & 0.17 & 0.3 & 0.4 & \\
\hline & $12 / 11 / 96$ & 22 & 4.27 & 2.40 & 0.03 & 0.0 & 0.4 & \\
\hline$\times 600-04 G$ & $10 / 10 / 96$ & 18 & & 0.01 & & 4.6 & & \\
\hline$\times 600-05 G$ & $10 / 10 / 96$ & 10 & & $0.00^{\circ}$ & & 0.2 & & \\
\hline \multirow[t]{15}{*}{ BGP1 } & $10 / 8 / 96$ & 66 & 0.21 & 0.01 & & 0.3 & & \\
\hline & $10 / 23 / 96$ & 63 & 0.60 & 0.07 & & 0.3 & & \\
\hline & $10 / 25 / 96$ & 60 & 0.28 & 0.10 & 0.00 & 1.2 & 0.0 & \\
\hline & $10 / 31 / 96$ & 66 & 0.42 & 0.01 & 0.07 & 0.5 & 0.5 & \\
\hline & $11 / 8 / 96$ & 48 & 0.40 & 0.11 & 0.07 & 0.4 & 0.0 & \\
\hline & $11 / 13 / 96$ & 51 & 0.29 & 0.11 & 0.05 & 0.0 & 0.0 & \\
\hline & $11 / 21 / 96$ & 61 & 0.22 & 0.25 & 0.06 & 0.3 & 0.4 & \\
\hline & $11 / 25 / 96$ & 66 & & 0.27 & 0.06 & 0.3 & 0.3 & \\
\hline & $12 / 3 / 96$ & 14 & 0.41 & 0.32 & 0.03 & 0.5 & 0.0 & \\
\hline & $12 / 11 / 96$ & 60 & 0.45 & 0.29 & 0.21 & 0.4 & 0.0 & \\
\hline & $7 / 17 / 97$ & 76 & 0.70 & 0.36 & 0.04 & 0.6 & 0.2 & \\
\hline & $7 / 24 / 97$ & 57 & 0.79 & 0.40 & 0.00 & 0.4 & 0.5 & 1.7 \\
\hline & $9 / 4 / 97$ & 38 & 0.58 & 0.78 & 0.22 & 0.7 & 0.3 & 0.3 \\
\hline & $9 / 6 / 97$ & 61 & 0.49 & 1.10 & 0.77 & 0.7 & 0.0 & 0.2 \\
\hline & $12 / 12 / 97$ & & & 2.48 & 2.07 & 0.8 & 0.0 & \\
\hline \multirow[t]{15}{*}{ BGP2 } & $10 / 8 / 96$ & 44 & 0.16 & 0.03 & & 0.1 & & \\
\hline & $10 / 8 / 96$ & & 0.26 & 0.04 & & 0.2 & & \\
\hline & $10 / 23 / 96$ & 48 & 0.24 & 0.72 & & 0.4 & & \\
\hline & $10 / 25 / 96$ & 52 & 0.56 & 2.40 & 0.06 & 0.5 & 0.1 & \\
\hline & $10 / 30 / 96$ & 146 & 0.48 & 0.03 & 0.02 & 0.1 & 0.0 & \\
\hline & $11 / 8 / 96$ & 46 & 0.58 & 0.47 & 0.03 & 0.5 & 0.1 & \\
\hline & $11 / 13 / 96$ & 8 & 0.37 & 0.36 & 0.01 & 0.3 & 0.1 & \\
\hline & $11 / 21 / 96$ & 64 & 0.30 & 0.10 & 0.03 & 0.1 & 0.2 & \\
\hline & $11 / 25 / 96$ & 78 & & 0.21 & 0.09 & 0.1 & 0.2 & \\
\hline & $12 / 3 / 96$ & 6 & 0.28 & 1.37 & 0.07 & 0.6 & 0.0 & \\
\hline & $12 / 11 / 96$ & 52 & 0.26 & 0.12 & 0.09 & 0.1 & 0.0 & \\
\hline & $7 / 17 / 97$ & 115 & 0.00 & 1.36 & 1.05 & 1.1 & 0.4 & \\
\hline & $7 / 24 / 97$ & 89 & 0.87 & 1.16 & 0.00 & 0.7 & 1.0 & 1.2 \\
\hline & $9 / 3 / 97$ & 62 & 0.40 & 0.33 & 0.06 & 0.2 & 0.5 & 0.1 \\
\hline & $9 / 6 / 97$ & 71 & 0.46 & 0.55 & 0.16 & 0.5 & 0.2 & 0.1 \\
\hline
\end{tabular}


Table F.8. cont. Inorganics concentrations in background monitoring locations, field laboratory analysis.

\begin{tabular}{|c|c|c|c|c|c|c|c|c|}
\hline Location & Date & $\begin{array}{c}\text { Alkalinity } \\
\text { as } \mathrm{CaCO} 3 \\
(\mathrm{mg} / \mathrm{L})\end{array}$ & $\begin{array}{c}\mathrm{K}+ \\
(\mathrm{mg} / \mathrm{L})\end{array}$ & $\begin{array}{c}\text { Total } \\
\mathrm{Fe} \\
(\mathrm{mg} / \mathrm{L})\end{array}$ & $\begin{array}{c}\mathrm{Fe} \mathrm{2+} \\
(\mathrm{mg} / \mathrm{L})\end{array}$ & $\begin{array}{c}\mathrm{Mn} \\
(\mathrm{mg} / \mathrm{L})\end{array}$ & $\underset{(\mathrm{Mg} / \mathrm{L})}{\mathrm{MnO} 4 * *}$ & $\begin{array}{c}\mathrm{Br}- \\
(\mathrm{mg} / \mathrm{L})\end{array}$ \\
\hline \multirow[t]{14}{*}{$\overline{\text { BGP3 }}$} & $10 / 10 / 96$ & 0 & 0.45 & 0.65 & & 0.6 & & \\
\hline & $10 / 23 / 96$ & 0 & 0.55 & 0.46 & & 0.6 & & \\
\hline & $10 / 25 / 96$ & 0 & 1.00 & 1.40 & & 0.7 & & \\
\hline & $10 / 30 / 96$ & 137 & 0.63 & 0.35 & & 0.7 & & \\
\hline & $11 / 9 / 96$ & 0 & 0.83 & 0.37 & 0.33 & 0.7 & 0.2 & \\
\hline & $11 / 13 / 96$ & 0 & 0.60 & 0.39 & 0.25 & 0.8 & 0.0 & \\
\hline & $11 / 20 / 96$ & 10 & 2.38 & 0.46 & 0.25 & 1.2 & 0.6 & \\
\hline & $11 / 25 / 96$ & 0 & & 0.32 & 0.26 & 0.6 & 0.1 & \\
\hline & $12 / 3 / 96$ & 0 & 0.57 & 0.26 & 0.24 & 0.7 & 0.1 & \\
\hline & $12 / 12 / 96$ & 0 & 0.60 & 0.32 & 0.32 & 0.5 & 0.1 & \\
\hline & $7 / 16 / 97$ & 0 & 0.60 & 1.06 & 0.66 & 0.7 & 0.1 & \\
\hline & $7 / 24 / 97$ & 0 & 1.82 & 0.74 & 0.62 & 0.6 & 0.1 & 0.5 \\
\hline & $9 / 4 / 97$ & 5 & 0.58 & 0.82 & 0.14 & 0.8 & 1.0 & \\
\hline & $9 / 6 / 97$ & 0 & 0.59 & 1.29 & 1.23 & 0.7 & 0.3 & \\
\hline
\end{tabular}

Blank table entry indicates not analyzed.

** $\mathrm{MnO} 4$ values, prior to 7/24/97, are not accurate due to the method used for analysis. The values are, however, precise relative to one another as the method used remained consistent. From 7/24/97 forward, the values are accurate within the constraints of the field instrument. 
Table F.9. Inorganics concentrations in Test Cell A monitoring locations, field laboratory analysis.

\begin{tabular}{|c|c|c|c|c|c|c|c|c|}
\hline Location & Date & $\begin{array}{c}\text { Alkalinity as } \\
\mathrm{CaCO} 3 \\
\text { (mg/L) }\end{array}$ & $\underset{(\mathrm{mg} / \mathrm{L})}{\mathrm{K}+}$ & $\begin{array}{l}\text { Total Fe } \\
(\mathrm{mg} / \mathrm{L})\end{array}$ & $\begin{array}{l}\mathrm{Fe} \mathrm{2+} \\
(\mathrm{mg} / \mathrm{L})\end{array}$ & $\underset{(\mathrm{mg} / \mathrm{L})}{\mathrm{Mn}}$ & $\underset{(\mathrm{MnO} 4 * *}{\mathrm{Mn} / \mathrm{L})}$ & $\underset{(\mathrm{mg} / \mathrm{L})}{\mathrm{Br}-}$ \\
\hline TA12 & $11 / 23 / 96$ & 65 & & 3.16 & 0.73 & 10.9 & 0.0 & \\
\hline \multirow[t]{13}{*}{ TA18 } & $10 / 10 / 96$ & 244 & 1.37 & 55.50 & & 8.8 & & \\
\hline & $10 / 23 / 96$ & 127 & 1.19 & 26.40 & & 21.9 & & \\
\hline & $10 / 25 / 96$ & 45 & 1.88 & 141.00 & & 10.8 & & \\
\hline & $10 / 30 / 96$ & 18 & 1.20 & & & 21.2 & & \\
\hline & $11 / 9 / 96$ & 81 & 2.77 & 29.00 & 25.80 & 7.6 & 1.0 & \\
\hline & $11 / 13 / 96$ & 87 & 1.56 & 23.00 & 20.90 & 17.2 & 0.2 & \\
\hline & $11 / 20 / 96$ & 47 & 1.24 & 26.30 & 22.80 & 6.5 & 2.1 & \\
\hline & $12 / 3 / 96$ & 86 & 1.38 & 20.00 & 18.90 & 19.2 & 2.0 & \\
\hline & $12 / 12 / 96$ & 118 & 0.96 & 22.70 & 60.00 & 9.7 & 9.1 & \\
\hline & $7 / 16 / 97$ & 20 & 1.75 & 1.00 & 0.04 & 0.1 & 1.3 & \\
\hline & $7 / 24 / 97$ & 89 & 1.81 & 11.55 & 4.10 & 17.8 & 3.6 & 5.4 \\
\hline & $9 / 3 / 97$ & 95 & 5.53 & 8.70 & 4.20 & 13.9 & 1.3 & \\
\hline & $9 / 6 / 97$ & 109 & 5.52 & 3.95 & 0.70 & 12.3 & 0.6 & \\
\hline \multirow[t]{14}{*}{ TAP1 } & $10 / 10 / 96$ & 60 & 1.26 & 1.12 & & 14.4 & & \\
\hline & $10 / 23 / 96$ & 70 & 0.97 & 1.44 & & 25.0 & & \\
\hline & $10 / 25 / 96$ & 62 & 1.11 & 6.40 & & 24.4 & & \\
\hline & $10 / 30 / 96$ & 42 & 1.37 & 1.73 & & 20.4 & & \\
\hline & $11 / 8 / 96$ & 69 & 0.31 & 1.96 & 1.94 & 33.8 & 0.2 & \\
\hline & $11 / 13 / 96$ & 62 & 1.42 & 1.61 & 1.60 & 28.4 & 0.0 & \\
\hline & $11 / 20 / 96$ & 46 & 1.28 & 0.88 & 0.67 & 17.7 & 0.0 & \\
\hline & $11 / 25 / 96$ & 55 & & 2.42 & 2.32 & 18.8 & 0.0 & \\
\hline & $12 / 3 / 96$ & 88 & 1.13 & 3.08 & 2.83 & 20.1 & 0.2 & \\
\hline & $12 / 12 / 96$ & 75 & 1.24 & 3.90 & 3.40 & 20.4 & 0.2 & \\
\hline & $7 / 16 / 97$ & 86 & 1.65 & 7.50 & 2.10 & 29.6 & 0.3 & \\
\hline & $7 / 24 / 97$ & 70 & 1.74 & 5.00 & 1.30 & 34.5 & 1.1 & 3.9 \\
\hline & 9/3/97 & 84 & 2.57 & 2.10 & 1.96 & 27.3 & 0.3 & \\
\hline & $9 / 6 / 97$ & 65 & 2.40 & 2.40 & 2.24 & 27.8 & 0.0 & \\
\hline
\end{tabular}

Blank table entry indicates not analyzed.

** MnO4 values, prior to $7 / 24 / 97$, are not accurate due to the method used for analysis. The values are, however, precise relative to one another as the method used remained consistent. From 7/24/97 forward, the values are accurate within the constraints of the field instrument. 
Table F.10 Inorganics concentrations in Test Cell B monitoring locations, field laboratory analysis.

\begin{tabular}{|c|c|c|c|c|c|c|c|c|}
\hline Location & Date & $\begin{array}{c}\text { Alkalinity as as } \\
\mathrm{CaCO} 3 \\
\text { (mg/L) }\end{array}$ & $\begin{array}{c}\mathrm{K}+ \\
(\mathrm{mg} / \mathrm{L})\end{array}$ & $\begin{array}{c}\text { Total Fe } \\
(\mathrm{mg} / \mathrm{L})\end{array}$ & $\begin{array}{c}\mathrm{Fe} \mathrm{2+} \\
(\mathrm{mg} / \mathrm{L})\end{array}$ & $\underset{(\mathrm{mg} / \mathrm{L})}{\mathrm{Mn}}$ & $\underset{(\mathrm{MnO} / \mathrm{L})}{\mathrm{MnO}}$ & $\begin{array}{c}\mathrm{Br}- \\
(\mathrm{mg} / \mathrm{L})\end{array}$ \\
\hline \multirow[t]{14}{*}{ TB16 } & $10 / 10 / 96$ & 139 & 2.51 & 20.70 & & 10.8 & & \multirow{14}{*}{5.1} \\
\hline & $10 / 23 / 96$ & 52 & 0.86 & 10.80 & & 2.7 & & \\
\hline & $10 / 25 / 96$ & 48 & 0.39 & 63.00 & & 2.8 & & \\
\hline & $10 / 31 / 96$ & 255 & 0.60 & 81.90 & & 4.4 & & \\
\hline & $11 / 10 / 96$ & 51 & 0.38 & 16.80 & 16.15 & 3.4 & 0.1 & \\
\hline & $11 / 13 / 96$ & 56 & 0.41 & 19.00 & 16.70 & 3.4 & 0.1 & \\
\hline & $11 / 20 / 96$ & 56 & 0.36 & 17.60 & 16.45 & 3.1 & 0.5 & \\
\hline & $11 / 25 / 96$ & 59 & & 22.70 & 21.60 & 2.3 & 1.2 & \\
\hline & $12 / 3 / 96$ & 21 & 0.24 & 15.85 & 14.80 & 2.3 & 0.1 & \\
\hline & $12 / 12 / 96$ & 50 & 0.45 & 13.20 & 12.00 & 1.9 & 0.0 & \\
\hline & $7 / 16 / 97$ & 24 & 0.17 & 3.00 & 1.20 & 0.6 & 0.6 & \\
\hline & $7 / 24 / 97$ & 130 & 0.59 & 28.10 & 20.80 & 11.6 & 2.0 & \\
\hline & 9/3/97 & 85 & 0.93 & 28.80 & 21.50 & 4.4 & 4.6 & \\
\hline & 9/6/97 & 178 & 0.00 & 77.50 & 54.00 & 4.2 & 5.1 & \\
\hline \multirow[t]{15}{*}{ TBP1 } & $10 / 8 / 96$ & 50 & 0.37 & 0.20 & & 0.9 & & \multirow{15}{*}{2.2} \\
\hline & $10 / 23 / 96$ & 66 & 0.90 & 0.10 & & 0.3 & & \\
\hline & $10 / 25 / 96$ & 45 & 0.32 & 0.50 & & 1.0 & & \\
\hline & $10 / 30 / 96$ & 61 & 0.48 & 0.08 & & 0.5 & & \\
\hline & $11 / 8 / 96$ & 68 & 0.47 & 0.61 & 0.08 & 0.9 & 0.4 & \\
\hline & $11 / 13 / 96$ & 67 & 0.18 & 0.34 & 0.11 & 0.7 & 0.1 & \\
\hline & $11 / 20 / 96$ & 70 & 0.25 & 0.88 & 0.31 & 0.8 & 0.4 & \\
\hline & $11 / 25 / 96$ & 60 & & 2.42 & 0.20 & 0.5 & 0.4 & \\
\hline & $12 / 3 / 96$ & 40 & 0.36 & 0.30 & 0.04 & 0.4 & 0.0 & \\
\hline & $12 / 12 / 96$ & 60 & 0.43 & 1.13 & 0.92 & 0.7 & 0.0 & \\
\hline & $7 / 16 / 97$ & 110 & 0.55 & 1.53 & 0.05 & 0.6 & 1.0 & \\
\hline & $7 / 24 / 97$ & 58 & 0.69 & 1.02 & 0.15 & 0.5 & 0.8 & \\
\hline & $9 / 3 / 97$ & 85 & 0.51 & 1.70 & 0.96 & 0.3 & 0.3 & \\
\hline & $9 / 6 / 97$ & 88 & 0.57 & 4.02 & 2.00 & 0.7 & 0.2 & \\
\hline & $9 / 6 / 97$ & 86 & 0.45 & 6.50 & 1.20 & 0.6 & 0.0 & \\
\hline
\end{tabular}

Blank table entry indicates not analyzed.

** MnO4 values, prior to $7 / 24 / 97$, are not accurate due to the method used for analysis. The values are, however, precise relative to one another as the method used remained consistent. From 7/24/97 forward, the values are accurate within the constraints of the field instrument. 
Table F.11 Inorganics concentrations in Test Cell C monitoring locations, field laboratory analysis.

\begin{tabular}{|c|c|c|c|c|c|c|c|c|}
\hline Location & Date & $\begin{array}{l}\text { Ikalinity a } \\
\mathrm{CaCO} 3 \\
(\mathrm{mg} / \mathrm{L})\end{array}$ & $\begin{array}{c}\mathrm{K}+ \\
(\mathrm{mg} / \mathrm{L})\end{array}$ & $\begin{array}{c}\text { Total Fe } \\
(\mathrm{mg} / \mathrm{L})\end{array}$ & $\begin{array}{c}\mathrm{Fe} 2+ \\
(\mathrm{mg} / \mathrm{L})\end{array}$ & $\begin{array}{c}\mathrm{Mn} \\
(\mathrm{mg} / \mathrm{L})\end{array}$ & $\begin{array}{c}\mathrm{MnO4} * * \\
(\mathrm{mg} / \mathrm{L})\end{array}$ & $\begin{array}{c}\mathrm{Br}- \\
(\mathrm{mg} / \mathrm{L})\end{array}$ \\
\hline \multirow[t]{14}{*}{ TC16 } & $10 / 10 / 96$ & 100 & 0.92 & 1.20 & & 0.5 & & \\
\hline & $10 / 23 / 96$ & 129 & 0.35 & 3.31 & & 1.3 & & \\
\hline & $10 / 25 / 96$ & & 0.34 & 26.00 & 0.37 & 3.3 & & \\
\hline & $10 / 31 / 96$ & 150 & 0.35 & 3.90 & 0.02 & 3.5 & & \\
\hline & $11 / 9 / 96$ & 135 & 0.29 & 9.40 & 0.01 & 1.2 & 1.0 & \\
\hline & $11 / 15 / 96$ & 153 & 0.20 & 6.10 & 0.09 & 1.4 & 0.1 & \\
\hline & $11 / 21 / 96$ & 166 & 0.54 & 6.31 & 0.04 & 1.8 & 1.2 & \\
\hline & $11 / 26 / 96$ & 183 & 0.06 & 6.90 & 0.05 & 0.8 & 0.1 & \\
\hline & $12 / 4 / 96$ & 182 & 0.14 & 3.05 & 0.01 & 0.7 & 0.2 & \\
\hline & $12 / 11 / 96$ & 207 & 0.21 & 4.30 & 0.50 & 1.2 & 0.0 & \\
\hline & $7 / 17 / 97$ & 120 & 0.67 & 10.75 & 0.30 & 0.3 & 1.1 & \\
\hline & $7 / 24 / 97$ & 57 & 0.50 & 4.15 & 0.32 & 0.5 & 1.0 & 3.3 \\
\hline & $9 / 3 / 97$ & 36 & 0.52 & 0.95 & 0.00 & 0.1 & 0.5 & 3.9 \\
\hline & $9 / 6 / 97$ & 24 & 0.44 & 1.25 & 0.04 & 0.3 & 0.4 & 3.7 \\
\hline \multirow[t]{15}{*}{ TCP1 } & $10 / 8 / 96$ & 143 & $0.50^{\circ}$ & 0.06 & & 0.5 & & \\
\hline & $10 / 23 / 96$ & 134 & 0.58 & 0.02 & & 0.6 & & \\
\hline & $10 / 25 / 96$ & 128 & 0.65 & 0.30 & 0.06 & 0.7 & & \\
\hline & $10 / 30 / 96$ & 50 & 0.48 & 0.84 & 0.80 & 1.1 & & \\
\hline & $11 / 8 / 96$ & 136 & 0.28 & 1.39 & 0.99 & 1.1 & 0.0 & \\
\hline & $11 / 15 / 96$ & 154 & 0.51 & 0.75 & 0.63 & 0.7 & 0.0 & \\
\hline & $11 / 21 / 96$ & 141 & 0.38 & 1.20 & 0.94 & 0.7 & 0.6 & \\
\hline & $11 / 26 / 96$ & 150 & 0.21 & 0.91 & 0.28 & 0.6 & 0.8 & \\
\hline & $12 / 4 / 96$ & 159 & 0.32 & 1.12 & 5.00 & 1.5 & 0.0 & \\
\hline & $12 / 11 / 96$ & 127 & 0.49 & 1.35 & 1.19 & 0.8 & 0.0 & \\
\hline & $7 / 17 / 97$ & 245 & 0.75 & 6.05 & 3.30 & 4.1 & 1.0 & \\
\hline & $7 / 24 / 97$ & 169 & 0.76 & 2.90 & 0.02 & 1.3 & 1.5 & 1.7 \\
\hline & 9/3/97 & 131 & 0.60 & 3.95 & 1.05 & 1.6 & 0.5 & 2.2 \\
\hline & 9/6/97 & 177 & 0.43 & 5.95 & 4.72 & 1.1 & 0.0 & 2.3 \\
\hline & $12 / 12 / 97$ & & & 16.1 & 11.65 & 2.3 & 0.6 & \\
\hline
\end{tabular}

Blank table entry indicates not analyzed.

** MnO4 values, prior to $7 / 24 / 97$, are not accurate due to the method used for analysis. The values are, however, precise relative to one another as the method used remained consistent. From 7/24/97 forward, the values are accurate within the constraints of the field instrument. 
Table F.12 Inorganics concentrations in Test Cell D monitoring locations, field laboratory analysis.

\begin{tabular}{|c|c|c|c|c|c|c|c|c|}
\hline Location & Date & $\begin{array}{c}\text { Alkalinity as } \\
\mathrm{CaCO} 3 \\
\text { (mg/L) }\end{array}$ & $\underset{(\mathrm{mg} / \mathrm{L})}{\mathrm{K}+}$ & $\begin{array}{l}\text { Total Fe } \\
(\mathrm{mg} / \mathrm{L})\end{array}$ & $\begin{array}{c}\mathrm{Fe} 2+ \\
(\mathrm{mg} / \mathrm{L})\end{array}$ & $\underset{(\mathrm{mg} / \mathrm{L})}{\mathrm{Mn}}$ & $\underset{(\mathrm{MnO} 4 / \mathrm{L})}{\mathrm{M})}$ & $\begin{array}{c}\mathrm{Br}- \\
(\mathrm{mg} / \mathrm{L})\end{array}$ \\
\hline \multirow[t]{13}{*}{ TD16 } & $10 / 10 / 96$ & 220 & & 0.00 & & 1.2 & & \\
\hline & $10 / 25 / 96$ & & & & & & 4220.0 & \\
\hline & $10 / 31 / 96$ & & & & & & 7840.0 & \\
\hline & $11 / 10 / 96$ & 765 & 142.00 & 3.25 & & 20.0 & 580.0 & \\
\hline & $11 / 15 / 96$ & 730 & 734.00 & 3.10 & & 40.0 & 800.0 & \\
\hline & $11 / 21 / 96$ & 689 & 12.68 & 3.20 & & 0.0 & 260.0 & \\
\hline & $11 / 26 / 96$ & 580 & 455.00 & 2.80 & 0.00 & 0.0 & 995.0 & \\
\hline & $12 / 4 / 96$ & 631 & 570.00 & 5.80 & & 51.0 & 805.0 & \\
\hline & $12 / 11 / 96$ & 413 & 3.11 & 0.00 & & 25.0 & 860.0 & \\
\hline & $7 / 17 / 97$ & 330 & 6.00 & 8.80 & 0.00 & & 40.0 & \\
\hline & $7 / 24 / 97$ & 440 & 465.00 & 2.07 & & 610.0 & 1170.0 & 0.0 \\
\hline & 9/4/97 & 554 & 1708.00 & 0.25 & & 1020.0 & 1807.3 & 0.0 \\
\hline & 9/6/97 & 1460 & 3076.00 & & & 5120.0 & 9227.5 & 0.1 \\
\hline \multirow[t]{15}{*}{ TDP1 } & $10 / 8 / 96$ & 11.9 & 3.00 & 0.00 & & 1.1 & & \\
\hline & $10 / 23 / 96$ & 238 & 5.64 & 0.01 & & 1.7 & & \\
\hline & $10 / 25 / 96$ & 126 & 5.87 & 0.00 & & 1.2 & 0.3 & \\
\hline & $10 / 31 / 96$ & & 6.19 & 0.00 & & 1.5 & 0.0 & \\
\hline & $11 / 8 / 96$ & 154 & 5.10 & 0.02 & 0.02 & 1.6 & 0.0 & \\
\hline & $11 / 15 / 96$ & 144 & 7.25 & 0.02 & 0.08 & 1.7 & 0.0 & \\
\hline & $11 / 21 / 96$ & 145 & 5.90 & 0.08 & 0.04 & 2.2 & 0.0 & \\
\hline & $11 / 26 / 96$ & 118 & 4.92 & 0.08 & 0.05 & 1.8 & 0.0 & \\
\hline & $12 / 4 / 96$ & 151 & 5.90 & 0.05 & 0.04 & 1.8 & 0.0 & \\
\hline & $12 / 11 / 96$ & 114 & 377.00 & 0.05 & 0.02 & 1.4 & 0.0 & \\
\hline & $7 / 17 / 97$ & 210 & 6.57 & 0.02 & 0.00 & 1.3 & 0.0 & \\
\hline & $7 / 24 / 97$ & 129 & 4.90 & 0.06 & 0.05 & 1.8 & 0.3 & 0.2 \\
\hline & $9 / 4 / 97$ & 86 & 3.75 & 0.04 & 0.27 & 1.1 & 0.3 & 3.0 \\
\hline & $9 / 6 / 97$ & 157 & 3.82 & 0.08 & 0.02 & 2.2 & 1.9 & 3.3 \\
\hline & $12 / 12 / 97$ & & & 1.97 & 1.61 & 1.5 & 0.3 & \\
\hline
\end{tabular}

Blank table entry indicates not analyzed.

** MnO4 values, prior to 7/24/97, are not accurate due to the method used for analysis. The values are, however, precise relative to one another as the method used remained consistent. From 7/24/97 forward, the values are accurate within the constraints of the field instrument. 
Table F.13. TOC, TSS, TDS, and inorganics concentrations in background monitoring locations, ORNL laboratory analysis.

\begin{tabular}{|c|c|c|c|c|c|c|c|c|c|c|c|c|}
\hline Location & Date & $\begin{array}{c}\text { TOC } \\
(\mathrm{mg} / \mathrm{L})\end{array}$ & $\begin{array}{c}\mathrm{TSS} \\
(\mathrm{mg} / \mathrm{L})\end{array}$ & $\begin{array}{c}\text { TDS } \\
(\mathrm{mg} / \mathrm{L})\end{array}$ & $\begin{array}{c}\mathrm{Cl} \\
(\mathrm{mg} / \mathrm{L})\end{array}$ & $\begin{array}{c}\mathrm{NO3} \\
(\mathrm{mg} / \mathrm{L})\end{array}$ & $\begin{array}{c}\mathrm{SO} 4 \\
(\mathrm{mg} / \mathrm{L})\end{array}$ & $\begin{array}{c}\mathrm{Ca} \\
(\mathrm{mg} / \mathrm{L})\end{array}$ & $\begin{array}{c}\mathrm{Fe} \\
(\mathrm{mg} / \mathrm{L})\end{array}$ & $\begin{array}{c}\mathrm{K} \\
(\mathrm{mg} / \mathrm{L})\end{array}$ & $\begin{array}{c}\mathrm{Mg} \\
(\mathrm{mg} / \mathrm{L})\end{array}$ & $\begin{array}{c}\mathrm{Mn} \\
(\mathrm{mg} / \mathrm{L})\end{array}$ \\
\hline X600-01G & $10 / 10 / 96$ & 0.876 & 6.5 & 3117.6 & & & & & & & & \\
\hline$\times 600-04 G$ & $10 / 10 / 96$ & 0.918 & 5.7 & 714.3 & & & & & & & & \\
\hline$\times 600-05 G$ & $10 / 10 / 96$ & 0.82 & 0.4 & 120.0 & & & & & & & & \\
\hline \multirow[t]{9}{*}{ "BGP1" } & $10 / 8 / 96$ & 1.511 & 12.0 & 150.0 & & & & & & & & \\
\hline & $10 / 17 / 96$ & 2.1 & 71.5 & 192.5 & & & & & & & & \\
\hline & $10 / 21 / 96$ & 1.638 & 12.0 & 209.5 & & & & & & & & \\
\hline & $10 / 23 / 96$ & & & & & & & & & & & \\
\hline & $10 / 25 / 96$ & 1.864 & 0.0 & 168.0 & & & & & & & & \\
\hline & $10 / 31 / 96$ & 1.968 & 26.5 & 76.5 & & & & & & & & \\
\hline & $11 / 8 / 96$ & 2.363 & 2.0 & 206.5 & & & & & & & & \\
\hline & $12 / 11 / 96$ & 0.652 & 5.0 & 214.0 & & & & & & & & \\
\hline & $7 / 17 / 97$ & & 0.0 & 180.0 & 47.4 & 0 & 1.4 & 5.617 & 0.3047 & 0.4701 & 4.249 & 0.6176 \\
\hline \multirow[t]{8}{*}{ BGP2 } & $10 / 8 / 96$ & 2.081 & 3.7 & 105.3 & & & & & & & & \\
\hline & $10 / 17 / 96$ & 2.755 & 34.0 & 122.5 & & & & & & & & \\
\hline & $10 / 21 / 96$ & 1.852 & 12.0 & 91.0 & & & & & & & & \\
\hline & $10 / 25 / 96$ & 2.072 & 0.5 & 102.5 & & & & & & & & \\
\hline & $10 / 30 / 96$ & 1.772 & 0.0 & 223.5 & & & & & & & & \\
\hline & $11 / 8 / 96$ & 3.085 & 0.0 & 144.5 & & & & & & & & \\
\hline & $12 / 11 / 96$ & 0.824 & 0.0 & 175.0 & & & & & & & & \\
\hline & $7 / 17 / 97$ & & 0.0 & 185.5 & 6 & 0 & 28.8 & 7.548 & 0.0721 & 0.2938 & 5.347 & 0.3494 \\
\hline \multirow[t]{8}{*}{$\overline{\text { BGP3 }}$} & $10 / 10 / 96$ & 14.09 & 1.0 & 50.0 & & & & & & & & \\
\hline & $10 / 17 / 96$ & 19.28 & 12.5 & 286.5 & & & & & & & & \\
\hline & $10 / 21 / 96$ & 18.39 & 10.5 & 227.0 & & & & & & & & \\
\hline & $10 / 25 / 96$ & 33.49 & 30.5 & 229.5 & & & & & & & & \\
\hline & $10 / 30 / 96$ & 23.22 & 70.5 & 193.0 & & & & & & & & \\
\hline & $11 / 9 / 96$ & 29.19 & 0.0 & 302.0 & & & & & & & & \\
\hline & $12 / 12 / 96$ & 43.17 & 0.0 & 284.0 & & & & & & & & \\
\hline & $7 / 16 / 97$ & & 0.0 & 361.0 & 108.4 & 2.2 & 0.6 & 9.423 & 0.9476 & 0.5524 & 16.69 & 0.8361 \\
\hline
\end{tabular}

Blank table entry indicates not analyzed. 
Table F.14. TOC, TSS, TDS, and inorganics concentrations in Test Cell A monitoring locations, ORNL laboratory analysis.

\begin{tabular}{|c|c|c|c|c|c|c|c|c|c|c|c|c|}
\hline Location & Date & $\begin{array}{c}\text { TOC } \\
(\mathrm{mg} / \mathrm{L})\end{array}$ & $\begin{array}{c}\mathrm{TSS} \\
(\mathrm{mg} / \mathrm{L})\end{array}$ & $\begin{array}{c}\text { TDS } \\
(\mathrm{mg} / \mathrm{L})\end{array}$ & $\begin{array}{c}\mathrm{Cl} \\
(\mathrm{mg} / \mathrm{L})\end{array}$ & $\begin{array}{c}\mathrm{NO} 3 \\
(\mathrm{mg} / \mathrm{L})\end{array}$ & $\begin{array}{c}\mathrm{SO} 4 \\
(\mathrm{mg} / \mathrm{L})\end{array}$ & $\begin{array}{c}\mathrm{Ca} \\
(\mathrm{mg} / \mathrm{L})\end{array}$ & $\begin{array}{c}\mathrm{Fe} \\
(\mathrm{mg} / \mathrm{L})\end{array}$ & $\begin{array}{c}\overline{\mathrm{K}} \\
(\mathrm{mg} / \mathrm{L})\end{array}$ & $\begin{array}{c}\mathrm{Mg} \\
(\mathrm{mg} / \mathrm{L})\end{array}$ & $\begin{array}{c}\mathrm{Mn} \\
(\mathrm{mg} / \mathrm{L})\end{array}$ \\
\hline \multirow[t]{6}{*}{ TA18 } & $10 / 10 / 96$ & 32.74 & 89.3 & 600.0 & & & & & & & & \\
\hline & $10 / 22 / 96$ & 4.008 & 20.5 & 273.5 & & & & & & & & \\
\hline & $10 / 25 / 96$ & 5.275 & 30.0 & 224.0 & & & & & & & & \\
\hline & $10 / 30 / 96$ & 4.21 & 47.0 & 250.0 & & & & & & & & \\
\hline & $11 / 9 / 96$ & 5.33 & 15.0 & 355.0 & & & & & & & & \\
\hline & $12 / 12 / 96$ & 0.381 & 39.0 & 335.5 & & & & & & & & \\
\hline \multirow[t]{8}{*}{ TAP1 } & $10 / 10 / 96$ & 1.854 & 1.4 & 136.4 & & & & & & & & \\
\hline & $10 / 16 / 96$ & 2.711 & 361.0 & 169.5 & & & & & & & & \\
\hline & $10 / 21 / 96$ & 1.381 & 14.5 & 121.0 & & & & & & & & \\
\hline & $10 / 25 / 96$ & 2.873 & 469.5 & 190.0 & & & & & & & & \\
\hline & $10 / 30 / 96$ & 2.321 & 0.0 & 136.5 & & & & & & & & \\
\hline & $11 / 8 / 96$ & & 13.0 & 223.5 & & & & & & & & \\
\hline & $12 / 12 / 96$ & & 101.5 & 271.5 & & & & & & & & \\
\hline & $7 / 16 / 97$ & & 3.0 & 171.0 & 46.9 & 0 & 44.2 & 12.35 & 8.967 & 1.396 & 8.047 & 33.49 \\
\hline
\end{tabular}

Blank table entry indicates not analyzed. 
Table F.15. TOC, TSS, TDS, and inorganics concentrations in Test Cell B monitoring locations, ORNL laboratory analysis.

\begin{tabular}{|c|c|c|c|c|c|c|c|c|c|c|c|c|}
\hline Location & Date & $\begin{array}{c}\text { TOC } \\
(\mathrm{mg} / \mathrm{L})\end{array}$ & $\begin{array}{c}\text { TSS } \\
(\mathrm{mg} / \mathrm{L})\end{array}$ & $\begin{array}{c}\text { TDS } \\
(\mathrm{mg} / \mathrm{L})\end{array}$ & $\begin{array}{c}\mathrm{Cl} \\
(\mathrm{mg} / \mathrm{L})\end{array}$ & $\begin{array}{c}\mathrm{NO3} \\
(\mathrm{mg} / \mathrm{L})\end{array}$ & $\begin{array}{c}\mathrm{SO} 4 \\
(\mathrm{mg} / \mathrm{L})\end{array}$ & $\begin{array}{c}\mathrm{Ca} \\
(\mathrm{mg} / \mathrm{L})\end{array}$ & $\begin{array}{c}\mathrm{Fe} \\
(\mathrm{mg} / \mathrm{L})\end{array}$ & $\begin{array}{c}\mathrm{K} \\
(\mathrm{mg} / \mathrm{L})\end{array}$ & $\begin{array}{c}\mathrm{Mg} \\
(\mathrm{mg} / \mathrm{L})\end{array}$ & $\begin{array}{c}\mathrm{Mn} \\
(\mathrm{mg} / \mathrm{L})\end{array}$ \\
\hline \multirow[t]{6}{*}{ TB16 } & $10 / 10 / 96$ & 228 & 149.3 & 857.1 & & & & & & & & \\
\hline & $10 / 22 / 96$ & 38.87 & 9.5 & 316.0 & & & & & & & & \\
\hline & $10 / 25 / 96$ & 11.56 & 0.0 & 210.0 & & & & & & & & \\
\hline & $10 / 31 / 96$ & 8.99 & 133.0 & 288.0 & & & & & & & & \\
\hline & $11 / 10 / 96$ & 2.364 & 0.5 & 245.0 & & & & & & & & \\
\hline & $12 / 12 / 96$ & & 0.0 & 231.0 & & & & & & & & \\
\hline \multirow[t]{8}{*}{ TBPI } & $10 / 8 / 96$ & 2.907 & 11.0 & 95.2 & & & & & & & & \\
\hline & $10 / 16 / 96$ & 4.795 & 113.0 & 174.5 & & & & & & & & \\
\hline & $10 / 21 / 96$ & 2.967 & 15.5 & 186.0 & & & & & & & & \\
\hline & $10 / 25 / 96$ & 2.834 & 10.5 & 144.5 & & & & & & & & \\
\hline & $10 / 30 / 96$ & 2.815 & 4.5 & 115.5 & & & & & & & & \\
\hline & $11 / 8 / 96$ & 3.106 & 62.0 & 189.5 & & & & & & & & \\
\hline & $12 / 12 / 96$ & 0.528 & 7.0 & 177.5 & & & & & & & & \\
\hline & $7 / 16 / 97$ & & 0.0 & 155.0 & 13 & 0 & 2.3 & 13.98 & 1.215 & 0.3157 & 8.958 & 0.6659 \\
\hline
\end{tabular}

Blank table entry indicates not analyzed. 
Table F.16. TOC, TSS, TDS, and inorganics concentrations in Test Cell C monitoring locations, ORNL laboratory analysis.

\begin{tabular}{|c|c|c|c|c|c|c|c|c|c|c|c|c|}
\hline Location & Date & $\begin{array}{c}\text { TOC } \\
(\mathrm{mg} / \mathrm{L})\end{array}$ & $\begin{array}{c}\text { TSS } \\
(\mathrm{mg} / \mathrm{L})\end{array}$ & $\begin{array}{c}\text { TDS } \\
(\mathrm{mg} / \mathrm{L})\end{array}$ & $\begin{array}{c}\mathrm{Cl} \\
(\mathrm{mg} / \mathrm{L})\end{array}$ & $\begin{array}{c}\text { NO3 } \\
(\mathrm{mg} / \mathrm{L})\end{array}$ & $\begin{array}{c}\mathrm{SO} 4 \\
(\mathrm{mg} / \mathrm{L})\end{array}$ & $\begin{array}{c}\mathrm{Ca} \\
(\mathrm{mg} / \mathrm{L})\end{array}$ & $\begin{array}{c}\mathrm{Fe} \\
(\mathrm{mg} / \mathrm{L})\end{array}$ & $\begin{array}{c}\mathrm{K} \\
(\mathrm{mg} / \mathrm{L})\end{array}$ & $\begin{array}{c}\mathrm{Mg} \\
(\mathrm{mg} / \mathrm{L})\end{array}$ & $\begin{array}{c}\mathrm{Mn} \\
(\mathrm{mg} / \mathrm{L})\end{array}$ \\
\hline \multirow[t]{6}{*}{ TC16 } & $10 / 10 / 96$ & 88.27 & 13.2 & 590.9 & & & & & & & & \\
\hline & $10 / 22 / 96$ & 123.4 & 37.5 & 603.0 & & & & & & & & \\
\hline & $10 / 25 / 96$ & 121.6 & 31.5 & 469.5 & & & & & & & & \\
\hline & $10 / 31 / 96$ & 12.97 & 16.5 & 430.5 & & & & & & & & \\
\hline & $11 / 9 / 96$ & 99.27 & 30.0 & 439.0 & & & & & & & & \\
\hline & $12 / 11 / 96$ & 78.87 & 6.0 & 430.0 & & & & & & & & \\
\hline \multirow[t]{8}{*}{ TCP1" } & $10 / 8 / 96$ & 2.454 & 18.4 & 157.9 & & & & & & & & \\
\hline & $10 / 16 / 96$ & 3.637 & 189.5 & 269.5 & & & & & & & & \\
\hline & $10 / 21 / 96$ & 2.147 & 37.0 & 275.0 & & & & & & & & \\
\hline & $10 / 25 / 96$ & 2.329 & 3.5 & 256.0 & & & & & & & & \\
\hline & $10 / 30 / 96$ & 2.342 & 0.5 & 175.0 & & & & & & & & \\
\hline & $11 / 8 / 96$ & 3.758 & 18.5 & 292.5 & & & & & & & & \\
\hline & $12 / 11 / 96$ & 2.005 & 17.5 & 298.5 & & & & & & & & \\
\hline & $7 / 17 / 97$ & & 0.0 & 299.0 & 44.3 & 0 & 0 & 18.2 & 2.825 & 0.4327 & 12.54 & 1.474 \\
\hline
\end{tabular}

Blank table entry indicates not analyzed. 
Table F.17. TOC, TSS, TDS, and inorganics concentrations in Test Cell D monitoring locations, ORNL laboratory analysis.

\begin{tabular}{|c|c|c|c|c|c|c|c|c|c|c|c|c|}
\hline Location & Date & $\begin{array}{c}\text { TOC } \\
(\mathrm{mg} / \mathrm{L})\end{array}$ & $\begin{array}{c}\text { TSS } \\
(\mathrm{mg} / \mathrm{L})\end{array}$ & $\begin{array}{c}\text { TDS } \\
(\mathrm{mg} / \mathrm{L})\end{array}$ & $\begin{array}{c}\mathrm{Cl} \\
(\mathrm{mg} / \mathrm{L})\end{array}$ & $\begin{array}{c}\mathrm{NO} 3 \\
(\mathrm{mg} / \mathrm{L})\end{array}$ & $\begin{array}{c}\mathrm{SO} 4 \\
(\mathrm{mg} / \mathrm{L})\end{array}$ & $\begin{array}{c}\mathrm{Ca} \\
(\mathrm{mg} / \mathrm{L})\end{array}$ & $\begin{array}{c}\mathrm{Fe} \\
(\mathrm{mg} / \mathrm{L})\end{array}$ & $\begin{array}{c}\mathrm{K} \\
(\mathrm{mg} / \mathrm{L})\end{array}$ & $\begin{array}{c}\mathrm{Mg} \\
(\mathrm{mg} / \mathrm{L})\end{array}$ & $\begin{array}{c}\mathrm{Mn} \\
(\mathrm{mg} / \mathrm{L})\end{array}$ \\
\hline \multirow[t]{6}{*}{ TD16 } & $10 / 10 / 96$ & 87.95 & 407.5 & 3166.7 & & & & & & & & \\
\hline & $10 / 22 / 96$ & 29.85 & 55.0 & 4185.0 & & & & & & & & \\
\hline & $10 / 25 / 96$ & 14.5 & 180.5 & 4967.0 & & & & & & & & \\
\hline & $10 / 31 / 96$ & 2.256 & 79.0 & 3902.5 & & & & & & & & \\
\hline & $11 / 10 / 96$ & 7.945 & 64.0 & 1591.0 & & & & & & & & \\
\hline & $12 / 11 / 96$ & 4.17 & 56.0 & 908.0 & & & & & & & & \\
\hline \multirow[t]{8}{*}{ TDP1 } & $10 / 8 / 96$ & 2.39 & 0.6 & 277.8 & & & & & & & & \\
\hline & $10 / 16 / 96$ & 27.38 & 9.5 & 297.0 & & & & & & & & \\
\hline & $10 / 21 / 96$ & 1.968 & 1.5 & 266.5 & & & & & & & & \\
\hline & $10 / 25 / 96$ & 2.13 & 0.0 & 223.5 & & & & & & & & \\
\hline & $10 / 31 / 96$ & 2.575 & 2.0 & 305.5 & & & & & & & & \\
\hline & $11 / 8 / 96$ & 5.516 & 0.0 & 285.0 & & & & & & & & \\
\hline & $12 / 11 / 96$ & 1.157 & 2.5 & 270.0 & & & & & & & & \\
\hline & $7 / 17 / 97$ & & 0.0 & 251.0 & 50.1 & 0 & 5.1 & 22.93 & 0 & 4.706 & 16.91 & 1.583 \\
\hline
\end{tabular}

Blank table entry indicates not analyzed. 
Table F.18 Groundwater quality parameters in background monitoring locations.

\begin{tabular}{|c|c|c|c|c|c|}
\hline $\begin{array}{l}\text { Sample } \\
\text { Location }\end{array}$ & $\begin{array}{c}\text { Date } \\
\text { Sampled }\end{array}$ & $\begin{array}{l}\text { Temp } \\
\left({ }^{\circ} \mathrm{C}\right)\end{array}$ & $\mathrm{pH}$ & $\begin{array}{c}\text { Conductivity } \\
\text { ( } \mu \text { mohs })\end{array}$ & $\begin{array}{c}\mathrm{DO} \\
(\mathrm{mg} / \mathrm{L})\end{array}$ \\
\hline \multirow[t]{2}{*}{$\overline{01 G}$} & $10 / 10 / 96$ & 16.2 & 5.25 & 1795 & \\
\hline & $12 / 11 / 96$ & 16.2 & 5.67 & 3460 & 3.3 \\
\hline \multirow[t]{2}{*}{$02 \mathrm{G}$} & $11 / 23 / 96$ & 14.3 & 5.47 & 2630 & 2 \\
\hline & $12 / 11 / 96$ & 16.2 & 5.86 & 2500 & over range \\
\hline $04 \mathrm{G}$ & $10 / 10 / 96$ & 16.5 & 5.18 & 169 & 3 \\
\hline $05 \mathrm{G}$ & $10 / 10 / 96$ & 16.4 & 5 & 193 & 2.5 \\
\hline \multirow[t]{16}{*}{ BGP1 } & $10 / 8 / 96$ & 21.4 & 5.84 & 280 & 6 \\
\hline & $10 / 17 / 96$ & 20.3 & 5.29 & 318 & 2.8 \\
\hline & $10 / 21 / 96$ & 21.3 & 5.82 & & 1.5 \\
\hline & $10 / 25 / 96$ & 20.6 & 5.67 & & 6.4 \\
\hline & $10 / 31 / 96$ & 19.3 & 5.68 & 198 & 1.5 \\
\hline & $11 / 8 / 96$ & 17.43 & 5.67 & 328 & 1.7 \\
\hline & $11 / 13 / 96$ & 17.66 & 5.81 & 323 & 0.5 \\
\hline & $11 / 21 / 96$ & 18.3 & 5.71 & 296 & 2.8 \\
\hline & $11 / 25 / 96$ & 17.8 & 4.93 & 286 & 1.8 \\
\hline & $12 / 3 / 96$ & 17.2 & 5.7 & 329 & 2.5 \\
\hline & $12 / 11 / 96$ & 19.1 & 6.4 & 284 & 2.8 \\
\hline & $7 / 17 / 97$ & 21.4 & 6.2 & 293 & 0.9 \\
\hline & $7 / 24 / 97$ & 19.5 & 6.4 & 301 & 0.6 \\
\hline & $9 / 4 / 97$ & 18.6 & 6.24 & 268 & \\
\hline & $9 / 6 / 97$ & 20.5 & 5.51 & 272 & \\
\hline & $12 / 12 / 97$ & 16.8 & 5.76 & 313 & 2.3 \\
\hline \multirow[t]{15}{*}{$\overline{B G P 2}$} & $10 / 8 / 96$ & 20.8 & 5.52 & 117 & 10.2 \\
\hline & $10 / 17 / 96$ & 20.8 & 5.57 & 94 & 4.9 \\
\hline & $10 / 21 / 96$ & 19.7 & 5.71 & 120 & 4.7 \\
\hline & $10 / 25 / 96$ & 20 & 5.27 & 53 & 3.7 \\
\hline & $10 / 30 / 96$ & 19.9 & 5.49 & 42 & 4 \\
\hline & $11 / 8 / 96$ & 17.42 & 5.62 & 262 & 3 \\
\hline & $11 / 13 / 96$ & 16.95 & 5.77 & 290 & 2.8 \\
\hline & $11 / 21 / 96$ & 17.2 & 5.38 & 194 & 3.5 \\
\hline & $11 / 25 / 96$ & 17.1 & 4.67 & 205 & 6.9 \\
\hline & $12 / 3 / 96$ & 16.7 & 5.79 & 375 & 2.8 \\
\hline & $12 / 11 / 96$ & 19 & 6.01 & 200 & 1.3 \\
\hline & $7 / 17 / 97$ & 19.8 & 6.1 & 286 & 0.6 \\
\hline & $7 / 24 / 97$ & 19.3 & 5.57 & 325 & 2.5 \\
\hline & 9/3/97 & 19.9 & 5.7 & 256 & \\
\hline & $9 / 6 / 97$ & 19.9 & 5.36 & 252 & \\
\hline
\end{tabular}


Table F.18 cont. Groundwater quality parameters in background monitoring locations.

\begin{tabular}{cccccc}
\hline $\begin{array}{c}\text { Sample } \\
\text { Location }\end{array}$ & $\begin{array}{c}\text { Date } \\
\text { Sampled }\end{array}$ & $\begin{array}{c}\text { Temp } \\
\left({ }^{\circ} \mathrm{C}\right)\end{array}$ & $\mathrm{pH}$ & $\begin{array}{c}\text { Conductivity } \\
(\mu \mathrm{mohs})\end{array}$ & $\begin{array}{c}\mathrm{DO} \\
(\mathrm{mg} / \mathrm{L})\end{array}$ \\
\hline BGP3 & $10 / 10 / 96$ & 19.2 & 4.13 & & 4.6 \\
& $10 / 17 / 96$ & 20.7 & 4.83 & 187 & 1.8 \\
& $10 / 21 / 96$ & 19.6 & 4.8 & 232 & 2.8 \\
& $10 / 25 / 96$ & 19.5 & 5.02 & 283 & 4.2 \\
& $10 / 30 / 96$ & 20.2 & 4.97 & 233 & 2.7 \\
& $11 / 9 / 96$ & 16.47 & 4.85 & 393 & 2.6 \\
$11 / 13 / 96$ & 16.64 & 4.92 & 387 & 4.4 \\
& $11 / 20 / 96$ & 17.6 & 4.8 & 409 & 4.4 \\
& $11 / 25 / 96$ & 17.4 & 3.89 & 374 & 3.5 \\
$12 / 3 / 96$ & 17.2 & 4.71 & 421 & 2.4 \\
& $12 / 12 / 96$ & & & & 1 \\
& $7 / 16 / 97$ & 19 & 4.09 & 477 & 0.7 \\
$7 / 24 / 97$ & 19.2 & 4.58 & 396 & \\
$9 / 4 / 97$ & 19 & 5.01 & 400 & \\
$9 / 7 / 97$ & 19.1 & 4.04 & 413 & \\
\hline
\end{tabular}

Blank table entry indicates measurement not taken. 
Table F.19 Groundwater quality parameters in Test Cell A monitoring locations.

\begin{tabular}{|c|c|c|c|c|c|}
\hline $\begin{array}{c}\text { Sample } \\
\text { Location }\end{array}$ & $\begin{array}{c}\text { Date } \\
\text { Sampled }\end{array}$ & $\begin{array}{l}\text { Temp } \\
\left({ }^{\circ} \mathrm{C}\right)\end{array}$ & $\overline{\mathrm{pH}}$ & $\begin{array}{c}\text { Conductivity } \\
\text { ( } \mu \text { mohs) }\end{array}$ & $\begin{array}{c}\mathrm{DO} \\
(\mathrm{mg} / \mathrm{L})\end{array}$ \\
\hline \multirow[t]{14}{*}{ TAP1 } & $10 / 10 / 96$ & 18.7 & 5.73 & 66 & 1.9 \\
\hline & $10 / 16 / 96$ & 21.9 & 5.8 & 298 & 0.85 \\
\hline & $10 / 21 / 96$ & 19.7 & 5.68 & 9 & 0.4 \\
\hline & $10 / 25 / 96$ & 18.9 & 5.92 & 329 & 1.5 \\
\hline & $10 / 30 / 96$ & 20.4 & 5.7 & 303 & 0.8 \\
\hline & $11 / 8 / 96$ & 15.04 & 5.78 & 395 & 2.1 \\
\hline & $11 / 13 / 96$ & 16.7 & 5.79 & 388 & 1.4 \\
\hline & $11 / 20 / 96$ & 16.9 & 5.45 & 425 & 1.7 \\
\hline & $12 / 3 / 96$ & 16.9 & 5.54 & 443 & 0.8 \\
\hline & $12 / 12 / 96$ & 19.3 & 5.76 & 485 & 2.9 \\
\hline & $7 / 16 / 97$ & 19.8 & 5.82 & 464 & 1.4 \\
\hline & $7 / 24 / 97$ & 19 & 5.32 & 426 & 1.6 \\
\hline & $9 / 3 / 97$ & 22.1 & 5.65 & 424 & \\
\hline & $9 / 6 / 97$ & 22.62 & 5.38 & 397 & \\
\hline \multirow[t]{15}{*}{ TA18 } & $10 / 10 / 96$ & 19.9 & 6.63 & 1584 & 4 \\
\hline & $10 / 17 / 96$ & 23 & 6.26 & 523 & \\
\hline & $10 / 18 / 96$ & 18.8 & 5.9 & 527 & \\
\hline & $10 / 22 / 96$ & 19.3 & 6.19 & 60 & 4 \\
\hline & $10 / 25 / 96$ & 19.9 & 6.1 & 88 & 3.2 \\
\hline & $10 / 30 / 96$ & 20.3 & 6.09 & 197 & 0.8 \\
\hline & $11 / 9 / 96$ & 23.94 & 6.07 & 579 & 1.7 \\
\hline & $11 / 13 / 96$ & 22.62 & 5.85 & 457 & 1.4 \\
\hline & $11 / 20 / 96$ & 19 & 5.3 & 532 & 2.5 \\
\hline & $12 / 3 / 96$ & 18.7 & 5.7 & 425 & 1.1 \\
\hline & $12 / 12 / 96$ & 20.4 & 6.04 & 663 & \\
\hline & $7 / 16 / 97$ & 19.1 & 6.08 & 594 & 5.5 \\
\hline & $7 / 24 / 97$ & 22.2 & 5.81 & 549 & 0.7 \\
\hline & $9 / 3 / 97$ & 29.7 & 6.16 & 572 & \\
\hline & $9 / 6 / 97$ & 32.1 & 6.33 & 501 & \\
\hline
\end{tabular}

Blank table entry indicates measurement not taken. 
Table F.20. Groundwater quality parameters in Test Cell B monitoring locations.

\begin{tabular}{|c|c|c|c|c|c|}
\hline $\begin{array}{c}\text { Sample } \\
\text { Location }\end{array}$ & $\begin{array}{c}\text { Date } \\
\text { Sampled }\end{array}$ & $\begin{array}{l}\text { Temp } \\
\left({ }^{\circ} \mathrm{C}\right)\end{array}$ & $\mathrm{pH}$ & $\begin{array}{c}\text { Conductivity } \\
(\mu \mathrm{mohs})\end{array}$ & $\begin{array}{c}\mathrm{DO} \\
(\mathrm{mg} / \mathrm{L})\end{array}$ \\
\hline \multirow[t]{15}{*}{ TBP1 } & $10 / 8 / 96$ & $\overline{21}$ & 4.64 & 47 & 5.3 \\
\hline & $10 / 16 / 96$ & 21 & 5 & 127 & 8.2 \\
\hline & $10 / 21 / 96$ & 20.3 & 5.51 & 345 & over range \\
\hline & $10 / 25 / 96$ & 20 & 5.17 & 114 & 4.6 \\
\hline & $10 / 30 / 96$ & 20.4 & 5.83 & 181 & 4.5 \\
\hline & $11 / 8 / 96$ & 16.73 & 5.52 & 249 & 3.5 \\
\hline & $11 / 13 / 96$ & 17.0 & 5.60 & 231 & 2.9 \\
\hline & $11 / 20 / 96$ & 18.9 & 5.52 & 224 & 4.8 \\
\hline & $11 / 25 / 96$ & 17.7 & 4.65 & 192 & 3.3 \\
\hline & $12 / 3 / 96$ & 17.2 & 5.35 & 184 & 3.2 \\
\hline & $12 / 12 / 96$ & 19.1 & 5.57 & 205 & 2.3 \\
\hline & $7 / 16 / 97$ & 20.2 & 5.4 & 275 & 1.4 \\
\hline & $7 / 24 / 97$ & 19 & 5.52 & 284 & 0.7 \\
\hline & 9/3/97 & 21.8 & 5.69 & 255 & \\
\hline & 9/6/97 & 21.9 & 5.38 & 267 & \\
\hline \multirow{17}{*}{ TB16 } & $10 / 10 / 96$ & 20.6 & 6.43 & 869 & \\
\hline & $10 / 17 / 96$ & 21.2 & 5.28 & 430 & \\
\hline & $10 / 18 / 96$ & 19.6 & 5.36 & 4 & \\
\hline & $10 / 22 / 96$ & 20 & 5.39 & & 3.1 \\
\hline & $10 / 25 / 96$ & 19.6 & 5.2 & 220 & 4.1 \\
\hline & $10 / 31 / 96$ & 19.06 & 6.86 & 136 & 1.8 \\
\hline & $11 / 10 / 96$ & 16.49 & 5.53 & 305 & 1.2 \\
\hline & $11 / 13 / 96$ & 16.97 & 5.6 & 231 & 2.9 \\
\hline & $11 / 13 / 96$ & 16.8 & 5.56 & 307 & 1.2 \\
\hline & $11 / 20 / 96$ & 18.2 & 5.46 & 302 & 2.9 \\
\hline & $11 / 25 / 96$ & 16.3 & 4.78 & 315 & 1.9 \\
\hline & $12 / 3 / 96$ & 18 & 5.37 & 277 & 1.1 \\
\hline & $12 / 12 / 96$ & 20.1 & 5.51 & 312 & 0.6 \\
\hline & $7 / 16 / 97$ & 20.5 & 5.75 & 499 & 1.7 \\
\hline & $7 / 24 / 97$ & 21.5 & 5.78 & 476 & 1.3 \\
\hline & $9 / 3 / 97$ & 25.3 & 5.7 & 388 & \\
\hline & 9/6/97 & 27.5 & 6.09 & 487 & \\
\hline
\end{tabular}

Blank table entry indicates measurement not taken. 
Table F.21. Groundwater quality parameters in Test Cell C monitoring locations.

\begin{tabular}{|c|c|c|c|c|c|}
\hline $\begin{array}{c}\text { Sample } \\
\text { Location }\end{array}$ & $\begin{array}{c}\text { Date } \\
\text { Sampled }\end{array}$ & $\begin{array}{l}\text { Temp } \\
\left({ }^{\circ} \mathrm{C}\right)\end{array}$ & $\mathrm{pH}$ & $\begin{array}{c}\text { Conductivity } \\
(\mu \mathrm{mohs})\end{array}$ & $\begin{array}{c}\mathrm{DO} \\
(\mathrm{mg} / \mathrm{L})\end{array}$ \\
\hline \multirow[t]{16}{*}{ TCP1 } & $10 / 8 / 96$ & 21.2 & 5.53 & 84 & 4.4 \\
\hline & $10 / 16 / 96$ & 21.3 & 6.01 & 438 & 3.6 \\
\hline & $10 / 21 / 96$ & 20.1 & 6.13 & 125 & \\
\hline & $10 / 25 / 96$ & 20.4 & 5.95 & 338 & 2.5 \\
\hline & $10 / 30 / 96$ & 20.3 & 5.91 & 97 & 1.5 \\
\hline & $11 / 8 / 96$ & 17.37 & 6.11 & 517 & 2.2 \\
\hline & $11 / 15 / 96$ & 16.93 & 6.31 & 525 & 1.1 \\
\hline & $11 / 21 / 96$ & 17.2 & 6.08 & 445 & 4 \\
\hline & $11 / 26 / 96$ & 15.9 & 7.99 & 435 & 2.7 \\
\hline & $12 / 4 / 96$ & 17.4 & 6.25 & 564 & 1.2 \\
\hline & $12 / 11 / 96$ & 19.4 & 6.9 & 425 & 5.5 \\
\hline & $7 / 17 / 97$ & 19.8 & 6.8 & 502 & 1 \\
\hline & $7 / 24 / 97$ & 18.45 & 6.08 & 466 & 6.6 \\
\hline & 9/3/97 & 19.8 & 6.23 & 403 & \\
\hline & 9/6/97 & 20.6 & 6 & 457 & \\
\hline & $12 / 12 / 97$ & 17.0 & 6.01 & 512 & 1.8 \\
\hline \multirow[t]{16}{*}{ TC16 } & $10 / 10 / 96$ & 20.6 & 6.56 & 93 & 2 \\
\hline & $10 / 17 / 96$ & 21.9 & 7.16 & 488 & \\
\hline & $10 / 18 / 96$ & 19.2 & 6.7 & 522 & \\
\hline & $10 / 22 / 96$ & 20.9 & 7.56 & 107 & 2.9 \\
\hline & $10 / 25 / 96$ & 20.5 & 7.41 & 460 & 1.1 \\
\hline & $10 / 31 / 96$ & 20.1 & 6.74 & 232 & 1.5 \\
\hline & $11 / 9 / 96$ & & & & 1.8 \\
\hline & $11 / 15 / 96$ & 16.83 & 7.75 & 475 & 0.3 \\
\hline & $11 / 21 / 96$ & 15.2 & 7.61 & 484 & 3.6 \\
\hline & $11 / 26 / 96$ & 16.8 & 8.87 & & 2.3 \\
\hline & $12 / 4 / 96$ & 17.6 & 7.74 & 445 & 1.2 \\
\hline & $12 / 11 / 96$ & 19.1 & 7.45 & 489 & 3.1 \\
\hline & $7 / 17 / 97$ & 20.5 & 8.7 & 259 & 3.1 \\
\hline & $7 / 24 / 97$ & 22.2 & 6.82 & 235 & 1.7 \\
\hline & 9/3/97 & 20.4 & 7.4 & 169 & \\
\hline & 9/6/97 & 20.9 & 7.16 & 167 & \\
\hline
\end{tabular}

Blank table entry indicates measurement not taken. 
Table F.22. Groundwater quality parameters in Test Cell D monitoring locations.

\begin{tabular}{|c|c|c|c|c|c|}
\hline $\begin{array}{l}\text { Sample } \\
\text { Location }\end{array}$ & $\begin{array}{c}\text { Date } \\
\text { Sampled }\end{array}$ & $\begin{array}{l}\text { Temp } \\
\left({ }^{\circ} \mathrm{C}\right)\end{array}$ & $\mathrm{pH}$ & $\begin{array}{c}\text { Conductivity } \\
(\mu \mathrm{mohs})\end{array}$ & $\begin{array}{c}\mathrm{DO} \\
(\mathrm{mg} / \mathrm{L})\end{array}$ \\
\hline \multirow[t]{16}{*}{ TDP1 } & $10 / 8 / 96$ & 21.7 & 6.08 & 259 & 3.6 \\
\hline & $10 / 16 / 96$ & 21.2 & 5.96 & 476 & 1.7 \\
\hline & $10 / 21 / 96$ & 19.8 & 6.21 & & 0.7 \\
\hline & $10 / 25 / 96$ & 20.7 & 6.11 & 354 & 2.2 \\
\hline & $10 / 31 / 96$ & 19.4 & 5.92 & 261 & 0.5 \\
\hline & $11 / 8 / 96$ & 17.97 & 6.6 & 550 & \\
\hline & $11 / 15 / 96$ & 15.42 & 6.38 & 593 & 0.7 \\
\hline & $11 / 21 / 96$ & 17.6 & 6.21 & 454 & 1.7 \\
\hline & $11 / 26 / 96$ & 15.9 & 7.9 & 417 & 0.9 \\
\hline & $12 / 4 / 96$ & 16.6 & 6.28 & 612 & 0.7 \\
\hline & $12 / 11 / 96$ & 19.1 & 6.47 & 425 & 4.1 \\
\hline & $7 / 17 / 97$ & 20.4 & 6.6 & 467 & 1 \\
\hline & $7 / 24 / 97$ & 19.68 & 6.09 & 529 & 0.5 \\
\hline & 9/4/97 & 20.2 & 6.86 & 410 & \\
\hline & 9/6/97 & 20.6 & 5.78 & 414 & \\
\hline & $12 / 12 / 97$ & 15.0 & 5.58 & 523 & 4.3 \\
\hline \multirow[t]{15}{*}{ TD16 } & $10 / 10 / 96$ & & & & 9.5 \\
\hline & $10 / 17 / 96$ & 21.7 & 6.52 & 4.05 & \\
\hline & $10 / 18 / 96$ & 20.2 & 6.5 & 3.9 & \\
\hline & $10 / 22 / 96$ & 22.1 & 7.61 & 788 & over range \\
\hline & $10 / 25 / 96$ & 21.2 & 8.39 & 692 & over range \\
\hline & $10 / 31 / 96$ & 20 & 5.27 & 208 & over range \\
\hline & $11 / 15 / 96$ & 16.41 & 10.15 & 2260 & \\
\hline & $11 / 21 / 96$ & 17.7 & 9.8 & 2010 & \\
\hline & $11 / 26 / 96$ & 17.9 & 10.8 & 1510 & \\
\hline & $12 / 4 / 96$ & 17.3 & 9.64 & 1550 & \\
\hline & $12 / 11 / 96$ & 18.8 & 7.66 & 1480 & \\
\hline & $7 / 17 / 97$ & 21.1 & 8 & 1720 & over range \\
\hline & $7 / 24 / 97$ & 21.4 & 8.08 & 2040 & \\
\hline & 9/4/97 & 20.4 & 7.36 & 6900 & \\
\hline & 9/6/97 & 21.7 & 7.11 & over range & \\
\hline
\end{tabular}

Blank table entry indicates measurement not taken. 
Table F.23 Water levels measured in all monitoring locations, by date.

\begin{tabular}{|c|c|c|c|c|c|c|c|c|c|c|c|}
\hline Date & $\begin{array}{c}\text { TAPI } \\
\text { (ft bgs) }\end{array}$ & $\begin{array}{c}\text { TA18 } \\
\text { (ft bgs) }\end{array}$ & $\begin{array}{c}\text { TBP1 } \\
\text { (ft bgs) }\end{array}$ & $\begin{array}{c}\text { TB16 } \\
\text { (ft bgs) }\end{array}$ & $\begin{array}{c}\text { TCP1 } \\
\text { (ft bgs) }\end{array}$ & $\begin{array}{c}\text { TC16 } \\
\text { (ft bgs) }\end{array}$ & $\begin{array}{l}\text { TDP1 } \\
(\mathrm{ft} \text { bgs })\end{array}$ & $\begin{array}{c}\text { TD16 } \\
\text { (ft bgs) }\end{array}$ & $\begin{array}{c}\text { BGPl } \\
\text { (ft bgs) }\end{array}$ & $\begin{array}{c}\text { BGP2 } \\
\text { (ft bgs) }\end{array}$ & $\begin{array}{l}\text { BGP3 } \\
\text { (ft bgs) }\end{array}$ \\
\hline $10 / 15 / 96$ & 11.3 & & 11.35 & & 11.06 & & 10.67 & & 11.08 & 11.22 & 11.37 \\
\hline $10 / 26 / 96$ & 11.88 & 14.47 & 11.78 & 13.43 & 11.34 & 11.26 & 10.94 & 10.78 & 11.33 & 11.58 & 12.29 \\
\hline $10 / 27 / 96$ & 11.7 & & 11.64 & & 11.24 & & 10.80 & & 11.23 & 11.45 & 11.61 \\
\hline $10 / 29 / 96$ & 11.68 & & 11.54 & & 11.04 & & 10.61 & & 11.01 & 11.36 & 11.47 \\
\hline $10 / 30 / 96$ & 11.19 & 12.03 & 11.34 & 11.72 & 10.80 & 11.24 & 10.38 & 10.83 & 10.77 & 11.14 & 11.19 \\
\hline $11 / 1 / 96$ & 11.68 & & 11.52 & & 11.10 & & 10.68 & & 11.09 & 11.28 & 11.45 \\
\hline $11 / 4 / 96$ & 11.86 & & 11.87 & & 11.42 & & 11.01 & & 11.42 & 11.63 & 11.77 \\
\hline $11 / 5 / 96$ & 11.63 & & 11.72 & & 11.27 & & 10.88 & & 11.26 & 11.48 & 11.62 \\
\hline $11 / 6 / 96$ & 11.62 & & 10.68 & & 11.21 & & 10.81 & & 11.19 & 11.42 & 11.55 \\
\hline $11 / 8 / 96$ & 11.32 & & 11.38 & & 10.83 & & 10.44 & & 10.83 & 11.11 & 11.61 \\
\hline $11 / 10 / 96$ & 11.63 & & 11.47 & 13.16 & 11.02 & 11.13 & 10.64 & 10.59 & 11.04 & 11.25 & 11.40 \\
\hline $11 / 11 / 96$ & 11.85 & & 11.70 & 13.31 & 11.25 & 11.34 & 10.86 & 10.78 & 11.26 & 11.48 & 11.63 \\
\hline $11 / 12 / 96$ & 11.98 & & 11.82 & 13.31 & 11.39 & 11.46 & 11.00 & 10.96 & 11.39 & 11.61 & 11.77 \\
\hline $11 / 13 / 96$ & 11.98 & & 11.83 & 13.32 & 11.36 & 11.45 & 10.95 & 10.89 & 11.35 & 11.59 & 11.75 \\
\hline $11 / 20 / 96$ & 11.94 & & 11.82 & & 10.87 & 11.97 & & 11.04 & 10.85 & 12.08 & 11.33 \\
\hline $11 / 22 / 96$ & 12.42 & & 12.05 & & 11.28 & 11.07 & 10.86 & 10.82 & 11.27 & 11.60 & 11.72 \\
\hline $11 / 24 / 96$ & 12.24 & & 12.16 & & 11.14 & 11.27 & 10.80 & 10.66 & 11.11 & 11.50 & 11.59 \\
\hline $11 / 25 / 96$ & 12.26 & & 12.31 & & 11.17 & 11.27 & 10.80 & 10.73 & 11.13 & 11.54 & 11.61 \\
\hline $11 / 26 / 96$ & 11.88 & 14.03 & 12.45 & 13.23 & 11.17 & 11.53 & 10.84 & 10.81 & 11.25 & 11.54 & 11.61 \\
\hline $12 / 2 / 96$ & 11.11 & 11.22 & 11.28 & & 10.79 & 10.92 & 10.40 & 10.37 & 10.80 & 11.02 & 111.17 \\
\hline $12 / 3 / 96$ & 11.39 & & 11.15 & 13.34 & 11.05 & 11.17 & 10.63 & 10.60 & 10.70 & 10.93 & 11.05 \\
\hline $12 / 6 / 96$ & 10.89 & 11.28 & 11.07 & & 10.55 & 10.72 & 10.15 & 10.11 & 10.55 & 10.80 & 10.94 \\
\hline $12 / 7 / 96$ & 11.06 & & 11.01 & & 10.52 & 10.73 & 10.14 & 10.15 & 10.53 & 10.76 & 10.92 \\
\hline $12 / 11 / 96$ & 10.94 & & 11.06 & & 11.18 & & 10.18 & & & 11.20 & 10.95 \\
\hline $12 / 14 / 96$ & 11.31 & & 11.26 & 11.50 & 10.96 & 11.06 & 10.58 & 10.51 & 10.98 & 11.14 & 11.27 \\
\hline $7 / 16 / 97$ & 10.43 & 10.55 & 10.37 & 10.64 & 10.10 & 9.85 & 9.71 & 9.70 & 10.13 & 10.28 & 10.45 \\
\hline $7 / 24 / 97$ & 10.69 & & 10.66 & & 10.24 & 9.78 & 9.84 & & 10.36 & 10.52 & 10.60 \\
\hline $9 / 3 / 97$ & 10.92 & & 10.87 & & 10.52 & 10.23 & 10.40 & 10.08 & 10.53 & 10.70 & 10.87 \\
\hline $9 / 6 / 97$ & 10.76 & 10.90 & 10.80 & 11.02 & 10.04 & 10.37 & 10.14 & 10.15 & 10.54 & 10.69 & 10.82 \\
\hline $12 / 12 / 97$ & & & & & 11.33 & & 10.83 & & 11.28 & & \\
\hline
\end{tabular}

Blank table entry indicates measurement not taken.

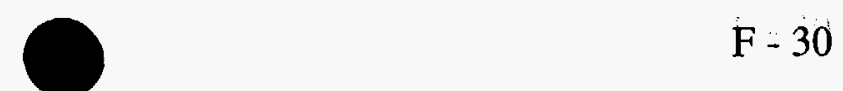


APPENDIX G. REACTIVE FRACTURE ZONE CHARACTERISTICS 
Table G.1. Characteristics of the iron metal fracture zone in December 1996.

\begin{tabular}{ccccccc}
\hline $\begin{array}{c}\text { Sample } \\
\text { I.D. }\end{array}$ & $\begin{array}{c}\text { Sample } \\
\text { location }\end{array}$ & $\begin{array}{c}\text { Media } \\
\text { color }\end{array}$ & $\begin{array}{c}\text { Eh } \\
(\mathrm{mV})\end{array}$ & $\begin{array}{c}\mathrm{pH} \\
(-)\end{array}$ & $\begin{array}{c}\text { WC } \\
(\% \text { d.w. })\end{array}$ & $\begin{array}{c}\text { TOC } \\
(\% \text { d.w. })\end{array}$ \\
\hline CF2-1 & $+5 \mathrm{~cm}$ & Yellow br. & 230 & 6.01 & $23.0 \%$ & 0.113 \\
CF2-2 & $+3 \mathrm{~cm}$ & Yellow br. & 264 & 5.82 & $22.3 \%$ & 0.109 \\
CF2-3 & $+1 \mathrm{~cm}$ & Yellow br. & 275 & 5.65 & $22.7 \%$ & 0.097 \\
CF2-4 & 0 & Black & -450 & 8.19 & $14.2 \%$ & 0.075 \\
CF2-5 & $-1 \mathrm{~cm}$ & Yellow br. & 272 & 5.97 & $21.4 \%$ & 0.075 \\
CF2-6 & $-3 \mathrm{~cm}$ & Yellow br. & 345 & 5.42 & $21.3 \%$ & 0.067 \\
CF2-7 & $-5 \mathrm{~cm}$ & Yellow br. & 385 & 5.43 & $20.2 \%$ & 0.071 \\
CF2-9 & $-10 \mathrm{~cm}$ & Yellow br. & 410 & 5.36 & $23.0 \%$ & 0.081 \\
CF2-9 & $-15 \mathrm{~cm}$ & Yellow br. & 410 & 5.31 & $21.0 \%$ & 0.07 \\
\hline
\end{tabular}

Table G.2. Characteristics of the iron metal fracture zone in July 1997.

\begin{tabular}{cccccc}
\hline $\begin{array}{c}\text { Sample } \\
\text { I.D. }\end{array}$ & $\begin{array}{c}\text { Sample } \\
\text { location }\end{array}$ & $\begin{array}{c}\text { Media } \\
\text { color }\end{array}$ & $\begin{array}{c}\text { Eh } \\
(\mathrm{mV})\end{array}$ & $\begin{array}{c}\mathrm{pH} \\
(1: 1 \mathrm{ext})\end{array}$ & $\begin{array}{c}\text { WC } \\
(\% \mathrm{~d} . \mathrm{w} .)\end{array}$ \\
\hline $\mathrm{A}$ & $+16 \mathrm{~cm}$ & Yellow br. & 150 & 6.47 & $20.2 \%$ \\
$\mathrm{H}$ & $+12 \mathrm{~cm}$ & Yellow br. & 112 & 5.82 & $20.4 \%$ \\
$\mathrm{~B}$ & $+6 \mathrm{~cm}$ & Yellow br. & 120 & 5.81 & $18.6 \%$ \\
$\mathrm{C}$ & $+1 \mathrm{~cm}$ & Yellow br. & 137 & 6.09 & $17.4 \%$ \\
$\mathrm{D}$ & 0 & Black & -570 & 7.34 & \\
$\mathrm{E}$ & $-4 \mathrm{~cm}$ & Yellow br. & 18 & 5.85 & $18.7 \%$ \\
$\mathrm{~F}$ & $-8 \mathrm{~cm}$ & Yellow br. & 246 & 4.87 & $20.3 \%$ \\
$\mathrm{G}$ & $-14 \mathrm{~cm}$ & Yellow br. & 370 & 4.71 & $21.4 \%$ \\
\hline
\end{tabular}

Table G.3. Degradation of DNAPL compounds in an iron metal fracture zone as measured in December 1996.

\begin{tabular}{|c|c|c|c|c|c|c|c|c|}
\hline $\begin{array}{c}\text { Sample } \\
\text { no. }\end{array}$ & Sample info & $\begin{array}{c}\text { DCA } \\
(\mathrm{ug} / \mathrm{kg})\end{array}$ & $\begin{array}{c}\text { TCA } \\
\text { (ug/kg) }\end{array}$ & $\begin{array}{c}\text { TCE } \\
\text { (ug/kg) }\end{array}$ & $\begin{array}{c}\text { PCE } \\
\text { (ug/kg) }\end{array}$ & $\begin{array}{c}\text { c-1,2- } \\
\text { DCE } \\
(\mathrm{ug} / \mathrm{kg})\end{array}$ & $\begin{array}{c}\text { Total VOCs } \\
(\mathrm{ug} / \mathrm{kg})\end{array}$ & $\begin{array}{c}\text { Reduction } \\
(\%)\end{array}$ \\
\hline 11 & GW Only & 407 & 104 & 143816 & 139 & & 144466 & \\
\hline 12 & $-1 \mathrm{~cm}+\mathrm{GW}$ & 306 & 98 & 133195 & 126 & & 133725 & $7.4 \%$ \\
\hline 13 & $+1 \mathrm{~cm}+\mathrm{DI}$ & 18 & $<1$ & 33 & $<1$ & & 51 & \\
\hline 14 & Frac+GW & & 23 & 103397 & 24 & 191 & 103635 & $28.3 \%$ \\
\hline 15 & $-5 \mathrm{~cm}+\mathrm{GW}$ & 254 & 96 & 132450 & 126 & 357 & 133283 & $7.7 \%$ \\
\hline 16 & $+5 \mathrm{~cm}+\mathrm{GW}$ & 219 & 89 & 124114 & 119 & 218 & 124759 & $13.6 \%$ \\
\hline
\end{tabular}


Table G.4. Degradation of DNAPL compounds in ground water 1 contacting an iron metal fracture zone with 24- and 48-hr reaction periods as measured in July 1997.

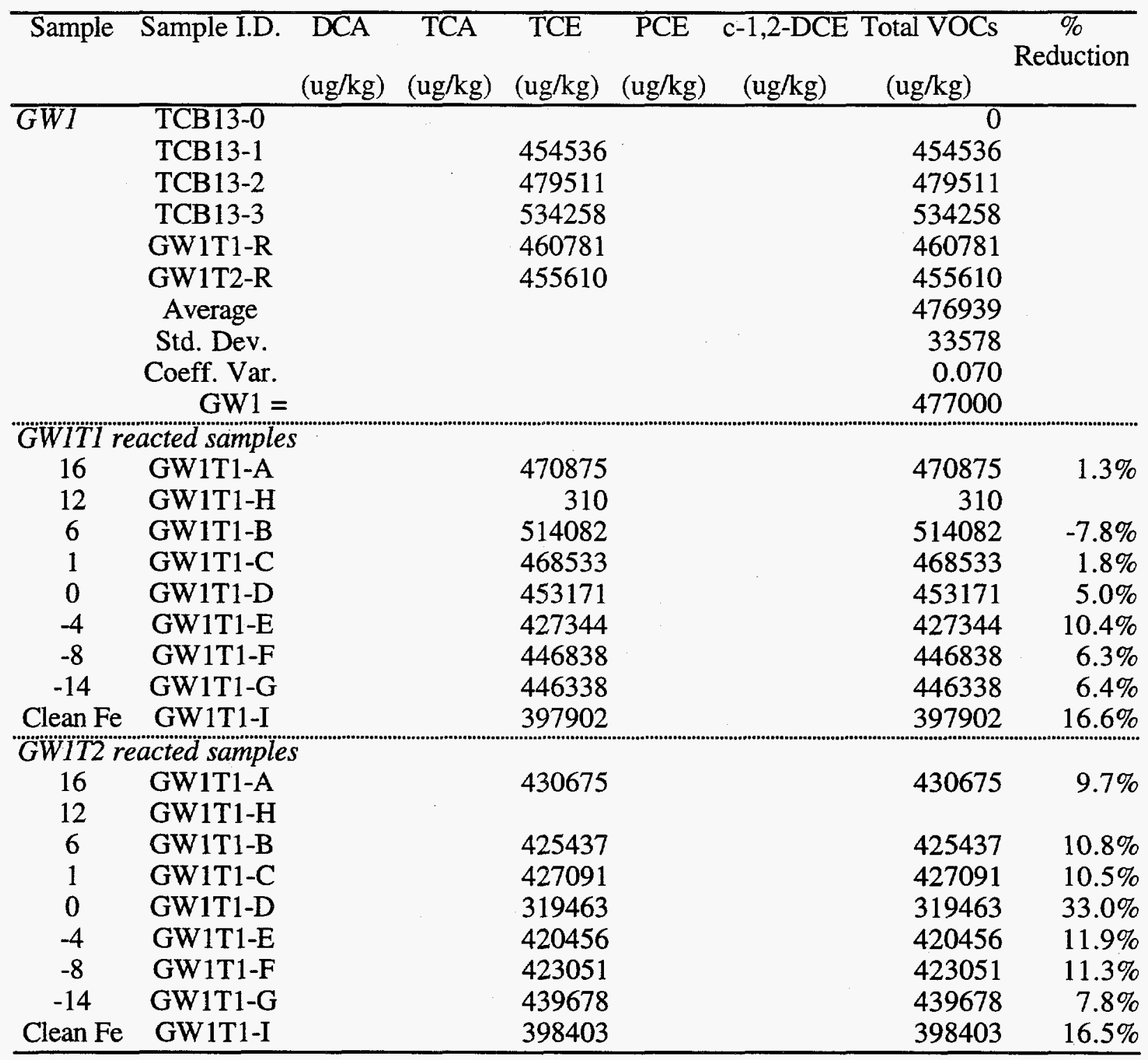


Table G.5. Degradation of DNAPL compounds in ground water 2 contacting an iron metal fracture zone with 24- and 48-hr reaction periods as measured in July 1997.

\begin{tabular}{|c|c|c|c|c|c|c|c|}
\hline Sample & $\begin{array}{lc}\text { Sample I.D. } & \text { DCA } \\
& (\mathrm{ug} / \mathrm{kg})\end{array}$ & $\begin{array}{r}\text { TCA } \\
(\mathrm{ug} / \mathrm{kg})\end{array}$ & $\begin{array}{c}\text { TCE } \\
(\mathrm{ug} / \mathrm{kg})\end{array}$ & $\begin{array}{c}\text { PCE } \\
(\mathrm{ug} / \mathrm{kg})\end{array}$ & $\begin{array}{l}\text { C-1,2- } \\
\text { DCE } \\
(\mathrm{ug} / \mathrm{kg})\end{array}$ & $\begin{array}{c}\text { Total VOCs } \\
(\mathrm{ug} / \mathrm{kg})\end{array}$ & $\begin{array}{c}\% \\
\text { Reduction }\end{array}$ \\
\hline$\overline{G W 2}$ & $\overline{\text { TCB13-4 }}$ & & 52653 & & & 52653 & \\
\hline & TCB13-5 & & 58156 & & & 58156 & \\
\hline & TCB13-6 & & 52047 & & & 52047 & \\
\hline & GW2T1-R & & 53645 & & & 53645 & \\
\hline & GW2T2-R & & 51906 & & & 51906 & \\
\hline & Average & & & & & 53681 & \\
\hline & Std. Dev. & & & & & 2593 & \\
\hline & Coeff. Var. & & & & & 0.05 & \\
\hline & $\mathrm{GW} 2=$ & & & & & 53700 & \\
\hline \multicolumn{8}{|c|}{ GW2TI Reacted Samples } \\
\hline 16 & GW2T1-A & & 52115 & & & 52115 & $3.0 \%$ \\
\hline 12 & GW2T1-H & & & & & & \\
\hline 6 & GW2T1-B & & 52798 & & & 52798 & $1.7 \%$ \\
\hline 1 & GW2T1-C & & 51909 & & & 51909 & $3.3 \%$ \\
\hline 0 & GW2T1-D & & 34197 & & & 34197 & $36.3 \%$ \\
\hline-4 & GW2T1-E & & 53217 & & & 53217 & $0.9 \%$ \\
\hline-8 & GW2T1-F & & 52843 & & & 52843 & $1.6 \%$ \\
\hline-14 & GW2T1-G & & 52799 & & & 52799 & $1.7 \%$ \\
\hline Clean $\mathrm{Fe}$ & GW2T1-I & & 39911 & & & 39911 & $25.7 \%$ \\
\hline \multicolumn{8}{|c|}{ GW2T2 Reacted Samples } \\
\hline $\begin{array}{l}16 \\
12\end{array}$ & GW2T2-A & & 46764 & & & 46764 & $12.9 \%$ \\
\hline 6 & GW2T2-B & & 49820 & & & 49820 & $7.2 \%$ \\
\hline 1 & GW2T2-C & & 51039 & & & 51039 & $5.0 \%$ \\
\hline 0 & GW2T2-D & & & & & & \\
\hline-4 & GW2T2-E & & 51531 & & & 51531 & $4.0 \%$ \\
\hline-8 & GW2T2-F & & 50818 & & & 50818 & $5.4 \%$ \\
\hline-14 & GW2T2-G & & 51265 & & & 51265 & $4.5 \%$ \\
\hline Clean $\mathrm{Fe}$ & GW2T2-I & & 37875 & & & 37875 & $29.5 \%$ \\
\hline
\end{tabular}

$G-3$ 
Table G.6. Characteristics of the permanganate fracture zone in December 1996.

\begin{tabular}{ccccccc}
\hline $\begin{array}{c}\text { Sample } \\
\text { I.D. }\end{array}$ & $\begin{array}{c}\text { Sample } \\
\text { location }\end{array}$ & $\begin{array}{c}\text { Media } \\
\text { color }\end{array}$ & $\begin{array}{c}\text { Eh } \\
(\mathrm{mV})\end{array}$ & $\begin{array}{c}\mathrm{pH} \\
(-)\end{array}$ & $\begin{array}{c}\text { WC } \\
(\% \mathrm{~d} . \mathrm{w} .)\end{array}$ & $\begin{array}{c}\text { TOC } \\
(\% \text { d.w. })\end{array}$ \\
\hline DF1 & $+25 \mathrm{~cm}$ & Yellow br. & 700 & 5.98 & $21.6 \%$ & 0.068 \\
DF2 & $+20 \mathrm{~cm}$ & Yellow br. & 670 & 5.91 & $21.4 \%$ & 0.072 \\
DF3 & $+15 \mathrm{~cm}$ & Yellow br. & 630 & 5.59 & $21.2 \%$ & 0.104 \\
DF4 & $+10 \mathrm{~cm}$ & Deep pink & 835 & 4.48 & $22.3 \%$ & 0.051 \\
DF5 & $+5 \mathrm{~cm}$ & Dark red & 910 & 4.22 & & \\
DF6 & $+3 \mathrm{~cm}$ & Dark red & 920 & 4.20 & $24.0 \%$ & 0.034 \\
DF7 & $+1 \mathrm{~cm}$ & Purple & 852 & 5.62 & $23.6 \%$ & 0.026 \\
DF8 & Frac & Purple & & 7.68 & & \\
DF10 & $-1 \mathrm{~cm}$ & Purple & 840 & 6.36 & & \\
DF9 & $-3 \mathrm{~cm}$ & Dark red & 910 & 4.39 & $26.3 \%$ & 0.033 \\
DF12 & $-5 \mathrm{~cm}$ & Dark red & 915 & 4.00 & $24.7 \%$ & 0.032 \\
DF11 & $-10 \mathrm{~cm}$ & Deep pink & 855 & 4.25 & $23.7 \%$ & 0.035 \\
DF13 & $-15 \mathrm{~cm}$ & Yellow br. & 755 & 5.15 & $20.6 \%$ & 0.05 \\
DF14 & $-20 \mathrm{~cm}$ & Yellow br. & 390 & 5.94 & $21.6 \%$ & 0.08 \\
DF15 & $-25 \mathrm{~cm}$ & Yellow br. & 330 & 5.98 & $21.3 \%$ & 0.05 \\
\hline
\end{tabular}

Table G.7. Characteristics of the permanganate fracture zone in July 1997.

\begin{tabular}{ccccccc}
\hline $\begin{array}{c}\text { Sample } \\
\text { I.D. }\end{array}$ & $\begin{array}{c}\text { Sample } \\
\text { location }\end{array}$ & $\begin{array}{c}\text { Media } \\
\text { color }\end{array}$ & $\begin{array}{c}\text { Eh } \\
(\mathrm{mV})\end{array}$ & $\begin{array}{c}\mathrm{pH} \\
(1: 1 \mathrm{ext})\end{array}$ & $\begin{array}{c}\text { WC } \\
(\% \mathrm{~d} . \mathrm{w} .)\end{array}$ & $\begin{array}{c}\text { MnO4- } \\
1: 1.5 \mathrm{mg} / \mathrm{L}\end{array}$ \\
\hline A & $+25 \mathrm{~cm}$ & Yellow br. & 670 & 4.71 & $17.4 \%$ & \\
M1 & $+23 \mathrm{~cm}$ & Yellow br. & 500 & 5.49 & & 7 \\
B & $+20 \mathrm{~cm}$ & Purple & 840 & 4.43 & $18.4 \%$ & \\
M2 & $+13 \mathrm{~cm}$ & Purple & 840 & 4.33 & & 730 \\
H & $+11 \mathrm{~cm}$ & Purple & 860 & 4.10 & $18.1 \%$ & \\
C & $+5 \mathrm{~cm}$ & Dark red & 850 & 4.23 & $17.0 \%$ & \\
M3 & $+3 \mathrm{~cm}$ & Dark red & 850 & 4.42 & & 3362 \\
D & 0 & Dark red & 850 & 5.76 & $21.5 \%$ & \\
M4 & $-3 \mathrm{~cm}$ & Dark red & 770 & 4.84 & & 3456 \\
E & $-5 \mathrm{~cm}$ & Dark red & 840 & 4.18 & $21.3 \%$ & \\
M5 & $-13 \mathrm{~cm}$ & Purple & 840 & 4.10 & & 1361 \\
F & $-15 \mathrm{~cm}$ & Purple & 840 & 4.22 & $21.2 \%$ & \\
M6 & $-23 \mathrm{~cm}$ & Yellow br. & 360 & 5.08 & & 5 \\
G & $-25 \mathrm{~cm}$ & Yellow br. & 370 & 5.03 & $21.2 \%$ & \\
\hline
\end{tabular}


Table G.8. Degradation of DNAPL compounds in the permanganate fracture zone as measured in December 1996.

\begin{tabular}{|c|c|c|c|c|c|c|c|c|}
\hline $\begin{array}{c}\text { Sample } \\
\text { No. }\end{array}$ & Sample info & $\begin{array}{c}\text { DCA } \\
(\mathrm{ug} / \mathrm{kg})\end{array}$ & $\begin{array}{c}\text { TCA } \\
(\mathrm{ug} / \mathrm{kg})\end{array}$ & $\begin{array}{c}\text { TCE } \\
(\mathrm{ug} / \mathrm{kg})\end{array}$ & $\begin{array}{c}\text { PCE } \\
(\mathrm{ug} / \mathrm{kg})\end{array}$ & $\begin{array}{c}\mathrm{c}-1,2-\mathrm{DCF} \\
(\mathrm{ug} / \mathrm{kg})\end{array}$ & $\begin{array}{c}\text { Total VOCs } \\
\text { (ug/kg) }\end{array}$ & $\begin{array}{c}\% \\
\text { Reduction }\end{array}$ \\
\hline 1 & GW Only & & 104 & 145207 & 145 & & 145456 & \\
\hline 2 & $-1 \mathrm{~cm}+\mathrm{DI}$ & & & 10 & $<1$ & & 10 & \\
\hline 3 & $+1 \mathrm{~cm}+\mathrm{GW}$ & & 105 & 5 & 5 & & 115 & $99.92 \%$ \\
\hline 4 & $+5 \mathrm{~cm}+\mathrm{DI}$ & & & 5 & $<1$ & & 5 & \\
\hline 5 & $-5 \mathrm{~cm}+\mathrm{GW}$ & & 98 & 39 & 89 & 256 & 482 & $99.67 \%$ \\
\hline 6 & $-10 c m+G W$ & & 104 & 125867 & 137 & & 126108 & $13.30 \%$ \\
\hline 7 & $-15 \mathrm{~cm}+\mathrm{GW}$ & & 106 & 146456 & 140 & 366 & 147068 & $-1.11 \%$ \\
\hline 8 & $+5 \mathrm{~cm}+\mathrm{GW}$ & & 103 & 6 & $<1$ & & 109 & $99.93 \%$ \\
\hline 9 & $+10 \mathrm{~cm}+\mathrm{GW}$ & & 88 & 69580 & 120 & 292 & 70080 & $51.82 \%$ \\
\hline
\end{tabular}


Table G.9. Degradation of DNAPL compounds in the permanganate fracture zone as measured in July 1997 with ground water 1 and reaction times 1 and 2.

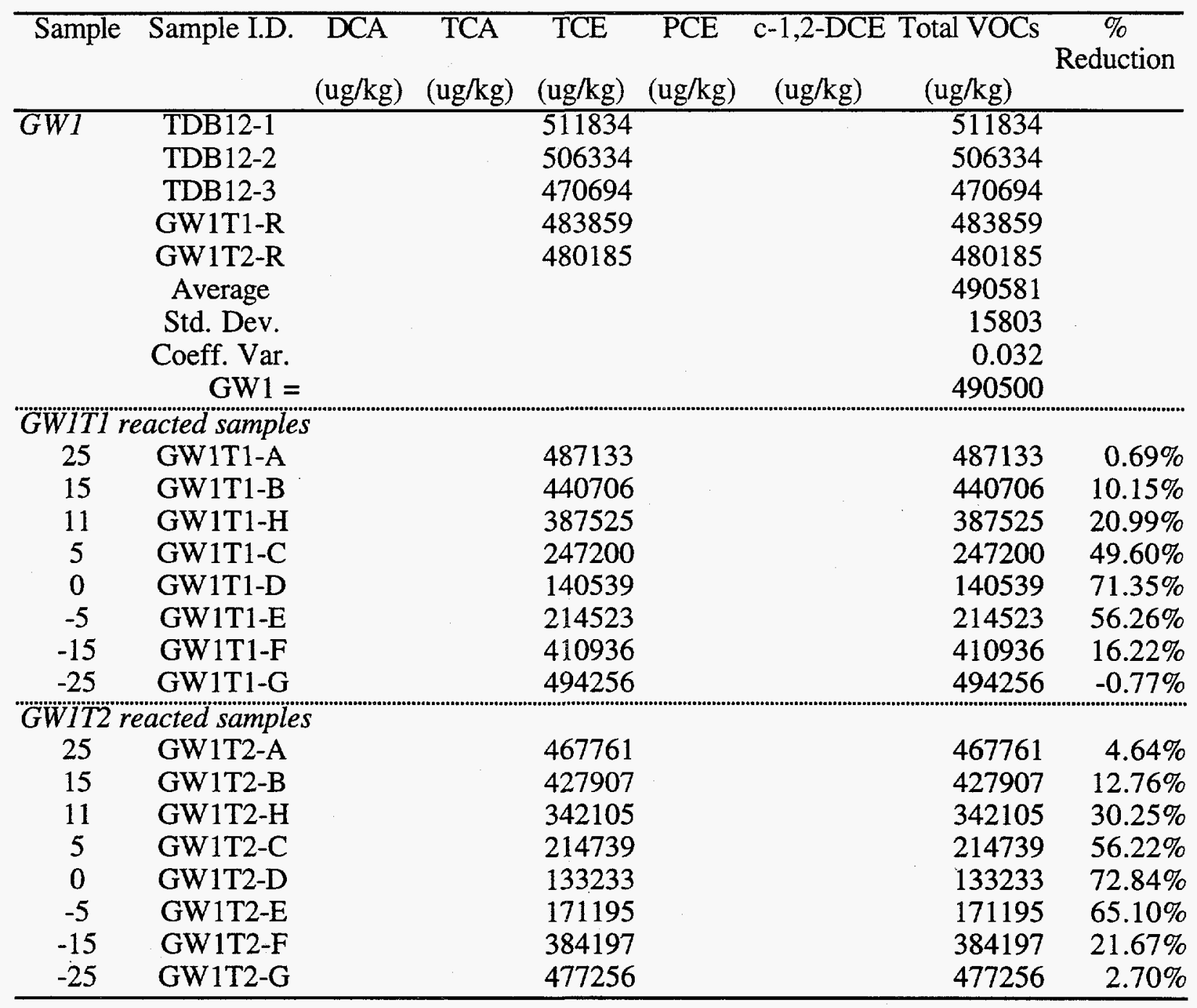


Table G.10. Degradation of DNAPL compounds in the permanganate fracture zone as measured in July 1997 with ground water 2 and reaction times 1 and 2.

\begin{tabular}{|c|c|c|c|c|c|c|c|c|}
\hline Sample & Sample I.D. & $\begin{array}{c}\text { DCA } \\
(\mathrm{ug} / \mathrm{kg})\end{array}$ & $\begin{array}{c}\text { TCA } \\
(\mathrm{ug} / \mathrm{kg})\end{array}$ & $\begin{array}{c}\text { TCE } \\
(\mathrm{ug} / \mathrm{kg})\end{array}$ & $\begin{array}{c}\mathrm{PCE} \\
(\mathrm{ug} / \mathrm{kg})\end{array}$ & $\begin{array}{c}c-1,2- \\
\text { DCE } \\
(\mathrm{ug} / \mathrm{kg})\end{array}$ & $\begin{array}{c}\text { Total VOCs } \\
(\mathrm{ug} / \mathrm{kg})\end{array}$ & $\begin{array}{c}\% \\
\text { Reduction }\end{array}$ \\
\hline \multirow[t]{9}{*}{$\overline{G W 2}$} & TDB12-4 & & & 53936 & & & 53936 & \\
\hline & TDB12-5 & & & 52356 & & & 52356 & \\
\hline & TDB12-6 & & & 55529 & & & 55529 & \\
\hline & GW2T1-R & & & 41875 & & & 41875 & \\
\hline & GW2T2-R & & & 48392 & & & 48392 & \\
\hline & Average & & & & & & 50418 & \\
\hline & Std. Dev. & & & & & & 4886 & \\
\hline & Coeff. Var. & & & & & & 0.097 & \\
\hline & GW2 $=$ & & & & & & 50500 & \\
\hline \multicolumn{9}{|c|}{ GW2T1 reacted samples } \\
\hline 25 & GW2T1-A & & & 48372 & & & 48372 & $4.2 \%$ \\
\hline 15 & GW2T1-B & & & 5973 & & & 5973 & $88.2 \%$ \\
\hline 11 & GW2T1-H & & & 0 & & & 0 & $100.0 \%$ \\
\hline 5 & GW2T1-C & & & 30 & & & 30 & $99.9 \%$ \\
\hline 0 & GW2T1-D & & & 0 & & & 0 & $100.0 \%$ \\
\hline-5 & GW2T1-E & & & 0 & & & 0 & $100.0 \%$ \\
\hline-15 & GW2T1-F & & & 2398 & & & 2398 & $95.3 \%$ \\
\hline-25 & GW2T1-G & & & 51146 & & & 51146 & $-1.3 \%$ \\
\hline \multicolumn{9}{|c|}{ GW2T2 reacted samples } \\
\hline 25 & GW2T2-A & & & 47074 & & & 47074 & $6.8 \%$ \\
\hline 15 & GW2T2-B & & & 5381 & & & 5381 & $89.3 \%$ \\
\hline 11 & GW2T2-H & & & 0 & & & 0 & $100.0 \%$ \\
\hline 5 & GW2T2-C & & & 0 & & & 0 & $100.0 \%$ \\
\hline 0 & GW2T2-D & & & 0 & & & 0 & $100.0 \%$ \\
\hline-5 & GW2T2-E & & & 0 & & & 0 & $100.0 \%$ \\
\hline-15 & GW2T2-F & & & 0 & & & 0 & $100.0 \%$ \\
\hline-25 & GW2T2-G & & & 48128 & & & 48128 & $4.7 \%$ \\
\hline
\end{tabular}


APPENDIX H. POST-DEMONSTRATION RECONNAISSANCE 


\section{POST-DEMONSTRATION RECONNAISSANCE}

One monitoring point installed in support of the soil fracturing study, a piezometer to monitor groundwater outside of the test cells (X231A-BGP3), indicated high levels of TCE in groundwater $(\sim 500 \mathrm{mg} / \mathrm{L})$. These levels were detected prior to initiation of treatment at the test cells and persisted throughout the study. During sample collection in July 1997, globules of a brown oily substance were pumped to the surface when the sample line intake was at the bottom of the piezometer. These globules would immediately sink to the bottom of a sample container. Analysis results of the free phase material recovered from X231A-BGP3 are presented in Table H.1.

The discovery of this free phase DNAPL prompted further reconnaissance sampling in the vicinity of X231A-BGP3 performed in December 1997. The objective of this soil sampling was to determine if the DNAPL in X231A-BGP3 was an isolated occurrence or if the contamination was more widespread south of the previous study area.

Eight soil sample boreholes (GP07 to GP14, Fig. 2.12) were sampled to $16 \mathrm{ft}$ bgs. Field GC results indicate an area of approximately $55 \mathrm{ft}$ by $45 \mathrm{ft}$ just south and slightly west of Test Cells $\mathrm{A}$ and B (borings GP07, 08, 12, and 13) with elevated levels of DNAPL compounds at depths ranging from near surface to $16 \mathrm{ft}$ bgs. The TCE concentrations ranged from $<1$ to $>$ $4,200 \mathrm{mg} / \mathrm{kg}$ with an overall average concentration of roughly $100 \mathrm{mg} / \mathrm{kg}$. The highest TCE concentrations were detected between 9 and $14 \mathrm{ft}$ bgs (average range from 20 to $50 \mathrm{mg} / \mathrm{kg}$ with concentrations up to $150 \mathrm{mg} / \mathrm{kg}$ at $14 \mathrm{ft} \mathrm{bgs}$ ) with consistently high concentrations in the 10 to $12 \mathrm{ft}$ bgs zone ( 50 to $4,200 \mathrm{mg} / \mathrm{kg}$ ). The highest concentration of TCE was $4,200 \mathrm{mg} / \mathrm{kg}$ at $11 \mathrm{ft}$ in GP07. Sample results are presented in Table H.2.

The distribution of DNAPL compounds such as TCE within the Minford deposit is controlled by the properties of the organic compound and the characteristic of the deposit. A variety of equilibrium and fugacity based approached are commonly used to assess how DNAPL compounds are distributed under a given set of conditions. A fugacity based model (Dawson 1997) was used for this purpose to assess the TCE distribution within the Minford. Based on literature data for key properties of TCE and using representative measured values of porosity $(40 \% \mathrm{v} / \mathrm{v})$, volume fraction of water $(36 \% \mathrm{v} / \mathrm{v})$, and mass fraction of organic carbon $(500 \mathrm{mg} / \mathrm{kg})$ for the Minford, a bulk concentration of $300 \mathrm{mg}$ TCE per $\mathrm{kg}$ of soil can result in $15 \%$ of the mass of TCE being present in a nonaqueous phase with $69 \%$ in the soil water, $14 \%$ on the soil solids, and $2 \%$ in the soil air. 
Table H.1. Analytical results from the aqueous phase of a DNAPL sample collected from X231A-BGP3, PORTS laboratory analysis.

\begin{tabular}{|c|c|c|c|c|c|c|c|c|c|c|}
\hline $\begin{array}{c}\text { Date } \\
\text { Collected }\end{array}$ & $\begin{array}{l}\text { Uranium } \\
\text { (total) } \\
\text { ug/L }\end{array}$ & $\begin{array}{l}\text { Tc-99 } \\
\text { pCi/L }\end{array}$ & $\begin{array}{l}\text { PCB } \\
\text { (total) } \\
\text { ug/L }\end{array}$ & $\begin{array}{c}\text { 1,1-DCA } \\
\mathrm{ug} / \mathrm{L}\end{array}$ & $\begin{array}{l}1,1,1- \\
\text { TCA } \\
\text { ug/L }\end{array}$ & $\begin{array}{c}\text { 1,1-DCE } \\
\mathrm{ug} / \mathrm{L}\end{array}$ & $\begin{array}{l}\text { c-1,2- } \\
\text { DCE } \\
\text { ug/L }\end{array}$ & $\begin{array}{l}\text { TCE } \\
\text { ug/L }\end{array}$ & $\begin{array}{c}\text { 1,1,2- } \\
\text { Trichloro- } \\
\text { 1,2,2- } \\
\text { trifluoroethane } \\
\text { ug/L }\end{array}$ & $\begin{array}{c}\text { Trichloro- } \\
\text { fluromethane } \\
\text { ug/L }\end{array}$ \\
\hline $7-23-97$ & $4.28^{\mathrm{a}}$ & $\mathrm{NA}$ & $3.6 \mathrm{~J}$ & ND & ND & ND & ND & 690,000 & ND & ND \\
\hline $3-17-98$ & 7.43 & 35 & $6.3 \mathrm{~J}$ & 310 & 5200 & 540 & 2100 & 480,000 & 5900 & 2900 \\
\hline $\begin{array}{l}3-17-98 \\
\text { duplicate }\end{array}$ & 7.96 & 36 & $7.6 \mathrm{~J}$ & 300 & 5300 & 580 & 2100 & 580,000 & 5900 & 2900 \\
\hline
\end{tabular}

a The two layers of sample were not individually analyzed; the uranium aliquot was taken from a well-mixed sample. $\mathrm{J}$ - estimated value

NA - not analyzed

ND - non detect

Table H.2. Analytical results from the free phase of a DNAPL sample collected from X231A-BGP3, PORTS laboratory analysis.

\begin{tabular}{|c|c|c|c|c|c|}
\hline $\begin{array}{c}\text { Date } \\
\text { Collected }\end{array}$ & $\begin{array}{l}\text { Uranium } \\
\text { (total) } \\
\text { ug/L }\end{array}$ & $\begin{array}{c}\text { PCB } \\
\text { (total) } \\
\text { ug/L }\end{array}$ & $\begin{array}{c}1,1,1, \mathrm{TCA} \\
\mathrm{ug} / \mathrm{kg}\end{array}$ & $\begin{array}{c}\mathrm{TCE} \\
\mathrm{ug} / \mathrm{kg}\end{array}$ & $\begin{array}{c}1,1,2- \\
\text { Trichloro- } \\
\text { 1,2,2- } \\
\text { trifluoroethane } \\
\text { ug/kg }\end{array}$ \\
\hline $7-23-97$ & $4.28^{a}$ & 13J ug/L & $2,900,000$ & $280,000,000 \mathrm{E}$ & $12,000,000$ \\
\hline $3-17-98$ & 2.3 & $10 \mathrm{~J}$ & $2,400,000$ & $250,000,000 \mathrm{E}$ & $13,000,000$ \\
\hline
\end{tabular}

a The two layers of sample were not individually analyzed; the uranium aliquot was taken from a well-mixed sample.

E - result exceeds calibration range (GC/MS flag)

$\mathrm{J}$ - estimated value

All other analytes were undetected at the detection limits required for TCE analysis.

$1: 1,000,000$ dilutions required for analysis resulting in detection limits of $2,000,000 \mathrm{ug} / \mathrm{kg}$

for methylene chloride, 1,1-DCA, 1,1-DCE, PCE, and cis- and trans-1,2-DCE. 
Table H.3 VOC concentrations in soil with depth from post-demonstration reconnaissance samples, December 1997.

\begin{tabular}{|c|c|c|c|c|c|c|c|}
\hline Location & $\begin{array}{c}\text { Depth } \\
\text { (ft bgs) }\end{array}$ & $\begin{array}{c}\text { Meth Chlr } \\
\text { (ug/kg) }\end{array}$ & $\begin{array}{c}\mathrm{t}-1,2-\mathrm{DCE} \\
\text { (ug/kg) }\end{array}$ & $\begin{array}{c}\mathrm{c}-1,2-\overline{D C E} \\
(\mathrm{ug} / \mathrm{kg})\end{array}$ & $\begin{array}{c}1,1,1, \mathrm{TCA} \\
\text { (ug/kg) }\end{array}$ & $\begin{array}{c}\text { TCE } \\
\text { (ug/kg) }\end{array}$ & $\begin{array}{c}\text { PCE } \\
(\mathrm{ug} / \mathrm{kg})\end{array}$ \\
\hline \multirow[t]{15}{*}{ GP 07} & 1 & & & 5072 & & 159 & 17 \\
\hline & 2 & & & 8114 & 25 & 9525 & \\
\hline & 3 & & & 3715 & 69 & 20658 & 29 \\
\hline & 4 & & & 3195 & 226 & 49706 & 20 \\
\hline & 5 & & & 3720 & 725 & 24905 & 57 \\
\hline & 6 & & & 3683 & 213 & 81416 & 21 \\
\hline & 8 & & & 1769 & 127 & 83489 & 29 \\
\hline & 9 & & & 1605 & 224 & 107784 & 49 \\
\hline & 10 & & & 6303 & 507 & 131404 & 38 \\
\hline & 11 & & & & 44471 & 4228235 & 5652 \\
\hline & 12 & & & 52574 & 182 & 149157 & \\
\hline & 13 & & & 80426 & & 127066 & \\
\hline & 14 & & & 116679 & 19468 & 21292 & \\
\hline & 15 & & & 67629 & & & \\
\hline & 16 & & & 46168 & & & \\
\hline \multirow[t]{14}{*}{ GP 08} & 1 & & & & & & \\
\hline & 4 & 16 & & 3504 & & 3718 & \\
\hline & 5 & 4 & 3 & 3390 & & 1543 & \\
\hline & 6 & 2 & 28 & 3849 & & 3281 & \\
\hline & 7 & & & 3387 & & 8564 & \\
\hline & 8 & & & 5437 & & 919 & \\
\hline & 9 & & & 10643 & & & \\
\hline & 10 & & & 10414 & & 249 & \\
\hline & 11 & & & & & 8928 & \\
\hline & 12 & & & & & 20454 & \\
\hline & 13 & 1229 & & & & 27160 & \\
\hline & 14 & & & & & 46553 & \\
\hline & 15 & & & 883 & 111 & 38846 & 42 \\
\hline & 16 & & & 305 & 78 & 24651 & 34 \\
\hline
\end{tabular}

$\mathrm{H}-3$ 
Table H.3. cont. VOC concentrations in soil with depth from post-demonstration reconnaissance samples, December 1997.

\begin{tabular}{|c|c|c|c|c|c|c|c|}
\hline Location & $\begin{array}{l}\text { Depth } \\
\text { (ft bgs) }\end{array}$ & $\begin{array}{l}\text { Meth Chlr } \\
\text { (ug/kg) }\end{array}$ & $\begin{array}{c}\text { t-1,2-DCE } \\
\text { (ug/kg) }\end{array}$ & $\begin{array}{c}\text { c-1,2-DCE } \\
\text { (ug/kg) }\end{array}$ & $\begin{array}{c}, 1,1, \mathrm{TCA} \\
(\mathrm{ug} / \mathrm{kg})\end{array}$ & $\begin{array}{c}\text { TCE } \\
(\mathrm{ug} / \mathrm{kg}) \\
\end{array}$ & $\begin{array}{c}\mathrm{PCE} \\
(\mathrm{ug} / \mathrm{kg})\end{array}$ \\
\hline \multirow[t]{16}{*}{ GP 09 } & 1 & & & & & 108 & \\
\hline & 2 & & & & & 120 & 17 \\
\hline & 3 & & & & & 6 & 18 \\
\hline & 4 & & & & & & \\
\hline & 5 & & & & & & \\
\hline & 6 & & & & & & \\
\hline & 7 & & & & & & \\
\hline & 8 & & & & & & \\
\hline & 9 & & & & & & \\
\hline & 10 & & & & & & \\
\hline & 11 & & & & & & \\
\hline & 12 & & & & & & 24 \\
\hline & 13 & & & & & & 20 \\
\hline & 14 & & & & & 2 & 23 \\
\hline & 15 & & & & & 4 & 17 \\
\hline & 16 & & & & & 7 & 15 \\
\hline \multirow{15}{*}{ GP 10} & 1 & & & & & 2 & 36 \\
\hline & 2 & & & & & & 29 \\
\hline & 3 & & & & & 2 & 42 \\
\hline & 4 & & & & & 8 & 25 \\
\hline & 5 & & & & & & 27 \\
\hline & 6 & & & & & 2 & 23 \\
\hline & 7 & & & & & 4 & 15 \\
\hline & 8 & & & & & & 26 \\
\hline & 9 & & & & & 1 & 19 \\
\hline & 10 & & & & & 2 & 21 \\
\hline & 11 & & & & & 1 & 15 \\
\hline & 12 & & & & & & 18 \\
\hline & 13 & & & & & 6 & \\
\hline & 14 & & & & & & \\
\hline & 15 & & & & & 11 & \\
\hline
\end{tabular}


Table H.3. cont. VOC concentrations in soil with depth from post-demonstration reconnaissance samples, December 1997.

\begin{tabular}{|c|c|c|c|c|c|c|c|}
\hline Location & $\begin{array}{l}\text { Depth } \\
\text { (ft bgs) }\end{array}$ & $\begin{array}{l}\text { Meth Chlr } \\
\text { (ug/kg) }\end{array}$ & $\begin{array}{c}\text { t-1,2-DCE } \\
\text { (ug/kg) }\end{array}$ & $\begin{array}{c}\text { c-1,2-DCE } \\
\text { (ug/kg) }\end{array}$ & $\begin{array}{c}1,1,1, \mathrm{TCA} \\
\text { (ug/kg) }\end{array}$ & $\begin{array}{c}\text { TCE } \\
\text { (ug/kg) }\end{array}$ & $\begin{array}{c}\text { PCE } \\
\text { (ug/kg) }\end{array}$ \\
\hline \multirow[t]{17}{*}{ GP 11 } & 1 & & & & & 18 & 12 \\
\hline & 2 & & & & & 3 & 27 \\
\hline & 3 & & & & & 7 & 18 \\
\hline & 4 & & & & & & \\
\hline & 5 & & & & & & \\
\hline & 6 & & & & & & 26 \\
\hline & 7 & & & & & & \\
\hline & 8 & & & & & & \\
\hline & 9 & & & & & & \\
\hline & 10 & & & & & & \\
\hline & 11 & & & & & & \\
\hline & 12 & & & & & & \\
\hline & 13 & & & & & & \\
\hline & 14 & & & & & & \\
\hline & 15 & & & & & & \\
\hline & 16 & & & & & & \\
\hline & 17 & & & & & & \\
\hline \multirow[t]{16}{*}{ GP 12} & 1 & & & 1020 & & 193 & \\
\hline & 2 & & & 251 & 14 & 1548 & \\
\hline & 3 & & & & & & \\
\hline & 4 & & & & 4 & 266 & \\
\hline & 5 & & & & 3 & 712 & \\
\hline & 6 & 30984 & & & & 107704 & \\
\hline & 7 & & & & 68 & 13701 & \\
\hline & 8 & & & & & 18517 & \\
\hline & 9 & & & & & 49436 & \\
\hline & 10 & & & & 1253 & 119448 & \\
\hline & 11 & & & & 4389 & 297590 & \\
\hline & 12 & & & & & 72007 & \\
\hline & 13 & & & 8463 & & 2935 & \\
\hline & 14 & & & 3802 & & 4 & \\
\hline & 15 & & & 3891 & & 5 & \\
\hline & 16 & & & 518 & & 28 & \\
\hline
\end{tabular}

$\mathrm{H}-5$ 
Table H.3. cont. VOC concentrations in soil with depth from post-demonstration reconnaissance samples, December 1997.

\begin{tabular}{|c|c|c|c|c|c|c|c|}
\hline Location & $\begin{array}{c}\text { Depth } \\
\text { (ft bgs) }\end{array}$ & $\begin{array}{l}\text { Meth Chlr } \\
\text { (ug/kg) }\end{array}$ & $\begin{array}{c}\text { t-1,2-DCE } \\
\text { (ug/kg) }\end{array}$ & $\begin{array}{c}\mathrm{c}-1,2-\mathrm{DCE} \\
\text { (ug/kg) }\end{array}$ & $\begin{array}{c}1,1,1, \mathrm{TCA} \\
\text { (ug/kg) }\end{array}$ & $\begin{array}{c}\text { TCE } \\
\text { (ug/kg) }\end{array}$ & $\begin{array}{c}\mathrm{PCE} \\
\text { (ug/kg) }\end{array}$ \\
\hline \multirow[t]{11}{*}{ GP 13} & 1 & & & & & 31 & \\
\hline & 2 & & & 338 & & 45 & \\
\hline & 3 & & & 1330 & & 223 & \\
\hline & 4 & & & 1072 & & 466 & \\
\hline & 5 & & & & & 1279 & \\
\hline & 6 & & & & & 22111 & \\
\hline & 8 & & & & & 30962 & \\
\hline & 10 & & & & & 67576 & \\
\hline & 12 & & & & 977 & 573667 & \\
\hline & 14 & & & 40115 & & 29632 & \\
\hline & 16 & & & 7416 & & 6217 & \\
\hline \multirow{8}{*}{ GP 14} & 2 & & & & & 5 & \\
\hline & 4 & & & & & 8 & \\
\hline & 6 & & & & & 10 & \\
\hline & 8 & & & & & 15 & \\
\hline & 10 & & & & & & \\
\hline & 12 & & & & & & \\
\hline & 14 & & & & & & \\
\hline & 16 & & & & & & \\
\hline
\end{tabular}

Blank table entries are non-detects

Table H.4. Radioactive materials in soil with depth from post-demonstration reconnaissance samples, PORTS laboratory analysis (December 1997).

\begin{tabular}{|c|c|c|c|c|c|c|}
\hline Location & $\begin{array}{l}\text { Depth } \\
\text { (ft bgs) }\end{array}$ & $\begin{array}{c}\text { Gross } \\
\text { alpha } \\
\text { (pCi/g) }\end{array}$ & $\begin{array}{c}\text { Gross } \\
\text { beta } \\
\text { (pCi/g) }\end{array}$ & $\begin{array}{l}\text { Technetium } \\
\text { (pCi/g) }\end{array}$ & $\begin{array}{l}\text { Total U } \\
\text { (ug/g) }\end{array}$ & $\begin{array}{c}\text { U } 235 \\
(\%)\end{array}$ \\
\hline GP 07 & 8 & $<4$ & $<8$ & $<0.2$ & 2.1 & 0.74 \\
\hline GP 08 & 1 & 21 & $<8$ & 2.9 & 6.6 & 5.2 \\
\hline GP 10 & 1 & $<4$ & $<8$ & $<0.2$ & 3.2 & 0.48 \\
\hline & 14 & 5 & $<8$ & $<0.2$ & 3.5 & 1.4 \\
\hline GP 14 & 6 & $<4$ & $<8$ & $<0.2$ & 3 & \\
\hline
\end{tabular}




\section{INTERNAL DISTRIBUTION}

1.

2. J. H. Cushman

3. T. O. Early

4. D. E. Fowler

5. B. $\mathrm{Gu}$

6. S. G. Hildebrand

7. G. K. Jacobs

8. P. Kanciruk

9. N. E. Korte

10. C. A. Little

11. J. M. Loar

12-13. K. S. Lowe

14. R. C. Mann
15. T. E. Myrick

16. S. M. Pffifner

17. D. A. Pickering

18. D. E. Reichle

19. D. S. Shriner

20-29. R. L. Siegrist

30. O. R. West

31. Central Research Library

32-33. ESD Library

34. Laboratory Records Dept

35. EMEF DMC-RC

\section{EXTERNAL DISTRIBUTION}

36. M. Broido, Director, Environmental Sciences Division, ER-74, Department of Energy, 19901 Germantown Road, Germantown, MD 20874

37. S. Chamberlain, Subsurface Contaminant Focus Area Program Manager, Department of Energy, EM-53, 19901 Germantown Road, Germantown, MD 20874

38. E. G. Cumesty, ORNL Site Manager, Department of Energy, Oak Ridge National Laboratory, P.O. Box 2008, Oak Ridge, TN 37831-6269

39. H. H. Hopkins, American Petroleum Institute, Health and Environmental Sciences Department, 1220 L Street, NW, Washington, DC 20005

40-53. T. C. Houk, Bechtel Jacobs Technology Applications, Portsmouth Gaseous Diffusion Plant, Highway 23 South, Building X-7725, MS 7602, Piketon, OH 45661

54. M. C. MacCracken, Director, Office of the U.S. Global Change Research Program, Code YS01, 300 E Street, SW, Washington, DC 20546

55. J. Moore, Technical Program Officer, Department of Energy, Oak Ridge Operations, 3 Main Street, Oak Ridge, TN 37830

56-57. L. C. Murdoch, Clemson University, 340 Brackett Hall, Box 341908, Clemson, SC 29634

58. E. Phillips, Subsurface Contaminant Focus Area DNAPL Product Line Manager, Department of Energy, Oak Ridge Operations, 3 Main Street, Oak Ridge, TN 37830 
59-60. W. W. Slack, Frx, Inc., P.O. Box 37945, Cincinnati, OH 45222

61. J. S. Walker, Office of Science and Technology, Department of Energy, EM-53, 12800 Middlebrook Road, Germantown, MD 20874

62. J. Wright, Subsurface Contaminant Focus Area Lead Office Manager, Department of Energy, Savannah River Operations, Building 703A, Rm B202, Highway 125, Aiken, SC 29802

63. Office of Assistant Manager for Energy Research and Development, U.S. Department of Energy, Oak Ridge Operations, P.O. Box 2001, Oak Ridge, TN 37831-8600

64-65. Office of Science and Technical Information, P.O. Box 62, Oak Ridge, TN 37831 